\title{
ANALES DEL INSTITUTO DE \\ INVESTIGACIONES \\ ESTÉTICAS
}

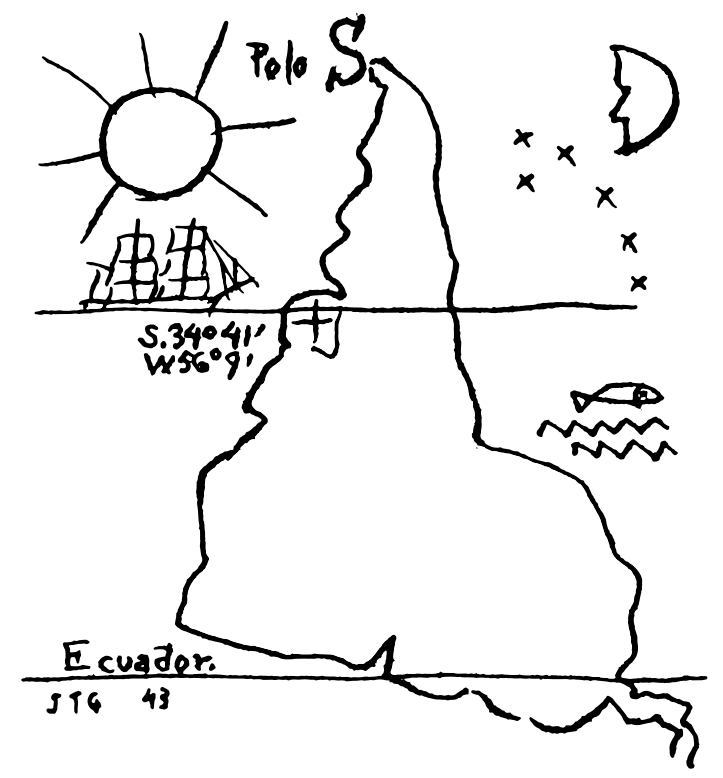

Número IO9 Otoño de 20 I6 México

UNIVERSIDAD NACIONAL AUTÓNOMA DE MÉXICO 
Anales del Instituto de Investigaciones Estéticas

volumen XXXVIII, número IO9, otońo de 2016

\title{
Consejo editorial
}

Catherine Rose Ettinger Mc Enulty, Universidad Michoacana de San Nicolás de Hidalgo; Danna Levín Rojo, Universidad Autónoma Metropolitana-Azcapotzalco; Nuria Salazar

Simarro, Coordinación Nacional de Monumentos Históricos-Instituto Nacional de Antropología e Historia; José de Santiago Silva, Facultad de Artes y Diseño, unam;

David M.J. Wood, Instituto de Investigaciones Estéticas, UNAM.

\section{Miembros honorarios}

Antonio Bonet Correa, Universidad Complutense de Madrid; Serge Guilbaut, University of California; Carol H. Krinsky, New York University; Helga von Kügelgen, Carl Justi Vereinigung; Alfredo López Austin, Instituto de Investigaciones Antropológicas, UnAM; Carlos Navarrete, Instituto de Investigaciones Antropológicas, UnAM; Antonio Rubial García, Facultad de Filosofía y Letras, UnAm; Mauricio Tenorio, University of Chicago; Gerhard Wolf, Kunsthistorisches Institut, Florencia.

\author{
Coordinación \\ Linda Báez \\ Emilie Carreón \\ Edición técnica \\ Karla Richterich, Jaime Soler \\ Corrección de estilo y lectura de pruebas \\ Gilda Castillo \\ Correspondencia \\ Ciudad Universitaria, 04510, Coyoacán, Ciudad de México \\ anliie@unam.mx/www.analesiie.unam.mx \\ $(52-55) 56227250$ ext. 85025
}

Anales del Instituto de Investigaciones Estéticas, Circuito Maestro Mario de la Cueva,

Portada: Joaquín Torres-García, "Sin título", I943, tomado de Dibujos del universalismo constructivo, catálogo de la exposición (Zaragoza: Departamento de Cultura y Turismo del Gobierno de Aragón/Museo Torres-García, 200I), 65.

Revista indexada en arthist.net; CLASE (Citas Latinoamericanas en Ciencias Sociales y Humanidades); Dialnet; ERIH Plus (European Reference Index for the Humanities and Social Sciences); Google Scholar; Google; HAPI (Hispanic American Periodicals Index); Latindex (Sistema Regional de Información en Línea para Revistas Científicas de América Latina, el Caribe, España y Portugal); miar (Information Matrix for the Analysis of Journals); Redalyc (Red de Revistas Científicas de América Latina y el Caribe, Espańa y Portugal); road (Directory of Open Access Scholarly Resources); Scielo (Scientific Electronic Library Online); Scielo Citation Index-WoS; Scopus; The Keepers Registry; Ulrich's.

D.R. (C) Anales del Instituto de Investigaciones Estéticas es una publicación semestral del Instituto de Investigaciones Estéticas de la Universidad Nacional Autónoma de México, Av. Universidad 300o, Ciudad Universitaria. Certificado de reserva de derechos al uso exclusivo del título, Instituto Nacional del Derecho de Autor, Secretaría de Educación Pública, número 04-2003-0416I254I500-IO2, expedido el I6 de abril de 2003 . Certificados de licitud de título y de contenido, Comisión Calificadora de Publicaciones y Revistas Ilustradas, Secretaría de Gobernación, números 6636 y 6936, respectivamente, expedidos el 7 de mayo de 1993. Editora responsable: Linda Báez Rubí. Apoyo jurídico: Lourdes Padilla. Asistente editorial: Karla Richterich. Diseńo: Armando Hatzacorsian. Diagramación: Fabiola Wong. Tipografía: El Atril Tipográfico, S.A. de C.V. Impresión: Offset Rebosán, S.A. de C.V. Av. Acueducto II5, Col. Huipulco, Tlalpan. Tiro: 500 ejemplares más separatas. Costo de la revista: 200 pesos. Suscripciones y ventas de números anteriores: área comercial, 56227250 ext. 85026, libroest@unam.mx. 


\section{Sumario}

LINDA BÁEZ

Presentación

\section{Articulos}

MARÍA AMALIA GARCÍA

Hacia una historia del arte regional. Reflexiones en torno al comparativismo

para el estudio de procesos culturales en Sudamérica

ANGÉLICA VELÁZQUEZ GUADARRAMA

De la caridad religiosa a la beneficencia burguesa: la dádiva social y sus imágenes CARLOS ARTURO SALAMANCA VILLAMIZAR

Religión, politica y espectáculo: narrativas del martirio en la primera modernidad

MARÍA ISABEL MARTÍNEZ RAMÍREZ

Los diseños en la cestería seri. Ensayo sobre técnicas de vinculación social

GEORGINA PARADA CARRILLO

Arquitectura y cerámica de Casas Grandes. Una comparación entre conceptos

espaciales arquitectónicos y pictóricos

\section{Obras, documentos}

ANA RAQUEL VANOYE CARLO

La pintura mural del convento de Santa Clara de Asís en Dzidzantún, Yucatán.

Generalidades sobre la ejecución de cuatro diferentes etapas

\section{Libros}

Ciudad y arquitectura. Seis generaciones que construyeron la América Latina moderna, de Silvia Arango Cardinal, por alejandrina escudero; El pincel de Elías. José Joaquín Magón y la orden de Nuestra Señora del Carmen, de Alejandro Andrade, por ANTONIO RUBIAL 
DOI: http://dx.doi.org/10.22201/iie.18703062e.2016.109.2623

4

Normas para la presentación de originales $\quad 287$

Submission Guidelines for Authors

295 


\section{Presentación}

Por esto, ya en otro tiempo, volvimos el mapa al revés, indicando que nuestro norte era el Sur, y así cortando, en cierto modo, con la tiranía espiritual de Europa. Reintegrémonos pues a la gran familia indoamericana.

Joaquín Torres-García, El nuevo arte de América

Análogo a la proyección de la imagen invertida en la cámara oscura a partir del cambio de perspectiva que vislumbra este número iog de la temporada de otoño 2016 de los Anales del Instituto de Investigaciones Estéticas se da a conocer la visión prismática formada a partir de las refracciones conceptuales generadas por las imágenes que se fragmentan y multiplican en este número.

En la primera faceta del prisma se da a conocer la región del Cono Sur vista desde una óptica hegemónica de gestión cultural. Desde su punta, la mirada se dirige al papel de la mujer como instrumento vital para la conformación de nuevos modelos necesarios para la formación de la nación mexicana. Por otra parte se analiza el registro de la violencia corporal, en el cual el tormento y la exposición del cuerpo castigado muestran cómo la imagen modela al observador mediante estrategias religioso-políticas. La visión prismática invertida, asimismo, conducirá al lector hacia superficies tejidas, pintadas y edificadas que se manifiestan y hacen evidente el concentrado entramado de recuerdos y narraciones subjetivas de los pueblos seri y de los antiguos habitantes del norte de México en Casas Grandes, culturas en las que no se ha enfocado la mirada, sino que se encuentran dispersas, pero las cuales aquí se logran visualizar mejor mediante la perspectiva en ángulo y espiral. 
DOI: http://dx.doi.org/10.22201/iie.18703062e.2016.109.2623

En la sección "Obras y documentos" se reconfiguran los fragmentos de pintura mural que emergen de los planos encalados de los conjuntos conventuales de la península de Yucatán. Finalmente las dos reseñas detienen la luz fracturada del prisma en la arquitectura y el urbanismo de la Ciudad de México, así como en la pintura novohispana de un pintor poblano hasta ahora poco conocido.

En su artículo "Hacia una historia del arte regional. Reflexiones en torno al comparativismo para el estudio de procesos culturales en Sudamérica”, María Amalia García presenta la maquinaria de promoción y gestión del arte moderno latinoamericano mediante bienales y museos en países de la región del Cono Sur. Al delinear las alianzas político-culturales reflejadas en la creación de proyectos de corte latinoamericano, la autora explica la compleja dinámica para la proyección de parámetros de gestión, prioritariamente brasileños, sobre la producción y exhibición del arte de países vecinos, como Paraguay y Argentina. En este marco muestra cómo la pintura monocroma se habilita a la práctica de análisis comparativos mediante escenarios culturales distintos, a la vez que se promueven intentos de constitución de redes culturales. Esto permite comparar tanto la producción generada en exposiciones, como su recepción en diferentes contextos para establecer así la importancia de la pintura como un eje de valor para cada coyuntura.

Mediante un análisis de las imágenes de la caridad vinculadas con la fundación de la congregación de san Vicente de Paul, que se expresan en la obra de varios artistas europeos y mexicanos, el texto de Angélica Velázquez Guadarrama "De la caridad religiosa a la beneficencia burguesa, la dádiva social y sus imágenes" permite contrastar de manera minuciosa la forma de representar la caridad y el contexto sociocultural de los personajes esbozados, así como delinear el estatuto moral de la emergente burguesía de aquella época. La autora deja que nos asomemos a esta organización femenina y de tal modo conocer sus costumbres y hábitos. Con precisión histórica da a conocer que las ideas ilustradas de la educación y el papel social asignado a la mujer por el pensamiento enciclopedista del siglo XviII, la delinean en discursos visuales que enfatizan y proyectan su papel como agente moral en la formación de la nación mexicana.

Carlos Arturo Salamanca Villamizar en "Religión, política y espectáculo: narrativas del martirio en la primera modernidad" aborda la representación de imágenes relacionadas con las prácticas de violencia religiosa difundidas mediante el grabado durante la época moderna. En ellas se proyecta un dis- 
curso martirológico que se caracteriza por su dinámica de obra abierta y en permanente actualización. El autor se enfoca en analizar la producción de un amplio registro de martirios que promueve conjuntos representativos de imágenes. A partir de su estudio reconoce estrategias compositivas y temáticas recurrentes con el fin de exponer el complejo carácter polisémico en la exposición de cuerpos castigados. Este análisis de la relación que existe entre prácticas de violencia y su representación pone de manifiesto la importancia de los martirologios como "medios" que canalizan modelos con el fin de influir en la conducta de los individuos al confrontarse visualmente con imágenes de esta naturaleza.

María Isabel Martínez Ramírez en "Los diseños en la cestería seri. Ensayo sobre técnicas de vinculación social” realiza un análisis de cómo las canastas cobran su luz definitiva mediante la integración de diseños para cubrir funciones utilitarias. El estudio traza estos tránsitos que van de valores simbólicos tradicionales, ceremoniales y rituales a valores asociados de tipo utilitario en circuitos mercantiles, develando otros aspectos de la producción gráfica de las mujeres seri. A partir del análisis de los dispositivos biográficos obtenidos en su trabajo de campo, la autora da a conocer, asimismo, el lugar que toma la mujer, quien desarrolla valores visuales manifestados en los tejidos enrollados a la vez que delinea la continuidad de la identidad seri. Simultáneamente el texto habla de la irradiación de nuevos modos de vida sujetos a los intereses de los embates de la modernidad, que, sin alejarse de tradiciones, conforman y adaptan nuevos ángulos, al reintegrarse.

El texto "Arquitectura y cerámica de Casas Grandes. Una comparación entre conceptos espaciales arquitectónicos y pictóricos", de Georgina Parada Carrillo, es una exploración importante para el entendimiento de una manifestación plástica singular de una de las culturas que habitaron el área norte de México entre 1300 y I450 d.C. En la producción de imágenes, tanto de corte geométrico como figurativo, se manifiesta y establece un estilo a partir de la estricta falta de centro en la composición pictórica y por la repetición de formas predominantemente geométricas. El análisis de la organización de la alfarería y arquitectura de Casas Grandes (Paquimé) permite entender plenamente la distribución y las relaciones de las imágenes (espiral y línea escalonada) y la manera mediante la cual se conjugan en diferentes soportes materiales. A partir de su confrontación y comparaciones visuales, la autora da a conocer la conformación del pensamiento y los rituales de este pueblo 
DOI: http://dx.doi.org/10.22201/iie.18703062e.2016.109.2623

al ofrecernos un espectro icónico de amplio interés que permite traspasar fronteras disciplinarias.

La sección de "Obras y documentos" se conforma por el texto de Ana Raquel Vanoye Carlo "La pintura mural del convento de Santa Clara de Asís en Dzidzantún, Yucatán. Generalidades sobre la ejecución de cuatro diferentes etapas". En éste se ofrece una reelaboración de los ciclos iconográficos de los programas franciscanos, hasta ahora poco conocidos y, por ende, poco estudiados. El prisma de análisis, mediante el cual se van desestratificando las capas que cubren las imágenes, permite llevar a cabo una reconstrucción de las diferentes temporalidades de las superficies cromáticas que caracterizaron los muros conventuales en determinadas épocas, permitiendo elaborar así un panorama más completo e histórico de los cambios de estilo que se sucedieron durante las misiones franciscanas y sus asentamientos en diferentes partes de la región peninsular. La labor de restauración que conforma la base de estos quiebres de luz presentados por la autora se concentra finalmente en un horizonte cromático donde las grisallas y los diseños dan cuenta de una historia por escribir.

Alejandrina Escudero en su reseña del libro de Silvia Arango Cardinal, Ciudad y arquitectura. Seis generaciones que construyeron la América Latina moderna muestra cómo, siguiendo la metodología generacional, la autora aprovecha para englobar y explicar la historiografía de la modernidad arquitectónica y urbanística latinoamericana. Captura los momentos iluminados de las generaciones de arquitectos, ingenieros y urbanistasa que de 1885 a 1970 edificaron la ciudad latinoamericana en Brasil, Chile y México, desarrollo de una creatividad regional.

A su vez, en la reseña del libro de Alejandro Andrade, El pincel de Elías. José Joaquín Magón y la orden de Nuestra Señora del Carmen, escrita por Antonio Rubial, se analiza la manera novedosa en la que Andrade exalta la obra de un pintor novohispano al delinear una serie de inferencias que permiten comparar los documentos de archivos con las pistas que ofrecen los cuadros de José Joaquín Magón. Este trabajo detectivesco, realizado por Andrade, consigue un bosquejo muy completo de la vida de uno de los pintores más importantes del periodo virreinal, quien desarrolló su actividad artística en Puebla en el siglo XviII.

Por último, los planos de refracción de luz y el uso del prisma han permitido, una vez que el mapa se invirtió, indicar que las transmisiones oscilantes a 
DOI: http://dx.doi.org/10.22201/iie.18703062e.2016.109.2623

PRESENTACIÓN

lo largo de varios siglos en los circuitos latinoamericanos y europeos se encuentran y desencuentran con energías alternas y continuas. Permítanos entonces reintegrarnos a la gran familia nativa americana que de manera fracturada lanza su mirada radiante hacia Europa y el resto del mundo.

Linda Báez Rubí

Bogotá, Colombia, junio de 2016 
DOI: http://dx.doi.org/10.22201/iie.18703062e.2016.109.2623 


\section{Hacia una historia del arte regional. Reflexiones en torno al comparativismo para el estudio de procesos culturales en Sudamérica}

\section{Towards a Regional Art History. Reflections on Comparative Methods for Studying South America Cultural Processes}

Artículo recibido el 22 de noviembre de 20I5; devuelto para revisión el 7 de junio de 2016; aceptado el 29 de junio de 2016. http://dx.doi.org/IO.2220I/iie.18703062e.2016.109.2576

María Amalia García Universidad de Buenos Aires-Facultad de Filosofía y Letras/Consejo Nacional de Investigaciones Científicas y Técnicas (Conicet), Argentina mamaliag@gmail.com

Líneas de investigación Arte abstracto sudamericano; relaciones culturales entre Argentina y Brasil; acercamientos comparativos en torno al arte moderno latinoamericano.

Publicaciones más relevantes El arte abstracto. Intercambios culturales entre Argentina y Brasil (Siglo XXI, 20II); "Vanguardia en doble página. Intervenciones del invencionismo argentino en la revista Joaquim", Revista do Instituto de Estudos Brasileiros, núm. 6I (agosto, 2015): I59-I82; "Hegemonies and Models of Cultural Modernization in South America. The ParaguayBrazil Case", Art Margins, vol. 3, núm. I (febrero, 20I4): 28-54; "Açôes e contatos regionais da arte concreta. Intervençốes do Max Bill em São Paulo em 1951", Revista USP, núm. 79 (septiembre-noviembre, 2008): 196-204; "Cities of Abstract Art: Urban Journeys through South America", Radical Geometry (2014): 32-55; "Entre revistas, exposiciones y bienales: instantáneas de la abstracción en Argentina y Brasil", América fría. La abstracción geométrica en Latinoamérica (1934-1973) (Madrid: Fundación Juan March, 201I), 43-47; "Max Bill on the Map of Argentine-Brazilian Concrete Art", en Mari Carmen Ramírez y Héctor Olea, eds., Building on a Construct: The Adolpho Leirner Collection of Brazilian Constructive Art at the MFAH (Houston: The Museum of Fine Arts-Yale University Press, 2009), 53-68.

Resumen Este trabajo busca revisar reflexiones historiográficas en torno al comparativismo como metodología de estudio y proponer un análisis para la construcción de historias del arte regionales. A partir de los debates considerados en un ajustado estado de la cuestión se 
busca volver a situar la historia comparada como una metodología idónea para pensar los procesos del arte moderno en las metrópolis sudamericanas y habilitar así lecturas que excedan las fronteras nacionales. Para este fin, la presente investigación propone la definición de "términos relacionales" y su puesta a prueba en el análisis de las artes visuales en Sudamérica. Los "términos relacionales" propuestos para el estudio metodológico son el "dispositivo de exhibición de intercambio diplomático" y la pintura monocroma, los cuales, considerados a partir de estudios de casos, habilitan el análisis comparativo. Se busca establecer núcleos de exploración para leer semejanzas y diferencias dentro un panorama común.

Palabras clave

Abstract

Keywords comparativismo; arte moderno; Sudamérica; región; historiografía.

This paper sets out to review considerations on the use of comparative approaches as a methodology of study and proposes a way of dealing with the construction of regional Art Histories. Following a brief overview and appraisal of the debates attested in the literature it aims to reposition Comparative History as an appropriate methodology for considering the processes of Modern Art in South American metropolises and to generate readings which go beyond national boundaries. With this purpose in mind, the article proposes the definition of "link-terms" which can be tested in the study of South America visual arts. The "link-terms" projected for this methodological approach are the "exhibition device for diplomatic exchange" and monochrome painting; these, applied to particular cases, facilitate a comparative analysis. The research was aimed at establishing exploration cores so as better to perceive similarities and differences within a common panorama.

comparative method; modern art; South America; region; historiography. 
DOI: http://dx.doi.org/10.22201/iie.18703062e.2016.109.2623

\author{
MARÍA AMALIA GARCÍA \\ UNIVERSIDAD DE BUENOS AIRES/CONSEJO NACIONAL \\ DE INVESTIGACIONES CIENTÍFICAS Y TÉCNICAS \\ ARGENTINA
}

\title{
Hacia una historia del arte regional Reflexiones en torno al comparativismo para el estudio de procesos culturales en Sudamérica
}

$\mathrm{I}$

ndagar más allá de las fronteras nacionales permite trazar otros mapas dentro de la continuidad continental, al vincular escenas culturales que plantean procesos autónomos. La apuesta por una mirada regional proyecta otras dimensiones sobre propuestas y acontecimientos previamente estudiados a la par que descubre núcleos casi ignorados para las escenas locales. La "historia regional" y el "comparativismo" son universos conceptuales que han sido largamente discutidos y en consecuencia se ha desconfiado de su productividad científica; ${ }^{\mathrm{I}}$ sin embargo, como una esperanza que nunca se pierde, vuelven a suscitar expectativas y relecturas.

I. Puede pensarse, por ejemplo, en la propuesta metodológica de Ángel Guido y Martín Noel para el estudio del arte colonial basada en la teoría visibilista. Tanto Guido como Noel entendían la comparación como una herramienta clave para la investigación del arte colonial americano y la definición del estilo mestizo. Su línea de investigación consistía en establecer comparaciones entre el barroco español y el mestizo y entre el barroco mestizo del norte de México y el del sur de Bolivia y Perú. Esta postura, reconocida como pionera, la cuestionaron mucho posteriores estudiosos del tema dada la escasa especificidad de la aproximación y sus conclusiones. Véase Ángel Guido, "La filosofía del arte en la actualidad. Wölfflin, Worringer, Dvořák, Pinder. Aplicación de sus teorías a temas americanos", en Redescubrimiento de América en el arte (Rosario: Universidad Nacional del Litoral, 194I), 35-80. Véase también Mario Buschiazzo, "El problema del arte mestizo", Anales del Instituto de Arte Americano de Investigaciones Estéticas X, núm. 22 (1969): 84-IO2. 
Comparar es central para percibir semejanzas y diferencias; por ende, el trabajo comparativo constituye un instrumento intrínseco del proceso de refinamiento de un objeto de estudio. Desde la lingüística, pionera al abordar este tipo de análisis, la antropología, la sociología y la historia, así como diversas disciplinas han encontrado en el comparativismo posibilidades metodológicas. Por su parte, la historia del arte tiene en la iconología y en el Atlas Mnemosyne de Aby Warburg un ejemplo majestuoso sobre las posibilidades cognitivas de la comparación de imágenes. ${ }^{2}$ Aunque no se conceptualizó en términos del comparativismo, esta estrategia ha sido uno de los criterios más extendidos para estudiar y pensar la historia del arte. Dos caminos han sido, en líneas generales, los más transitados en este sentido: por un lado, el enfoque formalista desde Heinrich Wölfflin hasta Roger Fry que se valieron de la comparación de los elementos y procedimientos plásticos como proceso de análisis de las imágenes. ${ }^{3}$ Por otra parte, los estudios iconográficos e iconológicos (siguiendo a Warburg, Erwin Panofsky y Ernst Gombrich, por mencionar algunos de los autores clásicos) se basaron en la comparación de imágenes figurativas (mitológicas, paganas, religiosas e históricas) para establecer vínculos entre los esquemas representacionales. ${ }^{4}$ Más allá de los valiosos aportes a la disciplina, tanto el enfoque iconográfico como el análisis basado en la comparación formal han llevado a poner en marcha procesos marcadamente distantes que han contribuido, muchas veces, más a la agudización que a la clarificación de los problemas: me refiero, por ejemplo, a la homologación del desarrollo del arte moderno latinoamericano en relación con los procesos europeos.

2. Aby Warburg, Atlas Mnemosyne, trad. Joaquín Chamorro Mielke (Madrid: Akal, 2oIo).

3. Heinrich Wölfflin, Conceptos fundamentales de la historia del arte, trad. José Moreno Villa (Madrid: Espasa Calpe, 1945); Roger Fry, Visión y diseño (Buenos Aires: Galatea-Nueva Visión, 1959).

4. Erwin Panofsky, El significado de las artes visuales, trad. Nicanor Ancochea (Madrid: Alianza, I977); Ernst Gombrich, Arte e ilusión. Estudio sobre la psicología de la representación pictórica (Barcelona: Gustavo Gili, 1978).

5. El arte latinoamericano tiene una larga tradición historiográfica de lectura en homologación con el arte europeo en la cual se utiliza una mirada desfasada y empobrecedora de las producciones locales; para un enfoque crítico de esta cuestión véase Marcelo Pacheco, "La Argentina y una mirada travestida. Emilio Pettoruti entre los espejos", en Renato González Mello y Juana Gutiérrez Haces, eds., Arte, historia e identidad en América: visiones comparativas (México: Universidad Nacional Autónoma de México-Instituto de Investigaciones Estéticas, 1994), 789-802; Andrea Giunta, "Adiós a la periferia. Vanguardias y neovanguardias en el arte de América Latina”, Blanco sobre Blanco. Miradas y Lecturas sobre Artes Visuales, núm. 5 (2013): 9-20. 
Sin embargo, la ausencia de una mirada panorámica que pueda trazar lineamientos generales, más allá de las particularidades de una obra, un artista o movimiento artístico-cultural, ha generado cierta miopía en el ámbito de las historias del arte nacionales. Este trabajo busca, en primera instancia, revisar una serie de reflexiones historiográficas en torno a las posibilidades del comparativismo para su aproximación al arte moderno en Latinoamérica. El material de análisis propuesto en torno al estado de la cuestión no pretende ser exhaustivo; más bien busca señalar algunos debates y sugerir puntos de partida para reflexionar sobre la comparación en el marco de la historia del arte. El objetivo es volver a situar la historia comparada como un método de análisis idóneo para pensar los procesos del arte moderno en las metrópolis sudamericanas y permitir así lecturas que rebasen las fronteras nacionales en la formulación de problemas. En la segunda parte del texto se propone examinar "términos relacionales" 6 para el análisis comparativo; resulta de particular interés establecer núcleos de exploración para leer semejanzas y diferencias en un panorama articulado. Finalmente, la idea rectora de esta investigación es proponer una lectura compartida para algunos periodos culturales en Latinoamérica.

\section{Pasado y presente en los estudios comparativos. Apuntes para un estado de la cuestión}

Romper las fronteras geopolíticas y proponer un área problemática común para el estudio de fenómenos culturales es un tema que ha ocupado la agenda intelectual latinoamericana desde al menos la última década. Desde mediados de los años noventa varios estudios contribuyeron a pensar nuevamente los estudios comparativos y sus perspectivas para la interpretación cultural.

En el contexto del ámbito académico mexicano surgió la necesidad de reflexionar en torno a la construcción de una nueva historia del arte latinoamericano que se evidenció en el XVII Coloquio Internacional de Historia del Arte, bajo el tema de Arte, historia e identidad en América: visiones comparativas $^{7}$ (Zacatecas, 1993), organizado por el Instituto de Investigaciones Estéticas de la UNAM y en la continuidad de esas discusiones guiadas por Rita

6. Por "términos relacionales" se entienden núcleos conceptuales que resumen problemas artístico-culturales específicos y que pueden actuar como instancias de articulación.

7. González Mello y Haces, eds., XVII Coloquio Internacional de Historia del Arte. 
Eder mediante la organización de varios seminarios durante casi diez años. ${ }^{8}$ En ese momento se planteó la necesidad de narrar una nueva historia del arte latinoamericano que revisara las generalidades difundidas por la historiografía precedente a partir de estudios de caso y el trabajo en archivo para renovar la investigación. En este conjunto de seminarios, en el cual participaron varias generaciones de críticos e historiadores del arte, se definieron debates y se conformaron agendas de investigación que exponen gran parte de la fisonomía de los conocimientos actuales sobre arte latinoamericano. ${ }^{9}$ Entre los diversos temas tratados (crítica al método historiográfico tradicional, ausencias y omisiones de las revisiones bibliográficas y museográficas, la inconformidad con la idea de un "arte latinoamericano") se buscó trabajar sobre la "visión prismática” para que no sólo expusiera la tensión entre la especificidad de la obra de arte y su dimensión social, sino que también mostrara la necesidad de ajustar ejes de articulación que realcionaran métodos y enfoques de estudio. De esta manera, la perspectiva comparativa se propuso, como uno de los puntos centrales, incluir los seminarios en la agenda de debate.

Precisamente, los criterios metodológicos fueron uno de los temas más discutidos: en ocasión de los simposios realizados en Oaxaca y Bellagio, Andrea Giunta propuso como modelo de trabajo confrontar hipótesis construidas a partir de un caso de estudio con otros espacios para exponer análisis articulados en torno a un conjunto de variables relativamente estables. ${ }^{\circ}{ }^{\circ}$ Me interesa, recuperando el planteo de Giunta, la posibilidad de definir conceptos continuos que habiliten el análisis comparativo; de hecho, en esta elección se basan los "términos relacionales" propuestos en la segunda parte de este texto. Tanto el "dispositivo de exhibición de intercambio diplomático" como la pintura monocroma se constituyen en núcleos de articulación que permiten relacionar escenas culturales diferentes.

8. Sandra M. Szir, "México y Latinoamérica. Arte y teoría. Entrevista de Caiana a Rita Eder", Caiana. Revista de Historia del Arte y Cultura Visual del Centro Argentino de Investigadores de Arte, núm. 6 (2015): 226-229.

9. En Rita Eder, dir., "Los estudios de arte desde América Latina: temas y problemas", consultado el 2I de septiembre de 20I5, www.esteticas.unam.mx/edartedal, se recopilan las ponencias de los siete simposios organizados entre 1996 y 2003.

Io. Andrea Giunta, "Comentarios sobre la reunión realizada en Oaxaca y propuestas para Bellagio", consultado el 2I de septiembre de 20I5, www.esteticas.unam.mx/edartedal/PDF/Bellagio/ complets/giunta_bellagiog6.pdf. 
En el marco del coloquio de Zacatecas antes mencionado, Katherine E. Manthorne presentó su propuesta en torno a los acercamientos comparativos. ${ }^{\text {II }} \mathrm{Mi}$ planteamiento se encuentra muy cercano a su horizonte de estudio en términos de una historia del arte transamericana que converge y comparte tradiciones intelectuales y modelos de representación y práctica artística. Manthorne privilegió el estudio de la pintura decimonónica del paisaje de plantaciones y las representaciones del gaucho y el cowboy para el análisis comparativo mediante un eje norte-sur del continente americano. ${ }^{\mathrm{I2}} \mathrm{Si}$ bien esta perspectiva es congruente con nuestro estudio, la presente investigación busca no limitar la estrategia comparativa con la similitud representativa de las producciones plásticas: los "términos de contraste" no siguen una línea privilegiada de análisis sino que apuntan a construir herramientas relacionales lo suficientemente heterogéneas que permitan obtener variabilidad y complejidad de lecturas.

Para continuar con el análisis de las presentaciones de Rita Eder en dichos coloquios es preciso señalar la postura de Roberto Amigo, para quien era necesario recuperar el alcance regional para la discusión de la historia del arte a partir de obras y fenómenos culturales que encontraran fundamento en ese marco. Se refiere, por ejemplo, a las imágenes de la guerra de la Triple Alianza, las cuales articulan diversos estilos y técnicas por medio de dibujantes, pintores y fotógrafos argentinos, paraguayos y europeos. Amigo también señala que las acciones de resistencia ante las dictaduras militares y los procesos de democratización entre las décadas de los setenta y ochenta trazan ejes conceptuales y visuales que dan cuenta de la constitución de un panorama regional. ${ }^{13}$ En este sentido, el monocromo se ubica en un punto de inflexión en el que surgieron diferentes propuestas modernas en Latinoamérica durante la posguerra, las cuales permitieron trazar un acercamiento analítico regional.

II. Katherine E. Manthorne, "A Transamerican Reading of 'The Machine in the Garden': Nature vs. Technology in $19^{\text {th }}$ Century Landscape Art", en González Mello y Gutiérrez Haces, eds., XVII Coloquio Internacional de Historia del Arte, t. I, 243-25I.

I2. Katherine E. Manthorne, “'Brothers Under the Skin'. Blanes's Gauchos and the Delineation of the Frontier Types of American West", The Art of Juan Manuel Blanes (Buenos Aires: Fundación Bunge y Born-Americas Society, 1997), 151-200; Katherine E. Manthorne, "Plantation Pictures in the Americas, circa I880 Land, Power, and Resistance", Nepantla: Views from South 2, núm. 2 (200I): 317-353.

I3. Roberto Amigo, "Consideraciones sobre el índice general 'Otras modernidades", consultado el 2I de septiembre de 20I5, http://www.esteticas.unam.mx/edartedal/bellagio/complets/ amigo_bellagio.pdf. 
Así, problematizar el tema de lo regional fue el foco del Encuentro Regional de Arte (ERAO7), organizado por Gabriel Peluffo Linari en Montevideo en 2007. En esta exposición-simposio se situó parte de la reflexión en torno a la definición de modelos de región. Se establecieron, por un lado, el concepto de región político-territorial forjado en el siglo XIX (asociado al Estado-nación) y, por otro, el más amplio de región (“invención de regiones”) considerados como "ámbitos definidos por tramas culturales que, ya sea mediante imaginarios colectivos transformables, mediante redes de comunicación electrónica y desplazamiento real, toman cuerpo social e histórico mediante un estatuto intergrupal de tipo estrictamente informacional y simbólico". ${ }^{14}$ Estos territorios otros no están definidos por la geografía política ni económica y tampoco por contenidos culturales de naturaleza telúrica; su "hipervínculo" construye nuevas regiones que no operan por obligación con cuerpos físicamente reunidos, sino como cuerpos comunicados, enmarcados en la globalización e internacionalización del capital financiero. La lectura de la región en términos político-territoriales y asociado al Estado-nación es altamente operativa para estudiar a partir del "término relacional", propuesto en este texto como "dispositivo de exhibición de intercambio diplomático". Asimismo, un concepto de región no territorial definido por tramas culturales ha sido abordado de manera profusa en los últimos años a partir del fuerte auge de las revistas culturales como núcleo de investigaciones académicas y museográficas.

El concepto de región, definido a partir del Estado-nación, ha sido central en los congresos y seminarios enmarcados por el programa Mercosur, los cuales se han enfocado en la necesidad de construir historias regionales. Se han generado encuentros e intercambios provenientes del ámbito diplomático con el fin, fundamentalmente, de ubicar las agendas académicas argentinas y brasileñas, países considerados los principales referentes culturales de la región. ${ }^{\text {Is }}$

En este sentido, Argentina y Brasil se han constituido como núcleos privilegiados para conjeturar y comprobar similitudes y diferencias históricas y culturales en la región del Cono Sur. Desde los estudios y reflexiones de Raúl Antelo y Jorge Schwartz (ambos argentinos, residentes en Brasil por décadas) sobre las relaciones literarias entre los modernistas brasileños y el grupo de Martín Fie-

I4. Gabriel Peluffo Linari, "Lugar del arte en el siglo xIx y discurso de lugar en el arte contemporáneo", en Memorias del encuentro regional de arte, t. I: Región: fricciones y ficciones (Montevideo: Museo Juan Manuel Blanes, 2007).

I5. José María Lladós y Samuel Pinheiro Guimarães, eds., Perspectivas Brasil-Argentina (Río de Janeiro: IPRI, 1999); VV. AA., A visão do Outro (Brasilia: Funag-Funceb, 2000). 
rro hasta las afinidades entre comunidades culturales de diversa índole (arte, música, literatura, danza, futbol, surf, entre otros) es amplia y profusa la histórica relación entre ambos países. ${ }^{16}$ Este marco de estudio ha sido frecuentado por numerosos investigadores que buscaron relaciones y proyectos comunes entre Argentina y Brasil. ${ }^{17}$ En esta línea de tradiciones comparativas, es preciso destacar el estudio de Boris Fausto y Fernando Devoto que confronta, desde la perspectiva de la historia comparada, un estudio de Argentina y Brasil desde mediados del siglo XIx hasta la actualidad; en él plantea sus características comunes, analiza las diferencias en sus desarrollos (por ejemplo, los fenómenos políticos de Getúlio Vargas y Juan Domingo Perón) y señala las transformaciones en sus relaciones bilaterales y posicionamientos internacionales. ${ }^{18}$

Me interesa este trabajo no sólo por el análisis histórico de dos de los países articuladores de la región del Cono Sur sino también por la perspectiva metodológica empleada. Fausto y Devoto recuperan la figura de Marc Bloch en tanto referente ineludible para la perspectiva comparada. Bloch atribuye un alto grado de utilidad científica a la posibilidad de comparar sociedades vecinas y contemporáneas constantemente influidas entre sí al considerar sus problemas específicos. Bloch enfatiza dos requisitos para hacerlo: cierta similitud

I6. Raúl Antelo, Confluencia. Literatura argentina por brasileños. Literatura brasileña por argentinos (Buenos Aires: Centro de Estudos Brasileiros, 1982); Jorge Schwartz, Vanguardia y cosmopolitismo en la década del veinte. Oliverio Girondo y Oswald de Andrade (Rosario: Beatriz Viterbo, 1993). Entre otros proyectos comunes considérese la revista Grumo que se propone establecer puentes literarios entre Buenos Aires y Río de Janeiro (www.salagrumo.org) y el trabajo de Ivana Vollaro en torno a proximidades lingüísticas entre el portugués y el español, en línea con las investigaciones de la poesía concreta, Ivana Vollaro, Vermello (São Paulo: Galería Vermelho, 2008).

17. Quiero destacar la investigación de Patricia M. Artundo sobre Mário de Andrade y su vinculación con artistas e intelectuales argentinos [Mário de Andrade e a Argentina: um pais e sua produção cultural como espaço de reflexão (Sáo Paulo: EDUSP-FAPESP, 2004)], el trabajo de Gustavo Sorá sobre las traducciones y las ediciones de literatura brasileńa en la Argentina (Traducir el Brasil. Una antropología de la circulación de ideas [Buenos Aires: Del Zorzal, 2004]) y el de Florencia Garramuño en torno a las filiaciones entre tango y salsa (Modernidades primitivas. Tango, samba y nación [Buenos Aires: Fondo de Cultura Económica, 2007]). También es preciso mencionar el estudio de María Amalia García sobre proximidades en torno al desarrollo del arte abstracto entre ambos países (El arte abstracto. Intercambios culturales entre Argentina y Brasil [Buenos Aires: Siglo XXI, 20II]). El texto de Gonzalo Aguilar es sugerente en torno a cuestiones comparativas, "La invención del espacio (Arte y cultura en la Argentina y en el Brasil, años 60)", en Pop, realismos y política. Argentina-Brasil Ig6os (Buenos Aires: Fundación Proa, 2012), 39-47.

I8. Boris Fausto y Fernando Devoto, Brasil e Argentina. Um ensaio de história comparada I8502002 (São Paulo: Editora 34, 2004). 
en los hechos observados y alguna diferencia entre los contextos sociales en que estos fenómenos han tenido lugar. ${ }^{19}$ Sólo esa combinación permitiría una confrontación fructífera de semejanzas y diferencias. Estas breves indicaciones de Bloch distinguen, para Devoto, la posición del historiador francés de posteriores ejecutores del método: para Bloch el comparativismo era un instrumento estrechamente vinculado con la práctica del historiador y no un método o un procedimiento teórico y, en este sentido, la ambigüedad (la ausencia de una línea homogénea de comparación) no fue una debilidad sino una fortaleza. ${ }^{20}$

Si bien la construcción de tipologías puede implicar simplificaciones o estilizaciones, las esquematizaciones pueden actuar como instrumentos útiles para pensar realidades complejas y su relación con otros casos particulares. Devoto señala algunos prerrequisitos a la hora de pensar en estos temas: "estudiar sociedades cercanas en el tiempo y en el espacio, buscar un equilibrio (difícil) en el nivel de conocimiento de los distintos casos y prestar atención a los problemas de traductibilidad de un código historiográfico a otro". ${ }^{21}$ Esta reflexión en torno al giro historiográfico en cada país permite hacer un cuestionamiento en torno a la conceptualización de lo moderno: codificaciones discursivas, modos de inscripción en el medio y definición de poéticas.

Adrián Gorelik también se ha ocupado de reflexionar en torno a las ventajas y debilidades del comparativismo señalando las dificultades que plantea un enfoque que, en pos de comparar, diluye las diferencias al crear objetos de estudios unificados bajo la idea de "ismos" que precisamente las historias nacionales han buscado especificar y clarificar. ${ }^{22}$ Asimismo, advierte la escasa rigurosidad analítica de un "latinoamericanismo" superficial, construido desde una mirada exógena y con criterios comparativistas en crisis, como por ejemplo el canon literario. ${ }^{23} \mathrm{Al}$ considerar estas precauciones, Gorelik propone dos líneas de análisis en tanto propuesta de renovación historiográfica: por un

19. Marc Bloch, "A favor de una historia comparada de las civilizaciones europeas", en Historia e historiadores, trad. Francisco Javier González García (Madrid: Akal, 1999), II5.

20. Fernando Devoto, "La historia comparada entre el método y la práctica. Un itinerario historiográfico", Prismas. Revista de Historia Intelectual, núm. 8 (2004): 229-243; véase ahí también Adrián Gorelik, "El comparativismo como problema”, I2I-I28; así como Alette Olin Hill y Boyd H. Hill, "Marc Bloch and Comparative History", The American Historical Review 85, núm. 4 (1980): 828-846, http://dx.doi.org/Io.I086/ahr/85.4.828.

2I. Devoto, "La historia comparada entre el método y la práctica", 243.

22. Gorelik, "El comparativismo como problema", I2I-I28.

23. Gorelik, "El comparativismo como problema". 
lado, la construcción de objetos transnacionales cuya delimitación de problemas no se agota exclusivamente en lo nacional. ${ }^{24}$ Por otro, señala la historización de contactos culturales: se trata del estudio de periodos específicos en que diversas culturas latinoamericanas han entrado efectivamente en contacto (mediante viajes, exilios, traducciones, entre otros), y han producido intentos efectivos de constitución de redes culturales de extensión regional o continental. De un tiempo a esta parte, este marco de estudio ha sido un objeto privilegiado de investigación académica.

$\mathrm{Al}$ seguir esta línea en el ámbito argentino, José Luis Romero ha realizado un planteamiento metodológico pionero para el estudio de los contactos y elementos culturales coincidentes, al constituirse estas manifestaciones en objetos privilegiados para la investigación científica. ${ }^{25}$ Sin embargo, el éxito que el concepto de "contacto cultural" ha tenido en el ámbito académico latinoamericano se debe en parte a la influencia producida por el libro Ojos imperiales de Mary Louise Pratt. A partir de su análisis sobre la literatura de viajeros en los siglos XVIII y XIX, Pratt delinea el concepto de "zonas de contacto" como espacios sociales de encuentro, de tensión, de conflicto y de negociación entre culturas dispares. ${ }^{26} \mathrm{Al}$ subrayar los espacios de interacción, Pratt adopta una perspectiva de "contacto" que hace hincapié en la constitución histórica de los sujetos en y por sus relaciones mutuas. Asimismo, James Clifford ha trabajado con las nociones de "contacto" y "viaje" como experiencias y prácticas de encuentro e interacción entre diversas regiones culturales. ${ }^{27}$

Este recorrido a lo largo de posturas historiográficas y propuestas metodológicas busca analizar antecedentes y recuperar reflexiones para pensar en torno a la construcción de una historia del arte moderno-regional para el ámbito latinoamericano. De hecho, la definición de variables relativamente estables que permitan el análisis comparativo es la base de la elección de "términos rela-

24. Con relación a la definición de objetos transnacionales sumo mi análisis en torno a la pintura monocroma, tema caro para la pintura moderna, que trasciende fronteras nacionales y habilita el análisis comparativo mediante diferentes escenarios culturales.

25. José Luis Romero, "Los contactos de cultura: bases para una morfología”, en La vida histórica (Buenos Aires: Sudamericana, 1988), I45-182.

26. Mary Louise Pratt, Ojos imperiales. Literatura de viajes y transculturación (Buenos Aires: Universidad Nacional de Quilmes, 1997).

27. James Clifford, Itinerarios transculturales, trad. Mireya Reilly de Fayard (Barcelona: Gedisa, 1999). 
DOI: http://dx.doi.org/10.22201/iie.18703062e.2016.109.2623

22

MARÍA AMALIA GARCíA

cionales" utilizados, ya que hacen posible trazar relaciones transnacionales y sincrónicas mediante periodos locales.

\section{La construcción de "términos relacionales" para el análisis comparativo}

A partir de estas reflexiones metodológicas e historiográficas propongo definir y poner a prueba "términos relacionales" que permitan el análisis comparativo. Puesto que condensan temas centrales para la coyuntura histórica, estos conceptos hacen posible confrontar fenómenos ocurridos en diferentes contextos artísticos al considerar similitudes y otorgarle apropiada atención a las diferencias. Entiendo que la definición de estos términos está estipulada por las necesidades de conocimiento del investigador y las posibilidades de análisis que propone el objeto, por ende, la definición del marco de investigación queda sujeta a la circunstancia de los fenómenos que se quieran estudiar. Si bien ya se ha mencionado, es preciso destacar que la construcción de términos relacionales para el análisis comparativo no sigue una línea privilegiada o predeterminada (formal, institucional), sino que más bien pretende que la construcción de estas herramientas relacionales sea lo suficientemente heterogénea para obtener variabilidad y complejidad de lecturas.

A partir de investigaciones realizadas sobre los procesos de modernización en Argentina, Brasil, Paraguay y Colombia, este texto define un área circunscrita al ámbito sudamericano. En este sentido, este planteamiento también abre la pregunta sobre la posibilidad de pensar Sudamérica como un recorte idóneo para el análisis cultural dentro del concepto más abarcador de "Latinoamérica". Asimismo, se confronta la división geográfico-económica del Cono Sur para analizar problemas artístico-culturales. La próxima etapa de esta investigación propone incorporar el caso mexicano, dada la fuerte hegemonía cultural continental de México, sobre los países andinos fundamentalmente.

En función de los tránsitos de esta investigación, propongo dos términos relacionales que permiten observar similitudes y diferencias y estudiar los procesos del arte moderno en diversos campos culturales. Por un lado, el "dispositivo de exhibición de intercambio diplomático" que genera una tipología, la cual permite comparar tanto las condiciones de producción de la exposición (vinculada a los sectores estatales y privados, cancillerías y embajadas) como 
la circulación y recepción de la misma en diferentes contextos. ${ }^{28}$ Por otro, se propone la pintura monocroma en tanto fenómeno pictórico altamente homogéneo y uniforme como un parámetro versátil para atravesar realidades artístico-culturales diferentes. La pintura monocroma, considerada como "término relacional", hace posible el análisis comparativo, ya que la aparente semejanza entre obras monocromas convoca un análisis contextual que permite entender qué significa una pintura con una paleta homogénea en el aspecto cromático y en el del valor para cada coyuntura.

\section{El "dispositivo de exhibición de intercambio diplomático": vinculos artísticos y contextos politicos}

Las exposiciones de arte y las gestiones políticas de los intercambios culturales son un núcleo interesante para abordar las disputas por la legitimidad y la hegemonía en el ámbito sudamericano. En tanto estudio de caso, se analizarán dos exposiciones de arte moderno brasileño realizadas una en Buenos Aires (Argentina), en 1957, y otra en Asunción (Paraguay), en 1959. Estas exhibiciones organizadas por el Museo de Arte Moderno de Río de Janeiro (MAM-RJ) y de Sáo Paulo (MAM-SP) — respectivamente — con el apoyo del Ministerio de Relaciones Exteriores brasileño (el Itamaraty), tienen características más bien comunes en tanto articulan negociaciones entre los museos de arte moderno — de carácter privado y vinculados al ámbito empresarial — con la cancillería estatal. ${ }^{29}$ En específico, ambas muestras se inscriben en lo que entiendo como modelo de promoción cultural brasileño de posguerra volcado al posicionamiento continental. ${ }^{30} \mathrm{Sin}$ embargo, más allá de las proximidades, las muestras plantean, tanto a partir de su concepción como desde la recepción, situaciones

28. Carol Duncan, "Art Museums and the Ritual of Citizenship", en Exhibiting Cultures. The Poetics and Politics of Museum Display (Washington/Londres: Smithsonian Institution, 199I), 88-ı03; Paulo Herkenhoff, "A Bienal de São Paulo e seus compromissos culturais e políticos", Revista USP, núm. 52 (200I-2002): II8-I2I; Ana Garduño, El curador de la guerra fría, Fernando Gamboa (México: Consejo Nacional para la Cultura y las Artes-Instituto Nacional de Bellas ArtesMuseo Mural Diego Rivera, 2009); María José Herrera, coord., Exposiciones de arte argentino 1956-2006. La confluencia de historiadores, curadores e instituciones en la escritura de la historia (Buenos Aires: Museo Nacional de Bellas Artes, 2009).

29. Rita Alves Oliveira, "Bienal de São Paulo. Impacto na cultura brasileira", São Paulo Perspec IS, núm. 3 (julio-septiembre, 200I), consultado el I4 de noviembre de 20I5, http://dx.doi.org/IO.I590/ solo2-88392001000300004.

30. María Amalia García, "Hegemonies and Models of Cultural Modernization in South 
altamente diferenciales: la confrontación de estas exposiciones permite analizar posicionamientos e intereses del aparato diplomático brasileño y sus modelos para la gestión cultural.

Ambas exposiciones tienen características semejantes en tanto ofician como instancias políticas de intercambio cultural. El hecho de que estén patrocinadas por el Itamaraty enmarca dicho propósito en el proyecto político-diplomático que busca asegurar la relevancia brasileña en el Cono Sur. La supremacía cultural de Buenos Aires en la región estuvo fuertemente comprometida después de la segunda guerra mundial, cuando posicionamientos políticos diferentes tuvieron repercusiones en los lineamientos culturales y artísticos (recuérdese que mientras que Argentina se mantuvo neutral frente al conflicto bélico, Brasil envió tropas a favor de los aliados). Esta alianza político-económica de Brasil con Estados Unidos estuvo en consonancia con la creación de proyectos culturales modernos e internacionalistas. Es bien sabido que a partir de finales de 1940, las ciudades brasileñas — tanto São Paulo como Río de Janeiro- desplegaron una poderosa maquinaria de promoción y gestión del arte moderno mediante la constitución de los nuevos museos y la Bienal de São Paulo. ${ }^{3 \mathrm{I}}$

Tanto la exposición de Buenos Aires como la de Asunción estuvieron orientadas por el objetivo de proponer el arte moderno y las instituciones culturales brasileñas como modelo para la práctica y la gestión artística en el ámbito regional. Esta aspiración de hegemonía cultural opera en la concepción, armado y difusión de ambas exposiciones. Sin embargo, más allá de las proximidades, las muestras disponen tanto a partir de su producción como desde la recepción situaciones marcadamente diferenciales. En este sentido, es preciso aclarar que si bien el Itamaraty apoyó ambos emprendimientos, el de Buenos Aires lo realizó el MAM-RJ bajo la gestión de Niomar Moriz Sodré y Jorge Romero Brest en el MNBA y el de Asunción, el MAM-sp, gestionado por el grabador Lívio Abramo, quien se desempeñaba tanto como asesor del museo paulista como de la Misión Cultural Brasileña en Asunción. ${ }^{32}$

America. The Paraguay-Brazil Case", Art Margins 3, núm. I (Santa Barbara: MIт Press, 20I4), 28-54, http://dx.doi.org/IO.II62/ARTM_a_00o69; García, El arte abstracto, 85-II2.

31. Aracy Amaral, Museu de Arte Contemporânea da Universidade de São Paulo. Perfil de um Acervo (São Paulo: techint-usp, 1982), I2-I8; Herkenhoff, "A Bienal de São Paulo e seus compromissos culturais e políticos", II8-I2I.

32. Arte moderno en Brasil (Buenos Aires: Museo Nacional de Bellas Artes, 1957); Museo de Arte Moderno de San Pablo, Brasil (Asunción, 1959). "Arte moderno en Brasil" fue una muestra itinerante que se exhibió también en Rosario, Santiago de Chile y Lima. 
Cuatro puntos nos permiten analizar los aspectos diferenciales entre ambos proyectos. En primera instancia tomemos la "curaduría" — salvando el anacronismo del término para la década de los cincuenta- de ambas exposiciones desde el punto de vista de la coherencia y homogeneidad de la propuesta. La exposición de Buenos Aires, con un total de 270 piezas, incluía 35 años de arte brasileño desde los protagonistas de la Semana del 22 hasta las tendencias más contemporáneas vinculadas a la abstracción. Por su parte, la exposición de Asunción era mucho más pequeña — sólo 69 piezas - y no planteaba un recorte tan homogéneo: consistía en una selección de artistas extranjeros y brasileños del siglo Xx de la colección del MAM-SP que buscaba, en líneas generales, dar cuenta de la evolución del arte moderno. Si bien ambas muestras pretendían posicionar el arte brasileńo de vanguardia como modelo para la región, esta tesis estaba expuesta de modo bien diferenciado en ambos conjuntos. En el caso de Asunción la selección efectuada parecía buscar paralelismos entre los maestros internacionales y los representantes brasileños para confirmar a Brasil como un referente regional para el arte moderno. Lo fragmentario del planteamiento redundaba en una exposición de escasa coherencia argumentativa. Por el contrario, en el caso porteño, un panorama dedicado en exclusiva a la plástica brasileña planteaba una selección ajustada y prolija que evidenciaba una mayor consideración hacia el público argentino.

Por otra parte, el valor de las piezas presentadas también era considerablemente distinguible. En el caso argentino se exhibía un conjunto de calidad que recuperaba lo mejor del arte moderno brasileño; estaban las piezas canónicas que armaban dicho relato como La boba (1915), de Anita Malfatti, La negra (1923), de Tarsila do Amaral, obras importantes de Maria Martins, Lasar Segall y Candido Portinari y un recorte de la plástica contemporánea que incluía a Hélio Oiticica, Lygia Clark, Ivan Serpa, Volpi, entre otros. Consecuente con el esfuerzo del museo carioca, la prensa porteña destacó el alto nivel y la originalidad del envío brasileño (fig. I). ${ }^{33}$

En contraposición, en Asunción la calidad de las piezas era bastante discutible y las definiciones en torno al arte moderno que proponía la exposición generaron debates en el ámbito asunceno. La artista hispano-paraguaya Josefina Plá dedicó a la exposición dos largos artículos aparecidos en el dia-

33. Damián Carlos Bayón, "La exposición de arte brasilero", Ars, núm. 77 (1957): s.p.; Germaine Derbecq, "En el Museo de Bellas Artes", Arte Nuevo, núm. 4 (1957): 8-13; J. A. García Martínez, "Museo, imaginario de la pintura brasileña", Histonium, núm. 218 (I957): 48-49. 
DOI: http://dx.doi.org/10.22201/iie.18703062e.2016.109.2623

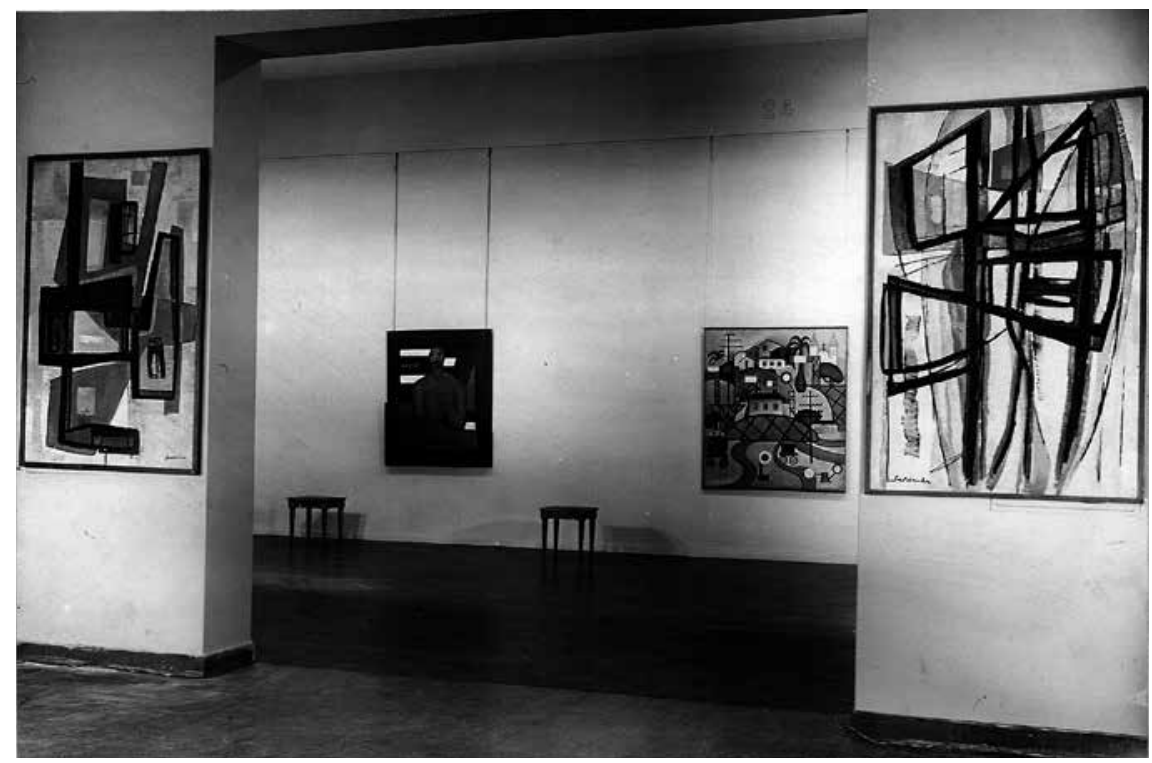

I. Vista de "Arte moderno en Brasil", Museo Nacional de Bellas Artes (en adelante MNBA), Buenos Aires, 1957. Al frente obras de Firmino Saldanha y en segundo plano A negra y Estação Central do Brasil, de Tarsila do Amaral. Archivos Curatoriales, Área de Investigación y Curaduría del MNBA, Brasil.

rio $L a T_{\text {ribuna }}{ }^{34}$ en los cuales, aunque señalaba la importancia de la muestra para el medio, marcaba la fragmentaria selección realizada de la plástica europea; por ejemplo, lamentaba la ausencia de los maestros de la Escuela de París y criticaba la selección de los artistas franceses contemporáneos. Además, Plá destacaba que más allá de la talla de los artistas presentes era muy cuestionable la calidad de las obras elegidas dentro de la producción de cada una de estas figuras. En este sentido refería especialmente a Gino Severini y a Giorgio de Chirico de quienes mencionaba sus aportes a la renovación artística del siglo $\mathrm{xx}$, pero aclaraba que éstos no eran visibles en las obras presentes en la

34. Josefina Plá, "El Museo de Arte Moderno de San Pablo en Asunción. Primer artículo", La Tribuna, Asunción, I9 de junio de I959, s.p.; Josefina Plá, "El Museo de Arte Moderno de San Pablo en Asunción. Segundo artículo", La Tribuna, Asunción, 26 de junio de 1959, Archivo Centro de Estudos Brasileiros, Asunción (en adelante Archivo CEB). 
muestra. ${ }^{35}$ Plá concluía, por tanto, que la selección privilegiaba las firmas por sobre la envergadura de las producciones expuestas.

Es preciso considerar que el acervo del MAM-SP contaba en 1959 con firmas y piezas mucho más relevantes que las enviadas a Asunción: no sólo las adquisiciones de su fundador, Ciccillo Matarazzo, y otros coleccionistas privados conformaban el conjunto sino también la donación de Nelson Rockefeller y los premios otorgados en las cuatro primeras bienales. ${ }^{36}$ Josefina Plá lamentaba la ausencia de Kandinsky, Braque, Picasso y Miró, pertenecientes a la colección del MAM-SP, pero omitidas en la muestra; estas obras, señalaba Plá, bien hubieran contribuido a explicitar el relato del arte moderno al que aspiraba la exposición. Mediante estos dos largos artículos, la artista paraguaya buscó mostrar que el ámbito asunceno resultaba conocedor de las tendencias modernas y que podía discernir con claridad entre los logros y las fallas del proyecto. Evidentemente, Abramo y el MAM-sp en su misión modernizadora desatendieron la información con la que contaban sus interlocutores paraguayos.

Asimismo, el seguimiento mediático que hizo la prensa brasileña difiere mucho en ambas exposiciones. En el caso argentino, varios titulares aludiendo a los preparativos de "Arte moderno en Brasil", a la importancia del evento para el ámbito porteño y a la centralidad de la plástica brasileña dentro de las nuevas tendencias fueron una constante, desde marzo de 1957, en el diario carioca Correio da Manhã. Este periódico dirigido por Paulo Bittencourt (el esposo de Niomar Moriz Sodré, directora del MAM-RJ) tuvo la cobertura más completa a cargo del crítico Jayme Mauricio, quien se dedicó a reseñar las opiniones del especializado y distinguido público porteño. ${ }^{37}$ En el caso paraguayo, la prensa brasileńa dedicó sólo una nota a informar sobre la muestra en la cual Abramo explicitaba sin tapujos los objetivos del emprendimiento: se refería a los artistas paraguayos y declaraba para los diarios brasileños que "la muestra del MAM impulsará decisivamente sus futuros trabajos, animan-

35. Nótese por ejemplo que de Gino Severini se exponía Mujer y arlequin (1946), pieza de lenguaje moderno decorativo y poco arriesgada; también se exhibía Gladiadores (ca. 1930-193I) de De Chirico, una obra figurativa y convencionalmente modernista con poca innovación plástica. A la luz de estas obras expuestas se entienden con claridad las objeciones realizadas por Josefina Plá.

36. Amaral, Museu de Arte Contemporânea da Universidade de São Paulo, I5; Regina Teixeira de Barros, "Revisão de uma história: a criação do Museu de Arte Moderna de São Paulo I946-1949", tesis de maestría (Universidade de São Paulo, 2002); Maria Cecília França Lourenço, Museus acolhem moderno (São Paulo: EDUsP, 1999).

37. Véase la "Exposición de 1957", Archivo MAM-RJ, Carpeta de prensa, núm. 2. 
do a estos artistas a realizar emprendimientos más audaces. ${ }^{38}$ De forma evidente, Abramo ubicaba la colección del mam y a los artistas brasileños como guías de la plástica paraguaya moderna (fig. 2).

En cuarta instancia es preciso analizar el significado político que adquirieron estas exposiciones para cada coyuntura. En el caso argentino "Arte moderno en Brasil" reabrió con la presencia del presidente Aramburu, ministros, representantes de la Iglesia y del ejército y numerosos embajadores, en las salas del MNBA de Buenos Aires bajo el mandato del nuevo gobierno militar en junio de $1957 . .^{39}$ Esta intervención militar que derrocó al gobierno de Juan Domingo Perón en septiembre de 1955 se autodenominó "revolución libertadora" y conllevó una profunda transformación políticosocial. A la par que los sectores obreros perdían los beneficios conseguidos y se proscribía la actividad sindical, otros sectores de la sociedad experimentaban la asunción del nuevo gobierno como una vuelta a la democracia: se había constituido un espacio social en el cual se imponían los sectores liberales. ${ }^{40}$

En este sentido, para el contexto argentino era por demás elocuente la trascendencia que tenía la reapertura del Museo Nacional con una exposición de arte brasileño. "Arte moderno en Brasil" es particularmente sintetizadora de determinados vínculos políticos y artístico-intelectuales entre ambos países: permite condensar un recorrido iniciado en el contexto de la segunda guerra mundial cuando sectores intelectuales argentinos opositores al régimen peronista y comprometidos con el conflicto bélico mantenían contacto e interés efectivo con Brasil, mientras el gobierno argentino se mantenía neutral y sostenía con el país vecino una relación de tensión y competencia. ${ }^{4 \mathrm{I}} \mathrm{A}$ partir de 1955 se inscribe el cambio de sentido de la "ecuación política": sectores opositores al peronismo eran los vencedores del nuevo momento y por ende, sus proyectos, objetivos y también sus vinculaciones. ${ }^{42}$

38. "Exposição do acervo do Museu de Arte Modena no Paraguai", Archivo ceв, O Estado de São Paulo, São Paulo, I2 de julio de 1959, s.p.

39. César Tcach, "Golpes, proscripciones y partidos políticos", en Daniel James, ed., Nueva historia argentina. Violencia, proscripción y autoritarismo 1955-1976 (Buenos Aires: Sudamericana, 2003), 20-24.

40. Daniel James, Resistencia e integración. El peronismo y la clase trabajadora argentina I9461976 (Buenos Aires: Sudamericana, 1990), cap. 2.

4I. García, El arte abstracto, IOI-II2.

42. Tcach, "Golpes, proscripciones y partidos políticos"; Carlos Escudé y Andrés Cisneros, orgs., Historia general de las relaciones exteriores de la República Argentina, t. XIII (Buenos Aires: Consejo Argentino para las Relaciones Internacionales, 1999). 


\section{Exposição do acervo do Museu de Arte Moderna no Paraguai}

Integrada no seu programa de intercambio com os paises estran. geiros, e nomeadamente com os da America Latina, o Museu de Arte Moderna de São Paulo abriu recentemente na capital paraguaia uma exposição do seu acervo. A inauguraçẫo da mostra assistíram - presidente da Republica, minis. tros, corpo diplomatico em Assunça e um vasto e interessado publico.

A ideia da exposição nasceu em 1956, durante uma conversa havida entre Livio Abramo e o en. tảo chefe da Missão Cultural Bra. sileira em Assuncăo, prof. Albino Peixoto, mas só agora foì possivel concretizá-la, apesar dos esforcos que desde logo desenvolveu o che. fe da missảo cultural brasileira. Concluiu a tarefa o atual responsavel pela missảo, prof. José Este. lita Lins, auxiliado pelo gravador Livio Abramo, que expressamente se deslocou a Assunçăo, como re. presentante do M.A.M, paulista, a fim de ultimar os preparativos da mostra: 70 pinturas, gravuras e de-

senhos, originais dos mais repre. sentativos artistas plasticos brasi.

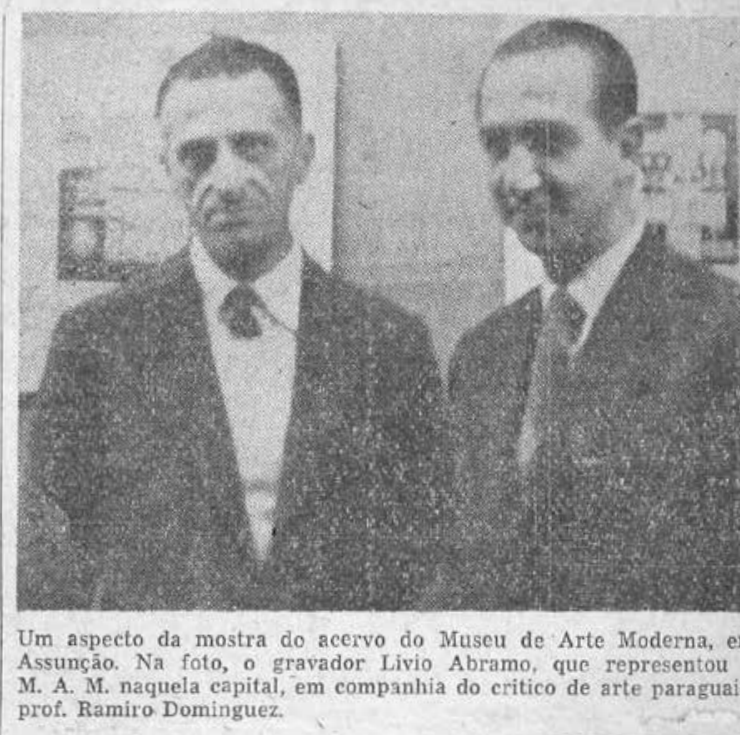

2. "Exposição do acervo do Museu de Arte Moderna no Paraguai", Archivo ceb, O Estado de São Paulo, I2 de julio de 1959, s.p.

Resulta por demás elocuente el papel que Romero Brest, director interventor del MNBA a partir de la "revolución libertadora", le adjudicaba a Brasil en su discurso inaugural de la exposición: "Los brasileños vienen [...] a ayudarnos en esa cruzada de rehabilitación del Museo, y más que para la rehabilitación del arte yo diría para la rehabilitación de la actividad creadora, que es la única que cuenta”. ${ }^{43}$ El triunfo del proyecto liberal sostenido por el gobierno militar provisional permitió que Brasil fuera considerado por

43. "Reabrióse el Museo con la Exposición de Brasil”, La Nación, Buenos Aires, 26 de junio de 1957,6 . 
DOI: http://dx.doi.org/10.22201/iie.18703062e.2016.109.2623

30

MARÍA AMALIA GARCÍA

algunos sectores artísticos locales como un modelo de modernización y desarrollo: la exposición "Arte moderno en Brasil" condensa este proceso.

En el caso paraguayo, la exposición del MAM-SP era parte del proceso de brasileirización de la vida paraguaya que estuvo enfatizada a partir de 1954 con la ascensión a la presidencia de Alfredo Stroessner y la relación cada vez más estrecha de este gobierno con el de Juscelino Kubitschek. ${ }^{44}$ En 1958 se firmó el tratado de construcción del Puente Internacional de la Amistad, para edificarse sobre el río Paraná y comunicar las ciudades de Foz do Iguaçu (Brasil) y Ciudad del Este (Paraguay). ${ }^{45}$ Durante la década de los sesenta tuvieron lugar intensas negociaciones entre los dos países para la construcción de la represa de Itaipú, con el fin de aprovechar los recursos hídricos del río Paraná. ${ }^{46}$ Además del creciente flujo de colonos brasileños en la región de la frontera este que implicaba la formación de importantes latifundios en los cuales radica, en parte, la causa de la inequidad en la distribución de tierras y los actuales conflictos por la reforma agraria.

Desde el punto de vista cultural, el ámbito artístico paraguayo, que recibió desde finales del siglo xix y comienzos del xx el influjo modernizador de Buenos Aires, mostró en la década de los cincuenta un marcado desplazamiento hacia la órbita brasileña. ${ }^{47} \mathrm{La}$ renovación de la plástica paraguaya a partir del primer lustro de dicha década se dio altamente asociada a las vinculaciones brasileñas. Por un lado, la interrelación con el medio asunceno de los artistas João Rossi y Abramo fue clave para la modernización de los lenguajes y la irrupción del Grupo de Arte Nuevo durante la década de los cincuenta. Por otro, mediante la acción institucional de la embajada, Brasil volcó sobre Paraguay su capacidad de acción en el ámbito cultural al reorganizar la escena asuncena. En 1943 se creó la Misión Cultural Brasileña en Asunción, órgano de difusión

44. Ceres Moraes, Paraguai. A consolidação da ditadura Stroessner 1954-1963 (Porto Alegre: Edipucrs, 2000), 99.

45. "Entrevista de Stroessner y Kubitschek", Patria, Asunción, 2 de octubre de 1958, s.p.; "Fraternidad americana. Los jefes de Estado de Brasil y Paraguay se abrazan hoy y con ellos, los dos pueblos", Archivo ceB, El País, Asunción, 4 de octubre de 1958, s.p.

46. Ronaldo Alexandre do Amaral e Silva, "Brasil-Paraguai: marcos da política de reaproximação bilateral, I954-I973”, tesis de maestría (Universidade de Brasília, 2006), consultada el 2I de septiembre de 20I5, http://repositorio.bce.unb.br/handle/IO482/2363.

47. Ticio Escobar, Una interpretación de las artes plásticas en el Paraguay (Asunción: Servilibro, 2007). Otros autores también consensúan respecto al tránsito de hegemonías en Paraguay: véase Roberto Amigo, Guerra, anarquía y goce. Tres episodios de la relación entre la cultura y el arte moderno en el Paraguay (Asunción: Museo del Barro-Centro de Artes Visuales, 2002), 73. 
de la lengua y la cultura brasileńa, cuyo objetivo era estrechar y fomentar el intercambio cultural, profesional y educativo entre ambos países. ${ }^{48}$ Durante la década de los cincuenta y comienzos de la siguiente, la Misión Cultural Brasileña conoció un momento de esplendor bajo la dirección de Albino Peixoto y de José Estelita Lins, con el asesoramiento artístico de Abramo. En este periodo la presencia de Brasil en el ámbito cultural y académico paraguayo se destacó por el número de profesores en la Universidad Nacional de Asunción y el otorgamiento de becas a estudiantes y profesionales paraguayos para estudiar en universidades brasileñas. ${ }^{49}$ Asimismo, en este momento se observaba la proyección de modelos de gestión brasileños sobre la producción y la exhibición del arte paraguayo. En el ámbito artístico es preciso señalar la acción de Abramo como nexo clave de estas intervenciones brasileńas en Paraguay. Vinculado al MAM-SP, Abramo llegó a Asunción en 1956, invitado por la Misión Cultural para realizar una exposición de sus obras. A partir de ese momento Abramo continuó las vinculaciones con el Paraguay por medio de la Misión y la embajada participando en numerosos emprendimientos de intercambio hasta su radicación definitiva en este país en 1962.

Entre los principales emprendimientos de la Misión, es preciso destacar el convenio de realización del Colegio Experimental Paraguay-Brasil, un colegio secundario que, inaugurado en 1964, contó con un proyecto pedagógico de avanzada y con un diseño arquitectónico de Affonso Reidy, quien continuaba la línea del MAM-RJ con la utilización de la planta libre y los pilotes en "V". Asimismo, es preciso señalar otros emprendimientos de la Misión Cultural como la creación de la Escuela de Arte en 1959, taller de plástica para niños que también seguía el modelo del MAM-RJ. Otro aspecto importante fueron las participaciones de Paraguay en la Bienal paulista, puesto que dicho país tuvo representación oficial desde la segunda edición en 1953. Además de la selección de artistas contemporáneos, en el marco de la V Bienal de São Paulo en 1959, Abramo organizó una pequeña exposición de ñandutis —encaje típico del Paraguay-y en el contexto de la VI Bienal, en 196I, una gran Exposición de Arte Religioso de las Misiones Jesuíticas del Paraguay, que implicó un trabajo inédito de investigación y selección de piezas en diversos sitios arqueo-

48. "Instituto Cultural Paraguay-Brasil", Archivo CEB, medio gráfico sin identificar, mayo de 1960. Véase también "Atos entre o Brasil e o Paraguai".

49. "Acordo entre os Estados Unidos do Brasil e o Paraguai destinado a sistematizar as funções da Missão Cultural Brasileira em Assunção", Archivo CEB, Río de Janeiro, 3I de marzo de 1952 (Brasil: Ministério de Relaçóes Exteriores), s.p. 
lógicos del país.5 Estas últimas muestras de arte y artesanía paraguaya en la Bienal habían sido pensadas como contraparte de la exposición de obras del MAM-SP previamente analizada.

En suma, si bien los objetivos de las muestras de arte brasileño tanto en Buenos Aires como en Asunción coincidían en potencializar la plástica brasileña y constituirse como modelos de promoción de lo artístico, los horizontes de inscripción eran bien diferentes en términos de magnitud de la apuesta e interés de proyección por parte de los organizadores. Evidentemente, entre estas ciudades del Cono Sur se tejían lazos de tensión y competencia: mientras que para las metrópolis brasileñas se planteaba una disputa por la hegemonía regional con Buenos Aires, con Asunción operaba un vínculo más desigual que ubicaba a Paraguay como un consumidor cautivo de bienes culturales brasileños. En suma, bajo la utilización de este término relacional, el análisis de dichas exposiciones permitió poner en contacto tres escenas culturales y entretejer las posiciones políticas activas en dichos intercambios en el marco del orden de la posguerra.

\section{El monocromo: el silencio del medium como instancia de pluralidad discursiva}

Superficies de un solo color llevan la pintura a una instancia límite; ponen en jaque sus posibilidades discursivas. Sin embargo, mucho dicen estas obras de la situación de la pintura en los ámbitos artísticos en los cuales se producen y además presentan un núcleo privilegiado para el análisis comparativo. Precisamente, el segundo "término relacional" que propongo es el fenómeno de la pintura monocroma. La considero - en tanto procedimiento plástico de homologación cromática y tonal- como otro "término-concepto" que habilita este tipo de análisis. La aparente semejanza entre obras monocromas convoca a un estudio contextual que permita entender qué significa una pintura con una paleta homogénea en el aspecto cromático y de valor para cada circunstancia. Se considerarán tres obras monocromas: sin título de la serie "Pinturas negras", de Alberto Greco (fig. 3), Espaço modulado, de Lygia Clark (fig. 4) y Homenaje a Malévich, de Carlos Rojas (fig. 5) para analizar el funcionamiento de este fenómeno pictórico en reelaboración diferencial de

50. García, "Hegemonies and Models of Cultural Modernization in South America". 
DOI: http://dx.doi.org/10.22201/iie.18703062e.2016.109.2623

HACIA UNA HISTORIA DEL ARTE REGIONAL

3. Alberto Greco, sin título, de la serie "Pinturas negras", 1960, brea, bleque y óleo sobre tela, $2 \times$ I m. MNBA, Buenos Aires.

Cortesía de Silvia Greco.

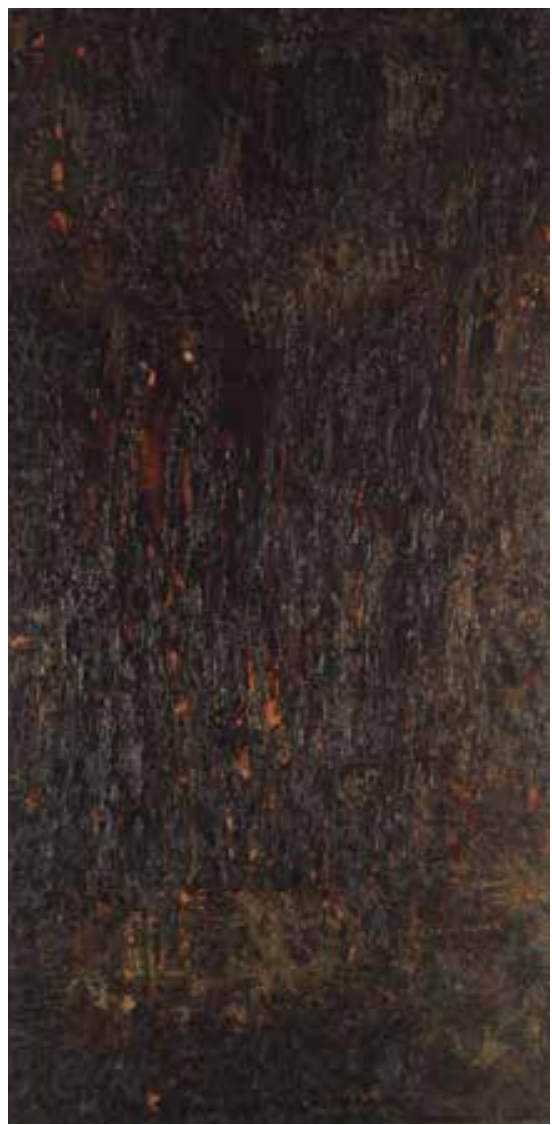

las tradiciones del arte moderno en Buenos Aires, Río de Janeiro y Bogotá. ${ }^{51}$ Tomar estos tres monocromos me permite situar los distintos momentos de la abstracción sudamericana, los procesos de consolidación y sus crisis.

Comienzo con Alberto Greco. Su serie "Pinturas negras" se expuso en la Galería Pizarro en 1960. Se trata de un conjunto de obras realizadas en brea,

5I. María Amalia García, "El monocromo en tanto término de análisis para la comparación de imágenes. Lygia Clark y Alberto Greco en el cruce de la pintura y el espacio", en V Congreso Internacional de Teoría e Historia de las Artes (Buenos Aires: Centro Argentino de Investigadores de Arte CaIA, 2009), 53-65. 
DOI: http://dx.doi.org/10.22201/iie.18703062e.2016.109.2623

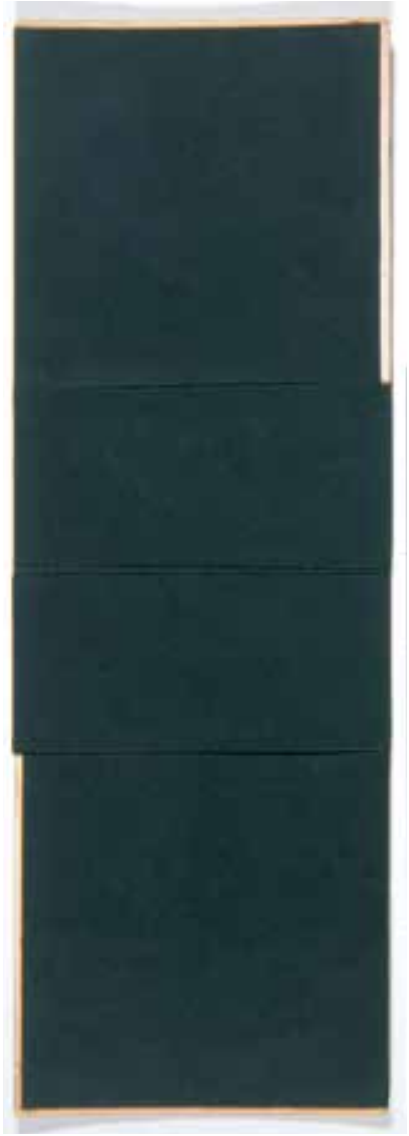

4. Lygia Clark, boceto para la serie "Espaço modulado", I958, collage sobre cartón, $29.8 \times 10 \mathrm{~cm}$. Foto: Marcelo Ribeiro Alvares Corrêa. Cortesía de "The World of Lygia Clark” Cultural Association, ref. O0222, núm. 217.

bleque y óleo sobre una tela de $2 \times$ I metros. Son superficies texturadas en las que prima la homogeneidad del valor bajo. La ausencia compositiva y la homogeneidad cromática están contrastadas por un acusado uso de textura visual y táctil que genera una variabilidad e intermitencia de la superficie..$^{52}$ Esta serie se inscribe en una línea pictórica muy transitada en la década de los cincuenta en la cual el orden compositivo y los procedimientos técnicos se han trastocado profundamente. La libertad expresiva del artista en la ejecución y la utili-

52. Francisco Rivas, "Alberto Greco. La novela de su vida y el sentido de su muerte", en Alberto Greco (Valencia: IVAM, 1992), 272-276. 
DOI: http://dx.doi.org/10.22201/iie.18703062e.2016.109.2623

HACIA UNA HISTORIA DEL ARTE REGIONAL

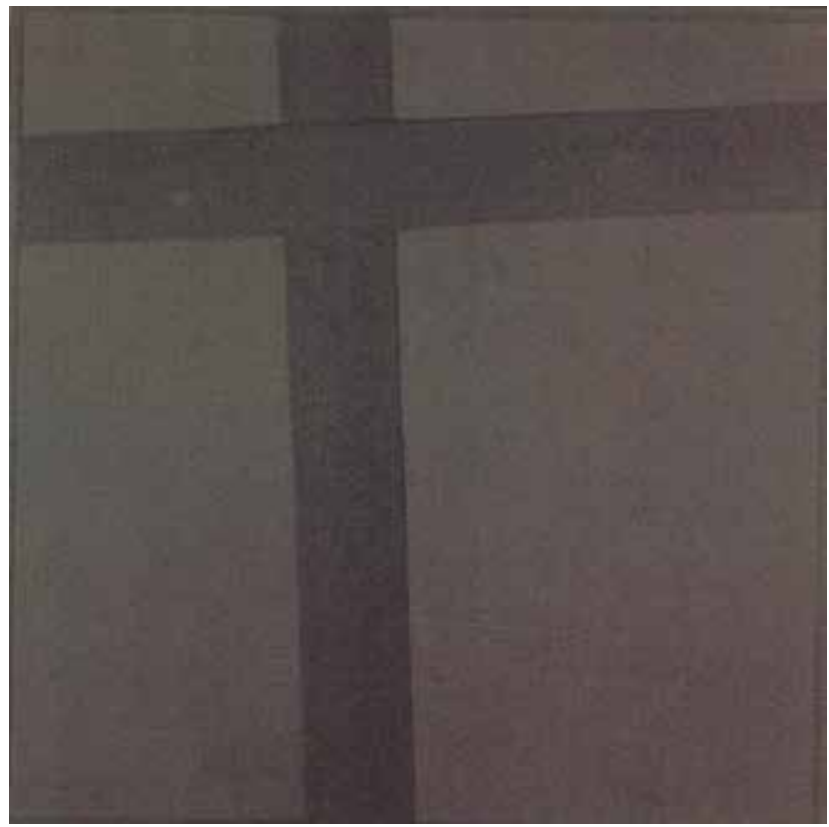

5. Carlos Rojas, Homenaje a Malévich de la serie "Ingeniería de la visión”, ca. 1960, acrílico sobre tela, $60 \times 60 \mathrm{~cm}$. Bogotá. Cortesía de Rosse Mary Rojas.

zación de materiales extraartísticos se constituyeron como recursos clave para estas nuevas prácticas en la escena internacional.

En el caso argentino, el desarrollo del informalismo surgió de la mano de la reactualización de la poética surrealista, que venía incidiendo en el campo de la poesía desde principios de la década de los cincuenta y que a finales de la misma influyó en la producción plástica. Tanto la acción en el panorama artístico de Aldo Pellegrini — primer introductor del surrealismo en América Latina - durante la década de los cincuenta, como la revista Boa, dirigida por Julio Llinás, son clave para este proceso. Azar y liberación del inconsciente adquieren un papel central en la obra de Greco. Es ya parte del anecdotario del arte argentino referir el modo en el que este artista trabajaba su serie negra: Jorge López Anaya recuerda que Greco 
sacaba el cuadro a la intemperie en un balcón, para que la noche, el viento, el hollín de la ciudad y la lluvia fueran cargándolo con su fuerza. En ocasiones, además de recurrir a ese procedimiento, orinaba sobre sus cuadros — invitaba a sus amigos a imitarlo- aduciendo que por ese medio obtenía reacciones orgánicas de la materia que la enriquecían con resultados inesperados..$^{53}$

La obra funciona, entonces, como huella del procedimiento creativo del artista que sale al encuentro del azar, del acontecimiento, de lo contingente. Su detonador estaba fuera no sólo de la convención pictórica figurativa sino también de la racionalidad geométrica: al recuperar el azar, aquel elemento central de la poética surrealista, Greco actuaba un encuentro imprevisible entre el arte y la vida. La necesidad de incorporar el exterior, lo orgánico de la realidad urbana y humana (el hollín, las hojas, el orín) da cuenta de esta investigación espacial a partir del cuadro que se profundiza en la trayectoria posterior de Greco en la cual el cuerpo, por medio de acciones y performance, se constituye en el depositario de su búsqueda creativa.

Por otra parte, consideremos Espaço modulado de Lygia Clark. ${ }^{54}$ Esta obra construye la totalidad rectangular a partir de tres cuadrados de $30 \times 30 \mathrm{~cm}$. El primer y tercer cuadrado están bordeados por una línea blanca en sus cuatro lados; a su vez, el cuadrado central está constituido por dos rectángulos: por la yuxtaposición de las placas de madera se genera una estructura lineal horizontal. El quiebre con la lógica del cuadro modernista tiene lugar en estas búsquedas de Lygia Clark. Si en su serie "Planos em superfície modulada" Clark exploraba esa línea de aire real que veía aparecer en la yuxtaposición de dos planos, en Espaço modulado operaba con el espacio real a partir de una línea blanca - línea-espacio- que actuaba entre los bordes externos de las superficies pictóricas y el montaje en la pared —-blanca— de exhibición. Una frontera blanca y elástica deshace los límites entre el espacio interior y exterior del cuadro. El cuestionamiento de los límites de la obra modernista y la introducción del espacio real en la obra se constituyen en ejes de su investigación perceptiva.

53. Jorge López Anaya, El arte en un tiempo sin dioses (Buenos Aires: Almagesto, 1989), I5I. 54. La obra que se reproduce en el presente artículo es un estudio para la serie "Espaço modulado". Este boceto que posee otra técnica y medidas que la obra a la cual hago referencia mantiene sí mucha proximidad en términos compositivos. Para la visualización de la obra Espaço modulado (1958) a la cual me refiero, véase AA.VV., Lygia Clark (Barcelona: Fundació Antoni Tàpies, 1997), IoI; Cornelia H. Butler y Luis Pérez-Oramas, eds., Lygia Clark, The Abandonment of Art, I948-1988 (Nueva York: MoMA, 2OI4), I42-I43. 
La búsqueda de Clark se enmarcaba en los debates sobre la tradición del arte concreto que los artistas cariocas venían llevando adelante desde mediados de la década de los cincuenta. En diciembre de 1956 en el MAM-sp y en febrero de 1957 en el MAM-RJ se presentó la I Exposición Nacional de Arte Concreto, que conformó un primer balance de las experiencias constructivas en Brasil. Esto llevó a una confrontación entre la obra de los artistas paulistas y cariocas que definieron quiebres y posicionamientos.55 Dos años después de este encuentro entre las experiencias abstracto-concretas en Brasil tuvo lugar la I Exposición Neoconcreta, inaugurada en el MAM-RJ el i9 de marzo de 1959. En dicha oportunidad se lanzó el Manifesto neoconcreto, firmado por los artistas y redactado por Ferreira Gullar. Las distintas acciones sobre la tradición del arte concreto, que habían sido evidenciadas en la exposición de 1956, tomaban en este momento un nuevo giro. Se habían impreso otros sentidos al vocabulario geométrico; para los artistas cariocas era necesario desarticular la ingeniería concretista. El neoconcretismo efectuaba una reacción contra el carácter racionalista y mecanicista que, en su mirada, había adquirido el arte concreto bajo las búsquedas paulistas. Si bien la recuperación de la herencia constructiva era evidente ésta se basó en la inclusión de un nuevo elemento: la dimensión corporal. La contraposición fue magníficamente explicitada por Ferreira Gullar en el Manifesto neoconcreto entre el "olho-máquina" concretista — concentrado en las relaciones internas de la imagen-y la organización perceptiva de las formas (se refería a la utilización por parte de algunos artistas concretos brasileños de las leyes de la Gestalt para la creación artística), ${ }^{56}$ versus el "olho-corpo" del neoconcretismo, que intentaba reponer la dimensión corporal, aunar el órgano de la vista a la totalidad del cuerpo. ${ }^{57}$ Esta búsqueda es cada vez más evidente en la obra de Clark: si en su obra bidimensional, como en Espaço modulado (1958), se concentraba la tensión en la línea de aire que se extiende más allá del espacio plástico, el desarrollo posterior de su obra desde los "bichos" a sus "objetos relacionales" evidencian

55. Lorenzo Mammi, cur., Concreta 's6: a raiz da forma (São Paulo: maM, 2006), 23-52.

56. Ana Maria Belluzzo, "Ruptura e arte concreta", en Arte construtiva no Brasil: Coleção Adolpho Leirner (São Paulo: Companhia Melhoramentos-DBA, I998), 95-I4I; Ronaldo Brito, Neoconcretismo. Vértice e ruptura do projeto construtivo brasileiro (São Paulo: Cosac \& Naify, I999).

57. Amilcar de Castro, Ferreira Gullar, Franz Weissmann, Lygia Clark, Lygia Pape, Reynaldo Jardim y Theon Spanúdis, "Manifesto neoconcreto”, Jornal do Brasil, Río de Janeiro, 22 de marzo de 1959 , 4-5. 
una investigación que rompe los límites del cuadro modernista en función de la expansión de los del arte..$^{58}$

En los monocromos de Greco y de Clark el cuadro se presenta en tanto superficie-objeto y su funcionamiento expositivo en la pared abre la cuestión por fuera de los límites del cuadro. En palabras de Benjamin Buchloh "en la medida en que se destierran de la pintura las relaciones internas, las condiciones externas salen a la luz: la pintura/relieve/objeto se convierte cabalmente en 'figura' sobre 'fondo' arquitectónico de la superficie que le sirve de soporte (el espacio perceptivo real del espectador)." " En ambos casos, el monocromo implica una salida del cuadro hacia la dimensión espacial y las posibilidades del cuerpo como parte integrante del proceso creativo.

Ahora bien, mientras que los monocromos de Greco y Clark inscriben en la superficie la dimensión espacial de lo real y dan cuenta de los quiebres que introdujeron el informalismo y el neoconcretismo en torno a este paradigma de la abstracción, la obra de Rojas se nos presenta como una reflexión que consolida ese universo. En Bogotá el contexto artístico era diferente al de Buenos Aires y Río de Janeiro en 1950. Mientras que en estas ciudades del Cono Sur la hegemonía del discurso sobre el arte concreto se encontraba en crisis desde el segundo lustro de la década de los cincuenta, en Bogotá, una exposición con un alto porcentaje de artistas abstractos inauguraba la Biblioteca Luis Ángel Arango, en 1957, mientras que la voz de Marta Traba señalaba estas nuevas producciones, volcadas a la reflexión sobre el lenguaje, como el único horizonte artístico posible. ${ }^{60}$

Homenaje a Malévich de Carlos Rojas forma parte de su serie "Ingeniería de la visión" que se inicia en la década de los sesenta e incluye obras de formato cuadrado, en tonos negros y grises, intervenidas con elementos lineales que sugieren plantas arquitectónicas. ${ }^{\text {II }}$ Esta serie — "Ingeniería de la visión"-

58. Paulo Herkenhoff, "A aventura planar de Lygia Clark: de caracóis, escadas e Caminhando", en Lygia Clark (São Paulo: Museu de Arte Moderna, 1999), 7-6r.

59. Benjamin Buchloh, Formalismo e historicidad. Modelos y métodos en el arte del siglo XX, trads. Carolina del Olmo y César Rendueles (Madrid: Akal, 2004), 226.

6o. Carmen María Jaramillo, Fisuras del arte moderno en Colombia (Bogotá: Fundación Gilberto Alzate Avendańo, 20I2); Sylvia Juliana Suárez, Salón de Arte Moderno 1957 (Bogotá: Biblioteca Luis Ángel Arango, 2008).

6I. Carmen María Jaramillo, Carlos Rojas (Bogotá: El Museo, 1995); Nicolás Gómez, Felipe González y Julián Serna, Carlos Rojas. Una visita a sus mundos (Bogotá: Museo Nacional de Colombia, 2008). 
de Rojas tiene su origen en una investigación sobre la vanguardia europea que comienza con sus collages realizados a partir de las pinturas cubistas y que se continúa en los monocromos inspirados en Van Doesburg, Mondrian y Malévich. Efectivamente, fueron las investigaciones de la vanguardia artística rusa sobre el reduccionismo de los elementos plásticos las que entendieron el monocromo como la conclusión lógica del problema pictórico. Rojas se sitúa en ese punto del enigma de la pintura moderna y desarrolla su investigación continuando esta línea de trabajo que la entiende como un homenaje a dicha tradición. Sin embargo, no accede a ese pasado de manera consagratoria sino que interroga la tradición por medio del humor que parece funcionar como su clave de lectura a la ingeniería geométrica. Estos planos monocromos con leves articulaciones lineales y tonales que aluden a las propiedades específicas de lo artístico son titulados por Rojas de modo que desdice el silencio y la antinarratividad de la trama o retícula modernista. Sus obras $O$ de espacio y Otra E de espacio (y Homenaje a mí mismo) nos permiten entrever un guiño risueño e irónico sobre los formalismos de la tradición abstracta. Si bien su posicionamiento no efectúa el cuestionamiento radical que realizó el informalismo o el neoconcretismo, tampoco entiende el trabajo en torno a las poéticas abstractas con el grado de ortodoxia que le imprimieron los artistas concretos argentinos y brasileños. Un tercer margen del río surge al confrontar el desarrollo bogotano de las poéticas abstractas.

Asimismo, es preciso realizar otra indicación en torno a la figura de Rojas y el desarrollo de las artes plásticas en Bogotá. La historiografía del arte colombiano ha señalado que el panorama local se caracterizó en los años cincuenta y sesenta por otorgar escasa relevancia a los manifiestos y por no preconizar las nociones de progreso, originalidad, autonomía, ruptura y novedad, típicas de los movimientos vanguardistas. ${ }^{62}$ En dicho ámbito, los presupuestos artísticos modernistas de alguna manera fueron flexibles e inclusivos, y posibilitaron la incorporación de referencias a la cultura visual precolombina o a la cultura popular. Éste fue el caso de la generación de artistas abstractos como Carlos Rojas, Eduardo Ramírez Villamizar, Edgar Negret, Judith Márquez y Lucy Tejada, por mencionar sólo algunos. ${ }^{63}$ Sin embargo, es posible pensar que la ruptura que no se visualizaba en el campo de la plástica sí era llevada adelante por estos artistas en términos de afectividad y vida cotidiana. En líneas

62. Jaramillo, Fisuras del arte moderno en Colombia, 56-59.

63. Jaramillo, Fisuras del arte moderno en Colombia, I45-I46. 
generales, los artistas mencionados vinculados a esta renovación abstracta de la década de los cincuenta junto con Enrique Grau, Hernán Díaz, Alejandro Obregón y Cecilia Porras buscaron subvertir el ambiente conservador y provinciano de Bogotá a partir de la inscripción de nuevas prácticas de sociabilidad, el cuestionamiento de normas patriarcales y la apertura hacia elecciones sexuales fuera de las normas establecidas. ${ }^{64}$ Esto sin duda marca una fuerte discrepancia respecto de los grupos abstracto-concretos argentinos que si bien propusieron una fuerte innovación artístico-cultural, no cuestionaron la heteronormatividad. ${ }^{65}$

Así, estos monocromos que constituyen un "mismo problema plástico" plantearon instancias bien diferenciadas de producción y recepción y habilitaron una lectura comparativa de los episodios del arte moderno en el panorama sudamericano. Se ha observado de qué manera una obra monocroma da cuenta de sus contextos de ejecución y, a su vez, hace referencia a la historia del arte modernista en tanto búsqueda de quiebre. El monocromo, pieza bisagra entre la apuesta modernista y el preludio de nuevos acontecimientos, revive la pregunta por lo nuevo y sus modos de aparición dentro y fuera del mundo del arte.

Por medio de las revisiones metodológicas y de los casos estudiados, se ha demostrado cómo la utilización de variables relativamente estables para el análisis comparativo de escenas artísticas diferenciales permite ampliar las lecturas efectuadas y ensanchar el horizonte de indagación. Por este motivo, esta investigación se propone continuar en el establecimiento de nuevos "términos relacionales" que permitan otras lecturas sobre las historias nacionales. En este sentido, se prevé considerar aspectos historiográficos como articulaciones

64. Si bien el tema no se ha desarrollado específicamente por la historiografía del arte colombiano, sí existen referencias que dan cuenta de las transformaciones en los patrones de relaciones sociales. Véase por ejemplo: David Ayala Alfonso, "Espacio interior", en Cecilia Porras. Cartagena y yo 1950-1970 (Bogotá: Fundación Gilberto Alzate Avendańo, 2009), 25-29; Lorenzo Morales, "La deshonra de la colina", Arcadia, Bogotá, 23 de junio de 20II, consultado el I8 de agosto de 20I5, www.revistaarcadia.com/periodismo-cultural-revista-arcadia/articulo/la-deshonra-la-colina/25443.

65. Juan Jacobo Bajarlía, Literatura de vanguardia. Del "Ulises" de Joyce a las escuelas poéticas (Buenos Aires: Araujo, 1946), I75; María Amalia García, "Lidy Prati y la instancia diferencial en la unidad del arte concreto", en Yente-Prati, catálogo de la exposición (Buenos Aires: Malba-Museo de Arte Latinoamericano de Buenos Aires, 2009), 87-99. 
comparativas: analizar la escritura de las historias del arte nacionales, estudiar de qué modo se establecen e interpretan "los héroes e hitos artísticos"; por ejemplo, la Semana del 22 en São Paulo, la exposición de Emilio Pettoruti en 1924 en la galería porteña Witcomb, la aparición de la revista Arturo en Buenos Aires, la I Bienal de São Paulo, la llegada de Marta Traba a Bogotá, por citar algunos casos. Me interesa pensar cómo esos hitos consagrados por las historias del arte nacionales enhebran discursos modernizadores que permiten tejer vínculos entre dichos relatos. Un caso interesante es, para continuar con los ejemplos, cómo la irrupción del proceso modernizador del arte paraguayo denominado la Primera Semana de Arte Moderno Paraguayo en I954 evidencia, en el título de la experiencia, la evocación a la semana paulista y la lectura del propio proceso de modernización a partir de la historiografía artística brasileña. ${ }^{66}$

También entiendo que los dispositivos de exhibición y las plataformas editoriales son núcleos clave para la articulación comparativa en Latinoamérica. En este sentido, la dimensión institucional permite establecer ejes comparativos para la inscripción de lo moderno: por ejemplo, me interesa pensar los proyectos de los museos brasileños (Museo de Arte de São Paulo, MAM-SP, MAM-RJ) en relación con la acción del Banco de la República en Colombia (emprendimiento mixto público-privado) y la creación de la Biblioteca Luis Ángel Arango, su sala de exposiciones, el Museo del Oro y diversos espacios museísticos en Colombia. Por su parte, las revistas, como ya lo han demostrado numerosos artículos académicos, articulan modelos y plantean situaciones de semejanza que permiten trazar análisis comparativos: el caso Ver y estimar y Prisma por la vinculación maestro y discípula entre Jorge Romero Brest y Marta Traba, sus directores respectivamente. Durante la década de los cincuenta, la revista Hábitat y Nueva Visión tuvieron un alto grado de proximidad en torno al recorte estético (Bauhaus, concretismo, neoconstructivismo en Estados Unidos) y a la apertura a intereses como la arquitectura y el diseño. Sin embargo, un estudio comparativo de la materialidad de las obras concretistas argentinas y brasileñas bien puede divergir con las proximidades formales y de modelos.

Esta investigación buscó reunir referentes historiográficos en torno al comparativismo para reflexionar sobre la escritura de una historia del arte regional. El objetivo fue, a partir de los textos y debates considerados, volver a situar la

66. Amigo, Guerra, anarquía y goce, 73; García, "Hegemonies and Models of Cultural Modernization in South America", 28-54. 
DOI: http://dx.doi.org/10.22201/iie.18703062e.2016.109.2623

42

MARÍA AMALIA GARCÍA

historia comparada como una instancia de análisis idónea para pensar los procesos del arte moderno en las metrópolis sudamericanas y habilitar así lecturas que excedan las fronteras nacionales en la formulación de problemas. La posibilidad de proponer una lectura compartida entre los fenómenos artísticos latinoamericanos es idea rectora de este estudio. En suma, considero que comparar escenas culturales en Sudamérica permitió ampliar las interpretaciones existentes y ubicar el horizonte de indagación próximo a la escritura de una historia del arte regional. s 


\section{De la caridad religiosa a la beneficencia burguesa: la dádiva social y sus imágenes}

From Religious Charity to Bourgeois Philanthropy: The Social Gift and its Images

Artículo recibido el II de diciembre de 20I5; devuelto para revisión el 2 de marzo de 20I6; aceptado el 27 de abril de 20I6. http://dx.doi.org/IO.2220I/iie.I8703062e.2016.I09.2577

Angélica Velázquez

Guadarrama

Líneas de investigación

Publicaciones más relevantes
Universidad Nacional Autónoma de México-Instituto de Investigaciones Estéticas. angelicavelazquezg@gmail.com

Arte moderno; estudios de género; mujeres artistas del siglo XIX; pintura costumbrista.

"Juliana and Josefa Sanromán. The Representation of Bourgeois Domesticity", Artelogie, núm. 5 (20I3); "La pintura costumbrista mexicana. Notas de modernidad y nacionalismo", en CAIANA. Revista Académica de Investigación en Arte y Cultura Visual, núm. 3 (diciembre, 2013); Primitivo Miranda y la construcción visual del liberalismo (México: Universidad Nacional Autónoma de México-Instituto de Investigaciones Estéticas/Instituto Nacional de Antropología e Historia, 20I2); coautora del Catálogo comentado del acervo del Museo Nacional de Arte. Pintura. Siglo XIX, t. II (México: Museo Nacional de Arte, 2009); coordinadora y coautora de La colección de pintura del Banco Nacional de México. Siglo XIX, 2 vols. (México: Fomento Cultural Banamex, 2004),

Resumen En el contexto de las luchas ideológicas, políticas y militares que libraron liberales y conservadores en México durante el siglo XIX, el texto encadena un conjunto de imágenes religiosas, alegóricas, devocionales y costumbristas con el tema de la caridad producidas en diferentes soportes y para diferentes públicos. A partir de una puntual investigación en la prensa, los archivos y otras fuentes primarias, el artículo da cuenta de las acciones de las Hermanas de la Caridad, de los civiles organizados en Conferencias y, particularmente de las mujeres, para paliar los estragos producidos por la modernidad. El análisis de las obras seleccionadas devela la capacidad simbólica de la cultura visual en el proceso de construcción de una sociedad moderna. 
Palabras clave caridad; mujeres; san Vicente de Paul; Hermanas de la Caridad; Severiano Hernández; José María Medina; José Justo Montiel; Alberto Bribiesca; Manuel Ocaranza; Conferencias masculinas y femeninas de san Vicente de Paul.

Abstract In the context of the ideological, political and military struggles that set Liberals against Conservatives in nineteenth-century Mexico, this text connects a set of religious, allegorical, devotional and genre images related to the subject of charity. These images were produced in different formats and for diverse audiences. Based on research in written media, archives, and other primary sources, the article examines the activities of the Sisters of Charity and lay individuals organized in "Conferences," mainly of women, to alleviate the ravages caused by modernity. The analysis of the selected works reveals the symbolic capacity of visual culture in the process of building a modern society.

Keywords charity; women; St. Vincent de Paul; Sisters of Charity; Severiano Hernández; José María Medina; José Justo Montiel; Alberto Bribiesca; Manuel Ocaranza; male and female lay Conferences of St. Vincent de Paul. 
DOI: http://dx.doi.org/10.22201/iie.18703062e.2016.109.2623

\author{
ANGÉLICA VELÁZQUEZ GUADARRAMA \\ UNIVERSIDAD NACIONAL AUTÓNOMA DE MÉXICO \\ INSTITUTO DE INVESTIGACIONES ESTÉTICAS \\ MÉXICO
}

\title{
De la caridad religiosa a la beneficencia burguesa: la dádiva social y sus imágenes
}

$\mathrm{E}$ n este artículo me propongo analizar un conjunto de imágenes realizadas en el contexto de las pugnas más álgidas entre el Estado y la Iglesia que se dieron en México durante el siglo XIX, en las cuales se representa la práctica social de la caridad. La primera parte se ocupa de una serie de pinturas e impresos en calendarios y revistas ilustradas que revelan el interés que suscitó el establecimiento de las Hermanas de la Caridad y de las Conferencias masculinas de la Sociedad de San Vicente de Paul, estas últimas como una respuesta de los civiles a los problemas de la pobreza y los estragos del capitalismo. En la segunda parte se examina el papel que tuvieron las mujeres en el ejercicio de la caridad, ya fuera como afiliadas a las Conferencias femeninas de la Sociedad de San Vicente de Paul o como laicas activas, y su representación en la pintura, partiendo de la premisa de que ofrecen una visión politizada de la intervención femenina, como agencia moral, en la formación del Estado-nación. En el estudio de las imágenes me interesa destacar las tensiones raciales, sexuales y de clase; así como la secularización paulatina del tema de la caridad y su dimensión política y simbólica, una característica de la cultura visual y literaria en la modernidad. 
DOI: http://dx.doi.org/10.22201/iie.18703062e.2016.109.2623

\title{
Las Hermanas de la Caridad y las Conferencias masculinas de la Sociedad de San Vicente de Paul
}

\author{
Vedlas... que pasan en la noche umbría, \\ y atraviesan las calles silenciosas, \\ como luces fantásticas, dudosas, \\ son la salud, la vida y el consuelo, \\ que implora la doliente humanidad
}

Anselmo de la Portilla, i844

En el Semanario de las Señoritas Mejicanas. Educación cientifica, moral y literaria del bello sexo, impreso en I84I por Vicente García Torres, se publicó un artículo traducido del francés sobre las Hermanas de la Caridad, ${ }^{\mathrm{I}}$ ilustrado con una litografía en la que aparece una de ellas socorriendo a una mujer enferma acompañada de su hija en un escenario que difícilmente podríamos calificar de humilde (fig. I). Así lo muestran el sillón mullido en el que se hallan la enferma y la religiosa, el cuadro que cuelga en la pared y la vestimenta y el acicalado peinado de la niña y la madre. Las publicaciones de este género, dirigidas a las mujeres de las clases media y alta, ofrecían textos de literatura, historia, ciencias naturales, geografía y religión, además de útiles consejos para desempeñar los papeles de buenas madres, esposas e hijas que pretendían instruir y guiar la conducta moral de sus lectoras.

En este sentido, el artículo "Hermanas de la caridad" exaltaba la labor de esta congregación de origen francés, fundada en 1640 por san Vicente de Paul en París, y describía las numerosas tareas filantrópicas que realizaban en diferentes partes del mundo con niños, mujeres, ancianos, enfermos, presos y "dementes", destacando la humildad y la entrega con las que ejercían sus funciones como enfermeras en las dolencias físicas y espirituales y de instructoras comprometidas con la niñez, pese al elevado rango al que generalmente pertenecían. Se trataba de un artículo, como todos los que se dirigían a las mujeres en estas ediciones, que tenía la intención de "cultivar", pero sobre todo de "conmover" la sensibilidad del público femenino, pues para ese momento la congregación de las Hermanas de la Caridad no se había establecido aún en México. Fue

I. "Hermanas de la caridad", Semanario de las Señoritas Mejicanas. Educación científica, moral y literaria del bello sexo, t. 2, I3 de julio de I84I (México: imprenta de Vicente García Torres), 265-272. Puede consultarse en http://liberalism-in-americas.org/927/ 
DOI: http://dx.doi.org/10.22201/iie.18703062e.2016.109.2623

DE LA CARIDAD RELIGIOSA A LA BENEFICENCIA

I. Anónimo, Las Hermanas de

la Caridad, siglo xIx, litografía en el Semanario de las Señoritas

Mejicanas, t. 2, I3 de julio de I84I (México: imprenta de Vicente

García Torres), 266. Hemeroteca

Nacional de México.

Reprografía: Ricardo Alvarado Tapia. Archivo Fotográfico Manuel

Toussaint, IIE-UNAM (en adelante AFMT).

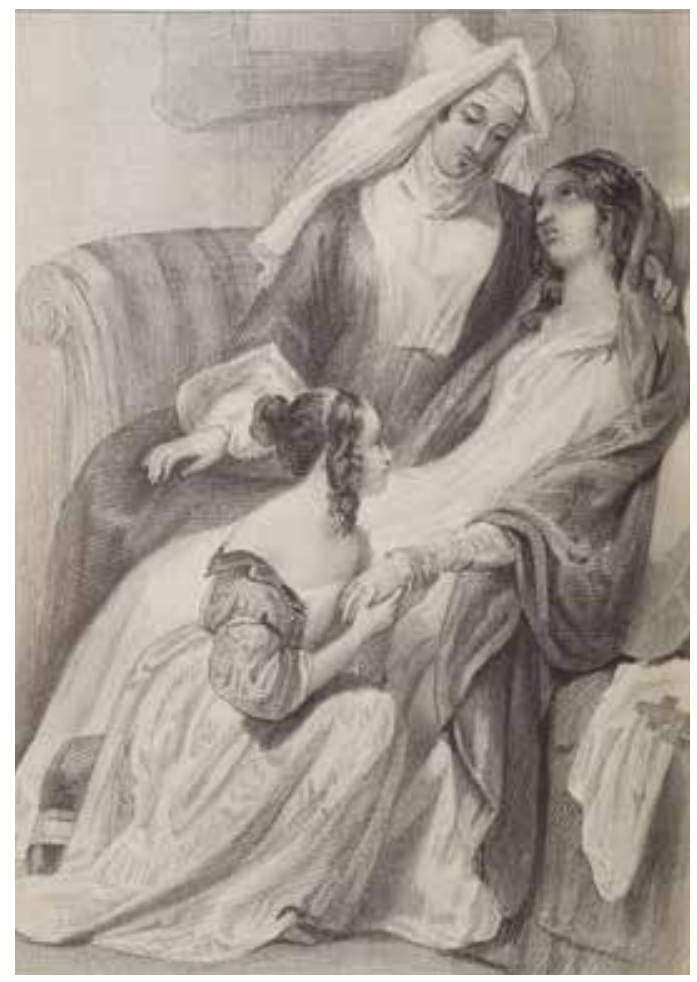

hasta I 842 cuando el médico Manuel Andrade y Pastor y la condesa María Ana Gómez de la Cortina iniciaron los trámites para su instalación en el país. ${ }^{2}$

Entre I833 y I836 Andrade residió en París, a donde se había trasladado para perfecccionar sus estudios en medicina. Ahí, durante sus prácticas en los hospitales, tuvo la ocasión de observar "los benéficos auxilios y los consuelos que prodigaban las hijas de San Vicente de Paul, las Hermanas de la Caridad, a los enfermos [...] con sus tiernos cuidados y sus palabras de dulzura, tranquilizaban y animaban los espíritus de los pacientes, ofreciendo así una curación

2. En I832 Tadeo Ortiz de Ayala había propuesto ya el establecimiento de las Hermanas de la Caridad sin éxito. Véase el apéndice del artículo de Mario González García, "El Colegio de las Bonitas", Boletín de Monumentos Históricos, tercera época, núm. 20 (septiembre-diciembre de 20I0): 66-67. 
moral". ${ }^{3}$ Y ahí también fue testigo de la creación de la primera Conferencia de la Sociedad de San Vicente de Paul formada por un grupo de jóvenes católicos (sólo hombres) preocupados por la creciente secularización del mundo moderno y por el anticlericalismo que había desatado la Revolución francesa. Este grupo de jóvenes piadosos decidió consagrarse a las obras de caridad para fortalecer su fe y, al mismo tiempo, auxiliar a los indigentes que pululaban en la ciudad, víctimas de los estragos de la revolución industrial y del capitalismo. Su método consistía en reunirse para orar y deliberar cuáles serían los hogares de familias necesitadas que visitarían para llevarles socorro material y espiritual. Pronto, a estos grupos se les dio el nombre de Conferencias, mismas que se propagaron bajo el nombre de Conferencias de la Sociedad de San Vicente de Paul en memoria de las obras caritativas de este santo; si bien, las Conferencias se mantuvieron como organizaciones laicas independientes. ${ }^{4}$

Diez años más tarde, ya de vuelta en México, Andrade promovió las gestiones ante el gobierno para que la congregación de las Hermanas de la Caridad se estableciese en el país y, pese a la proverbial lentitud de la administración, el general Vicente Canalizo, entonces presidente de la República, aprobó con presteza el decreto de su asentamiento en todo el territorio nacional el 9 de octubre de I843. Es probable que para ello haya influido el interés particular que en este asunto tenía la condesa De la Cortina, quien, según Bernardo Copca, su biográfo y uno de sus albaceas, después de leer la descripción que Walter Scott hiciera de las Hermanas de la Caridad en un pasaje de El pirata, "como si la hubiese herido un destello del cielo, el ingreso a México de este instituto, fue la idea única que la predominó". S Sin duda, las diligencias de Andrade poco efecto hubieran tenido sin el apoyo decidido de María Ana, quien solventó los gastos que supuso el traslado y el establecimiento en la Ciudad de México de aquellas religiosas. A su iniciativa se sumaron otras señoras de la antigua nobleza colonial como las hermanas Faustina y Julia Fagoaga, sobre todo la última, con quien la

3. Marcos Arroniz, Manual de biografía mejicana o Galería de hombres célebres de Méjico (París: Librería de Rosa Bouret y Ca, 1857), 46.

4. Silvia Arrom, "Filantropía católica y sociedad civil: los voluntarios mexicanos de San Vicente de Paul, I845-1910”, Revista Sociedad y Economía, núm. Io (abril de 2006): 69-97.

5. Bernardo Copca, "María Ana Gómez de la Cortina, condesa de la Cortina", en Antonia Pi-Suñer Llorens y Arturo Soberón, coords., México en el Diccionario Universal de Historia y Geografía, vol. IV: Instituciones civiles y religiosas novohispanas, selección y est. introd. Aurora Flores Olea, Daniel Escorza Rodríguez y Othón Nava Martínez (México: Universidad Nacional Autónoma de México, 2004), 321. 
condesa había colaborado en otras empresas de beneficencia, ${ }^{6}$ y quien sería una de las primeras mexicanas en tomar el hábito de las hermanas vicentinas, junto con Ana Moncada. ${ }^{7}$

El 4 de noviembre de I844 la fragata española Isis arribó al puerto de Veracruz con once Hermanas de la Caridad acompañadas de dos padres vicentinos. ${ }^{8}$ Andrade se reunió con ellas en Puebla para acompañarlas en su trayecto a la Ciudad de México, en donde:

una multitud entusiasta salió a recibirlas hasta el Peñón, y las acompañó por todo el camino y las calles de la capital, hasta que al medio día entraron en el palacio arzobispal, donde fueron recibidas por el Ilmo. Sr. Arzobispo [...] Entraron todos al salón de etiqueta, bajo cuyo dosel estaba colocado un lienzo con S. Vicente de Paul, representado en el pasaje de recoger los nińos de entre los escombros de la miseria. Allí se ordenó la procesión, que luego salió por la puerta del costado del arzobispado, a la iglesia de Santa Teresa la Antigua, donde descubierto el Divinísimo, el prelado [...] entonó el Te Deum, que prosiguieron las monjas carmelitas [...] bendijo el mismo prelado a sus nuevas hijas con el Sacramento [...] y todos regresaron al mismo palacio donde se sirvió un espléndido almuerzo.

A las tres de la tarde fueron conducidas las Hermanas a la casa de la Sra. Cortina, que tanta parte ha tenido en su venida y establecimiento. ${ }^{9}$

Poco le duró, sin embargo, el gusto a la condesa De la Cortina, pues dos años después murió el 6 de enero, vistiendo el hábito de las Hermanas de la Caridad y legando a la congregación la suma nada despreciable de 162000 pesos. ${ }^{10}$ Andrade no tuvo mejor suerte, falleció el 9 de junio de 1848 víctima de una fiebre

6. Véase "Escuela en la cárcel de la Acordada", en El Mosaico Mexicano. Colección de amenidades curiosas e instructivas, t. V (México: Ignacio Cumplido, I84I): 562-563 y las referencias a las obras de beneficencia señaladas por Frances Calderón de la Barca en La vida en México, trad., pról. y notas de Felipe Teixidor (México: Porrúa, 1977), 450, 465-466, 478-486 y 489-490.

7. Francisco Fernández del Castillo, Apuntes para la historia de San Ángel, San Jacinto Tenanitla y sus alrededores. Tradiciones, historias, leyendas, etc. (México: imprenta del Museo Nacional de Arqueología, Historia y Etnología, 1913), I72.

8. El Siglo XIX, 9 de noviembre de $1844,4$.

9. "Hermanas de la caridad", El Siglo XIX, I6 de noviembre de I844, 4.

ıo. Copca, "María Ana Gómez de la Cortina”, 323-324. 
DOI: http://dx.doi.org/10.22201/iie.18703062e.2016.109.2623

tifoidea que contrajo visitando a la "desgraciada familia del general Juan Pérez", como socio de san Vicente de Paul. ${ }^{\text {II }}$

Si antes de su llegada la prensa había despertado en la opinión pública un genuino interés por las Hermanas de la Caridad, luego del aviso de su inminente llegada al país, los diarios empezaron a anunciar la venta de publicaciones que narraban la historia de la congregación, sus reglas y encomiables obras. Por ejemplo, el Sétimo [sic] Calendario de Abraham López, arreglado al meridiano de México, antes publicado en Toluca para el año de 1845 incluía un grabado de hechura popular de una religiosa de esta congregación (fig. 2) y un breve relato dedicado a ellas en el que, con agudeza, el autor comparaba a estas religiosas con las monjas recluidas de por vida, sin ninguna función social, a veces sin vocación y que desde la época colonial y hasta entonces habitaban los conventos mexicanos:

Qué diferencia de nuestras antiguas monjas que pronuncian muchas veces sus votos por compromisos particulares [...] y cuando el tiempo ha descorrido las circunstancias que las obligaron a un acto involuntario ¡qué de arrepentimientos! Qué vida tan triste [...] estos establecimientos no presentan ningún auxilio para los desgraciados, sino tal parece que se calcularon para el bien particular de las que viven en su recinto: las Hermanas de la caridad todas son para el bien de sus semejantes. ${ }^{12}$

La tendencia liberal del texto se manifiesta en la postura negativa sobre la clausura y la nula utilidad social de los conventos (que, por cierto, habían visto mermada considerablemente su población en el siglo XIX) nos lleva a considerar como autor del artículo al mismo Abraham López, pues los calendarios que publicó entre I838 y 1855 se caracterizaron por registrar y comentar desde una perspectiva crítica los sucesos políticos y culturales más destacados del acontecer nacional. ${ }^{13}$ Por otra parte, la cita permite también calibrar la novedad que debió haber producido entre los habitantes de la ciudad la presencia de las Hermanas de la Caridad en las calles, los colegios y los hospitales, habituados a concebir a las monjas sólo en reclusión; así como la de los estatutos de la congregación,

II. La nota necrológica se publicó bajo el anonimato de "un amigo desconsolado", en El Siglo $X I X, \mathrm{r} 6$ de junio de I848, 2.

I2. Sétimo [sic] Calendario de Abraham López, arreglado al meridiano de México, antes publicado en Toluca para el año de I845 (México: imprenta de Vicente García Torres, I845), 57.

I3. Sobre la trayectoria de este impresor y su papel en la historia de la producción de calendarios de la década de I840, véase el artículo de María José Esparza Liberal, "Abraham López, un calendarista singular”, Anales del Instituto de Investigaciones Estéticas XXVI, núm. 84 (primavera de 2004): 5- 52. 

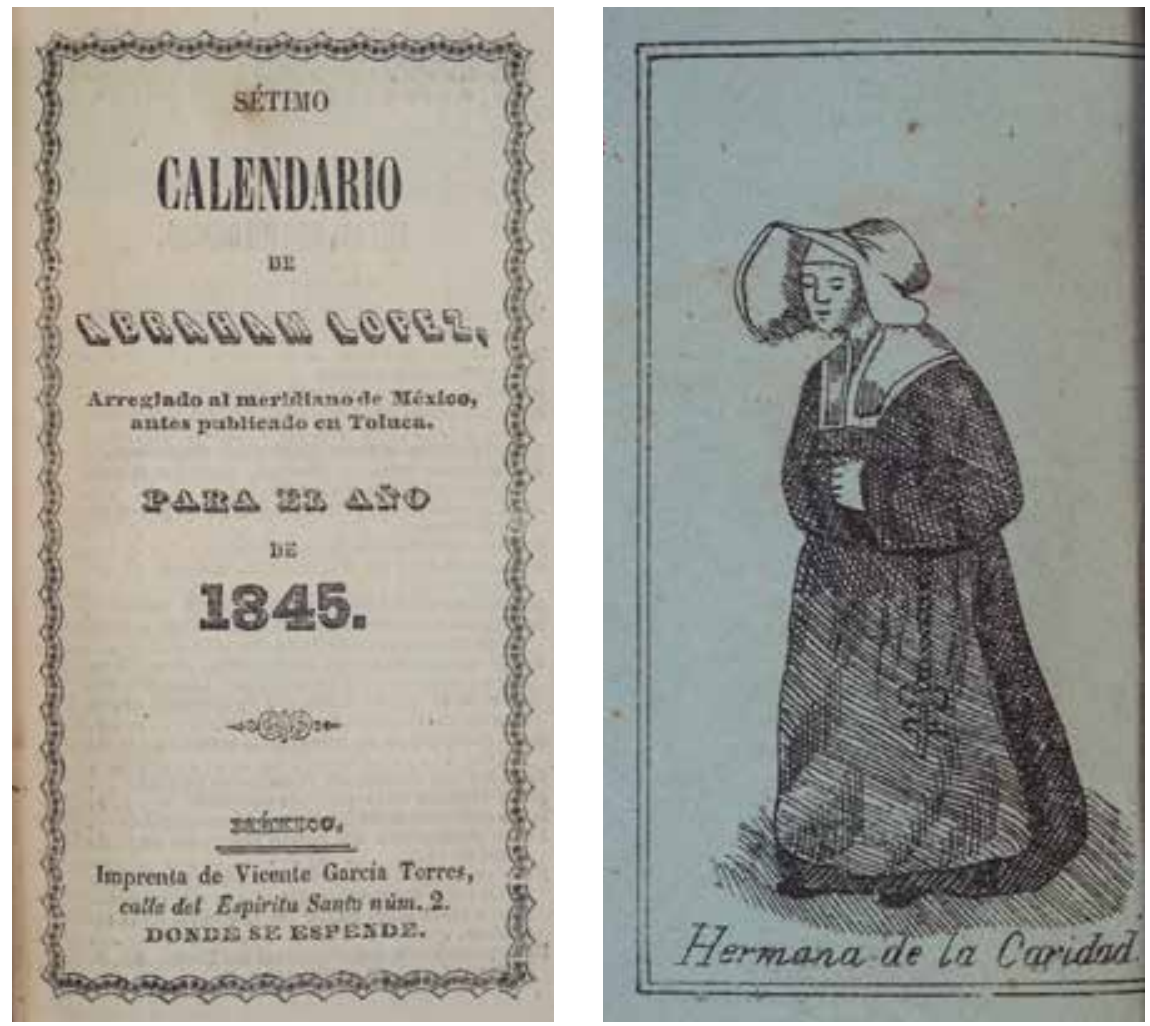

2. Anónimo, Hermana de la Caridad, siglo xIx, grabado, en Sétimo [sic] Calendario de Abraham López, arreglado al meridiano de México, antes publicado en Toluca para el año de 1845 (México: imprenta de Vicente García Torres), portada y s.p. Biblioteca del Instituto de Investigaciones Históricas-Fondo Antonio Alzate, unAm. Reprografía: Ricardo Alvarado Tapia, AFMT.

que les concedían la facultad de renovar o renunciar a los votos cada año; a diferencia de las religiosas de todas las órdenes establecidas hasta entonces en el país que los juraban a perpetuidad.

Apenas instaladas en una casa que De la Cortina les cedió en la calle del Puente del Monzón, las Hermanas de la Caridad iniciaron sus actividades en algunos hospitales de la Ciudad de México y abrieron una escuela gratuita para niñas en la planta baja del domicilio que habitaban, antes de asentarse definitivamente en el colegio de Las Bonitas en $1847 .{ }^{14}$ Las obras que llevaban a cabo en

I4. González García, "El Colegio de las Bonitas”, 56-57. 
DOI: http://dx.doi.org/10.22201/iie.18703062e.2016.109.2623

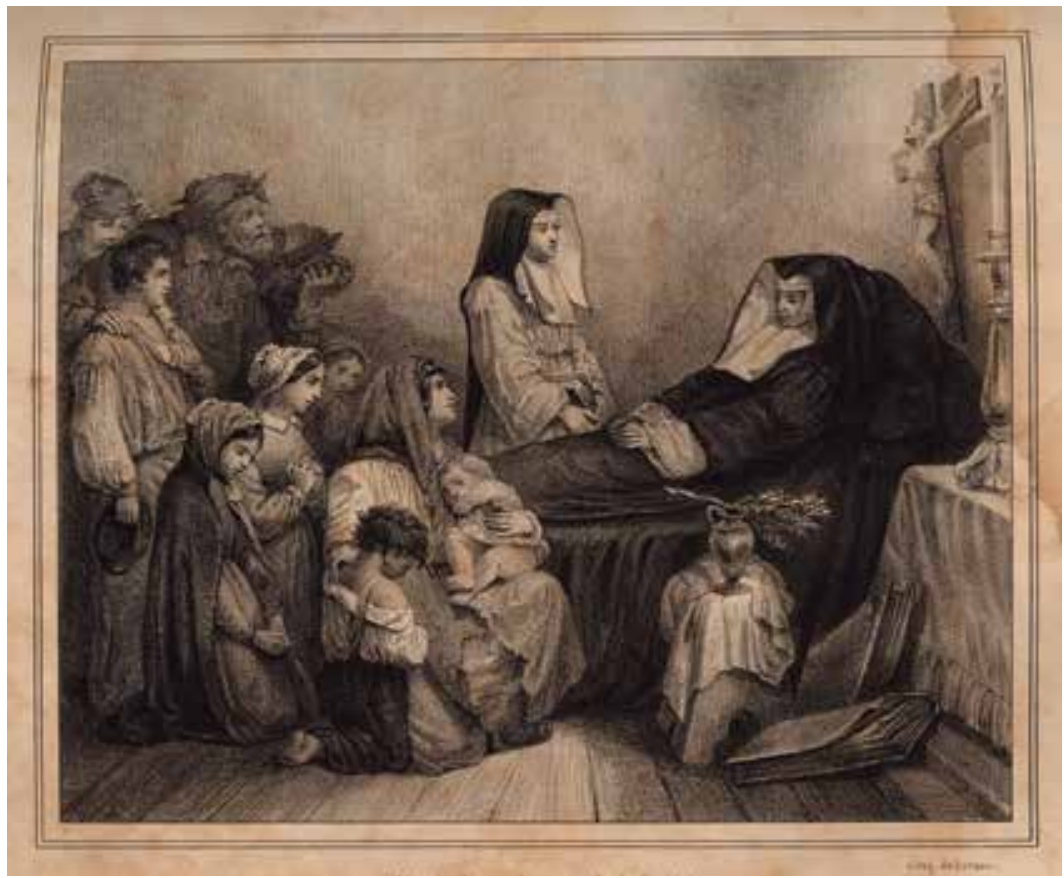

3. Litografía de José Decaen, copia de un cuadro de Isidore Pils, La muerte de una Hermana de la Caridad, en La Ilustración Mexicana (México: imprenta de Ignacio Cumplido, I85I), entre las páginas 256 y 257. Colección de María José Esparza Liberal. Reprografía: Ricardo Alvarado Tapia, AFMT.

los hospitales y su labor como instructoras les ganaron la simpatía de la sociedad y pronto se convirtieron, tanto ellas como san Vicente de Paul, su patrono titular, en tema de litografías y grabados publicados en revistas lujosas. Ejemplo de ello es La Ilustración Mexicana, que reprodujo en I85I (fig. 3) una copia de la conocida pintura La muerte de una Hermana de la Caridad del artista francés Isidore Pils (fig. 4), fechada en I850, en la que un numeroso grupo de indigentes, encabezados por una madre acompañada de sus hijos y por otras dos mujeres de un estrato social diferente, asiste al lecho de muerte de su protectora en una imagen que evoca las solemnes composiciones neoclásicas sobre la muerte de los grandes personajes históricos y religiosos. Así, las hermanas lazaristas y su santo patrono se convirtieron en un tema recurrente en las artes gráficas (tanto 


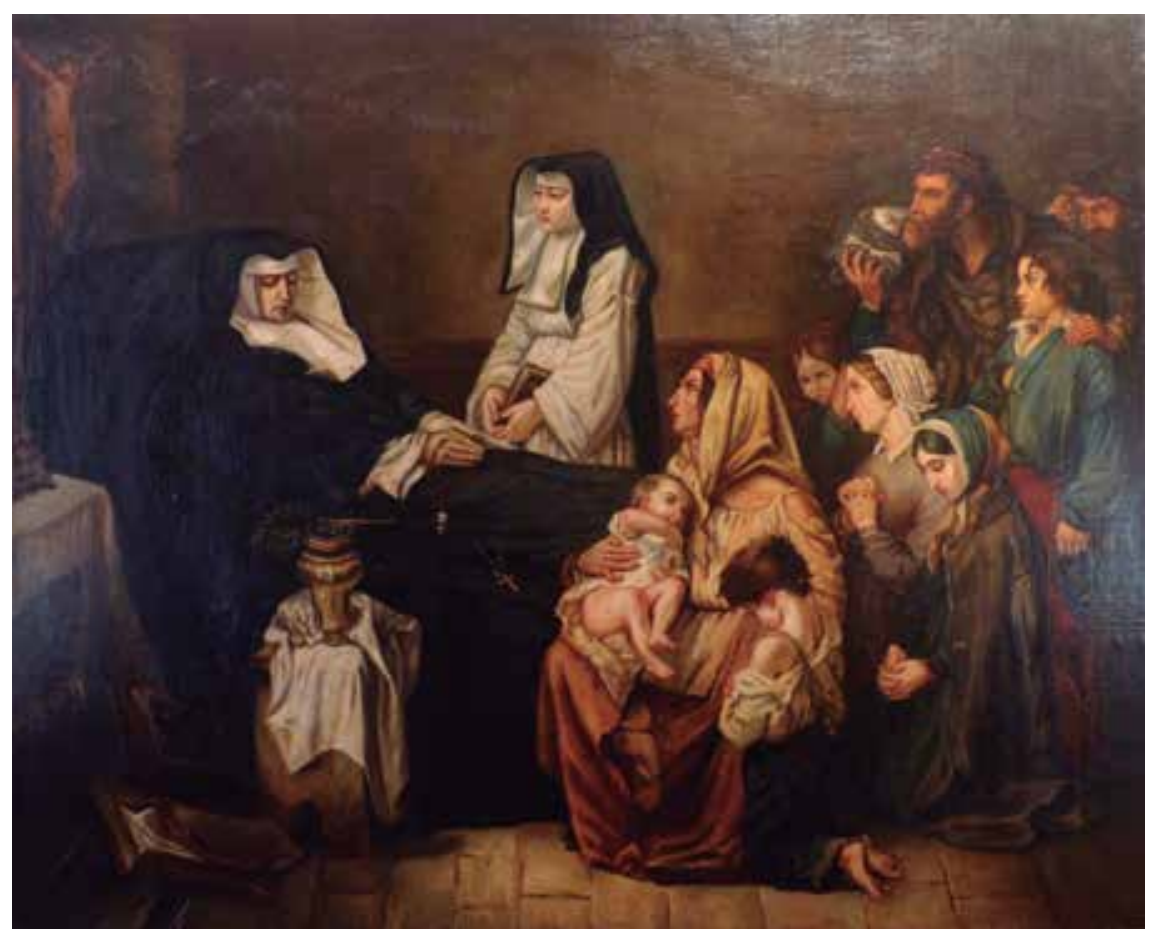

4. Isidore Pils, La muerte de una Hermana de la Caridad, I850, óleo sobre tela, 2.4I ×3.05 m. Museo de los Agustinos, Toulouse, Francia.

en suntuosas revistas como en modestos calendarios que se propagaron con amplitud en todas las clases sociales) y, en menor medida, en la pintura.

Para complementar la obra social que las Hermanas de la Caridad realizarían en México, en I844 Andrade inició también los trámites para que se establecieran en el país las Conferencias masculinas como él las había conocido en París. El is de septiembre de i844 se fundó una primera asociación a la que se nombró Sociedad de San Vicente de Paul y el I5 de septiembre de i845 el Consejo general de París "acordó la agregación de la Asociación de México a la Sociedad de San Vicente de Paul, con el carácter de Conferencia" con la adopción del reglamento francés. ${ }^{15}$ Enseguida se procedió a la votación de los funcionarios, resultando electos, como presidente, el obispo in partibus de Tanagra y arcediano de

I5. Sociedad de San Vicente de Paul. Consejo Superior de México (México: imprenta y litografía de Francisco Díaz de León, I895), i5-16. 
DOI: http://dx.doi.org/10.22201/iie.18703062e.2016.109.2623

la Catedral Metropolitana, Joaquín Fernández Madrid; como vicepresidente, Andrade; y como secretario, Pedro Rojas. El gobierno puso bajo su cuidado el hospital de Mujeres Dementes y el arzobispado les cedió un local para celebrar las sesiones e instalar las oficinas de la sociedad en la iglesia del antiguo hospital del Espíritu Santo. ${ }^{16}$

En el coro del sagrario metropolitano, la parroquia más importante de la Ciudad de México, se encuentra un óleo de generosas dimensiones de formato vertical rematado en arco, firmado por Severiano Hernández y fechado en I849 (fig. 5). ${ }^{17}$ Es muy probable que esta pintura haya sido comisionada por los miembros de la Sociedad de San Vicente de Paul a manera de imagen fundacional y como un tributo a la memoria del infatigable Andrade, fallecido apenas un año antes.

El cuadro se halla en el paso entre la pintura colonial y la pintura de mediados del siglo XIX de temas hagiográficos, anterior al apogeo de la escuela de Pelegrín Clavé, el maestro catalán contratado en 1845 por la Academia de San Carlos para dirigir el ramo de pintura. ${ }^{18}$ Pero lo que resulta novedoso en la imagen de Hernández es la solución iconográfica que combina la alegoría con el género religioso, el costumbrista y el retrato. Es una obra que bien pudo servir de modelo, a su vez, a José Salomé Pina, discípulo de Clavé, para la realización del óleo San Carlos Borromeo repartiendo limosna al pueblo, hoy en el Museo Nacional de Arte de México, con el que ganó la pensión para estudiar en Europa en I853.

Sobre un fondo que simula un palacio francés del gusto clasicista del siglo XVII, con columnas dóricas, friso, triglifos, arcos y una elaborada herrería, se halla la figura de san Vicente de Paul en el centro de la composición, de pie en un cirro, levantando el brazo derecho en señal de protección a la vez que de exhorto y acompañado de dos infantes (tal como lo representa la iconografía que le es peculiar, por la asistencia que le brindaba a la niñez). Su presencia protagónica domina las escenas celestes y terrenas que suceden a su alrededor. A la izquierda asoma la luz del Espíritu Santo en un rompimiento de gloria que

16. Sociedad de San Vicente de Paul, 22-23.

17. Agradezco la sugerencia de Jaime Cuadriello de integrar a mi investigación esta obra, registrada por María Esther Ciancas en su tesis de maestría en Historia del Arte, "La pintura mexicana del siglo xix" (México: Universidad Nacional Autónoma de México-Facultad de Filosofía y Letras, 1959), 89 .

I8. Salvador Moreno, El pintor Pelegrin Clavé (México: Universidad Nacional Autónoma de México-Instituto de Investigaciones Estéticas, 1966), 3I. 
DOI: http://dx.doi.org/10.22201/iie.18703062e.2016.109.2623

DE LA CARIDAD RELIGIOSA A LA BENEFICENCIA

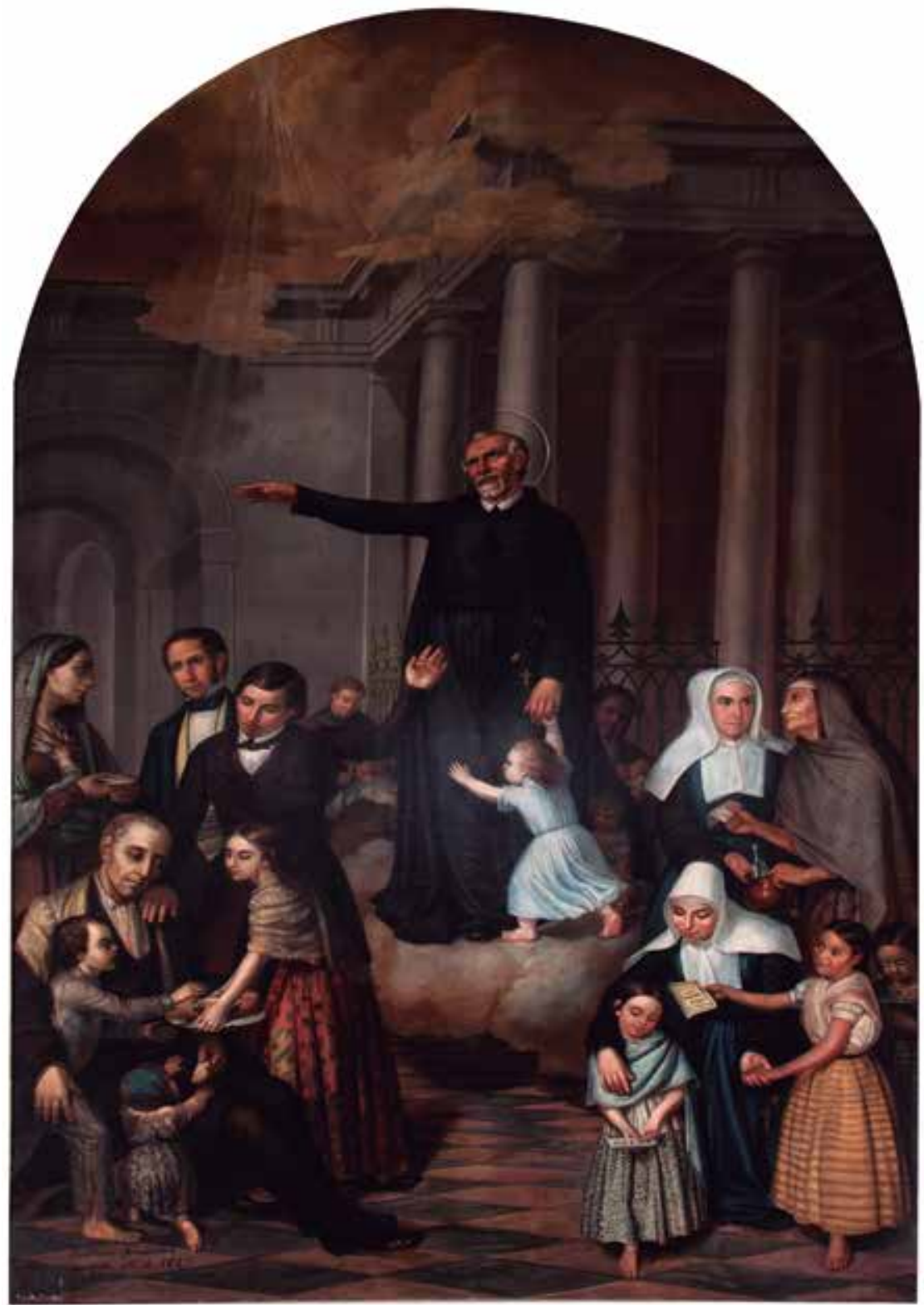

5. Severiano Hernández, La obra de san Vicente de Paul, 1849, óleo sobre tela, $3.56 \times 2 \mathrm{~m}$. Sagrario Metropolitano, Ciudad de México. Foto: Eumelia Hernández Vázquez, Laboratorio de Diagnóstico de Obras de Arte, unAM. 
DOI: http://dx.doi.org/10.22201/iie.18703062e.2016.109.2623

56 ANGÉLICA VELÁZQUEZ GUADARRAMA

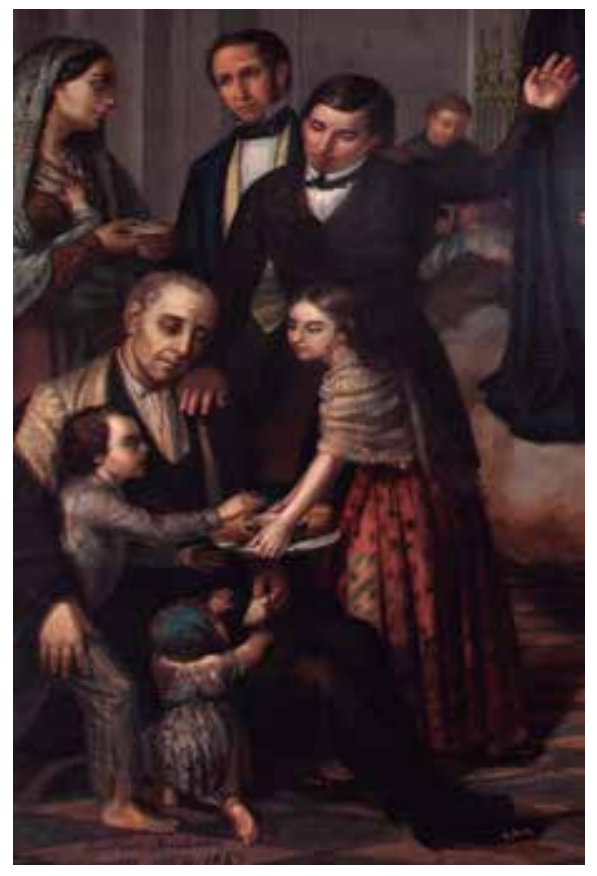

6. Severiano Hernández, detalle de $L a$ obra de san Vicente de Paul. Foto: Eumelia Hernández Vázquez.

"ilumina" las acciones benéficas del santo; detrás de éste se halla un religioso vicentino asistiendo a un moribundo y una mujer con un niño en brazos.

En la parte inferior, el artista distribuyó las tareas de la comunidad lazarista mexicana en dos partes: por un lado, representó en plena actividad a los miembros de la Sociedad de San Vicente de Paul y, por otro, a las Hermanas de la Caridad. En el extremo izquierdo (fig. 6), dos jóvenes vestidos con pulcritud y elegancia auxilian a una numerosa familia menesterosa; uno de ellos socorre a la madre cubierta con un rebozo roto y con un bebé en los brazos a quien le entrega un vale remitido por la conferencia, el parecido de éste con una litografía de Manuel Andrade (fig. 7) lleva a identificarlo como un retrato. En el primer plano, el otro joven (con seguridad también un retrato) ha llevado el alimento a una nińa que, vestida con falda de castor remendada, lo ofrece en una charola a sus hermanos, vestidos con harapos, y a su padre enfermo (con el rostro demacrado y las ropas y los zapatos estropeados en señal de su miseria).

En el extremo derecho (fig. 8), dos Hermanas de la Caridad se ocupan de su misión, la primera en asistir a una anciana que intercambia un vale por un jarro y una botella con una poción medicinal (es probable que se trate, igualmente, 
7. Casimiro Castro, litografía de José Decaen, Manuel Andrade, en La Ilustración Méxicana, t. I (México: imprenta de Ignacio

Cumplido, I851), entre las páginas 4 y 5.

Colección de María José Esparza Liberal. Reprografía: Ricardo Alvarado Tapia, AFMT.

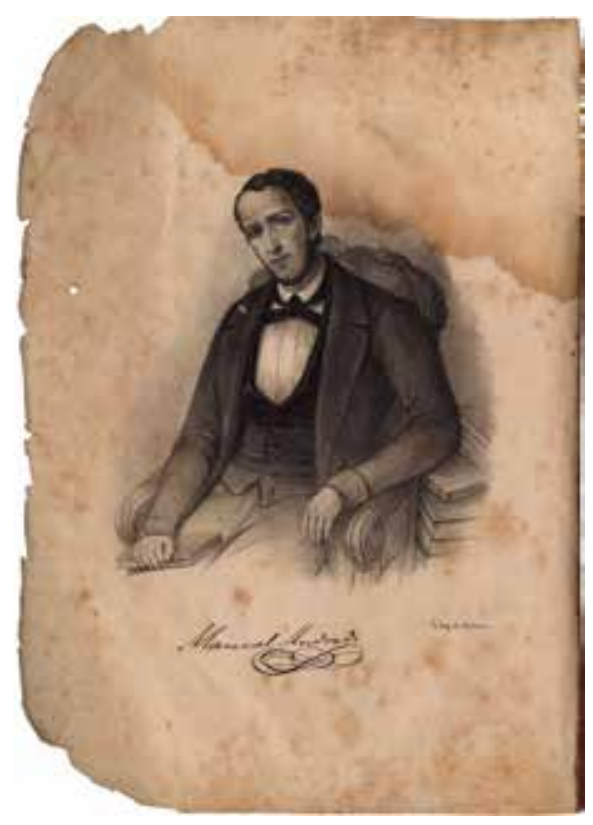

del retrato de la superiora Agustina Inza); y la segunda, en atender a tres niñas indigentes, vestidas de manera humilde, pero digna: una va cubierta por un rebozo y la otra por un tápalo, aunque ambas están descalzas: la primera lleva en la mano un papel con las vocales escritas; la siguiente, un cuadernillo con el título "Libro segundo"; y la tercera baja la mirada para leer un libro. La secuencia del proceso de aprendizaje resulta, pues, evidente.

La pintura de Hernández trata de evocar las labores vicentinas de las siete obras de misericordia corporales y espirituales que recomendaba la Iglesia ${ }^{19}$ y la moderna noción de la incidencia de la identidad católica en el mundo contemporáneo: por una parte, la participación activa de los civiles representada por Andrade y su compañero como miembros de una conferencia; y, por otra, las congregaciones religiosas, representadas por el misionero vicentino que auxilia

19. Las siete obras de misericordia corporales preconizadas por la Iglesia católica son: visitar a los enfermos, dar de comer al hambriento, de beber al sediento, posada al necesitado, vestir al desnudo, visitar a los presos y enterrar a los muertos; y las siete obras de misericordia espirituales consisten en: enseñar al que no sabe, dar buen consejo al que lo necesite, corregir al que se equivoca, perdonar las injurias, consolar al triste, sufrir con paciencia los defectos del prójimo y rogar a Dios por los vivos y difuntos. 


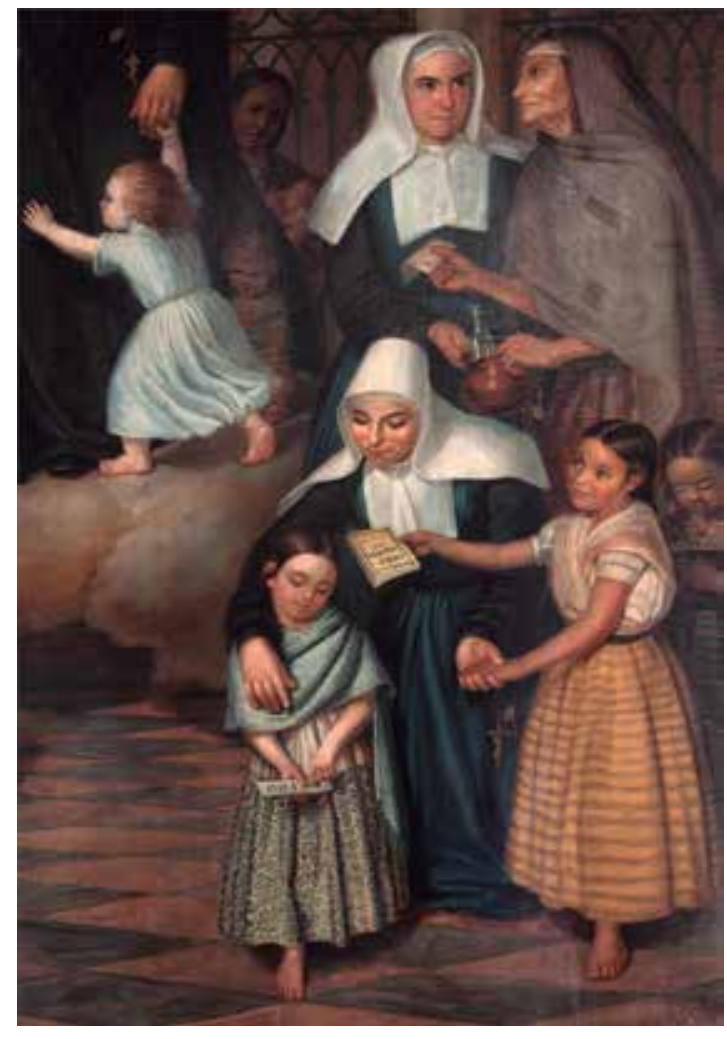

8. Severiano Hernández, detalle de La obra de san Vicente de Paul. Foto: Eumelia Hernández Vázquez.

a un moribundo y por las Hermanas de la Caridad, que aquí figuran en su doble papel de enfermeras e instructoras de la niñez desvalida. En este sentido, las escenas aluden a su trabajo en los hospitales y en las escuelas gratuitas para niñas que, como ya se apuntó, las religiosas abrieron inmediatamente después de su llegada a la Ciudad de México. Entre enero y marzo de 1845, varios periódicos de la capital insertaron el aviso que anunciaba su apertura:

Las hermanas de la caridad se esmeran en dar a sus discípulas una educación cristiana, civil y doméstica; su gran cuidado se dirige a inspirarlas el santo temor y amor a Dios; una tierna afección, respeto y obediencia para con sus padres y superiores; la amabilidad y cortesía para con todos. Las enseñan a leer, escribir, la gramática castellana, la ortografía y la aritmética; en la inteligencia de que la enseñanza religiosa constituye su ocupación principal. Las imponen también en toda clase de labores de manos; 
DOI: http://dx.doi.org/10.22201/iie.18703062e.2016.109.2623

DE LA CARIDAD RELIGIOSA A LA BENEFICENCIA

9. José Juárez, Milagros del beato Salvador de Horta,

siglo XVII, óleo sobre tela, $3.99 \times 3.25 \mathrm{~m}$. Museo

Nacional de Arte-INBA. Reproducción autorizada por el Instituto Nacional de Bellas Artes y Literatura, 2016.

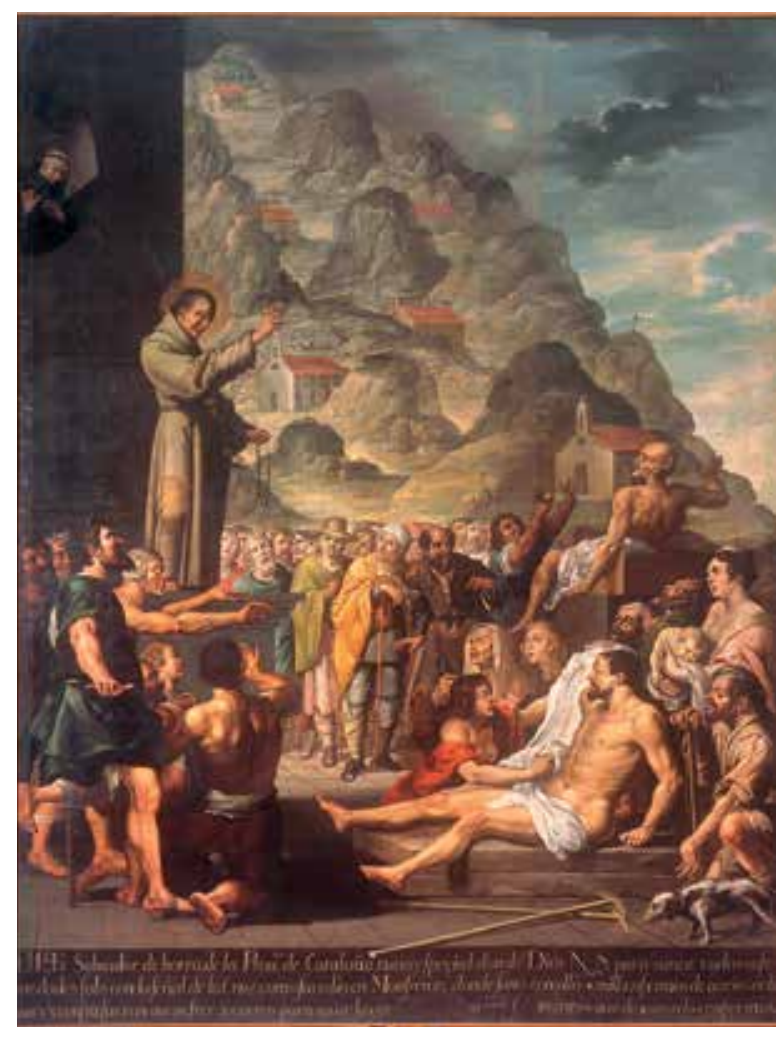

como hacer medias, tirantes, doblones y elásticos; a marcar, coser, etc., bordar en blanco, sedas, algodón, felpillas y en oro; así como lo que respecta a abalorios [...] y algunas otras obras de agrado y utilidad. ${ }^{20}$

Como se ha señalado, la obra de Hernández se ubica en la tradición de la pintura colonial de representaciones hagiográficas, visible en la producción de artistas como José Juárez, como se puede observar en Milagros del beato Salvador de Horta (fig. 9), cuya composición parece derivar del prestigioso modelo de Los milagros de san Francisco Javier de Peter Paul Rubens (fig. IO). ${ }^{2 \mathrm{I}}$ Es muy probable

20. En El Siglo XIX, México, 30 de enero de 1845,4 . El aviso se publicó durante los meses de febrero y marzo.

2I. Nelly Sigaut, José Juárez. Recursos y discursos del arte de pintar, catálogo de la exposición (México: Consejo Nacional para la Cultura y las Artes-Instituto Nacional de Bellas Artes/Museo 


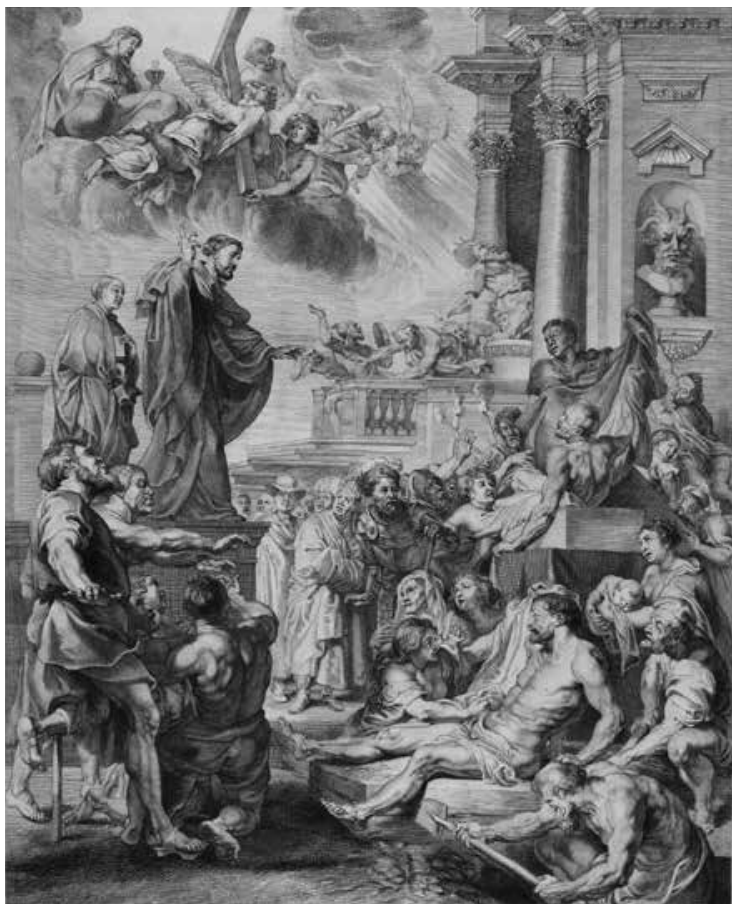

Io. Ignatius Cornelius Marinus a partir de una pintura al óleo de Peter Paul Rubens, Los milagros de san Francsico Javier, ca. 1615I639, grabado, $57.2 \times 44.6$ $\mathrm{cm}$. (C) The Metropolitan Museum of Art-http:// www.metmuseum.org. The Elisha Whittelsey Collection 51.501.7134.

que esta obra en específico le haya servido de inspiración a Hernández (la pintura de Juárez se hallaba en una de las escaleras del convento de San Francisco en la Ciudad de México), ${ }^{22}$ pues es claro que ambas forman parte del mismo modelo barroco que para 1849 resultaba un tanto "arcaizante": la incorporación de diferentes escenas distribuidas en el campo pictórico, el rompimiento de gloria y la manipulación arbitraria del espacio y el orden temporal y narrativo de la representación, son todos ellos rasgos propios de una estética barroca muy lejana de las representaciones hagiográficas del siglo XIX, en concreto de las que, desde la óptica del nazarenismo, el catalán Pelegrín Clavé trabajaría con sus discípulos en la Academia de San Carlos. Y como ejemplo de ello puede compa-

Nacional de Arte/Universidad Nacional Autónoma de México-Instituto de Investigaciones Estéticas/Banco Nacional de México, 2002), 253-259.

22. La pintura se hallaba en el cubo de la escalera que subía a la sala De Profundis, véase Bernardo Couto, Diálogo sobre la historia de la pintura en México, ed., pról. y notas de Manuel Toussaint (México: Fondo de Cultura Económica, 1979), 66. 
DOI: http://dx.doi.org/10.22201/iie.18703062e.2016.109.2623

DE LA CARIDAD RELIGIOSA A LA BENEFICENCIA

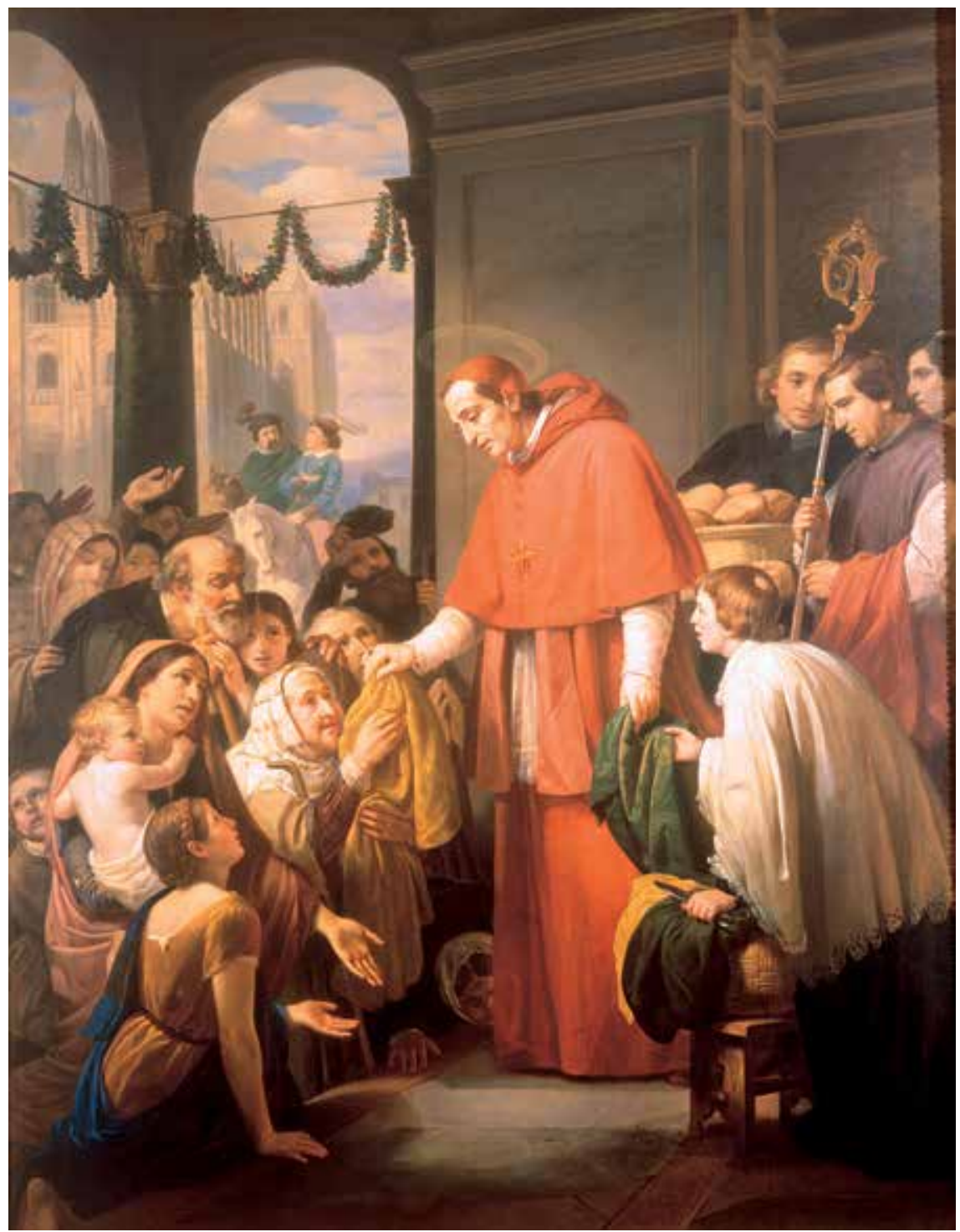

II. José Salomé Pina, San Carlos Borromeo repartiendo limosna al pueblo, I853, óleo sobre tela, $2.83 \times 2.12 \mathrm{~m}$. Museo Nacional de Arte-INBA. Reproducción autorizada por el Instituto Nacional de Bellas Artes y Literatura, 2016. 
rarse la composición de La obra de san Vicente de Paul (fig. 5) con la pintura ya mencionada que trata igualmente el tema de la caridad asociada a las acciones de un santo: San Carlos Borromeo repartiendo limosna al pueblo, de Pina (fig. II), presentada en la VI exposición de la Academia.

La solución compositiva que adoptó Hernández no desmiente su inspiración en la pintura barroca en pleno siglo XIx con todo y que el arreglo iconográfico parezca innovador, e incluso moderno en el ámbito mexicano, al combinar la alegoría con el género religioso, el costumbrista y el retrato, representando a los personajes con trajes contemporáneos y con una clara intención realista tanto en la exposición de la pobreza y el sufrimiento de los protegidos por la misión lazarista como en su labor educativa. Las divergencias con el San Carlos Borromeo de Pina resultan evidentes: el obispo de Milán, a diferencia del santo francés, no se halla sobre las nubes sino bien plantado en la loggia de su palacio, ayudado por su séquito y repartiendo pan y telas a un numeroso grupo de indigentes compuesto por mujeres, ancianos y niños, todos ellos víctimas de la peste. La vista de la catedral de Milán sirve de fondo a la escena, comentada por un par de caballeros que cabalgan en un plano intermedio entre la escena principal y la construcción religiosa. ${ }^{23} \mathrm{Si}$ bien ambas pinturas poseen dimensiones similares, la de Pina se centra, en contraposición a la de Hernández, en un acontecimiento único que monopoliza la atención del espectador y deja fuera toda alusión a lo sobrenatural.

En poco tiempo, la congregación de las Hermanas de la Caridad y las Conferencias se extendieron a diferentes ciudades del país. En Puebla, a donde habían llegado al mismo tiempo que a la Ciudad de México, las Hermanas se hicieron cargo desde el I7 de julio de I846 del antiguo hospital de Niños Expósitos de San Cristóbal, ${ }^{24}$ que funcionaba desde $1703 ;{ }^{25}$ y, más tarde, del colegio de San Vicente de Paul para niñas y señoritas. ${ }^{26}$ En I858 el poblano José María Medina remitió a la XI Exposición de la Academia de San Carlos una pintura bajo el título de Interior del hospital de San Cristóbal, ocupado por los niños expó-

23. Véase el comentario de Fausto Ramírez sobre esta obra, "José Salomé Pina. San Carlos Borromeo repartiendo limosna al pueblo", Catálogo comentado del acervo del Museo Nacional de Arte. Pintura. Siglo XIX, t. II (México: Instituto Nacional de Bellas Artes-Museo Nacional de Arte, 2009), I87-195.

24. Antonio Carrión, Historia de la ciudad de Puebla de los Ángeles (Puebla: Tipografía de las Escuelas Salesianas de Artes y Oficios, 1897), 394.

25. Hugo Leicht, Las calles de Puebla (Puebla: Secretaría de Cultura/Lunarena, 2006), 394.

26. Carrión, Historia de la ciudad de Puebla, 493. 
DOI: http://dx.doi.org/10.22201/iie.18703062e.2016.109.2623

DE LA CARIDAD RELIGIOSA A LA BENEFICENCIA

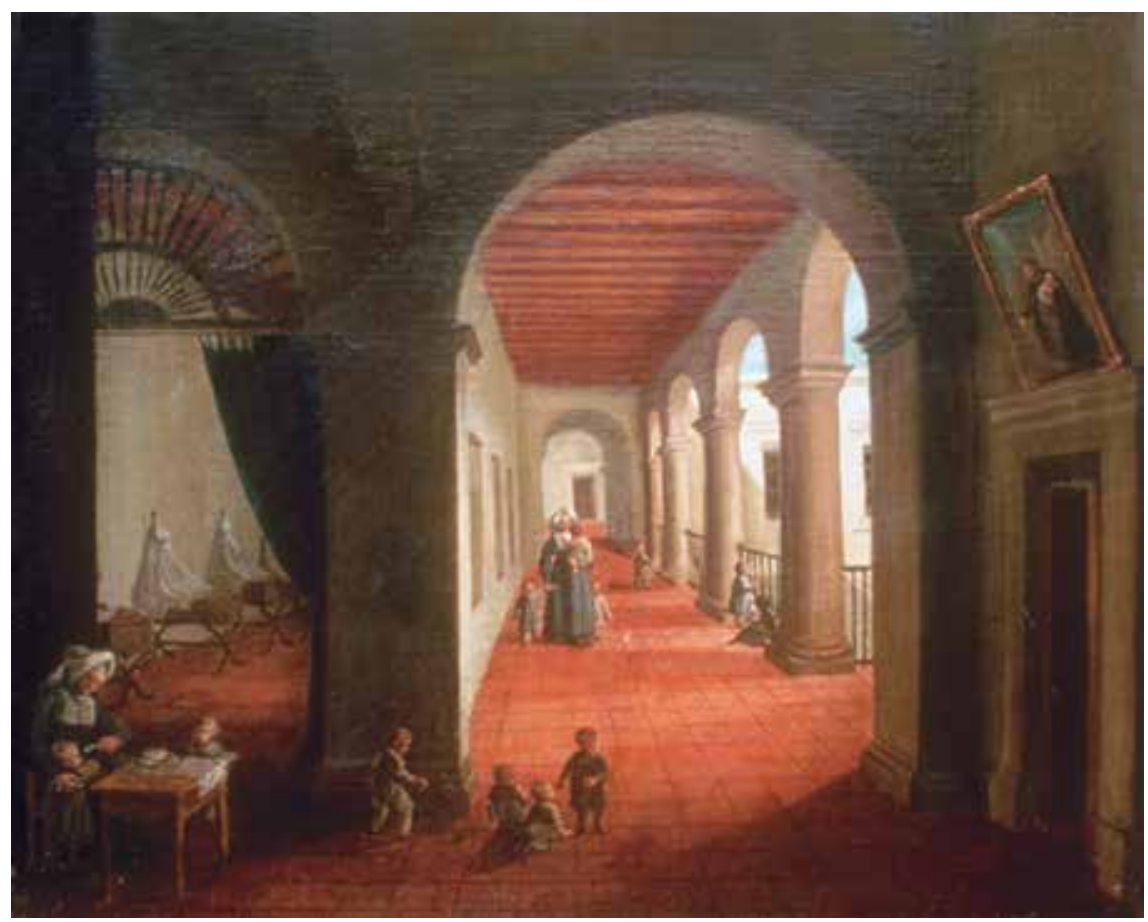

I2. José María Medina, Interior del hospital de San Cristóbal, ocupado por los niños expósitos de Puebla, I858, óleo sobre tela, $53 \times 66.5 \mathrm{~cm}$. Colección particular. Foto: Angélica Velázquez Guadarrama.

sitos de Puebla (fig. I2). ${ }^{27}$ La crítica capitalina fue implacable con la obra de este pintor de provincia que no manifestaba en sus composiciones el dominio de la perspectiva en la representación de los interiores arquitectónicos, una asignatura que desde I855 formaba parte del plan de estudios de la clase de paisaje, bajo el magisterio del italiano Eugenio Landesio en la Academia de San Carlos. El periodista se expresaba en los términos siguientes:

No podemos entrar en un análisis de su ejecución artística, porque se conoce a primera vista que su autor sólo es aficionado y la crítica no tiene lugar en las cosas

27. Manuel Romero de Terreros, ed., Catálogo de las exposiciones de la antigua Academia de San Carlos de México (I850-1898) (México: Universidad Nacional Autónoma de México-Instituto de Investigaciones Estéticas, 1963), 306. 
que se hacen líricamente, mas a juzgar por las cualidades que destella el Sr. Don José Medina en sus cuadritos, creemos que aplicando los preceptos del arte en el género al que se dedica, obtendrá felices resultados, y en el año entrante nos detendremos con gusto delante de otras producciones que nos regale su talento. ${ }^{28}$

Sin duda, la crítica dejaba fuera la originalidad del tema representado: la vista interior del hospital (un género en el que los pintores poblanos habían sido precursores), con la presencia de dos Hermanas de la Caridad al cuidado de una docena de infantes, una sentada a la mesa y ocupada en alimentar a un nińo y otra de pie en el corredor cargando a uno de ellos y llevando de la mano a otro más. A la izquierda se observa el dormitorio con las cunas cubiertas por lienzos blancos y a la derecha, sobre el marco de una puerta, una pintura con la imagen de san Vicente de Paul.

Sin duda, durante la década de I850 la proliferación de las Conferencias y el paulatino crecimiento de la comunidad vicentina en el país ${ }^{29}$ provocó una demanda considerable de imágenes asociadas a la figura de san Vicente de Paul y como muestra de ello se puede citar, además del cuadro anterior, una copia que el veracruzano José Justo Montiel realizó del San Vicente de Paul de Madrazo ${ }^{30}$ y la serie de seis lienzos que representaban la vida de este santo ejecutada por él mismo a solicitud de los padres vicentinos de la ciudad de León, Guanajuato, la cual fue expuesta, también con pésima fortuna crítica, en los salones de la Academia en la IX exposición de $1856 .{ }^{31}$

De las I2 telas que los lazaristas le encargaron, Montiel realizó seis y actualmente sólo se conoce el paradero de dos de ellas, firmadas y fechadas en 1852, las cuales representan a san Vicente y a Ana de Austria presidiendo una asamblea eclesiástica y al mismo santo implorando la misericordia divina en el campo de batalla. Ambas se conservan ahora en el Museo de Arte del Estado de Veracruz

28. Véase "Exposición de Bellas Artes", en La Sociedad, México, 5 de febrero de 1859, 2.

29. Tan sólo para I859 la Sociedad contaba con I5 Conferencias en la Ciudad de México y se habían establecido otras tantas en las ciudades de Puebla, Oaxaca, Toluca, San Miguel Allende, Guanajuato, Guadalajara, León, Cholula, Mellado, Morelia, Zamora, Actopan, Celaya, Irapuato, Amoles, Pátzcuaro y Tulancingo. Véase Sociedad de San Vicente de Paul, 50-52.

30. "Números premiados en la rifa de objetos de bellas artes, verificada en la Academia Nacional de San Carlos, el domingo 27 de enero de 1850 ", El Universal, 29 de enero de $1850,3$.

3I. Fausto Ramírez, José Justo Montiel: vocación y fortuna de un pintor regional (México: Fomento Cultural Banamex/Instituto Veracruzano de la Cultura, 2015), 29 y 33. 
y forman parte de la colección del Gobierno del Estado de Veracruz. ${ }^{32}$ Para la ejecución de las seis pinturas Montiel tomó como modelo los grabados de las II pinturas que los padres de san Lázaro de París habían encomendado a diferentes artistas entre los que se encontraban Jean-François de Troy, Jean Restout, Louis Galloche y Jean-Baptiste Féret y fueron colocadas en 1732 en la capilla del leprosario que ocupaba la congregación en el faubourg Saint Denis en París. En I737, en ocasión de la canonización de san Vicente de Paul, Antoine Herisset grabó las pinturas en cobre a partir de los dibujos de Nicolas Bonnart hijo. ${ }^{33}$ De esta manera, las composiciones se difundieron mediante los grabados que "circularon ampliamente, sobre todo en el siglo XIX" ${ }^{34}$

Para la ejecución de San Vicente implorando la misericordia divina en el campo de batalla o Misiones enviadas por san Vicente de Paul (fig. 13), Montiel trasladó al lienzo el grabado de la pintura realizada por Jean-Baptiste Féret que actualmente se ubica en la iglesia de Santa Margarita en París bajo el título de Saint Vincent de Paul présente à Dieu les Lazaristes. ${ }^{35}$ Como Hernández, Montiel recurrió a la composición de escenas múltiples y sucesivas en el campo pictórico. Según Fausto Ramírez, las pinturas ejecutadas por Montiel para la comunidad vicentina de León, acusan su origen gráfico, no sólo en la disposición general y los pormenores, sino en la incorporación de una larga leyenda al calce explicando la escena. Para este autor, la obra de la que me ocupo presenta defectos de dibujo, una confusión en el tratamiento de los planos espaciales, una disposición abigarrada del cúmulo de figuras y episodios y un cálculo deficiente en la escala de los personajes conforme a su jerarquía y al papel correlativo que desempeñan en la narración. ${ }^{36}$ Entre los episodios representados en la pintura aparecen, en el segundo plano, dos Hermanas de la Caridad socorriendo a un herido en un campo de batalla y, aunque de la misma manera que Pina, Montiel eludió en su pintura a las referencias barrocas celestiales del grabado que le sirvió como modelo tales como el rompimiento de gloria, ubica al santo en el extremo derecho de la pintura, en un campo abierto con los pies en la tierra.

32. María Dolores Páez Cruz, "Un pintor orizabeño y su tiempo: José Justo Montiel (I824-I899)”, tesis de maestría en Historia del Arte (Universidad Nacional Autónoma de México-Facultad de Filosofía y Letras, 2013), 64-70 y I9I y I92.

33. www.culture.gouv.fr/public/mistral/palissy-fr?ACTION=CHERCHER\&FIELD-I=REF\&VALUE_I= PM75002729

34. Ramírez, José Justo Montiel, 32.

35. Véase n. 33.

36. Ramírez, José Justo Montiel, 32-33. 
DOI: http://dx.doi.org/10.22201/iie.18703062e.2016.109.2623

66

ANGÉLICA VELÁZQUEZ GUADARRAMA

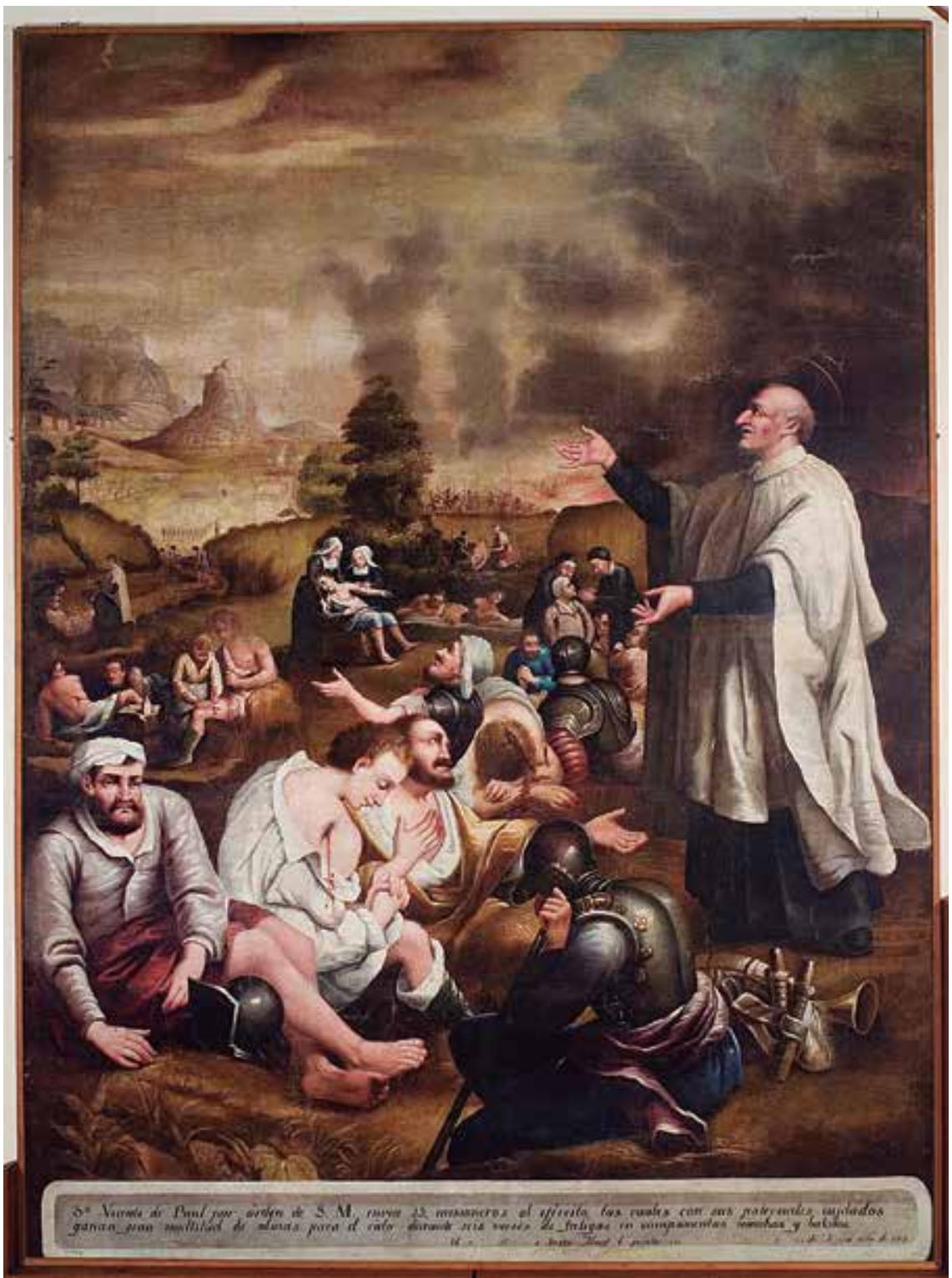

I3. José Justo Montiel (I824-I899), Misiones enviadas por san Vicente de Paul, I852, óleo sobre tela, $4.02 \times 2.97 \mathrm{~m}$. Museo de Arte del Estado de Veracruz. Autorización otorgada por el Instituto Veracruzano de la Cultura, Subdirección de Artes y Patrimonio. 
Pese a las novedades visibles en la pintura de Hernández con sus referencias a un hecho contemporáneo, su obra, como la de Montiel, exhibe su deuda con los modelos barrocos y la pintura religiosa colonial, a diferencia de la de filiación nazareniana de Pina. Y en este sentido resulta pertinente la reflexión que Francisco de la Maza hiciera, a propósito de una exposición sobre José María Estrada, de la revaloración que en la década de 1940 se hizo de los llamados "pintores populares" y de "provincia" (en 1942, luego de la presentación de algunas de sus obras en la Galería de Arte Decoración en la Ciudad de México, José Justo Montiel fue "redescubierto" y revalorado como un pintor "popular"):

No es posible sostener ya la hipótesis de la independencia absoluta de los pintores populares de mediados del siglo pasado respecto de sus predecesores académicos, coloniales y europeos. No es sólo la pretendida intuición espontánea, desierta, desheredada, la que les mueve a pintar, sino también haber visto la pintura colonial en iglesias y conventos, la pintura académica y la pintura europea en grabados y aun en originales. ${ }^{37}$

Con el triunfo del partido liberal en la guerra de tres años en enero de i86r y el ejercicio de la Constitución de I857 y de las Leyes de Reforma, la vida política, social y económica del país se transformó radicalmente. Basados en los principios que emanaban de estos textos, los liberales pretendían llevar a México por la vía de la modernidad con la separación absoluta entre el Estado y la Iglesia, la secularización del espacio público y de la vida cotidiana, el libre comercio y el control del Estado sobre la población en cuanto al registro de nacimientos, matrimonios y defunciones, educación y salud. Como efecto de las nuevas leyes puestas en vigor, todas las órdenes religiosas, masculinas y femeninas se suprimieron y los miembros que las componían, exclaustrados; los grandes conjuntos conventuales de la época colonial fueron derruidos o parcelados, destruyendo así la antigua traza procesional y el aspecto "levítico" que hasta entonces conservaba la mayoría de las ciudades virreinales. Pese a todas estas medidas, que mucho dividieron y escandalizaron a los habitantes de la capital, el gobierno liberal al mando de Benito Juárez decidió exceptuar a las Hermanas de la Caridad de tales disposiciones por la labor filantrópica que desempeñaban, a diferencia del resto de las congregaciones monjiles.

37. “José María Estrada”, El Hijo Pródigo, año II, vol. V, núm. I7 (Is de agosto de 1944): 96. Esta cita se reproduce también en el texto ya citado de Fausto Ramírez sobre José Justo Montiel, i9. 
Sin embargo, los ataques al establecimiento de las Hermanas de la Caridad por parte del ala liberal más radical se habían iniciado al poco tiempo de su llegada. Ya en I846 Andrade tuvo que salir en su defensa con un exaltado artículo para replicar otro publicado por El Monitor Republicano..$^{38}$ Más tarde se vieron en peligro de ser expulsadas, primero en 1858 cuando el vizconde Alexis de Gabriac, ministro francés de asuntos exteriores en México, trató de poner bajo la protección de Napoleón III a las comunidades lazaristas izando la bandera francesa en los establecimientos que ocupaban, con el pretexto de que eran de nacionalidad francesa y, luego, nuevamente en I86I, debido a la desafortunada intervención de Jean-Pierre Dubois de Saligny, sucesor del anterior. Antonio García Cubas refiere que este último hecho se suscitó a raíz de la complicidad de las Hermanas al prestarse a guardar en su casa el tesoro de las concepcionistas cuando habían sido obligadas a salir de su convento, como de hecho sucedió (tal vez por la cercanía del convento de la Concepción con el colegio de Las Bonitas, sede de las Hermanas). Saligny se opuso a la ejecución de la orden judicial y el asunto, que hubiera podido terminar en un conflicto diplomático, acabó en I863 con la salida de los liberales y la instauración de la Regencia y el Segundo Imperio;39 por lo que más tarde Ignacio Manuel Altamirano se referiría despectivamente a las Hermanas de la Caridad como "las vivanderas de Saligny". ${ }^{\circ}$

Una vez derrocado y fusilado Maximiliano de Habsburgo en I867 y con los liberales vueltos al poder, las Hermanas de la Caridad continuaron con su obra social mientras Benito Juárez ocupó la presidencia de la República, pero no sin el recelo de los liberales más acendrados como Altamirano, quien en I87I publicó en El Federalista un editorial sobre la educación, en el que descalificaba la labor de las Hermanas de la Caridad como educadoras de la niñez, e incluso como enfermeras:

Para nosotros, la hermana de la caridad es una infeliz mujer llena de ignorancia y de preocupaciones, manejada por un jesuita ambicioso, y que es absolutamente inútil para la enseñanza [...]

Pero, ¡qué van a enseñar esas pobres mujeres alucinadas e histéricas! Lo que ellas enseñan es una devoción tan inútil como estúpida; lo que ellas enseñan, es la esclavitud mujeril, la abyección, el odio a la libertad que va perpetuando la generación de mujeres sin patriotismo, la indiferencia a la libertad, todas esas doctrinas malsanas,

38. El Monitor Republicano, I de febrero de I846, 3.

39. García Cubas, El libro de mis recuerdos (México: Patria, 1978), 57-64.

40. Ignacio Manuel Altamirano, Obras completas XVIII. Periodismo político, ed., pról. y notas, Carlos Román Celis, t. I (México: Consejo Nacional para la Cultura y las Artes, I989), I35. 
oscuras, innobles, que nacen en el claustro, en las frías naves de la capilla, en los extravíos del misticismo corruptor, en las peligrosas intimidades del confesionario, y en las lecturas banales de los librillos que vienen de la casa central de París.

[...] Acépteselas, si se quiere, en los hospitales; yo, aún allí les disputaría su utilidad [...] sí, aceptémoslas; pero cerrarles las puertas de la escuela republicana, de la escuela del Estado, no sólo es conveniente; es un deber sagrado. ${ }^{4}$

Una despiadada diatriba surgida en el seno de las enardecidas polémicas que caracterizaron al periodo posreformista y que presagiaba las resoluciones que finalmente tomaría el gobierno. En I874, el presidente de la República, Sebastián Lerdo de Tejada, incorporó las Leyes de Reforma a la Constitución de I857 y decretó la expulsión de las Hermanas de la Caridad, bajo el pretexto de que la ley prohibía el establecimiento de órdenes religiosas en el territorio nacional. Una acalorada controversia se desató en la prensa. No sólo los católicos declarados, sino incluso algunos miembros del partido liberal, como Rafael Martínez de la Torre, trataron de echar abajo esta disposición, a la postre sin éxito. Las súplicas de las señoras de la capital y de provincia al jefe de estado para derogar el decreto de destierro también fueron vanas. En enero de 1875, 4IO Hermanas de la Caridad, de las cuales 355 eran mexicanas, abandonaron el país en medio de la consternación pública. No cabía duda de que la salida de las Hermanas de la Caridad y los padres vicentinos era la respuesta del partido liberal a los desafortunados sucesos ya referidos, ocurridos durante la guerra de Reforma y la intervención francesa; aunque en realidad, la voz del liberalismo más extremo se opuso desde siempre a su establecimiento en el país.

El tema de las Hermanas de la Caridad, ya fuese referido a su obra filantrópica, a sus protegidos o a su deportación, formó rápidamente parte del imaginario popular y como muestra de ello pueden citarse numerosos textos literarios, piezas teatrales y novelas en las que las heroínas se refugian en esta congregación ya sea a causa de una relación amorosa malograda o para redimirse. Este último es el caso de Clemencia, la protagonista de la novela del mismo título de Altamirano (1869), ${ }^{42}$ ambientada en Guadalajara durante la intervención francesa. Para expiar su reprobable conducta, Clemencia "la hermosa, la coqueta,

4I. Ignacio Manuel Altamirano, "Bosquejos. El maestro de escuela", El Federalista, 20 de febrero de I87I, recogido en Catalina Sierra Casasús y Jesús Sotelo Inclán, eds. y notas, Obras completas XV. Estudios sobre educación, t. I (México: Consejo Nacional para la Cultura y las Artes, I986), I09-II2.

42. Ignacio Manuel Altamirano, Clemencia, en José Luis Martínez, ed. y pról., Obras completas III. Novelas y cuentos, t. I (México: Secretaría de Educación Pública, I986), I53-3II. 
DOI: http://dx.doi.org/10.22201/iie.18703062e.2016.109.2623

la sultana, la mujer de las grandes pasiones" toma el hábito de las Hermanas de la Caridad que la consagra a consolar "a los que sufren" y luego de residir en la Casa Central, parte a Francia. Rafael Delgado, en su novela Angelina (1893), presenta a la protagonista como miembro de la conferencia de damas vicentinas de un pueblo cercano a Orizaba en el estado de Veracruz. Huérfana y fruto de una relación "que no había recibido la bendición de Dios"; Angelina decide renunciar al amor de Rodolfo para unirse a las Hermanas de la Caridad, no por resentimiento, sino por vocación: "Tampoco creas que si elijo un estado distinto del que prefieren todas las mujeres, que lo hago por despecho o atraída por una falsa vocación. No; considera que si no he querido engañar a un hombre, no he de querer engañarme yo misma, ni engañar a Dios", y al final, sale expulsada del país con la orden de ir a residir a París y luego a la Conchinchina para "servir a los pobres, a los enfermos y a los huérfanos como yo, para quienes el mundo es un desierto". ${ }^{43}$

Un relato positivo y detallado de la obra filantrópica que las Hermanas de la Caridad realizaban en Guadalajara en favor de los huérfanos, los enfermos y los ancianos, así como de su deportación en I875, lo presenta José López Portillo y Rojas en su novela Los precursores (1908). ${ }^{44}$ Prácticamente el locus de la novela es el Hospicio Cabañas, ocupado por las lazaristas y sus favorecidos, en donde se desarrolla una exitosa historia de amor entre dos expósitos criados por ellas y que culmina con las lamentaciones de los hospicianos por la expulsión de las Hermanas:

Una voz íntima y secreta decía a éstos que iban a perder para siempre [...] una gran protección, irreparable y preciosa; que no contarían en adelante con la abnegación heroica de quienes se consagraban a la caridad por amor a Dios y a ellos [...]. Íbanse para no volver sus fieles compañeras, sus amigas carińosas, sus bienhechoras infatigables y santas; y ellos, los desamparados, los llorosos, los pobres de fortuna y espíritu, iban a quedar más tristes, pobres y míseros que nunca [...] No, aquel golpe no iba dirigido contra las hermanas, sino contra ellos; contra ellos, que no disponían de escudo para defenderse $[\ldots]$ contra ellos; que no tenían más que postración y miseria, sufrimiento y lágrimas. ${ }^{45}$

Las novelas señaladas y, en especial, la de López Portillo muestran cómo pese al corto periodo de tan sólo 30 ańos (I844-1874) en que estuvo establecida su

43. Rafael Delgado, Angelina (México: Porrúa, 1985), I22-I23 y 420-425.

44. José López Portillo y Rojas, Los precursores (Guadalajara: Gobierno de Jalisco-Secretaría de Cultura, 20I2).

45. López Portillo y Rojas, Los precursores, 374. 
congregación en México, las Hermanas de la Caridad llegaron a constituirse como un referente de la filantropía católica y del imaginario romántico sobre la caridad. ${ }^{46}$ La partida de las Hermanas no suspendió las labores de las Conferencias masculinas ni tampoco de las femeninas, creadas durante la regencia; conformadas, como ya se ha anotado, por seglares. Pero, después de la incorporación de las Leyes de Reforma a la Constitución, llevaron a cabo sus actividades filantrópicas en paralelo con las políticas de beneficencia del Estado durante la república restaurada y el porfiriato, sin la subvención de éste, como solía ocurrir en otros países.

Tras la salida de las Hermanas de la Caridad, su presencia visual en la prensa ilustrada como en la pintura disminuyó hasta casi desaparecer. En la última exposición de la Escuela Nacional de Bellas Artes, celebrada en I899, el pintor valenciano Joaquín Agrasot exhibió en la sección española el cuadro Las Hermanas de la Caridad (fig. I4), ${ }^{47}$ en el que representó a las religiosas en su papel de enfermeras en el interior de un hospital, como hiciera Medina casi 50 años antes. Por el contrario, su figura en la cultura literaria como un referente romántico del reciente pasado nacional no sólo se mantuvo sino que se incrementó y como ejemplo de ello están no sólo las novelas ya mencionadas, sino una constante alusión a la congregación en la prensa diaria, desde noticias que informaban en I877 que "circulaban varias listas, firmadas ya por miles de personas, pidiendo al gobierno que se permita a las Hermanas de la Caridad que regresen a México", ${ }^{8}$ seguramente en ocasión del cambio de gobierno, hasta una nota que instruía

46. Además de las pinturas señaladas en este artículo con el tema de san Vicente de Paul o con el de las Hermanas de la Caridad, existe un gran número de copias y originales en colecciones públicas y privadas en todo el país; entre las que se pueden mencionar Santa Luisa de Marillac y San Vicente de Paul (catedral de Oaxaca) de Daniel Dávila (Elodia Isabel Rosario Chávez Carretero, "Daniel Dávila Domínguez I843-I924. Medio siglo de creación artística”, tesis de maestría en Historia del Arte [Universidad Nacional Autónoma de México-Facultad de Filosofía y Letras, 20I2], 213 y 295); Una hermana de la caridad (copia), de Bernardino Esqueda; San Vicente de Paul (copia), de Inés Gutiérrez; La redención social, de Jacobo Gálvez; San Vicente de Paul, de Felipe Castro; San Vicente de Paul, de M. Adam (Arturo Camacho Becerra, Catálogo de las exposiciones de la Sociedad Jalisciense de Bellas Artes [Zapopan: El Colegio de Jalisco, 1998], 3I, 47, 52, 76 y 95); y San Vicente de Paul, de García (México: Casa de Subastas Morton, 2015), Io9, n. 765). Nada se sabe de las pinturas que decoraban la iglesia de San Vicente de Paul en el Colegio de Las Bonitas, que ocuparon las Hermanas de la Caridad.

47. Romero de Terreros, Catálogos de las exposiciones, 626.

48. "Las Hermanas de la Caridad", La Colonia Española, 7 de enero de I877, 3. La misma noticia se publicó en otros diarios como El Combate, La Voz de México y El Siglo XIX. Es probable que con el cambio de gobierno, después del triunfo de la Revolución de Tuxtepec que llevó a Porfirio 


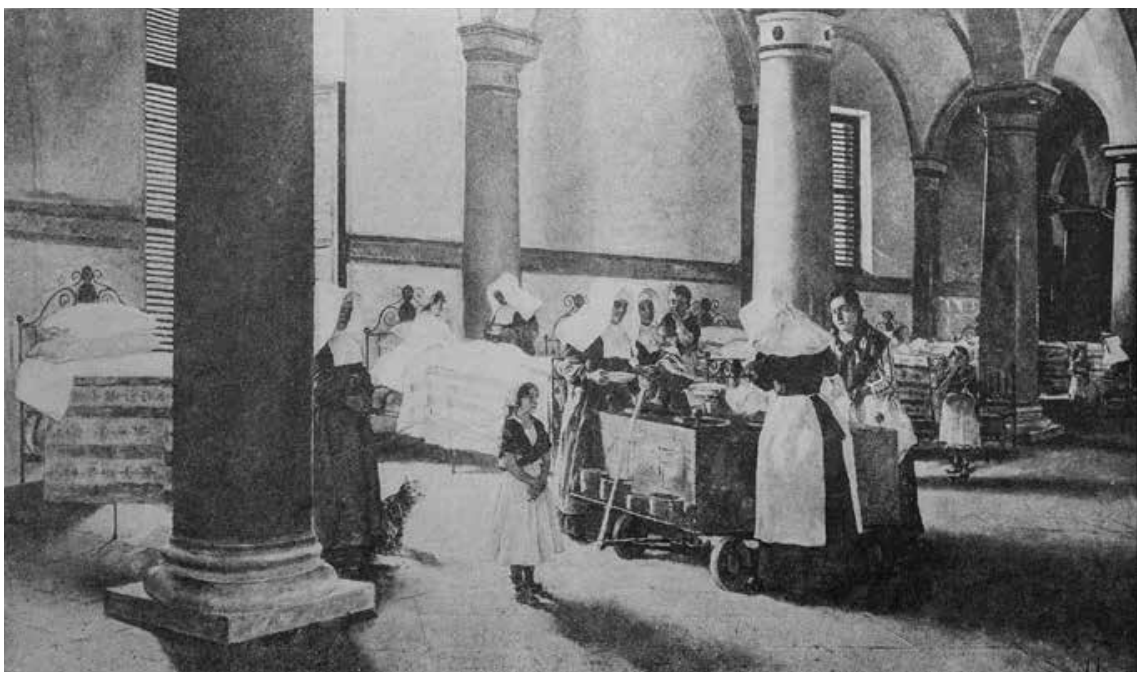

I4. Joaquín Agrasot, Las Hermanas de la Caridad (ubicación actual desconocida), reproducido en El Mundo Ilustrado, Is de abril de i899. Hemeroteca Nacional de México, s.p. Reprografía: Ricardo Alvarado Tapia, AFMT.

a los lectores sobre el origen de la toca de las Hermanas de la Caridad ${ }^{49}$ o las recriminaciones de la prensa católica en las conmemoraciones de la muerte de Sebastián Lerdo de Tejada por haberlas desterrado. ${ }^{50}$

Feminización y secularización de la caridad, su representación visual

La caridad tiene mucho de celestial, y hermana a las mujeres con los ángeles.

Baronesa de Wilson, Biografía de Carmen Romero Rubio, 1902

Desde finales de la época colonial, la caridad había constituido para las mujeres una actividad prestigiosa, auspiciada por la Iglesia y aprobada por la sociedad,

Díaz a ocupar la presidencia de la República por primera vez en I877, los partidarios y partidarias de las Hermanas de la Caridad itentaran su restablecimiento en el país.

49. "Origen de la cofia de las hermanas de la caridad", La Patria, I7 de diciembre de I879, 3.

50. Véase, por ejemplo, el editorial de La Voz de México, 25 de abril de 1889, I. 
que les permitía salir al espacio público para visitar hospitales, hospicios y las viviendas de las clases más necesitadas; en realidad, estas actividades eran consideradas una extensión de sus tareas en el ámbito doméstico. Los problemas sociales que agudizaron el proceso de modernización en el siglo XIX tales como las epidemias, las guerras, las crisis económicas, la industrialización, la pobreza, la prostitución, el alcoholismo, la violencia, la mendicidad y el desvalimiento de la niñez abandonada, intensificaron a su vez la participación en las labores filantrópicas de las mujeres, reunidas en numerosas asociaciones laicas y religiosas.

Como las labores domésticas que realizaban en sus casas, las relativas a la caridad eran igualmente gratuitas, pero altamente prestigiosas. Fue así como las siete obras de misericordia, corporales y espirituales, cuya práctica preconizaba la Iglesia católica y que fueron representadas en grandilocuentes composiciones pictóricas a partir de la Contrarreforma — entre las que pueden citarse las de Caravaggio, Murillo y Rubens, así como los grabados de Abraham Bosse—; transformaron, desde la segunda mitad del siglo XVIII, en meritorias actividades representadas en la pintura costumbrista y celebradas por una élite culta e instruida. Los aristócratas y los burgueses ilustrados, algunas veces identificados y otras anónimos, empezaron así a convertirse en los protagonistas de edificantes escenas de género y sustituyeron gradualmente el repertorio hagiográfico asociado a la caridad. Un caso aparte lo constituirían los estadistas, quienes utilizarían las escenas de beneficencia como una forma de autopromoción.

En México se encuentran numerosas referencias en la literatura y en la prensa como testimonio de las actividades que las mujeres realizaban en este campo, anteriores a la creación de las Conferencias de las Señoras de la Caridad de San Vicente de Paul. Una de las más interesantes, por su elocuencia, es la que hace Frances Erskine Inglis Calderón de la Barca sobre la obra de las señoras mexicanas en la Casa de Cuna cuando fue testigo del pago a las nodrizas contratadas por este establecimiento:

Estos infortunados niños, cuyo linaje procede de la pobreza más abyecta o del delito, les depositan en la puerta del establecimiento, en donde se les recibe sin más averiguaciones; y desde ese momento se les protege y se les cuida por las mejores y más nobles familias del país. La Junta se compone de personas de ambos sexos,

5I. Sobre la representación de las obras de misericordia, véase el libro de Jean Starobinski, Largesse (París: Gallimard, 2007), 80-86. 
pertenecientes a la mejor sociedad de México. Los hombres proporcionan el dinero; las mujeres, tiempo y solicitud.[...]

Cada seńora de la Junta atiende a cierto número de nińos, y hace donación de aquellos vestidos, que, aunque suyos, no han de desentonar con la manera de vestir en el pueblo. [...]

Era un placer contemplar la bondad de las señoras con estas pobres mujeres [las nodrizas]; cómo encomiaban el cuidado que se habían tomado criando a los niños; cómo admiraban la salud y la robustez de algunos, que lo eran en su mayoría; cómo se interesaban en aquellos que se miraban pálidos o menos robustos, y qué aficionadas y orgullosas se mostraban de su carga las nodrizas, tan inmunes a ese tufo alquilón y mercenario de "hospital". ${ }^{2}$

Otra referencia es la nota que publicó en I850 el diario El Universal bajo el título de "Señoras caritativas", durante la epidemia de cólera que azotó la capital:

Hemos sabido que en algunos puntos de la ciudad, unas seńoras recorren todos los días las calles que se han designado para asistir a los enfermos indigentes, llevándoles además de ropa, medicinas y todos los recursos posibles para aliviar su situación. Así es como estas nobles y piadosas damas hacen sentir los dulces efectos de la caridad y de la beneficencia. Su presencia en la casa del pobre, del desvalido que yace en su lecho de dolor y miseria, es la de un ángel que trae consigo el alivio y el consuelo.

Al consignar nosotros en estas pocas líneas hechos tan hermosos de abnegación y poseídos del más dulce enternecimiento y caridad cristiana, ofrecemos a estas señoras tan dignas y virtuosas un humilde tributo de gracias en nombre de la doliente humanidad. ${ }^{53}$

Como se ha visto, durante el siglo XIX el tema de la caridad se representó en su vertiente religiosa $y$, paulatinamente, como virtud laica. $\mathrm{Al}$ igual que otros temas de la pintura, el de la caridad pasó también por un proceso de secularización en el que las imágenes de ésta convivieron en contextos religiosos y civiles; si bien, estas últimas fueron ganando más terreno a partir de i850. Como muestra de ello están las pinturas exhibidas en las exposiciones de la Academia de San Carlos, la mayor parte de las cuales conocemos ahora sólo por su descripción o

52. Frances E.I. Calderón de la Barca, La vida en México, 464-466.

53. "Señoras caritativas", en El Universal, 6 de junio de i850, 4. Agradezco a María José Esparza Liberal el hallazgo y transcripción de esta nota. 
DOI: http://dx.doi.org/10.22201/iie.18703062e.2016.109.2623

DE LA CARIDAD RELIGIOSA A LA BENEFICENCIA

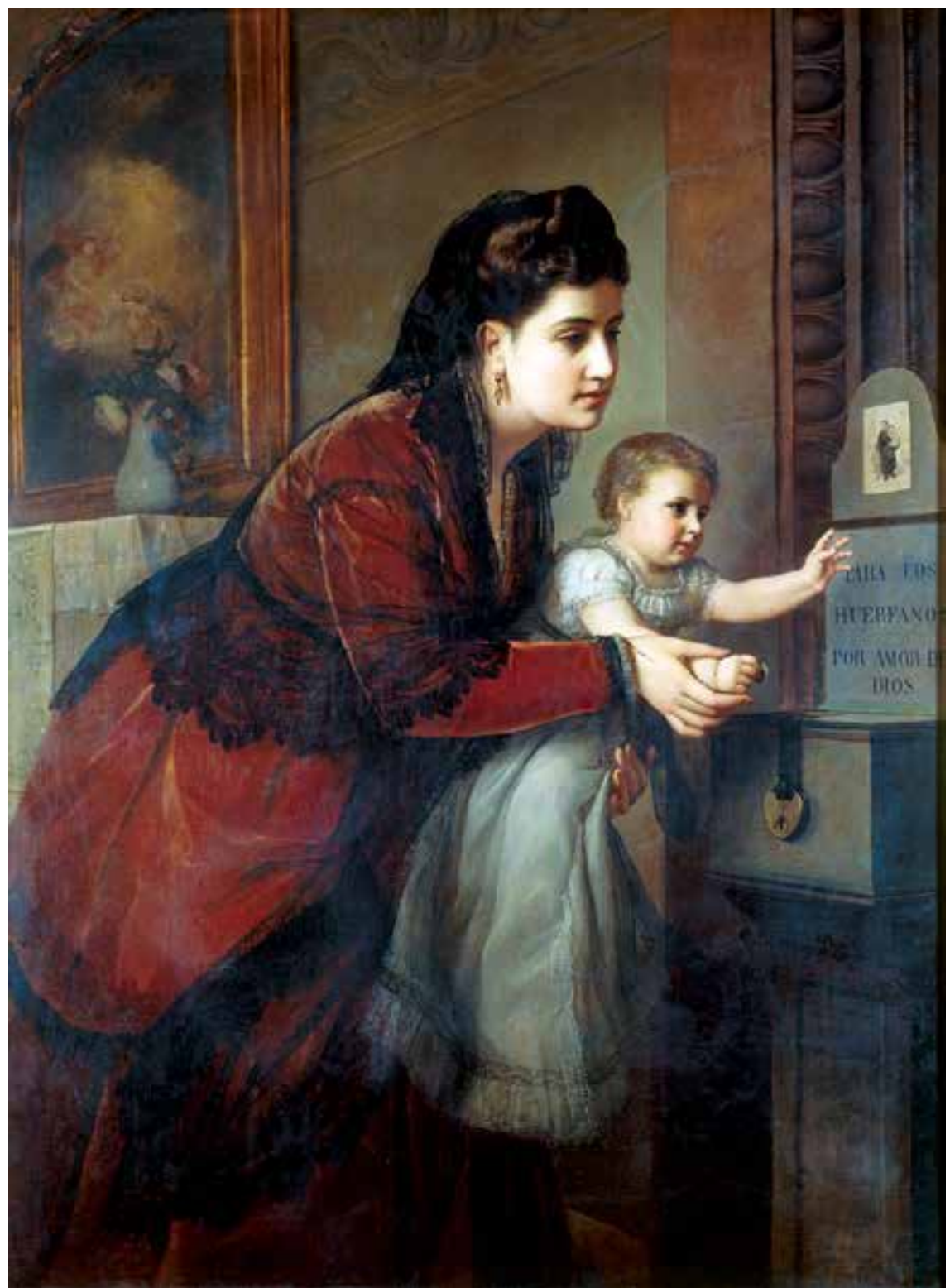

I5. Manuel Ocaranza (atribuido), La caridad, I871, óleo sobre tela, I.40× I.03 m. Museo Nacional de Arte. Foto: Ramiro Valencia. Reproducción autorizada por el Instituto Nacional de Bellas Artes y Literatura, 2016. 
DOI: http://dx.doi.org/10.22201/iie.18703062e.2016.109.2623

por sus títulos, registrados en los catálogos de las exposiciones de I849 a I899, compilados por Manuel Romero de Terreros. ${ }^{54}$

Además de las obras registradas en los catálogos de las exposiciones, la prensa informa también sobre otras pinturas con el tema de la caridad como la que realizó Petronilo Monroy a solicitud del notable editor, impresor y filántropo, Ignacio Cumplido. 55 Hoy, desafortunadamente, con pocas excepciones, la mayoría de estos cuadros se hallan en paraderos desconocidos; en cambio, se conocen otros que no fueron documentados por las fuentes de la época, como La caridad, atribuido a Manuel Ocaranza, y otro con el mismo tema, firmado por José Carbó.

En la actualidad, la pintura de La caridad forma parte del acervo del Museo Nacional de Arte, no está firmada ni fechada, pero ha sido atribuida a Ocaranza (I84I-I882) (fig. I5). Como ya se ha señalado en otros textos, la atribución se basa en un argumento un tanto endeble: el diseño del marco de la ventana en otra obra de Ocaranza (El amor del colibrí, i869) es el mismo que se percibe detrás del cepo de limosnas en La caridad; sin embargo, esta semejanza puede deberse a un modelo común, o bien, a que el autor de esta última lo haya retomado de Ocaranza. ${ }^{56} \mathrm{La}$ ausencia de firma en el cuadro no es un obstáculo para asegurar que lo realizó una mano instruida en los preceptos formales académicos, patentes en el dibujo, la composición y en la acertada gama cromática; pero si, desde sus primeras obras, Ocaranza se caracterizó por firmar sus lienzos

54. Entre éstas pueden citarse las siguientes: Rasgo de beneficencia de María Antonieta, de Édouard Pingret (I850); El buen cura, de Hipólito Bellangé (I852); La caridad, de Lorenzo Aduna (1855); El sueño de un mendigo, de Antonio Orellana (1856); Un viejo que recoge una moneda, copia, de Tiburcio Sánchez (1858); El mendigo (1865), de Antonio Bejarano; La limosna, de José Obregón (I87I); Educación moral. Una madre conduce a su hija a socorrer a un menesteroso de Alberto Bribiesca (I879); La limosna, de Alejandro Casarín (I88I) y Las hermanas de la caridad, de Joaquín Agrasot (I899). A esta lista deben sumarse las tres pinturas realizadas para el concurso bienal de I883 para el que José Salomé Pina —entonces director del ramo de pintura- propuso "representar un acto sublime de caridad", en el que participaron Alberto Bribiesca, con El buen samaritano, Gonzalo Carrasco, con La caridad de san Luis Gonzaga y José María Ibarrarán, con La caridad cristiana. Véase Romero de Terreros, Catálogos de las exposiciones, 83, 132, 225, 252, 308, $389,428,515,626$ y 567 , respectivamente.

55. "La caridad", en La Voz de México, 25 de noviembre de 1870, 3. La misma nota se publicó también en El Siglo XIX en la misma fecha y en Le Trait d'Union, el 27 de noviembre de I870, 3. Lamentablemente, ninguno de los diarios describe o comenta la obra.

56. Angélica Velázquez Guadarrama, "Manuel Ocaranza (atribución), La caridad", en A.V., Catálogo comentado del acervo del Museo Nacional de Arte. Pintura. Siglo XIX, t. II (México: Instituto Nacional de Bellas Artes-Museo Nacional de Arte/Universidad Nacional Autónoma de México-Instituto de Investigaciones Estéticas, 2009), II3-II8. 
¿por qué habría de ser esta obra la excepción? Además, a estas consideraciones, debe añadirse el hecho de que la tela se hallaba en la Caja Infantil de Ahorros de la Secretaría de Educación Pública, de donde se trasladó a las galerías de la Academia de San Carlos en 1942 a solicitud de Juan de Mata Pacheco, ${ }^{57}$ lo cual indicaría su anterior paradero en un hospicio. En cuanto a la fecha de su ejecución, el diseño del vestido con polisón de la protagonista de la obra la ubica en la década de i870, lo mismo que la estampa de san Vicente de Paul, pues fue en estos años cuando a raíz de la expulsión de la comunidad lazarista el tema volvió a despertar el interés en la sociedad mexicana.

La imagen representa el interior de una iglesia en la que una mujer de tez blanca y de cabello castaño, vestida con un lujoso traje de terciopelo carmesí y cubierta con una fina mantilla negra, lleva en brazos a su rubio bebé y le toma la mano para que deposite una moneda en un cepo. Sobre éste se alza un tablero con la leyenda: "PARA LOS HUÉRFANOS POR AMOR DE Dios", rematado con una imagen de san Vicente de Paul. En el extremo superior izquierdo del cuadro se observa una pintura con el tema de la Anunciación. Si bien esta obra ha sido ya estudiada, ${ }^{58}$ me parece que podría ser objeto de una relectura a la luz de la expulsión de la congregación vicentina y, muy particularmente, con relación a las Conferencias de las Señoras de la Caridad de la Sociedad de San Vicente de Paul, fundadas en agosto de I863 durante la regencia, las que rápidamente se extendieron por todo el país llevando a cabo una importante labor filantrópica paralela a la del Estado.

La historia de las asociaciones femeninas de la caridad ha suscitado un interés académico en los últimos años como lo prueban los excelentes artículos de Silvia Arrom "Filantropía católica y sociedad civil: los voluntarios mexicanos de San Vicente de Paul, I845-I9Io", ya citado con relación al establecimiento de las Hermanas de la Caridad y a las Conferencias masculinas, y "Las Señoras de la Caridad: pioneras olvidadas de la asistencia social en México, I863-1910", 59

57. Velázquez, "Manuel Ocaranza (atribución), La caridad", II7.

58. Velázquez, "Manuel Ocaranza (atribución), La caridad", II3-II8, y de la misma autora "La pintura costumbrista mexicana: notas de modernidad y nacionalismo", CAIANA. Revista de Historia del Arte y Cultura Visual del Centro Argentino de Investigadores de Arte, http://caiana.caia.org.ar/ template/caiana.php?pag=articles/article_2.php\&obj=II3\&vol=3 (diciembre de 20I3).

59. Arrom, "Filantropía católica y sociedad civil"; Silvia Arrom, "Las Señoras de la Caridad: pioneras olvidadas de la asistencia social en México, I863-19ıo", Historia Mexicana LVII, núm. 2 (2007): 445-490. 
así como algunas otras investigaciones. ${ }^{60}$ Con todo, no existe aún un estudio que dé cuenta en forma sistemática de la destacada labor que realizaron las mujeres en este rubro, agrupadas tanto en asociaciones civiles como religiosas y a veces actuando por cuenta propia; su actividad ha permanecido al margen de la historiografía sobre la beneficencia. Como bien señala Arrom, aunque las Conferencias femeninas o Sociedades de las Señoras de la Caridad se habían establecido I4 años después que las masculinas, la nueva Sociedad pronto superó a su homóloga varonil con un número mayor de socias, benefactores, conferencias y, sobre todo, con un total superior de asistentes. Para 1894 la Conferencia masculina contaba con I, 536 socios activos, mientras que la femenina en I895, con 9,875, en esta misma fecha la masculina había visitado I,IIo familias cuando la femenina había visitado 70,537; es decir, que "cada señora visitaba un promedio de 7.I familias cada año, en comparación con 7 familias visitadas por cada señor" ${ }^{61}$ La diferencia entre una y otra era que la organización femenina estaba controlada directamente por los padres vicentinos y los párrocos. Y no conformes con cumplir con las tareas básicas que su reglamento les señalaba, fundaron además hospitales, hospicios, escuelas, talleres para artesanos y costureras y cajas de ahorro, con el objeto de aliviar la pobreza mediante un cambio en lo material y lo espiritual.

Una muestra de la eficiencia de las actividades de las Conferencias femeninas en momentos difíciles fue la colecta y venta que organizaron Ángela Andrade de Ortega (probablemente hija del doctor Andrade), Soledad Paredes, Consuelo Fernández, Francisca Obregón de Iberri y Concepción Arnaldo, todas ellas miembros de la Sociedad de Caridad de San Vicente de Paul, exhortando al público de todas las condiciones sociales y de todas las edades a cooperar con dinero o con objetos para aliviar los estragos de la rebelión tuxtepecana en enero de 1877. Para ello redactaron una nota persuasiva que se publicó en varios diarios de la capital:

Las que suscriben, pertenecientes a la sociedad de caridad de San Vicente de Paul, hondamente conmovidas por la espantosa situación que guardan las familias de

6o. Me refiero a los trabajos de Laura Catalina Díaz-Robles, "Medicina, religión y pobreza, las señoras de la caridad de san Vicente de Paul, enfermeras religiosas en Jalisco (I864-I9I3)", tesis doctoral (El Colegio de Michoacán), 20I0 y a su artículo "Señores y Señoras de las Conferencias de San Vicente de Paul, educadores católicos e informales ¿por tanto invisibles”, Revista de Educación y Desarrollo, núm. 20 (enero-marzo de 20I2): 69-76.

6I. Arrom, "Filantropía católica y sociedad civil", 82. 
la clase más pobre de la sociedad, las que, acosadas cada día más por la epidemia, aniquiladas por el hambre, sumergidas en la orfandad por la guerra, corren locas por conseguir trabajo de cualquiera clase que sea, no encontrando ninguno; ocurren al triste recurso de pedir limosna y se les niega también; acuden esas madres desvalidas, esos padres desventurados, a nosotras, pues saben somos socias de la caridad, pero ¡ay! también los recursos de nuestra sociedad se han agotado y sólo lágrimas les podemos dar. Hondamente conmovidas, decidimos, al palpar tan alarmante situación, creemos llegado el momento de hacer una invitación universal, así a nacionales como extranjeros, a todas las clases, a todos los partidos, a que cooperen con nosotras a aliviar de algún modo tan desesperada situación, siquiera mientras el tifo y la guerra dejan algún reposo a las infelices familias. Para conseguirlo sin grandes sacrificios, hemos concebido el siguiente proyecto [...] Cada persona se dignará cooperar con la cantidad que pueda por pequeña que sea, más si no puede con dinero, que dé algún objeto de gusto o utilidad: las seńoras un juguete de sus tocadores, una obra curiosa de sus manos; el comerciante alguna pieza de género, sencillas, objetos de mercería; el artesano, los sirvientes, los niños, un centavo aunque sea, y así todos los demás [...].

Imploramos, pues, de todos los corazones dignos, cooperen con nosotras a un fin tan loable. Uníos todos a nuestra idea, hacedla vuestra [...] Un obsequio para los que mueren de hambre y de dolores, es todo lo que imploramos de vosotros: ¿nos lo negaréis? ${ }^{62}$

El Reglamento de la Asociación de las Señoras de la Caridad, publicado en I863, estipulaba que quienes desearan ser aceptadas como miembros deberían "estar lejos de las ociosidades y de las vanidades mujeriles; de la ira, del enojo, de las imprecaciones y de las palabras obscenas que tan comunes suelen ser hoy, aun a su sexo". El segundo capítulo señalaba que "las señoras usarán de toda la caridad posible, particularmente para con los pobres enfermos, les socorrerán no sólo con las limosnas de la Asociación, sino también con prestarles cualquiera otro servicio, como sería barrer el cuarto, hacer la cama y cosas semejantes; y sobre todo, manifestándoles la más viva compasión y consolándolos" .63 La asociación debía contar con un presidente, que tenía que ser un párroco, una presidenta, una vicepresidenta y una tesorera, todos ellos elegidos por votación; un se-

62. "Invitación”, El Siglo XIX, $\mathrm{I}^{\circ}$ de enero de 1877, 4.

63. Reglamento de la Asociación de las Señoras de la Caridad instituida por san Vicente de Paul en beneficio de los pobres enfermos, y establecida en varios lugares por los padres de la Congregación de la Misión con licencia de los ordinarios (México: imprenta de Andrade y Escalante, I863), 6. 
cretario, un procurador y socias activas y honorarias. La presidenta debía mantener y aun fomentar la incorporación de nuevas socias, custodiar la ropa blanca y "tener en la capilla de San Vicente o en la iglesia sede una caja fuertemente asegurada en la pared, cerrada con dos llaves de las que ella tendrá una, y la otra el señor cura [...] Sobre dicha caja se escribiría: LIMOSNAS PARA LA ASOCIACIÓN DE LA CARIDAD, O PARA LOS POBRES ENFERMOS".

Desde esta perspectiva, es muy probable que la pintura atribuida a Ocaranza esté vinculada a las sociedades de las Señoras de la Caridad. No sólo por la inclusión de la caja rematada con la imagen de san Vicente de Paul, antes mencionada, y el interior religioso que era el lugar de operaciones de las Conferencias femeninas; sino también por el origen étnico y el ostentoso atuendo de la mujer, pues en sus inicios, como lo señalaba el reglamento de fundación, éstas debían componerse "de las señoras principales de los lugares en que se establece". Si bien en las décadas siguientes, y particularmente en provincia, las Conferencias estuvieron también integradas por personas de la clase media, e incluso por mujeres provenientes de familias de artesanos o costureras. Así, aunque la imagen remite a un espacio religioso que exhibe, no por azar, una imagen mariana y otra del santo lazarista, el tema se centra en la acción de la caridad realizada por las mujeres católicas en su papel de madres, depositarias y transmisoras para las nuevas generaciones de los valores morales y religiosos.

Como bien apunta Arrom:

Las Señoras de la Caridad lograron construir una vibrante organización nacional. Se hicieron aliadas indispensables de la Iglesia en su proyecto de reforma social. Aliviaron la miseria de cientos de miles de mexicanos. Ayudaron a resolver — aunque de modo parcial — los problemas de la pobreza, el hambre, la enfermedad, el analfabetismo y el desempleo [...] La eficacia de sus esfuerzos mostró la capacidad de la mujer y reforzó la ideología del marianismo que a finales del siglo xix la romantizaba como moralmente superior al hombre. ${ }^{64}$

Así, sin conocer el nombre del autor de la pintura ni el del comitente, La caridad demanda una lectura vinculada a la obra de las Señoras de la Caridad que revela, en este caso, el papel que la Iglesia otorgó a la mujer como el catalizador moral y benefactor de la sociedad. 
Las tareas capitales de las Conferencias consistían en las visitas a las casas de los indigentes y los enfermos para llevarles alimento y medicinas, la asistencia a los moribundos y a los muertos y la instrucción de la nińez; en cambio, "la limosna" otorgada a los mendigos en las calles se desaprobaba, pues se creía que fomentaba la holgazanería y perjudicaba el camino a una vida dignificada por medio del trabajo.

Pero no sólo para los católicos asociados a las Conferencias, sino también para el Estado, la mendicidad era uno de los grandes problemas sociales del mundo moderno. La posición de Justo Sierra en 1875, periodo de la realización de las obras de Ocaranza y Carbó, parece pertinente:

Turgot ha dicho: "Aliviar los sufrimientos de los hombres desgraciados es el deber de todos y la obra de todos." Este bello principio, de donde puede deducirse la fórmula de la caridad social, tiene, entre otras, esta rigurosa consecuencia: los desgraciados tienen el derecho no sólo al auxilio directo de sus semejantes, sino a que la sociedad separe de ellos a los que no siendo desgraciados sino en apariencia, disminuyen la parte que toca al verdadero infeliz. Además de ésta hay otras consideraciones que ha tenido presentes la sociedad moderna en tan grave materia: el mendigo dańa la libertad general, el mendigo es por regla general un individuo inmoral y desmoralizador, empieza por matar en su conciencia toda noción de pudor, su lema es la resistencia al trabajo [...] La indigencia es santa, pero la mendicidad es criminal. ${ }^{65}$

Resulta interesante comparar la postura de Sierra — basada en una frase de Jacques-Robert Turgot, uno de los reformistas económicos más ilustres del siglo XVIII y colaborador de la Enciclopedia-, que, aunque temprana en su carrera política, se encuentra vinculada a la postura "oficial" y a la afinidad con el pensamiento y acción de las sociedades vicentinas que, superando la antigua noción de caridad como limosna, concebían la ayuda al prójimo necesitado como parte de una acción global o integral, que iba desde la educación y la asistencia espiritual hasta la atención a sus necesidades materiales más inmediatas, de la cuna a la tumba. Y en esta acción, la sociedad civil, fiel a sus convicciones religiosas, ejercía una acción filantrópica en el seno mismo de la población más vulnerable. La práctica religiosa dejaba de ser así un acto ritual y personal para con-

65. Justo Sierra, "La mendicidad en México", El Federalista, 6 de abril de I875, recogido en Agustín Yánez, ed. ordenada y anotada, Obras completas IV. Periodismo político (México: Universidad Nacional Autónoma de México-Coordinación de Humanidades, 1984), 306. 
vertirse en un apostolado social como manifestación de la verdadera caridad, tal como llegó a entenderse este término como sinónimo de amor a Dios mediante la ayuda a "los miserables". No por acaso los miembros de las Conferencias se veían a sí mismos como "reformadores sociales". Las aportaciones de estas sociedades habían sido ignoradas por la historiografía oficial hasta entonces por diferentes motivos. No cabe duda, sin embargo, que su labor fue fundamental, principalmente la de las mujeres, en un momento en que el Estado carecía de la estructura y las posibilidades materiales para dotar con suficiencia las instituciones educativas y de salud de las que la Iglesia se había ocupado desde el siglo XVI y que el Estado no pudo atender cabalmente en el turbulento siglo XIX hasta su consolidación política y económica en las postrimerías del porfiriato y después de la institucionalización de la Revolución de igro.

En la pintura de José Carbó (fig. I6) es justo una escena de "limosna" el tema de la obra. Este artista cubano había llegado a nuestro país procedente de Filadelfia en 1876 , muy probablemente alentado por su compatriota José Martí, quien se encontraba en la Ciudad de México y le dio la bienvenida en una nota periodística, informando al público sobre su relación con Pina en Roma. ${ }^{66} \mathrm{Al}$ parecer, sus intereses se dirigieron a los tipos y a las escenas de costumbres como lo anunciaba Martí y como lo muestran las obras con las que participó en las exposiciones de la Escuela Nacional de Bellas Artes: Una indita tomando agua bendita en Santiago Tlatelolco (1877) y ¿Qué dirá mamá? (188I). ${ }^{67}$

La pintura de Carbó representa el cubo de la escalera de un patio de vecindad en el que una mujer blanca, vestida de azul, con una capa corta y la cabeza cubierta, todos ellos signos que revelan su clase social, detiene su paso y se inclina para entregar una moneda a un músico callejero de piel morena y evidentes rasgos indígenas que va cubierto con un sarape roto, un sombrero viejo y calza huaraches. Dos mujeres de condición humilde son testigos de la escena, una de pie llevando un cántaro sobre la cabeza y otra sentada amamantando a su pequeño bebé. Otros dos personajes completan la escena; en el primer plano, un perro echado sobre el piso rascándose el cuello y, detrás de la caritativa mujer una niña vestida de blanco con un cinto rosa y una muñeca en la mano. Podría pensarse que la mujer vestida de azul ha visitado esta vecindad acompañada

66. José Martí, "El pintor Carbó", en Ida Rodríguez Prampolini, La crítica de arte en México en el siglo XIX, t. II (México: Universidad Nacional Autónoma de México-Instituto de Investigaciones Estéticas, 1997), 405-406.

67. Romero de Terreros, Catálogos de las exposiciones, 484 y 53 I. 
DOI: http://dx.doi.org/10.22201/iie.18703062e.2016.109.2623

DE LA CARIDAD RELIGIOSA A LA BENEFICENCIA

I6. José Carbó, La caridad, ca. I877, óleo sobre tela (ubicación actual desconocida). Foto: Angélica

Velázquez Guadarrama.

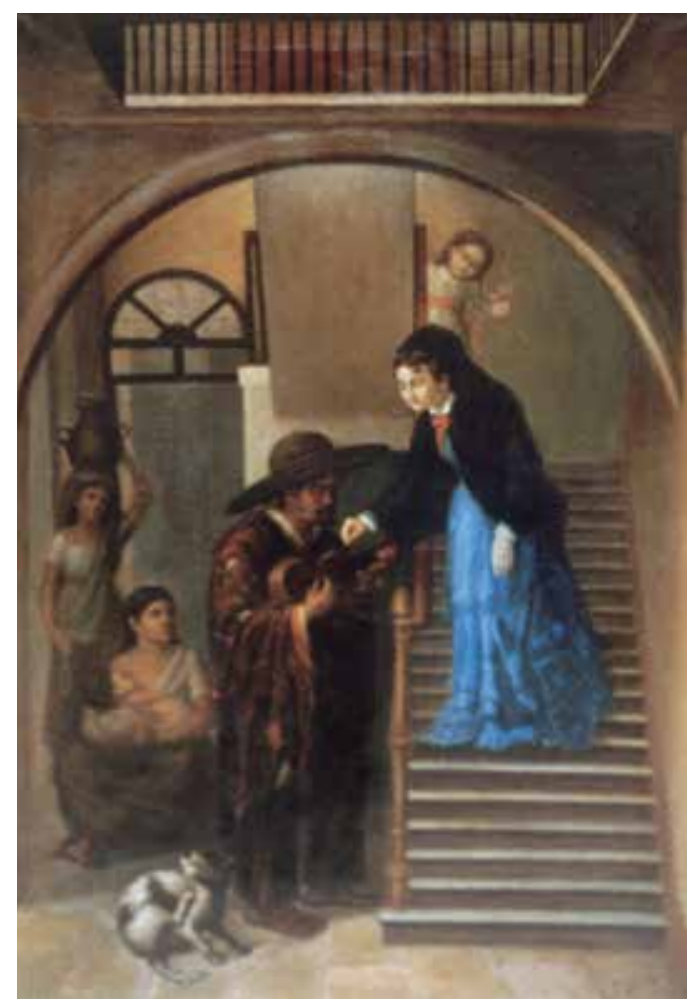

de su hija (la niña vestida de blanco) para auxiliar a los menesterosos que ahí habitan. Sin embargo, sería posible imaginar también que ella misma viviera ahí.

Sabemos, por las novelas costumbristas publicadas en la segunda mitad del siglo XIX, que en las vecindades, muchas de ellas construidas en la época colonial, convivían familias de diferentes orígenes sociales y económicos. En general, en la planta baja se encontraban las viviendas de los vecinos más pobres y en la planta alta las de los que contaban con mejores medios de subsistencia, en la mayoría de los casos, familias "decentes" venidas a menos. Así lo atestiguan novelas como El fistol del diablo (1845-1846), de Manuel Payno, Historia de Chucho El Ninfo (187I), de José T. de Cuéllar y La Calandria (I89I), de Rafael Delgado, entre otras. Sin embargo, el texto literario que mejor ejemplifica esta circunstancia es La clase media, de Juan Díaz Covarrubias (I858), en la que el autor titula al segundo capítulo "La casa de vecindad"; en éste hace una descripción de la arquitectura: 
En el piso inferior hay de ambos lados unos cuartos pequeños y oscuros que habitan algunos miserables artesanos.

Al final del patiecito hay una escalera angosta, que expuesta completamente al desamor de la intemperie, se ha destartalado, de modo que se ven las piedras desnudas de su pasamano; se termina por un corredor ancho y bastante largo, hacia el cual dan las cinco puertas de las únicas cinco viviendas que en el piso superior tiene la casa.

Ciertamente no debe esta finca medio arruinada y situada en uno de los barrios más solitarios de la ciudad atraer muchos habitantes ni dar gran producto a su poseedor. ${ }^{68}$

Luego de hacer la relación del aspecto lamentable del inmueble, el autor describe a los moradores que ocupan la planta alta: la viuda de un militar muerto en la batalla de Padierna y su hija adoptada, "una niña hermosa, modesta, con una fisonomía dulce y resignada como la de un ángel, con unos ojos azules vueltos naturalmente hacia el cielo"; un estudiante de derecho, discípulo de Juan Bautista Morales, el Gallo Pitagórico, quien entretenía a la viuda y a su hija con la lectura de las obras de Lamartine; una joven "vestida pobremente de luto", pero que "por sus maneras y su traje aseado, aunque modesto, revelaba que sólo la miseria podía haberla obligado a vivir en tan aislada habitación"; un joven médico de "fisonomía interesante y distinguida"; y, por último, una familia formada por un ex militar que había combatido para defender el territorio nacional y que había quedado paralítico a causa de las heridas de guerra y "medio loco" al verse en la miseria, su esposa, ejemplo de "todas las virtudes domésticas", dos niños, una "hermosa nińa" de i8 años y un joven de 25, poeta, músico y sostén de la familia. ${ }^{69}$

La estrategia narrativa de Díaz Covarrubias, en este breve capítulo, era contrastar el aspecto ruinoso y miserable del inmueble con las virtudes morales de sus habitantes, quienes, como suele suceder en las narraciones literarias de la época, sobre todo para el caso de las mujeres, son blancas y de ojos azules, y sólo algunas veces, pocas, de "tez apińonada". No sería, pues, disparatado considerar que la mujer caritativa que aparece en la pintura sea una inquilina de la vecindad, lo cual avaloraría aún más el acto de beneficencia dada su limitada situación económica, mejor que la del músico callejero, pero totalmente diferenciada

68. Juan Díaz Covarrubias, "La clase media", en Clementina Díaz y de Ovando, t. II, est. prel., ed. y notas, Obras completas (México: Universidad Nacional Autónoma de México-Instituto de Investigaciones Estéticas, 1959), 337.

69. Díaz Covarrubias, "La clase media", 338-343. 
y superior desde el punto de vista de la educación y los valores morales. Tal y como Díaz Covarrubias describe a los inquilinos de su vecindad: honrados, limpios, trabajadores, educados, comprometidos con las causas patrióticas por las que han dado la vida y, como si fuera poco, lectores de Lamartine.

De la misma forma en que Díaz Covarrubias exalta en su novela la superioridad moral de la clase media comparándola con la clase baja y, particularmente, con la inmoralidad de la oligarquía de la Ciudad de México; Carbó enaltece la acción benefactora de una mujer de apariencia burguesa dando una moneda a un pobre músico callejero a la vista de su hija, con la intención de darle un ejemplo de virtud. Pero ya se trate de una inquilina "decente" de la propia vecindad o de una mujer que ha visitado la vivienda para llevar el alivio material y espiritual a los indigentes (como suele ocurrir en numerosas novelas extranjeras y nacionales entre las que se encuentran, por sólo citar las más conocidas, Los misterios de París (I842-I843), de Eugène Sue, Los miserables (I862), de Víctor Hugo, El fistol del diablo (I845-1846), de Manuel Payno o Ironías de la vida, de Pantaleón Tovar), ${ }^{\circ 0}$ las habilidades plásticas del artista exponen con claridad la supremacía moral, social y étnica de la mujer de azul. Gracias a su emplazamiento en las escaleras, e incluso con su postura inclinada, ocupa el nivel más alto en la escala compositiva, por encima del viejo músico, quien con todo y su enorme sombrero, apenas llega a la cintura de su benefactora y sin atreverse a verla, baja la mirada en signo de gratitud y sumisión. Las mujeres del extremo izquierdo aparecen en un segundo plano y en una escala menor, como testigos mudos de la escena, pero imprescindibles en la composición para marcar el contraste entre su situación miserable y el de la bienhechora; su contraparte en el extremo opuesto, es la niña, quien con su vestido blanco y su muñeca, detrás de su madre, marca igualmente, el estado de desigualdad entre su afortunada posición y la del bebé asido del pecho de su progenitora.

Este mismo encuentro/enfrentamiento entre dos estratos sociales diferenciados y opuestos se encuentra en la obra que Alberto Bribiesca presentó en I879 en la XIX exposición de la Escuela Nacional de Bellas Artes, la segunda verificada bajo el gobierno de Porfirio Díaz, con el título Educación moral. Una

70. Me refiero, en el caso de Los misterios de París a la visita que hacen tanto Rodolfo como la marquesa d'Harville a la desdichada familia Morel; en el de Los miserables a la que hacen Jean Valjean y Cosette a la familia de Thénardier; en El fistol del diablo a la de Arturo a la familia de Celeste; y en Ironías de la vida a la de don Pedro y doña Ricarda a Tomasa. 
madre conduce a su hija a socorrer a un menesteroso (fig. 17 ). ${ }^{71}$ La pintura recrea con detalle el interior de un acogedor salón burgués iluminado por los destellos matinales y ocupado por una madre y su hija que parecen haber interrumpido su labor de costura (así lo hace suponer el cesto que se encuentra al lado de un mullido sillón Luis XV) para atender el llamado de un anciano que aparece en la puerta en el extremo izquierdo del cuadro. Vestido con un humilde pantalón de manta, chaleco y un abrigo gastado, el mendigo sostiene con la mano izquierda un bastón y con la derecha extiende su sombrero para recibir la moneda que la nińa, alentada por su madre, está a punto de darle.

El tema de la madre burguesa socorriendo a un menesteroso lo recreó por primera vez en el arte occidental el artista francés Jean-Baptiste Greuze en 1775 en su cuadro La dama de caridad (fig. I8), expuesto en su propio taller ubicado en el Louvre. La pintura representa a una mujer de clase alta acompañada de su hija, ambas vestidas con suma elegancia, junto con una Hermana de la Caridad, mientras visitan a una familia venida a menos compuesta por un anciano enfermo que yace sobre el lecho, su esposa y su hijo. Los tres personajes femeninos de la derecha encuentran su contraparte en los de la izquierda: la niña, conducida por su madre, con la del nińo de pie detrás del lecho de su padre; la madre burguesa, con la del anciano y, la Hermana de la Caridad, con la esposa del enfermo. La humildad de la habitación y su aspecto rústico enmarcan el acto de caridad realizado por una madre para educar a su hija con el ejemplo in situ.

La obra de Greuze se encuadra en el contexto de las ideas ilustradas sobre la educación y el papel social que los pensadores de la Enciclopedia asignaron a las mujeres como educadoras, ya que consideraban que su sensibilidad "innata” las hacía propensas a las obras de beneficencia. Se trataba, además, de un tema inédito en la pintura, ya que tradicionalmente el papel de la educación moral de los hijos había estado restringida a la figura masculina del padre de familia. ${ }^{72}$ La obra de Jean-Jacques Rousseau, en especial Emilio o de la educación (I762), ampliamente conocida en México, tuvo un papel fundamental en la propagación del ideal social de la mujer como educadora: "A ti dirijo estos renglones, madre amorosa y prudente que has sabido apartarte del camino trillado, y preservar el naciente arbolillo del choque de las humanas opiniones" y en una nota ampliaba su opinión:

7I. En esta misma exposición Bribiesca presentó también La Virgen María en contemplación, en Romero de Terreros, Catálogos de las exposiciones, 514 y 515.

72. Véase el análisis que hace de La dama de caridad, Emma Barker, en su libro Greuze and the Painting of Sentiment (Cambridge University Press, 2005), 177-204. 
DOI: http://dx.doi.org/10.22201/iie.18703062e.2016.109.2623

DE LA CARIDAD RELIGIOSA A LA BENEFICENCIA

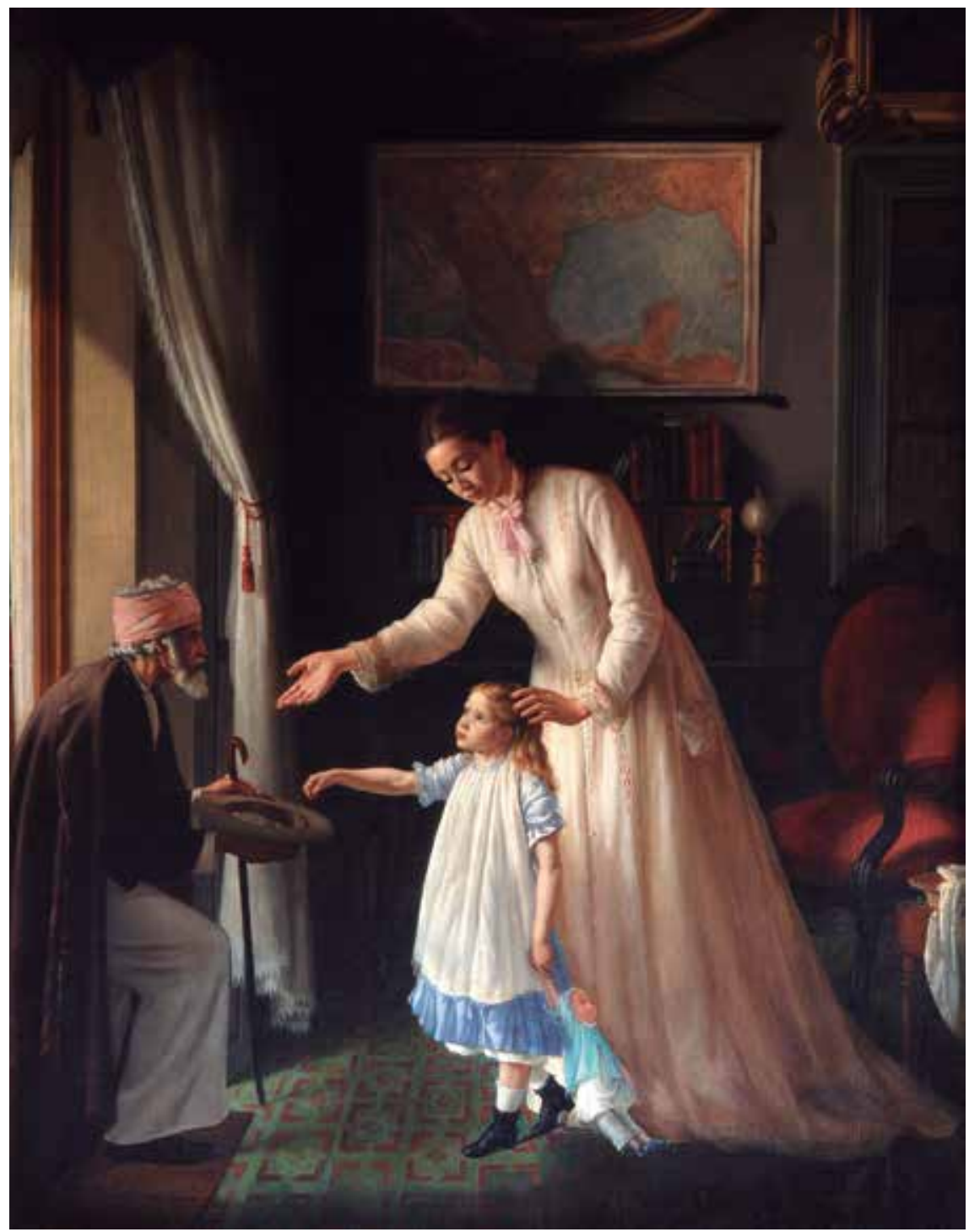

17. Alberto Bribiesca (1856-1909), Educación moral. Una madre conduce a su hija a socorrer a un menesteroso, I879, óleo sobre tela, I.42×I.I4 m. Museo Regional de Querétaro, INAH. Digitalización: Teresa del Rocío, AFMT. Secretaría de Cultura-INAH-Méx. "Reproducción autorizada por el Instituto Nacional de Antropología e Historia”. 
La educación primera es la que más importa, y ésta sin disputa compete a las mujeres; y si el autor de la Naturaleza hubiera querido fiársela a los hombres, les hubiera dado leche para criar a los niños. Así, en los tratados de educación se ha de hablar especialmente con las mujeres, porque además de que pueden celarla más de cerca que los hombres, y de que tiene más influjo en ella, el logro las interesa mucho más. ${ }^{73}$

No es casual así que la escritora, pedagoga e institutriz Stéphanie-Félicité de Genlis, en su novela Adèle et Théodore: ou Lettres sur l'Education, publicada en tres volúmenes en 1782 , haya tomado deliberadamente como punto de partida la pintura como una "puesta en escena" para formar parte de la narración. En la carta XXIV, la autora da nombre y edad a la dama de Greuze: la caritativa condesa de Lagaraye de 24025 años y a su hija de siete que la acompaña, así como al anciano (Saint-André de Vilmore) y a su esposa (Blanche) en alusión directa a la pintura, que ella considera "bella". ${ }^{74} \mathrm{La}$ visita a esta desdichada familia era, para la condesa, una oportunidad para la educación moral de su hija, quien lloraba emocionada por la escena que se le presentaba mientras su madre la exhortaba: "Mirad bien esta recámara y los conmovedores objetos que la llenan, que este recuerdo no salga jamás de vuestra memoria; tened, continuó ella, id a depositar esta bolsa sobre el pie de esta cama; acercaros con respeto, esto se debe a la desgracia; no lo olvidéis jamás, y vuélvase digna algún día de la encomienda sagrada con la que yo la honro."75 Cabe señalar que las obras de Genlis fueron sobradamente conocidas en México. ${ }^{76}$ En la novela Pobres y ricos de México de

73. Juan Jacobo Rousseau, Emilio o de la educación (México: Porrúa, 20I4), I.

74. En una nota la autora revela su fuente para la escena descrita: "No se ha hecho aquí que sino poner en acción el admirable cuadro del Sr. Greuze que representa la Dama de caridad. No se ofrece, es verdad, mas que un muy débil bosquejo del cuadro; pero el original es tan bello, que la copia más imperfecta parecerá siempre interesante", Stéphanie-Félicité de Genlis, Adèle et Théodore: ou Lettres sur l'Education, $4^{\mathrm{a}}$ ed., revisada, corregida y aumentada, vol. 2 (París: imprenta de Crapelet, I8OI), 222-223.

75. Genlis, Adèle et Théodore, 223-224. "Regardez bien cette chambre et les touchants objets qui la remplissent, qu'un tel souvenir ne sorte jamais de votre mémoire; tenez, continua-t-elle, allez déposer cette bourse sur le pied de ce lit; approchez-en avec respect, on en doit au malheur; ne l'oubliez jamais, et rendez-vous digne un jour de l'emploi sacré dont je vous honore".

76. Además de esta novela, las referencias sobre ella en la prensa son numerosas a lo largo del siglo XIX, desde biografías y anuncios sobre la venta de sus obras, hasta la reproducción de extractos de éstas. Véase El Sol, I8 de febrero de I825, 4; El Recreo de las Familias, I de enero de I838, 25; Panorama de las Señoritas, I de enero de I842, I84-I85; El Siglo XIX, 21 de febrero de I850, 3; La Cruz, I4 de agosto de 1856, 28; El Constitucional, 17 de octubre de 1868, 4; La Voz de México, I5 
José Rivera y Río, publicada en I884, doña Úrsula, madre de una familia "arruinada", solía leer a sus hijas "alguna de las obras de madama Genlis" mientras éstas cosían para ganarse la vida en un miserable cuarto de vecindad. ${ }^{77}$ Para Genlis como para los pensadores ilustrados como Denis Diderot, la pintura de costumbres era un medio para elevar la moral de los espectadores por medio de la presentación de espectáculos edificantes como el de La dama de caridad. No por azar, la obra se difundió ampliamente a partir de un grabado realizado por Jean Massard en 1778 bajo el título de La dame bienfaisante ${ }^{78}$ y marcó el inicio, no sólo en Francia sino en toda Europa y América, de una serie de pinturas con el tema de la caridad ya no como parte de los siete actos de misericordia y despojado de sus connotaciones religiosas para convertirse en un tema moderno y laico que fue muy socorrido por los artistas durante el siglo XIx. ${ }^{79}$

Como en La dama de caridad, los cuadros de Carbó y Bribiesca se centran en la lección moral transmitida por la vía femenina de una generación a otra, pero han ańadido un elemento más a este mensaje: la muñeca que ambas nińas llevan en la mano no es sólo un juguete, signo de su género y posición social, sino el símbolo de su maternidad futura y la factura de seguro de los valores morales que más tarde ellas también legarán a sus hijas. ${ }^{80}$ Otra diferencia notable entre los cuadros analizados es la presencia o ausencia de los beneficiados y los espacios en los que tienen lugar las escenas. En oposición a la obra atribuida a Ocaranza, en la que el destinatario de la caridad es anónimo y virtual y sólo queda sugerido de forma implícita en el cepo de limosnas con la imagen del santo vicentino, el resto de las obras presentan al receptor y a los donantes en un encuentro amable, exento de conflicto entre ricos y pobres. Por otra parte, los espacios representados en las pinturas son las casas de los socorridos (Hernández, Carbó y Greuze), hospicios y hospitales (Medina y Agrasot), recintos religiosos

de julio de I884, 2; Violetas del Anáhuac, I5 de abril de 1888, 5; El Monitor Republicano, 29 de noviembre de I892, 2; La Voz de México, 2I de marzo de I902, i; y El País, I4 de julio de I9IO, 7.

77. José Rivera y Río, Pobres y ricos de México (México: imprenta de la Librería HispanoMexicana, I884).

78. Véase el artículo de Emma Barker, "From Charity to Bienfaisance: Picturing Good Deeds in Late Eighteenth-Century France", Journal for Eighteenth-Century Studies 33, núm. 3 (2010): 285-3II.

79. Véase el catálogo de la exposición Petits Théâtres de l'intime. La peinture de genre française entre Révolution et Restauration (Toulouse, Francia: Musée des Augustins [octubre de $201 \mathrm{I}$ a enero de 20I2], 20II).

80. Sobre el papel de la muñeca en la proyección de la futura maternidad de las niñas en el siglo XIX, véase el capítulo "El amor a los cinco años. La muñeca”, en Jules Michelet, La mujer, trad. Stella Mastrangelo (México: Fondo de Cultura Económica, 1999), 77-8I. 
DOI: http://dx.doi.org/10.22201/iie.18703062e.2016.109.2623

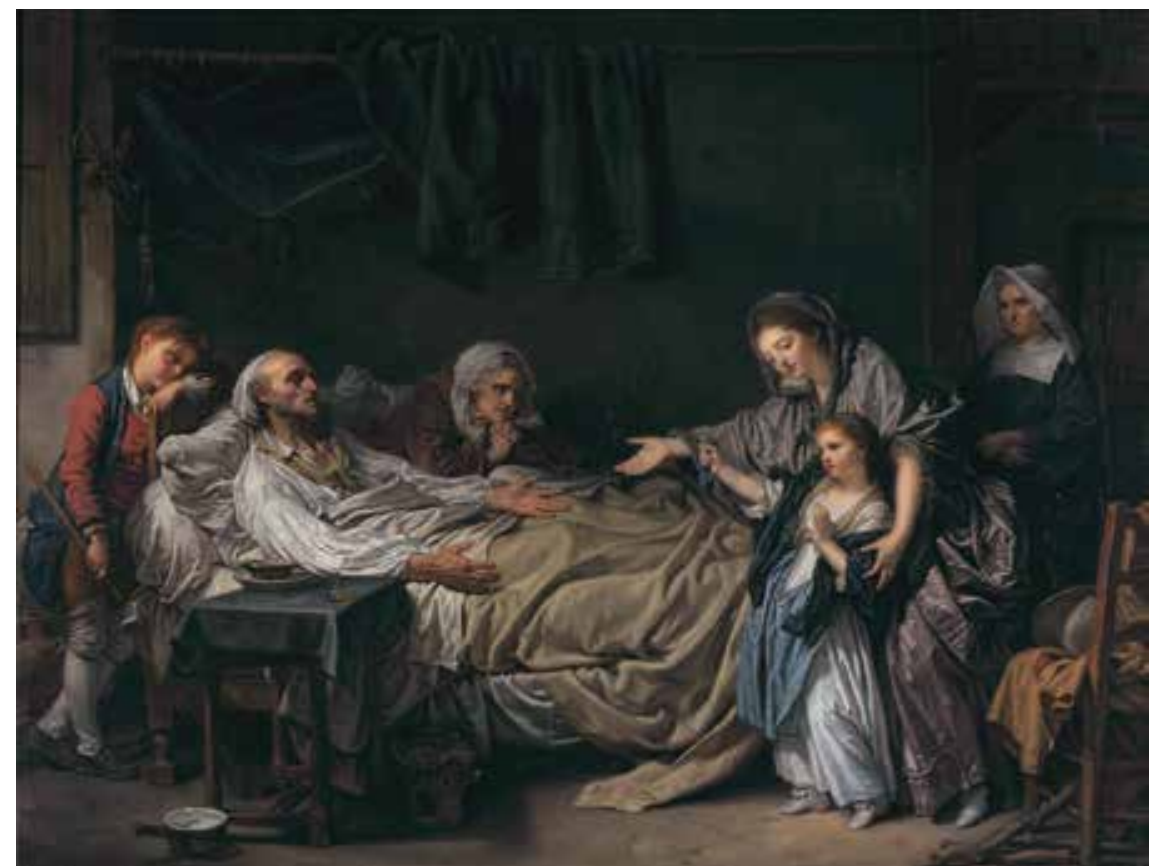

I8. Jean-Baptiste Greuze (I725-I805), La dama de caridad, I775, óleo sobre tela, I.I2 × I.46 m. Musée des Beaux Arts de Lyon, Francia.

(Ocaranza) y la calle. ${ }^{81}$ En este sentido, la pintura de Bribiesca muestra el lugar más insólito para este tipo de escenas, ahí el mendigo ha llegado a irrumpir en el espacio más "sagrado" de la cultura burguesa: la intimidad del hogar.

No cabe duda que el modelo que inspiró a Bribiesca para la elaboración del tema, pero sobre todo, para la representación de la madre, fue La dama de

8I. Muchas de las obras presentadas en las exposiciones de la Academia de San Carlos con el tema de la caridad o la mendicidad tenían como escenario las puertas o los atrios de las iglesias. Como ejemplo de ello pueden citarse las tres pinturas siguientes, hoy en paradero desconocido: La caridad de Lorenza Aduna, cuya descripción es la siguiente: "Un anciano ciego, sentado en el atrio de un templo y con un niño al lado que descansa sobre sus rodillas, excita la caridad de una joven, que al paso pone una moneda de plata en su mano. En segundo término se elevan algunos edificios de la ciudad" (VIII exposición); El mendigo de Antonio Bejarano: "Sentado en un banco, al lado de una iglesia, recibe de un muchacho la colecta del día. A su lado se ve su alforja y un jarro" (XIII exposición); y Una joven mendiga en la puerta de un templo de Marcos Jaso (XVIII exposición). Las descripciones se encuentran en Romero de Terreros, Catálogos de las exposiciones, 225, 389 y $49 \mathrm{I}$. 
caridad de Greuze. La retórica gestual de sus brazos exhortando a su hija a colocar la moneda en el sombrero es una cita literal de la pintura francesa, ${ }^{82}$ con la diferencia de que en el caso de la pintura mexicana, el beneficiario del acto de caridad no es un "pobre vergonzante" enfermo en el lecho de su casa, es decir una persona de nivel medio o superior caída en desgracia como en las obras de Hernández y Greuze, lo que sitúa casi en el mismo nivel moral a los donantes y al receptor; sino un anciano menesteroso de piel morena y barba encanecida cuya pobreza no le impide vestir con pulcritud para acudir a una casa burguesa en busca de auxilio. Desde esta perspectiva, resulta interesante llamar la atención tanto sobre el aspecto aseado como sobre el perfil clásico con que el artista dibujó al indigente, recursos de los que se sirvió para dignificarlo, lo que lo hace tan diferente del músico anciano de Carbó con sus rasgos claramente indígenas y su ropa roída y sucia. Fue tal vez esta estrategia de fusionar una figura de apariencia clásica cubierta con el ropaje del realismo, manifiesto en la vestimenta y el tono de piel, lo que llevó a Altamirano a considerar en sus comentarios sobre la obra de Bribiesca en el Salón de I879, como el personaje mejor logrado:

Aquí estuvo mejor inspirado este alumno, que en su cuadro de San José. El pensamiento es bellísimo (una madre conduce a su hija a socorrer a un menesteroso). La ejecución tiene algunos defectos; pero en general es buena. La madre es de un tipo triste y no tiene gran expresión. Valía la pena de haberla dibujado con mayor valentía; la nińa también es poco expresiva. En cambio el anciano mendigo es magnífico, su ejecución tiene una naturalidad que encanta. ${ }^{83}$

Nada dice el crítico sobre el contraste racial de los personajes que componen la obra (él, que era indígena), pero el tema le parece "bellísimo". En cambio la falta de expresión que atribuye a la madre y a la nińa pueden interpretarse como una decisión deliberada del autor, precisamente para evitar un enfrenta-

82. El pintor José María Ibarrarán y Ponce, condiscípulo de Bribiesca, y alumno de José Salomé Pina en San Carlos, recurrió a la misma composición de Greuze, en el lienzo La familia del mártir, presentado en la misma exposición en la que Bribiesca mostró Educación moral en I879. El cuadro se encuentra actualmente en el Museo de Aguascalientes. Este hecho indica que el modelo compositivo de ambas obras pudo ser propuesto por Pina.

83. Ignacio Manuel Altamirano, "El Salón en I879-I880. Impresiones de un aficionado", en La Libertad, 3 de febrero de I88o, 2, reproducido en José Luis Martínez, selección y notas, Obras completas XIV. Escritos de literatura y arte, t. 3 (México: Consejo Nacional para la Cultura y las Artes, 1989), I66. 
miento racial y social. Desde este ángulo, tampoco es fortuita la escala de los personajes, pues como en la obra de Carbó, Bribiesca ha maximizado la altura de la madre en relación con el mendigo, quien aparece empequeñecido frente a ella, inclinado y temeroso de invadir el hogar burgués; de esta manera, cada personaje ocupa el sitio que le corresponde sin transgredir las normas impuestas por una sociedad de enormes contrastes, como lo sigue siendo y lo era la mexicana de la época porfiriana. Cabe subrayar, también, que tanto en la obra de Greuze como en las de Carbó y Bribiesca, el beneficiado es un hombre anciano. Esta diferencia de edad vendría a invalidar cualquier alusión de tipo sexual entre las benefactoras, pues además la madre viste un camisón, y sus inofensivos protegidos ubicados estratégicamente en las composiciones en un plano inferior que revela su mansedumbre. Por otra parte, el estado de ancianidad aunado al de pobreza fue visto durante el siglo XIX como uno de los sectores más susceptibles de compasión. Un buen ejemplo de este tema en la escultura mexicana es La caridad (I88I) de Gabriel Guerra, en el que dos jóvenes burgueses sostienen a un pordiosero semidesnudo para aliviar sus penas, poniendo en práctica las enseñanzas caritativas, en este caso, de una madre ausente en la obra. ${ }^{84}$

De la misma forma en que en el siglo XvIII Greuze inauguró las imágenes secularizadas de la caridad y planteaba en términos visuales el tema de la beneficencia, uno de los que más interesaron a los pensadores ilustrados, quienes empezaron a ver las desigualdades sociales y económicas como un problema y no como un "estado natural de las cosas"; vista en su contexto, Educación moral exponía un ejercicio de la caridad desprovisto de referencias religiosas, particularmente para las mujeres. Así lo pregonaban los ideológos liberales como Altamirano o Sierra; por ello no es casual que en el salón no se encuentre una sola alusión a la religión y, por el contrario, se presenten objetos que remiten al nuevo ideal de la mujer mexicana y su papel como educadora en la conformación de la República, tales como el estante lleno de libros y la lámpara que evocan la imagen de una madre lectora e instruida, capaz de formar buenos ciudadanos; el mapa de México que además de informar sobre el lugar donde tiene lugar la escena, sugiere el conocimiento que de la historia y la geografía

84. Angélica Velázquez Guadarrama, "Gabriel Guerra, La caridad", en A.V., Catálogo comentado del acervo del Museo Nacional de Arte. Escultura. Siglo XIX, t. I (México: Instituto Nacional de Bellas Artes-Museo Nacional de Arte/Universidad Nacional Autónoma de México-Instituto de Investigaciones Estéticas, 2000), II5-II8. 
nacionales posee la madre para transmitirlos a las generaciones siguientes, el cesto de costura como símbolo ancestral de la domesticidad femenina y los elaborados marcos de las pinturas cuyo asunto no se alcanza a percibir, pero que son indicadores del ambiente culto y refinado en el que viven las benefactoras.

En un texto retrospectivo sobre su novela inconclusa El ángel del porvenir, publicada por entregas en la revista El Renacimiento durante 1869, Sierra explicaba la trama y el papel de la mujer en el proceso de construcción de la nación mexicana: "La mujer mexicana será el ángel del porvenir, ella nos salvará socialmente, pero se regenerará por el sentimiento religioso, substituyente de la devoción y la superstición; el amor de la patria será parte integrante de esta religión, como en los Estados Unidos". ${ }^{85}$ La cita es reveladora respecto a las transformaciones políticas y sociales que la ideología liberal pretendía establecer entre la población mediante la legislación, la educación, la prensa, la literatura y el arte: la secularización de las costumbres mediante el relevo de los símbolos religiosos por los patrióticos, la exaltación del nacionalismo y el papel social que hombres y mujeres debían cumplir para la consolidación del Estado, con los que Educación moral respondería cumplidamente. No por azar la obra, sorteada entre los suscriptores de la exposición de 1879, perteneció al eminente filántropo poblano Alejandro Ruiz Olavarrieta, fundador del Monte de Piedad VidalRuiz. A su muerte en 1907, legó a la Escuela Nacional de Bellas Artes un lote de piezas de cerámica y pinturas, entre las que se encontraban dos de la autoría de Bribiesca: Educación moral y La Virgen en contemplación. Sin embargo, las obras permanecieron en San Carlos sólo algunos años, pues en i9ıo (a solicitud del gobernador de Querétaro, Francisco González de Cosío, y del director de la Academia de Bellas Artes de ese estado, Germán Barragán Patiño), 53 óleos y siete esculturas, seleccionados por Leandro Izaguirre y Gerardo Murillo, fueron cedidos a la academia queretana. ${ }^{86}$ En la actualidad, la pintura forma parte del acervo del Museo Regional de ese estado.

85. Justo Sierra, José Luis Martínez, ed., notas e índices, Obras completas VI. Viajes (México: Universidad Nacional Autónoma de México-Coordinación de Humanidades, 1977), 202.

86. La donación de Ruiz Olavarrieta a la ENBA y su posterior cesión a la academia queretana, están aún por estudiarse. Algunos documentos señalan que Ruiz donó su colección completa y, otros, que sólo una parte. Es probable que Ruiz haya cedido la totalidad de su colección a la academia capitalina y que ésta haya hecho la "selección" que mencionan los documentos, desde las premisas del modernismo imperante en I9ıо. Véase, entre otras fuentes, Eduardo Báez, Guía del Archivo de la Antigua Academia de San Carlos, I78I-I9Io (México: Universidad Nacional Autónoma de México-Instituto de Investigaciones Estéticas, 2003), 237 y 408-4IO; Xavier Moyssén, La críti- 
DOI: http://dx.doi.org/10.22201/iie.18703062e.2016.109.2623

\section{Colofón}

En I86I, en la tercera exposición de la Sociedad Jalisciense de Bellas Artes, Jacobo Gálvez presentó el cuadro Redención social, hoy perdido. Sin especificar ninguna obra en particular, el catálogo correspondiente apunta que para su ejecución, el artista jalisciense se inspiró en el marsellés Dominique-Louis Papety, un pintor influido por las ideas de Charles Fourier. ${ }^{87}$ Según la descripción, la pintura mostraba, con Jesucristo al centro, a una pléyade de personajes del Antiguo Testamento (Moisés), de la Antigüedad clásica (Homero, Platón, Sócrates y Diógenes) y de la época moderna (Newton, Fourier y san Vicente de Paul). Completaban la composición un grupo que "representa los esclavos de Oriente" y "dos figuras agrupadas significando a la mujer de Occidente explotada por la miseria” ${ }^{88}$ En el contexto tapatío, no resulta insólita la presencia del santo vicentino, cuya comunidad para I86I se había extendido en todo el estado; sino su vecindad con el socialista francés, ubicado al lado izquierdo de Jesucristo y, conforme a la indicación del catálogo, "el lado del corazón, lado de honor". La cercanía del utopista y de san Vicente con la figura de Jesucristo (que pareciera corresponder a la imagen de un "Cristo social", articulada en el siglo xIx), revela la preocupación de Gálvez y, probablemente, la de los promotores de la Sociedad Jalisciense por los trastornos provocados por la modernidad hacia los sectores más vulnerables de la humanidad y su solución mediante el cristianismo y el socialismo. Por otra parte, la pintura manifiesta la actualidad del tema en la cultura visual de Occidente, abordado en diferentes soportes y géneros artísticos y desde las más variadas ideologías.

Así, las pinturas de Hernández, Medina y la atribuida a Ocaranza y los impresos de calendarios y revistas ilustradas analizados en el artículo muestran la caridad según las premisas de un "catolicismo social", en el que los protagonistas (las hermanas lazaristas y los miembros de las Conferencias masculina y femenina) la ejercen como un apostolado, como un medio de servir a Dios y ganar así la propia salvación mediante el auxilio a los menesterosos, mientras que

ca de arte en México I896-I92I, t. I (México: Universidad Nacional Autónoma de México-Instituto de Investigaciones Estéticas, 1999), 368 y 398-399; y José Luis Bello y Zetina y Enrique Cordero y Torres, Galerías pictóricas de Puebla (Centro de Estudios Históricos de Puebla, 1967), II3-II9.

87. Marion Doublet, "Le Rêve d'une société idéale", Revue d'Histoire de l'Art sur les Peintres Méconnus du XIXème Siècle, http://lespetitsmaitres.com/20I4/Io/le-reve-dune-societe-ideale/

88. Arturo Camacho Becerra, comp., Catálogo de las exposiciones de la Sociedad Jalisciense de Bellas Artes (México: El Colegio de Jalisco, I998), 52. 
las de Carbó, Bribiesca y Greuze presentan a las mujeres como laicas y a la beneficencia como una forma de compromiso moral en el contexto de la formación de un ideal burgués de comportamiento. Con todo, ambas visiones, la religiosa y la laica, tienen en común la exposición de la caridad como una coyuntura para manifestar la superioridad social, económica, pero sobre todo, moral de los donantes en una línea vertical, de arriba abajo, que subraya la posición antagónica entre los benefactores y los destinatarios y que, sin embargo, gracias a las soluciones compositivas y a los artilugios plásticos, evocan la imagen de una convivencia armoniosa entre las clases sociales en la que los latentes choques económicos, raciales y culturales entre los protagonistas, pretenden anularse. Las obras estudiadas en la primera parte tendrían así la función de enaltecer el catolicismo mediante sus prácticas caritativas y su efectiva respuesta a los problemas de la sociedad moderna, mientras que las de la segunda desvelarían el deseo de legitimar y exaltar el estatus moral de la emergente burguesía en su relación con los desposeídos, encomiando el papel de las mujeres como agentes morales de las futuras generaciones, de ahí que se las represente en su calidad de madres.

Queda pendiente la localización de las numerosas pinturas que con el tema del ejercicio de la caridad, en sus diferentes modalidades, se realizaron en el siglo XIX y el estudio de su coleccionismo vinculado a las figuras de benefactores como Ignacio Cumplido, Vidal Alcocer, Francisco Fagoaga, Juan Abadiano, Francisco Díaz de León o Joaquín García Icazbalceta; pero, sobre todo, a la multitud de mujeres que se entregaron a esas tareas y cuyos nombres permanecen en el anonimato. $s$

N.B. Una primera versión de este trabajo la presenté en el seminario Tradición Moderna. La Modernidad en América Latina: Tránsitos y Desdoblamientos, que se realizó en Quito, Ecuador, en 20I4, como parte del proyecto Unfolding Art History in Latin America, patrocinado por The Getty Foundation. Agradezco la lectura y los comentarios de mis colegas Fausto Ramírez, Hugo Arciniega, Jaime Cuadriello y María José Esparza Liberal. 
DOI: http://dx.doi.org/10.22201/iie.18703062e.2016.109.2623 


\section{Religión, política y espectáculo: narrativas del martirio en la primera modernidad}

\section{Religion, Politics and Spectacle: Narratives of Martyrdom in the First Modernity}

Artículo recibido el 26 de junio de 20I5; devuelto para revisión el 8 de enero de 20I6; aceptado el 24 de febrero de 20I6. http://dx.doi.org/I0.2220I/iie.I8703062e.20I6.109.2578

\section{Carlos Arturo Salamanca \\ Villamizar}

Líneas de investigación

Publicaciones más relevantes
Universidad Nacional de Rosario/Consejo Nacional de Investigaciones Científicas y Técnicas, Argentina, salamanca.carlos@gmail.com

La relación entre territorio, violencia y memoria, especialmente, las condiciones que permiten la emergencia de ciertas narrativas e imágenes acerca de las prácticas de violencia en determinados contextos políticos, sociales e históricos; las representaciones de violencia y los relatos de la alteridad en el contexto de la primera Modernidad en diálogo con el trabajo etnográfico en el marco de una investigación comparativa sobre la cuestión en Argentina, Colombia y Guatemala.

"Saberes geográficos, tensiones de alteridad y teatros del martirio en las cartografías jesuíticas del Nuevo Mundo", Revista Española de Antropología Americana (en prensa); "Das catacumbas às últimas fronteiras: violência, sentido e representação nas marchas do martírio", Topoi. Revista de História I6, núm. 30 (2015): 260-292; "Herejes e infieles: imaginación etnográfica, experiencia histórica y prácticas comunicativas de la alteridad en la obra de De Bry", Revista Brasileira de História das Religióes 19, núm. 7 (mayo, 20I4): 9I-IO6, en http:// www.periodicos.uem.br/ojs/index.php/RbhrAnpuh/index

Resumen Se analizan las representaciones del martirio en el contexto de las guerras de religión, centrándose en sus procesos de producción y circulación. Los vínculos pueden trazarse entre acontecimiento y registro, sitúo el surgimiento del martirologio en un contexto de adelantos técnicos, polémicas religiosas e intensificación de la conquista y la colonización. Después estudio tres martirologios: el primero caracterizado por un dispositivo de glorificación que busca evadir la exaltación sacralizada de los mártires. El segundo que evidencia la tensión entre verdad "teológica" y verdad "histórica", y un tercero en el que la crueldad es puesta en escena sin ambigüedades ni matices. Concluyo estableciendo una síntesis del aporte que este análisis ofrece a las discusiones sobre la violencia y sus representaciones. 
Palabras clave martirio; mártir; memoria; religión; Foxe; Verstegan; Perrissin y Tortorel.

\begin{abstract}
This article analyzes the representation of martyrdom in the context of the Wars of Religion, giving special attention to production and circulation processes. The article examines the links that can be drawn between the events and their chronicling, and the emergence of martyrdom in a context of technical developments, religious controversies and the accelerating process of conquest and colonization. This is followed by the analysis of three particular martyrologies, revealing different representational strategies: the first contrives to glorify without sacralizing the martyrs; the second evidences the tension existing between "theological" and "historical" truth; the third presents cruelty without ambiguities or nuances. The study closes with a summary of the impact the systematic analysis of these works can bring to discussions on violence and its representation.
\end{abstract}

Keywords martyrdom; martyr; memory; religion; Foxe; Verstegan; Perrissin and Tortorel. 
DOI: http://dx.doi.org/10.22201/iie.18703062e.2016.109.2623

\author{
CARLOS ARTURO SALAMANCA VILLAMIZAR \\ UNIVERSIDAD NACIONAL DE ROSARIO/ \\ CONSEJO NACIONAL DE INVESTIGACIONES CIENTÍFICAS Y TÉCNICAS
}

ARGENTINA

\title{
Religión, política y espectáculo: narrativas del martirio en la primera modernidad
}

\section{Polémicas religiosas, violencia y espectáculo}

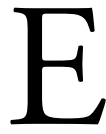
n marzo de 1562, seis semanas después de la firma del edicto del rey de Francia que autorizaba a los protestantes a celebrar sus oficios al exterior de las ciudades, un grupo se había congregado en una granja al interior de la ciudad de Vassy en el principado de Joinville, gobernado entonces por el católico Francisco I de Lorena, II duque de Guisa. En hechos confusos de los que se tienen diversas versiones y que generaron numerosas controversias, las tropas del duque asesinaron alrededor de 50 personas e hirieron a unos I5O. ${ }^{1}$ La llamada masacre de Vassy se produjo en un contexto en el que las políticas represivas contra los protestantes en Francia coexistían con un régimen de inquisición consolidado en España y Portugal, y las consecuencias de la coronación de María Tudor, la Sangrienta, como reina de Inglaterra en 1553 , de la creación en Roma de la Congregación del Santo Oficio en I542, y de las reformas de Calvino y de Lutero. Al funcionar como detonante de estas tensiones, la masacre de Vassy fue el inicio de las guerras de religión en las que católicos y protestantes se envolvieron durante casi tres décadas hasta la firma del Edicto de Nantes en

I. Sobre estas diversas interpretaciones véase Pierre Deyon, "Sur Certaines formes de la propagande religieuse au XVI ${ }^{\mathrm{e}}$ siècle”, Annales 36, núm. I (I98I): I6-25; Henri Hauser, "Un Récit catholique des trois premières guerres de religion les 'acta Tumultuum Gallicanorum”, Revue Historique 108, núm. I (1911): 59-74. 
DOI: http://dx.doi.org/10.22201/iie.18703062e.2016.109.2623

IOO

CARLOS ARTURO SALAMANCA VILLAMIZAR

I598, el último de una serie de tratados de paz. Estas confrontaciones dejaron innumerables e intensas experiencias de terror, desplazamiento y se calcula que entre 2 y 4 millones de muertos. ${ }^{2}$

Casi simultáneamente a las disputas religiosas se produjo una expansión a gran escala de la producción impresa, lo que dio lugar a la aparición y la circulación de un número inusitado de libros, mapas, atlas, volantes, panfletos, gramáticas, muchos de ellos de carácter religioso. ${ }^{3}$ Incluso más que de dos procesos paralelos, algunos autores no dudan en subrayar su estrecha articulación; ${ }^{4}$ el mismo Lutero por ejemplo, afirmaba que "la imprenta [en cuyo desarrollo los protestantes aventajaron a los católicos ampliamente] era el último de los regalos de Dios ya que por medio de ella y la voluntad de Dios las cosas de la verdadera religión pueden ser difundidas $[\ldots]$ en todas las lenguas y sobre la tierra entera". ${ }^{5}$

Desde el inicio mismo de las tensiones, católicos y protestantes representaron en textos, imágenes de acontecimientos y prácticas de violencia religiosa. ${ }^{6}$ Un mayor acceso a los círculos editoriales sumado a la necesidad creciente de elaborar narrativas de los sucesos, convirtieron la impresión en medio y lugar

2. Robert Knecht, The French Religious Wars, I562-I598 (Óxford: Osprey Publishing, 2002), 86 y 91.

3. Para profundizar sobre este fenómeno de difusión véase Michael Baxandall, Painting and Experience in Fifteenth Century Italy (Oxford University Press, I988), 2 y 3; Jeremy Black, "Government, State, and Cartography: Mapping, Power, and Politics in Europe, I650-1800", Cartographica 43, núm. 2 (2008): 95-I05; Chandra Mukerji, "Printing, Cartography and Conceptions of Place in Renaissance Europe", Media, Culture \& Society 28, núm. 5 (2006): 65I-669, http://dx.doi. org/IO.II77/or634437006067020; acerca de la relación entre los protestantes y la producción a gran escala de imágenes y contextos más recientes, véase: David Morgan, Protestant and Pictures. Religion, Visual Culture and the Age of American Mass Production (Nueva York y Óxford: Oxford University Press, 1999).

4. Elizabeth Eisenstein y Gérard Mansuy, "L’Avènement de l'imprimerie et la Réforme", Annales 26, núm. 6 (197I): I355-I382, http://dx.doi.org/I0.3406/ahess.I971.422418.

5. "L'imprimerie est le dernier et le plus important des présents, car par elle et selon la volonté de Dieu, les choses de la vrai religion peuvent être diffusées [...] dans toutes les langues et sur la terre toute entière", Deyon, "Sur Certaines formes", I6 (la traducción es mía).

6. Entre las obras recientes sobre el tema del martirio, véase Susannah Brietz Monta, Martyrdom and Literature in Early Modern England (Cambridge University Press, 2005); Peter Burschel, Sterben und Unsterblichkeit. Zur Kultur des Martyriums in der frühen Neuzeit (Múnich: Oldenbourg, 2004); Thomas S. Freeman y Thomas F. Mayer, eds., Martyrs and Martyrdom in England, ca. I400-I700 (Rochester: Boydell \& Brewer, 2007); John Knott, Discourses of Martyrdom in English Literature, I563-1694 (Cambridge University Press, 1993); Friedericke Pannewick, ed., Martyrdom in Literature: Visions of Death and Meaningful Suffering in Europe and the Middle East from Antiquity to Modernity (Wiesbaden: Reichert, 2004). 
de la confrontación en el cual la violencia se constituyó como un espectáculo necesario de evocar, narrar, conmemorar, y hacer ver. Nobles, sacerdotes y ministros, artistas y mecenas, católicos o protestantes contribuyeron a la elaboración de diversas representaciones y narrativas sobre la violencia. En ese contexto, la figura del martirio adquirió un lugar preponderante.

El martirio es una puesta en escena polisémica, que combina la práctica judicial del interrogatorio, el ritual religioso y el acto espectacular de los juegos de circo de la Roma imperial.7 El mártir, reivindicado como instrumento de la imitación de Cristo, "habla" a Dios, a los testigos, a sus victimarios y a sus pares (a otros que murieron como él, a otros que morirán como él) a quienes se une por el mismo acto, constituyendo una comunidad en torno al acontecimiento.

El martirio reúne en las figuras de victimario y de víctima el arquetipo de dos individualidades extremas por la naturaleza misma del acto de matar y ser matado y la significación que se le atribuye. No obstante, por medio de la representación, victimario y víctima se funden, cada uno, en dos comunidades de sentido contrapuestas que se extienden tanto en el espacio (hacia sus contemporáneos) como en el tiempo (hacia quienes los precedieron, hacia aquellos que están por venir).

La potencia del martirio reside no sólo en la reproducción del rito primordial del sacrificio, sino en la proyección del discurso nuevo que de allí emerge. Es en las prácticas de personas singulares, en lugares específicos y a través de medios concretos que tal acto tiene lugar; pero es por medio de su vinculación con redes más amplias de significación que el acto sagrado toma forma.

\section{El martirologio como género de representación de la violencia}

El interés en la representación del martirio no era nuevo y se constituyó a partir de la recuperación de distintos elementos de varias épocas y tradiciones, entre los que sobresalen, por una parte, legados medievales como tropos y temáticas provenientes de obras como la Masacre de los inocentes (fig. I) o leyendas como santa Úrsula y su martirio a manos de los hunos. ${ }^{8}$ Por otro

7. Frank Lestringant y Pierre-François Moreau, "Overture", Martyrs et martyrologes, Revue de Sciences Humaines, 269 (Presses Universitaires du Septentrion, 7-13, y Frank Lestringant, "Témoignage et martyre: donner à voir, donner à croire (XVI ${ }^{\mathrm{e}}$-XVIII ${ }^{\mathrm{e}}$ siècles)", en Martyrs et martyrologes.

8. Acerca del uso de las imágenes como propaganda luterana, véase, por ejemplo, Max Geisberg, The German Single Leaf Woodcut I500-I550 (Nueva York: Walther L. Strauss, 1974). 
DOI: http://dx.doi.org/10.22201/iie.18703062e.2016.109.2623

IO2

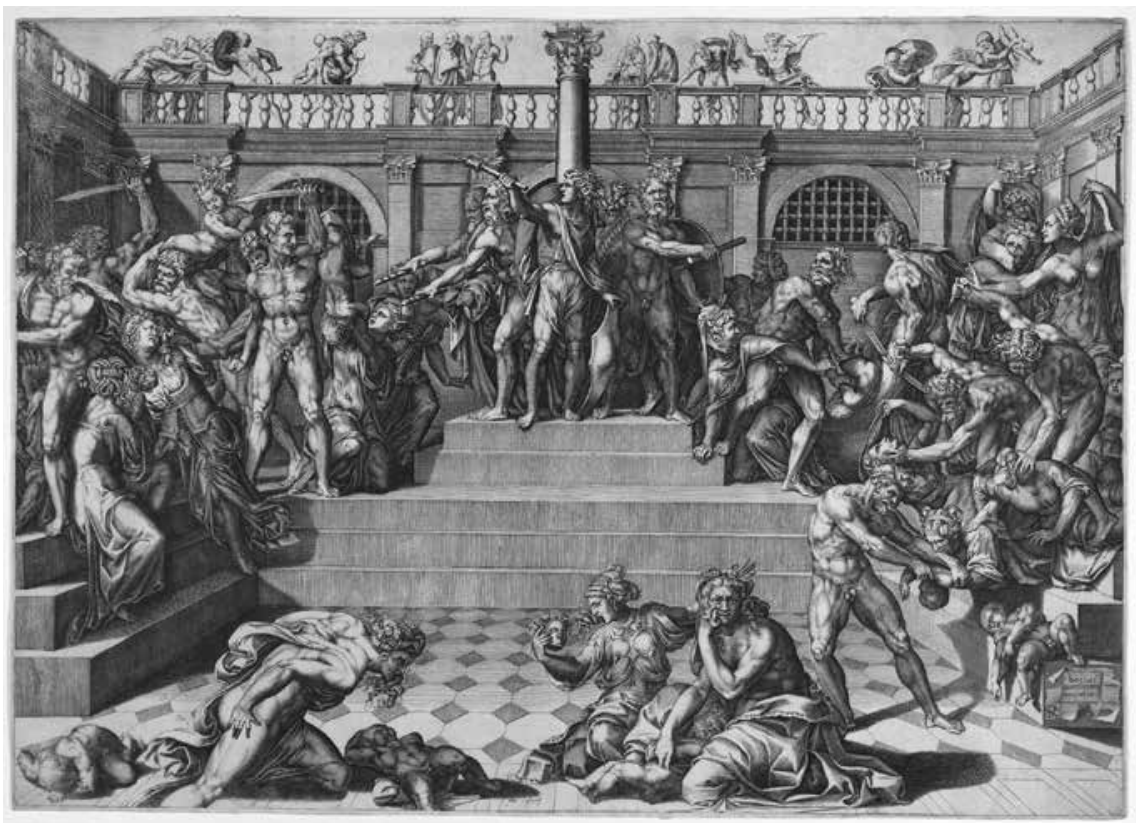

I. Marco Dente da Ravenna (atribuido), a partir de Baccio Bandinelli, Masacre de los inocentes, s.f., $39.8 \times 56.5 \mathrm{~cm}$. (C) The Metropolitan Museum of Art - www.metmuseum.org. The Elisha Whittelsey Fund, 1949 .

lado, la idea del mundo como un teatro, ${ }^{9}$ que emergió en la época clásica, se estaba expandiendo en diversas esferas de la representación. Estos elementos dieron lugar a la aparición de un nuevo género para manifestar la violencia, el martirologio, teatral, didáctico, emotivo y con un gran potencial de difusión y movilización.

El martirologio (del griego martyr, "testigo", y logos, "discurso") inscribe el suceso del martirio en redes específicas de significación y lo dota de atributos como la sacralidad y la trascendencia. De esta forma, contribuye a la constitución de marcos interpretativos para la comprensión de las controversias, las tensiones y las violencias religiosas. En contextos histórico-políticos, como el que analizo, en los que se enfrentan versiones contrapuestas, el martirologio

9. Sobre esta temática véase Lina Bolzoni, Giulio Camillo. La idea del teatro, trad. Jordi Raventós (Madrid: Siruela, 2006); Frances A. Yates, The Art of Memory. Selected Works (Londres y Nueva York: Routledge, 1999). 
propone además una narrativa y una mirada particular y localizada de lo acontecido. Los martirologios se caracterizan también por tensiones morales que se manifiestan en lecturas contrapuestas; como afirma El Kenz; aquel que de un lado es visto como héroe de la fe, del otro puede ser considerado parricida. ${ }^{\text {Io }}$ Aunque se produjeron martirologios bajo otros formatos como conjuntos de frescos realizados en iglesias, aquellos a los que me refiero aquí aparecieron en libros impresos impulsados por la expansión editorial.

El martirologio es una obra "abierta", dinámica y en permanente actualización, que se modifica con cada nueva edición para insertarse en los panoramas locales en busca de mayor eficacia al aumentar el número de ilustraciones, incluir prólogos o epílogos distintos o traducir los textos a diversos idiomas "más accesibles"; no obstante, más que hablar exclusivamente de obras transformándose en función de las audiencias, se trata de un proceso bidireccional en el cual los martirologios también "producían" las audiencias en torno a distintos sentidos; sensibilidades y temores son resultado tanto de la acción colectiva como personal; al tenerse en cuenta esta tensión, los martirologios pueden pensarse como conjuntos heterogéneos en donde la copia, la referencia, la síntesis, y la edición priman por sobre el acto creativo puro y la estricta autoría individual. ${ }^{I I}$ Se trata de obras frente a las que la noción moderna de autor resulta inestable, no sólo por aquello que se entiende como tal sino porque en su producción —obra "abierta", dinámica y en permanente actualización— participan varios agentes.

$\mathrm{Al}$ mantener una relación poco transparente con los acontecimientos, los martirologios requieren ser estudiados en función de los contextos históricopolíticos en los que se insertaron. Al retomar cada martirologio como unidad de estudio, mi análisis se despliega en tres aspectos; primero me detengo en el estudio de los procesos de producción, posteriormente analizo conjuntos representativos de imágenes seleccionadas para describir temáticas recurrentes y estrategias compositivas; en tercer lugar analizo las formas en que cada martirologio "media" entre las audiencias y los acontecimientos de violencia, proponiendo interpretaciones, significaciones y sentidos específicos. Antes de hacer el análisis son necesarias algunas precisiones conceptuales y metodológicas.

Io. David El Kenz, "Les Usages subversifs du martyre dans la France des troubles de religion: de la parole au geste", Revue de Sciences Humaines, núm. 269 (2003), 43.

II. Mukerji, "Printing, Cartography and Conceptions", 652. 
DOI: http://dx.doi.org/10.22201/iie.18703062e.2016.109.2623

IO4

CARLOS ARTURO SALAMANCA VILLAMIZAR

\section{Precisiones conceptuales y metodológicas}

Hayden White subrayó el papel central de la narración en la construcción de la historia y señaló la porosidad de las fronteras entre las formas y el contenido de la narración histórica. ${ }^{\mathrm{I2}} \mathrm{El}$ análisis dialéctico del acontecimiento y de su registro requiere asociar las significaciones y los sentidos a las formas materiales que las transmiten, reconociéndolas como unidad de sentido y como conjunto representacional en torno al cual se dan múltiples mediaciones. ${ }^{13}$ Por cesión del martirologio el mártir trasciende el círculo de los testigos, interpela a una comunidad más amplia y, convertido en arquetipo moral y espiritual, se proyecta en un horizonte espacio-temporal más amplio. ${ }^{14} \mathrm{El}$ martirologio reconstituye el martirio como acontecimiento trascendente y lo incorpora en una figuración narrativa sagrada. ${ }^{\mathrm{IS}}$

Trabajos recientes han subrayado que los martirologios tendieron a reproducir una imagen homogénea y simplificada de las comunidades religiosas ocultando, entre otros, sus particularidades regionales o locales, sus diferencias internas, así como la complejidad de las relaciones interconfesionales. ${ }^{16} \mathrm{No}$ obstante, análisis más recientes han señalado diversos campos de investigación que no se restringen a estudiar la veracidad de las narrativas y que se han demostrado fecundos.

I2. Hayden White, "El pasado práctico", en Verónica Tozzi y Nicolás Lavagnino, Hayden White. La escritura del pasado y el futuro de la historiografia (Buenos Aires: Eduntref, 20I2), 19-40, 32 y 38.

13. Roger Chartier, Escribir las prácticas. Foucault, De Certeau, Marin (Buenos Aires: Manantial, 2006).

I4. Diversos autores han mostrado que ni los misioneros ni la Iglesia mantuvieron el monopolio del uso de los mártires y de las reliquias. Véase, por ejemplo, Charlotte de Castelnau-L’Estoile, "Compartir las reliquias. Indios tupíes y jesuitas frente a los huesos de un misionero chamán en el Brasil de inicios del siglo XvII", en Guillermo Wilde, ed., Saberes de la conversión. Jesuitas, indigenas e imperios coloniales en las fronteras de la cristiandad (Buenos Aires: SB, 20II), 225-250; Kenneth Maxwell, "The Spark: Pombal, the Amazon and the Jesuits", Portuguese Studies I7 (200I): I68-I83; Pierre-Antoine Fabre, "Reliquias romanas en México, historia de una migración”, en Wilde, Saberes de la conversión, 205-224.

I5. Jean-Philippe Pierron, "La Dimension figurative du témoignage: l'exemple des premières martyres chrétiens", Revue de Sciences Humaines 269 (2003): 15-32, 3I.

I6. Al respecto, véase por ejemplo, Paul Quinn, "Richard Woodman, Sussex Protestantism and the Construction of Martyrdom”, en Art, Literature and Religion in Early Modern Sussex: Culture and Conflict, eds. Matthew Dimmock, Andrew Hadfield y Paul Quinn (Farnham y Burlington: Ashgate, 20I4), 195-220. 
En efecto, el análisis de la relación entre prácticas de violencia y representación ha tenido un crecimiento exponencial en los últimos años. ${ }^{17} \mathrm{Al}$ partir de investigaciones sobre la teatralización de la política ${ }^{18}$ y el papel del lenguaje $y$ discurso en las relaciones de poder ${ }^{19}$ me intereso en los martirologios tanto como medios así como en sus mediaciones; para glosar a Clifford Geertz, me propongo la exégesis de la violencia hecha una y otra vez con el insistente vocabulario ya no sólo del ritual sino de su representación. ${ }^{20}$

Diversas investigaciones recientes se han interesado en la influencia del desarrollo exponencial de la imprenta en las guerras de religión ${ }^{21} \mathrm{y}$ al orientarse a indagar en aspectos como la construcción social del sentido, se han detenido en el estudio de las representaciones en tanto componentes fundamentales de los procesos históricos y elementos constructores del orden social. ${ }^{22}$

Al hablar de mediaciones me refiero por una parte, al proceso de comunicación mediante el cual se imaginan, preparan, elaboran y ponen en circulación representaciones de la violencia por medio de los martirologios; asimismo, aludo a las formas en que quienes son sus destinatarios se relacionan con los acontecimientos de violencia mediante las narrativas que se hacen de aquéllas. En uno y otro caso me propongo analizar las relaciones sociales de producción y uso de discursos y representaciones en contextos particulares.

17. Stephen Eisenman, The Abu Ghraib Effect (The University of Chicago Press, 2007); Arthur Kleinman y Joan Kleinman, "The Appeal of Experience: The Dismay of Images: Cultural Appropriations of Suffering in Our Times”, Daedalus I25, núm. I (1996): I-23; José Emilio Burucúa y Nicolás Kwiatkowski, "Cómo sucedieron estas cosas". Representar masacres y genocidios (Buenos Aires: Katz, 20I4).

I8. Georges Balandier, Le Pouvoir sur scène (París: Fayard, 2006[1980]); Clifford Geertz, Negara. The Theater State in Nineteenth Century in Bali (Princeton University Press, 1980); Clifford Geertz, "Centros, reyes y carisma: una reflexión sobre el simbolismo del poder", en Conocimiento local, trad. Alberto López Bargados (Barcelona: Paidós, I994[1977]), I47-I72.

19. Geertz, "Centros, reyes y carisma”, 152.

20. Geertz, Negara, IO2.

2I. Véase Gabriele Haug-Moritz y Lotar Schilling, dirs., Médialité et Interprétation contemporaine des premières guerres de Religion (Berlín, Múnich y Boston: Walter de Gruyter, 20I4).

22. Roger Chartier y Jean Martin, Histoire de l'Édition française (París: Fayard, 1989); Burschel, Sterben und Unsterblichkeit, 220; Paul-Alexis Mellet y Jérémie Foa, "Le Bruit des armes: mises en formes et désinformations en Europe pendant les guerres de Religion, I560-I6IO", en Paul-Alexis Mellet y Jérémie Foa, eds., Actes du Colloque International, Tours, 5-7 novembre, 2009; David El Kenz, "La Mise en scène médiatique du massacre des huguenots au temps des guerres de Religion: théologie ou politique?", Sens Publique Revue Web, 24 de septiembre de 2006, consultado el I8 de enero de 20I6, www.sens-public.org/article333.html?lang=fr. 
DOI: http://dx.doi.org/10.22201/iie.18703062e.2016.109.2623

I06

CARLOS ARTURO SALAMANCA VILLAMIZAR

En los estudios contemporáneos sobre la representación de la violencia, uno de los ejes más prolíficos es el de los estudios de la memoria. Desde diversas perspectivas desarrolladas, muchas de ellas a partir de los trabajos de Michel Foucault, ${ }^{23}$ se ha reconocido la mediación como característica propia de las prácticas de la memoria y para referirse a "los medios" se ha hecho uso de distintas definiciones como "lugares", 24 "vehículos", 25 "artefactos", ${ }^{26}$ "tecnologías", 27 o "instituciones de poder". ${ }^{28}$ Estas denominaciones resultan insuficientes por tender a reproducir la idea dicotómica de emisores/receptores y a focalizar la observación en una de las partes, por detenerse exclusivamente en el medio o en su naturaleza, por no dar cuenta de las relaciones y de los vínculos que se establecen entre el medio y los agentes que intervienen, por ignorar que la producción del medio tiene un destinatario con el cual se busca, pretende o supone una relación o un vínculo específico, o por pasar por alto que las relaciones entre los actores intervinientes deben ser integradas al análisis del medio mismo.

Para mi análisis del martirologio como género de representación de la violencia religiosa he seleccionado tres obras: Acts and Monuments de John Foxe (I563), ${ }^{29}$ los 40 cuadros de Jacques Perrissin y Jean Tortorel $\left(\mathrm{I}_{570}\right)^{30}$ y El teatro de las cruel-

23. Entre otros, a partir de los conceptos de formación discursiva y dispositivo, véase Michel Foucault, Archeologie du savoir (París: Gallimard, 1969).

24. Pierre Nora, Les Lieux de mémoire (París: Gallimard, 1984), xIx y ss.

25. Paul Ricoeur, La memoria, la historia, el olvido, trad. Agustín Neira (Buenos Aires: Fondo de Cultura Económica, 2008), 498.

26. Javier Alejandro Lifschitz y Sandra Patricia Arenas Grisales, "Memoria política y artefactos culturales", Estudios Políticos, núm. 40 (2012): 98.

27. Karen Till, "Artistic and Activist Memory-work: Approaching Place-based Practice", Memory Studies I, núm. I (2008): IOI.

28. Benedict Anderson, Comunidades imaginadas, trad. Eduardo L. Suárez (México: Fondo de Cultura Económica, 2000), 228.

29. El análisis de la obra de Foxe que aquí se presenta ha sido realizado a partir de la edición de 1563 , editada en Londres por John Day y puesta en línea en el marco del proyecto "John Foxe" de la Universidad de Sheffield, https://www.johnfoxe.org/index.php? realm=info\&type=about \&gototype $=$ \&static $=$ works

30. Jacques Perrissin y Jean Tortorel, Premier Volume contenant quarante tableaux ou histoires diverses qui sont mémorables touchant les guerres massacres et troubles advenus en France en ces dernières années. Le tout recueilli selon les tesmoignage de ceux qui y ont esté en personne, et qui les ont veus, lesquels sont pourtrais à la verité (s.i., I570). 
DOI: http://dx.doi.org/10.22201/iie.18703062e.2016.109.2623

RELIGIÓN, POLÍTICA Y ESPECTÁCULO

dades de los heréticos de nuestro tiempo, en adelante El teatro de Verstegan. ${ }^{3 \mathrm{I}}$ He escogido estos martirologios en razón de su utilización de texto e imagen, por ser éstos tanto de origen protestante como católico, por estar inscritos en el despliegue del auge de la imprenta y por ser contemporáneos, lo cual permite el análisis transversal.

John Foxe, Acts and Monuments y el heroismo del héroe sin rostro

Acts and Monuments también conocido como el Book of Martyrs, del inglés John Foxe, es una publicación en la que se describen los martirios de los protestantes en Inglaterra a manos de los católicos en los acontecimientos desatados con la llegada de María I a la Corona que llevarían a la hoguera a más de 300 protestantes y al exilio a cientos de ellos. Es un trabajo de recopilación de poemas, cuentos, obras de la cultura popular, bulas papales y documentos oficiales que incluía material de archivo impreso, testimonios de testigos y pasajes de otros martirologios como el de Jean Crespin, publicado previamente. ${ }^{32}$

La obra se caracteriza, en primer lugar, por su proyección simultáneamente teatral y política, en función de la doble acepción del vocablo inglés acts. Por una parte, opera en un registro dramático y teatral (los actos) de las experiencias de suplicio. Por otra, en un registro histórico-político (las actas) en el que el martirio emerge como una acción pública deliberada, religiosa y política, planificada y ejercida colectivamente. ${ }^{33}$

La segunda característica del martirologio de Foxe es el interés compilatorio como criterio para dar forma a la obra; fue uno de los más difundidos y leídos de su tiempo con cuatro ediciones en inglés en el breve lapso de 20 años (I563, I570, 1576 y I583), antecedidas por dos obras preliminares en latín publicadas en I554 y I559. Ya desde 1563, año en que se integraron a la edición 53 grabados, los ejemplares del libro se dispusieron para el público en iglesias, escuelas, palacios y librerías privadas, ${ }^{34}$ mientras que circulaban como préstamo entre miembros

31. Richard Verstegan, Théatre des Cruautés des hérétiques de notre temps (París: Chandeigne, I995[I587]), consultado el I2 de marzo de 20I4, http://gallica.bnf.fr/ark:/I2I48/bpt6kio40506g.

32. Jean Crespin, Actes de Martyrs (Ginebra: imprenta de Jean Crespin, 1554).

33. Dominique Weber, "Dieu est-il anglais? La question du martyre dans la philosophie de Thomas Hobbes", Revue de Sciences Humaines, núm. 269 (2003): 207-230.

34. Isabelle Fernandes, "Les Représentations du martyr dans The Acts and Monuments de John Foxe”, Revue de Sciences Humaines, núm. 269 (2003): I34-I5I. 
DOI: http://dx.doi.org/10.22201/iie.18703062e.2016.109.2623

IO8

CARLOS ARTURO SALAMANCA VILLAMIZAR

de la corte. El Parlamento inglés adquirió ejemplares de la versión de 1570 para disponerlos en espacios públicos, mientras que la siguiente versión recibió la aprobación oficial, y se ordenó que el libro fuera colocado en iglesias de toda Inglaterra. Para reducir el precio del libro y facilitar una mayor distribución, la edición de 1576 se realizó en un papel más económico y en un formato más pequeño. Estas medidas hicieron de Acts and Monuments una obra popular, difundida rápidamente por toda la isla y luego por Europa. ${ }^{35}$ La obra contribuyó a la formación de una conciencia nacionalista inglesa forjada en torno a una identidad protestante y en oposición al catolicismo romano ${ }^{36}$ y fue fuente de manifiestos políticos de matriz religiosa al menos hasta finales del siglo XVII. ${ }^{37}$ En las procesiones londinenses en I680, por ejemplo, al pontífice se le representó sentado, con un pie en el cuello de un monarca postrado a sus pies, tal como había sido representado por Foxe un siglo antes..$^{8}$

En tercer lugar, el trabajo de Foxe ejemplifica la manera acelerada en que las imágenes adquirieron protagonismo en la representación de la violencia derivada de los conflictos religiosos. Para la década de 1570 su eficacia como herramienta para facilitar el acceso a los martirologios era reconocida por protestantes y católicos por igual; de hecho, años antes Lutero había separado claramente la idolatría y los excesos sacrílegos del uso pedagógico de las imágenes. ${ }^{39}$ En esta línea, la primera edición de Acts and Monuments se publicó en latín y sin imágenes lo que restringía su acceso, pero a partir de la segunda edición se fueron incorporando cada vez más imágenes hasta que en la edición de I570 se contaban más de IOO grabados. ${ }^{40}$

Una cuarta característica del martirologio de Foxe tiene que ver con la emergencia de las tensiones entre lo individual y lo colectivo. De firme fe protestante, cuando Foxe cumplió 35 años ya había publicado varios tratados políticoreligiosos, traducido a Lutero e intentado evitar — sin éxito— la ejecución de

35. David Loades, "The Early Reception”, John Foxe's Acts and Monuments On-line. HRI, consultado el 4 de julio de 20I3, www.johnfoxe.org.

36. John King, "Introduction", en Foxe's Book of Martyrs. Select Narratives (Oxford University Press, 2009), XI-XL.

37. Loades, "The Early Reception", s. p.

38. Recientemente se ha puesto en cuestión la influencia protestante en la identidad inglesa y la aceptación a ciegas de la oposición entre catolicismo e identidad británica. Véase Christopher Highley, Catholics Writing the Nation in Early Modern Britain and Ireland (Oxford University Press, 2008).

39. Deyon, "Sur Certaines formes", 17.

40. Fernandes, "Les Représentations du martyr", I47. 
protestantes en la hoguera. Al igual que para cientos de protestantes, el nombramiento de María I le significó el exilio. Foxe empezó un periplo por Amberes, Róterdam, Fráncfort y finalmente Estrasburgo, en donde inició su trabajo sistemático en la historia de los mártires. En efecto, el martirologio para Foxe representaba un asunto personal. Acts and Monuments es también el resultado de una empresa colectiva. Entre I554 y 1559 personajes político-religiosos como John Bale o Edmund Grindal que reunían historias de mártires y martirios impulsaron a Foxe a recopilar y difundir información sobre la violencia religiosa contra los protestantes. Entusiasmados con la primera edición, los familiares de los martirizados y muchos otros protestantes agradecieron a Foxe ofreciéndole testimonios de testigos directos, cartas de los mártires y otros recuerdos personales que se utilizarían en las ediciones siguientes.

En quinto lugar, el martirologio de Foxe aborda las tensiones por la veracidad y supremacía de la fe mediante múltiples operaciones compositivas. Para la construcción de la proyección histórica el autor vinculó a los mártires protestantes con los primeros cristianos perseguidos por el imperio romano evocando similitudes en las formas de violencia ejercidas. Simultáneamente, la alianza establecida por ese entonces entre la Iglesia católica y la monarquía española permitió ubicar a los católicos en el lugar de los victimarios, emparentarlos con los verdugos de los primeros cristianos y por extensión del mismo Jesucristo.

Foxe recurre a lecturas de opuestos dicotómicos para la crítica moral en varios grabados; en uno de ellos se presentan varias escenas en las que los papas aparecen con joyas y trajes lujosos rodeados de reyes y nobles en palacios y plazas ejerciendo con orgullo su poder, político o "temporal" que de acuerdo con la doctrina protestante era privilegiado por encima del poder espiritual (fig. 2). Estas imágenes reproducen la idea de la riqueza y el poderío político de la Iglesia católica, presente desde los inicios de la Reforma protestante -incluso desde la Edad Media - de la mano de los primeros cuestionamientos que hiciera Lutero en Wittenberg, en I517, respecto a la venta de las indulgencias.

La crítica moral también se manifestó bajo la forma de la narración en primera persona. En 1560 Foxe publicó de forma anónima la narración de un ficticio anticristo papal, en la que éste describía cómo había conquistado el poder y abusado del mismo. ${ }^{4 \mathrm{I}} \mathrm{A}$ Solemne contestation of divers Popes estaba compuesto de citas de bulas papales y otros materiales con los que se pretendía una apariencia 
DOI: http://dx.doi.org/10.22201/iie.18703062e.2016.109.2623

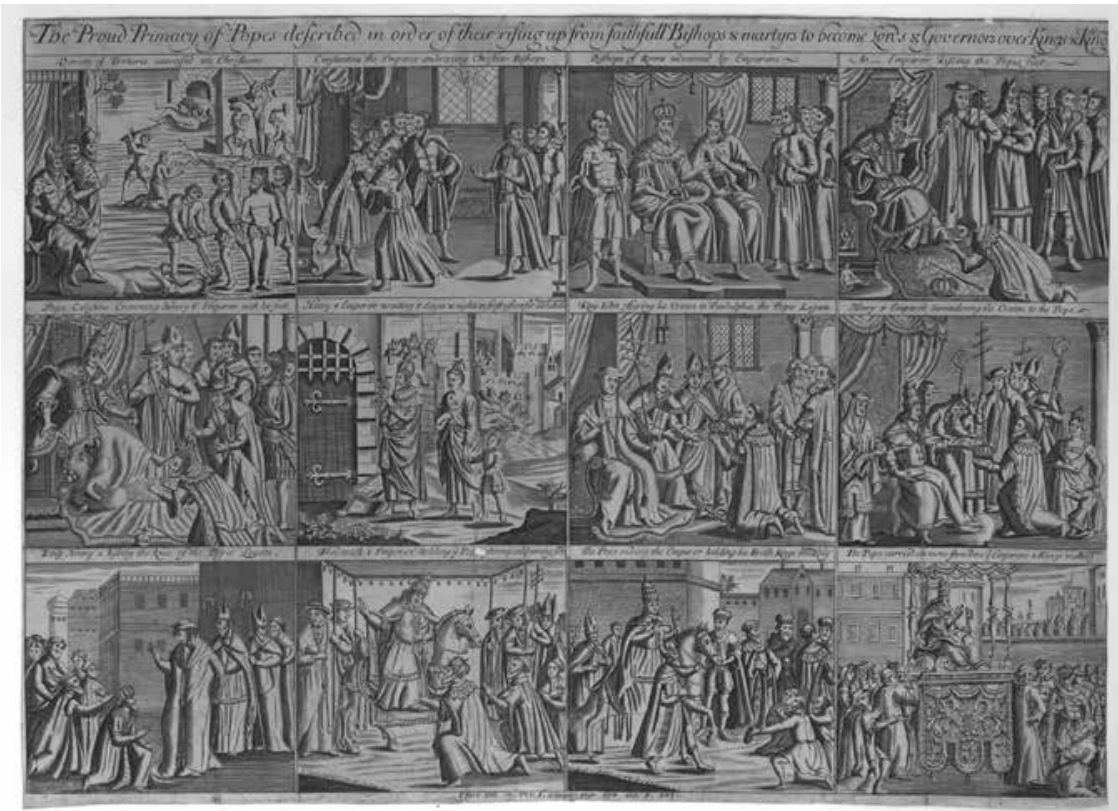

2. John Foxe, Descripción de la primacía del orgullo papal, grabado, $39 \times 55 \mathrm{~cm}$, tomado de Acts and Monuments, vol. I, I684, encarte entre los folios 884 y 885 . Londres, British Museum, núm. ref. 1994,0515.I2. (C) The Trustees of the British Museum CC-BY-NC-SA-4.O

de autenticidad. La publicación se imprimiría nuevamente meses después como parte del Acts and Monuments.

El grabado Descripción de la primacía del orgullo papal apareció en las ediciones de 1576 y 1583 e ilustra la incorporación del testigo activo; evocando obras emblemáticas, ${ }^{42}$ en la imagen aparece el rey sentado y observando los vejámenes contra los protestantes: en primer plano, un hombre arranca a otro un ojo, allí otro es latigado, un poco más allá, un tercero es decapitado (véase el primer recuadro de la figura 2). Al ilustrar los juegos de escala, esta imagen se publicó tanto de manera individual en las ediciones de 1576 y 1583 como integrada a

42. Entre otras, "El martirio de los diez mil cristianos", de Alberto Durero, I508, Museo de Historia del Arte de Viena y "Passional Christi und Antichristi", de Cranach, el Viejo, I52I, Biblioteca Nacional de Dinamarca y Copenhague, consultado el 20 de enero de 20I6, www.kb.dk/ en/nb/tema/webudstillinger/luther/passion/index.html. Para un análisis de la obra de Durero, véase: Burschel, Sterben und Unsterblichkeit, 28. 
una obra más amplia. La presencia de un hombre al ser devorado por leones y de otro crucificado hace del rey un testigo partícipe también de las violencias del pasado, de aquellas ejercidas por Roma contra los primeros cristianos. Una misma estrategia se utilizaría para convertir en testigos partícipes al papa y a los integrantes del clero; aunque sin ser protagonistas estos personajes se incorporan en tanto testigos partícipes en la interpretación sobre la violencia.

La última composición de la obra de Foxe es la síntesis de escenas en las que la crueldad y la violencia se exhiben en unidades autónomas. Ésta puede constatarse en imágenes que incorporan, refieren y citan otros grabados presentes en la misma obra como El emperador Enrique III humillado con su familia a las puertas de la ciudad de Canossa ${ }^{43}$ o El papa Alejandro pisando el cuello de Federico, el emperador. ${ }^{44}$ Estas imágenes dan lugar a mensajes que se hacen explícitos por asociación como la responsabilidad del emperador romano en la crueldad ejercida en contra de los primeros cristianos, o sus vínculos con la Iglesia católica. La figura 3 muestra, a la manera de un esquema descriptivo y didáctico, más de 30 prácticas de violencia en contra de cristianos primitivos que son aperreados, desmembrados, desollados, descuartizados, quemados vivos en hornos, casas, piras, parrillas y calderos, colgados o apedreados hasta la muerte. En continuidad con lo ya referido con respecto al primer recuadro de la figura 2, en este caso, la presencia de las figuras de papas y reyes a los costados de la imagen propone una síntesis necesaria para producir tres sentencias articuladas: el emperador y la Iglesia católica son figuras intercambiables, unos y otros ejercen las mismas formas de violencia, unos y otros atacan a los cristianos verdaderos (fig. 3).

Introduzco esta parte refiriendo la rapidez con la que se incorporaron las imágenes a la obra de Foxe; queda por analizar la manera en que se escenifica el martirio sin recurrir a la exaltación del mártir como tal ni dar lugar a interpretaciones erradas o idolátricas, una preocupación muy presente entre los protestantes.

Primero, los escenarios en los cuales los creyentes son martirizados son genéricos lo que impide una identificación de los creyentes con lugares específicos. Segundo, se utilizan las mismas imágenes para ilustrar el martirio de personajes diferentes, limitando la identificación popular con determinados mártires mediante imágenes específicas. La flexibilidad del vínculo entre el mártir y la

43. Foxe, Acts and Monuments, L. IV, fol. $4 \mathrm{I}$.

44. Foxe, Acts and Monuments, L. IV, fol. 56. 
DOI: http://dx.doi.org/10.22201/iie.18703062e.2016.109.2623

II2

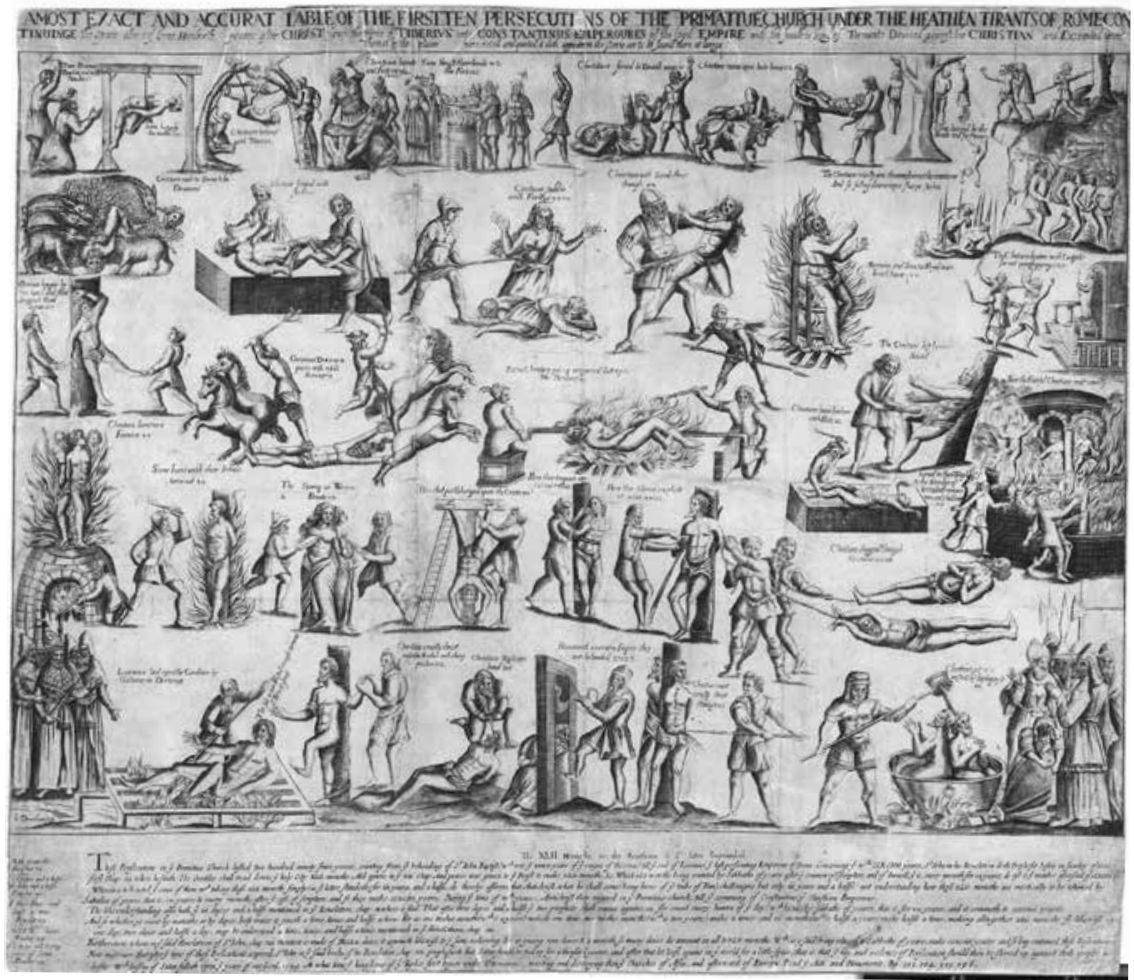

3. Anónimo, según John Droeshout, Una tabla más precisa y certera sobre las primeras diez persecuciones de la Iglesia primitiva bajo los tiranos paganos de Roma, grabado posterior a la edición de 1563, 3.98 $\times 4.92 \mathrm{~cm}$, tomado de John Foxe, Acts and Monuments, Londres, British Museum, núm. ref. I868, 0808.I3419. (C) The Trustees of the British Museum CC-BY-NC-SA-4.O.

representación de su martirio se observa también en imágenes que cambian con las ediciones. Una misma imagen (fig. 4) ilustra las dos operaciones. En el primer caso, esta imagen se utilizó para ilustrar no sólo el martirio de Christopher Shoomaker sino al de otros protestantes como Mill, Hytten y Stilman; repitiéndose siete veces en la edición de 1570 y nueve en la de 1583 . En el segundo, esta misma imagen, que se utilizó para ilustrar el martirio del obispo Farrar en la edición de 1563 , fue reemplazada por otra en la edición de 1570 . 
K. Hen, 8. Williwn Sweeting, fames Brewfer, and Chriflopher Shoonaker, Marigrs.

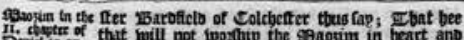

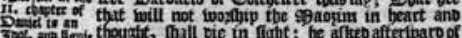

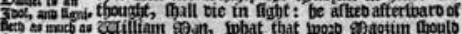

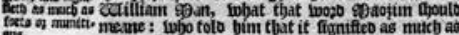
the matifing $\Theta_{00}$, to twit the sutrament of the Altar.

3ttan, that be hab unach conferente fitth gentrp jert, againt oblations ano 3 mages, ano tyat tt was better betioluse monep woticb was giben to the
pwise, than that that was offereo in pilgrtmage.

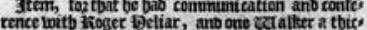
ker offaint elements, concerning bibers fatb mat: ters of pilgrimage, offering to 3 mages, ivosflip ping of sainte, ano tbe sacrament of the ailear.

pung of gaints, ano tbe sacrament of the aitar.

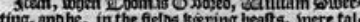
ting, anobe, in the ficlos the ping bealts, were tal king together of the facrament of the 2 ozos boobs

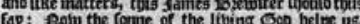
far: fow toe fome of the living Oco beipe us. ner, foto alturigbtic $\sigma_{00}$ to 00.

Ino tfus babe pou tbe caules littetuife ano crimes lapo atainf 3 ames 25 sctofter, upontinbich be imtith

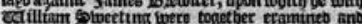
sonocumeb. Ében betng aftite, as the itounith mant nee is, lphetber be bab anp caule lwbe bee thould not be abjutoger for relapice ; be trutting to finoe fabout ano grace in fubrnitting bimselfe, faib, that bee fabuntttes bim to the mercio of Alurightie $\sigma_{00}$, ano to the fabourable goonetife of bim bis 3ubge.

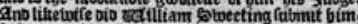
felfe; trutting bettite that thes thoulo finoe rom fabour ant relicfe it this bumble frubjecting them feloes unto theic gooutetie.

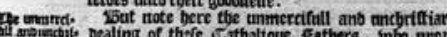

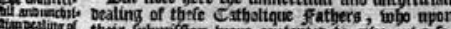

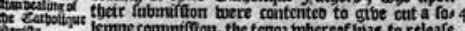
lemme comnifiton, the tenos whercof toas to releaf ant paroour tbem frain the fentence of excoinumunt cation, wibceutro tbeg bro incurre : But unmed atelgater upon toe fante, the 2bibop, all this net

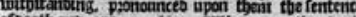

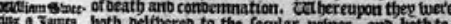

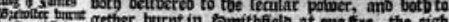
geter burnt in somitbitelo at one fire, the eigh - Chriftopher Shoomaker Martyr.

$T$ D tuefe blefreoraints befoye nanneb, be will alfo this 7 finoe bicfely in the

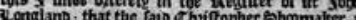
paritomer of great coimtonen cume to the bet, of Jobn sur, anb after of to bun out of a littie 5 solke the wozos which Chriet 60 fpalse to bis mirecinleg. In thas conmung to hit boure about foute times, at cocre time hee reas bim not to be becerven in the paiefts celebstion of Sgatie, ano octiaring that it mas not the rante bers

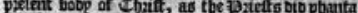
he; bet in fubetante breao, bearng the remem bjance of Chrift: and taught bim moseober, that pil. grimage, woskipving ano cetting up canoles to

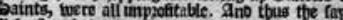
Kobn oar baing taugbt be tuis ebititopter, anval

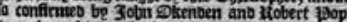
was byougbt to the anotoleste of the fame tDo

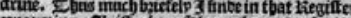

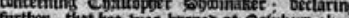

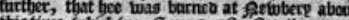

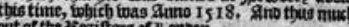
out of the jiesiofors of $L$ onbori.

If furning obet the 3aegifters ano zaerojos of

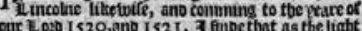
our L $0: 01520$, ano $152 \mathrm{I}$. 3 finbe tbat as the ligbt of the Eofpell tegan niope to appeare, anto tbe unm,
ber of the pzofetiogs to grotw, to tbe bebrnencie of perfecution, ant ititre of toe 1 sithops, begun atio to enereare. cabertupon enfued great perturbatt on ano griebous affitiotion in bivers anb finnogie quarters of this titealme, efipectallp abcut isnct ingbam ditre ano gameribom, varbyloge, Dents Petwberp, in the Dioctie of nonbon, in eficer, Colcbetter, Euffolthe, ano foztbolke, ano otber flaces ntce. Suno this was befoze the naine of Lu Eoce was bearo of in toece ccumtries among the peo. phe.

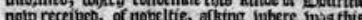
Churction

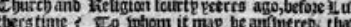
therstime? Eo mojom it map be aurfwerebs tbat

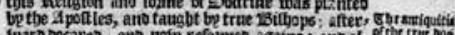

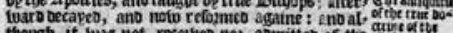
though it was not retribeo no3 aomitteb of the sicistil jaopes clergie befose 3 uthers time, neitber net is; pet it was recetbero of other, in tobefo bearts it pleafor the Lozo fecretto to wojke, ano that cf a

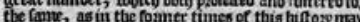
appeare. Andif tbes tounte this botrine be ? neis that it was not bearo of befose Luthers time, bot then came farb great perieruticn brfore entbers time bere in englano? zi theíe bere of the lams profeftion ibbicb tbee were of, then luas tbeic cruel tie unirearionable, to to periecute thetr ofune Cattio isque fraternitp. Ino if tbee twere otberwife, bolo

I The burning of Chrillopher Shoomaker.

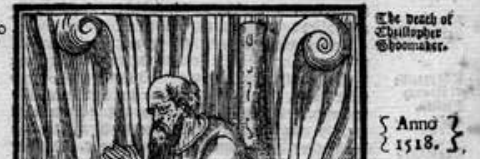

so

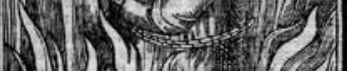

$\left\{\begin{array}{l}\text { Annd } \\ 1518 .\end{array}\right.$

4. John Foxe, El mártir protestante Christopher Shoomaker, grabado en madera, tomado de John Foxe, Acts and Monuments, edición posterior a la de 1563, fol. 3I. Londres, British Museum, núm. ref. I871, I209.64. (C) The Trustees of the British Museum CC-BY-NC-SA-4.O. 
DOI: http://dx.doi.org/10.22201/iie.18703062e.2016.109.2623

II4

CARLOS ARTURO SALAMANCA VILLAMIZAR

En tercer lugar, no existe una relación sacralizada con las imágenes: las mismas se alteraban, modificaban y editaban en cada nueva edición. ${ }^{45}$ La ya referida del protestante Christopher Shoomaker se utilizó para ilustrar la quema del obispo Farrar como repetida tres veces en el sentido horizontal para representar la muerte de otros protestantes.

Finalmente, lejos de orientarse a un protagonismo demasiado explícito del mártir las imágenes representaban martirios colectivos en escenas en las que se incluyen tres o más mártires, en momentos y lugares diferentes en una misma imagen, o incorporaban a la muchedumbre resaltando la dimensión colectiva del acontecimiento (fig. 5 ).

En síntesis, las principales características de la obra de Foxe son: la proyección simultáneamente teatral y política, la incorporación del criterio editorial en la forma misma de la obra, la importancia creciente atribuida a las imágenes, las tensiones entre lo individual y lo colectivo, y el despliegue de mecanismos representacionales mediante las cuales se pone en escena el martirio sin exaltar al mártir como tal. Aunque también elaborada desde "el punto de vista protestante", en su obra, Jacques Perrissin y Jean Tortorel prefirieron enfrentarse a otro desafío: contribuir a comprender "la verdad histórica".

\section{La historia en escena, los 40 cuadros de Jacques Perrissin y Jean Tortorel}

Jean Perrissin fue un pintor protestante lionés que se exilió en Ginebra a finales de la década de 1560 . Allí conocería a Jacques Tortorel, también francés, con quien sería contratado por dos empresarios textiles holandeses para la realización de imágenes sobre las guerras de religión en Francia entre 1562 y 1570. El contrato para la realización de la obra, firmado en 1569 , establecía la dedicación exclusiva de los artistas a quienes se les aseguraba un pago mensual y los insumos para la elaboración de los grabados; ${ }^{46}$ la colección se publicó el año siguiente.

Aunque recurrieron a varias estrategias de representación utilizadas por Foxe como la figura del "testigo activo" y el recurso de la multitud, los 40 cuadros presentan características particulares significativas. En primer lugar, tal como quedó consignado en la portada de la obra, sus autores pretendían resguardar

45. Loades, "The Early Reception”, s. p.

46. Philip Benedict, Graphic History. The Wars, Massacres and Troubles of Tortorel and Perrissin (Ginebra: Droz, 2007). 


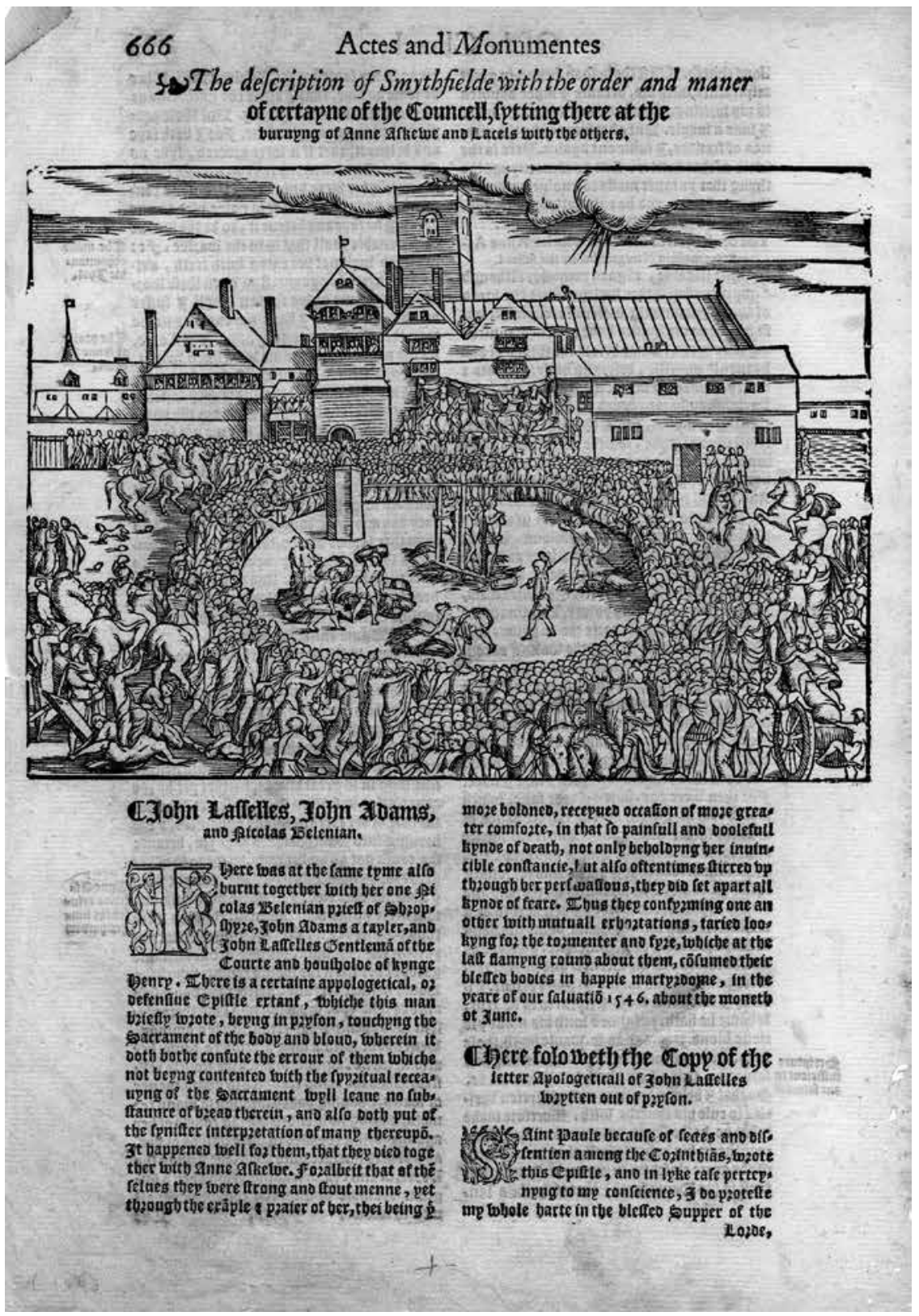

5. John Foxe, La descripción de Smythfielde con el orden y manera del innegable Consejo presente ante Anne Askew y Lacels entre otros que se calcinarían en la hoguera; grabado en madera, tomado de John Foxe, Acts and Monuments, siglo xvi, fol. 666. Londres, British Museum, núm. ref. I87I,I209.64 (C) The Trustees of the British Museum CC-BY-NC-SA-4.o. 
DOI: http://dx.doi.org/10.22201/iie.18703062e.2016.109.2623

la memoria de los acontecimientos: "para que la posteridad sea fielmente advertida, para que estas cosas [los hechos que ilustran los grabados] puedan estar siempre ante tus ojos". ${ }^{47}$ El que sólo "la verdad" sea digna de ser mostrada y recordada no es excepcional pues otros martirologios de la época se proponían objetivos similares; lo inusual en este caso es que se postula que la verdad sólo es posible si se preserva de las pasiones que conducen al engaño. Vemos aquí una voluntad manifiesta de contribuir a la comprensión de los acontecimientos.

En segundo lugar, la obra persigue la verdad histórica y lo hace por medio de unas imágenes que, lejos de limitarse a ilustrar el texto escrito, se presentan como emancipadas del mismo. ${ }^{4}$ En este marco, el espacio adquiere un protagonismo activo por medio de elementos como el fuego, el humo, las aguas agitadas, las murallas y los castillos destruidos, que dan cuenta del dramatismo de una escena, de la adversidad de una situación o de lo sorpresivo de un ataque (fig. 6).

Una tercera característica se vincula al interés de los artistas por ofrecer una síntesis clara de los sucesos, para lo cual recurrieron a imágenes panorámicas, perspectivas y vistas a vuelo de pájaro. En composiciones que resultan del entrecruzamiento de los registros cartográfico, teatral y pictórico (fig. 7), proponen imágenes que evidencian el uso de la perspectiva, los cortes transversales, las relaciones entre espacios públicos y privados, y la disposición de los personajes en patios, salones, castillos, periferias de ciudades y poblados, cuyas características se describen con detalle en busca de realismo y autenticidad.

La problematización del vínculo entre acontecimiento y representación da lugar a la cuarta característica de la obra. Las variaciones de los límites espaciales y temporales de las imágenes invitan a reflexionar sobre la naturaleza del suceso; un primer grupo de imágenes se distingue por recurrir a una escala "ampliada" en la que se incorpora la representación de decisiones o acontecimientos políticos vinculados a los hechos de violencia (fig. 7).

De manera opuesta, un segundo grupo de imágenes representa las prácticas de violencia con una visión "restringida" sin incluir ningún otro tipo de referencia (fig. 8). Este juego de escalas se desarrolla tanto en términos espaciales (res-

47. "Présentation générale de l'oeuvre de Tortorel et Perrissin", Dossier réalisé par le service éducatif de la Médiathèque du Grand Troyes, 2, consultado el Io de septiembre de 2016, www. cndp.fr/crdp-reims/fileadmin/documents/preac/patrimoine_mediatheque_troyes/Commentaire_des_gravures_BR.pdf.

48. Philip Benedict, Lawrence Bryant y Kristen Neuschel, "Graphic History: What Readers Knew and Were Taught in the 'Quarante Tableaux' of Perrissin and Tortorel”, French Historical Studies 28, núm. 2 (2005): 175-229. 
DOI: http://dx.doi.org/10.22201/iie.18703062e.2016.109.2623

RELIGIÓN, POLÍTICA Y ESPECTÁCULO

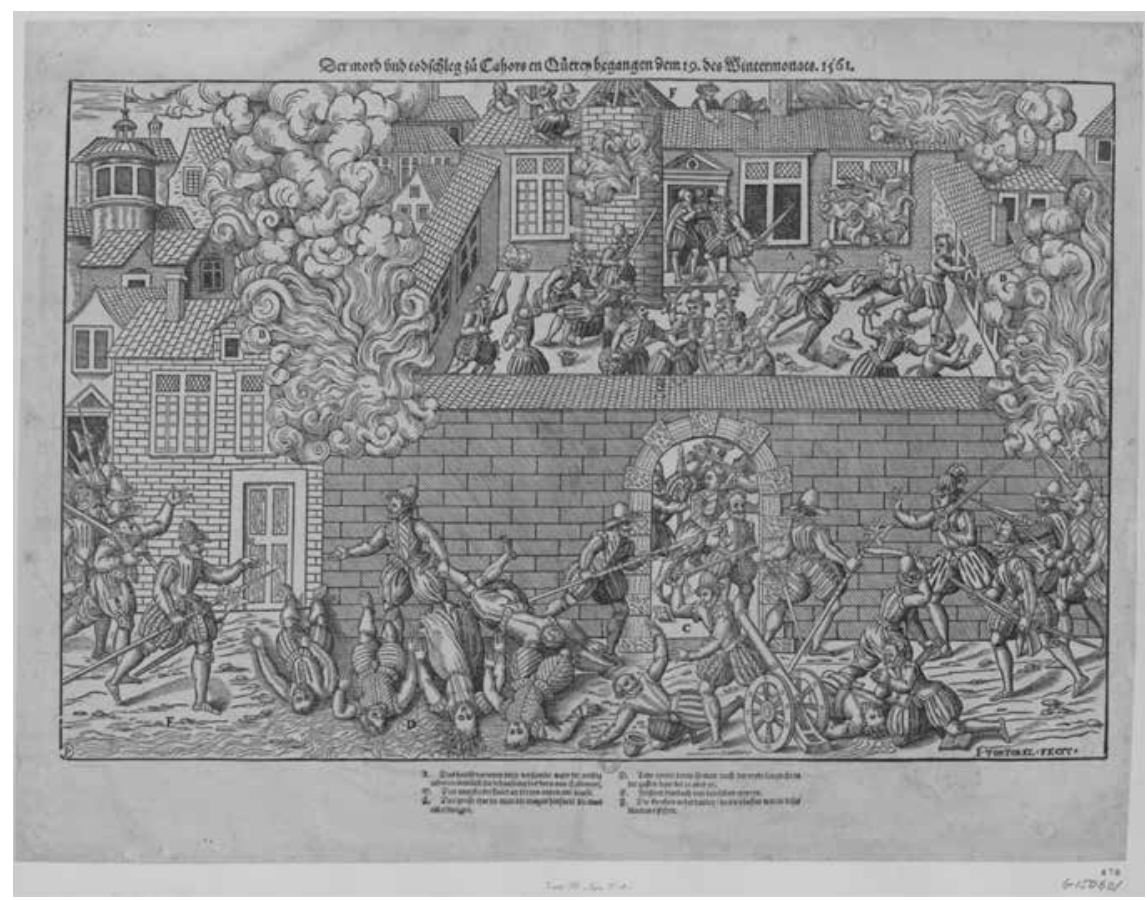

6. Jacques Tortorel, La matanza y asesinatos en Cahors, disputas que comenzaron el I9 del mes invernal de 1561 , s.i. 1570 , grabado en madera, $20 \times 27 \mathrm{~cm}$. (C) Bibliothèque Nationale de Francehttp://gallica.bnf.fr.

pecto a eventos ocurridos en distintos lugares) como temporales (con relación a sucesos de diferentes momentos); en uno y otro caso, y tanto en su versión expandida como restringida, las imágenes se componen mediante múltiples unidades de paisajes caracterizados por la sincronía representacional, una técnica común de la época, ${ }^{49}$ que consiste en descomponer el acontecimiento general de episodios puntuales. Las imágenes no presentan los hechos en una secuencia de sucesos cronológicamente ordenados ni se organizan en función del tiempo. Más bien, éstos se muestran respecto del espacio compositivo y la separación de las unidades se resuelve incorporando dichos episodios a una misma composición y resguardando así la idea de totalidad del acontecimiento.

49. Bucher ha denominado a un artificio similar el "método rotativo". Véase Bernadette Bucher, La Sauvage aux seins pendants (París: Hermann, 1977), 33-34. 
DOI: http://dx.doi.org/10.22201/iie.18703062e.2016.109.2623

II8

CARLOS ARTURO SALAMANCA VILLAMIZAR

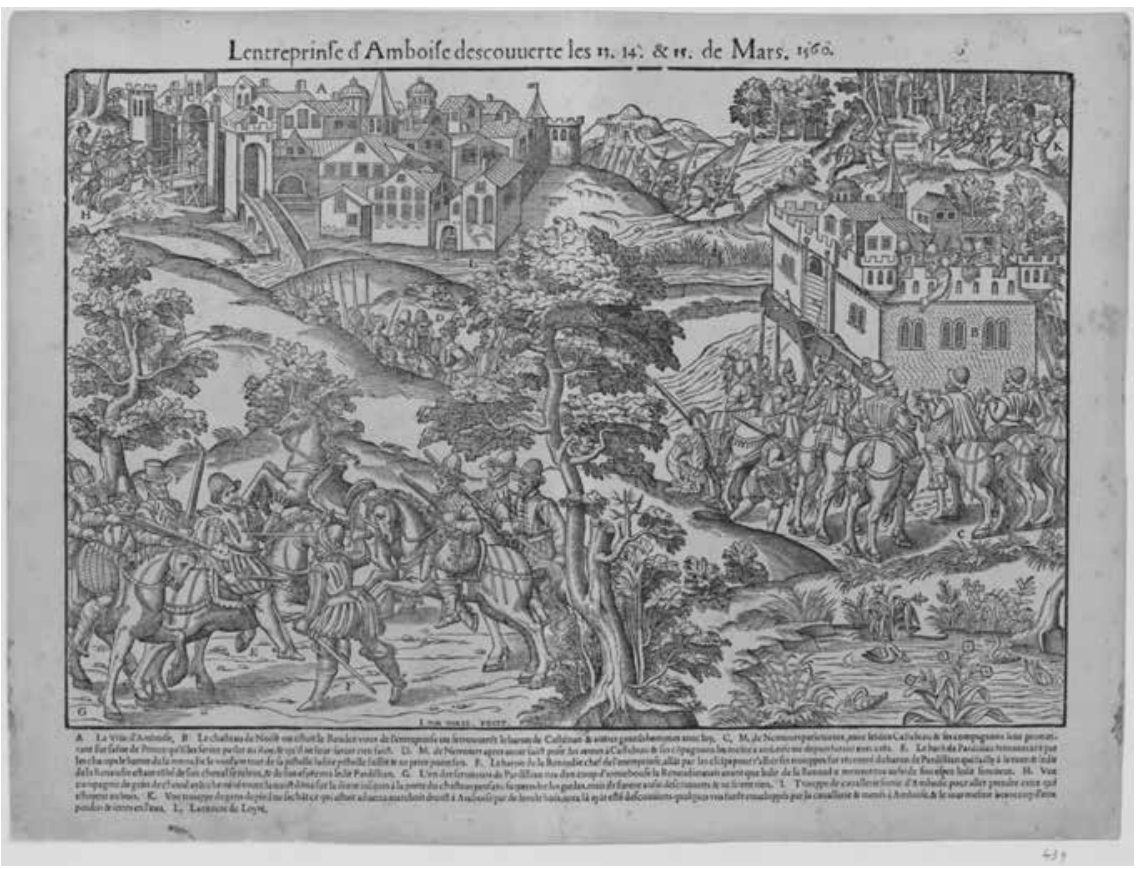

7. Jacques Tortorel, La conjura de Amboise descubierta el I3, I4 y IS de marzo de I560, I570, grabado en madera, $20 \times 27 \mathrm{~cm}$. (C) Bibliothèque Nationale de France-http://gallica.bnf.fr.

En La matanza y asesinatos en Cahors, disputas que comenzaron el ig del mes invernal de I56I, La conjura de Amboise descubierta el I3, I4 y I5 de marzo de I560 y en La derrota de la batalla de Moncontour se ejemplifica la versión expandida, en $\mathrm{La}$ masacre en Nismes en Languedoc el I de octubre de 1567 por la noche, la restringida. Para no extenderme describo solamente la figura 9 que constituye un punto intermedio y retoma elementos de ambos aspectos: desde el punto de vista del espacio la imagen registra lo que sucede en el tejado, los muros, la puerta o el lugar central de la construcción, en su perímetro, e incluso un poco más allá. En la sucesión temporal se han incluido imágenes sobre el inicio del ataque, las desdichas de un hombre, el terror de una mujer, la muerte en masa, el periplo de alguien que huye, y del cardenal de Lorraine, que, apoyado en el borde de un muro, observa a distancia la masacre. 
DOI: http://dx.doi.org/10.22201/iie.18703062e.2016.109.2623

RELIGIÓN, POLÍTICA Y ESPECTÁCULO

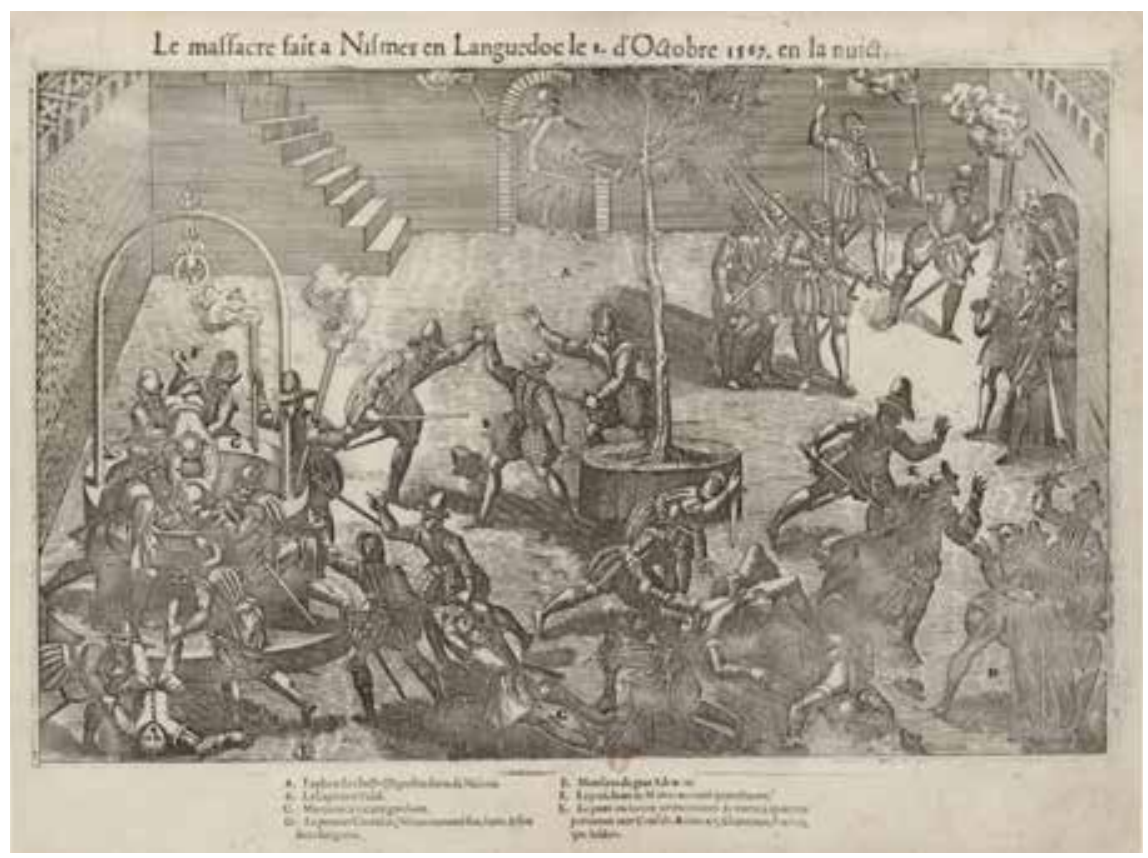

8. Jacques Tortorel, La masacre en Nismes en Languedoc el I de octubre de 1567 por la noche, 1570, grabado en madera, $20 \times 27 \mathrm{~cm}$. (C) Bibliothèque Nationale de France-http://gallica.bnf.fr.

Quinta característica. A diferencia de la obra de Foxe que exhibe un claro posicionamiento frente a las tensiones religiosas, en Perrissin y Tortorel la verdad histórica se superpone a la lectura teológica. Para esto recurren a la construcción de acontecimientos históricos con ubicaciones espacio-temporales específicas, la incorporación en el título de cada grabado del lugar y la fecha de los acontecimientos, la identificación explícita de los protagonistas y, en general, de todos los episodios representados a partir de un sistema de referencias y notación por medio de letras (fig. 8).

Esta voluntad de historicidad se constata en la secuencia que puede establecerse entre las imágenes mismas. Los grabados refieren acontecimientos históricos sucedidos entre 1559 y I570; de ellos, I2 son sobre los acontecimientos que llevaron a la primera guerra de religión en la primavera de 1562 , mientras que otro grupo de 15 versa sobre las tres primeras guerras de religión (I562-1563, I567-I568, y I568I570), el resto se dedica a ataques, emboscadas y otras confrontaciones. 
DOI: http://dx.doi.org/10.22201/iie.18703062e.2016.109.2623

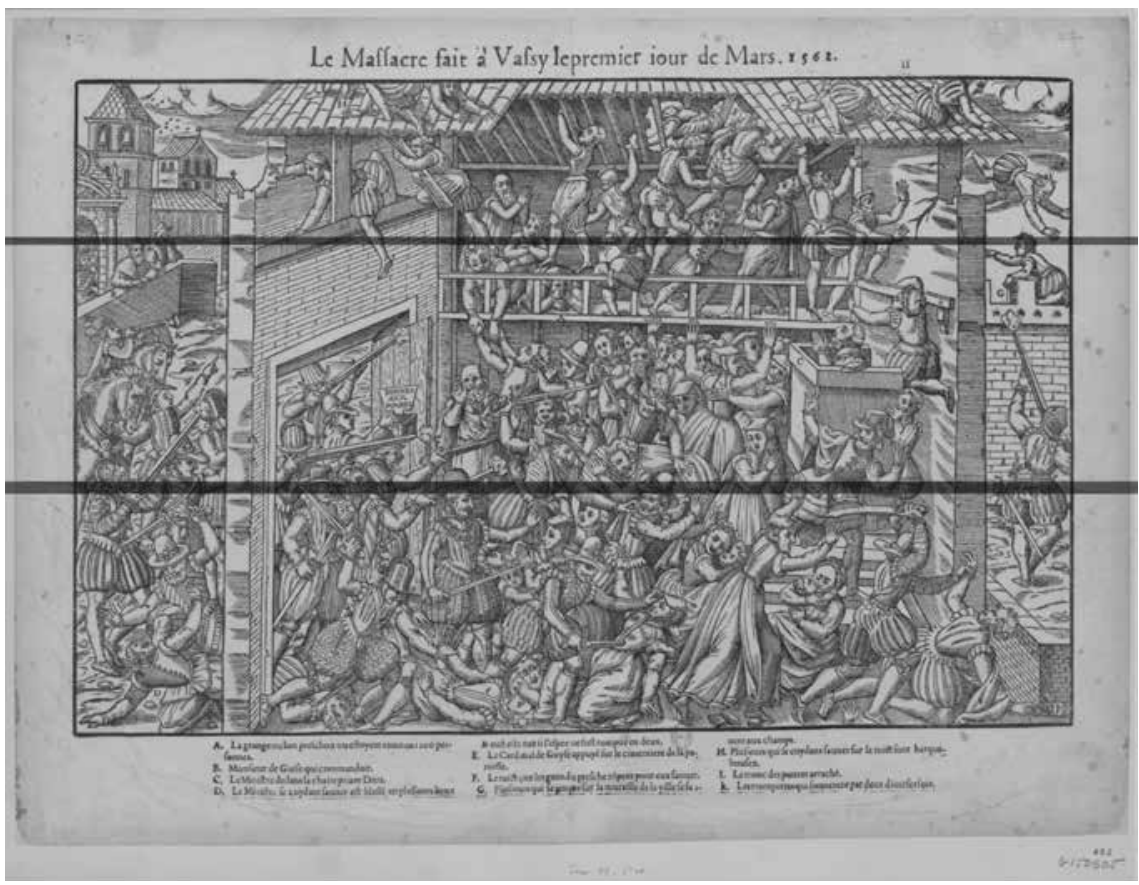

9. Jacques Tortorel, La masacre en Vassy el primero de marzo de 1562 [1569], I570, grabado en madera, $20 \times 27 \mathrm{~cm}$. (C) Bibliothèque Nationale de France-http://gallica.bnf.fr

Una sexta característica de los 40 cuadros que se deriva de la anterior se vincula con el posicionamiento de los artistas frente a la violencia. En su colección, Perrissin y Tortorel incluyeron un acontecimiento en el que la violencia es ejercida por el grupo religioso al que, en principio, pertenecen; se trata de la masacre de la Michelade en Nismes en la que un grupo de protestantes mató a I2O cristianos, tirándolos en pozos (fig. 8). El registro de este acontecimiento requiere del desplazamiento del énfasis en la emoción (la identificación con las víctimas, la descalificación moral de los otros en tanto victimarios) al de la comprensión del suceso por parte de sus realizadores. La narrativa subyacente aquí no es una crítica monolítica a la crueldad y los excesos de violencia de un otro visto como adversario. Más bien, se trata de una descripción que, alejándose de las perspectivas particulares de hechos singulares, propone leer las violencias más allá de las posiciones circunstanciales que católicos o 


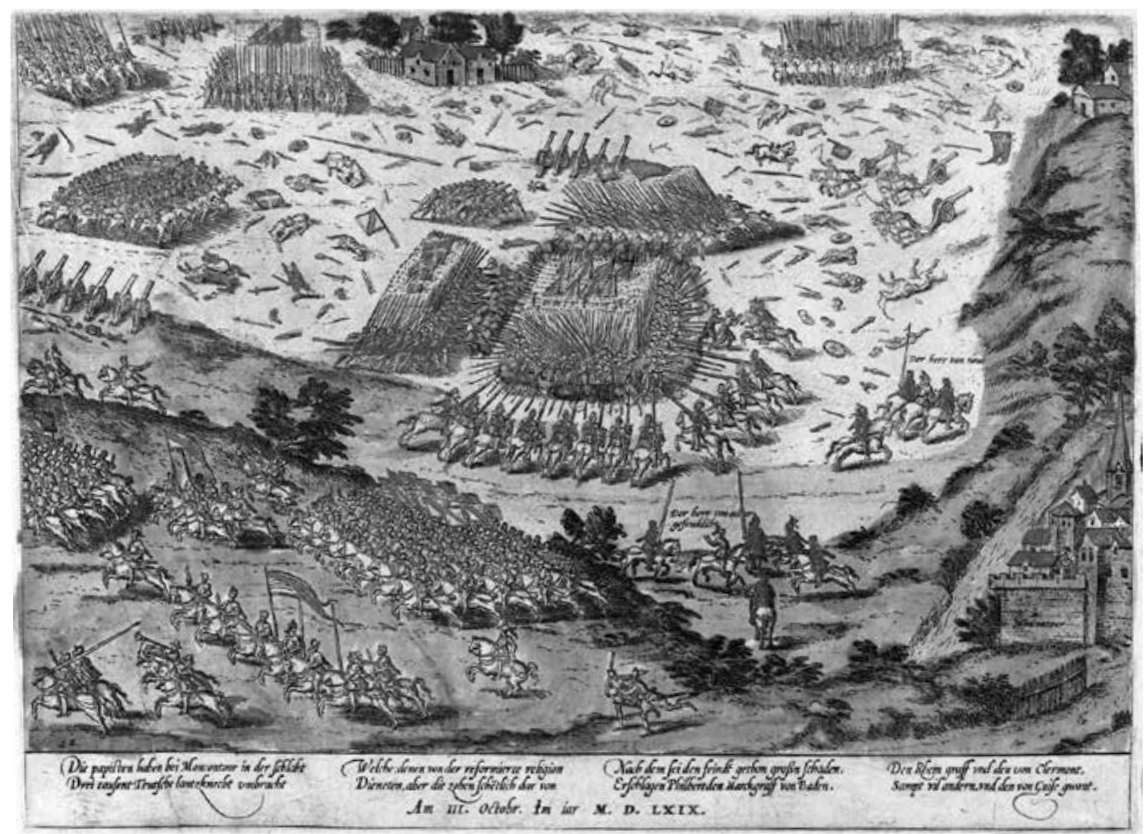

IO. Frans Hogenberg a partir de la obra de Tortorel y Perrissin, La derrota de la batalla de Moncontour, siglo xvi, aguafuerte, $20 \times 27 \mathrm{~cm}$. (C) Musée National du Château de Pau. Réunion des Musées Nationaux-www.photo.rmn.fr.

protestantes pueden ocupar en las casillas de victimarios y de víctimas. Así, los artistas enmarcan las violencias como un "enfrentamiento fratricida", una guerra entre "ejércitos franceses luchando el uno contra el otro" (fig. Io)..$^{50}$

Podría sugerirse que este cambio responde a razones prosaicas como las características del mercado editorial en expansión: haciendo uso de cierta neutralidad, la publicación alcanzaría un público tan internacional como multiconfesional. Asimismo, podría decirse que este cambio da cuenta de unas audiencias que, de la mano de la emergencia del pensamiento moderno, se despojaban poco a poco de la religión como marco interpretativo. Es posible afirmar también, que se vincula con lo antojadizo de la confesionalidad de dos artistas protestantes que apenas una década después de la publicación de

50. Benedict, Graphic History, 8. 
DOI: http://dx.doi.org/10.22201/iie.18703062e.2016.109.2623

$\mathrm{I} 22$

su obra, se adscribirían al catolicismo. Responder a este interrogante sobrepasa los objetivos de este trabajo. No obstante, es pertinente subrayar que la tesis de la secularización (del mercado, de las audiencias, de los marcos interpretativos, de los autores) dejaría sin explicar el éxito editorial que por los mismos años cosechaban los martirologios que movilizaban las pasiones religiosas. De igual manera, la conversión religiosa de los artistas protestantes podría interpretarse a la luz de la hostilidad que durante esos años encontraban los protestantes en el país galo al ser la masacre de San Bartolomé ocurrida en agosto de 1572 el evento emblemático de tal animadversión.

La obra trasciende el relato que sitúa la crueldad exclusivamente en el otro y que excluye a ese otro — violento, cruel, amenazante — de la comunidad de sentido en la que la verdad teológica predomina por sobre la histórica. Asimismo, con un discurso más descriptivo que propagandístico, las imágenes proponen una postura moderada, sin referencias emotivas o expresiones de autoexaltación..$^{\text {I }}$

La última característica tiene que ver con la noción de la autoría. En $L a$ derrota de la batalla de Moncontour (fig. Io) propongo al lector acceder a los 40 cuadros por medio de otro artista, el alemán Frans Hogenberg, quien elaboró sus obras a partir de las de aquéllos. Los mismos Perrissin y Tortorel se apoyaron en los trabajos de Jean Vredeman de Vries para componer algunas de sus obras y durante la época había "motivos" que eran retomados una y otra vez por artistas como François Dubois y Antoine Caron..$^{52}$ En este caso, la autoría se hace relativa en razón de los múltiples agentes que intervienen en la producción de la obra.

Interés por la verdad histórica, inteligibilidad de la violencia mediante las imágenes, entrecruce de registros representacionales, problematización del acontecimiento, voluntad de historicidad y desdibujamiento de los límites clásicos del autor son los aspectos que sobresalen de la obra de Perrissin y Tortorel. Me ocuparé ahora de la obra de Verstegan que a diferencia de los martirologios ya analizados se elaboró desde "el punto de vista católico".

5I. Benedict, Graphic History, 26.

52. Jean Ehrmann, "Massacre and Persecution Pictures in Sixteenth Century France", Journal of the Warburg and Courtauld Institutes, núm. 8 (1945): 197. 
DOI: http://dx.doi.org/10.22201/iie.18703062e.2016.109.2623

RELIGIÓN, POLÍTICA Y ESPECTÁCULO

Verstegan y $\mathrm{El}$ teatro de las crueldades. La crueldad es puesta en escena

Richard Rowlands, más conocido como Richard Verstegan o Verstegen, nació en Londres en I548. Hijo de un inmigrante alemán católico, su infancia y juventud estuvieron marcadas por experiencias personales que daban cuenta de la creciente hostilidad que los católicos encontraban en Inglaterra. Cuando cumplió 30 años, Verstegan ya había publicado panfletos denunciando la muerte y los sufrimientos de sacerdotes católicos en Inglaterra, en los que los reconocía como mártires; en I58I contribuyó para la elaboración de un panfleto sobre el jesuita Edmund Capion ahorcado y descuartizado en Londres por orden de la reina Isabel I de Inglaterra después de negarse a la apostasía. Descubierta su participación, fue desterrado. Entre 1581 y 1584 Verstegan vivió en Rouen, Reims y París, en donde hizo varias publicaciones similares. En 1584, fue arrestado en París a solicitud del embajador inglés, acusado de ofender a la reina misma de Inglaterra con sus imágenes; después de una breve temporada en prisión, ese mismo año viajó a Roma en donde se sometió a la protección del papa Gregorio XIII.

Allí, Verstegan encuentra una ciudad en la que por esos años se redescubrían las catacumbas y las reliquias de los primeros mártires, se reeditaba el martirologio romano y se incorporaba la figura del mártir en la renovación de muchas iglesias en el marco de la preparación de la celebración del Jubileo de 1600.53

Theatrum crudelitatum haereticorum nostri temporis (El teatro de las crueldades de los heréticos de nuestro tiempo) se publicó en 1587 en Amberes, convertida en bastión católico después de su reconquista por las tropas de Felipe II en 1585. La publicación cuenta con 29 imágenes elaboradas por el grabador flamenco Jan Wierix a partir de bosquejos de Verstegan. Las imágenes consisten en la reproducción de escenas de martirio y tormentos sufridos por los católicos, ${ }^{54} \mathrm{y}$ puede reconocerse como una respuesta a los martirologios de Crespin, Foxe, Perrissin y Tortorel.

El teatro fue una pieza fundamental en la iconografía católica de finales del siglo XVI y varios autores han señalado la continuidad entre El teatro y otros conjuntos artísticos como los frescos de Tommaso Cavalieri de la iglesia de San

53. Rodríguez G. de Ceballos, "El mártir, héroe cristiano", 89. Véase también Mónica Montoro Castillo, "Los oratorianos de San Felipe Neri y los inicios de la arqueología cristiana," CuPAUAM, núm. 34 (2008): 150.

54. El análisis se realizó a partir de la edición de 1592 del Theatrum crudelitatum haereticorum nostri temporis. 
DOI: http://dx.doi.org/10.22201/iie.18703062e.2016.109.2623

Estefano Rotondo en Roma, centrales en las representaciones del martirio del siglo XVI europeo. 55

Los grabados retoman el dispositivo dramático anunciado desde el título, explicitando el propósito de "hacer ver", y apelando a los protagonistas como joueurs, en la doble acepción del vocablo en francés de quien juega y de quien interpreta una pieza teatral.

Señores, hemos construido este teatro para presentarles las miserables tragedias que los herejes han actuado en nuestra Europa, y para hacerles ver aquello que han cometido y perpetrado [...] Ustedes los verán satisfaciéndose con derramar, regar y extraer la sangre humana, [y] bañarse, adobarse [y] regocijarse en la abundancia [...] Así verán a los herejes en este Teatro, sangrientos, humeantes, con mucho polvo, regresando de cazar católicos. ${ }^{56}$

El teatro propone entre las audiencias y los protagonistas de las imágenes una relación basada en la ejecución y la observación de un performance, apela a la emoción por encima de la comprensión del acontecimiento y privilegia el espacio teatral al geográfico. Por medio de estas operaciones se promueve un lector/espectador conmovido, escenografías imparciales e imágenes que proponen un argumento más dramático que explicativo sobre las violencias de los protestantes. ${ }^{57}$

Verstegan pone en escena la crueldad explícita y directa sin ambigüedades ni matices, en busca del efecto retórico que se deriva de una exposición reiterativa de actos de martirio. Pero a diferencia de Foxe y su interés en las víctimas y sus sufrimientos, en El teatro el acento está puesto en los victimarios y sus crueldades, siendo éstos y no los mártires los protagonistas: "Hemos construido este Teatro", dice el autor en la introducción, "con el fin de representarles las mise-

55. Véase, por ejemplo, Lestringant, "Témoignage et martyre”, II3 e Isabelle Engammare, "Le Théâtre des Cruautés des hérétiques de notre temps de Richard Verstegan", en Bibliothèque d'Humanisme et Renaissance 58, núm. I (1996): 305-307, 306.

56. "Messieurs, nous avons dressé ce théâtre afin de vous représenter les misérables tragédies que les hérétiques ont joué en notre Europe, et pour vous faire voir ce qu'ils ont commis et perpétré [...] Vous y verrez les joueurs se plaire à répandre, à verser, à tirer le sang humain, s'y baigner, s'y étuver, se réjouir en l'abondance [...] Tel verrez-vous les hérétiques sur ce théâtre, sanglants, fumeux, poudreux, revenant de la chasse de catholiques" (Verstegan, Théatre des Cruautés, 49,50, el subrayado es mío).

57. Lestringant y Moreau, "Overture", IO. 
rables tragedias que los heréticos han actuado en nuestra Europa, y para hacerles ver aquello que han cometido y perpetrado"..$^{8}$

En El teatro, lugares, tiempos y circunstancias pasan a un segundo plano; aunque en algunos casos los subtítulos de los grabados dan indicios de la localización de los acontecimientos, éstos son generales y poco precisos. Mientras que en la escena principal una larga sucesión de cuerpos son emasculados, colgados, despellejados, descuartizados y quemados. Monjes, sacerdotes o creyentes, las víctimas parecen ser siempre las mismas, abnegadas e inocentes. Los espacios anodinos y los cuerpos sufrientes constituyen el escenario propicio para resaltar el protagonismo de los victimarios que parecen acudir rutinariamente a cumplir su papel con la naturalidad de quien practica una tarea cotidiana, haciendo aún más explícita la violencia.

La profanación de símbolos y espacios religiosos es un tema que, inexistente en los martirologios protestantes analizados, hace su aparición en El teatro. En cinco de los 29 grabados los atacantes se empeñan en la destrucción de iglesias y objetos sagrados (fig. II).

La representación de la "poderosa violencia sacrílega" 59 en varias imágenes se refiere a la tensión entre los protestantes que propugnaban por la separación entre la "verdadera doctrina" y los objetos de representación, y los católicos que insistían en la imposibilidad de tal separación y calificaban la violencia iconoclasta como herética. La controversia acerca de la doctrina y su representación, parafraseando a Giorgio Agamben, era entre separar algo que no debía estar unido y en mantener unido aquello que originalmente lo había estado. ${ }^{60} \mathrm{Me}-$ diante la destrucción, los protestantes se proponían separar signo y significado

58. Lestringant, "Témoignage et Martyre", II9-I2O.

59. Todd Olson, "Pitiful Relics: Caravaggio’s Martyrdom of St. Matthew”, Representations 77, núm. I (2002): IO7-I42, I28.

6o. De acuerdo con Agamben, en la máquina del sacrificio, sagrado y profanado se representa un sistema de dos polos en los cuales transita un significado que aunque flotante, no deja de referirse a un mismo objeto. La formulación tiene que ver con dos operaciones: una consagratoria en la cual el poder es garantizado mediante la referencia a un modelo sagrado, y una profanatoria por la que se desactivan los dispositivos de poder. Ambas operaciones se caracterizan por una ambigüedad constitutiva. Tanto en la operación consagratoria como en la profanatoria persisten residuos, tanto de profanidad en toda cosa consagrada, como de sacralidad en cada objeto profanado. Esta persistencia de lo inacabado, de lo nunca definitivo, explica la necesidad de reiteración de toda operación. Una y otra vez, el martirologio se propone ya unir aquello que ha sido separado, ya separar aquello que ha sido unido. Véase Giorgio Agamben, Profanaciones, trads. Flavia Costa y Edgardo Castro (Buenos Aires: Adriana Hidalgo Editora, 2005), Ioo. 


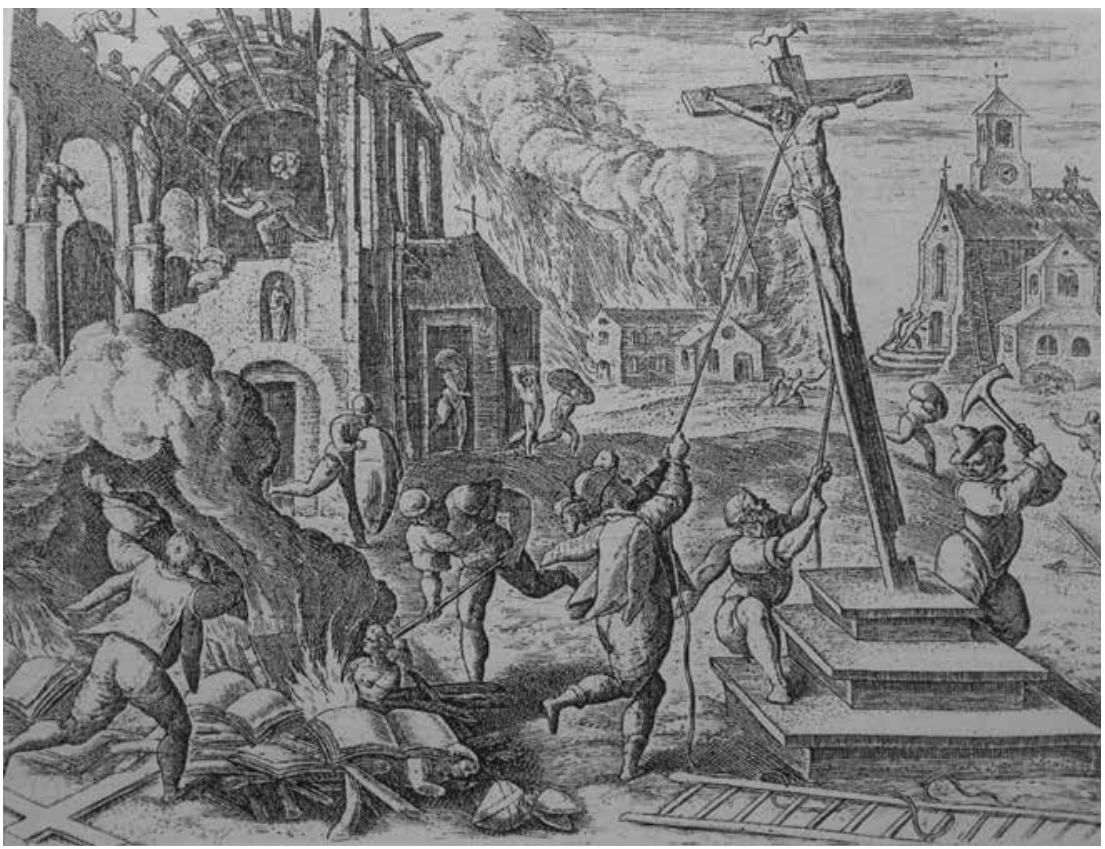

II. Anónimo, El nuevo fruto del Evangelio, 1588 [I557], I3, calcografía, I2 $\times 15 \mathrm{~cm}$, atribuido en primer término a Verstegan; también a Wierix a partir de los bosquejos de Verstegan. (C) Bibliothèque Nationale de France-http://gallica.bnf.fr.

cuya unión les resultaba sacrílega y neutralizar así el signo que considerado sagrado, profanaba. Al reconocer tal destrucción como herética, los católicos mantenían dicha unión originaria.

La importancia acordada a la profanación se produce además en un contexto marcado por el redescubrimiento de las catacumbas romanas que puso de relieve las disputas por unir y separar: las reliquias con la sacralidad, los primeros mártires con aquellos que mueren en el presente a manos de sus enemigos religiosos, el inframundo de las catacumbas con la superficie, los primeros cristianos y las "últimas fronteras" en donde los misioneros se enfrentaban al martirio. ${ }^{61}$

6I. Carlos Salamanca Villamizar, "Herejes e infieles: imaginación etnográfica, experiencia histórica y prácticas comunicativas de la alteridad en la obra de De Bry", Revista Brasileira de História das Religióes 7, núm. I9 (2014): 9I-I06; Gérard Labrot, L'Image de Rome: une arme pour la Contre-Réforme, 1534-1677 (París: Champ Vallon, 1987). 


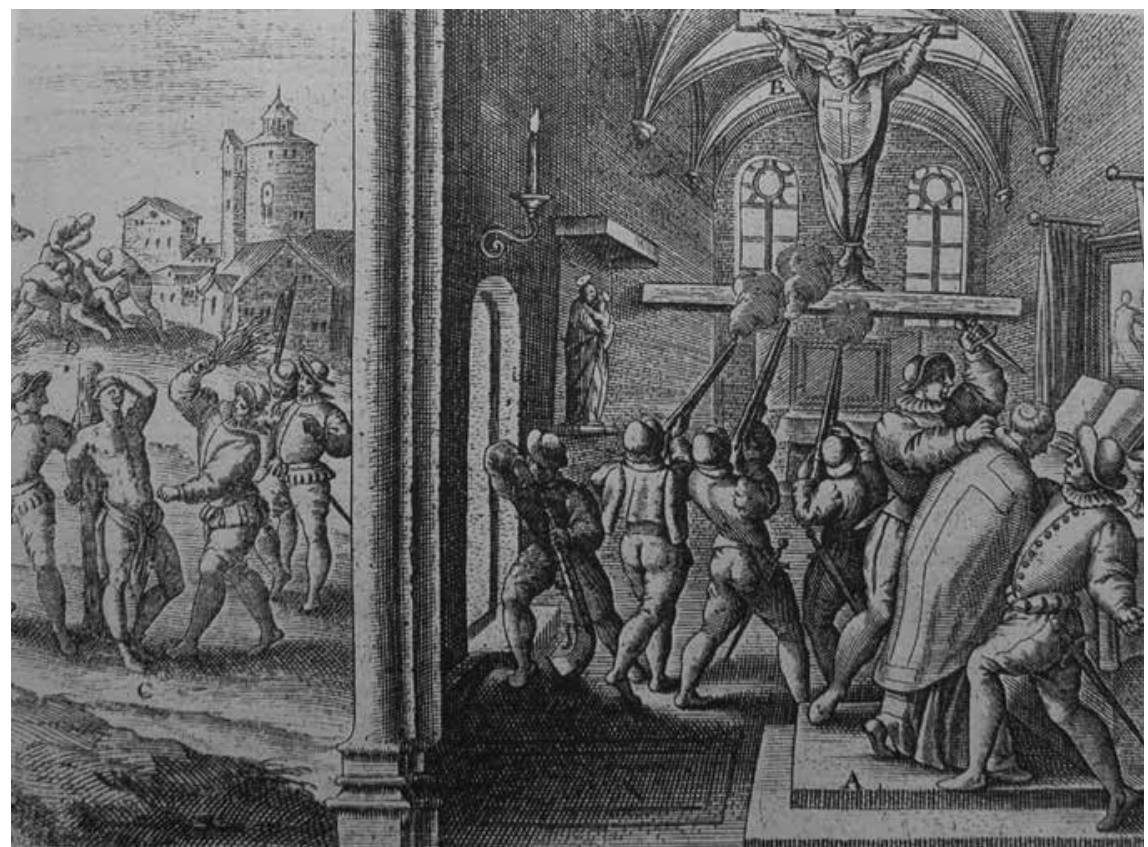

I2. Anónimo, Terribles crimenes cometidos en Francia por los hugonotes, I588 [I557], 45, calcografía, $\mathrm{I} 2 \times 15 \mathrm{~cm}$, atribuido en primer término a Verstegan; también a Wierix a partir de los bosquejos. (C) Bibliothèque Nationale de France-http://gallica.bnf.fr.

En varios grabados las víctimas son sorprendidas y ultimadas en sus casas, bajo sus doseles, en sus camas. En esta inscripción de la violencia en el espacio cotidiano, sobresale el uso recurrente de los perpetradores de lo que tienen a mano para infligir muerte y dolor: el fuego de una chimenea se convierte en una hoguera, un pozo de agua en el vacío al que son arrojadas las víctimas, un crucifijo en una iglesia en una cruz para crucificar (fig. I2). La violencia que avanza sobre el espacio de lo cotidiano se extiende hasta los lugares más íntimos; actos de profanación de los cuerpos se ilustran en 2I de los 29 grabados. La comprensión "amplia" de la profanación se vincula con la doctrina que declara la sacralidad del cuerpo en tanto casa de Dios y templo primordial. ${ }^{62}$

62. Levítico 19: 28, Corintios 6:19. 
DOI: http://dx.doi.org/10.22201/iie.18703062e.2016.109.2623

I28

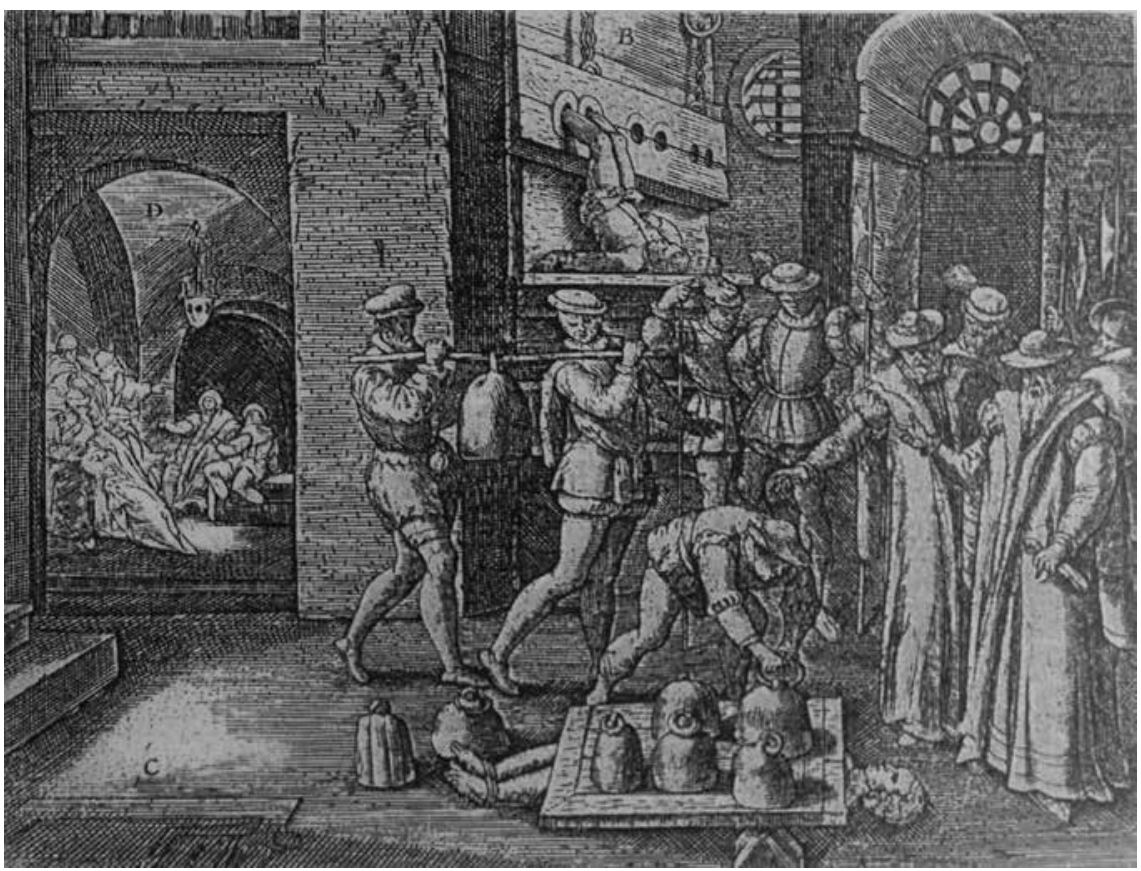

13. Anónimo, Persecución de los protestantes contra los católicos en Inglaterra, I588 [1557], 77, calcografía, I2 $\times 15 \mathrm{~cm}$, atribuido en primer término a Verstegan; también a Wierix a partir de los bosquejos de Verstegan. (C) Bibliothèque Nationale de France-http://gallica.bnf.fr.

$\mathrm{Al}$ inscribirse en iglesias, casas y cuerpos, la profanación atraviesa toda la obra; en los Terribles crimenes cometidos en Francia por los hugonotes (fig. I2), por ejemplo, se ilustra el interior de una iglesia en la que los victimarios disparan sus fusiles contra el cuerpo de un sacerdote que ha sido crucificado en un crucifijo, sintetizando las tres formas de profanación (de espacios, de cuerpos, de objetos).

Un número importante de grabados (22/29) ilustran la segunda característica: la exhibición de algún tipo de conocimiento en el arte de infligir dolor. Las imágenes incluyen el uso de armas como cuchillos, espadas, hachas, picas, lanzas $\mathrm{y}$ venablos, o instrumentos como martillos, tenazas y pinzas puestas al servicio del martirio. Aunque presentes en las obras de otros artistas ya analizados, en Verstegan se destacan las técnicas diseñadas y creadas específicamente con el fin de matar y torturar, como la elaboración de nudos, formas específicas de efectuar los cortes y otros tratamientos del cuerpo de las víctimas (fig. 13). 
Además de cadalsos y horcas, en aproximadamente la mitad de los grabados (I4/29), aparecen máquinas como cepos y caballetes con rodillos, y otras más complejas construidas con pesas, poleas y manivelas. Estas imágenes reflejan el interés creciente en las máquinas e instrumentos que se expandía por entonces en Europa, inaugurado por Jacques Besson en 1578 con un tratado con ilustraciones de todo tipo de máquinas; ${ }^{63}$ con una misma vocación ilustrativa el sacerdote italiano Antonio Gallonio publicó otra obra en la que describe diversos tipos de instrumentos y técnicas de martirio. ${ }^{64}$

Respecto a la tercera característica de la obra es preciso evocar los martirologios protestantes en donde la muchedumbre tenía una presencia activa. En varios grabados de Verstegan (19/29) la masa también tiene un papel protagónico aunque con otra particularidad: en este caso, más que de "masa" sería más preciso hablar de un cuerpo cohesionado, que sigue una organización, una secuencia y un orden. Como se observa en los Horribles crímenes perpretados en Francia por los hugonotes (fig. I4), cinco grupos de personas ejecutan acciones coordinadamente; a lo lejos fusilan, allí arrancan dientes, aquí lancean, un poco más acá, torturan con fuego; hay quien inicia y preserva el fuego, hay quien detiene a la víctima, y hay quien se encarga del martirio propiamente dicho. Aquí no hay ejércitos como en los 40 cuadros ni ejecuciones públicas relativamente institucionalizadas como en Acts and Monuments; más bien, un colectivo de personas que se organiza para martirizar.

Esto nos lleva a la cuarta característica; en las imágenes los victimarios parecen causar tormentos como resultado de la repetición rutinaria y la violencia parece formar parte de un programa sistemáticamente repetido, sin muchas variaciones. Es en este marco donde puede ubicarse la imagen en la que unos hombres juegan a la petanca con la cabeza de sus víctimas combinándose la tortura rutinaria, la banalización del dolor y la muerte, la complicidad, la confraternidad y la emergencia de lo lúdico en tanto "inversión de lo sagrado". 65

63. Se trata de Theatrum instrumentorum machinarum, consultado el I de diciembre de 2013, www.sil.si.edu/DigitalCollections/Hst/Besson/besson-introduction.htm.

64. Antonio Gallonio, Tratatto degli Instrumenti di martirio e delle varie manière di martirizare (Grenoble: Jerôme Millon, 2002 [I59I]). Al respecto, véase por ejemplo: Alfonso Rodríguez G. de Ceballos, "El mártir, héroe cristiano. Los nuevos mártires y la representación del martirio en Roma y en España en los siglos xvi y xvı", Quintana: Revista de estudios do Departamento de Historia da Arte, núm. I (2002): 84-99.

65. Agamben, Profanaciones, Ioo. 
DOI: http://dx.doi.org/10.22201/iie.18703062e.2016.109.2623

I3O

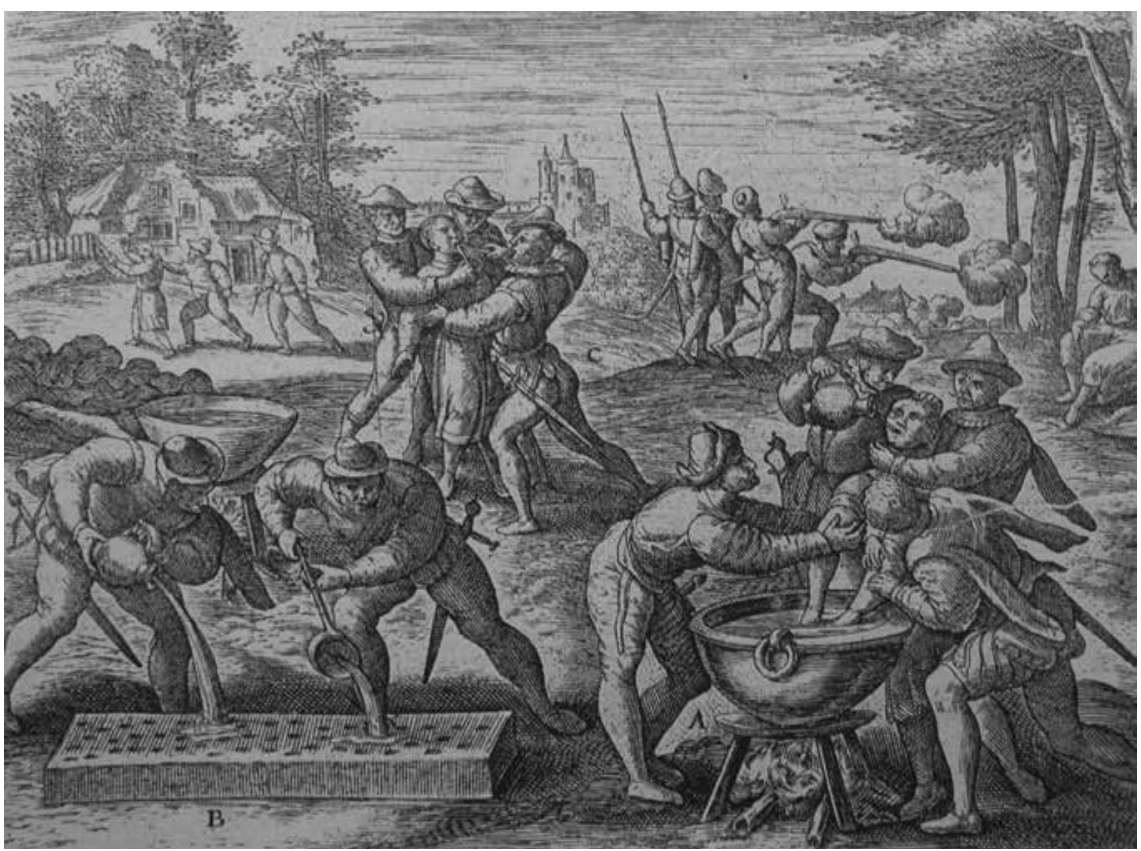

I4. Anónimo, Horribles crimenes perpetrados en Francia por los hugonotes, I588 [I557], 39, calcografía, $12 \times 15 \mathrm{~cm}$, atribuido en primer término a Verstegan; también a Wierix a partir de los bosquejos de Verstegan. (C) Bibliothèque Nationale de France-http://gallica.bnf.fr.

La quinta característica es la de El teatro en tanto marco interpretativo versátil. Todos los participantes que aparecen en los grabados, sean víctimas, victimarios o testigos, y sin importar la acción que lleven a cabo, son anónimos. Este anonimato resalta los suplicios y las torturas realizadas por encima de sus protagonistas. Tal característica, sumada al recurso de lugares genéricos, hace que la imagen pueda pensarse como la representación de violencias no sólo ocurridas en diferentes lugares sino en contra de diferentes personas. ${ }^{66}$

66. Tal maleabilidad dialoga con el hecho de que múltiples grupos en otros contextos históricos o políticos y a pesar de la distancia histórica o geográfica, incorporaron el martirio y otras figuras religiosas en diversos tipos de procesos identificatorios. Stievermann, por ejemplo, se refiere a la incorporación de estas figuras por congregaciones alemanas en la región de Pensilvania a mediados del siglo XviII. Jan Stievermann, "A 'Plain, Rejected Little Flock': The Politics of Martyrological Self-Fashioning among Pennsylvania's German Peace Churches, 1739-1765", The William and 
Para sintetizar, he identificado seis características principales: la condición de un género difuso derivado de su localización a medio camino entre el registro histórico y el testimonial, la forma directa y sin matices en que la crueldad es puesta en escena, las prácticas de profanación como dimensión del martirio, el conocimiento en el arte de infligir dolor, la dimensión colectiva y cohesionada de los perpetradores, la ejecución rutinaria del martirio, y la forma en que $E l$ teatro se convierte en una herramienta interpretativa flexible y en instrumento apto para dar cuenta de violencias ocurridas en diversos lugares.

Concluiré mencionando que en El teatro se incluye la imagen del ataque a un barco que transportaba misioneros católicos hacia el Brasil por parte del corsario Jacques Soria en 1570 en el que murieron 39 jesuitas. En efecto, de la misma forma que las tensiones religiosas trascendieron las fronteras europeas expresándose en obras como las de fray Bartolomé de las Casas, ${ }^{67}$ temas ligados a la Conquista y el descubrimiento del Nuevo Mundo como la evangelización hicieron su aparición en obras que hacían referencia a las guerras de religión europeas. ${ }^{68}$

\section{Comentarios finales}

He analizado la relación entre prácticas de violencia y representación interesándome en las prácticas del martirio y en sus narrativas pues su potencia reside no

Mary Quarterly, Third Series, 66, núm. 2 (2009): 287-324, 289. Véase también Carlos Salamanca Villamizar, "Saberes geográficos, tensiones de alteridad y teatros del martirio en las cartografías jesuíticas del Nuevo Mundo", Revista Española de Antropología Americana, 5 (en prensa).

67. Bartolomé de las Casas, Historia de las Indias (Madrid: Aguilar, 1927) [1552]).

68. Durante el siglo XvI varias congregaciones, pero principalmente franciscanos y jesuitas, impulsaron la constitución de una verdadera "cultura del martirio", en un contexto en el que la expansión europea daba lugar a una apertura mundial del campo misional. En el siglo XvII las narrativas del martirio se expandieron en todos los rincones de la extensa labor misional y la figura de los mártires se inscribió en distintos espacios en el territorio americano. Acerca de la forma en que el vínculo entre las prácticas del martirio y las prácticas misioneras impulsó la proyección del tropo del martirio en las narrativas sobre la conquista religiosa, véase por ejemplo: Salamanca Villamizar, "Das catacumbas às últimas fronteiras", 270-275; para otros análisis, Artur Barcelos, "Os Jesuítas e a ocupaçao do espaço platino nos séculos xvII e XvıII", Revista Complutense de Historia de América 26 (2000): 93-I16; Christophe Giudicelli y Pierre Ragon, "Les Martyrs ou la Vierge? Frères martyrs et images outragées dans le Mexique du Nord (xvième-xvirème siècles)", Nuevo Mundo. Mundos Nuevos, 2005, consultado el I8 de noviembre de 2013, http://nuevomundo. revues.org/6I5 y Maria Cristina Gómez-Géraud, "Le Théâtre des premiers martyrs japonais: la leçon de théologie", Revue de Sciences Humaines, núm. 269 (2003): 175-187. 
DOI: http://dx.doi.org/10.22201/iie.18703062e.2016.109.2623

I32

sólo en la reproducción del rito primordial, sino en su reproducción en el presente y su proyección hacia el futuro. El martirologio, tal como lo he analizado aquí, es un género de representación de la violencia cuya especificidad se deriva de su relación con la expansión editorial; como consecuencia de este vínculo emergen cuestiones como los mecanismos y los procesos de reproducción, la censura, los problemas de traducción, y en un lugar especial las audiencias que lejos de ser estables pueden ser simultáneamente vagas y bien delimitadas, imaginadas y reales, constituidas o en proceso de constitución.

Pero los martirologios analizados también obtienen la especificidad de su papel en las guerras de religión, deviniendo campo y herramienta en la disputa por la hegemonía religiosa. Los martirologios se enfrentan al desafío de convertirse en marcos interpretativos de los acontecimientos en una verdadera guerra por la representación ejecutada mediante la representación misma. En este contexto el martirologio puede proponerse dar cuenta de los sufrimientos de las víctimas, narrar "la verdad histórica" o poner en escena y denunciar la crueldad de los victimarios. A cada uno de estos propósitos le corresponden formas específicas de describir los acontecimientos, de elaborar las narrativas de las prácticas de violencia las que, a su vez, están acompañadas de operaciones y estrategias compositivas. El martirologio así abordado permite complementar las investigaciones que privilegian el análisis de "los medios", con interrogantes acerca de las mediaciones. Las relaciones sociales de producción y uso de discursos y representaciones en contextos particulares son el resultado de diversas mediaciones; el martirologio "media" entre las audiencias y los acontecimientos de violencia y propone interpretaciones, significaciones y sentidos específicos.

No obstante, enfatizar la dimensión comunicativa del martirologio y las mediaciones a las que da lugar no es sugerir que el martirio se limite a ser una práctica discursiva, que el mártir se restrinja a ser el emisor de un discurso religioso o los actos de violencia de un metalenguaje a ser interpretado. Las guerras de religión dejaron experiencias de terror, desplazamiento y muerte y los mismos artistas elaboraron sus narrativas de la religión y la violencia en un campo geopolítico en tensión; Foxe en Estrasburgo, Perrissin y Tortorel en Ginebra, Verstegan en Roma, todos ellos narraron la violencia religiosa desde sus propias experiencias de exilio, persecución y refugio.

El martirologio ubica el acto del martirio en coordenadas espacio-temporales y en una narrativa más amplia; tanto dicha ubicación como dicha narrativa se articulan circunstancialmente en diversas prácticas: fechas de martirios con calendarios y rituales conmemorativos, lugares de martirio con geografías 
religiosas y prácticas de peregrinación, figuras de mártires y ejercicios de imitación. A partir del análisis de tres martirologios emblemáticos de la primera modernidad he demostrado que por intermedio de las representaciones de la violencia no sólo se describen los acontecimientos sino que al hacerlo se producen y afianzan identidades colectivas en torno a ciertos valores, principios y marcos interpretativos. \&

N.B. Versiones preliminares de este trabajo se presentaron en el seminario Espacio, Historia y Poder, llevado a cabo entre 2012 y 2014 en universidades de Argentina y Colombia. Agradezco a Germán Rey del Centro Ático de la Pontificia Universidad Javeriana de Bogotá y a Guillermo Wilde de la Universidad de San Martín la invitación a exponer algunos avances de esta investigación. Asimismo doy gracias a los participantes, quienes con sus comentarios y preguntas me impulsaron a revisar parte de los argumentos que aquí se presentan, así como a los evaluadores de esta revista por sus estimulantes observaciones. Asimismo doy gracias también a Mark Greengrass del proyecto "John Foxe" por su colaboración, así como al equipo editorial de la revista Anales del IIE por su minucioso trabajo. 
DOI: http://dx.doi.org/10.22201/iie.18703062e.2016.109.2623 
DOI: http://dx.doi.org/10.22201/iie.18703062e.2016.109.2623

\section{Los diseños en la cestería seri. Ensayo sobre técnicas de vinculación social}

\section{Designs in Seri Basketry: an Essay on Techniques of Social Relationships}

Artículo recibido el I9 de junio de 20I5; devuelto para revisión el 9 de diciembre de 20I5; aceptado el 29 de febrero de 20I6. http://dx.doi.org/IO.2220I/iie.I8703062e.20I6.109.2579

María Isabel Martínez Programa de Becas Posdoctorales, Coordinación de Humanidades,

Ramírez Universidad Nacional Autó noma de México, México.

isamartinez79@gmail.com

Líneas de investigación: El Estado mexicano desde la mirada de los rarámuri. La relación entre el desarrollo institucional del Estado mexicano durante los siglos xx y xxI; imagen, corporalidad y temporalidades indígenas en México.

Publicaciones más relevantes

Estudios sobre parentesco rarámuri y ranchero en el noroeste de México, coords. María Isabel Martínez y María Eugenia Olvarría (México: Universidad Autónoma Metropolitana/Porrúa, 20I2); "Tejiendo como caminos la vida social: teoría rarámuri de la socialidad y la persona”, en Hilando al norte: nudos, redes, vestidos, textiles, ed. Arturo Gutiérrez (México: El Colegio de San Luis, 20I2); coordinadora del número II2, de Artes de México: Tarahumaras. El camino, el hilo, la palabra (2014).

Resumen El objeto de este artículo es describir, desde la organización del conocimiento y de la práctica de algunas tejedoras seris de El Desemboque, Sonora, qué significan los diseños en la cestería. Mostraré que éstos son a) índices de las relaciones que se establecen durante su elaboración y transmisión (la variación individual, la construcción del consenso familiar y de la "tradición") y b) técnicas de vinculación para producir, reproducir e intensificar su sociedad. Asimismo, exploro el problema de la variabilidad individual en la manufactura y denominación de los diseños, lo cual implica desplazar el análisis desde el significado de los diseños hacia el sentido otorgado por sus productoras dentro del contexto de uso y práctica.

Palabras clave seri; cestería de rollo; diseños en cestería; técnicas sociales; tradición; variación individual. 
Abstract With reference to the organization of knowledge and practice of some Seri weavers from El Desemboque, Sonora, this article addresses the meanings of the designs on their basketry. It identifies these as: I) indicators of relations established during the basketry production and transmission of knowledge (individual variation, building of family consensus and "tradition") and, 2) techniques of social bonding that help to produce, reproduce and intensify Seri society. The problem of individual variability in the manufacture and denomination of designs will also be explored, which means shifting the analysis from the general signification of the designs towards the meanings endowed on them by their creators within the context of their use and practice.

Keywords Seri, coil basketry, designs in basketry, tradition, individual variation. 
DOI: http://dx.doi.org/10.22201/iie.18703062e.2016.109.2623

\author{
MARÍA ISABEL MARTÍNEZ RAMÍREZ \\ PROGRAMA DE BECAS POSDOCTORALES \\ COORDINACIÓN DE HUMANIDADES
}

UNIVERSIDAD NACIONAL AUTÓNOMA DE MÉXICO

\title{
Los diseños en la cestería seri Ensayo sobre técnicas de vinculación social
}

$\mathrm{E}$ 1 objetivo de este artículo es describir, desde la organización del conocimiento y de la práctica, qué son los diseños en la cestería para las mujeres seris. Mostraré que al fungir como técnicas de vinculación social, los diseños condensan en su manufactura y figuración procedimientos de transmisión del conocimiento como el consenso parental, la "tradición" y la memoria, así como formas de producción social o de reproducción del colectivo, tales como la distinción individual, la variabilidad familiar y la intensificación de las relaciones con los no seris. ${ }^{\mathrm{I}}$ Desde los años sesenta del siglo $\mathrm{xx}$, la cestería de rollo seri ha sido elaborada exclusivamente para su venta ${ }^{2}$ y el primer registro fotográfico de canastas con diseños data de principios del siglo pasado. ${ }^{3}$ Por ello, la literatura se ha concentrado en discernir el origen y el desarrollo de los

I. A lo largo de este texto haré uso de la noción de alteridad para referirme a los vínculos que los seris mantienen con otros seris no contemporáneos, tohono o’odham a quienes llaman pápago, mexicanos y estadounidenses. Advierto que la alteridad no necesariamente remite a relaciones interétnicas - puesto que me interesa explorar el punto de vista de algunas tejedoras seris, quienes no se conceptualizan a sí mismas ni a otros como una etnia- ni a relaciones interculturales -ya que la alteridad, como advertirá el lector, transita por aquello que es entendido por los seris como natural.

2. Thomas Bowen, "Seri", en Alfonso Ortiz, ed., Handbook of North American Indians (Washington: Smithsonian Institution, 1983), 239.

3. Federico García y Alva, "La expedición a la isla Tiburón de I904, 'las manos yaqui' ”, Raza seri (Sonora: Directorio del Estado de Sonora, Hermosillo, 1905), consultado el 3 de mayo de 20I5, http://clima.dicym.uson.mx/archivo/misces/articulos/expedicionI904.htm. 
diseños a partir de la mercantilización de la cestería ${ }^{4}$ y en explicar la variación individual de su producción y denominación, entendida como descriptiva, inconsistente y carente de significado. ${ }^{5}$

El tránsito de un valor simbólico, ceremonial, mágico y chamánico, hacia un uso ornamental y utilitario asociado con contextos mercantiles o decorativos ha sido recurrente para explicar éstas y otras producciones gráficas de los seris, como la pintura facial ${ }^{6}$ y los diseños pintados en la cerámica. ${ }^{7}$ Como la manifestación de un proceso más amplio de aculturación ${ }^{8}$ y desintegración de un sistema de creencias, ${ }^{9}$ se ha descrito cómo estas expresiones se liberan de su contenido simbólico para adquirir un carácter ornamental, cuyo fin sería la producción de objetos más bellos para la venta ${ }^{\mathrm{IO}} \mathrm{o}$ para el adorno personal. ${ }^{\mathrm{II}}$

Durante el siglo xx, el estilo de vida de los seris, fundamentado en la caza, la pesca y la recolección, la ocupación del territorio en campamentos ${ }^{\mathrm{I2}} \mathrm{y}$ una organización en unidades sociales diferenciadas, cambió. ${ }^{13}$ Este proceso de in-

4. Margarita Nolasco, "Los seris, desierto y mar", Anales del INAH, vol. i8 (1967): I50; Berenice Johnston, The Seri Indians of Sonora Mexico (Tucson: University of Arizona Press, 1980 [1970]), 8; Edward Moser, "Seri Basketry", The Kiva 38, núms. 3 y 4 (1973): I30; Richard S. Felger y Mary B. Moser, People of the Desert and Sea: Ethnobotany of the Seri Indians (Tucson: University of Arizona Press, 1985), 195; Seth M. Schindler, "The Material Culture and Technoeconomic View System of the Seri Indians: an Experimental Reconstruction", tesis de doctorado (Southern Illinois University, 198I), $4 \mathrm{I} 6$.

5. Schindler, "The Material Culture," 406.

6. Gwyneth Harrington Xavier, "Seri Face Painting", The Kiva II, núm. 2 (1946): 19; Nolasco, "Los seris, desierto y mar", I50; Edward Moser y Richard S. White Jr., "Seri Clay Figurines", The Kiva 33, núm. 3 (1968): I46; Schindler, "The Material Culture”, 407; Gabriela Robledo Hernández, Los seris (México: Instituto Nacional Indigenista, 198I), s. p.

7. Thomas Bowen y Edward Moser, "Seri Pottery", The Kiva 33, núm. 3 (1968): IIO-III.

8. Moser, "Seri Basketry", I38.

9. Bowen, "Seri”, 247.

Io. Bowen y Moser, "Seri Pottery", III.

II. Xavier, "Seri Face Painting”, I9; Nolasco, "Los seris, desierto y mar", I50.

I2. Edward H. Spicer, "Seris", en Cycles of Conquest. The Impact of Spain, Mexico, and the United States of the Indians of the Southwest, I533-1960 (Tucson: The University of Arizona Press, 1997 [1962]), II4-II7; William B. Griffen, Notes of Seri Indian Culture Sonora, Mexico, Latin American Monographs Io (Gainesville: University of Florida Press, 1959), I-5; William B. Griffen, "A Survey of Present Day Seri Culture", tesis de maestría (Mexico City College-Centro de Estudios Universitarios, I955), I-I2; Bowen, "Seri”, 235; Felger y Moser, People of the Desert and Sea, I4-I9.

13. Edward Moser, "Bandas seris", Calafia, núm. 3 (1976); Spicer, "Seris"; Griffen, Notes of Seri Indian Culture Sonora, I-5; Griffen, "A Survey of Present Day Seri Culture", I-I2. 
tegración y dependencia a una economía monetaria y capitalista, ${ }^{14}$ seguido por campañas de evangelización que iniciaron en la década de $1960,{ }^{15}$ ha sido entendido como: una mudanza radical e impuesta por diversas políticas de despojo y exterminio o como un cambio gradual motivado por el interés de los seris en el acceso a bienes de servicio como el agua, el desarrollo de la pesca comercial y la venta de artesanías. ${ }^{16}$ Cada perspectiva ofrece versiones más o menos distintas que será preciso revisar críticamente en otro lugar. Como anotó Marshall Sahlins,${ }^{17}$ cuyo interés sigo, en este texto me interesa reflexionar sobre la manera en que los seris extrajeron sus condiciones de existencia con el fin de complejizar nuestras narrativas y su lugar en ellas.

Así, los problemas sobre los diseños en la cestería seri, como plantearon Seth M. Schindler ${ }^{18}$ y Edward Moser ${ }^{19}$ al entenderlos como el producto de influencias externas por sus rasgos gráficos o al clasificarlos por asociación con contextos ceremoniales y comerciales, no se limitan a un análisis formal y de los estilos, y como discutiré adelante, retomarlos implica ir más allá de ellos. Como advirtieron estos autores, la variación individual es constitutiva de la producción y denominación de los diseños, pero nuestra comprensión no puede reducirse a una lectura idiosincrática ${ }^{20} \mathrm{o}$ utilitaria. ${ }^{2 \mathrm{I}}$ La distinción propuesta por Franz Boas ${ }^{22}$ entre el elemento gráfico y el plástico, así como entre el valor formal y el valor estético, fue cuestionada desde la antropología por Claude

I4. Nolasco, "Los seris, desierto y mar", I5I-I53; Maya Lorena Pérez Ruiz, Seris, Colección Pueblos Indígenas de México (México: Instituto Nacional Indigenista, I993), 8-II; Maya Lorena Pérez Ruiz, "Seris", en Etnografía contemporánea de los pueblos indígenas de México (México: Instituto Nacional Indigenista-Secretaría de Desarrollo Social, 1995), 73; Robledo Hernández, Los seris.

I5. Spicer, "Seris", II7; Rodrigo Rentería, Seris. Pueblos indígenas del México contemporáneo (México: Comisión Nacional para el Desarrollo de los Pueblos Indígenas, 2007), 20.

I6. Felger y Moser, People of the Desert and Sea, I7-I9; Stephen A. Marlett, "Introduction", en A Grammar of Seri, última modificación 20 de septiembre de 2010 , consultado el 27 de marzo de 20I5, www.und.nodak.edu/instruct/smarlett/Stephen_Marlett/GrammarDraft.html, 37; Carolyn O’Meara, "Seri Landscape Classification and Spatial Reference”, tesis de doctorado (Nueva York: University at Buffalo, 20I0), 15-20.

17. Marshall Sahlins, "O 'pessimismo sentimental' e a experiência etnográfica: por que a cultura não é um 'objeto’ em via de extinção (parte I)”, Mana 3, núm. I (I997): 5I, 53.

I8. Schindler, "The Material Culture".

19. Moser, "Seri Basketry".

20. Schindler, "The Material Culture", 408.

2I. Moser, "Seri Basketry", I22, I3O.

22. Franz Boas, El arte primitivo, trad. Adrián Recinos (México: Fondo de Cultura Económica, 1947 [1927]), 94 . 
Lévi-Strauss, ${ }^{23}$ quien al postular su integración, abrió un campo de indagación hacia otras ontologías, es decir, al estudio de otros existentes, como utensiliosornamentos, objetos-animales o cajas-que-hablan y, en consecuencia, al conocimiento de lógicas-prácticas distintas. Por ello, parafraseando a este autor, describiré qué son estos diseños para las mujeres seris, considerando que las canastas no son objetos preexistentes que se decoran a posteriori con el fin de ser objetos de venta. Por el contrario, solamente logran su existencia definitiva (técnicas de vinculación social) mediante la integración del decorado (diseños) y la función utilitaria (objetos de venta). Para lograrlo, durante el trabajo de campo que realicé en los inviernos de 2013 y 2014 en El Desemboque del Río San Ignacio o de los Seris, municipio de Pitiquito, Sonora, México, ${ }^{24}$ los diseños funcionaron como un vínculo de relaciones por medio del cual se cocrearon ${ }^{25}$ métodos de indagación junto con las tejedoras seris. ${ }^{26}$ Es decir, mediante un proceso de reflexividad mutua donde construimos herramientas de investigación a partir de formular preguntas conjuntamente, conocí parte de la "organización del conocimiento y práctica" 27 de estas mujeres, exploré el "rendimiento epistemológico y conceptual de los diseños" ${ }^{28}$ y determinamos las premisas para su análisis. Por ello, como las tejedoras seris lo manifestaron y como lo indicaron otros autores para distintos casos en Amazonía, ${ }^{29}$

23. Claude Lévi-Strauss, "El desdoblamiento de la representación en el arte de Asia y América", en Antropología Estructural (Barcelona: Páidos, 2013[1974]), 282.

24. La información contenida en este artículo se fundamenta en estas dos estancias que suman nueve semanas de campo.

25. Si bien Roy Wagner habla de invención y por tanto de coinvención siguiendo su propuesta y considerando los procesos de producción del conocimiento en este texto hablaré de co-creación, Roy Wagner, The Invention of Culture [The University of Virginia Press, 1975], 17-I8).

26. En este proyecto participaron Francisca y Marta Morales, Ana Torres, Aurelia Molina, Martha Monroy, Berta Estrella, María Luisa Astorga, Ana Victoria Rodríguez, Adriana Estrella Romero, Ángela Torres Cubias, María Luisa Molina, Genoveva Hoeffer Félix, Raquel Hoeffer Félix, María de Jesús Félix Molina (Carolina) y Lourdes Hoeffer Félix.

27. Sahlins, "O 'pessimismo sentimental'".

28. Pedro Cesarino, "A escrita e os corpos desenhados: transformaçóes do conhecimento xamanístico entre os Marubo", Revista da Antropologia 55, núm. I (2012): 77.

29. Anne-Christine Taylor, "Les Masques de la mémoire: essai sur la fonction des peintures corporelles jivaro", L'Homme, núm. I65 (2003), 223-248; Pierre Déléage, "Les Répertoires graphiques amazoniennes", Journal de la Société des Américanistes 93, núm. I (2007), 744-764; Cesarino, "A escrita e os corpos", 74-I39. 
en América del Norte ${ }^{30}$ y en México ${ }^{31}$ fue preciso explorar los modos internos de categorización, de fabricación y producción de los diseños, comprender su contexto de transmisión, los campos de sociabilidad implicados y reconocer hacia quién estaban dirigidos, entenderlos en fin como técnicas de vinculación social.

Además, fue necesario atender a las críticas sobre el simbolismo en la antropología del $\operatorname{arte}^{32}$ y reconocer que no me encontraba ante tropos visuales simbólicos que al ser definidos como textos culturales ${ }^{33}$ me conducirían irremediablemente a declarar, junto con otros autores, sobre la existencia de un simbolismo inerte o muerto, ${ }^{34}$ ya que como para otras producciones gráficas seris, ${ }^{35}$ al ser cuestionados explícitamente sobre el simbolismo de los diseños en la cestería, las tejedoras aludían exclusivamente a su belleza. Si, de forma alterna, presuponía que la producción de los diseños en la cestería no tenía por finalidad generar significados sino relaciones de sentido entre el objeto y la realidad ${ }^{36}$ — definida desde los términos de sus productoras, en tanto que el tejido es una labor exclusiva de las mujeres y esto particulariza las formas de producción social que describiré-, entonces aquello que debía cuestionar era en qué consistía esa categoría de belleza y cómo se articulaba con la transmisión del conocimiento y la producción social.

Finalmente, mediante el registro de léxico de formas de canastas y diseńos advertí que, a diferencia de otros conceptos nativos de imagen documen-

30. Carlo Severi, "Une Forme mnémonique amérindienne. Pictographie et Parallélisme”, en Le Principe de la Chimère (París: Rue d'Ulm/Musée du Quai Branly, 2007); Pierre Déléage, "Les Pictographies narratives amérindiennes", en Christian Jacob, ed., Les Mains de l'intellect, Lieux de Savoir 2 (París: Albin Michel, 20II).

31. Johannes Neurath, La vida de las imágenes (México: Artes de México, 20I4); Diana Magaloni, Los colores del nuevo mundo. Artistas, materiales y la creación del Códice florentino (México: Universidad Nacional Autónoma de México/The Getty Research Institute, 20I4).

32. Cesarino, "A escrita e os corpos desenhados", I06-II8; Els Lagrou, "O que nos diz a arte kaxinawá sobre a relação entre identidade e alteridade?”, Mana 8, núm. I (2002), 45-53.

33. Cesarino, "A escrita e os corpos desenhados", II4.

34. Severi, "Une Forme mnémonique amérindienne", ios.

35. Xavier, "Seri Face Painting", 19; Bowen y Moser, "Seri Pottery", IIo; Moser y White, "Seri Clay Figurines”, 143.

36. Véase Claude Lévi-Strauss, "La ciencia de lo concreto", en El pensamiento salvaje, trad. Francisco González Aramburu (México: Fondo de Cultura Económica, 2006 [196I]), 95-96, I24, I26, I37. 
tados en México ${ }^{37}$ y en Amazonía, ${ }^{38}$ el verbo en cmiique iitom para hablar de los diseños (cahóospoj) ${ }^{39}$ remitía a una técnica que durante el tejido producía simultáneamente diseños y vínculos sociales. Los denominaré técnicas porque ambos se fabrican y su condición de existencia es mutua. ${ }^{40}$

La cestería de rollo manufacturada por las mujeres seris o comcaac que habitan los poblados de Punta Chueca (Socaaix), municipio de Hermosillo, y El Desemboque (Haxöl Iihom) se teje con una técnica de enroscamiento simple

37. Como el nierika huichol, definido como objetos, imágenes, el "don de ver" o la "habilidad visionaria". Neurath, La vida de las imágenes, 6I.

38. Por ejemplo, los xapiripë yanomami, imágenes de imágenes que se multiplican como espejos o cristales y cuya traducción más cercana es espiritu. Véase Eduardo Viveiros de Castro, "A floresta de cristal: notas sobre a ontologia dos espíritos amazônicos", Cadernos de campo, núms. I4/I5 (2006); Els Lagrou, "Existiria um arte das sociedades contra o Estado?", Revista da Antropologia 54 , núm. 2 (20II). Otro caso ejemplar son los patrones gráficos de los marubo como el yochi que remite nuevamente a los espíritus y a un instrumento chamánico de transformación. Cesarino, "A escrita e os corpos desenhados." Finalmente puedo mencionar el kene, dami y yuxin kaxinawá que implican también la transformación. Els Lagrou, "Perspectivismo, animismo y quimeras: una reflexión sobre el grafismo amerindio como técnica de alternación de la percepción”, Mundo Amazónico, núm. 3 (20I2): II3.

39. Para la escritura de la lengua seri o cmiique iitom utilizaré la ortografía empleada en Mary B. Moser y Stephen A. Marlett, comps., Comcaac quih yaza quih hant ihiip hac: Diccionario seriespañol-inglés (México: Plaza y Valdés/Universidad de Sonora, 2005), de donde tomo los siguientes ejemplos. En sus derivaciones, este verbo se utiliza para referirse a la escritura y las fotografías (caaspoj), superficies con dibujos o pintados (coospoj) y diversos animales, insectos o moluscos manchados (raya águila, hatip coospoj, pez gallo, ctomliispoj, mariposa monarca, seneliispoj, lenguado, caasquim coospoj, almeja china, spiitcam coospoj, jaguar, xazoj coospoj, o que con su movimiento dibujan la arena, hant iti yeemej coospoj).

40. Respecto a otras reflexiones sobre técnica, tecnología, máquinas y antropología del arte en México véase Alejandro Fujigaki, "La disolución de la muerte y el sacrificio. Contrastes de las máquinas de transformaciones y mediaciones de los rarámuri y los mexicas", tesis de doctorado (Universidad Nacional Autónoma de México, 2015), I-47; Alejandro Fujigaki, "Construir el camino del olvido. Rituales mortuorios", Artes de México. Tarahumaras. El camino, el hilo, palabra, núm. II2 (20I4); Federico Navarrete, "Máquinas para dar forma al tiempo, los monolitos mexicas" (ponencia presentada en el Coloquio Experiencias Temporales y Formas de la Memoria. Una Perspectiva Comparativa, Instituto de Investigaciones Históricas, Universidad Nacional Autónoma de México, D.F., 22 y 23 de mayo de 20I4), s.p.; Antonio Jaramillo, "La cuenca del Caribe como unidad diversa: el juego de pelota, una máquina para lidiar con la alteridad", en Raúl Román Romero, Jorge Elías Caro y Antonio Vidal, comps., Sistemas Políticos, Relaciones Internacionales e Identidades. Memorias III Congreso Internacional de Estudios Caribeños (San Andrés Isla: Universidad Nacional de Colombia, 20I4), 228-253. 
de anillos cerrados o abiertos que recubre un fajo fundacional en sentido antihorario. El rollo se perfora desde el exterior generando, con una calidad similar, el mismo diseño y tejido en ambas caras. Para elaborar una canasta se recolecta el torote —en lengua seri haat (Jatropha cuneata)—, se queman y descascaran las ramas, procesan las fibras (en dos fases: elaboración de zeee y de hamizj), producen las tinturas, se tiñen las fibras y tejen (figs. Ia-If)..$^{4 \mathrm{r}}$ Las canastas con diseños y sin ellos se manufacturan de la misma manera. El nudo y el inicio del canasto son el punto de fuga para tejer los diseños, a partir de ellos se cuentan los puntos que definen su distribución y posición.

En estos poblados, donde residen cerca de 900 personas, ${ }^{42}$ una de las principales fuentes de ingresos económicos para mujeres ha sido la comercialización de la cestería. Durante los años cincuenta y sesenta del siglo xx, la producción de la cestería transitó de los usos domésticos y ceremoniales hacia la venta. Moser ${ }^{43}$ describió este proceso como aculturación ya que su venta contribuía con la adaptación de los seris en una economía monetaria y la demanda de los compradores estimulaba cambios plásticos y técnicos en su manufactura. Bajo

4I. Sobre el registro de manufactura de cestería de rollo seri, además de la información detallada de Moser, "Seri Basketry"; véase Felger y Moser, People of the Desert and Sea, 179-206; véase Richard S. Felger y Mary B. Moser, "El espíritu de los coritas seris", Artes de México. Cestería, núm. 38 (1997): 44-49, en Barbara Johnson, "Seri Indian Basketry”, The Kiva 25, núm. I (1959): IO-I3; y William Smith, "Observations Regarding Seri Indian Basketry", The Kiva 25, núm. I (1959): I4-I7, quienes publicaron algunas anotaciones breves sobre cestería, así como William McGee, Los seris (México: Instituto Nacional Indigenista, 1980 [1898]), 347-348. Recientemente he discutido los procesos de permanencia y cambio en la cestería - María Isabel Martínez Ramírez, "Pensando a través de la cestería seri: permanencia, innovación y memoria" (en prensa). En décadas recientes es posible destacar el trabajo de David Burckhalter, Among Turtle Hunters and Basket Makers: Adventures with the Seri Indians (Tucson: Treasure Chest Books, 1999), 45-66, quien desde 1970 realiza visitas a esta región, y los trabajos de Donaciano Gutiérrez, "Cestería seri”, en Efraín Cortés Ruiz y Catalina Rodríguez Lazcano, coords., Tejedores de la naturaleza en cinco regiones de México (México: Instituto Nacional de Antropología e Historia, 1999), I63-176, y Alejandro Aguilar Zeleny, "Con la memoria en las manos. La artesanía de los pueblos originarios de Sonora. Saaptim. Hilando los arbustos del desierto, la cestería y otros símbolos", Correo del Maestro, núm. 2II (2013), 47-55. Otros autores cuentan con descripciones breves dentro de trabajos generales como Nolasco, "Los seris, desierto y mar", I63-I7I; Griffen, Notes of Seri Indian Culture Sonora, I26-I3I; Griffen, "A Survey of Present Day Seri Culture", 22-27; Johnston, The Seri Indians of Sonora, 8-9; Arturo José Cuéllar, La comunidad primitiva y las políticas de desarrollo. (El caso seri) (Universidad Nacional Autónoma de México, I980), I09-II4; Pérez Ruiz, Seris, I6; y Rentería, Seris, 2I-25.

42. O’Meara, "Seri Landscape Classification and Spatial Reference”, I5.

43. Moser, "Seri Basketry", 138 . 
esta visión, las canastas son definidas como un objeto mercantil. Algunos autores las describen como un objeto artesanal y afirman que forman parte de un "sistema de creencias desintegrado" 44 donde las relaciones de venta generan el despliegue de las habilidades artísticas de las mujeres seris, ${ }^{45}$ como si los vínculos con el mercado fuesen su condición de existencia, o bien que su producción se enmarca en la cristalización de un capitalismo mercantil dentro del cual se destacan actitudes empresariales por parte de los seris. ${ }^{46}$ En contraposición, desde la perspectiva de Donacio Gutiérrez ${ }^{47}$ y Alejandro Aguilar ${ }^{48}$ la cestería, al entenderse como una actividad prehispánica, es una práctica ancestral integrada a un simbolismo que ha sido importante para su conservación.

En otro texto he discutido ${ }^{49}$ cómo implícitamente ambas posiciones comparten la premisa donde el conocimiento seri sobre la cestería sería un tipo de thesaurus de origen endógeno..$^{50} \mathrm{De}$ tal manera que su permanencia testimoniaría su continuidad y sus modificaciones entrañarían una irrupción exógena, cancelando la posibilidad de que estos conocimientos no sean necesariamente antiguos y que aquello que permanezca no sean contenidos o referentes, sino los procedimientos para su producción. Uno de los efectos de esta premisa es que las explicaciones para la permanencia y los cambios técnicos o plásticos de las canastas aludan tendencialmente a factores ajenos a las motivaciones de los seris, al extraer la cestería de su campo de producción, de discurso y de la organización del conocimiento y de la práctica a los que pertenece.

La relación entre los contextos mercantiles y la producción de la cestería seri ha sido un argumento central en la literatura que me antecede para explicar los procesos de cambio y permanencia en su manufactura, así como para determinar que los diseños tejidos en las canastas carecen de un valor simbólico. Al considerar estos vínculos, así como el resto de las transformaciones sociales por las que han transitado los seris durante el siglo xx, el objetivo de este artículo es explorar la perspectiva de las tejedoras. En consecuencia, desplazar la discusión del significado simbólico de los diseńos tejidos en las canastas hacia el sentido

44. Bowen, "Seri", 247.

45. Felger y Moser, People of the Desert and Sea, 179.

46. Cuéllar, La comunidad primitiva y las politicas de desarrollo (El caso seri), I6.

47. Gutiérrez, "Cestería seri".

48. Aguilar, "Con la memoria en las manos".

49. Martínez, "Pensando a través de la cestería seri".

50. Manuela Carneiro da Cunha, "'Cultura’ e Cultura: conhecimentos tradicionais e direitos intelectuais”, en Cultura com aspas (Brasil: Cosac Naify 2014 [2009]), 364. 


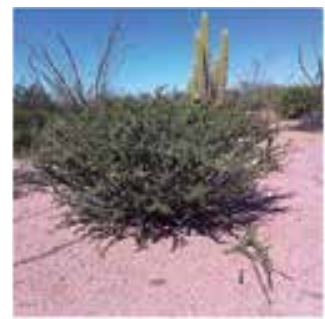

a

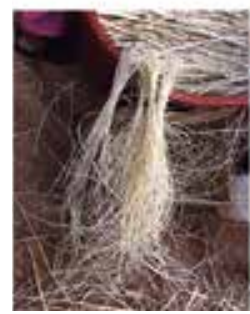

d

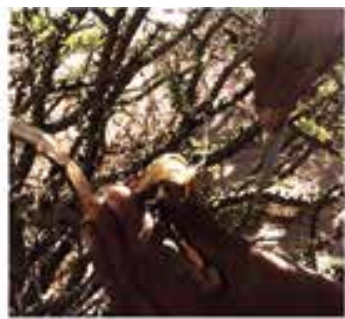

b

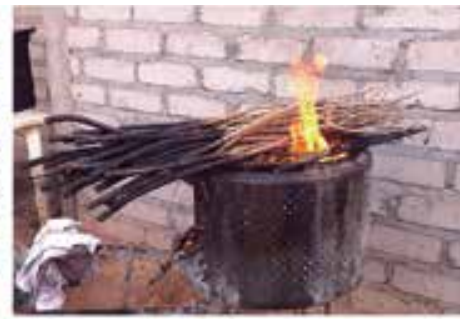

c

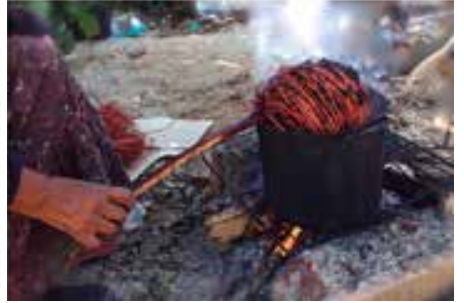

$\mathrm{e}$

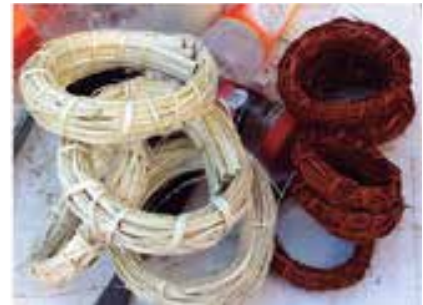

f

I. Procesos de manufactura de las fibras de torote para producir cestería de rollo: a) arbusto de torote; b) prueba de flexibilidad de las ramas durante la recolección por Aurelia Molina; c) quema por Martha Monroy; d) zeee o fibras para tejer el interior del rollo, elaboradas por Martha Monroy; e) teñido con la raíz heepol por Ana Torres; f) rollo con hamizj crudo y teñido de heepol por Berta Estrella. Fotos: María Isabel Martínez Ramírez.

otorgado por sus productoras dentro del contexto de uso y práctica a partir de los métodos que construimos conjuntamente.

\section{Entre frases, nombres y diseños: reflexión sobre el levantamiento del léxico}

El punto de partida de esta investigación fue la configuración de una base de datos representativa de la cestería durante la segunda mitad del siglo xx. Ésta se conformó con 2I fotografías de canastas de la Colección Etnográfica del Museo Nacional de Antropología (MNA) ${ }^{5 \mathrm{I}}$ y 35 imágenes del artículo de Moser, "Seri

5I. La visita al Museo Nacional de Antropología se realizó el ro de octubre de 20I3. Agradezco a Leopoldo Trejo su ayuda para la realización de dicha base de datos, así como a Sergio Torres, encargado del Acervo de Antropología, y a Carolyn O’Meara del Instituto de Investigaciones Filológicas, unam. De acuerdo con las fichas de catalogación, la mayoría de las piezas ingresaron a la colección en 1978,1985 y 1999. 


\section{I46 MARÍA ISABEL MARTÍNEZ RAMÍREZ}

Basketry." El objetivo era conocer el léxico para describir las formas y los diseños de las canastas. ${ }^{52}$

Uno de los resultados permitió identificar que, como en otras tradiciones gráficas documentadas en América, ${ }^{53}$ para las mujeres seris la relación entre las frases nominales y los diseños no era reductible a la representación, producida para su interpretación ni conformaba un diccionario de símbolos. Esta articulación expresaba vínculos sociales a partir de tres formas de producción: por figuración ${ }^{54}$ (7.I4 por ciento de la muestra), por invención 55 (7.I4 por ciento) y por reconocimiento posterior por analogía ${ }^{56}$ (85.7 por ciento).

Ejemplos de la primera son los registros: canasta en forma de plato diseñada con manta raya (hasaj hatip cöcoospoj) y canasta en forma de plato con diseño de flor de incienso (hasaj yaspoj hehe yapxöt cotx) (fig. 2a). ${ }^{57}$ Para corroborar la

52. El procedimiento para el levantamiento de datos consistió en una serie de preguntas en cmiique iitom a las que respondía una tejedora seguida por la traducción simultánea de la intérprete traductora. Yo les mostraba las imágenes de la base de datos y procedíamos al cuestionario. Las entrevistas las transcribí en campo junto con Debora Perales, quien corregía el documento e incluía información sobre la cestería y sus diseños.

53. Déléage, "Les Pictographies narratives amérindiennes", 97-I04; Cesarino, "A escrita e os corpos desenhados", I04-II8; Taylor, "Les Masques de la mémoire”, 305-309; Severi, "Une Forme mnémonique amérindienne", 98-II4.

54. Por su simplicidad conceptual, utilizo el término figuración para referirme a lo que ciertos autores han calificado como representación. A diferencia de ésta, que supone una serie de operaciones cognitivas y fenomenológicas, así como ciertas epistemologías y ontologías que están siendo revisadas críticamente, la figuración es un tipo de producción donde cada artista reproduce lo que considera real.

55. Por invención se entiende un vínculo personalizado entre la productora y los diseños, que como las tejedoras señalan, surgen de su mente.

56. El reconocimiento posterior por analogía trata sobre la relación que se genera a partir de la evidencia visual común entre un diseño y otra imagen mediante una relación indexical. A diferencia de la figuración, este vínculo no sucede entre un objeto y su representación, sino entre dos figuraciones enlazadas a partir de una memoria parental.

57. Los dibujos a línea son míos, éstos siguen el patrón del tejido de cestería de rollo seri, ya que son reproducciones de: a) algunas fotografías de las colecciones etnográficas del Museo Nacional de Antropología de la Ciudad de México y del Arizona State Museum; o b) algunas imágenes del artículo de Edward Moser (vid n. 4). Estos dibujos reproducen el diseńo sobre el tejido por tres motivos. En primer lugar, como se argumenta a lo largo de este texto, la comprensión del diseño depende de su materialidad. En segundo, al realizar dibujos a línea continua, en ocasiones, los diseños se modificaban y, finalmente, la información presentada en este artículo se fundamenta en el conocimiento cocreado con algunas tejedoras seris de El Desemboque. Modificar estas imágenes implicaría alterar las condiciones de producción de dicho conocimiento. 
figuración, las mujeres me mostraron fotos de sus colecciones personales. A lo largo de nuestras caminatas por el desierto o la playa me indicaron los animales y plantas tejidos, manifestando un lazo con su entorno, el cual, como han advertido Stephen A. Marlett ${ }^{58}$ y Carolyn O'Meara, ${ }^{59}$ no se percibe como un sitio duro o desagradable, tal como podría ser para quien lo desconoce y lo definiría por su aparente escasez de recursos, así como por sus temperaturas extremas. La segunda forma de producción, la invención, surgía "de la mente" de cada mujer, generalmente combinaciones de patrones geométricos (fig. $2 \mathrm{~b}$ ).

La tercera forma, reconocimiento posterior por analogía, la analizó AnneChristine Taylor ${ }^{60}$ entre los shuar o achuar y Pierre Déléage ${ }^{6 \mathrm{I}}$ entre los sharanaua, en ambos casos el lazo entre los nombres y los diseños era un índice mnemotécnico. Para los shuar y achuar, los diseños eran la marca o el índice del encuentro individual entre un muerto y un guerrero que generaba vínculos de memoria y olvido colectivos. Así, el reconocimiento entre la semejanza de las pinturas corporales y los diseńos, por ejemplo, de alguna serpiente, era posterior a dicho encuentro. Para los seris, este proceso analógico englobaba motivos geométricos (ondulado, cocömonjc, tener forma dentada, catéemloj, tener forma de gancho, queefe, rayado, cocpátyax), en ocasiones reconocidos como diseños (diseño en forma de red, cool yaspoj, con anillos, cöcaafija, y en espiral, cocpaaija), estrellas (izoj canoj), flores (hehe yapxöt) y diseños retomados por los tohono o'odham también denominados pápago. Como describiré, su designación era indicativa de la relación entre la tejedora y la fuente de transmisión del conocimiento (una mujer, las almejas piedreras o los pápago) (fig. 2c).

Al cuestionar la correspondencia como único método de comprensión de la relación entre la palabra y la imagen, algunos estudios han criticado el valor icónico, codificado, comunicativo, ilustrativo, decorativo y narrativo de las imágenes. En contraposición, al indagar criterios epistemológicos y ontológicos nativos, así como las formas de producción y por tanto la vinculación entre el ejercicio oral, los signos gráficos y el colectivo que lo emplea, se han documentado tecnologías de transformación, ${ }^{62}$ técnicas de memoria, ${ }^{63}$ estructuras

58. Marlett, "Introduction", 39.

59. O’Meara, "Seri Landscape Classification and Spatial Reference", 23.

6o. Taylor, "Les Masques de la mémoire".

6I. Déléage, "Les Pictographies narratives amérindiennes".

62. Cesarino, "A escrita e os corpos desenhados", I6-I8; Neurath, La vida de las imágenes.

63. Taylor, "Les Masques de la mémoire"; Severi, "Une Forme mnémonique amérindienne". 
DOI: http://dx.doi.org/10.22201/iie.18703062e.2016.109.2623

I 48 MARÍA ISABEL MARTÍNEZ RAMÍREZ

a
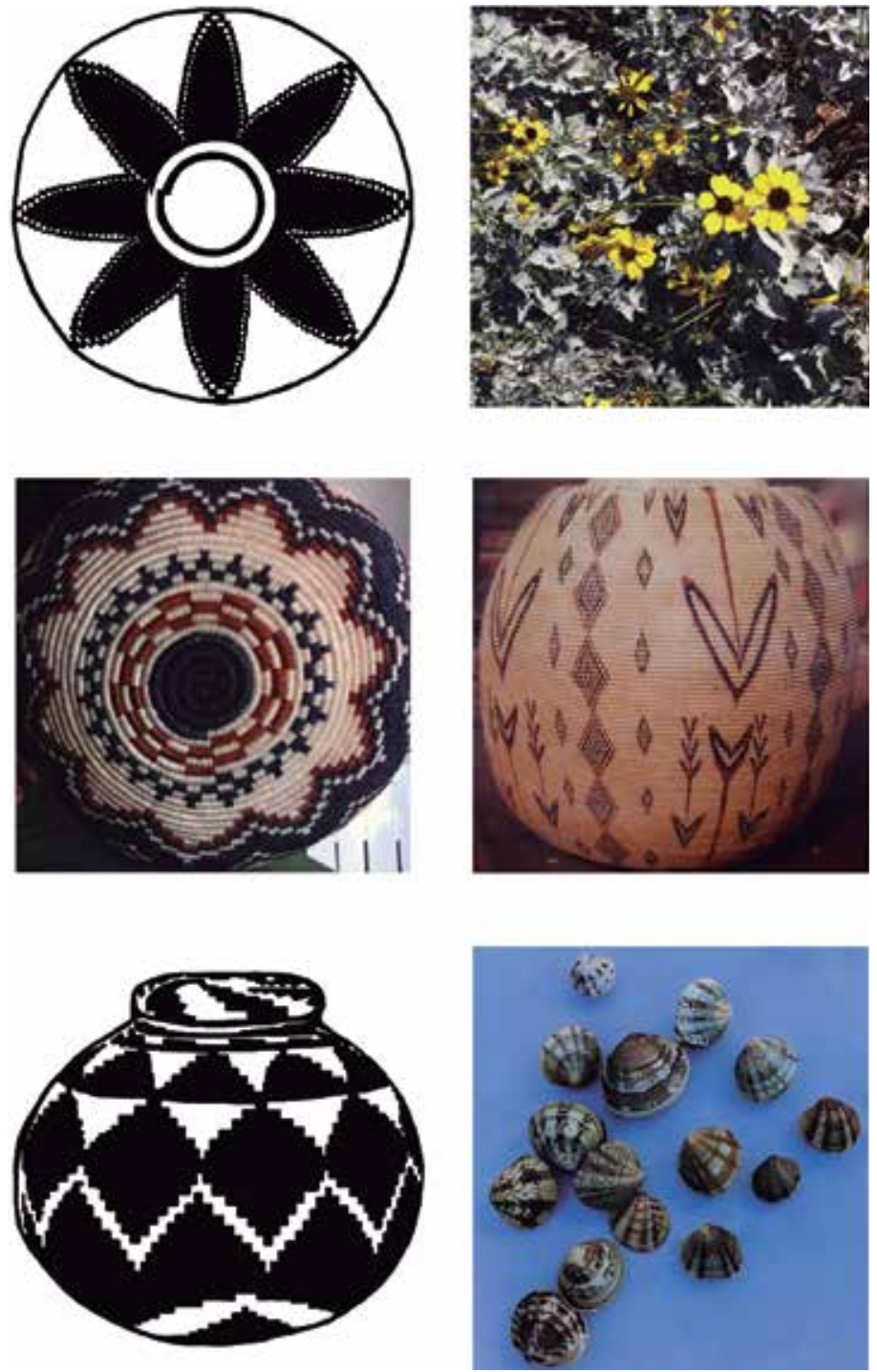

2. Tres formas de producción de los diseños que expresan vínculos sociales: a) figuración: la flor de incienso (Encelia farinosa), tomada de Moser, "Seri Basketry" (vid supra n. 4), fig. I3c; b) dos ejemplos de invención; c) reconocimiento posterior por analogía: en este caso almejas piedreras ( haxöl heecto, Leukoma grata), fig. I2b en Moser, "Seri Basketry" (vid supra n. 4). Agradezco la autorización de las mujeres de El Desemboque y Cathy Marlett para reproducir las imágenes. 
paralelísticas ${ }^{64} \mathrm{y}$ discursos de resistencia histórica. ${ }^{65} \mathrm{~A}$ partir del léxico de los diseños tejidos en la cestería seri puedo señalar la coexistencia de la figuración, la invención y el reconocimiento posterior por analogía para cuestionar que al privilegiar alguna de estas formas de producción se corre el riesgo de velar la complejidad de las tradiciones gráficas, generando una visión parcial. Resulta necesario reconocer que al menos en el caso seri la figuración es una forma de producción de los diseños, y preguntar cómo se articula con la invención y el reconocimiento posterior por analogía. ${ }^{66}$ Además, es preciso destacar que sea con el entorno, con la creatividad individual o con una fuente del saber, la relación entre los nombres y los diseños remite a técnicas de vinculación social. Éstas condensan procedimientos de transmisión del conocimiento, formas de producción y reproducción social, tanto al interior como al exterior de la sociedad seri.

\section{Los diseños como indices de relaciones: consenso familiar y "tradición"}

La variabilidad individual ${ }^{67}$ en la producción y denominación de los diseños en la cestería vinculó mis problemáticas y las de la literatura que me antecedía

64. Déléage, "Les Pictographies narratives amérindiennes".

65. Magaloni, Los colores del nuevo mundo; Silvia Rivera Cusicanqui, "Sociología de la imagen. Una visión desde la historia colonial andina”, en Chixi nakax utxiwa. Una reflexión sobre prácticas $y$ discursos descolonizadores (Buenos Aires: Retazos y Tinta y Limón, 2010), 19-52.

66. E. Lagrou señaló el papel de la figuración en Amazonía como un camino óptico para la visualización de imágenes virtuales dentro del campo de la transformación. Lagrou, "Existiria um arte das sociedades contra o Estado?", 769; también J. Neurath destacó la coexistencia de la representación iconográfica y de la visión chamánica en los cuadros de estambre huicholes como dos operaciones artísticas que se establecen al contemplar la obra antes y después de la experiencia de nierika. Neurath, La vida de las imágenes, 95 .

67. La individualidad seri ha sido destacada y descrita por otros autores como Felger y Moser, People of the Desert and Sea, 196. Entendida en el marco de la manufactura de los diseños tejidos en las canastas será definida a lo largo del texto como una forma de producción social. Para una discusión sobre la problematización y reflexión crítica de esta categoría analítica en la antropología y su díada (la sociedad) véase Marilyn Strathern, O efeito etnográfico (São Paulo: Cosac Naify, 20I4); Marilyn Strathern, The Gender of the Gift. Problems with Women and Problems with Society in Melanesia (The University of California Press, 1988); y Roy Wagner, "The Fractal Person", en Maurice Godelier y Marilyn Strathern, eds., Big Men and Great Men (Cambridge University Press, I99I), I59-173. Para un estudio de caso sobre la construcción de la individualidad, como una categoría nativa, y su papel en la sociedad entre los rarámuri en México, véase María Isabel 
con las preocupaciones de las mujeres, ya que de las 56 fotografías que conformaron mi base de datos, sólo ocho descripciones coincidieron en el registro de las cinco mujeres que participaron en el registro léxico (figs. 3a-3h). Al cocrear métodos, las tejedoras de El Desemboque ofrecieron otras herramientas y plantearon preguntas distintas. En el proceso de transmisión sobre los diseños les interesaba definir el vínculo entre el conocimiento y la "tradición". Así, después del levantamiento de léxico, la bifurcación, entendida como un acontecimiento etnográfico capaz de alterar nuestras teorías, ${ }^{68}$ surgió una tarde, cuando dos tejedoras me comentaron que las frases de los diseños debían corregirse. Particularmente deseaban definir la distinción entre las estrellas y las flores, ya que al discutirlo con sus parientes por afinidad —a quienes consideraban con mayor conocimiento- discordaban. Organizaron reuniones familiares donde, a partir de las cualidades gráficas de los diseños, reflexionaron sobre esta distinción y llegaron a un acuerdo, determinado en gran medida por un hombre que consideraban con mayor conocimiento "tradicional": "las estrellas tienen cinco picos" y "las flores tienen menos o más pétalos".

$\mathrm{Al}$ proponer este método de indagación, las mujeres me mostraron una de las condiciones para la transmisión del conocimiento: el consenso familiar. Ésta, constitutiva de la manufactura de la cestería, configura un canon familiar que potencialmente genera variación durante la producción, ${ }^{69}$ y fue documentada durante el surgimiento y desarrollo de las tallas de palo fierro. ${ }^{70}$ De tal forma que la familia extensa sería el centro de la vida social seri, ${ }^{71}$ así como el eje rector de la transmisión del conocimiento y, por tanto, un campo potencial para

Martínez Ramírez, "Tejiendo como caminos la vida social: teoría rarámuri de la socialidad y la persona”, en Arturo Gutiérrez, ed., Hilando al norte: nudos, redes, vestidos y textiles (México: El Colegio de San Luis-El Colegio de la Frontera Norte, 20I2), 552-602. Entre los huicholes véase Johannes Neurath, "Alteridad constituyente y relaciones de tránsito en el ritual huichol: iniciación, antiiniciación y alianza", Cuicuilco I5, núm. 42 (2008), 29-44 y entre los nahuas, Marie Noelle Chamoux, "La Notion nahua d'individu: Un aspect du tonalli dans la región de Huachinango, Puebla”, en Guy Stresser-Péan y Dominique Michelet, coords., Enquêtes sur l'Amerique Moyenne (México: Instituto Nacional de Antropología e Historia/Consejo Nacional para la Cultura y las Artes/Centro de Estudios Mexicanos y Centroamericanos, 1989), 303-310.

68. Marilyn Strathern, "Binary License", Common Knowledge I7, núm. I (201I), 90.

69. Martínez, "Pensando a través de la cestería seri".

70. Berenice Johnston, "Seri Ironwood Carving", The Kiva 33, núm. 3 (1968), 164; Johnston, The Seri Indians of Sonora Mexico, I2; Felger y B. Moser, People of the Desert and Sea, I74; Schindler, "The Material Culture", 420; Pérez Ruiz, "Seris", 383.

7I. Felger y B. Moser, People of the Desert and Sea, 3. 

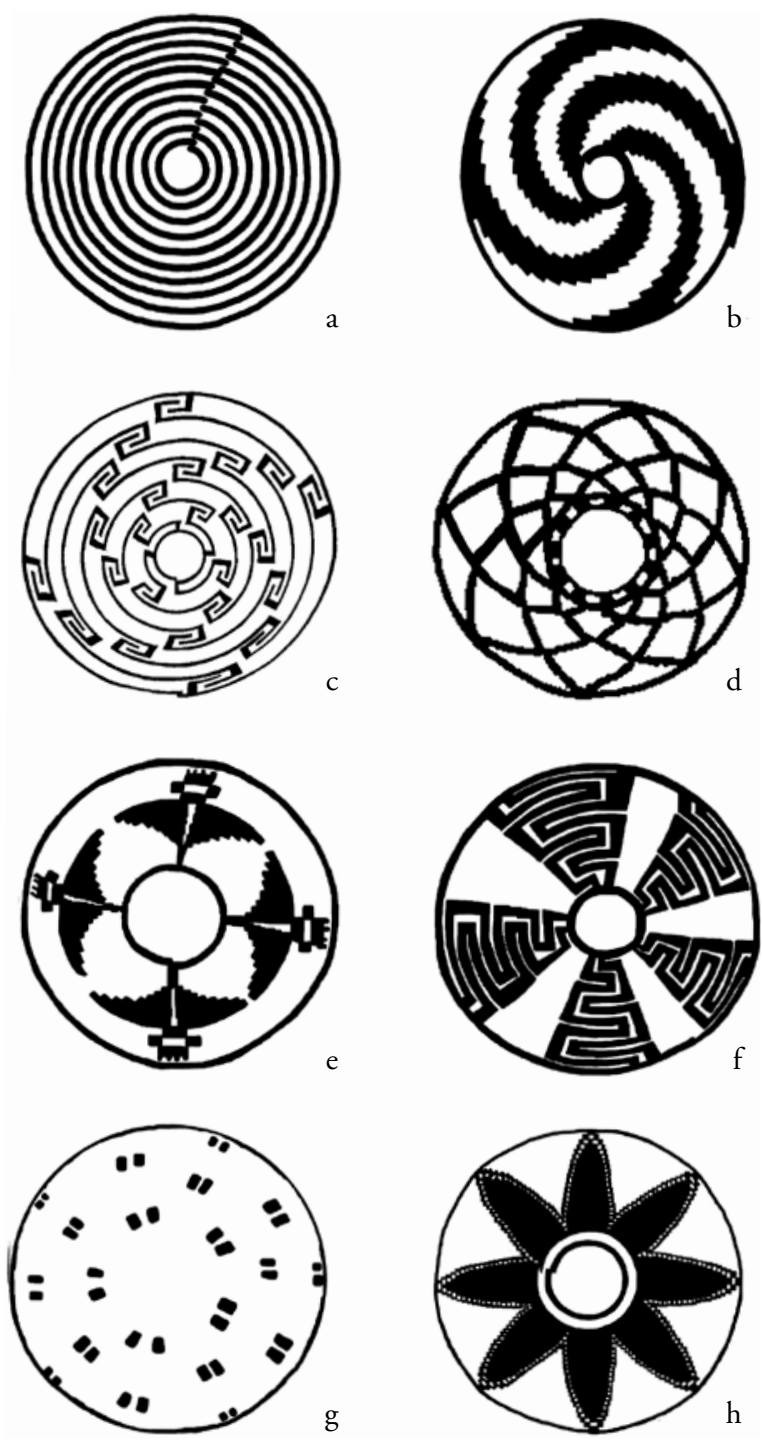

3. Ocho descripciones que coincidieron en el registro de las cinco mujeres que participaron en el registro léxico de diseños: a) con círculos (cöcaafija), fig. I2e; b) espiral (cocpaaija), fig. Iza; c) forma de gancho (queefe), fig. I2d; d) forma de red (cool), fig. I5b; e) manta raya (hatip), fig. I2b; f) ondulado (cocömonjc), fig. I6e; g) manchado (iti hapáhtolca), fig. I6e; h) flor de incienso (hehe yapxöt cotx), fig. I3c. Dibujos tomados de Moser, "Seri Basketry" (vid supra n. 4). 
engendrar su diversificación. Como una tejedora me indicó: "lo que te dicen en una familia es distinto a lo que te dicen en otra". Por este motivo, las mujeres de otros grupos familiares señalaron que las flores se distinguían de las estrellas porque tenían las puntas redondas mientras que los astros tenían picos. ¿Por qué era importante generar un consenso parental que simultáneamente producía variación?, ¿por qué aquel hombre con autoridad "tradicional" determinó el consenso del conocimiento que me transmitían sobre los diseños?

$\mathrm{Al}$ conversar con algunas personas de El Desemboque que constituyen un Consejo de Ancianos, ${ }^{72}$ generalmente señalaban que no todas las familias seris eran "tradicionales." Para definir su posición, en algunos casos aludían a su genealogía, donde no había matrimonios interétnicos (con indígenas o mestizos), resaltando la pureza familiar sobre la que se fundamentaba su conocimiento. La "tradición" se describía como conocimientos concretos en los que eran expertos (pintura facial, danza, cantos, astronomía), experiencias que habían atestiguado (forma de vida en la Isla Tiburón, uso de las canastas y de la cerámica) y aprendizajes heredados de sus padres. Su transmisión implicaba implícitamente una transformación. Un hombre que relató cómo durante su infancia y juventud había aprendido solo, es decir, observando e imitando durante la ejecución ritual, ha impartido clases de cantos, danzas y lengua "tradicionales" a nińos seris y a turistas, investigadores nacionales y extranjeros, así como a cualquier interesado sobre estos tópicos en un edificio conocido como la Escuela de Danza Tradicional Comcaac en El Desemboque. Narró cómo, ante la atracción de las nuevas generaciones por la escuela mexicana, consideró que la escolarización era el mejor método para transmitir la "tradición" —entendida por este anciano como "la enseñanza de los antepasados"-, e incluso al finalizar los cursos entregaba una credencial donde acreditaba a las personas como artistas "tradicionales." Otra mujer, a quien pregunté si las canastas se utilizaban en alguna ceremonia o fiesta, respondió: "sí usamos las canastas para las fiestas, como en el Año Nuevo, para que la gente que viene de fuera vea como se hacía antes".

He colocado entre comillas "tradición" para destacar el proceso de apropiación que los seris han hecho de este término. Como categoría de ida y vuelta ${ }^{73}$ ha sido utilizada por estos ancianos para hablar de una serie de conocimientos

72. De acuerdo con Pérez Ruiz (Seris, 392), es posible que este Consejo de Ancianos sea la forma actual del Consejo Supremo que se conformó y registró en 1969 promovido, junto con la constitución de un gobernador tradicional, por el Consejo Nacional de Comunidades Indígenas (CNC).

73. Manuela Carneiro da Cunha, "'Cultura’ e Cultura: conhecimentos tradicionais e direitos intelectuais", $3 \mathrm{I} 2$. 
concretos y de relaciones exclusivas que los vinculan por parentesco, corporalidad y experiencia —empírica o transmitida — con ciertos eventos que remiten a un tiempo que consideran antiguo. ${ }^{74}$ Esto cimenta su autoridad para transmitir contenidos concretos, como la definición de los diseños y la distinción entre las estrellas y las flores, y para transformar los procedimientos de su reproducción. Incluso, esta autoridad "tradicional" es una potencia para modificar contenidos concretos. Por ejemplo, al comparar mi registro de léxico con el de $\operatorname{Moser}^{75}$ y Schindler ${ }^{76}$ advertí que el diseño mariposa (seenel), reportado como un motivo tradicional 77 y como de reciente introducción, ${ }^{78}$ lo identificaban algunas tejedoras como manta raya y la manufactura era atribuida a sus madres. De igual manera, los diseños que Schindler ${ }^{79}$ identificó con motivos de origen pápago y apache fueron reconocidos como "tradicionales" (cool, bolsa de red, cöcaafija, hecho con círculos, y cocpaaija, espiral) (figs. 3a-3h). En este sentido es preciso ir más allá del análisis formal y de los estilos y, al atender los cuestionamientos cocreados con las mujeres seris, dar cuenta de la transmisión del conocimiento y de la conformación del consenso.

Además, esto explica por qué, al comparar los resultados de mi registro léxico con los de estos autores el resultado parecía aleatorio. Aquello que alguna vez se experimentó como una invención o como un préstamo de los pápago, era reconocido como parte de la "tradición." El conocimiento sobre los diseños y la manufactura de la cestería, tal como he discutido en otro texto al analizar

74. Pese a la aparente semejanza con la propuesta de Eric J. Hobsbawn, "Introduction: Inventing Traditions", en Eric J. Hobsbawn y Terence Ranger, eds., The Invention of the Tradition (Cambridge University Press, I983), I-I4, sobre las tradiciones inventadas, aquí la tradición no se entiende como una ficción en tanto que tiene efectos concretos. Tampoco es posible distinguir, como este autor lo propone, entre tradición y costumbre, ya que el fundamento del análisis son categorías nativas. De hecho, éstas no se contraponen necesariamente con la variabilidad, sino que resultan constitutivas como ha documentado la literatura etnográfica y describiré en este texto. Contrapuesta a las ideas de este autor, la etnografía del siglo xx ha demostrado que la convención, e incluso aquello que llamamos pasado, se crea. Sin embargo, coincido en que existen procesos de innovación, ruptura y continuidad. Por ello, considero que Hobsbawn analizó procesos de invención particulares que no configuran un modelo general capaz de utilizarse en el caso seri. Problema que discutiré en otro momento. Agradezco a Deborah Dorotinsky sus comentarios críticos y sugerencias en este sentido.

75. Moser, "Seri Basketry", I25-130.

76. Schindler, "The Material Culture", 408.

77. Moser, "Seri Basketry", I25, fig. I2b.

78. Schindler, "The Material Culture", 408.

79. Schindler, "The Material Culture", 4II,4I5, figs. I05, I06, y I09. 
detalladamente cada uno de los procesos de producción, ${ }^{80}$ no estaba organizado como un conjunto cerrado de saberes transmitido desde tiempos inmemoriales y preservado (mas no enriquecido) por las generaciones actuales.

$\mathrm{Al}$ igual que en otras tradiciones gráficas en América, ${ }^{8 \mathrm{I}}$ los procedimientos para la transmisión del conocimiento de los diseńos, tanto como sus contenidos concretos estaban abiertos al cambio. De ahí la relevancia y preocupación de las mujeres seris por generar de manera constante consensos parentales y colectivos fundamentados en la "tradición" para su transmisión, ya que, como advirtió Debbora Battaglia, ${ }^{82}$ al trabajar entre los sabarl en Melanesia, la cultura es un proceso y no un sistema cerrado de signos, y esto implica reconocer, por una parte, que no existe un conocimiento absoluto, fijo o estable que las personas reconocerían previamente a su construcción y, por otra parte, que existe un aura de estabilidad que permite controlar el flujo de tal construcción. Por ello, pese a esta abertura al cambio, las tejedoras seris distinguían entre diseños antiguos, diseños de reciente invención y diseños de origen pápago.

De acuerdo con algunos autores, el tejido de los diseños en la cestería inicia aproximadamente en $1900,{ }^{83}$ para otros, por su complejidad e importancia, no podría ser un desarrollo contemporáneo ${ }^{84}$ y en tanto que hacía parte de la manufactura de los canastos ceremoniales, posiblemente fue una práctica que se abandonó durante la intensificación de las hostilidades entre los mexicanos y los seris durante el siglo XIX para retomarse a principios del siglo xx. ${ }^{85}$ Para las tejedoras de El Desemboque, el reconocimiento de un diseño como antiguo respondía a otros parámetros.

Por sugerencia de algunas mujeres seris y con el fin de ampliar su conocimiento sobre diseños, conformé una segunda base de datos con algunas fotografías de cestería de la Colección Etnográfica del Arizona State Museum (recolectadas entre 1921 y 2000). ${ }^{86} \mathrm{Al}$ observar las fotografías señalaron que

8o. Martínez, "Pensando a través de la cestería seri".

8I. Janet C. Berlo y Ruth B. Phillips, Native North American Art (Nueva York: Oxford University Press, 1998), 29; Cesarino, "A escrita e os corpos desenhados", iıo.

82. Debbora Battaglia, On the Bones of the Serpent. Person, Memory, and Mortality in Sabarl Island Society (Chicago y Londres: The University of Chicago Press, I990), Io.

83. McGee, Los seris, 289; Moser, "Seri Basketry", II7; Schindler, "The Material Culture", 390.

84. Johnson, "Seri Indian Basketry", II.

85. Moser, "Seri Basketry", I22.

86. En la muestra de esta colección sólo hay cuatro canastas de la década de los años veinte, es visible que durante la década de los años treinta y años posteriores a esta fecha proliferaron los diseños de estrellas, redes y flores. Entre 1940 y 1960 aparecen formas nuevas, como canastos 
todos estos cestos eran antiguos. Desde mi perspectiva, y aludiendo a un proceso gradual de figuración, podría describir sobre una línea temporal el desarrollo de algunos diseños como los saguaros o cactus, recolectados en 192I por Louis Wetherill (fig. 4a); en 1930 por James Mason (figs. 4b y 4c) y en 1948 por William Smith (fig. 4d) destacando con Moser ${ }^{87}$ el papel de la demanda comercial. Sin embargo, esto no parecía ser relevante gráficamente para las mujeres seris de El Desemboque. Más aún, conscientes de que eran manufacturados para la venta, los denominaban como antiguos y tradicionales. Esto confirma que para dar cuenta de qué son los diseños en la cestería es preciso ir más allá de un análisis formal.

El valor de antiguo estaba definido por la forma del canasto y su relación con contextos de uso o bien por el vínculo entre el diseño, el canasto y su utilización. Por ejemplo, indicaban que las canastas más antiguas eran aquellas que tenían forma de olla pues en ellas se almacenaban semillas. Posteriormente narraban experiencias personales sobre su vida en los campamentos y describían escenas de comensalidad. La falta de diseño o el diseño de círculos, espiral y zigzag también confirmaba la antigüedad del canasto, señalaban que ellas no tejerían un diseño en un canasto para usarlo y que, en consecuencia, las mujeres antiguas tampoco lo harían. Finalmente, lo antiguo se evaluaba a partir del proceso de manufactura del diseño, pero no así de sus cualidades gráficas. Éste fue el caso de los diseños cöcaafija (hecho con círculos) (fig. 3a) o cocpaaija (remolino) (fig. 3b), cuya evaluación radicaba en que técnicamente eran de fácil elaboración. Por tanto, eran los primeros que toda tejedora aprendía y los primeros que las mujeres antiguas debieron manufacturar.

Pese a que la apreciación de las mujeres de El Desemboque pueda ser paralela a nuestro registro visual, ya que en las primeras fotografías las canastas con diseños ${ }^{88}$ estaban tejidas con cöcaafija e incluso $\operatorname{Moser}^{89}$ reportó que María Luisa

cuadrados, así como diseños distintos y de mayor complejidad técnica, tal como los que Moser, "Seri Basketry", presenta en su artículo. Visita realizada del i al 7 de noviembre. Agradezco el apoyo de Carolyn O’Meara, de Diane D. Dittemore y Andrew T. Higgins, curadores de la colección etnográfica.

87. Moser, "Seri Basketry", 195.

88. García y Alva, Raza seri, 2I y 23. Estas fotografías son parte del reporte de la expedición a la Isla Tiburón de 1904 destinado al entonces gobernador de Sonora, Rafael Izábal, a quien se conoce por sostener los "diez años de la guerra de Encinas" con los seris (Spicer, "Seris", II4). Es preciso mencionar la nota al pie de las fotos donde aparecen "los canastos" y las mujeres que los sostienen sobre sus cabezas: "Mujeres seris detenidas por la Primera Avanzada de los Pápagos de la Expedición”.

89. Moser, "Seri Basketry", II7. 

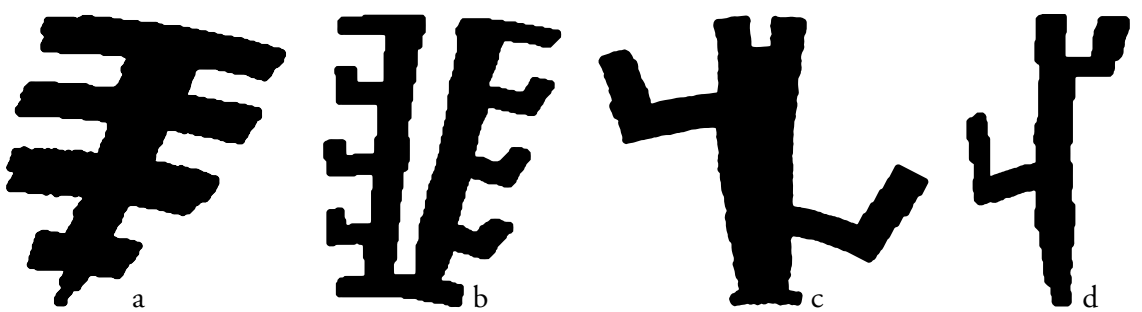

4. Diseños que presentan la figuración de los saguaros y cactus.

Chilón, mujer seri nacida aproximadamente en 1887 , consideró que la primera canasta decorada que observó fue en una fiesta de pubertad, quizá en I900, con el diseńo cocpaaija, ${ }^{90}$ la definición de lo antiguo es diferente. Para ellas lo relevante es cómo el diseño ha transformado la cestería en una técnica potencial de lazos sociales, ya que posiblemente la finalidad de la creación de estos objetos, como diría Lévi-Strauss, ${ }^{91}$ es ampliar el conocimiento sobre ellos, al dar un nuevo sentido empírico y conceptual a su estructura, y al mismo tiempo extender la realidad, en ocasiones de manera imprevista, a la que pertenecen.

Por este motivo, para las mujeres seris la evaluación de un diseńo como antiguo radicaba en un vínculo que desde el presente hacían con el pasado y no su inverso, funcionando de manera análoga a las marcas sabarl en Melanesia, donde lo relevante era la conexión social entre la imagen y su productor. ${ }^{92}$ Así, a diferencia de lo reportado por Moser, ${ }^{93}$ desde la perspectiva de las tejedoras seris, los nombres otorgados a los diseños responderían a un uso doméstico, ceremonial, comercial y antiguo al estar en un campo de transmisión del co-

90. Durante la década de los años veinte encontramos distintos registros visuales con estos mismos diseńos. En la colección etnográfica del Arizona State Museum hay un canasto en forma de olla, colectado en I92I por Louisa Wetherill con diseño cöcaafija. En algunas de las fotografías de Edward H. Davis, de 1924 y I925, quien trabajó como fotógrafo y coleccionista de objetos etnográficos para George G. Heye (Museum of the American Indian en Nueva York) de I9Io a I944, el único diseño identificable fue cocpaaija. Véase la fotografía OPI496I-534 con fecha de 1924, consultada el 20 de abril de 2015, www.sandiegohistory.org, Colección de Fotos de San Diego History Center Online y la fotografía I5/4246 colectada en 1925, consultada el 20 de abril de 20I5, www.nmai.si.edu, Colección de fotos del National Museum of American Indian. En el trabajo de Schindler, "The Material Culture", también hay fotos de canastos de la Heye's Foundation (HF I2/98I6) en forma de olla con diseńo cöcaafija (plate 98) que fueron colectados en I923.

91. Lévi-Strauss, "La ciencia de lo concreto", I06.

92. Battaglia, On the Bones of the Serpent, 6, 8.

93. Moser, "Seri Basketry". 

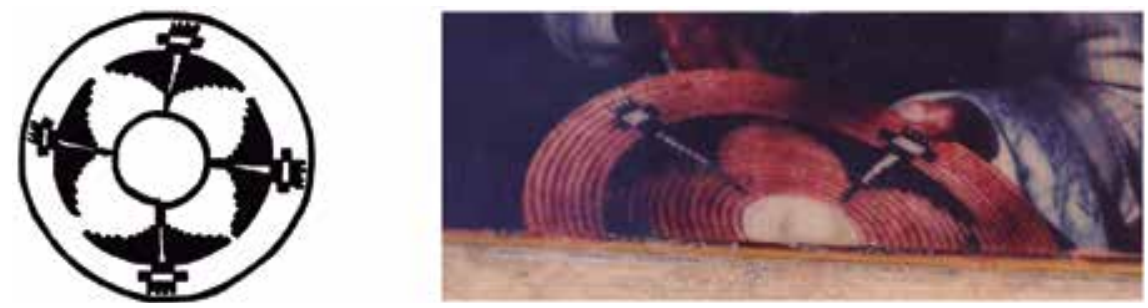

5. a) A la izquierda la fig. I2b de Moser, "Seri Basketry" (vid supra n. 4); b) a la derecha la reproducción de un detalle de una foto que muestra a la madre de Berta Estrella sosteniendo el canasto registrado por Moser. Colección personal de Berta Estrella, 2014.

nocimiento o de vinculación social en el presente, pues es ahí donde adquieren valor para sus poseedores — como señaló Pierre Déléage ${ }^{94}$ para los diseños en Amazonía- y no por los rasgos formales o estilísticos per se o por una relación ceremonial o mercantil que podría presumirse estática a lo largo del tiempo. Además, lo notable de la experiencia de las tejedoras sobre lo antiguo es que, una vez más, está relacionada con la transmisión de un conocimiento familiar, particularmente femenino.

Un ejercicio constante al mirar estas fotografías fue la identificación de las mujeres que habían manufacturado las canastas. Las tejedoras de El Desemboque destacaban que el reconocimiento se producía a partir de una experiencia empírica - estar presentes durante el tejido o venta de la canasta y en ocasiones me mostraban fotografías de sus colecciones personales para demostrarlo- o por una experiencia enseñada — recordaban que a esa mujer le gustaba tejer ese diseño o utilizar ciertos tonos para las fibras. Cabe recordar que, como señalé, estos dos procedimientos forman parte de la transmisión de la "tradición" y del conocimiento. Al mirar la imagen de Moser,"95 una mujer dijo: "esa canasta la tejió mi mamá", acto seguido me mostró una fotografía donde su madre la sostenía entre sus brazos (fig. 5b). Incluso, a esta canasta se le calificó como antigua. Por todo lo anterior, sugiero que para estas tejedoras seris la noción de lo antiguo, vinculada con la cestería, se articula con la memoria de los lazos parentales femeninos que desde el presente la mujer que manufactura los diseños crea con el pasado.

94. Déléage, "Les Pictographies narratives amérindiennes", ııо.

95. Moser, "Seri Basketry", fig. I2b, I26. 
Hasta este momento he mostrado cómo el lazo entre las designaciones de los diseños y los propios diseños es un índice de relaciones sociales que, por una parte, implica generar consensos familiares por la variación individual sobre la cual se fundamenta su producción-nominación y, por otra, involucra una nueva variación a nivel parental cimentada en la "tradición". Esto explicaría las ocho recurrencias en mi registro, ya que, desde esta perspectiva, conformarían un tipo de repertorio gráfico que las tejedoras reconocerían como "tradicional" y antiguo (figs. 3a-3h). Éste, antes que configurar un conjunto cerrado de diseños relacionados con nombres determinados que permanecería intacto a lo largo del tiempo, sería la expresión gráfica de vínculos de experiencia y práctica —empírica o transmitida - compartidos por distintos grupos familiares y fundamentados en la "tradición".

Aún queda por explorar ¿por qué los nombres otorgados remiten a la figuración (estrellas, flores, etc.)? Más aún, ¿por qué ésta es una forma de producción de diseños y cuál es el papel de la invención en este sistema de producción? Es preciso volver al problema inicial de este texto: la variación individual en la producción y denominación de los diseños. La finalidad es dar cuenta de cómo los diseños seris funcionan como técnicas de distinción entre las tejedoras y de intensificación de los vínculos sociales que mantienen con los no seris por medio de la venta de las canastas.

\section{Los diseños como técnicas de vinculación: distinción e intensificación}

La variación individual forma parte del proceso de transmisión y manufactura de la cestería. Ésta se produce durante la recolección del torote en el desierto, ya que por lo general las ramas cortadas suelen ser propiedad de cada mujer, y en los espacios de producción de la cestería, determinados por la composición de cada unidad habitacional ${ }^{96}$ y por la organización y uso que cada mujer

96. A principios de la década de los veinte, los seris se desplazaron gradualmente hacia un antiguo campamento permanente a orillas de Bahía de Kino (Spicer, "Seris," II6), dando inicio a un proceso de sedentarización que culminaría con el establecimiento de la cooperativa pesquera en El Desemboque en 1938 (Spicer, "Seris", II5); Felger y Moser, People of the Desert and Sea, I6. Entre 1974 y 1984, los gobiernos federal y estatal promovieron la construcción, tanto en El Desemboque como en Punta Chueca, de viviendas permanentes de block y concreto cuyo trazo obedecía a una cuadrícula urbana (Pérez Ruiz, "Seris", 80; Rentería, Seris, 30-3I), la cual hasta el día de hoy organiza estos poblados. Por este motivo, los espacios donde se manufactura la cestería 
hace de ellos. En tales espacios - conformados por áreas para cortar y preparar las ramas; quemarlas y producir tinturas; lavar, procesar las fibras y tejer- es posible ver a consanguíneas y afines intercambiando conocimientos y prácticas. Pese a que se reproduzca un canon familiar, durante el tejido de la cestería y la manufactura de los diseños cada tejedora genera un estilo personal. ${ }^{97}$ Como afirmó una mujer: "cada quien tiene su forma de hacer las cosas", ya que el objetivo de esta variación es producir distinción; es decir, el reconocimiento de un proceso creativo personalizado.

El siguiente método que propusieron las tejedoras seris para continuar con la indagación de los diseños fue realizar historias de vida, con las cuales elaboraríamos fichas para identificar sus canastas en las ventas. Pese a que las mujeres recordaban con alegría y orgullo cuáles fueron los primeros diseños que tejieron, en sus relatos destacaban que al adquirir experiencia la variación individual en sus diseños surgía de forma natural. Sin embargo, durante el aprendizaje y la transmisión del conocimiento, esta experiencia creativa también era percibida como algo construido..$^{98}$ Una mujer enseñaba a su hija cómo manufacturar el motivo de la mariposa (seenel) y ésta procuraba alargar las alas y modificar las antenas para generar su estilo. Simultáneamente intentaba recordar motivos de mariposa tejidos por otras mujeres, familiares y vecinas, con el fin de no hacer copias idénticas. $\mathrm{Al}$ mostrarme su canasto, esta aprendiz, recurriendo una vez a la experiencia donde la variación era algo natural que se incorporaba en un proceso creativo, me dijo: "aunque copien, los diseños siempre salen diferentes" (figs. 6a-d). Por esta razón, pese a que Schindler ${ }^{99}$ indicó que los diseños podían ser replicados porque, al no ser propiedad de una familia o de ciertos individuos eran compartidos, sumaría que cada diseño y cada motivo se experimentaba como producto de la creatividad de la mujer que lo manufacturó, tal y como Richard S. Felger y Mary B. Moser señalaron. ${ }^{100}$ Como advirtieron estos autores, esto no es un proceso de copia, sino de apropiación, mediante el cual la variación se crea para posteriormente incorporarse como algo natural.

se alternan con ramadas, particularmente durante el verano (para una descripción de las ramadas o hasóoma véase Felger y Moser, People of the Desert and Sea, II7-II9).

97. Moser, "Seri Basketry", I30; Martínez, "Pensando a través de la cestería seri".

98. Véase Wagner, The Invention of Culture, 36-37.

99. Schindler, "The Material Culture", $4 \mathrm{I} 6$.

I00. Felger y Moser, People of the Desert and Sea, 196. 

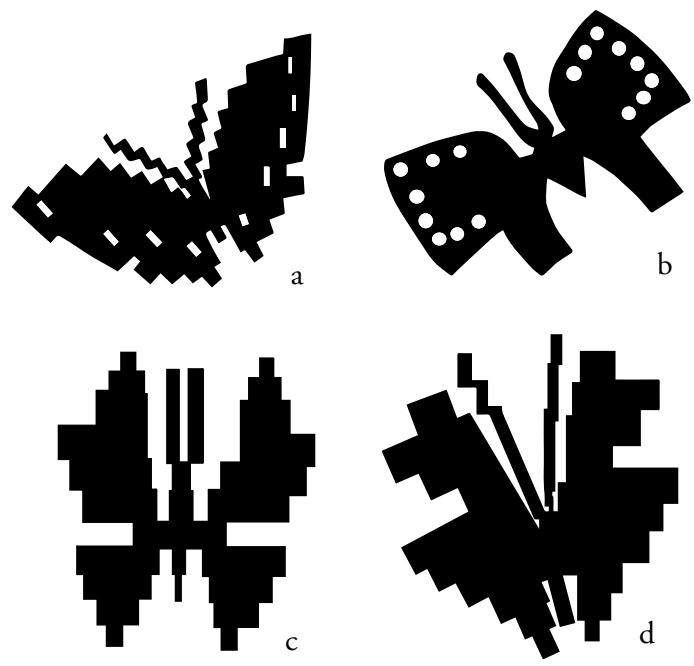

6. Variación de motivos de mariposa creados por algunas mujeres de El Desemboque, diseño de: a) María Luisa Molina;

b) Francisca Morales; c) Ana Victoria Rodríguez; y d) Ana Torres.

El campo para evaluar la producción de esta distinción es la belleza. ${ }^{\text {Ior }}$ Por ello, cuando las tejedoras exponen sus productos para vender esperan que quien los mira, sea un comprador o no, admire la belleza de su trabajo y tal vez no hacerlo sería una descortesía. ;Taziim ih! (¡qué bonito!) es una de las expresiones más comunes entre las mujeres, ya que quizá lo que se aprecia es la capacidad, creatividad, iniciativa e innovación individual plasmada en cada creación. Esta evaluación difiere de aquella del comprador, ya que las premisas sobre las que se fundamenta son distintas. Pese a que los coleccionistas suelen evaluar mercantil y estéticamente las piezas por la calidad del tejido, del tinte y los diseńos, para las tejedoras estas cualidades expresan la distinción individual que se genera por variación durante la manufactura y constituye una técnica de vinculación social. Inclusive la elaboración de los diseńos no necesariamente atiende la demanda del mercado. En mi registro, la mariposa era el diseño con mayor presencia y

IoI. En relación con otras categorías nativas de belleza en Amazonía para los kayapó véase Terence Turner, "Imagens Desafiantes: a Apropriação Kaiapó do Vídeo", Revista da Antropologia, vol. 36 (1994): 36. La belleza para los kayapó es la transformación de la naturaleza en cultura o bien la organización secuencial, repeticiones sucesivas del mismo padrón que con cada integración se aproxima a su perfección. También en México para los rarámuri véase María Isabel Martínez Ramírez, "Crear un mundo caminando", Artes de México. Tarahumaras. El camino, el hilo y la palabra, núm. I22 (20I4): 40, donde lo bello es análogo a lo bueno, donde proceder de manera colectiva y correcta se resume en el término wee gárá júku ("está bueno"). 
empero uno de los intermediarios me comentó que estaba un poco aburrido, era el que más emoción y entusiasmo causaba entre las mujeres.

Recordemos que los canastos no son objetos anteriores a su decoración, sino una totalidad que conjuga la plástica y la gráfica para crear un objeto nuevo. Como he mostrado en otro sitio, ${ }^{\mathrm{IO} 2}$ la producción de fibras, de tinturas y, en el caso que nos ocupa, los diseños tejidos en las canastas condensarían en su manufactura y figuración técnicas que generarían simultáneamente la distinción individual, la ampliación de las relaciones con otros seris (su "tradición" y lazos parentales) y con los no seris. Desde esta perspectiva es preciso indagar a quién están dirigidos los diseños.

Las tejedoras de El Desemboque, ${ }^{\mathrm{IO} 3}$ de acuerdo con mi reporte y visitas de investigación durante los inviernos de 2013 y 2014 en Bahía de Kino, Sonora; Ciudad de México y Tucson, Arizona; comercializaban sus canastos de forma personalizada en un mercado: a) local (El Desemboque, Punta Chueca y Bahía de Kino, Sonora) (fig. 7a); b) regional y nacional (Hermosillo, Sonora) (figs. 7 b y $7 \mathrm{c}$ ), donde por lo general asistían a ferias de artesanía organizadas por Fonart (Fondo Nacional para el Fomento de las Artesanías), el Museo de Culturas Populares y otras fundaciones privadas; y c) internacional (especialmente en el suroeste de los Estados Unidos de América), donde también vendían personalmente sus piezas y asistían a ferias o eventos bajo el apoyo de viajeros y voluntarios de asociaciones como William Penn House.

Dentro del primer circuito las mujeres solían vender sus canastos como parte de un conjunto más amplio de objetos: collares de concha, hueso, chaquira y tela, piezas talladas de palo blanco, palo fierro y coral negro, muñecas de tela, aretes de escama de pez, pulseras, entre otros. El Desemboque se ubica al norte del territorio seri y cuenta con dos vías de comunicación terrestres, ambas de terracería: la primera es costera y la conecta con Punta Chueca y Bahía de Kino, la segunda se vincula con una carretera, extensión de Calle 36 que enlaza Hermosillo y Bahía de Kino, cuyo punto intermedio es Puerto Libertad, pero que comunica con la ciudad de Caborca. ${ }^{104}$ Las condiciones inadecuadas para transitarlas permiten la presencia esporádica de visitantes locales como investigadores, estudiantes, trabajadores temporales e integrantes de organizaciones

IO2. Martínez, "Pensando a través de la cestería seri".

I03. Gutiérrez, "Cestería seri”, I73-I76, presenta una categorización diferente de los mercados para comercializar la cestería en Punta Chueca y El Desemboque: los campamentos o pueblos seris, Bahía de Kino y Hermosillo y los Estados Unidos de América.

I04. Marlett, "Introduction", 36; Pérez Ruiz, Seris, 368. 
DOI: http://dx.doi.org/10.22201/iie.18703062e.2016.109.2623

I62

MARÍA ISABEL MARTÍNEZ RAMÍREZ

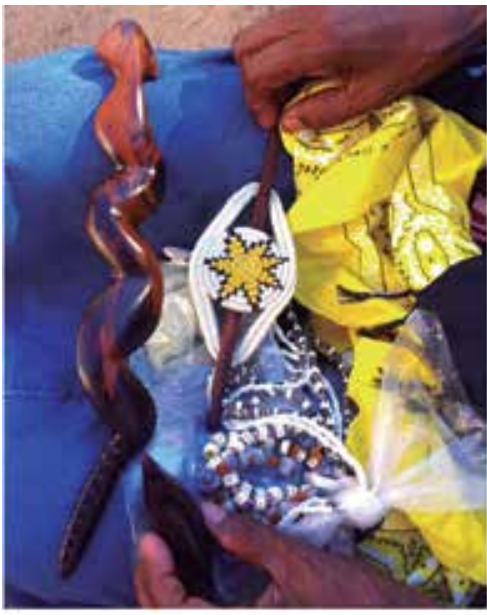

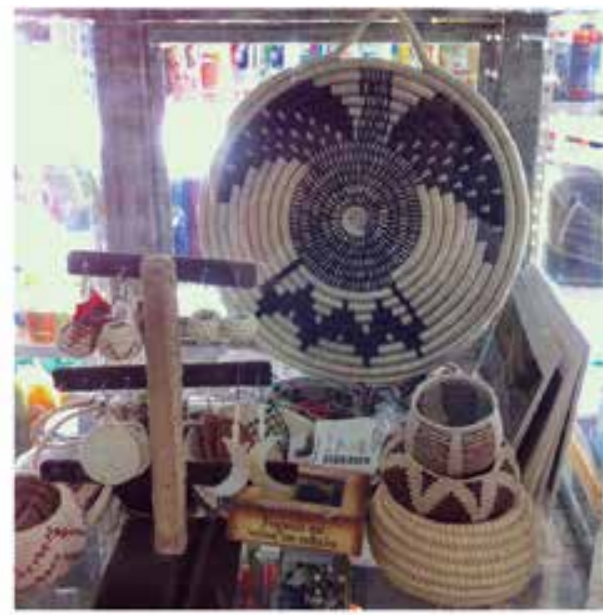

b

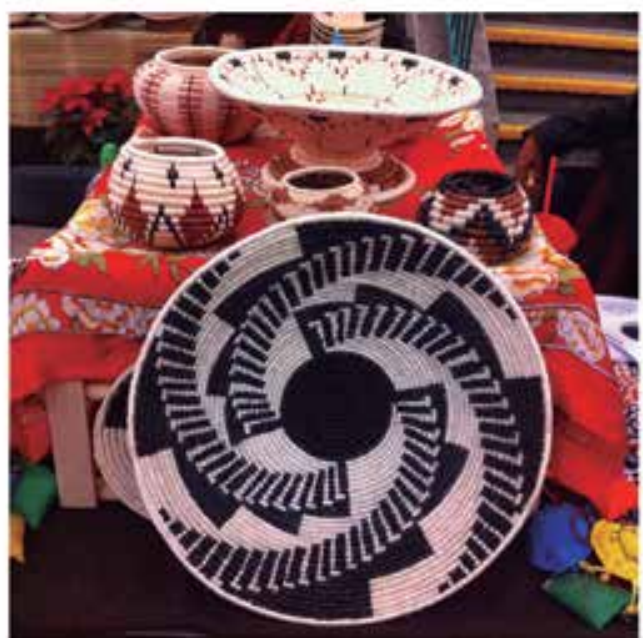

C

7. Contextos de venta de las mujeres seris de El Desemboque: a) María Luisa Molina muestra sus productos de venta; b) vitrina en un local en Bahía de Kino; c) exposición "El arte popular" en la Ciudad de México en diciembre de 20I4. Fotos: María Isabel Martínez Ramírez. 
no gubernamentales, quienes conforman un grupo de compradores potenciales. En ocasiones, las vendedoras no eran las productoras. La venta por consignación opera en todos los circuitos, particularmente en aquellos que requieren desplazamiento. Por último, una de las principales formas de venta es la participación en ferias internacionales y, en ocasiones nacionales, así como la venta directa a intermediarios de Native American art ${ }^{\mathrm{TO}}$ que desde hace décadas mantienen una relación personalizada de compra-venta con algunas tejedoras de El Desemboque.

Durante la manufactura, la variabilidad de los diseños — así como el procesamiento de fibras, tinturas y formas de la cestería— ${ }^{106}$ se articula con la distinción individual entre las tejedoras, evaluada a partir del campo de la belleza. Al ingresar en el circuito de venta, las seris han potencializado este sistema de producción de belleza al manufacturar canastas tejidas con diseños. Es decir, han ampliado las relaciones con los no seris mediante el intercambio y la compraventa, generando nuevas maneras de "alcanzar y crear lo real." Al igual que en los procesos de "intensificación cultural" (cultural enhancement) documentados en Nueva Guinea, ${ }^{107} \mathrm{al}$ innovar e inventar diseños, las mujeres han vigorizado sus mecanismos de distinción y variabilidad internos (sean individuales o familiares), al mismo tiempo que han expandido sus lazos con los no seris. Al ser una técnica para generar distinción individual y consensos familiares, la variabilidad en la producción y denominación de los diseños no sería un indicio de pérdida

I05. La vinculación de la producción de la cestería seri con los circuitos de venta debe enmarcarse en las exploraciones que durante finales del siglo xIx y principios del siglo xx, viajeros como W.J. McGee realizaron entre los seris - y en general en todo el noroeste mexicano y el suroeste de los Estados Unidos de América con la finalidad de coleccionar materiales de culturas que se presuponía no sobrevivirían. Esto produciría un interés generalizado en el sur de los Estados Unidos de América que, aunado al desarrollo de Bahía de Kino - como centro turístico y de pesca comercial entre las décadas de los ańos veinte y cuarenta- y al papel de intermediarios comerciales como Smith, propiciarían un mercado de Native American art que continúa activo bajo la forma de venta en ferias y museos en los Estados Unidos de América. Además, durante la década de los años setenta surgieron en México instituciones cuyo objetivo era el rescate y la revitalización de las artesanías, en tanto patrimonio cultural, que buscaron estimular la organización de talleres familiares para complementar sus ingresos. Pese a que éste no fue el caso seri, actualmente algunos circuitos de venta locales, regionales y nacionales precisan de la intermediación de instituciones públicas como el Fondo Nacional para el Fomento de las Artesanías (Fonart) y el Consejo Nacional de Culturas Populares. Véase Martínez, "Pensando a través de la cestería seri".

Io6. Martínez, "Pensando a través de la cestería seri”.

I07. Véase Richard Salisbury en Sahlins, "O 'pessimismo sentimental”, 53. 
cultural, carencia de significado o la expresión del estatus utilitario de las canastas; sino la manifestación del fortalecimiento de la producción y reproducción de la sociedad. En este sentido, cabe cuestionar en qué medida los seris hacían referencia a este proceso cuando calificaron como bellas sus pinturas faciales y los motivos pintados en la cerámica.

Ejemplo de esto es la producción mediante la innovación, entendida como la apropiación de diseños de una creatividad personal o familiar y proveniente de la variación generada durante la manufactura, la cual permite replicar motivos antiguos, "tradicionales" y de otras tradiciones gráficas, como la de los pápago. Una mujer tejió una canasta con el diseño cocömonjc (ondulado) (fig. 8a) basado en una fotografía que William Smith tomó en 195I en la Isla Tiburón — publicada por David Burckhalter- ${ }^{\text {ro8 }}$ indicando que su costo monetario sería más alto por su antigüedad. También fue el caso de otra tejedora, quien luego de apreciar la belleza de una foto de la colección etnográfica del Museo Nacional de Antropología, decidió tejer una canasta con un diseño análogo (fig. 8b). La finalidad era que la compráramos, estableciendo de esta forma lazos con su "tradición" y con nosotras. Por una parte, estos casos manifiestan que los diseños son técnicas de vinculación que articulan lo antiguo o la "tradición" con su valor en el mercado, al expresar que la relación con una mujer antigua y con un comprador son mutuas e indispensables, una es la condición de intensificación de la otra. En las canastas tejidas con diseños, literalmente se tejen lazos de alteridad internos y externos, una canasta no podría ser "tradicional" sin la que se ha tejido en el presente y sin la conexión que se crea hacia el pasado. Al mismo tiempo, reconocer un canasto como "tradicional" genera, como advertía Battaglia, ${ }^{\mathrm{IO} 9}$ un aura de estabilidad y continuidad. Por otra parte, estos diseños podrían ser dispositivos de memoria, entendida como la producción de vínculos que a partir de la variación individual y durante la manufactura crean las tejedoras desde el presente hacia el pasado.

Como advirtió Carlo Severi, ${ }^{\text {IIO }}$ al igual que para las pictografías de la Biblia Dakota sioux y las producidas por los indios de América del Norte que estuvieron en la prisión Fort Marion, Florida entre i873 y 1875, los diseños seris expresan no sólo las formas en que se transmite la memoria y la "tradición", sino

I08. David Burckhalter, "William Neil Smith and the Seri Indians", Journal of the Southwest 55, núm. I (2013): 76.

I09. Battaglia, On the Bones of the Serpent, 7.

IIO. Severi, "Une Forme mnémonique amérindienne", II4-I64. 

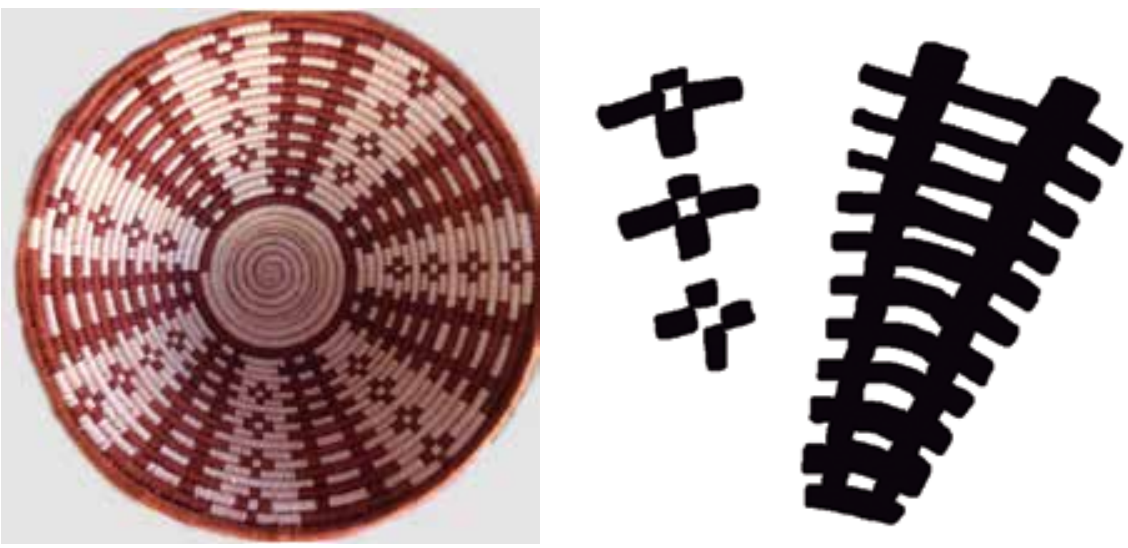

b
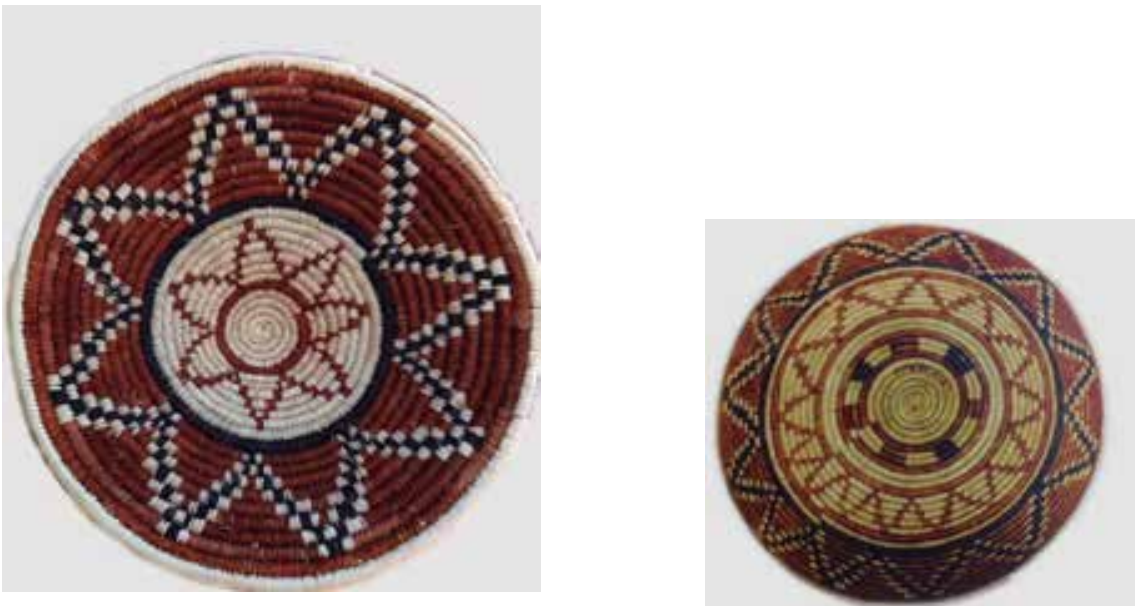

8. Ejemplos de innovación en los cuales se tejen relaciones de alteridad internas y externas, en: a) canasta con el diseño cocömonjc (ondulado), retomado de una fotografía de William Smith de I95I en la Isla Tiburón, tejida por María Luisa Molina. A la derecha se replica un dibujo del diseño original; b) a la izquierda, se muestra el canasto de Berta Estrella, quien replicó el diseño a partir de una foto de la Colección Etnográfica del Museo Nacional de Antropología, a su derecha. Fotos: María Isabel Martínez Ramírez. 
también cómo se crean. Al ser mnemotécnico, su espacio de organización no es exclusivamente visual, también se articula en la conciencia y se suma a los vínculos sociales que condensa y produce. Es posible que, al igual que para los sabarl de Melanesia, ${ }^{\mathrm{III}}$ la memoria no sólo sea una capacidad para recordar, sino una potencia productiva capaz de fijarse en los objetos. Por este motivo quizá el proceso de figuración de los saguaros o cactus no resultó gráficamente relevante para las tejedoras, ya que sean geométricos o figurativos, su importancia radica en la producción social (distinción individual), en la reproducción del colectivo (variación familiar por consenso y creación de la "tradición") y en la intensificación de su sociedad mediante su contacto con los no seris (potencia de distinción y variación). Además, como Severi señala para su caso, los diseños en la cestería seri también son creaciones individuales que fungen como identificación para reconocer a su productora en el tiempo así como dispositivos biográficos, ya que a partir de los vínculos que desde el presente se establecen con el pasado es posible recrear historias sobre las tejedoras y la forma de vida de otros seris no contemporáneos.

Finalmente, los diseños pápago o aquellos que provienen de otras tradiciones, luego de su identificación como fuentes de conocimiento externos, se incorporan a una creatividad individual o familiar. En la literatura, este proceso ha sido entendido como copia ${ }^{\mathrm{II} 2}$ o aprendizaje $\mathrm{e}^{\mathrm{II} 3}$ y como el resultado de la influencia que inició en los años veinte, luego de la relación de compra-venta que algunos coleccionistas privados como Edward H. Davis y William Smith entablaron con los seris. ${ }^{\mathrm{II}} \mathrm{A}$ partir de proveer a los seris de fotos y diseños pimas, papágos y apaches, los motivos de otras tradiciones gráficas del suroeste de los Estados Unidos de América se difundieron, modificando de manera radical su producción. ${ }^{\mathrm{II}}$ Así, surgirían representaciones zoomórficas y nombres de personas. ${ }^{\mathrm{II}} \mathrm{He}$ indicado que los repertorios gráficos seris y los procedimientos de su transmisión están abiertos al cambio. Y es posible que la incorporación de elementos exógenos en la cestería sea un proceso que no necesariamente inicia con su comercialización. ${ }^{\mathrm{II}}$

III. Battaglia, On the Bones of the Serpent, 8.

II2. Moser, "Seri Basketry", I30; Felger y Moser, People of the Desert and Sea, 196.

II3. Felger y Moser, People of the Desert and Sea, I95.

II4. Schindler, "The Material Culture", 416.

II5. Schindler, "The Material Culture", $4 \mathrm{I} 6$.

II6. Moser, "Seri Basketry", izo.

II7. Para un estudio arqueológico comparativo véase T. Bowen, “Seri Basketry: A Comparative View", The Kiva 38-3, núm. 4 (1973): I4I-I72. 
Desde la perspectiva de las tejedoras de El Desemboque, los motivos de otras tradiciones gráficas se incorporan en su creatividad por medio de la variación individual durante la manufactura de los diseńos y una creatividad familiar mediante la transmisión del conocimiento, la construcción del consenso parental y la "tradición". Por tanto, la innovación no expresaría degradación o ruptura, sino que sería una de las cualidades intrínsecas de este sistema de conocimiento y práctica. ${ }^{\mathrm{II} 8}$ Desde este punto de vista, es pertinente cuestionar a Schindler, ${ }^{\mathrm{II}}$ quien indicó que ante la transparencia de esta influencia externa, la innovación y la invención así como la individualidad seri, no se manifestaban en la creación de los diseños, reduciéndola a un proceso de copia y repetición. Afirmaciones que se contraponen con la experiencia de las tejedoras de El Desemboque.

Considero que el proceso de invención de los diseños y de sus denominaciones se articula con la figuración y, en consecuencia, con la potencia de apertura y elasticidad de la tradición gráfica de los seris; hecho que daría cuenta de por qué los diseños se nombran de tal o cual manera. Un ejemplo de esto es el diseño llamado ráama (fig. 9a) que asemeja la cuadrícula del juego de damas chinas, reportado por Moser ${ }^{120}$ como de reciente creación. La forma de producción de éste y otros diseños era reconocida por las tejedoras seris como una invención. Una mujer indicó que el diseño de la imagen IIg de Moser la inventó su madre y narró cómo durante días planeó la manufactura. Denominado por dos mujeres de El Desemboque como canasto en forma de balde con diseño de bolsa de red para colgar ollas con agua (liitro cool cöcoospoj), tanto la forma del canasto como el diseño tejido aludían a su función como contenedores de agua (fig. 9b). ${ }^{22 I}$ De tal manera que, pese a que la forma y el diseño oscilaran entre lo "tradicional" y la invención — pues como demuestra una vez más este ejemplo, éstas no son posiciones opuestas sino constitutivas-, para las mujeres ambas eran figurativas. Por tal motivo, me enseñaron fotos del balde de metal y de la red. Éste también fue el caso de otra mujer, quien al relatarme cómo su madre inventó el diseño cocpaaija (espiral), describió que su objetivo era representar un ventilador. Inclusive, aún aludiendo a fuentes de conocimiento que las vinculaban con su entorno y las remitían a la "tradición", la figuración estaba presente. Una tarde, una tejedora me mostró unas almejas

II8. Véase Rena Lederman en Sahlins, "O 'pessimismo sentimental" ", 64.

II9. Schindler, "The Material Culture", $4 \mathrm{I} 6$.

I20. Moser, "Seri Basketry", I30.

I2I. Moser, "Seri Basketry", II9, imagen IIg. 

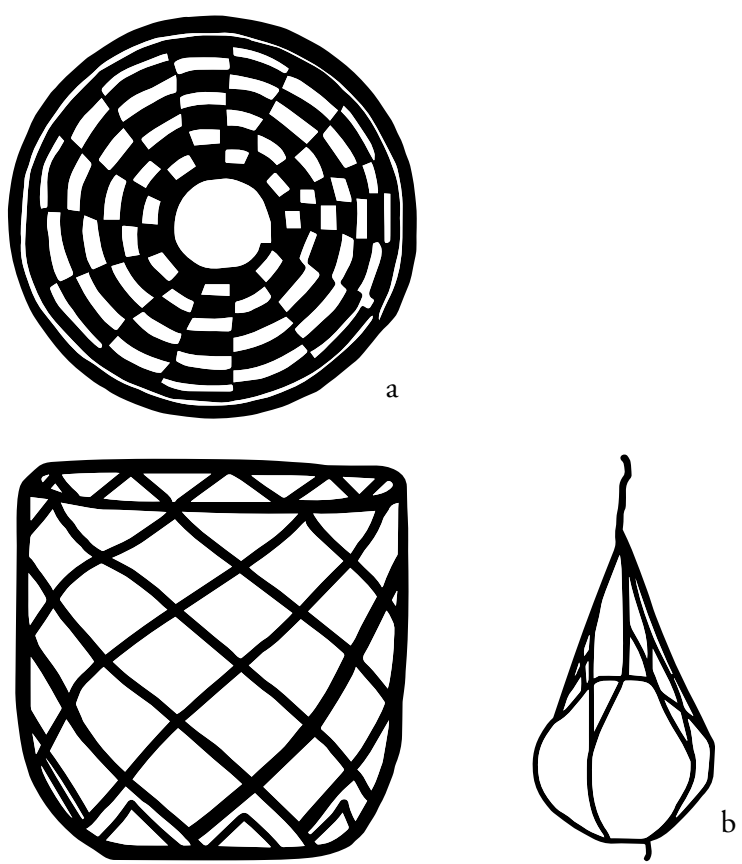

9. Ejemplos de figuración e invención: a) en el diseño denominado ráama figura la cuadrícula del juego de damas chinas, reportado por Moser, "Seri Basketry" (vid supra n. 4), fig. Isd; b) a la izquierda, dibujo de bolsa de red tomado de Moser y Marlett, Comcaac quih yaza (vid. supra n. 37), 222, a su derecha dibujo de un liitro cool cöcoospoj, diseño de bolsa de red, tomado de Moser, "Seri Basketry" (vid supra n. 4), fig. IIg.

piedreras (haxöl heecto, Leukoma grata) a la orilla de la playa para relatarme cómo las seris antiguas habían figurado en sus canastas los diseños que estos animales dibujaban en sus conchas, inventando motivos nuevos. ${ }^{122}$

I22. Por ejemplo, C. Marlett reportó que Raquel Moreno describió cómo una mujer usó el diseño de la concha oot icamazjij (Tivela byronensis), llamado haxöl hasaj o literalmente "almeja (diseño de) canasta", y una vez tejido lo nombraría haxöl yap "diseño de almeja canasta"; Cathy Moser, Shellson a Desert Shore. Mollusks in the Seri World (Tucson: The University of Arizona Press, 2014), I25. 
Aquello que trato de mostrar, por una parte, es que el reconocimiento posterior por analogía no se opone a la invención, sino que, como en el caso de la innovación, los motivos se incorporan a una creatividad propia a partir de vínculos individualizados de transmisión de conocimiento, memoria y "tradición". Por otra parte, al experimentarse como invenciones, cada tejedora genera una relación con los diseños, desde la cual otorga un nombre figurativo que materializa dicho vínculo individual. La figuración y la invención serían procedimientos de incorporación o apropiación a la memoria individual y a la "tradición". Esto explicaría la variación individual en mi registro léxico y en el de otros autores, ${ }^{123}$ fundamento de la producción social de los seris, según mi propuesta. A su vez, daría cuenta del porqué las mujeres de El Desemboque estaban tan preocupadas por crear consensos para transmitirme el conocimiento sobre sus diseños, pues aquello que está dado como natural ${ }^{124}$ es la individualidad, la variabilidad y el cambio y lo que debe construirse constantemente es el consenso en distintas escalas (familiar y colectivo) y la "tradición". Como Taylor advirtió para los shuar y achuar, también en este caso: "no se trata de [crear] una diferencia dentro del marco de una identificación, sino más bien de [generar] una identificación exacerbada dentro del marco de una diferenciación". ${ }^{125} \mathrm{Al}$ reflexionar sobre procesos de variación en la cestería de los rarámuri de Chihuahua advertí que la diferencia era mínima y que debía surgir desde dentro y no desde fuera, es decir, desde donde los canastos podían ser semejantes potencialmente, de lo contrario se corría el riesgo de alterar el modelo inicial. ${ }^{126}$ Para el caso seri y el descrito por Taylor, ${ }^{127}$ la diferencia está latente y debe reducirse de manera constante. Este contraste evidencia que ante objetos que podríamos caracterizar por su semejanza plástica como la cestería, la variación y la individualidad implicadas en su producción pueden ser diferentes.

El problema de la variación individual abrió así un campo de indagación donde los diseños en la cestería seri o, para decirlo de otra forma, las canastas tejidas con diseños serían técnicas de vinculación que articulan la producción de la sociedad seri (distinción individual evaluada mediante un sistema de belleza),

I23. Moser, "Seri Basketry", I24.

I24. Wagner, The Invention of Culture, 36-37.

I25. Taylor, "Les Masques de la mémoire", 320.

I26. Martínez, "Crear un mundo caminando"; Isabel Martínez, "Alteridad, multiplicidad y reversibilidad en clave rarámuri. Crónica de un viaje por la antropología del otro”, tesis de doctorado (Universidad Nacional Autónoma de México, 2012).

I27. Taylor, "Les Masques de la mémoire", 320. 
DOI: http://dx.doi.org/10.22201/iie.18703062e.2016.109.2623

170

MARÍA ISABEL MARTÍNEZ RAMÍREZ

su reproducción (variación familiar, creación de la "tradición") y la intensificación con los no seris por medio de la venta (sistema de belleza y distinción). Más aún, al ser parte de un sistema de relaciones sociales, la producción y existencia de algunos de estos vínculos depende de los otros, expresando que al igual que la plástica y la gráfica, las canastas tejidas con diseños no sólo son otro tipo de objetos sino la expresión de otro modo de conocimiento sobre el mundo, de pensarlo, recrearlo y actuar sobre él. ${ }^{128}$ is

I28. Lévi-Strauss, "La ciencia de lo concreto".

N.B. Agradezco el apoyo del proyecto papiIt ia4OoII3, coordinado por Carolyn O’Meara del Instituto de Investigaciones Filológicas, UNAM, "El léxico nominal en seri” de la DGAPA, UNAM; a las tejedoras seris que coprodujeron esta investigación, Francisca y Marta Morales, Ana Torres, Aurelia Molina, Martha Monroy, Berta Estrella, María Luisa Astorga, Ana Victoria Rodríguez, Adriana Estella Romero, Ángela Torres Cubias, María Luisa Molina, Genoveva Hoeffer Félix, Raquel Hoeffer Félix, María de Jesús Félix Molina (Carolina), Lourdes Hoeffer Félix. A Debora Perales y Karen Selene Rodríguez, traductoras seris y participantes en las entrevistas, así como a Miguel Estrella, entre otros, por el conocimiento que aquí describo. A Carolyn O'Meara y Cathy Marlett por las revisiones de cmiique iitom y sus valiosos comentarios, así como a Steve A. Marlett por su apoyo y asesoría lingüística durante el trabajo de campo. A los dictaminadores anónimos por sus atinadas críticas y sugerencias que dieron profundidad y precisión a mi texto. 


\section{Arquitectura y cerámica de Casas Grandes. Una comparación entre conceptos espaciales arquitectónicos y pictóricos}

\section{Casas Grandes Architecture and Pottery: A Comparison between Architectural and Pictorial Spatial Concepts}

Artículo recibido el 6 de diciembre de 20I5; devuelto para revisión el II de febrero de 20I6; aceptado el Io de marzo de 20I6. http://dx.doi.org/Io.2220I/iie.I8703062e.20I6.IO9.2580

Georgina Parada Carrillo Maestra en Historiadel Arte por partedela unam.giny_p@hotmail.com

Líneas de investigación Arte indígena precolombino orientado al análisis del espacio en la escultura en piedra, pintura cerámica y arquitectura.

Resumen El artículo tiene como objetivo hacer un análisis comparativo entre determinados conceptos espaciales de la arquitectura de la ciudad precolombina de Casas Grandes y los diseños pictóricos de su cerámica polícroma. Dicha comparación revelará profundas similitudes que apuntan hacia una posible relación con los ya perdidos rituales de la cultura Casas Grandes. Sin intención de perseguir una interpretación, o de atender problemas de índole histórica o arqueológica, el texto se enfoca en cuestiones exclusivamente plásticas, en las que el modo de representar la llamada greca escalonada tendrá un papel predominante.

Palabras clave arquitectura precolombina; cerámica; espiral; greca escalonada; geometría; Paquimé; Casas Grandes; diseńos pictóricos, ritual.

Abstract The essay focuses on certain spatial concepts that emerge from the comparative analysis of the architecture of the pre-Columbian city of Casas Grandes and the pictorial designs on its polychrome pottery. This comparison reveals profound similarities that point to plausible correspondences with long lost Casas Grandes rituals. Without seeking to present an unequivocal interpretation or address problems of an archaeological or historical nature, the text concentrates on plastic issues; among these, a preeminent role is played by the way the stepped fret is executed.

Keywords Pre-Columbian architecture; pottery; spiral; step fret; geometry; Paquimé, Casas Grandes; pictorial designs; ritual. 
DOI: http://dx.doi.org/10.22201/iie.18703062e.2016.109.2623 
DOI: http://dx.doi.org/10.22201/iie.18703062e.2016.109.2623

\author{
GEORGINA PARADA CARRILLO
}

\title{
Arquitectura y cerámica de Casas Grandes \\ Una comparación entre conceptos espaciales arquitectónicos y pictóricos
}

\section{L} a ciudad precolombina de Casas Grandes (Paquimé) está inmediatamente ligada a la persona de Charles C. Di Peso, el arqueólogo estadounidense encargado de su excavación entre 1958 y 1961. A pesar de las interminables discusiones a favor y en contra de sus polémicas hipótesis, tuvo la suficiente sensibilidad para sacar a la luz aspectos arquitectónicos que atañen a la historia del arte, y que hoy día, a más de medio siglo de sus conjeturas, son poco o nulamente estudiados. Me refiero al esquema urbano "revertido", donde las estructuras ceremoniales no se encuentran al centro, sino dispersas en torno a la vivienda, las complejas habitaciones de muros escalonados vistos en planta, y los montículos con diseños curvos y zoomorfos, ${ }^{\mathrm{I}}$ cuya identificación, como propone el autor, es dudosa, pero están configurados mediante recorridos en espiral. Estos rasgos son expresamente distintivos de Casas Grandes e inclusive muestran cierta excepcionalidad.

Lo que me interesa demostrar en este ensayo es que todos estos aspectos tienen su paralelo en los diseños pictóricos de la cerámica polícroma de Casas Grandes, cuya mayor producción coincide con el lapso del florecimiento de

I. Charles C. Di Peso, Casas Grandes: A Fallen Trading Center of the Gran Chichimeca, vol. 2 (Dragoon: The Amerind Foundation, 1974), 394 y 429; y Charles C. Di Peso, John B. Rinaldo y Gloria J. Fenner, Casas Grandes: A Fallen Trading Center of the Gran Chichimeca, vols. 4 y 5 (Dragoon: The Amerind Foundation, 1974), 201 y 647. 
DOI: http://dx.doi.org/10.22201/iie.18703062e.2016.109.2623

174

GEORGINA PARADA CARRILLO

su arquitectura, ${ }^{2}$ entre 1300 y I450 d.C., dentro del llamado periodo Medio. Desde el punto de vista de la alfarería, sus diseños también guardan cierta excepcionalidad y peculiaridad como la estricta falta de centro en la composición pictórica, la repetición casi obsesiva de dos elementos escalonados girados uno frente a otro y a menudo designados en negro y rojo, y la extrańa configuración de elementos zoomorfos con un grado de estilización que varía de un extremo naturalista a uno geométrico y en cuya composición casi siempre está implicada la espiral.

Estas comparaciones están condensadas en la figura I. Lejos de demostrar las semejanzas superficiales indicadas en la imagen, pues no ignoro las distintas problemáticas y soluciones de cada soporte artístico, el texto revelará similitudes más profundas que apuntan hacia un origen común, posiblemente relacionado con los ya perdidos rituales de la cultura de Casas Grandes. Sin intención de perseguir una interpretación inequívoca, mi objeto es proponer un punto de vista para aproximarnos a un arte tan poco entendido dada su predominancia geométrica y el sorprendente modo de representar un concepto tan enigmático como la simbiosis entre la espiral y la escalera.

\section{La arquitectura}

La expresividad de la arquitectura de Casas Grandes no ha sido ignorada por los estudiosos contemporáneos, quienes la han analizado desde nuevos enfoques como el animismo y la fenomenología. El primero ha buscado superar la limitada interpretación funcional tanto de su arquitectura como de otros objetos; ${ }^{3}$ el segundo ha demostrado que los contrastes entre las dos porciones de la ciudad no pueden expresarse a partir de la dualidad, pues cada una define a la otra mediante una interacción permanente. ${ }^{4}$

Esta dicotomía se refiere a dos patrones bien definidos: uno al oriente donde se concentran las unidades habitacionales, de rígidos muros ortogonales y

2. Michael E. Whalen y Paul E. Minnis, The Neighbors of Casas Grandes: Excavating Medio Period Communities of Northwest Chihuahua, Mexico (Tucson: The University of Arizona Press, 2009), iI8.

3. Christine S. VanPool y Todd L. VanPool, "Breath and Being: Contextualizing Object Persons at Paquimé, Chihuahua, Mexico", en Kathryn Roundtree, Christine Morris y Alan A.D. Peatfield, eds., Archaeology of Spiritualities (Nueva York: Springer, 2012), 87-106.

4. Delain Hughes, "Complementary Dualities: The Significance of East/West Architectural Difference in Paquimé”, tesis de Maestría en Artes (University of North Texas, 2005), 63. 


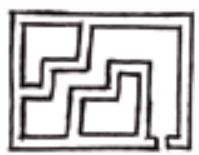

a. Viviendas de la Unidad 8.

Detalle de la vasija CG-698.
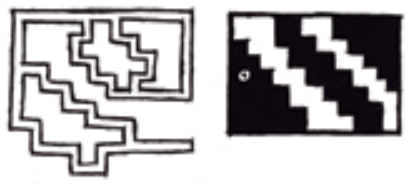

c. Viviendas de la Unidad I4.

Detalle de la vasija CG-6062.
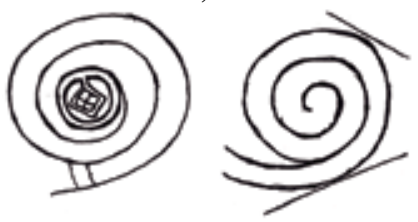

e. Torre sobre cerro Moctezuma.

Detalle de la vasija CG-4307.
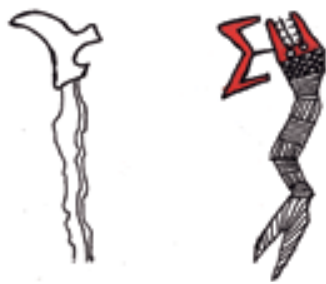

g. Montículo de la Serpiente.

Detalle de la vasija CG-3642.
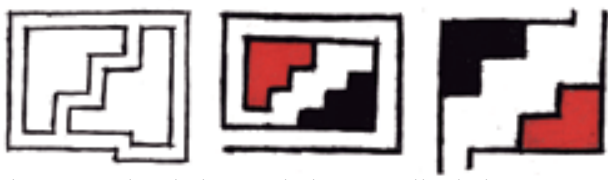

b. Viviendas de la Unidad 8. Detalle de las vasijas CG-269 y CG-4304.
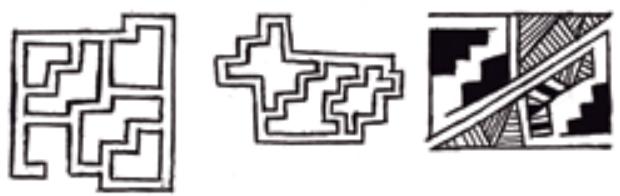

d. Viviendas de la Unidad I4. Detalle de la vasija CG-8566.
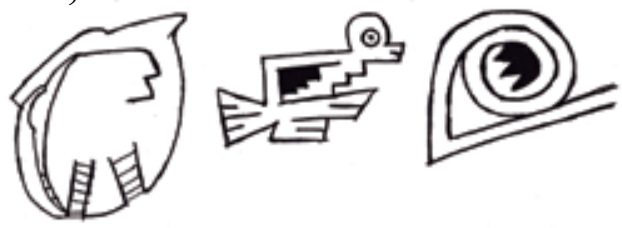

f. Montículo del Pájaro. Detalle de la vasija CG-6062.
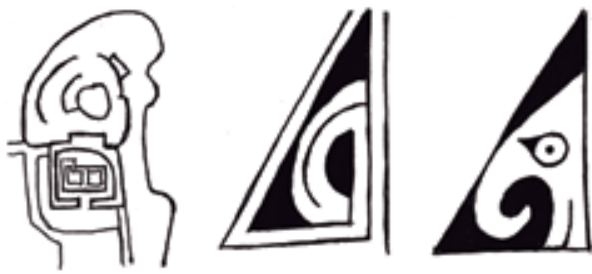

h. Montículo de las Ofrendas. Detalle de las vasijas CG-4368 y CG-O83O.

I. Comparación entre estructuras arquitectónicas y diseños pictóricos en la cerámica de Casas Grandes. Dibujo: Georgina Parada. 


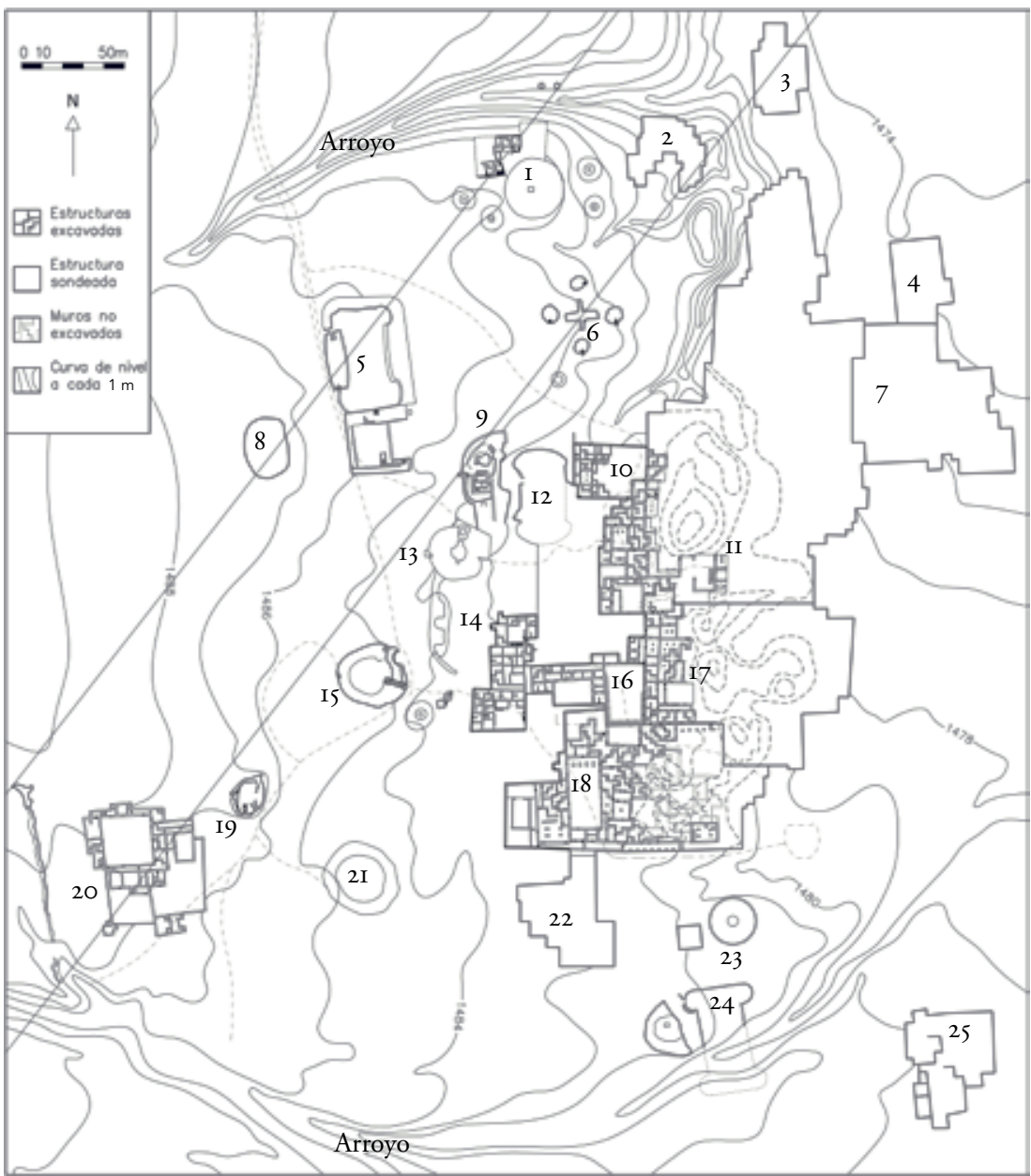

I. Unidad I, Casa de los Hornos

2. Unidad 23

3. Unidad $2 \mathrm{I}$

4. Unidad 22

5. Cancha I

6. Unidad 2, Montículo de la Cruz

7. Unidad I9

8. Unidad 5

9. Unidad 4, Montículo de las Ofrendas
Io. Unidad 6

II. Unidad 8, Casa de la Noria

I2. Cancha III

I3. Aljibe I

I4. Unidad I2, Casa de las Guacamayas

I5. Unidad 9, Montículo de los Héroes

I6. Unidad I3, Casa de los Muertos

I7. Unidad I6, Casa de los Cráneos
I9. Unidad ıo, Montículo del Pájaro 20. Unidad II, Casa de la Serpiente 2I. Aljibe 2

22. Unidad I5

23. Unidad I6

24. Cancha II

25. Unidad 20

2. Casas Grandes, plano de la ciudad con dos líneas paralelas a 38․ Dibujo: Georgina Parada, a partir del levantamiento y la digitalización de estructuras arquitectónicas realizadas por el Instituto Nacional de Antropología e Historia y del plano publicado en Di Peso, Rinaldo y Fenner, Casas Grandes (vid. supra n. I), vol. 5, fig. 285. 


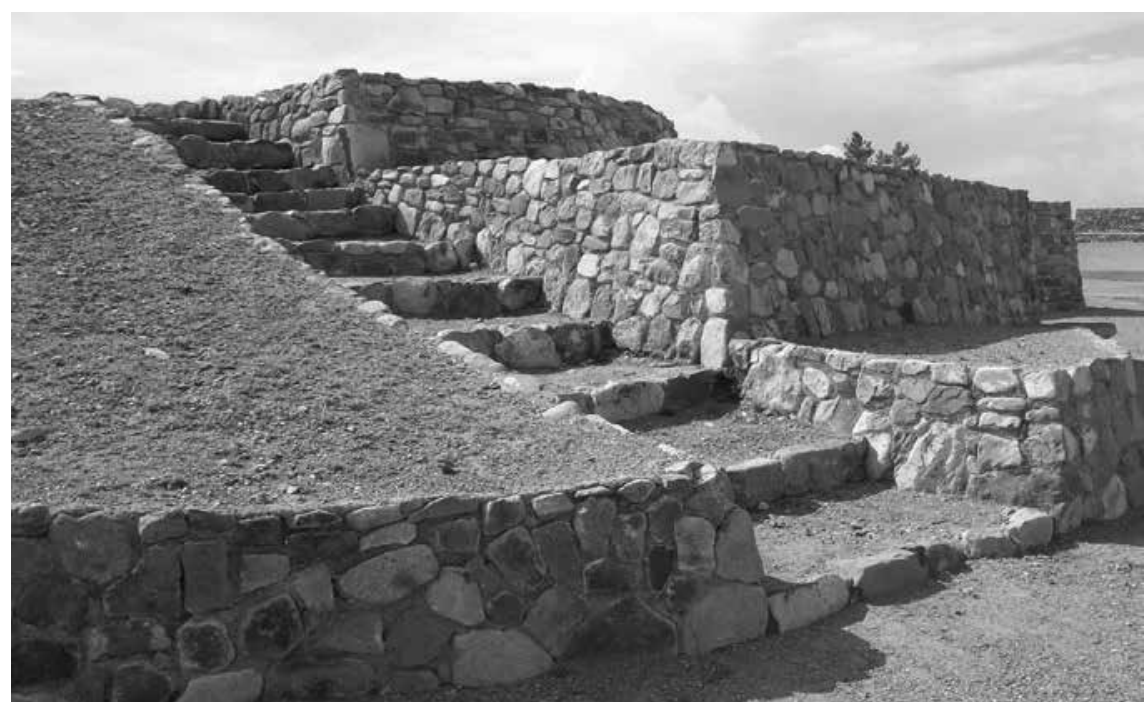

3. Casas Grandes, Montículo de los Héroes (Unidad 9). Foto: Georgina Parada. Secretaría de Cultura-INAH-Méx. "Reproducción autorizada por el Instituto Nacional de Antropología e Historia”.

escalonados; otro al poniente y sur donde se diseminan algunas viviendas aisladas y las estructuras consideradas como públicas o ceremoniales con la predominancia de formas curvas, más libres (fig. 2).5 La segmentación espacial entre estas mitades responde más bien a un eje diagonal, derivado del contorno escalonado del complejo y de las estructuras individuales alineadas en sentido noreste-suroeste, con una inclinación cercana a $38^{\circ}$.

Es probable que las entradas a la ciudad se encontraran al sur y principalmente al este del conjunto habitacional, ${ }^{6}$ que coincide con el arribo desde el río y se evidencia por las columnatas en la Unidad I4. Desde esta perspectiva las estructuras público-ceremoniales, siete montículos y dos canchas de juego de pelota, se desenvuelven tímidamente detrás de la gran masa de viviendas

5. Para mi análisis considero sólo las 23 unidades que Di Peso excavó y sondeó, tal como aparecen en la figura 2, por tanto, rechazo la controvertida existencia de una plaza central y de un conjunto situado al oriente, propuestos por él, y que todavía son materia de discusión entre investigadores, postura que he tomado al seguir la incomparable experiencia del arqueólogo Eduardo Gamboa en el sitio de Casas Grandes.

6. Eduardo Gamboa, comunicación personal, 2013. 
DOI: http://dx.doi.org/10.22201/iie.18703062e.2016.109.2623

178

GEORGINA PARADA CARRILLO

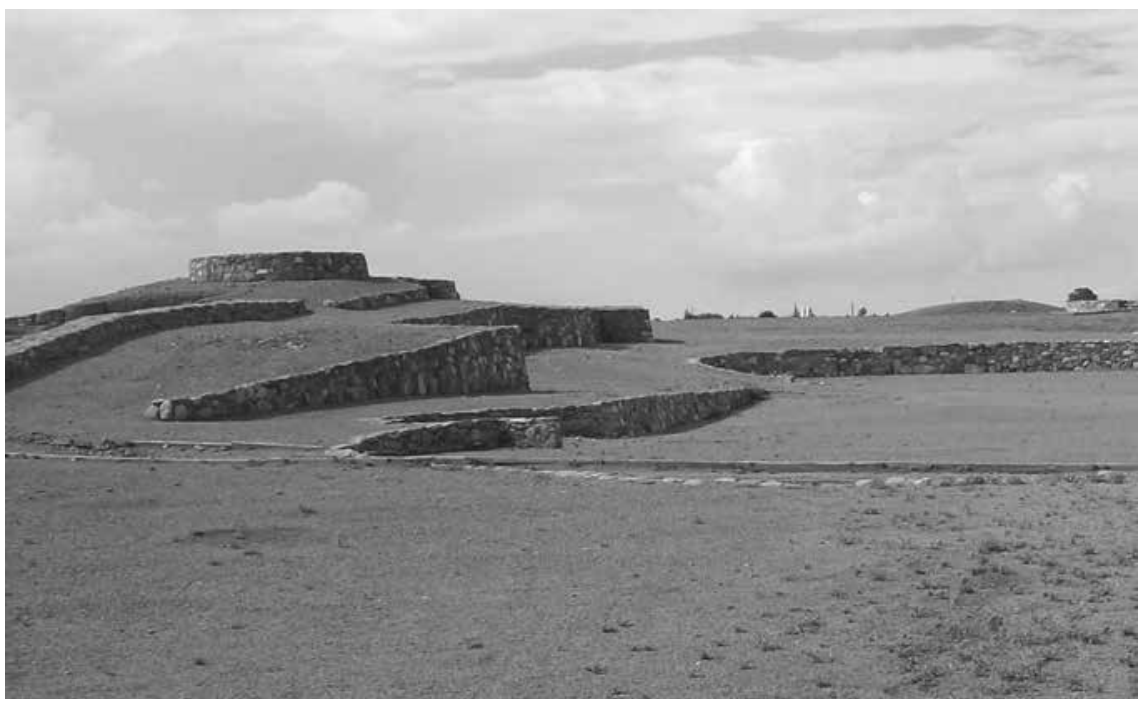

4. Casas Grandes, Montículo de las Ofrendas (Unidad 4). A la derecha se observa una cancha de juego de pelota. Foto: Georgina Parada. Secretaría de Cultura-INAH-Méx. "Reproducción autorizada por el Instituto Nacional de Antropología e Historia”.

(quizá sobrepasaba los tres niveles de altura), 7 sin intención de destacar en el paisaje (figs. 3-5). Cinco de los montículos mantienen una alineación suroeste-noreste, la cual corre desde el extremo sur del Montículo de la Serpiente (al poniente de la Unidad II) hasta el Montículo de la Cruz (Unidad 2), e incluso puede extenderse a dos unidades más (las unidades habitacionales 23 y 2I), que se hallan aproximadamente sobre la misma altitud. Los cinco se suceden de manera rítmica con un espaciamiento más o menos constante. Ninguno domina sobre otro, por lo que puede sugerirse que todos gozaban de la misma

7. Baltasar de Obregón en el siglo Xvi refiere seis o siete niveles (citado por Di Peso, Rinaldo y Fenner, Casas Grandes, vol. 4, II3). John R. Bartlett, durante su visita en I850, calcula hasta 50 pies o seis pisos de altura (John R. Bartlett, A Personal Narrative of Explorations and Incidents in Texas, New Mexico, California, Sonora and Chihuahua. Connected with the United States and Mexican Boundary Comission during the Years 1850-1853, vol. II [Chicago: The Rio Grande Press, I965], 350). Adolph Bandelier, quien visitó las ruinas a finales del siglo XIx, considera la posibilidad de cuatro niveles (Bandelier, The Southwestern Journals of Adolph F. Bandelier, I883-1884, eds. Charles Lange y Carroll L. Riley [Alburquerque: The New Mexico University Press, 1970], 295). 


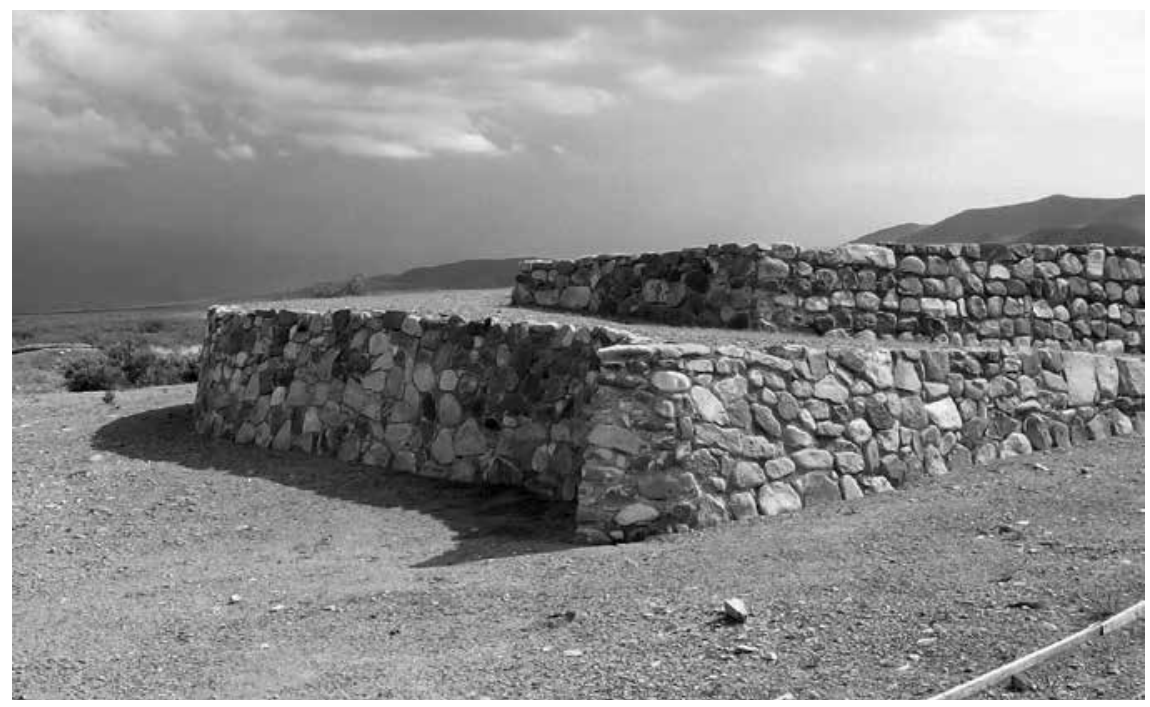

5. Casas Grandes, Montículo del Pájaro (Unidad 19). Foto: Georgina Parada. Secretaría de Cultura-INAH-Méx. "Reproducción autorizada por el Instituto Nacional de Antropología e Historia”.

posición jerárquica. Dichas estructuras se han relacionado con el sistema de clanes, en el que cada una representaría un grupo social encargado de tareas específicas. $^{8}$

Esta disposición urbana merece especial atención, pues las estructuras ceremoniales se alinean con la torre cilíndrica de rampa helicoidal sobre la cima del cerro Moctezuma, un cerro de trincheras ubicado a seis kilómetros al suroeste de la ciudad (fig. 6).9 Si ignoramos la distancia que separa este elemento de la ciudad, concepto por demás relativo, dicha torre se inserta como una "estación" más en la cadena de montículos ceremoniales. Su forma no es propiamente una singularidad, pues las espirales son un elemento recurrente en los cerros de

8. El clan de la serpiente podría ser un ejemplo de ello, el cual tendría a su cargo los trabajos de irrigación (Gamboa, 2013).

9. Las relaciones visuales entre uno y otro montículo se desarrollaron extensamente en un trabajo al que ya hice mención; por supuesto el autor no ignora las distintas alineaciones posibles entre estructuras arquitectónicas, aunque no hace mención a la línea con el cerro (Hughes, "Complementary Dualities", 76-78). 
DOI: http://dx.doi.org/10.22201/iie.18703062e.2016.109.2623

I80

GEORGINA PARADA CARRILLO

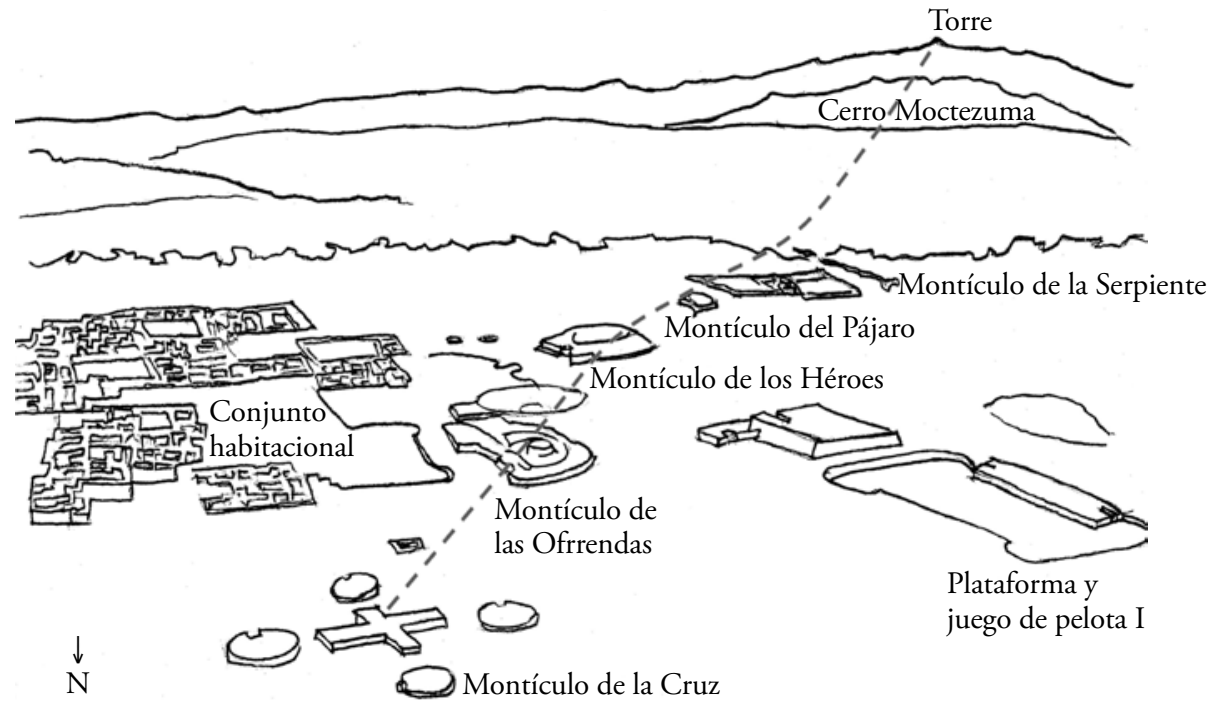

6. Casas Grandes, relación entre las estructuras ceremoniales y la torre sobre el cerro Moctezuma. Dibujo: Georgina Parada, basado en una fotografía publicada por el Centro INAH Chihuahua (www.inahchihuahua.gob.mx). Secretaría de Cultura-INAH-Méx. "Reproducción autorizada por el Instituto Nacional de Antropología e Historia”.

trincheras, así como las pequeñas torres o corrales construidos en las cimas. ${ }^{\text {IO }}$ Di Peso identificó el cerro y su torre con un supuesto culto a Ehécatl, ${ }^{\mathrm{II}}$ aunque la discusión de dicha hipótesis está fuera de la temática de este ensayo, la relación entre la espiral y el viento es incuestionable. Efectivamente embisten a la ciudad fuertes vientos provenientes del suroeste, más en concreto desde el cerro, y se confirma de este modo la importancia capital que este elemento paisajístico juega en el urbanismo.

Otro aspecto sustenta que esta alineación sea un elemento primordial en la arquitectura; me refiero a la observación astronómica publicada por Di Peso sobre la ocultación de Sirio, la estrella más brillante del firmamento, fenóme-

Io. Bridget Zavala, "Elevated Spaces: Exploring the Symbolic at Cerros de Trincheras", en Christine S. VanPool, Todd L. VanPool y David A. Phillips, eds., Religion in the Prehispanic Southwest (Lanham: AltaMira Press, 2006), I42. La estructura más famosa de este tipo es sin duda "El Caracol" en Cerro de Trincheras, Sonora.

II. Di Peso, Casas Grandes, vol. 2, 365 y 549 . 
no que sucede detrás de la referida torre, vista desde el Montículo de la Cruz. ${ }^{\text {I2 }}$ Esta observación no debería ignorarse, pues la cruz tenía un carácter estelar entre los pueblos precolombinos del noroeste. ${ }^{\mathrm{I3}}$ Aunque se ha identificado este montículo como una representación de Venus, ${ }^{14}$ un vistazo al complejo religioso de los indios pueblo denota un panorama astral considerablemente más rico. Hago esta comparación porque es muy probable que en Casas Grandes existiese una fuerte tradición pueblo. ${ }^{15}$ En esta cultura las estrellas actúan como guías del hombre, y Sirio parece cumplir un papel de mediador entre el ser humano y el mundo animal: "Ésta es la estrella que controla la vida de todos los seres en el reino animal. Su aparición completa el patrón armónico del Creador, quien ordenó que el hombre debe vivir en armonía con todos los animales de este mundo". ${ }^{16}$

Respecto a las estructuras zoomorfas es difícil deducir una identificación precisa con imágenes de aves o guacamayas como Di Peso propone, con excepción de la serpiente (fig. 2, esquina suroeste). Si llegaron a representar un objeto concreto, la restauración no permite apreciarlo. Considero más valioso su papel dentro de la actividad y el ritual, pues su escasa altura y los recorridos que dibujan proponen conceptos de movimiento y dirección en el contexto religioso de Casas Grandes, además de aludir a imágenes de contenido simbólico. El Montículo de la Serpiente ilustra esta suposición. Son por demás conocidas las evocaciones acuáticas otorgadas a la representación de este animal, tema demasiado extenso para ser tratado aquí: ${ }^{17}$ lo significativo para este trabajo es que la posición de su cabeza indica un desplazamiento hacia el norte, al igual que el río Casas Grandes, de modo que es el movimiento y

I2. Di Peso, Rinaldo y Fenner, Casas Grandes, vol. 4, 288.

13. Carroll L. Riley, The Kachina and the Cross: Indians and Spaniards in the Early Southwest (Salt Lake City: The University of Utah Press, 1999), 156.

I4. Marc Thompson, "Pre-columbian Venus: Celestial Twin and Icon of Duality", en Religion in the Prehispanic Southwest, 165-183.

I5. Stephen Lekson, "Was Casas a Pueblo?", en Curtis F. Schaafsma y Carroll L. Riley, eds., The Casas Grandes World (Salt Lake City: The University of Utah Press, 1999), 84-92.

16. Frank Waters, Book of the Hopi (Nueva York: Ballantine Books, 1963), I84 (la traducción es mía). En otra ocasión los animales dicen a los hombres del clan de la Niebla en uno de los mitos hopi: "Tu estrella protectora será Ponóchona [Sirio], la estrella a quien debes pedir para incrementar el reino animal", Waters, Book of the Hopi, 299.

17. La conexión entre el control del agua y el citado montículo (relacionado iconográficamente con la serpiente de agua cornuda de otras partes del noroeste) ha sido desarrollada de manera amplia por los VanPool. Véase sobre todo VanPool y VanPool, "Breath and Being", 87-ro6. 

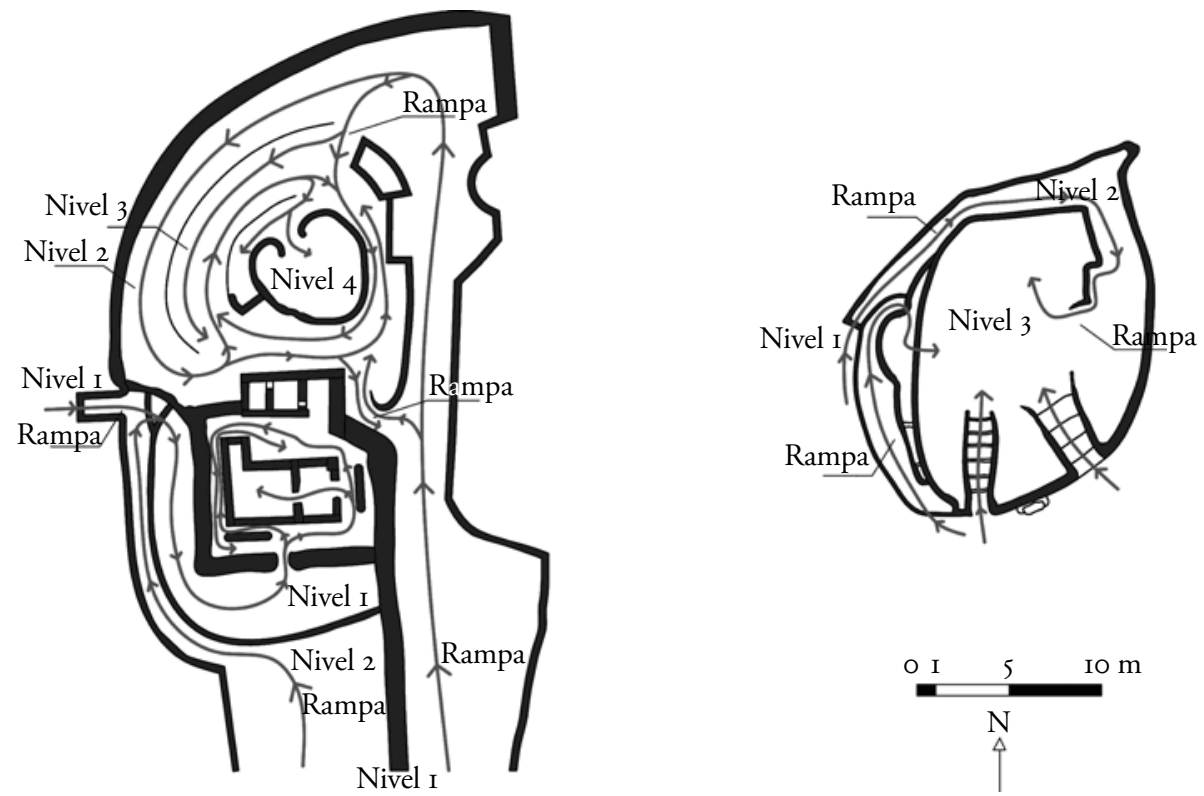

7. Casas Grandes, recorridos en el Montículo de las Ofrendas (Unidad 4) y en el Montículo del Pájaro (Unidad 19). Dibujos: Georgina Parada, a partir del levantamiento y la digitalización de estructuras arquitectónicas realizados por el Instituto Nacional de Antropología e Historia y los planos publicados en Di Peso, Rinaldo y Fenner, Casas Grandes (vid. supra n. I), vol. 4, 307 y 472 , figs. 218 y 324 .

la direccionalidad lo que aquél sustrae del agua, más allá de su forma u otra característica. Más adelante, al analizar las imágenes figurativas en la cerámica, esta conjetura se definirá con mayor claridad.

Además de la torre del cerro, otras dos estructuras presentan recorridos en espiral, los cuales describen un movimiento ascendente hacia el interior (fig. 7 ). En el Montículo de las Ofrendas los posibles caminos a lo largo de las rampas combinan el desplazamiento de la espiral y el meandro (o curvas paralelas). En el Montículo del Pájaro una espiral termina en forma escalonada. Todas ellas son configuraciones que encontramos en la cerámica (figs. re, $\mathrm{fy}$ h).

De nuevo un acercamiento a los indios pueblo induce a plantear seriamente la primacía de conceptos de movimiento, dirección y sentido en el mundo ritual de Casas Grandes. Durante la festividad Wúwuchim (primera ceremonia de invierno donde se pide por la germinación de todas las formas de vida 
en la tierra), cuatro grupos hopi realizan sucesivamente cuatro circuitos alrededor de la villa, cada uno más chico que el otro; distinguiendo entre un movimiento dextrógiro, cuando se vincula con el sol, y uno contrario, cuando se relaciona con la tierra. Al final se colocan frente a la kiva (casa comunal semisubterránea) desplazándose lentamente de derecha a izquierda en forma de arco, dejando un patrón armónico (¡escalonado?) en la arena. ${ }^{18}$

El concepto de movimiento que propone la sucesión y ausencias de jerarquías entre las estructuras ceremoniales se confirma por la inexistencia de un elemento troncal que supondría cierto estatismo en el urbanismo. La misma plaza referida como central en el proyecto de excavación, ubicada al sur del Juego de Pelota III (fig. 2), dista mucho de ser un centro, pues no existe ninguna característica que le confiera tal atributo, la mayoría de los muros de la vivienda que le rodean son ciegos y parte de la plaza en realidad pertenece a una cancha en forma de I cuya restauración está incompleta. ${ }^{19} \mathrm{La}$ falta de relaciones axiales en Casas Grandes ha generado que los principales estudios sobre el tema no contemplen una organización entre las estructuras ceremoniales. ${ }^{20}$ Más bien habría que pensarla bajo su propia lógica del espacio, independiente de cualquier distribución axial o centralizada. Lógica que se hará más patente al analizar el espacio interior de la vivienda.

Los arqueólogos coinciden en el supuesto de que la ciudad fue presa en determinado momento de una remodelación planeada, relacionada con un cambio político significativo. Durante estas transformaciones las unidades habitacionales, antes aisladas, crecieron hasta apiñarse en un solo conjunto masivo de varios niveles, que produjo manifiestos cambios en el espacio interior. Un esquema cercano a lo que llamaríamos central o arborescente, con habitaciones en torno a una plaza, a menudo rectangular y con columnas o pórticos, parece haber sido trastocado por elementos constructivos predominantemente escalonados. Se sabe que esta multitud de esquinas fueron benéfi-

18. Waters, Book of the Hopi, I8I.

19. Agradezco la observación de Gamboa, quien me indicó que efectivamente ésta es una cancha de juego de pelota (comunicación personal, 20I3); Di Peso no la contempla a pesar de tener las mismas dimensiones y un montículo adyacente al igual que los otros dos juegos.

20. A propósito de las unidades ceremoniales Beatriz Braniff dice: "En el plano de la ciudad vemos que estas unidades se encuentran frente al ala oeste, y la rodean por el norte y por el sur. Ninguna de ellas se ubica en forma organizada o simétrica con respecto a las demás, pues cada una ocupa un lugar y posición diferentes", Beatriz Braniff, Paquimé (México: Fondo de Cultura Económica, 2008), 67. 
DOI: http://dx.doi.org/10.22201/iie.18703062e.2016.109.2623

I84

GEORGINA PARADA CARRILLO

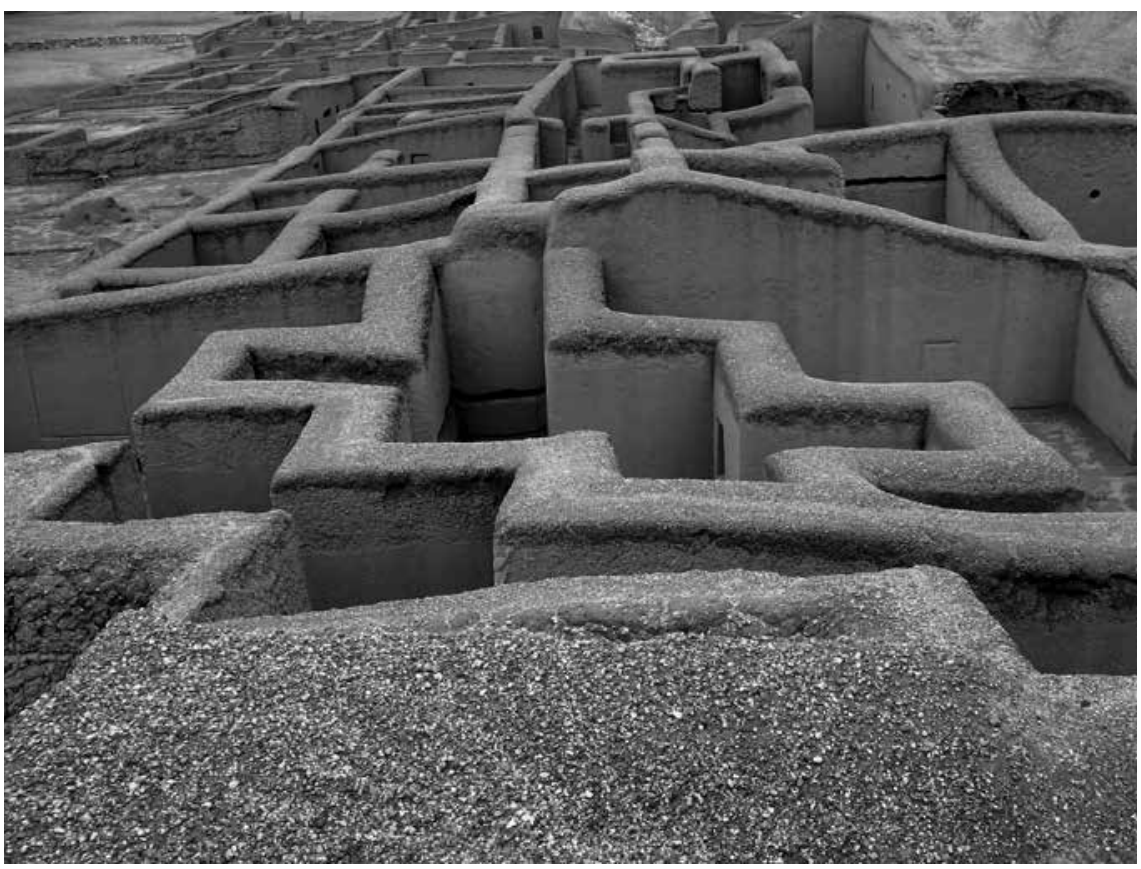

8. Casas Grandes, Casa de los Pilares (Unidad I4). Foto: Georgina Parada. Secretaría de Cultura-INAH-Méx. "Reproducción autorizada por el Instituto Nacional de Antropología e Historia”.

cas para sobrellevar el paso del tiempo, ${ }^{21}$ por lo cual es posible observar cómo estas construcciones sincretizan una necesidad trascendental con la gran cantidad de ángulos que requiere la construcción con tierra (fig. 8).

Proponer un punto de partida para analizar el espacio interior no es tarea fácil, debido a su confusa distribución laberíntica y al hecho de que más de la mitad del conjunto aún yace bajo tierra. Al examinar la planta arquitectónica desde la geometría analítica, es decir, con relación a su ubicación en un sistema de coordenadas cartesianas, pronto se descubre que su organización no concuerda con la percepción real. No es casualidad que David R. Wilcox haya adoptado un método procedente de las matemáticas modernas y la topología,

2I. Según Bartlett todas las esquinas y paredes cortas que formaban ángulos se mantenían en pie, al menos, durante su visita a mediados del siglo xix (Bartlett, A Personal Narrative, 353). 
como la teoría de grafos, para analizar el espacio interior en Casas Grandes. ${ }^{22} \mathrm{Su}$ propuesta demuestra que la importancia y el uso de los espacios se fundamentan en la relación entre ellos, y no por conceptos de forma, ubicación o tamaño. Cada habitación se define por factores como su accesibilidad respecto al exterior, si controla la permeabilidad de otra, o si existe una o más rutas alternas para llegar a ella. Sin intención de aplicar estrictamente su método, éste me proporcionó un comienzo para analizar el intrincado espacio habitacional (tres de estas unidades están reproducidas en la fig. 9). ${ }^{23}$ De modo que nos encontramos con grupos de habitaciones conectadas entre sí a los que Di Peso llamó clusters, sin vínculo directo con otros grupos adyacentes. A primera vista este agrupamiento se presenta arbitrario, no responde a una estructura discernible en planta. En los niveles superiores los grupos o clusters pueden no coincidir, por lo cual una habitación puede asirse a distinto grupo en cada nivel, concibiendo la totalidad del conjunto como una compleja red tridimensional, donde el intrincado y escalonado diseño en planta se repite en sección vertical.

El esquema escalonado produce pares de habitaciones divididas por un muro de dos, tres o hasta cuatro ángulos, los cuales recrean uno de los diseños más abundantes en la cerámica: las dos figuras escalonadas inscritas en un rectángulo (figs. Ia-d). Es significativo que a pesar de su proximidad estas parejas pueden estar remota o nulamente vinculadas, pues no hay forma de corroborar si era posible pasar de una a otra sin salir por completo del conjunto habitacional, a menos que existiese un camino, hoy desaparecido, a través de los niveles superiores (por ejemplo las habitaciones 7 y 8 de las Casas de la Noria y de los Pilares, fig. 9).

El tránsito entre un grupo y otro sólo es posible mediante patios o plazas interiores que, a su vez, se conectan entre ellos por habitaciones que debieron

22. Su método presenta una combinación entre una teoría sobre la lógica social del espacio desarrollada por Hillier y Hanson en 1984, que busca responder cómo nuestras acciones configuran el espacio para acomodarse a nuestras necesidades; y la teoría de grafos, un modo abstracto de expresar las relaciones entre los objetos, representado gráficamente por medio de nodos unidos con líneas (David R. Wilcox, "A Preliminary Graph-theoretic Analysis of Access Relationships at Casas Grandes", en The Casas Grandes World, 93-I04).

23. Para este análisis tomo en conjunto tan sólo las dos primeras fases constructivas del periodo Medio propuestas por Di Peso, pues posteriores pruebas de datación demuestran la dudosa separación entre ellas, y la falta de datos para determinar la temporalidad de la tercera (Jeffrey $S$. Dean y John C. Ravesloot, "The Chronology of Cultural Interaction in the Gran Chichimeca", en Anne I. Woosley y John C. Ravesloot, eds., Culture and Contact: Charles C. Di Peso's Gran Chichimeca [Dragoon: Amerind Foundation, 1993], 96 y 97). 
DOI: http://dx.doi.org/10.22201/iie.18703062e.2016.109.2623

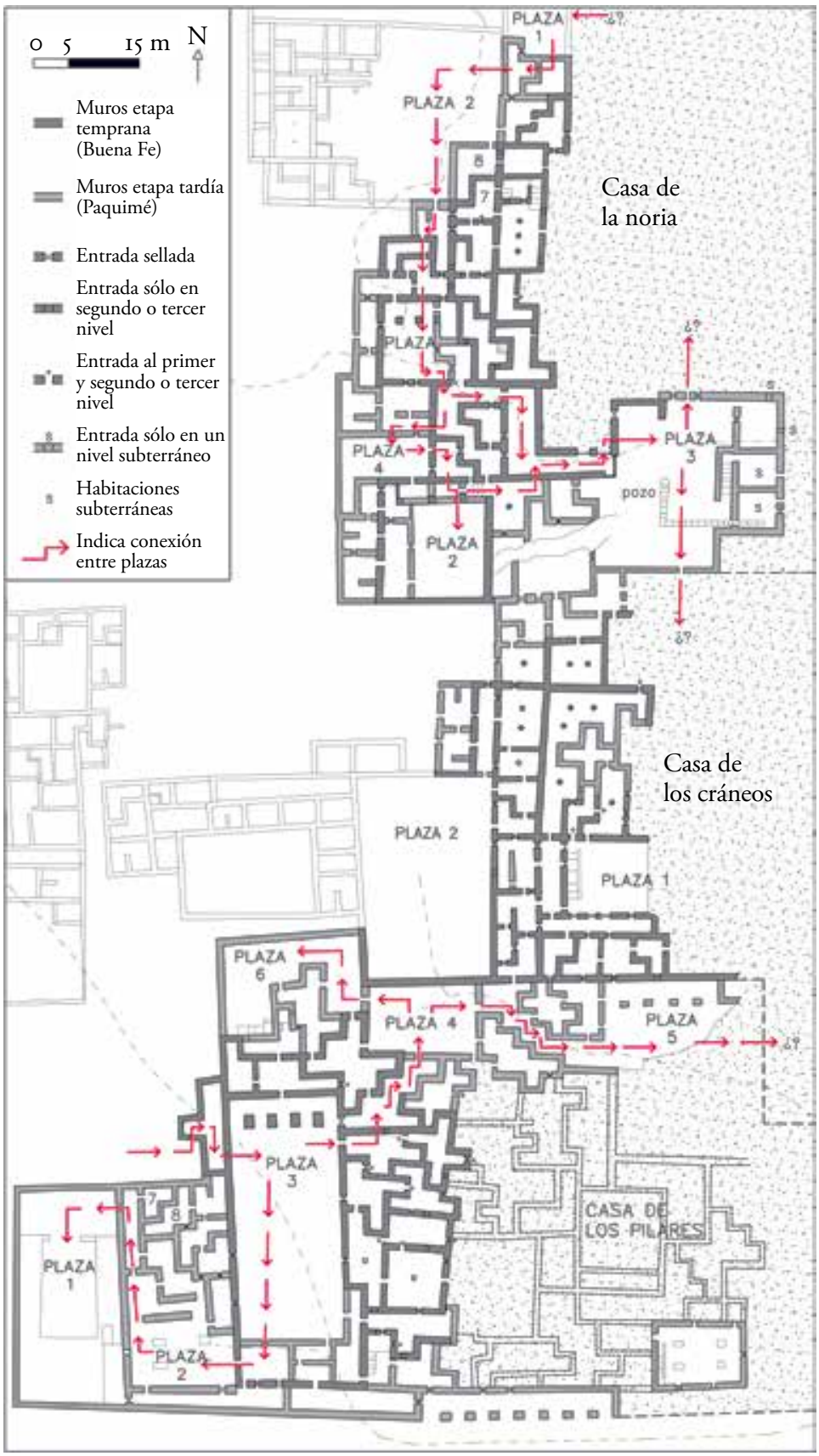


DOI: http://dx.doi.org/10.22201/iie.18703062e.2016.109.2623

ARQUITECTURA Y CERÁMICA DE CASAS GRANDES

9. Casas Grandes, planta arquitectónica de la Casa de la Noria (Unidad 8), de la Casa de los Pilares (Unidad I4) y de la Casa de los Cráneos (Unidad I6). Se muestran las dos principales fases constructivas del Periodo Medio, conservo entradas selladas tal como los expuso Di Peso. Dibujo: Georgina Parada, a partir del levantamiento y la digitalización de estructuras arquitectónicas realizados por el Instituto Nacional de Antropología e Historia y los planos publicados en Di Peso, Rinaldo y Fenner, Casas Grandes (vid supra, n. I), vols. 4 y 5, 364, 6I4 y 718.

poseer una función más o menos pública. Algunas de estas últimas tienen forma de largos pasajes angulosos que recuerdan el espacio vacío del mismo elemento pictórico que acabo de mencionar (fig. Io).

La distribución de las plazas provee un indicio para comprender las leyes que rigen el espacio interior de Casas Grandes. Éstas no se distribuyen a partir de un elemento de mayor magnitud considerado troncal o central, lo cual mantendría una estructura arborescente con jerarquías bien definidas, más cercana a nuestra noción funcionalista de orden. Más bien se intercalan entre la compleja red de habitaciones, tornándose cada vez más internas e inaccesibles, dado el elevado número de niveles a transitar para llegar a ellas (en la figura 9 los trayectos entre plazas se muestran con flechas rojas). Lo admirable de esta distribución es que presenta tal grado de volubilidad que cerrar o abrir un solo acceso puede perturbar significativamente el orden: espacios sin proximidad se tornan vecinos, o lo que era inaccesible e interno se vuelve externo y accesible, o viceversa.

Desde este punto de vista el espacio interior en Casas Grandes se acerca a lo que Gilles Deleuze y Félix Guattari llaman rizoma. En oposición a la forma arborescente, en el rizoma no existe un pivote o centro a partir del cual se divida $\mathrm{u}$ ordene el espacio, pues se considera una multiplicidad sin relación con la unidad. Cualquier punto, por más diverso que sea, puede conectarse con otro, sin que esté preestablecido por una estructura. Además, puede romperse en cualquier parte sin que esto sea significativo, ya que todas sus líneas remiten constantemente unas a otras, pues no tiene origen ni fin, sino múltiples entradas. ${ }^{24}$ En Casas Grandes cada habitación no está definida por

24. Para el concepto de rizoma me baso en la descripción hecha por Gilles Deleuze y Félix Guattari en la "Introducción” de Mil mesetas: capitalismo y esquizofrenia, trad. José Vázquez Pérez (Valencia: Pre-Textos, 2004), I3-18. 


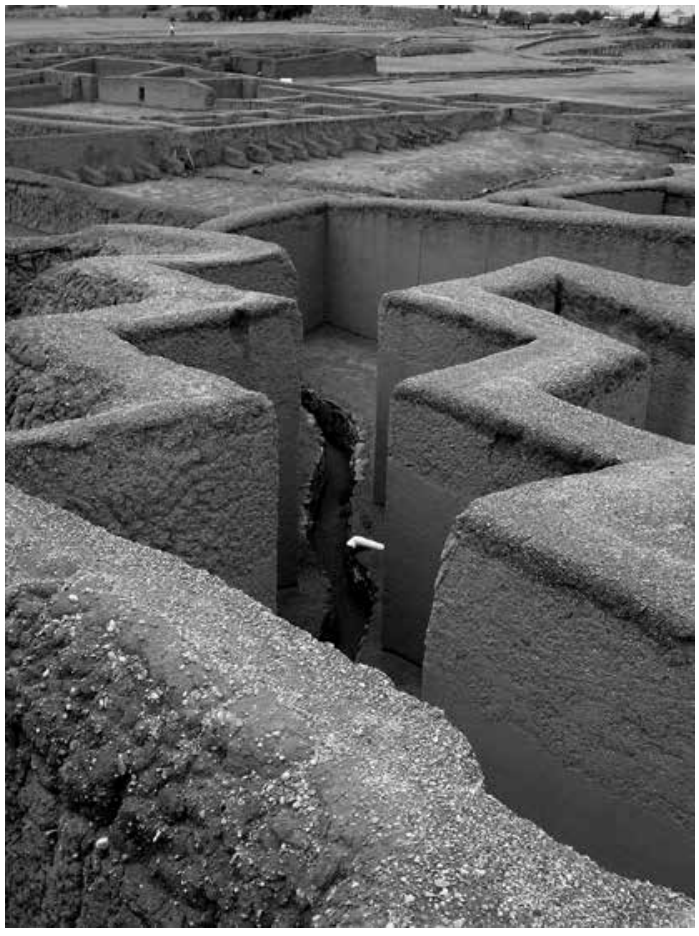

Io. Casas Grandes, Casa de los Pilares. Esta habitación unía las plazas 4 y 5 . Foto: Georgina Parada. Secretaría de CulturaINAH-Méx. "Reproducción autorizada por el Instituto Nacional de Antropología e Historia”.

su relación con un elemento externo a ella (la unidad), más bien se inserta en un contínuum, afectada sólo por los elementos que le anteceden o preceden.

A pesar de su aparente amorfismo, la vivienda no es una masa que creció indistintamente. Sabemos que estuvo en constante transformación durante los años en que fue habitada, pero es posible que durante este proceso se mantuviera un equilibrio. El perímetro del conjunto habitacional guarda cierta igualdad entre la parte norte y la sur, no por medio de una simetría axial (o reflexión especular), sino puntual. Esta última, llamada también "simetría respecto al origen", se da cuando cada parte tiene otra que le corresponde a la misma distancia de un punto central imaginario, pero en dirección contraria. Puede comprobarse al trazar líneas de un extremo a otro en el plano: se verá que las principales salientes de la vivienda tienen su contraparte, girada I8 $0^{\circ}$, del lado contrario (fig. 2). El punto de convergencia se encuentra cerca del famoso pozo subterráneo de Casas Grandes, que Di Peso considera único 
en América. ${ }^{25} \mathrm{~A}$ este pozo, de más de $\mathrm{I} 4$ metros de profundidad, se llega por un pasaje subterráneo desde una habitación a su vez oculta (subterránea), ubicada al sur de la Unidad 8 (Casa del Pozo). Christine y Todd VanPool consideran este elemento como la representación más elaborada de un axis mundi en todo el noroeste, más en concreto, el punto de apertura entre mundos, la conexión entre el agua y Casas Grandes, a la que suponen metafóricamente como una ciudad de agua. ${ }^{26} \mathrm{La}$ existencia de un "centro" parecería contradecir lo antes expuesto. Debo aclarar que este pozo, contenido en el interior de la tierra, es un elemento oculto y vedado; al parecer el ingreso estaba restringido y su ubicación es imperceptible desde las viviendas. Podría decirse que este elemento, aunque omnipresente, está más allá de la dimensión habitable.

\section{La cerámica}

Traducir en palabras la complejidad y riqueza de la composición pictórica de la cerámica parece una tarea imposible en este reducido artículo, he de aclarar que las conjeturas expuestas aquí se basan en un minucioso estudio de cada una de las 45 piezas polícromas que forman parte de mi corpus, entre las que se encuentran ollas, cántaros, cuencos y vasijas-efigie. Todas proceden del sitio arqueológico de Casas Grandes y fueron elegidas debido a que ya sea por observación personal, o por reproducciones realizadas por los arqueólogos, fue posible tener una imagen total de sus diseńos. Presento 20 de ellas (figs. 16-35), la mayoría dibujos de mi autoría, con la esperanza de acrecentar nuestro conocimiento sobre Casas Grandes, puesto que no se encuentran en la publicación de Di Peso.

Un carácter distintivo de esta cerámica es que no parece existir una relación entre formas y diseños con sus diversos usos, conclusión a la que llegué después de examinar con detenimiento el contexto arqueológico de cada pieza. En pocas palabras, las mismas imágenes se plasmaron desde ofrendas funerarias,

25. Di Peso, Casas Grandes, vol. 2, 356. Una descripción explícita del pozo se encuentra en Di Peso, Rinaldo y Fenner, Casas Grandes, vol. 4, 37I-38I; cabe señalar la considerable cantidad de objetos votivos que se encontraron aquí.

26. Christine S. VanPool y Todd L. VanPool, Signs of the Casas Grandes Shamans (Salt Lake City: The University of Utah Press, 2007), 27 y 28. 
DOI: http://dx.doi.org/10.22201/iie.18703062e.2016.109.2623

190

GEORGINA PARADA CARRILLO

hasta aquellas vasijas utilizadas para almacenar o preparar y servir alimentos. ${ }^{27}$ Del mismo modo las diferentes tipologías locales en las que se clasifica la cerámica polícroma de Casas Grandes (mi corpus incluye los tipos Ramos, Babícora, Villa Ahumada y Escondida), distinguidas por la composición de las pastas y cualidades estilísticas, también comparten las mismas concepciones espaciales.

Para atender al análisis que propongo debe tenerse en cuenta que no me baso en semejanzas de formas ni rasgos iconográficos, sino en las articulaciones del espacio pictórico, donde concluí que a pesar de la infinidad de variaciones de un reducido número de elementos, formas y colores, todos los diseños evocan una misma estructura que consiste en una sucesión entre línea quebrada y espiral, en la que cada sección, hasta la mínima, remite a la totalidad. Podrá objetarse que la clasificación mostrada más adelante no es del todo clara y que muchas vasijas fluctúan en otras secciones; sin embargo, de todas las posibilidades consideradas, fue la que arrojó mayores frutos. Esta clasificación es valiosa porque deja de lado la organización espacial cuatripartita y los conceptos de oposición y dualidad bajo los cuales la cerámica de Casas Grandes se analiza comúnmente. ${ }^{28}$

En un primer grupo la superficie se segmenta o articula por medio de una línea quebrada o angulada a lo largo del plano horizontal, y presenta cuatro variaciones: I) los segmentos de la línea quebrada son continuos e iguales (figs. I6-I8); 2) los segmentos están separados y cada uno desarrolla diseños independientes (figs. I9-2I);3) la línea quebrada se repite girada cuatro veces, generando un diseño romboidal (fig. 22); 4) la línea quebrada se separa hasta conformar objetos independientes (fig. 23).

Un segundo grupo comprende aquellas vasijas en las que la primera articulación no se realiza con líneas anguladas, sino curvas. Se presentan como dos helicoidales enfrentadas o como anillos concéntricos (figs. 24 y 25, respectivamente).

En un tercer grupo la línea quebrada, la cual recorre el cuerpo de la olla, no tiene prioridad frente a las espirales (curvas o anguladas) que rellenan el espa-

27. Además de los diseños pictóricos, ningún tipo, forma volumétrica o tratamiento de superficie se utilizó exclusivamente para algún propósito en específico. Véase Di Peso, Casas Grandes, vol. 2, 6Io y 6II; y Di Peso, Rinaldo y Fenner, Casas Grandes, vol. 6, 85 y 86.

28. Véase, por ejemplo, la obra citada de VanPool y VanPool, Signs of the Casas Grandes Shamans, y la de Barbara Moulard, "Archaism and Emulation in Casas Grandes Painted Pottery", en Richard Townsend, ed., Casas Grandes and the Ceramic Art of Ancient Southwest (The Art Institute of Chicago, 2006), 66-97. 
cio sobrante. Por lo cual, espirales y rectas aparecen simultáneamente con tres variantes: I) la recta se enrosca hacia un lado y otro a modo de espiral doble divergente (fig. 26); 2) la línea recta unida a la espiral se sucede continua por toda la superficie; 3 ) la recta y la espiral pueden separarse para formar objetos independientes (fig. 27).

En el último grupo se encuentran aquellas piezas en las cuales el diseño pictórico está condicionado primigeniamente por la forma volumétrica. Pueden articularse a lo largo del plano horizontal cuando la olla tiene forma radial, lo cual presenta segmentos iguales (figs. 28 y 29); o en el plano vertical, que muestra segmentos desiguales, como sucede con las vasijas-efigie (figs. 30-35).

Sobra decir que, posteriormente, cada uno de los segmentos resultantes se articulará de nuevo en una de las operaciones anteriores, y así, hasta que la superficie de la vasija o el equilibrio que buscó el artista muestren pertinente detener la segmentación.

La relación entre el todo y las partes puede darse en distintos grados. En muchos casos es evidente, pues todavía se nota cierta semejanza entre una forma y otra. El ejemplo más claro es la figura escalonada que se construye una y otra vez dentro de sí misma.

Puede ser que la diagonal de la figura escalonada se asocie con las formas espirales de arriba y abajo, y no con la vertical, por lo que adquiere la configuración de una espiral doble divergente, imagen que en ocasiones retorna dentro de ella.

A menudo un proceso compositivo que aparece en cierto nivel no se repite en el diseño de la misma pieza, sino en cualquiera de los niveles de otra vasija. Esto me interesa sobremanera porque sugiere que cada una es parte de un conjunto mayor, de una totalidad.

En otros casos la relación es más compleja y se define mejor como similitud entre sus partes. A diferencia de la semejanza que indica una aserción unívoca y siempre la misma, la similitud multiplica las afirmaciones, y remite más bien a la relación entre las cosas. ${ }^{29}$ La filosofía de la ciencia ha adoptado el término matemático de homomorfismo a fin de desafiar el limitado concepto de semejanza en el arte. Éste parte del supuesto de que puede existir una correspondencia entre dos objetos sin necesidad de una relación de semejanza (en la que se comparten cierto número de propiedades) ni de isomorfismo (donde

29. Michael Foucault, Esto no es una pipa. Ensayo sobre Magritte, trad. F. Monge (Barcelona: Anagrama, 198I), 68. 
DOI: http://dx.doi.org/10.22201/iie.18703062e.2016.109.2623

192

GEORGINA PARADA CARRILLO

los elementos pueden variar mientras se preserve la estructura); pues ellas no constituyen la esencia de la representación, pudiendo existir relaciones más profundas entre un objeto y otro. ${ }^{30}$ Desde el punto de vista matemático, el homomorfismo se refiere a una representación que preserva la estructura entre dos conjuntos algebraicos, sin necesidad de una correspondencia uno-a-uno, es decir, que no todos los elementos de un conjunto A deben ser necesariamente proyectados en un conjunto B. ${ }^{3 \mathrm{I}}$ Esto requiere que haya correspondencia entre las propiedades (simetría/asimetría, reflexividad/irreflexividad) y las operaciones (relaciones entre los elementos) de los dos conjuntos; aunque no sea necesario que se mantengan las mismas operaciones, por ejemplo, la adición puede proyectarse en multiplicación. ${ }^{32}$ De esta manera es posible ampliar las relaciones de oposición a las que alude Foucault (lo que está a la derecha, está a la izquierda; lo que está arriba, está abajo; lo que está oculto, está visible), por medio de un juego donde las propiedades de la forma de un conjunto no sólo reaparecen -invertidas o no- en las formas del otro, sino en el modo en el que se articulan dichos elementos. Al tomar ejemplos de la cerámica aquí estudiada obtenemos la similitud que existe entre una línea recta, articulada por elementos curvos y una línea curva, articulada por elementos rectos, o lo que es lo mismo. O la relación entre una línea recta continua articulada por elementos angulares discontinuos y elementos angulares discontinuos, articulados cada uno mediante una línea recta continua.

La policromía de la cerámica de Casas Grandes se limita al uso de dos pigmentos sobre la pasta o el engobe, de modo que en cada pieza sólo se presentan tres colores, a menudo ubicados dentro de las variaciones de un tono rojizo o café: el claro, que va de crema a ocre; el medio, que presenta un rojo más oscurecido o cobrizo que el rojo puro; y el oscuro, que varía de café a negro, es decir, que las diferencias se perciben en la categoría de intensidad luminosa, más que de tonalidad. Tan sólo el análisis de esta tricotomía podría abarcar un estudio independiente, me restrinjo a exponer los tres usos principales que identifiqué, los cuales pueden convivir en una misma pieza. I) el

30. Mauricio Suárez, "Scientific Representation: Against Similarity and Isomorphism", en International Studies in the Philosophy of Science 17, núm. 3 (2003): 230. Aunque el autor se refiere al problema de la representación en el campo científico, otros estudiosos como Chiara Ambrosio lo han transportado al ámbito de la historia del arte.

3I. Chiara Ambrosio, "Iconicity as Homomorphism: The Case of Picasso's Guernica", Ideas in Action, Nordic Studies in Pragmatism I (Helsinki: Nordprag, 20I0), I57.

32. Ambrosio, "Iconicity as Homomorphism", I57. 
rojo designa o limita el borde de la vasija (figs. 27, 28, 33, 35) o una sección del espacio pictórico (figs. 2I y 22), mientras el resto del diseño puede o no hacer uso de dicho color. Dejo abiertas las posibilidades de que en este caso el rojo pueda sugerir tanto una abertura, como delimitar el espacio de manera más incisiva, es decir ideal, absoluta; ${ }^{33}$ 2) el rojo y el negro rellenan superficies distintas. Aquí los dos colores tienen la función de acentuar la diferencia entre dos elementos que por su propia forma ya eran disímiles. Esto produce los muy conocidos juegos ambiguos entre fondo y figura; característicos de esta cerámica, pues un color puede intervenir como figura en relación con uno o como fondo en relación con el otro (figs. 23, 27 y 29); 3) el rojo y el negro rellenan superficies semejantes. En este caso los dos colores mantienen la misma relación con el fondo, su uso tiene la función de diferenciar espacios que parecían iguales (figs. 17, 19, 26, 32).

Ahora el artista no sólo cuenta con las variaciones entre formas escalonadas y espirales para diferenciar, sino que se vale del color para construir distintos intervalos compuestos. Al advertir esta vinculación o más correctamente "indisociabilidad" entre forma y color, ${ }^{34}$ la novedosa incursión de policromía en la cerámica (que vimos está ligada a un momento histórico) no emerge como un simple agregado a los diseños, sino que éstos son impensables sin la intervención de tres colores; especialmente me refiero al Ramos polícromo que equipara en número al corpus de estudio (33 piezas). ${ }^{35}$ Es sugerente que a pesar de que existen piezas de este tipo que carecen de rojo, siempre se recurre a un tercer término conformado por un entramado negro-crema.

También se observó que el borde rojo podía delimitar o contener el espacio biese articulado a su vez por los tonos antagónicos oscuro-claro. Si se concibiésemos una analogía con la composición espacial antes vista, donde se

33. "El artista aísla el espacio para definirlo como una totalidad, como una unidad independiente y autosuficiente. El marco mismo significa al espacio, no sólo lo delimita, sino que lo nombra y define”, Dúrdica Šégota, Valores plásticos del arte mexica (México: Universidad Nacional Autónoma de México-Instituto de Investigaciones Estéticas, I995), IO2.

34. La "indisociabilidad absoluta" entre volumen, línea y color ha sido planteada por la misma historiadora en el arte mexica, donde descubre una relación intencionada y significativa en el modo en que el artista articula estos elementos con el fin de matizar o subrayar contrastes plásticos (Š́egota, Valores plásticos del arte mexica, I2I y I22).

35. Me tomo la libertad de acudir a esta tipología como modelo, pues se considera el tipo por excelencia y culminación de la cerámica de Casas Grandes, además, tipologías de antigüedad mayor como Villa Ahumada y Babícora, que también forman parte de mi corpus, adquirieron características propias del nuevo tipo Ramos como el delineado de las superficies rojas con color negro. 
DOI: http://dx.doi.org/10.22201/iie.18703062e.2016.109.2623

194

GEORGINA PARADA CARRILLO

II. Casas Grandes, urna funeraria tipo Ramos polícroma. Museo Nacional de Antropología. Foto: Diego Flores Olmedo. Secretaría de Cultura-INAHMéx. "Reproducción autorizada por el Instituto Nacional de Antropología e Historia”.

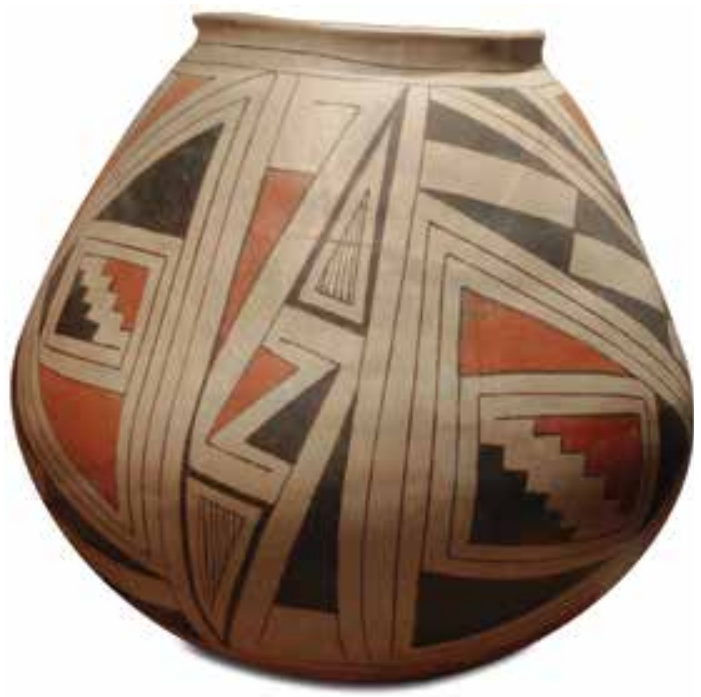

planteó una sucesión infinita, en la que cada parte remite a la totalidad, y donde un elemento con el mínimo de articulaciones repite la estructura de uno con mayor número, es posible suponer que el uso de los tres colores implica plenamente estos conceptos, pues el rojo (con relación a los otros dos, no por sí mismo) insinúa nuevas articulaciones inclusive en elementos que carecen de segmentación. Es significativo que las superficies demasiado grandes siempre se rellenan de rojo, nunca de negro ni crema (figs. 20, 23), como si este espacio no necesitara más segmentación al ser un elemento híbrido.

Al observar con detalle el diseño de cada pieza se descubre un número de particularidades en sumo reveladoras; lamentablemente me vi en la necesidad de exponer tan sólo una. Se trata de una gran olla de cuerpo curvo-convergente y base convexa exhibida en el Museo Nacional de Antropología, que guardaba los restos de un posible gobernante, dentro de una habitación oculta en el Montículo de las Ofrendas (Unidad 4) (figs. II y 19). Su composición sorprende por el rigor geométrico, pues carece de toda imagen figurativa. Conforme se examina esta pieza la aparente heterogeneidad de sus formas se traduce en una sobria armonía organizada con precisión matemática. Su diseño pictórico se sometió al método de clasificación antes descrito, con el fin de obtener la desarticulación de sus partes (fig. I2). Indico con la letra $A$ (mayúscula 


\section{Conjunto}
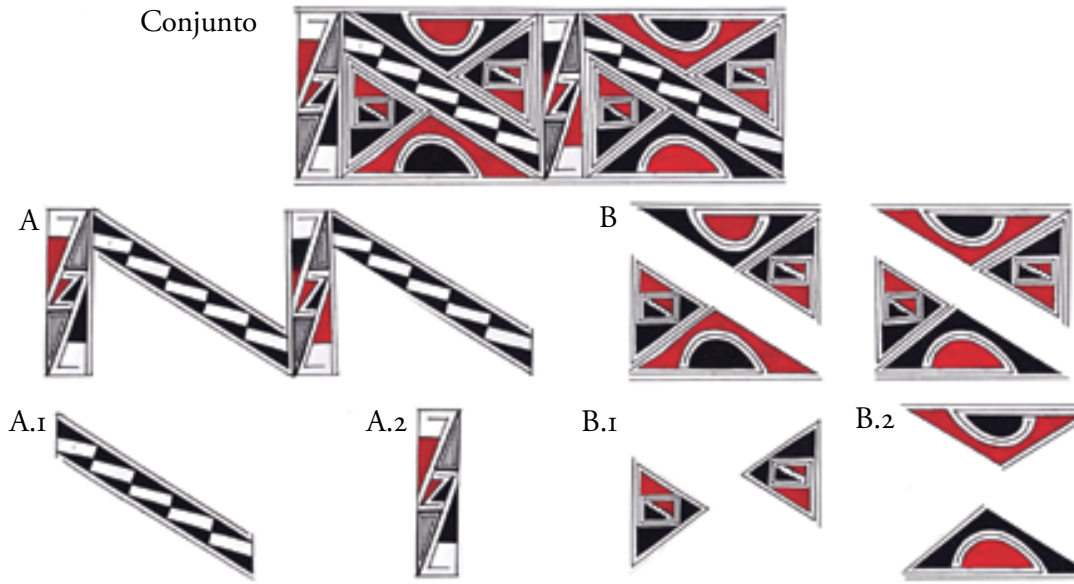

B.I

B.2
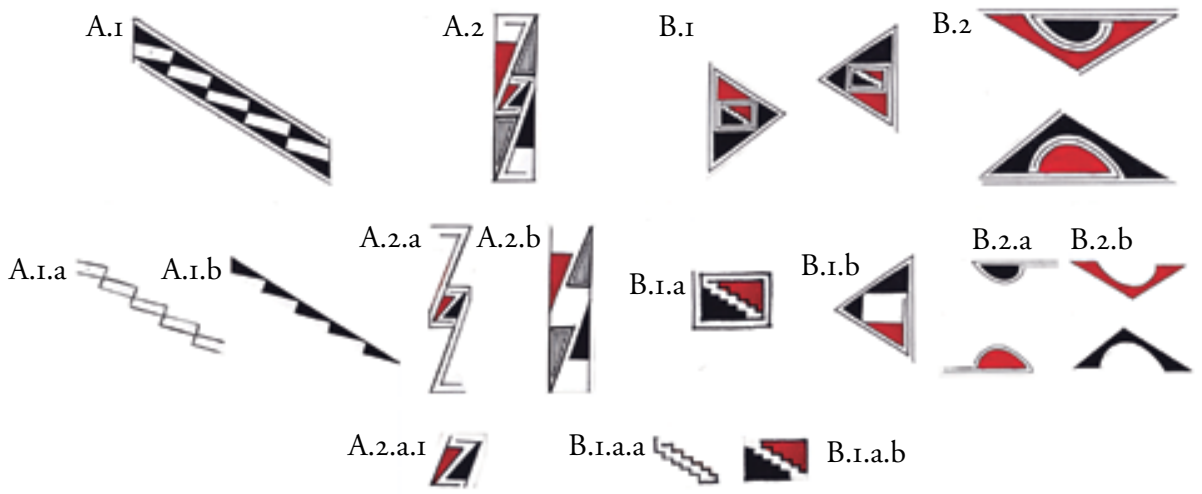

I2. Segmentación del diseño pictórico de una vasija de Casas Grandes (fig. II). La letra $a$ indica los elementos angulados que dividen el espacio, la letra $b$, los espacios que resultan de dicha segmentación. Los números indican variaciones del mismo elemento. Tabla: Georgina Parada.

o minúscula) los elementos quebrados o angulados que dividen el espacio en dos, y con la letra $B(b)$ los espacios que resultan de dicha segmentación. Los números I y 2 indican si hay variaciones del mismo elemento.

Este método permite observar claramente las correlaciones entre las partes. Así se obtiene que la banda quebrada A corresponde con A.2.a y en cierta medida con A.I.a. El subconjunto B reaparece en A.r.b y A.2.b, pues los tres poseen triángulos escalenos sucedidos uno tras otro, con su repetición girada $180^{\circ}$. El conjunto completo (A-B) puede encontrarse tanto en A.2, como en A.2.a.I.

¿Qué sucede con las figuras triangulares constantes en toda la cerámica? Si se observa el grupo B.I, la división en nuevos triángulos no es simultánea, surgen a lo largo de la banda blanca que se enrosca en espiral. Si se imagina esta figura desenrollada no es más que el mismo elemento quebrado con formas 
DOI: http://dx.doi.org/10.22201/iie.18703062e.2016.109.2623

196

GEORGINA PARADA CARRILLO

13. Casas Grandes, olla tipo Ramos polícroma.

Bodegas del Museo de las

Culturas del Norte. Foto:

Georgina Parada. Secretaría de Cultura-INAH-Méx.

"Reproducción autorizada por el Instituto Nacional de

Antropología e Historia”.

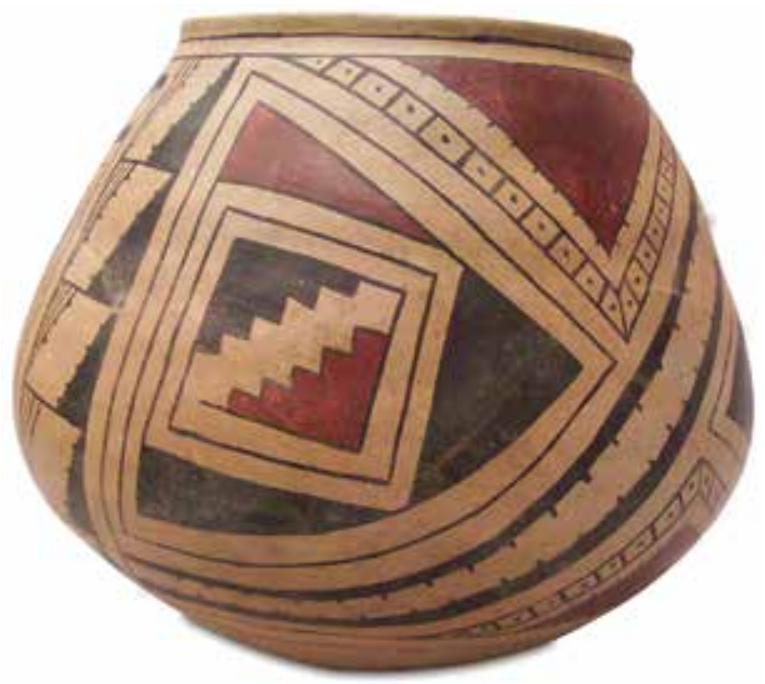

angulares en su interior, de modo que, bandas quebradas y triángulos se segmentan por la misma sucesión de pequeños triángulos, pero su diferencia reside en el movimiento. En el primer caso los triángulos se proyectan hacia los extremos, en el segundo, se configuran en espiral hacia el interior (o del interior hacia afuera).

Un vistazo a otras vasijas muestra cómo las articulaciones de $A$ y $B$ admiten una serie de variantes sin perder la esencia de su estructura (fig. I3). Por ejemplo, la sucesión de triángulos, que aparece dentro de las bandas quebradas, puede intercambiarse por círculos, líneas, formas escalonadas o espirales dobles (figs. I6, 20, 2I y 35, respectivamente), conservando la misma idea de ritmo; o bien, las espirales curvas pueden volverse angulosas (fig. 22).

Parte de la perfección que le atribuyo a esta pieza (fig. II) es una característica que no he encontrado en ninguna otra. En ella los dos triángulos cercanos a la boca no son idénticos, lo mismo sucede con los contiguos a la base, mantienen la forma pero los colores se invierten. La imagen idéntica surge cuando se gira $180^{\circ}$, por lo cual presenta una simetría puntual, descrita en la sección de la arquitectura, que aparece tanto en sentido longitudinal como transversal (en $\mathrm{B}$, de la figura I2, los dos triángulos superiores mantienen esta simetría con los inferiores; o bien, los dos de la derecha con los de la izquierda). Esta simetría es propia de la greca escalonada. En un exhaustivo trabajo sobre la composición gráfica de este elemento se muestra cómo la figura y su repetición 
producida automáticamente como fondo no mantienen un eje de simetría sobre el plano, lo cual produciría una imagen tipo espejo, sino que proviene de una tercera dimensión que lo atraviesa, es un eje de rotación..$^{36}$ Una imagen creada de esta manera mantiene tal cual el orden de sus partes, pero cambia su dirección. No es insignificante que esta simetría encuentre su construcción plena en una superficie convexa, casi esférica, como la olla. En una esfera cada punto presupone, sin excepción, su antípoda, es decir, un punto diametralmente opuesto. La repetición de diseños girados $180^{\circ}$ en toda la cerámica de Casas Grandes parece responder a esta propiedad intrínseca del soporte. En esta vasija se presenta una simetría asombrosa, pues cada elemento atraviesa su centro real, el del espacio contenido, y reaparece invertido en el otro lado. De nuevo nos encontramos con un centro invisible sobre la superficie, pero que domina silenciosamente la composición en su totalidad.

Ya mencioné que cada segmento del diseño está sujeto a las mismas leyes, por tanto, la simetría puntual se repite en todos los niveles. En una escala más pequeña el centro imaginario se transfiere del interior del volumen a la superficie (por ejemplo, A.2 de la figura 32). La imagen, al repetirse, puede conservarse idéntica o admitir las más ingeniosas variaciones, mientras se mantenga la relación de homomorfismo que describí con anterioridad.

No existe un solo elemento en sus diseños que pueda aislarse de la totalidad. Aquéllos se entrelazan unos con otros formando caminos que se enrollan hacia distintas direcciones, vinculándose en un orden muy distinto al de su ubicación sobre la superficie de la cerámica, si ésta se piensa como un sistema de coordenadas. En otras palabras, la relación entre los objetos deviene más significativa que el propio objeto representado. Obsérvese la imagen más característica de la cerámica a la que ya hice mención: los dos elementos escalonados, negro y rojo, inscritos en un rectángulo. Pictóricamente se representa de dos modos distintos: uno en el que las dos figuras escalonadas se unen con la misma greca o espiral que los rodea, y otro en el que cada una se relaciona con una espiral independiente (las vasijas de las figs. 16 y 25 presentan ambas versiones). En arquitectura también se vio cómo estos elementos pueden o no estar conectados.

Antes de terminar con la pieza elegida, muestro un ejercicio que no obstante su simpleza sorprende por la trascendencia de los resultados. Me refiero a la proyección polar de la olla en vez de la proyección longitudinal que había utilizado,

36. Mauricio Orozpe Enríquez, El código oculto de la greca escalonada (México: Escuela Nacional de Artes Plásticas, 2010), 39. 
DOI: http://dx.doi.org/10.22201/iie.18703062e.2016.109.2623

198

GEORGINA PARADA CARRILLO

I4. Proyección polar de una vasija de Casas Grandes (fig. 3I). Se

observa cómo la banda escalonada se transforma en dos curvas. Dibujo:

Georgina Parada.

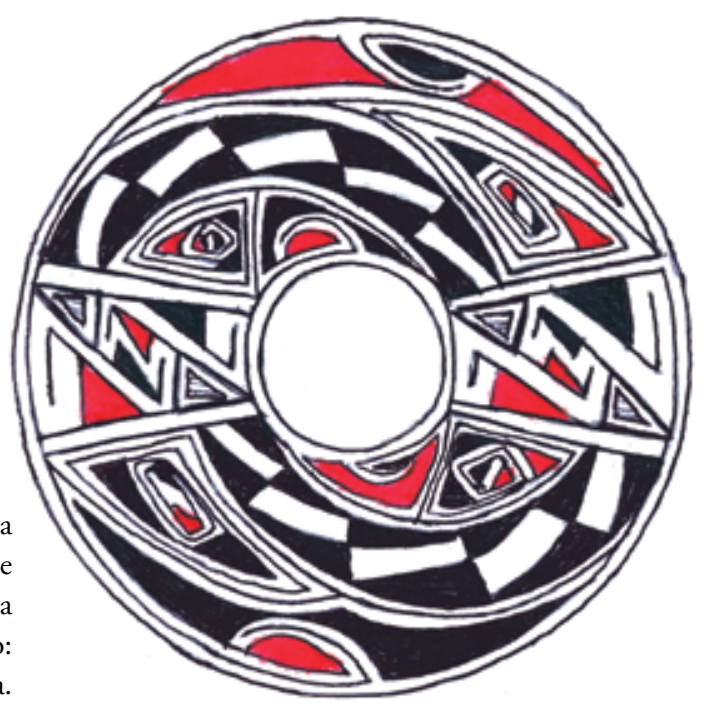

con el fin de observar qué pasaría si el diseño no se mirara por medio de un recorrido lineal, sino desde el centro superior hacia afuera, como se muestra en la figura I4. Encontré que la banda escalonada que recorre toda la superficie no es más que la figura formada por dos curvas opuestas (a manera de dos letras P invertidas) tal como aparece en otras piezas (figs. 17, 25). Stricto sensu se trata de dos helicoidales (curva en tres dimensiones) divergentes, pues geométricamente el espacio pictórico de la vasija es una superficie curva bidimensional. ${ }^{37}$ En un espacio de tales características cada recta (camino más corto entre dos puntos) es en realidad la línea de menor curvatura, la sección de un círculo máximo o geodésica. Debido a que la curvatura de la vasija no es homogénea, toda línea (mientras no sea absolutamente horizontal), en vez de ser un semicírculo, será sin excepción una espiral o hélice. Este hallazgo, en apariencia simple, tiene significativas repercusiones y resulta imprescindible tenerlo presente al atender las conclusiones; demuestra que las diferencias y semejan-

37. Esta superficie es un ejemplo de la llamada geometría elíptica o riemanniana que consiste en un modelo de geometría no euclidiana, ya que no satisface el quinto postulado de Euclides, pues las paralelas sí convergen en un punto. Aquí, todas las rectas son arcos de un círculo máximo, y aunque pueden extenderse indefinidamente, tienen longitud finita. Al igual que la línea, punto y superficie son entidades distintas a las de la geometría plana. 
zas entre formas curvas y escalonadas sólo existen con relación al punto donde se transfiere la visión.

No toda la cerámica de Casas Grandes ostenta el mismo grado de estilización. Son conocidas sus vasijas de formas humanas, animales e inclusive vegetales; y la representación bidimensional de animales restringida exclusivamente a aves y serpientes..$^{38} \mathrm{La}$ articulación de estas piezas responde a las mismas leyes de la vasija antes vista, siempre se presentan las correspondencias entre el todo y las partes, sin excluir elementos figurativos como animales o rostros humanos.

El diseño de estos últimos se configura con las mismas prácticas de variación entre formas curvas y anguladas, e introducción de ritmos y direcciones. En la vasija-efigie femenina (figs. I5 y 30) la pintura facial se conforma por dos bandas con puntos intermitentes, las cuales no discrepan mucho de la banda con círculos de otras piezas. La gran diferencia del diseño de los rostros radica en que presentan una simetría bilateral (reflexión especular) propia de la naturaleza y no puntual, la cual abunda en la mayor parte de los diseños de Casas Grandes y en cierto grado es poco natural. ${ }^{39} \mathrm{La}$ simetría bilateral nunca aparece sobre la superficie lisa de la vasija, sólo en las que tienen un modelado tridimensional, como cabezas animales y humanas, aunque apenas estén sugeridas como en la figura 33. Por alguna razón significativa la simetría puntual (giro de $180^{\circ}$ ) es "indisociable" del volumen no articulado, del espacio indefinido; la bilateral, del espacio articulado o definido.

No creo que haya una intención de retratar o evocar el rostro o el cuerpo humano, tal acercamiento puede ser mejor expresado como un devenir-hombre, pues la vasija toma algo de éste sin perder sus cualidades propias. ${ }^{\circ} \mathrm{Con}-$

38. Como lo menciona Di Peso, es posible que otros diseños zoomorfos estén presentes en algunos fragmentos, pero son demasiado incompletos para comprobarlo (Di Peso, Rinaldo y Fenner, Casas Grandes, vol. 6, 283).

39. Basta intentar hacer los mismos movimientos con el brazo derecho e izquierdo, pero girados $\mathrm{I}^{8} \mathrm{O}^{\circ}$, para percatarse de lo difícil que es. En cambio compárese con la relación que Franz Boas establece entre los abundantes diseños con simetría vertical y los movimientos simétricos del cuerpo determinados psicológicamente; no porque las imágenes se realicen con ambas manos, sino porque están en concordancia con una sensación motora (Franz Boas, Primitive Art [Nueva York: Dover, 1995], 33).

40. Para Deleuze y Guattari devenir es un proceso de aproximación, que no busca imitar, identificar o proporcionar relaciones formales con el objeto: "Devenir es, a partir de las formas que se tiene, del sujeto que se es, de los órganos que se posee o de las funciones que se desempeña, extraer partículas, entre las que se instauran relaciones de movimiento y de reposo, de velocidad y de lentitud, las más próximas a lo que se está deviniendo, y gracias a las cuales se de-viene”, 
DOI: http://dx.doi.org/10.22201/iie.18703062e.2016.109.2623

200

GEORGINA PARADA CARRILLO

15. Casas Grandes, vasija-efigie tipo

Ramos polícroma. Museo de las

Culturas del Norte. Foto: Georgina

Parada. Secretaría de Cultura-INAH-

Méx. "Reproducción autorizada por el Instituto Nacional de Antropología e Historia”.

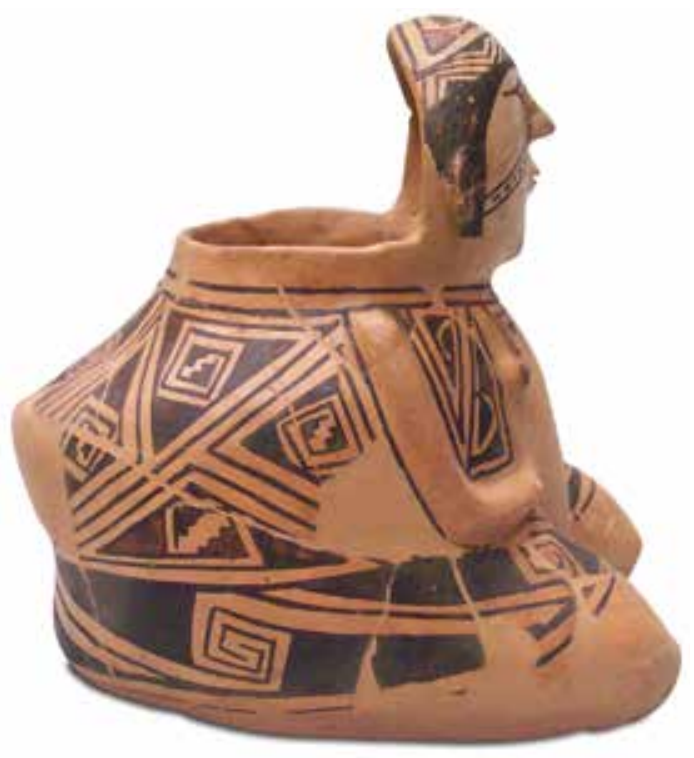

clusiones semejantes pueden hallarse en los elementos zoomorfos. Dentro del triángulo opuesto al rectángulo con escalera doble a menudo aparece una imagen semejante a un pájaro, o aquella interpretada como cabeza de guacamaya. Este devenir-ave puede estar en distintos grados de estilización. En algunos casos la figura es independiente del exterior (las patas del pájaro de la fig. 2I están separadas de las bandas concéntricas, pero en cierta medida las evocan), en otras se fusiona con las formas espirales de las cuales proviene (fig. 34), es decir, aparece ligada a los elementos que antecede o precede, es un instante temporal entre el continuo juego entre dos movimientos disímbolos: el que se proyecta a los extremos y el que se desarrolla hacia el interior.

Podrá objetarse que existen animales representados de modo relativamente realista. La figura 24 contiene una imagen muy exacta del coralillo falso, ¿̨buscaba el artista evocar al animal en sí?, lo creo muy poco probable, pues se sabe que la mayor parte de las serpientes de la cerámica no corresponde a especies del mundo natural. ${ }^{4 \mathrm{I}} \mathrm{La}$ razón de que dicha serpiente esté representada, y no

Deleuze y Guattari, "I730-devenir-intenso, devenir-animal, devenir-imperceptible”, en Mil mesetas. Capitalismo y esquizofrenia, 275.

4I. VanPool y VanPool, Signs of the Casas Grandes Shamans, 90. 
otras, tal vez responde a que el maravilloso diseño de su piel (triángulos rojos y negros enfrentados y separados por bandas blancas) se aproxima asombrosamente a la plástica de su cerámica.

¿Qué sucede con la representación de la figura humana? Tengo conocimiento de una sola pieza en la ciudad de Casas Grandes que exhibe una figura bidimensional de un hombre (fig. I8). ${ }^{42}$ VanPool la considera una posible representación de un chamán o sacerdote en proceso de metamorfosis. ${ }^{43} \mathrm{Sin}$ intención de discutir su hipótesis, me interesa reiterar su forma: el torso es una figura alargada donde se suceden tres imágenes parecidas al signo de numeral (\#) con un círculo al centro (a su vez esta figura se encuentra invertida en los triángulos inferiores, el círculo "contenido" se vuelve "contenedor"), los brazos, a manera de banda, ciñen dos espacios triangulares opuestos, el perfil de la cabeza es una línea escalonada, y, por último, el tocado no es más que una espiral fusionada a la cabeza escalonada.

No niego que estas imágenes sean inequívocamente hombres, aves y serpientes, pero dudo que su verdadera intención fuese aludir a ellas, pues no retratan una existencia previa, sea real o imaginaria. A propósito del caracol, Paul Westheim cuestiona si el uso reiterado de este ornamento en el arte precolombino se justifica, no en el objeto mismo, sino en la formación extraordinaria que posee. ${ }^{44}$ Wilhelm Worringer, más directo que su alumno, opina simplemente: "el ornamento vegetal (en este caso cualquier elemento natural) no reproduce originalmente la planta misma sino la ley a que está sujeta su formación exterior." 45 Habría que preguntarse más bien por qué estos elementos son depositarios de los principios trascendentales que el arte de Casas Grandes eternizó. Pero dichos elementos sólo se utilizan cuando se cumplen ciertas condiciones dentro de un sistema. Resulta revelador que la cerámica exhiba un repertorio considerable de animales representados volumétricamente, como felinos, tortugas, osos, marsupiales, peces, roedores o lechuzas; pero

42. Di Peso menciona II fragmentos donde aparecen figuras humanas, lamentablemente los ejemplos que muestra son muy pequeños. Sin embargo, en uno de ellos sí es posible distinguir dos siluetas humanas invertidas (Di Peso, Rinaldo y Fenner, Casas Grandes, vol. 6, 284 y 285).

43. Christine S. VanPool, "The Shaman-Priests of the Casas Grandes Region, Chihuahua, Mexico", American Antiquity 68, núm. 4 (2003): 705.

44. Paul Westheim, Arte antiguo de México, trad. Mariana Frenk (México: Era, 1970), I77.

45. Wilhelm Worringer, Abstracción y naturaleza, trad. Mariana Frenk (México: Fondo de Cultura Económica, 1953), 68. 
que no figuren en dos dimensiones, reservadas tan sólo a aves y serpientes. ${ }^{46}$ A esto puedo agregar que formas de estructura radial, como calabazas y cruces, no se representan en dos dimensiones, pero sí en volumen (fig. 29). ¿Qué estructura y leyes internas veían en estos objetos que cumplieran las necesidades compositivas en una dimensión pero no en otra; y viceversa? Por obvias razones, el volumen de la cerámica sí acepta la simetría radial y axial, y por tanto, a los animales y objetos con dicha simetría, pero vimos que la superficie sin articulaciones respondía a otras necesidades. La serpiente es poco identificable de frente, su mayor expresividad se percibe de perfil o desde arriba, es decir, desde su vista asimétrica. Del mismo modo el ave, al carecer de cuatro patas, produce un perfil asimétrico, donde la redondez de la cabeza se contrapone a la rectitud del cuerpo y cola, más acorde a los diseńos ostentados sobre la superficie no articulada.

La aproximación de estos animales con escaleras y espirales no puede explicarse por simple semejanza formal, pues ni un ave posee aquellas formas, ni precisamente una serpiente, ya que las adquiere sólo por medio del movimiento. Este concepto devela la verdadera relación entre las imágenes figurativas en la cerámica y los famosos montículos "zoomorfos" (figs. If, g y h), cuya identificación como indiqué, es incierta, pero también se reducen al movimiento.

En un principio se dijo que la composición pictórica de la cerámica destacaba por la falta de centralidad. En realidad posee innumerables centros, si se considera que todos los diseños invertidos $180^{\circ}$ se generan a partir de un centro imaginario. Esto evoca en cierta medida el trazo de algunas espirales, pues cada sección de arco deriva de distintos focos (recuérdese que todas las líneas sobre la cerámica son espirales o hélices). La consecuencia inmediata que observo es la evasión o la indiferencia a englobar un espacio único, ya sea terrestre o imaginario, donde pueda darse el acontecimiento. Al carecer de un punto regulador, desaparece todo orden jerárquico entre elementos pictóricos, además de disolver el contraste entre lo externo y lo interno. Por supuesto la

46. VanPool cuestionó seriamente el problema de los animales representados en la cerámica, ¿por qué hay animales importantes que no están representados, por qué algunos que no existen en Paquimé son comunes en la cerámica, o por qué se combinan representaciones de animales reales e imaginarios?, problema que desarrolla a partir de su hipótesis sobre la distinción entre lo local y lo exótico (VanPool y VanPool, Signs of the Casas Grandes Shamans, 20 y 2I). Moulard indica que muchos de los animales representados bidimensionalmente en la cerámica de Mimbres (Nuevo México) sólo se reinterpretaron en Casas Grandes en tres dimensiones, mas no en dos (Moulard, "Archaism and Emulation", 78). 
vasija tiene un sólo centro volumétrico, pero mantiene la misma distancia y relación con cualquier punto de la superficie, por tanto, sólo reitera la igualdad entre términos.

También existen los bordes de la vasija que definen el espacio pictórico como una totalidad, pero es posible que no indiquen un límite o final. En la mayoría de los diseños las bandas blancas (o líneas negras, según se prefiera ver), enroscadas en espiral, se cortan cuando llegan al borde superior o inferior, simulando propagarse hacia un espacio imposible de representar, vinculándose quizá, con el lado contrario. Puede apreciarse mejor en la figura I4, imagen que ha revelado que sus diseños tienen múltiples realidades: son proyecciones distintas de una idea mayor, restringida a una superficie que necesariamente presenta un borde o límite en la boca de la vasija; del mismo modo que un cuadrado, un rectángulo o un hexágono son proyecciones reducidas de un cubo.

Es probable que los creadores de estas piezas no concibieran una separación tajante entre lo que nosotros clasificamos como dimensiones del espacio, pues las combinan indistintamente: los puntos nunca son adimensionales, pues siempre se suceden formando líneas; éstas juegan ambiguamente con el fondo confundiéndose con un elemento de dos dimensiones; y las superficies se ven afectadas por la tridimensionalidad de la olla. En otras palabras todo elemento pictórico participa de una dimensión mayor a él.

\section{Conclusiones: correlación entre el diseño pictórico y la arquitectura}

Este ensayo develó cómo la plástica de Casas Grandes se sujeta a la unicidad espiral-escalera. Westheim ve en estos dos elementos formales dos movimientos antagónicos, ${ }^{47}$ en Casas Grandes los dos elementos no operan uno frente a otro, sino que evocan un punto de contacto. Ambos son construcciones lineales que pueden continuarse al infinito por cualquiera de sus extremos sin perder la esencia que los define: una sección cualquiera contiene la forma del todo. Oscilan entre dos dimensiones, pues abarcan virtualmente una superficie o un espacio volumétrico sin necesidad de delimitarlo. Se distinguen en que los ángulos o segmentos de curva de la espiral giran siempre en la misma dirección, mientras que en la escalera se alternan entre dos direcciones.

47. Westheim, Arte antiguo de México, 168. 
La forma espiral y la escalonada son proyecciones distintas de lo mismo, ${ }^{48}$ expresan diferencias transitorias, no oposiciones; significado reiterado tal vez con el cromatismo de la cerámica. Si en la greca escalonada mesoamericana la fuerza destructora de la espiral empuja la ascensión de la escalera "hacia el nivel de donde partió", 49 en Casas Grandes esta alternancia de fuerzas se traslada a un nivel inusitado. Cuando la espiral termina continúa desde su extremo la nueva línea escalonada, y de ésta emerge una nueva espiral. Del mismo modo no hay antagonismo cuando los peldaños de una figura escalonada pueden configurarse por medio de espirales. Estamos ante una imagen que se contiene infinitamente, aunque pueda tomar diversas formas. Es, de manera simultánea, contenido de un elemento mayor y contenedor de uno menor; una construcción fractal que no obedece a semejanzas, sino a similitudes más profundas. En vista del peculiar modo de llevar a cabo este concepto habría que repensar la aserción de Braniff sobre la posibilidad de que la greca escalonada en el norte de México haya conservado un sentido más cercano al original, ya perdido en Mesoamérica, ${ }^{50}$ aunque no menciona cuál podría ser. Al menos en Casas Grandes espiral y forma escalonada se presentan como variaciones de un mismo tema, contenidas una dentro de la otra, cuyas diferencias radican, si se me permite la expresión, en la "relatividad" del movimiento del observador. ${ }^{51}$

Uno de los primeros aspectos que destaqué en el urbanismo fue la alineación de elementos arquitectónicos, especialmente aquellos montículos que se sucedían a ritmo y espaciamiento constante, como las estaciones en una procesión. Estos elementos se extienden de manera indefinida sin intención de envolver un espacio o evocar imágenes específicas desde determinadas ubicaciones estáticas. En su lugar, establece un dinamismo, donde el movimiento se superpone al acontecimiento sujeto a un espacio físico. Dentro de los elementos que componen esta "procesión" no están excluidos aquellos que se hallan

48. Por ejemplo, la proyección transversal de una hélice cónica es una espiral, mientras que la longitudinal toma la apariencia de una escalera que se dilata o contrae. Lo mismo puede decirse de la hélice esférica.

49. Westheim, Arte antiguo de México, 168.

50. Beatriz Braniff, "Greca escalonada en el norte de México", Boletín del Instituto Nacional de Antropología e Historia, núm. 42 (1970): 40.

5I. Un presupuesto básico de la relatividad es que el estado del objeto (longitud, intervalo temporal) es relativo al estado de movimiento del observador, "el espacio y el tiempo son cantidades dinámicas: cuando un cuerpo se mueve, o una fuerza actúa, afecta la curvatura del espacio y del tiempo, y, en contrapartida, la estructura del espacio-tiempo afecta al modo en que los cuerpos se mueven y las fuerzas actúan” (Stephen Hawking, Historia del tiempo [Barcelona: Planeta, I992], 56). 
fuera de la ciudad propiamente dicha, como la estructura espiral sobre el cerro; de hecho ¿no son los mismos cerros y atalayas, así como su sistema de comunicación, parte del mismo concepto de sucesión trasladado a un mayor tamaño? 52 Esta representación va más allá de la simple recreación de una geografía física, el que se encuentre en otras manifestaciones artísticas demuestra sus raíces en las categorías profundas del pensamiento. Regresando a los pequeños elementos repetidos a lo largo de las bandas quebradas de la cerámica, además de enfilarse en una diagonal, ¿no indican la misma predominancia de movimiento y ritmo dentro de un elemento, la greca escalonada, cuyos ángulos ya contienen estas nociones?

A diferencia de las estructuras públicas que crecen y se proyectan hacia el exterior, en la vivienda los espacios también se suceden uno a otro, pero se dirigen hacia un punto cada vez más interno. Respecto a otro de los procesos compositivos de la pintura: los triángulos, que a su vez se segmentan en nuevos triángulos, siguen un orden de sucesión también en dirección al interior. Las diferencias observadas al confrontar el espacio público y el habitacional (abierto/cerrado, libre/rígido, disperso/comprimido) no son tan amplias si se subyugan a la noción de movimiento. Recuérdese el descubrimiento en la figura 34, con tan sólo cambiar la dirección de la mirada, lo cual es posible traducir al espacio habitable: si me muevo acorde a mi entorno, éste se percibirá como un espacio continuo, símil; si el movimiento no es el mismo que el de mi exterior, éste aparecerá discontinuo, opuesto.

Cabría recordar la organización descentralizada tanto del urbanismo como de la cerámica, pues es una característica clave para entender la relación entre los dos modos de concebir el espacio. Los elementos plásticos se desenvuelven sin acatar leyes propias de la organización espacial, conceptos como arriba/ abajo, lejos/cerca, periférico/central, se vuelven inútiles para definirlos. Por el contrario está la predominancia de adverbios temporales como antes/después, sincrónico/diacrónico. La composición se construye a lo largo de un orden cronológico, podría afirmarse que todos los diseńos evocan sucesos, ${ }^{53}$ inmersos en

52. Di Peso describe un sistema durante el Periodo Medio en el cual estarían involucradas torres y cimas de cerros, algunos asociados a cerros de trincheras, con el fin de comunicarse de un punto a otro. Ubicada principalmente a lo largo del perímetro oeste, es posible que esta red convergiera en el cerro Moctezuma (Di Peso, Casas Grandes, vol. 2, 364 ).

53. "Designs refered to event not object or idea" (Ruth Bunzel, The Pueblo Potter. A Study of Creative Imagination in Primitive Art [Nueva York: Columbia University Press, 1969], 69). Las informantes zuñi dejan claro que la asociación del nombre de un diseño con el objeto real 
una especie de eternidad, pues no presentan ni punto de inicio ni final. Del mismo modo, los supuestos diseños figurativos parecen suspendidos entre dos realidades, sin posibilidad de discernir si corresponden al mundo animado o al puramente geométrico. La supremacía de representar un aspecto temporal del mundo, más que espacial, dirige a los probables dominios del mito, y por consiguiente, al ritual.

Para Cassirer el verdadero mito nace cuando el hombre atribuye conceptos temporales (nacimiento, devenir, vida) a la figura de los dioses. La primacía de la acción es tal, que es ella, investida en las formas del culto y el ritual, el origen y fundamento del mito. ${ }^{54}$ Mirar el espacio arquitectónico mediante el análisis pictórico, y viceversa, permitió comprender que es la actividad, y por ende el ritual, la que se encuentra inmersa en ambos soportes artísticos. Pero esta ritualidad no debe comprenderse en absoluto ajena al modo normal de vida, pues "la fuerza del sentimiento religioso se manifiesta precisamente en que abarca la totalidad indivisa del ser y del actuar, sin excluir ninguna esfera de la existencia físico-natural, penetrando hasta sus elementos fundamentales y originarios".55 De este modo tanto la pintura como la arquitectura de Casas Grandes, al igual que el ritual, actúan como medio, ${ }^{56}$ su plástica no es representación objetiva de la realidad, sino el culto mismo, el reflejo direc-

es efímero, no significa nada; una alfarera nunca puede explicar la forma, sólo la composición. Curiosamente no hay semejanzas evidentes entre los elementos pictóricos de esta cerámica y la de Casas Grandes, pero las similitudes de los procesos compositivos son sorprendentes, entre los cuales encontramos la inexistencia de simetría bilateral, la composición sometida a la diagonal, variaciones infinitas con el uso de una cantidad ínfima de elementos, la construcción por medio de líneas más que por superficies, búsqueda de equilibrio entre espacio vacío y lleno, y repetición por medio de un carácter rítmico (Bunzel, The Pueblo Potter, 20-7I).

54. Ernst Cassirer, Filosofía de las formas simbólicas II: El pensamiento mítico, trad. Armando Morones (México: Fondo de Cultura Económica, 2013), I4I y 272.

55. Cassirer, Filosofía de las formas simbólicas II, 281.

56. Como medio me refiero al mediador entre el hombre y el mundo circundante del que habla Warburg, aquel que con grandes esfuerzos "hace del espacio una zona de contemplación", Aby Warburg, El ritual de la serpiente, trad. Joaquín Etoreno Homaeche (México: Sexto Piso, 2004), 66.

N.B. El presente ensayo surgió a partir de mi tesis de maestría en Historia del Arte en la Universidad Nacional Autónoma de México. Agradezco el apoyo de John Ware, Eric Kaldahl y Mark Cattanach, de la Amerind Foundation, y de Luis Tena, del Museo de las Culturas del Norte, fundamental para la realización de dicha investigación. Agradezco especialmente a Eduardo Gamboa, director de la Zona Arqueológica de Paquimé, por sus oportunas observaciones sobre el sitio arqueológico. 
to de la conciencia de un pueblo en un determinado momento de su historia; cada una con sus recursos y materiales propios del ámbito en el que operan.

Lamentablemente el conocimiento de sus rituales se limita a los despojos, como los muy citados entierros de aves decapitadas, que en nada traslucen la integridad del rito que seguirá siendo desconocido a nuestros ojos, pero cuyo fondo reside en las manifestaciones que sí se conserva. A partir de sus elementos plásticos el arte de Casas Grandes habla sobre la inexistencia de conceptos de inicio y final en el universo religioso de sus habitantes. El mundo no es comprendido como una totalidad absoluta, sino con relación al movimiento del hombre. Rehúye de la unidad (y por tanto de la dicotomía) a favor de la multiplicidad, pues evita sujetarse a un espacio y tiempo absolutos. Todos sus elementos tienen la capacidad de generar nuevas formas, nuevos espacios. Punto, línea y superficie no existen, salvo como transición entre una forma y otra. ¿De qué rituales habla esta inherente mutabilidad? ¿Recuerdos de un pasado nómada, o persistencias de vida nómada en el presente? ¿ 


\section{Anexo documental}

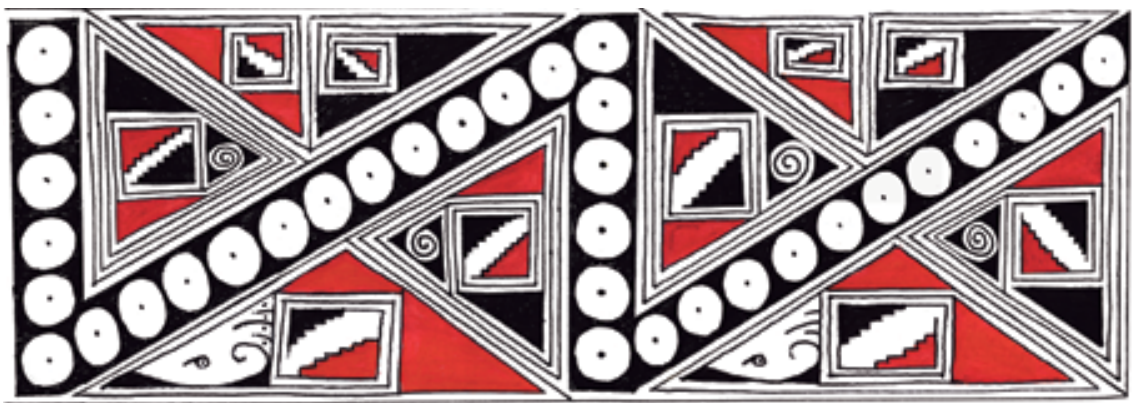

I6. Casas Grandes, diseño de una urna funeraria tipo Ramos polícroma, I300-I450 d. C.

Contenía los huesos largos, sin cráneo, de un hombre mayor. Actualmente en el Museo de las Culturas del Norte. Dibujo: Georgina Parada.

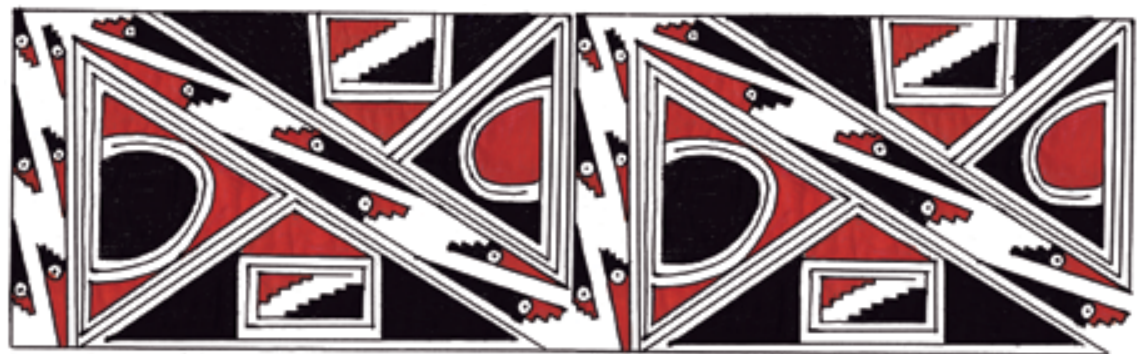

17. Casas Grandes, diseño de una olla tipo Ramos polícroma, I300-I450 d. C. Se encontró como ofrenda funeraria al lado del cuerpo de un niño. Contenía restos de alimento. Actualmente en el Museo de las Culturas del Norte. Dibujo: Georgina Parada.

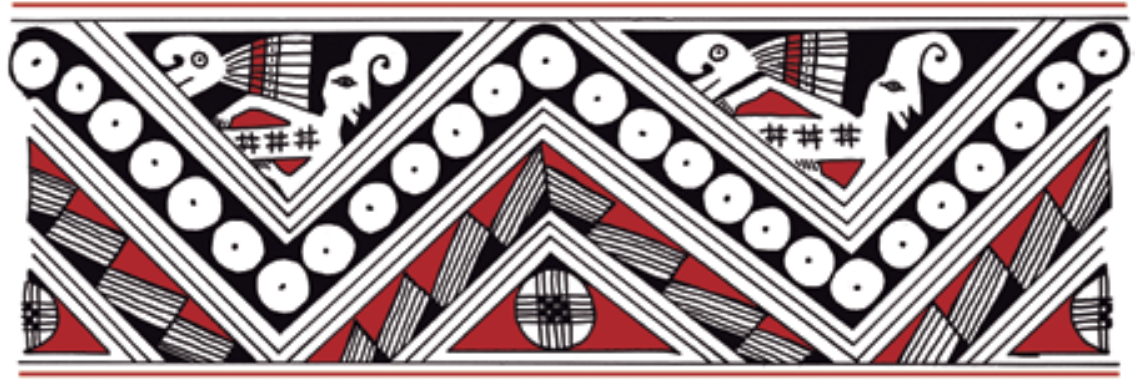

I8. Casas Grandes, diseño de una olla tipo Ramos polícroma, I300-I450 d. C. Actualmente en el Museo de las Culturas del Norte. Dibujo: Alice Wesche, tomado de Di Peso, Rinaldo y Fenner, Casas Grandes (vid. supra n. I), vol. 6, 272 [el color rojo es de la autora]. 


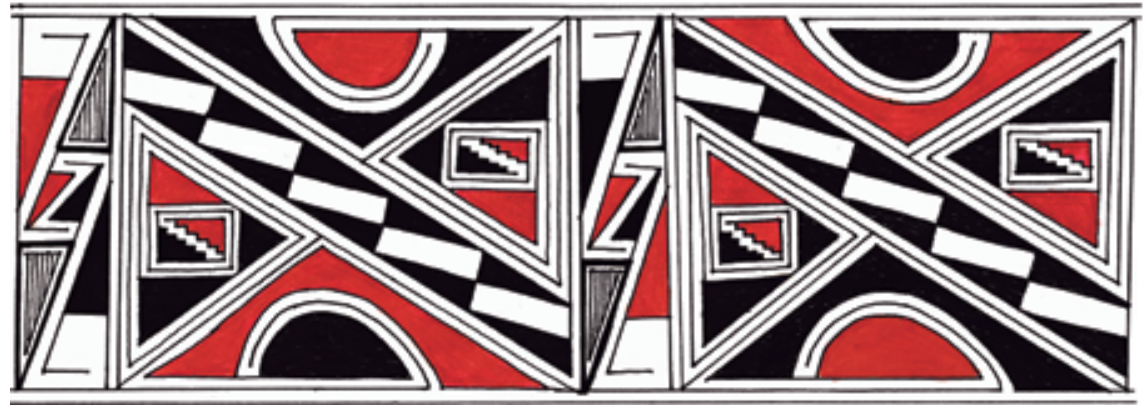

I9. Casas Grandes, diseño de una urna funeraria tipo Ramos polícroma, I300-I450 d. C., Contenía los huesos largos, sin cráneo, de un hombre. Actualmente en el Museo Nacional de Antropología. Dibujo: Georgina Parada.

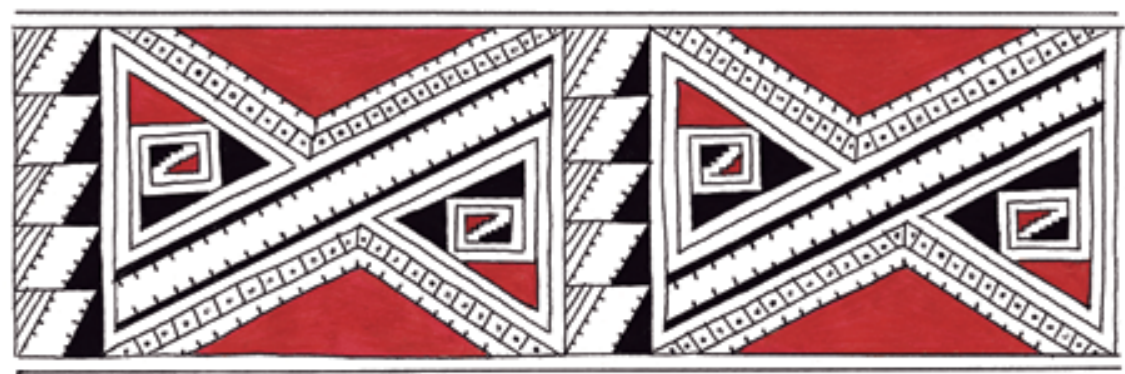

20. Casas Grandes, diseño de una olla tipo Ramos polícroma, I300-I450 d. C. Se encontró como ofrenda funeraria sobre el cuerpo de un hombre. Actualmente en el Museo de las Culturas del Norte. Dibujo: Georgina Parada.

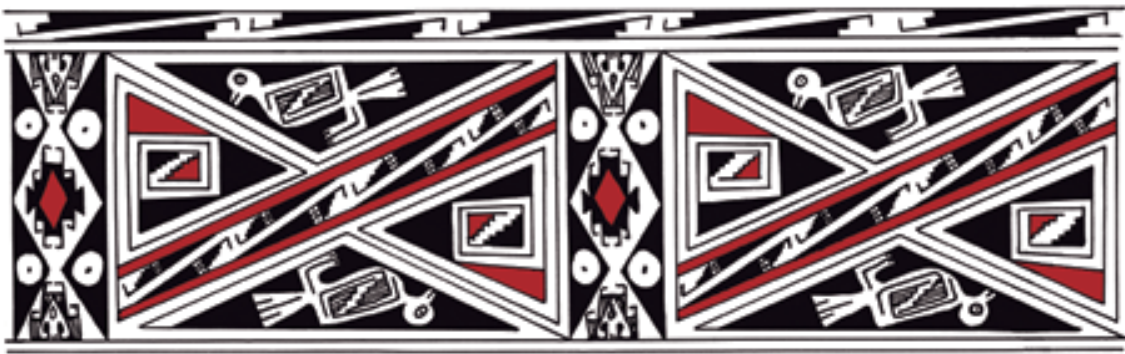

2I. Casas Grandes, diseño de una olla tipo Ramos polícroma, I30O-I45O d. C. Actualmente en el Museo de las Culturas del Norte. Dibujo: Alice Wesche, tomado de Di Peso, Rinaldo, y Fenner, Casas Grandes (vid. supra n. I), vol. 6, 267 [el color rojo es de la autora]. 
DOI: http://dx.doi.org/10.22201/iie.18703062e.2016.109.2623

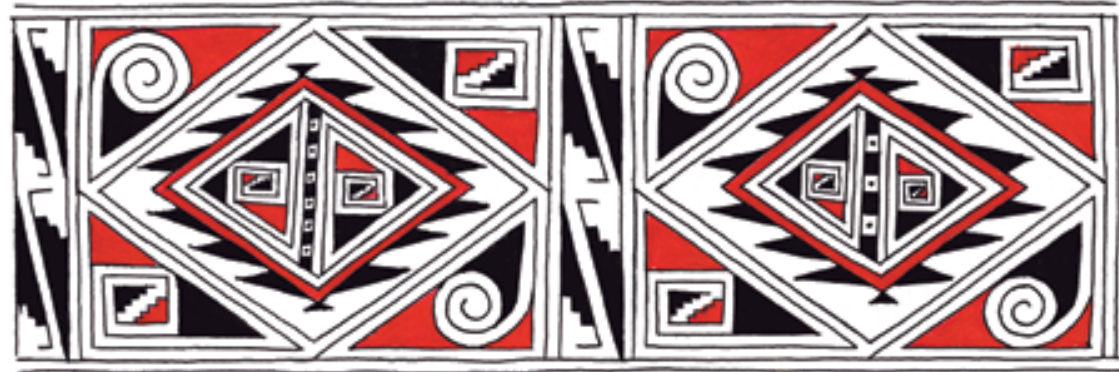

22. Casas Grandes, diseño de una olla tipo Ramos polícroma, I300-I450 d.C. Actualmente en el Museo de las Culturas del Norte. Dibujo: Georgina Parada.

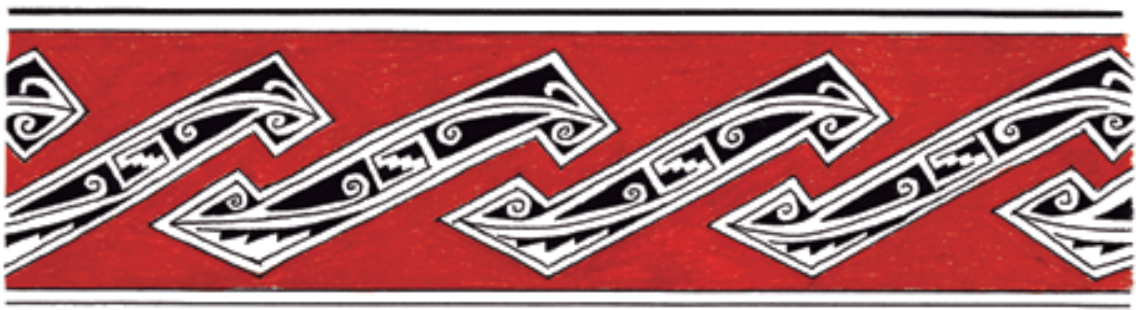

23. Casas Grandes, diseño de una olla tipo Escondida polícroma, I300-I450 d.C. Se encontró como ofrenda funeraria al lado del cuerpo de un hombre. Actualmente en el Museo de las Culturas del Norte. Dibujo: Georgina Parada.

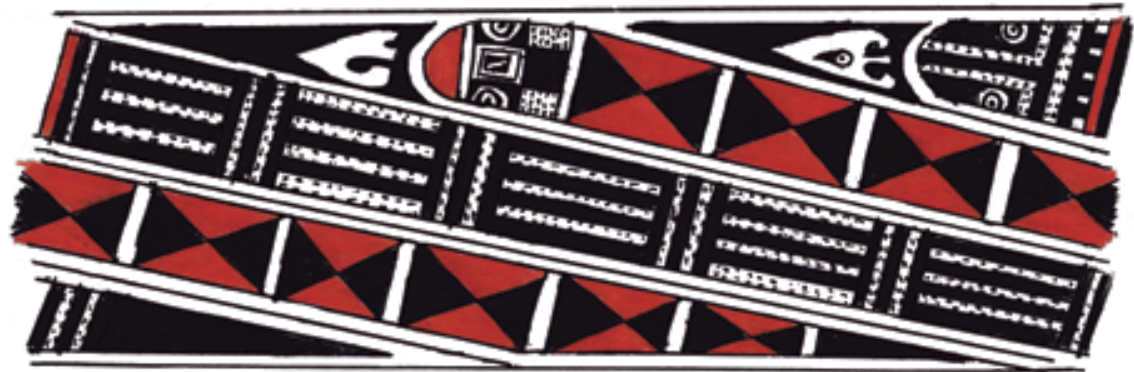

24. Casas Grandes, diseńo de una olla tipo Ramos polícroma, I300-I450 d.C. Actualmente en el Museo de las Culturas del Norte. Dibujo: Georgina Parada. 


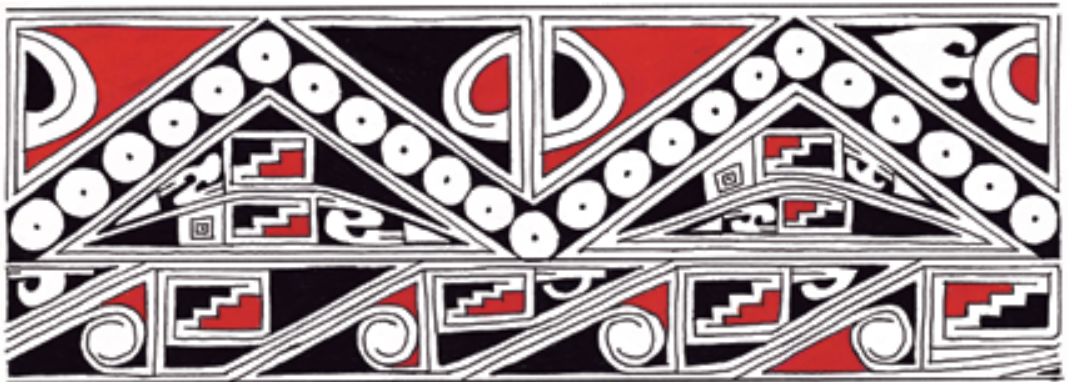

25. Casas Grandes, diseño de una urna funeraria tipo Ramos polícroma I300-I450 d.C. Contenía los huesos largos, sin cráneo, de una mujer. Actualmente en el Museo de las Culturas del Norte. Dibujo: Georgina Parada.

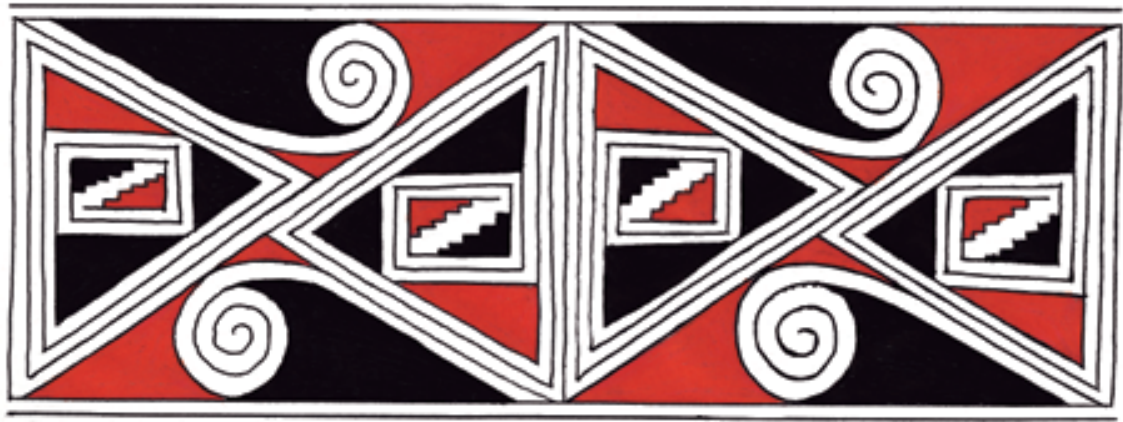

26. Casas Grandes, diseño de una olla tipo Ramos polícroma, I300-I450 d.C. Se encontró como ofrenda funeraria al lado del cuerpo de un hombre. Actualmente en el Museo de las Culturas del Norte. Dibujo: Georgina Parada.

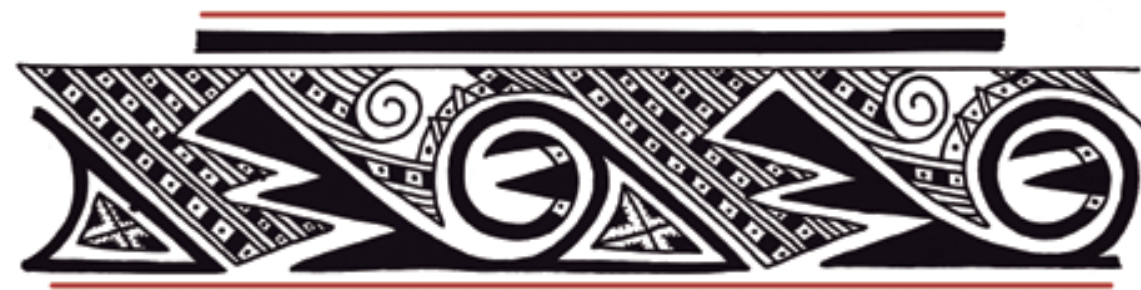

27. Casas Grandes, diseño de una olla tipo Escondida polícroma, I300-I450 d.C. Se encontró como ofrenda funeraria al lado del cuerpo de una mujer. Actualmente en el Museo Nacional de Antropología. Dibujo: Alice Wesche, tomado de Di Peso, Rinaldo y Fenner, Casas Grandes (vid. supra n. I), vol. 6, 235 [el color rojo es de la autora]. 
DOI: http://dx.doi.org/10.22201/iie.18703062e.2016.109.2623

$2 \mathrm{I} 2$

GEORGINA PARADA CARRILLO
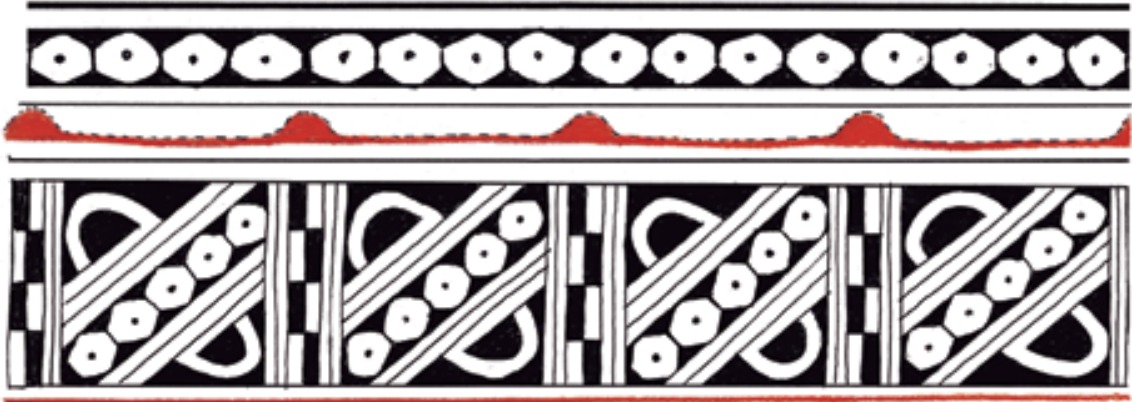

28. Casas Grandes, diseño de una olla tipo Villa Ahumada polícroma, I300-I450 d.C. Actualmente en el Museo Nacional de Antropología. Dibujo: Georgina Parada.

29. Casas Grandes, diseño de un cajete tipo Ramos polícromo, I300-I450 d.C. Actualmente en el Museo Nacional de Antropología. Dibujo: Georgina Parada.
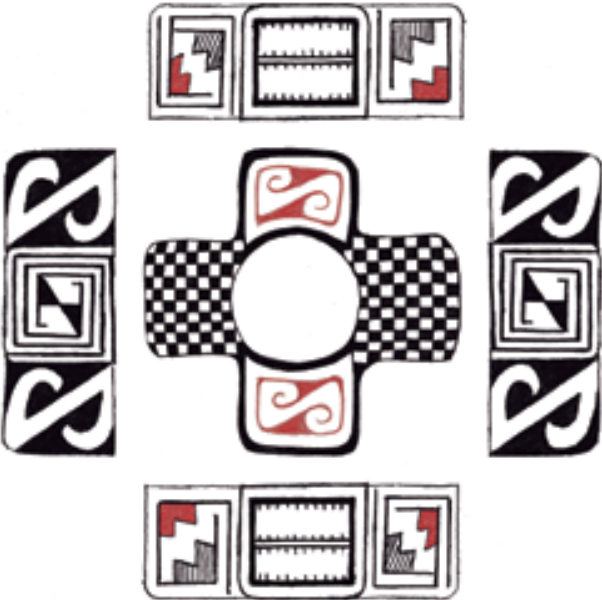


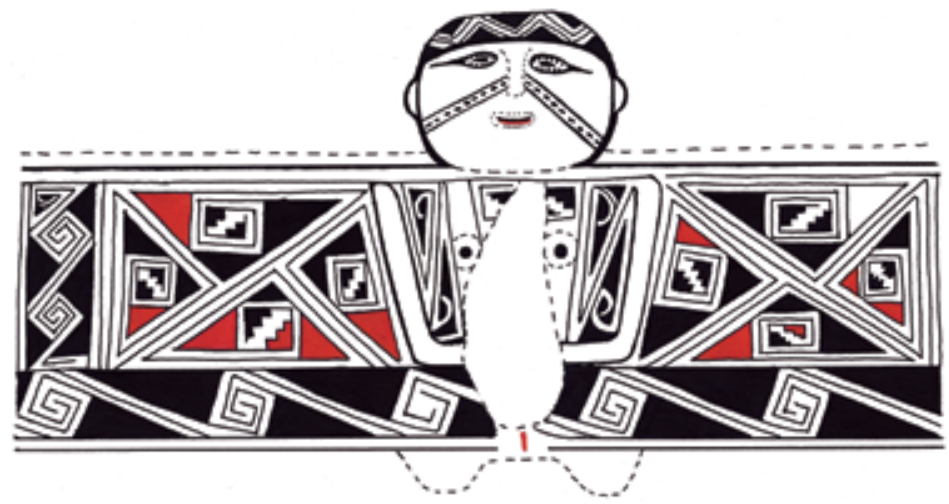

30. Casas Grandes, diseño de una vasija-efigie tipo Ramos polícroma, I300-I450 d.C. Actualmente en el Museo de las Culturas del Norte. Dibujo: Georgina Parada.

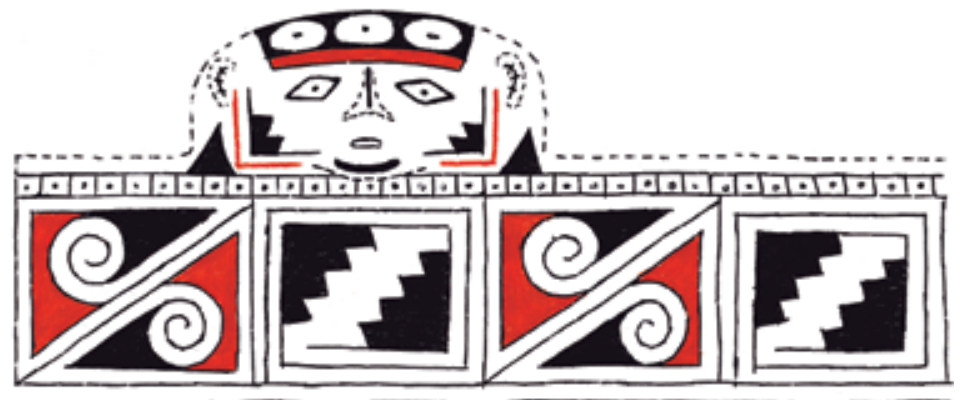

31. Casas Grandes, diseño de una vasija-efigie tipo Ramos polícroma, ızooI45o d.C., se le contró como ofrenda al lado del cuerpo de un niño y los huesos de un infante. Actualmente en el Museo Nacional de Antropología. Dibujo: Georgina Parada.

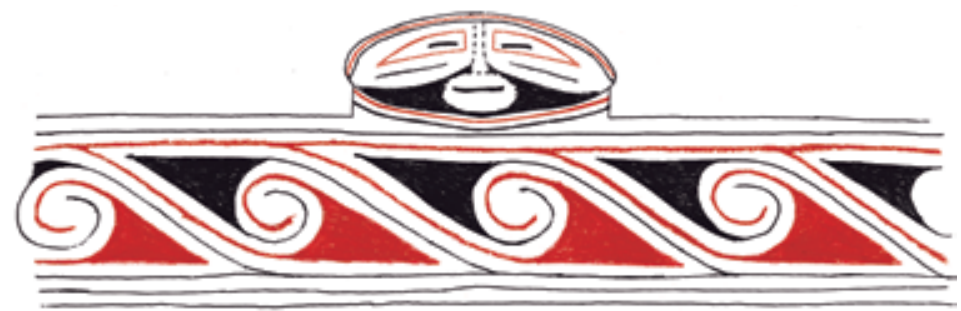

32. Casas Grandes, diseño de una vasija-efigie tipo Villa Ahumada polícroma, I300-I45o d.C. Se encontró como ofrenda funeraria al lado del cuerpo de un nińo. Actualmente en el Museo de las Culturas del Norte. Dibujo: Georgina Parada. 
DOI: http://dx.doi.org/10.22201/iie.18703062e.2016.109.2623

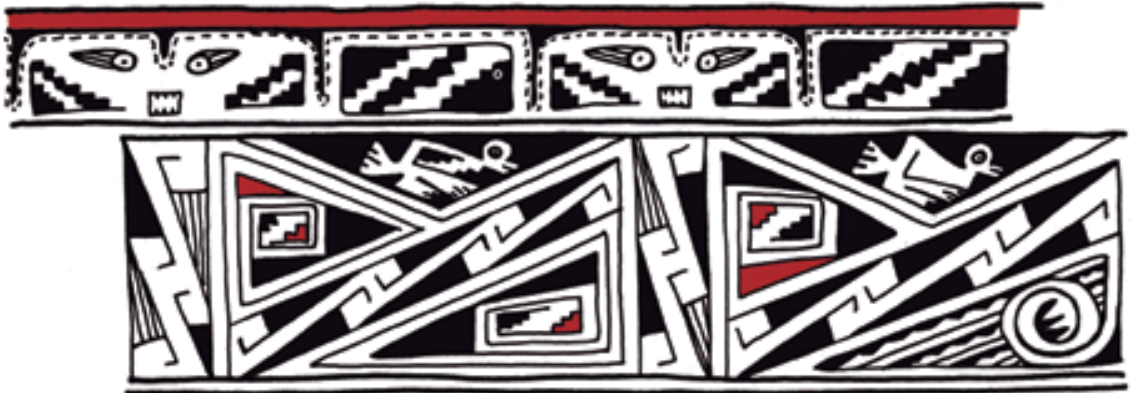

33. Casas Grandes, diseño de una vasija-efigie tipo Ramos polícroma, I300-I450 d.C. Se encontró como ofrenda funeraria al lado de los cuerpos de dos hombres. Actualmente se en el Museo de las Culturas del Norte. Dibujo: Alice Wesche, tomado de Di Peso, Rinaldo y Fenner, Casas Grandes (vid. supra n. I), vol. 6, 268 [el rojo es de la autora].

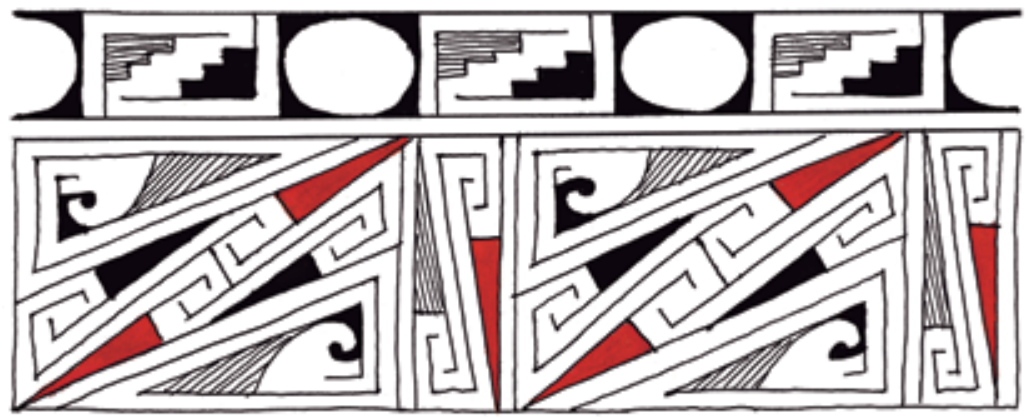

34. Casas Grandes, diseño de una olla tipo Ramos polícroma, I300-I450 d.C. Se encontró como ofrenda funeraria al lado del cuerpo de una mujer mayor. Actualmente en el Museo Nacional de Antropología. Dibujo: Georgina Parada.

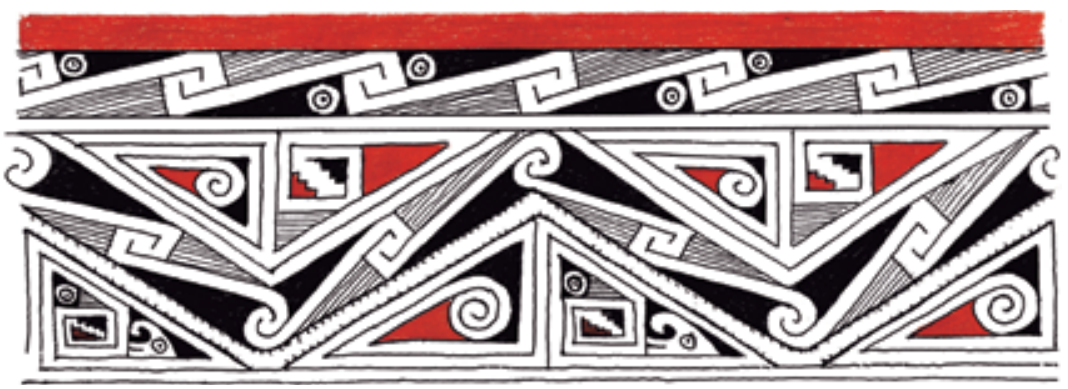

35. Casas Grandes, diseño de una olla tipo Ramos polícroma, I300-I450 d.C. Se le encontró como ofrenda funeraria a los pies de un adolescente. Actualmente en el Museo de las Culturas del Norte. Dibujo: Georgina Parada. 
DOI: http://dx.doi.org/10.22201/iie.18703062e.2016.109.2623

Obras, documentos 
DOI: http://dx.doi.org/10.22201/iie.18703062e.2016.109.2623 
DOI: http://dx.doi.org/10.22201/iie.18703062e.2016.109.2623

\section{La pintura mural del convento de Santa Clara de Asís en Dzidzantún, Yucatán. Generalidades sobre la ejecución de cuatro diferentes etapas}

\section{The Mural Paintings of the Santa Clara de Asis Convent in Dzidzantún, Yucatán. General Terms of the Different Four Phases of Execution}

Artículo recibido el 25 de junio de 20I5; devuelto para revisión el 2 de marzo de 20I6; aceptado el 5 de mayo de 20I6. http://dx.doi.org/Io.2220I/iie.I8703062e.20I6.IO9.258I

Ana Raquel Vanoye Carlo

Líneas de investigación

Publicaciones más relevantes
Maestra en Historia del Arte por parte de la UNAM. raquelvanoye@ gmail.com

La arquitectura y la pintura mural de los conventos franciscanos del norte de la Península de Yucatán.

"Sobre la historia de la arquitectura de los conventos franciscanos del norte de la Península de Yucatán: desde la llegada de los franciscanos a Campeche en 1544 hasta la construcción del convento de Santa Clara de Asís en 1567", Revista Fronteras de la Historia del ICANH I8, núm. 2 (2013), 213-246.

Resumen Hasta hace muy pocos años sólo era posible caracterizar la pintura mural de los conventos franciscanos del norte de la península de Yucatán como un conjunto pequeño que agrupaba elementos fragmentados y disconexos que exhibían un deterioro gradual y continuo, lo cual dificultaba su documentación y su investigación, en particular, el desarrollo de una propuesta sobre el orden seguido en su ejecución. La aparición de los murales del convento de Santa Clara de Asís cambió este panorama porque constituyen un grupo numeroso de pinturas, la mayoría sin intervenir, distribuidas en diferentes encalados. Estas características facilitaron la identificación y definición de una serie de etapas a las que era posible asociar un orden y organizarlas en una secuencia. La intervención de la pintura mural, en 20II, puso al descubierto otros ejemplos que proporcionaron información que contribuyó a precisar un determinado número de detalles útiles para complementar dicha secuencia. Este trabajo presenta las etapas que integran esta secuencia y los rasgos que caracterizan a cada una de ellas, así como su potencial contribución en los estudios de la pintura mural que albergan otros conventos de la región. 
Palabras clave Pintura mural; franciscanos; Yucatán; Dzidzantún; conventos; arquitectura religiosa.

Abstract Until a few years ago, it was only possible to regard the mural paintings in the Franciscan convents located in the northern Yucatan peninsula as a small set grouping fragmented and unconnected elements, which exhibited, moreover, a gradual and continuous deterioration; this complicated their recording and examination, making it difficult to arrive at a hypothesis regarding the order of the paintings' execution. The finding of the murals in the Santa Clara de Asis convent transformed the panorama since these form a large group of paintings, most of which have never been altered/interfered with, distributed over several different layers of whitewash. These features helped identify and define several phases that were placed in order and sequentially organized. The murals' restoration in $201 \mathrm{r}$ brought other examples to light, providing additional information helpful in pinning down a series of relevant details that complete the classification. The analysis defines the features that characterize each one of the phases in the sequence and the results are an important contribution to the study of mural painting preserved in other regional convents.

Keywords mural painting; Franciscans; Yucatán; Dzidzantún; convents; religious architecture. 
DOI: http://dx.doi.org/10.22201/iie.18703062e.2016.109.2623

\author{
ANA RAQUEL VANOYE CARLO
}

\title{
La pintura mural del convento de Santa Clara de Asís en Dzidzantún, Yucatán
}

Generalidades sobre la ejecución de cuatro diferentes etapas

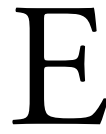

n el norte de la península de Yucatán no hay muchos conventos franciscanos que alberguen pintura mural. Más aún, en cada uno de estos edificios religiosos hay pocas pinturas y, en ocasiones, sólo fragmentos que no corresponden al mismo mural. Ambos rasgos han dificultado la posibilidad de establecer relaciones incluso entre pinturas que se encuentran en un mismo convento. Esta situación es el resultado de diversos factores ambientales, como la humedad presente en la región, y las circunstancias históricas como la guerra de castas y el proceso de secularización que sufrieron los conventos.

Otro rasgo que caracteriza a la pintura de esta región es que la mayoría es polícroma, a diferencia de otros lugares, como por ejemplo, el centro de México, donde la mayor parte de los conjuntos de murales conservados exhiben la técnica de la grisalla. Por su parte, los murales de la península de Yucatán muestran diversas paletas de color: desde las más limitadas que emplean sólo dos o tres colores hasta las más amplias que incluyen toda la gama.

Además, los murales se han sometido a pocas intervenciones en las cuales han participado algunos restauradores. En la década de los ochenta, la región recibió al primer equipo de especialistas en restauración, encabezado por Miguel Ábrego, quien se encargó de descubrir y estabilizar la pintura mural de 
DOI: http://dx.doi.org/10.22201/iie.18703062e.2016.109.2623

los conjuntos conventuales más representativos de la región como San Miguel Arcángel (I549), en Maní, y Santa Clara de Asís (I567), en Dzidzantún. Por diversas razones, este proceso se interrumpió algunos años, sin embargo, al final de la década de los noventa, la restauración de la pintura mural la retomó Fernando Garcés Fierros, quien se encargó de distintos conjuntos muralísticos de diferentes conventos, proceso que estuvo a su cargo hasta 20Ir. El hecho de que la mayoría de las intervenciones se hayan llevado a cabo por el mismo especialista presenta algunas ventajas: es posible conocer el estilo que caracteriza su trabajo y eliminarlo, en la medida de lo posible, para poder observar y estudiar la pintura original. La uniformidad en los procedimientos es otra de las ventajas con las que contamos, Garcés Fierros, por ejemplo, realizó los respectivos levantamientos fotográficos que documentan el aspecto que tenían los murales antes de su intervención y en sus dictámenes explicó la técnica a la que se sometieron los murales.

A pesar de que en la actualidad es posible visitar y apreciar la gran mayoría de los conjuntos de murales, el acceso a algunos de ellos sigue siendo complicado, éste es el caso de la iglesia de la hacienda de la Blanca Flor, en Campeche, la de San Bernabé, en Pencuyut o de la de San Antonio de Padua, en el poblado de Xocnaceh, lo cual dificulta la documentación de los cambios que estos recintos han sufrido con el paso del tiempo, así como la problemática para someterlos a cualquier estudio prolongado.

Sin duda, el planteamiento del estado actual de la pintura mural del norte de la península de Yucatán revela muchos de los aspectos que aún están pendientes por estudiar; al respecto este trabajo se aboca primero a presentar y describir los murales que sobreviven en el convento de Santa Clara de Asís, en Dzidzantún, pinturas intervenidas durante 20Ir. En la mayoría de los casos el procedimiento incluyó la consolidación de los enlucidos y la reintegración de grandes extensiones de la capa pictórica, lo cual aseguró el aspecto uniforme que actualmente tienen. Por otro lado está relacionado con una característica que dichos murales presentan: antes de la intervención de Garcés Fierros en 2011 muchos mostraban faltantes suficientes en sus enlucidos y en la capa pictórica para determinar que las pinturas no se ejecutaron al mismo tiempo y para establecer, en algunos casos, un orden de elaboración, la paleta de color empleada, el tema representado y las decoraciones preferidas.

El aspecto uniforme de la pintura mural actual es razón suficiente para investigar su apariencia anterior y para tratar de reconstruir el orden de su ejecución. La documentación y comprensión de un orden, al menos parcial, en 
la ejecución de la pintura mural de este convento, constituye un punto de partida para el desarrollo de otros estudios de diversa naturaleza, por ejemplo, los que se centran en aspectos específicos como la iconografía o la función de las pinturas, o aquellos que explican las relaciones o los vínculos con otros conjuntos muralísticos localizados en otros edificios religiosos franciscanos. Además, la cantidad de detalles incluidos en las descripciones también permite emplear estas etapas para inferir algunas características de las decoraciones que, por diversas razones, ya no existen.

En este estudio se analizarán las similitudes entre la pintura del convento de Santa Clara de Asís en Dzidzantún y algunos murales en el ex convento de San Miguel Arcángel, en Maní, con el fin de establecer que la pintura mural que existe en el primer edificio religioso es representativa de la decoración mural de los conventos de la región. Asimismo, se estudiará el parecido que tienen algunos murales del convento de Santa Clara de Asís, en Dzidzantún con algunas pinturas localizadas en diversos conventos del centro de México, por ejemplo, el convento franciscano de San Miguel Arcángel, en Huejotzingo, Puebla, y el agustino de San Miguel Arcángel, en Ixmiquilpan, Hidalgo, con el fin de evitar presentar el caso de la pintura mural franciscana de la península de Yucatán como un fenómeno aislado; finalmente se abordarán algunas explicaciones sobre el significado de los elementos que se reiteran con mayor frecuencia como, por ejemplo, los monogramas y las armas de Cristo, entre otros.

\section{Conjuntos murales}

La mayoría de los conjuntos de murales que sobreviven en los conventos franciscanos del norte de la península de Yucatán son pequeños y fragmentados. Además, debido al clima de la región que presenta altos índices de humedad, muchas de las pinturas muestran un deterioro acelerado y continuo. Estas situaciones hacían casi imposible identificar los temas representados y, en consecuencia, las relaciones existentes entre diferentes escenas localizadas en un mismo recinto, y las características materiales más representativas. Todas estas carencias, en conjunto, impedían determinar los rasgos más generales de la pintura mural de cualquier convento y, en particular, la reconstrucción del orden de ejecución más simple. Esto último limitó la posibilidad de establecer similitudes y diferencias entre pinturas murales pertenecientes a diversos edificios religiosos, por ejemplo, las relativas a los temas y la paleta de 
color. Tampoco era factible comparar fragmentos de murales para encontrar semejanzas ornamentales entre pinturas localizadas en diferentes conventos.

El descubrimiento entre 1983 y $1985^{1}$ de la pintura mural del convento de Santa Clara de Asís, en Dzidzantún, cambió el panorama anterior porque ahí existía un conjunto numeroso de murales. Los fragmentos que faltan hoy día en los muros indican que las pinturas se distribuyeron en diversos encalados, lo cual demuestra su pertenencia a diversas etapas de ejecución además de que sus dimensiones permiten la identificación y determinación de los temas representados, la paleta de color empleada, la ornamentación preferida y las proporciones de las pinturas murales ubicadas debajo de la capa exterior. Todo lo anterior facilitó e hizo posible identificar y definir las etapas que integraron la secuencia.

La intervención de 2011 puso al descubierto nuevas pinturas que proporcionaron información útil para precisar algunos detalles de la secuencia planteada, relacionados sobre todo con la ornamentación preferida en cada una de las diferentes etapas y con los cambios que experimentó la relación entre la pintura y la arquitectura. Este trabajo se centra en la presentación de una secuencia integrada por cuatro etapas y de los rasgos que caracterizan a cada una de ellas.

Antes de abordar el tema mencionaré que la ornamentación arquitectónica de este edificio religioso es más abundante y de mejor calidad que la exhibida en el resto de los conventos franciscanos de la península de Yucatán. Estas características probablemente se transmitieron también a la pintura mural, por lo cual su factura es más destacada, la cantidad de murales más numerosa o su proceso de renovación más continuo, es decir, las condiciones arquitectónicas del convento de Dzidzantún sugieren que sus murales son un ejemplo de los mejores ciclos pictóricos de la región. De ser así, se desconoce todo lo relacionado con la factura de los ciclos pictóricos de menor calidad, es decir, quizá la pintura mural del convento de Santa Clara centra las investigaciones en el extremo más favorable y beneficiado de la producción muralística, lo cual dificulta la reconstrucción de cualquier situación promedio.

Por último, es importante señalar que Santa Clara de Asís es el único edificio religioso del norte de la península de Yucatán que fue cabecera de doctrina y el cual conserva un número adecuado de murales en buen estado para

I. Entre esos años, Miguel Ábrego llevó a cabo las primeras intervenciones en la pintura mural de los conventos de San Miguel Arcángel, en Maní, y Santa Clara de Asís, en Dzidzantún. Comunicación personal con Miguel Ábrego, técnico restaurador, septiembre de 2013. 
esbozar o reconstruir el aspecto que algunos ciclos pictóricos debieron haber exhibido en la Provincia de San José de Yucatán. ${ }^{2}$

\section{Sobre la localización de la pintura mural}

La pintura mural que se considerará en este trabajo se localiza en el ábside 3 de la iglesia; en las bóvedas de cañón corrido que techan el claustro bajo y los recintos del ala norte; en el vano de la puerta que comunica el claustro con la nave de la iglesia y en el muro sur de la portería del convento (figs. Ia-d). Hasta antes de la intervención de 20II, las diferentes superposiciones de enlucidos y lechadas de cal indicaban que la pintura correspondía a diferentes periodos. Además, la mayor parte no se había trabajado, lo cual permitió identificar algunos aspectos originales que fueron de utilidad para la reconstrucción de una secuencia. ${ }^{4}$

La misma intervención descubrió una serie de pinturas murales sobre las bóvedas de cañón corrido del claustro bajo del convento. Sin embargo, este conjunto no se considera en este estudio debido a que el objetivo principal es organizar en etapas la pintura mural del ábside y mostrar que algunas pinturas murales del convento pueden relacionarse con alguna de ellas.

\section{A propósito de la técnica de las pinturas murales}

Al parecer, en la ejecución de todos los murales del convento de Santa Clara de Asís se empleó la técnica al temple. La observación detenida de los soportes de las pinturas no revela la presencia de tareas, lo cual indica que el enlucido fino se aplicó

2. Con seguridad, en la pintura mural de la Provincia de San José de Yucatán también sucedió lo que algunos autores como Constantino Reyes Valerio han señalado para el altiplano central: "Los estudios que hemos realizado en los conventos que todavía poseen suficientes escenas, nos han permitido percibir que [éstas] no fueron distribuidas al azar sino que, por el contrario los misioneros las distribuyeron con la intención de que sirvieran para enseñar los fundamentos de la doctrina por medio de ellas" (Constantino Reyes Valerio, El pintor de conventos. Los murales del siglo XVI en la Nueva España, Colección Científica [México: Instituto Nacional de Antropología e Historia, I985], II2).

3. A pesar de ser parte del mismo espacio el ábside se refiere a los muros que se encuentran detrás del altar mayor, mientras que el presbiterio al lugar donde se encuentra el altar mayor.

4. Antes de septiembre de 20 II los trabajos de restauración sólo habían avanzado hasta la fase de desencalamiento. Actualmente, las pinturas se han consolidado y reintegrado. 


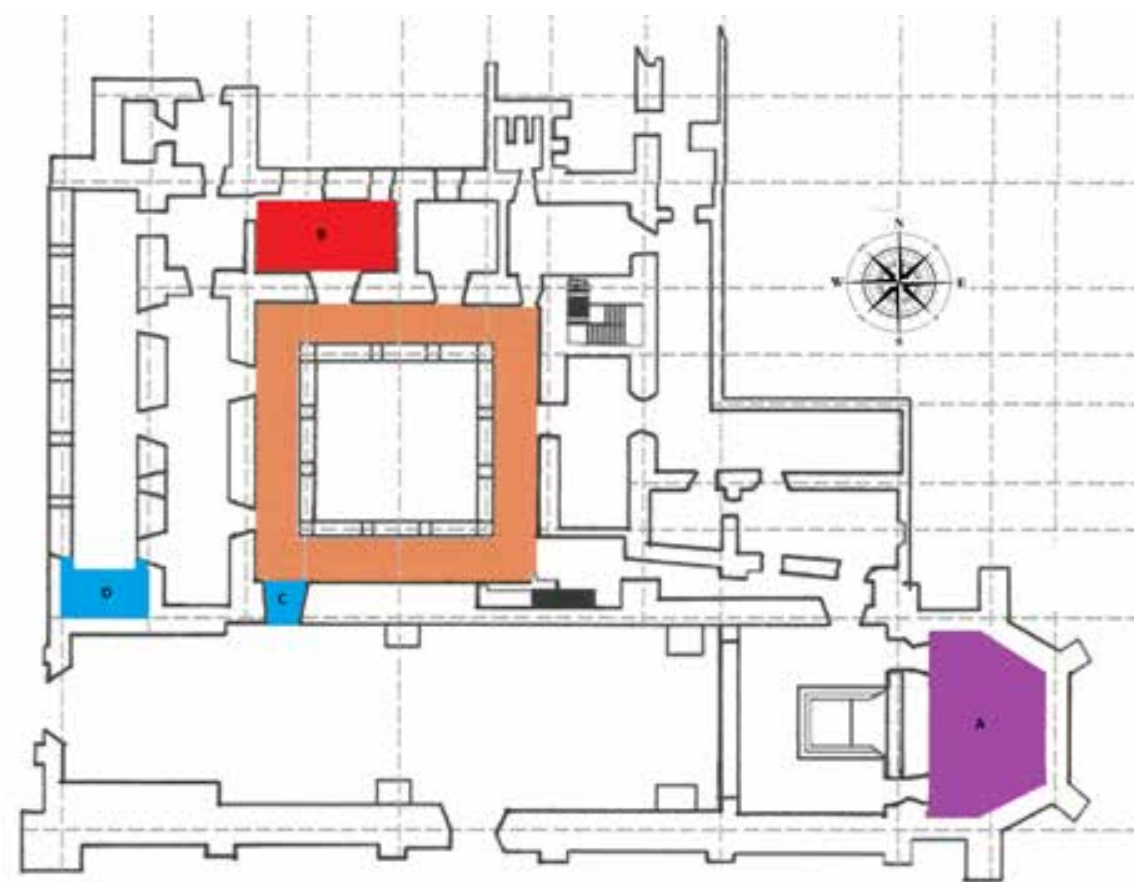

I. Localización de la pintura mural dentro del convento de Santa Clara de Asís, Dzidzantún, Yucatán: a) en el presbiterio de la iglesia; b) en las bóvedas de cañón corrido que techan el claustro bajo y en los recintos del ala norte; c) en el vano de la puerta que comunica el claustro con la iglesia; d) en la portería del convento. Bosquejo de Enrique Sadek-Palazuelos, octubre, 20I5.

sobre el muro antes de comenzar la pintura mural. El bruñido aplicado a este enlucido es otro de los rasgos que también sugieren que se trata de pinturas al temple.

Hasta el momento existen pocos estudios sobre la técnica empleada para ejecutar los murales del convento de Santa Clara de Asís. Sobre este tema, Garcés Fierros, en su "Restauración de la pintura mural de la iglesia de Santa Clara de Asis, de Dzidzantún, Yucatán" incluye una serie de conclusiones obtenidas a partir de "lo que apreciamos en los cortes estatigráficos y en la observación macro y microscópica de los acabados y la pintura mural". 5 Aunque estas afirmaciones aportan información sobre la materialidad de estos objetos,

5. Cuauhtémoc Fernando Garcés Fierros, "Restauración de la pintura mural de la iglesia de Santa Clara de Asís, Dzidzantún, Yucatán”, Archivo de la Coordinación Nacional de Conservación del 
también presentan muchas imprecisiones que deben tomarse en cuenta al momento de considerarlas.

De acuerdo con el restaurador: "el aplanado se efectuó en dos capas, ambas más ricas de cal que las del revoco y con una carga fina. La capa final o segunda es muy delgada y presenta un ligero bruñido". ${ }^{6}$ No todos los encalados tenían estas características sólo los más tempranos. De hecho, entre más reciente fuera el enlucido y mayor el número de revocos que le antecedían, aumentaba la posibilidad de que esta última capa fuera más delgada, y de que, por ejemplo, se construyera usando solamente algunas lechadas de cal. Éste es el proceso evolutivo que distingue a los enlucidos que existen en el ábside de la iglesia del convento de Santa Clara de Asís, por lo cual, el trabajo de Garcés Fierros se refiere sólo a los primeros, sobre los restantes aún no existen estudios.

Respecto a la capa pictórica, el restaurador menciona:

la pintura mural presenta un trazo previo, hecho con grisalla y con diseños incisos, posteriormente se aplicó la pintura con diferentes tipos de pincel y utilizando pintura al temple magro, de proteína, se indica en el estudio que muy probablemente de clara de huevo, por las características de insolubilidad y absorción de agua de la pintura. ${ }^{7}$

El restaurador no incluye los datos del estudio al que hace referencia, pero en el dictamen incorporó una microscopía de tres muestras, lo cual sugiere su existencia. Según la información proporcionada, éstas proceden del retablo del muro 2 incluido en la tercera etapa, por lo cual sólo es posible afirmar que el temple fue la técnica empleada en la ejecución de los murales de este periodo.

Hasta el momento no se han llevado a cabo más estudios de la pintura mural localizada en otras partes del convento.

\section{La pintura mural del ábside de la iglesia}

La mayor parte de la pintura mural que conserva el convento se encuentra en el ábside original de la iglesia actualmente detrás del muro que sostiene el

Patrimonio Cultural-Instituto Nacional de Antropología e Hisotria (en adelante CNCPC-INAH), 4OI.F(2I)IO8.2010/24, 2010, 25.

6. Garcés Fierros, "Restauración de la pintura mural", 25.

7. Garcés Fierros, "Restauración de la pintura mural”, 26. 


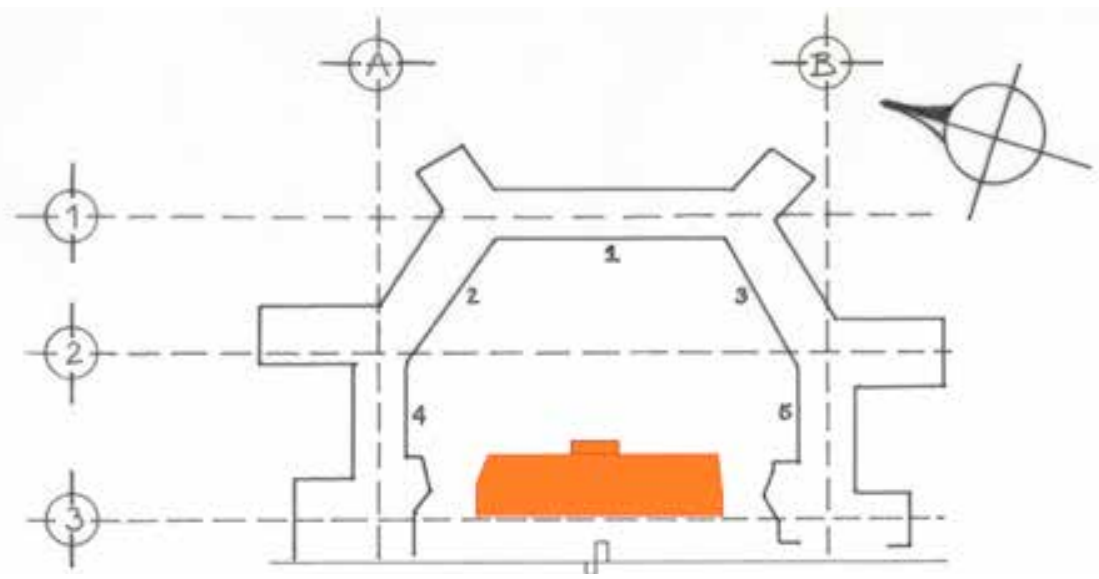

2. Planta del presbiterio original de la iglesia, convento de Santa Clara de Asís, Dzidzantún, Yucatán. La numeración del I al 5 hace alusión a cada uno de los muros del presbiterio de la iglesia. Bosquejo de Enrique Sadek-Palazuelos, octubre, 20I5.

retablo principal (fig. I). En la figura 2 se aprecian los cinco muros que forman esta estructura arquitectónica; los diversos problemas estructurales que presentó la bóveda de lacerías, entre ellos que desde el inicio de su construcción obligaran a los frailes a construir, frente a este ábside y a unos 8 metros de distancia, un muro con su pilastra central para apuntalarla. Esta nueva estructura dividió en dos partes desiguales la nave de la iglesia. El espacio que quedó al oeste, el de mayores dimensiones, siguió funcionando como iglesia y el que quedó al este, de tamańo menor, se utilizó como la sacristía. ${ }^{8}$ La construcción de este muro significó también el aislamiento de la pintura, lo cual, junto con la serie de intervenciones llevadas a cabo por diferentes instituciones y organizaciones, determinó su conservación.

La última de estas intervenciones se llevó a cabo en 2oIr. Ese año, el restaurador Garcés Fierros, adscrito al centro INAH-Yucatán, comenzó el rescate de varias áreas del convento, entre ellas la pintura mural, misma que, de manera general, limpió, consolidó y reintegró. De manera específica, retiró algunos

8. Este lugar albergó la sacristía hasta 20II, año en que los pobladores de Santa Clara de Asís, por instrucciones del presbítero Gabriel Luz Calvillo, rehabilitaron la antigua sacristía, localizada en los recintos del norte de la iglesia. El objetivo era cerrar el espacio localizado detrás del altar mayor y con ello contribuir a la preservación de la pintura mural del ábside. 
encalados de los muros 2, 3, 4 y 5, lo cual le permitió descubrir nuevos murales que hicieron más comprensibles los que ya eran visibles. ${ }^{9}$ La figura 26 muestra el aspecto actual que tiene esta estructura.

La aparición de estos últimos murales fue útil para entender, en el caso de algunas pinturas que anteriormente parecían aisladas, los temas representados, las composiciones elegidas y su relación con el resto del conjunto. La presencia de tales características hizo posible abandonar las explicaciones que privilegiaban las descripciones muro por muro y comenzar a considerar aquéllas en las cuales el ábside se ve como una unidad.

Hasta el momento he identificado cuatro conjuntos de murales que corresponden a cuatro diferentes tipos de decoraciones que el ábside pudo haber exhibido en momentos distintos y que presentaré a continuación. Para introducir los murales que se encuentran en el resto del convento identificaré la probable etapa a la cual pertenecen de acuerdo con los rasgos que comparten con alguna de las decoraciones del ábside, e incluiré su presentación en ese apartado. De este modo, la pintura del antiguo presbiterio funciona como el eje alrededor del cual se organiza el resto de los murales que sobreviven en el convento.

Las pinturas que no caben dentro de alguno de los conjuntos son suficientes para afirmar que esta estructura arquitectónica debió haber albergado otros programas pictóricos cuyo aspecto y determinación de sus características están pendientes para un estudio próximo.

\section{La primera decoración del ábside (I575-I700)}

Las pinturas que pertenecen al primer conjunto se encuentran en los muros I, 2, y 3 del ábside y en la bóveda de lacerías. La figura 27 muestra qué partes permanecen actualmente de los murales de esa época. Con esta decoración sobrevive una mayor cantidad de murales y rastros de pintura. Se trata de un conjunto ejecutado con una paleta que incluye la grisalla y los colores azul y rojo en distintas tonalidades. Éstos se aplicaron sobre enlucidos gruesos y

9. Véase Raquel Vanoye Carlo, "Esbozo de la historia de la pintura mural virreinal de Yucatán", tesis de maestría en Hisotria del Arte (México: Universidad Nacional Autónoma de MéxicoFacultad de Filosofía y Letras, 20II), 35-78; en la sección que corresponde al capítulo 2, titulado "La pintura mural del convento de Santa Clara de Asís", hay una descripción amplia y detallada de toda la pintura mural que era visible en este convento hasta antes de junio de 201 . 
bruñidos de color rosa pálido. ${ }^{\text {Io }}$ Se hicieron en grisalla todos los elementos arquitectónicos que, en general, son de gran tamaño, corren a todo lo largo del muro, y están profusamente ornamentados con motivos vegetales y geométricos, ángeles y monogramas. Su escala indica que una de las características principales de las pinturas correspondientes a esta decoración es su papel preponderante en la configuración de los espacios, pues la arquitectura real queda oculta detrás de la que recrea la pintura. Sobre los tres muros del ábside se pintó un sillar al que interrumpen tres elementos: un retablo mural flanqueado por un par de arcos de medio punto. El retablo de grandes dimensiones es el elemento central de la composición y ocupa casi toda la pared; está coronado por una representación de los símbolos pasionarios ejecutada en el tímpano que remata el muro central del ábside. El autor organizó la composición usando dos estructuras arquitectónicas que enmarcan tres elementos dispuestos verticalmente: una representación de la Coronación de la Virgen es el elemento superior, la escena de la Asunción, el central, y un rectángulo de color crudo, el inferior (fig. 3). La primera estructura (la exterior) está formada por un tímpano, que alberga la escena de la Coronación y que descansa sobre un entablamento apoyado sobre un par de columnas. Dicha estructura funciona como el marco de una segunda, similar en diseńo y composición a la anterior: un frontón curvo que alberga la escena de la Asunción, apoyado también sobre soportes laterales.

Tanto la arquivolta como el entablamento que enmarcan la escena de la Coronación están profusamente ornamentados. Para la primera se alternaron rostros de querubines, con sus alas extendidas, con cartelas apergaminadas. En total hay siete cartelas y seis querubines. Del lado izquierdo hay tres cartelas mientras que del derecho, cuatro: la primera, la cuarta, que además ocupa el lugar central y es ovalada, y la quinta han perdido sus representaciones; en la segunda cartela, sobre un fondo rojo, se pintó, con letras blancas y coronado, el monograma de María (fig. 4a); en la tercera, sobre un fondo negro y con letras rojas, el de Jesús coronado por la letra griega omega (fig. 4b) y, en la sexta se colocó nuevamente, sobre un fondo negro y con letras blancas, el de María, coronado también con la letra griega omega; en

Io. El color de los enlucidos de los conventos franciscanos del norte de la península de Yucatán se debe a algunas sustancias que se agregaron a la cal durante su preparación para mejorar su calidad. También conocido como color crudo, información proporcionada por Rocío Jiménez $(\dagger)$, restauradora adscrita entonces al Centro INAH-Yucatán. Comunicación personal, septiembre de 201 I. 
DOI: http://dx.doi.org/10.22201/iie.18703062e.2016.109.2623

MURAL DEL CONVENTO DE SANTA CLARA DE ASÍS

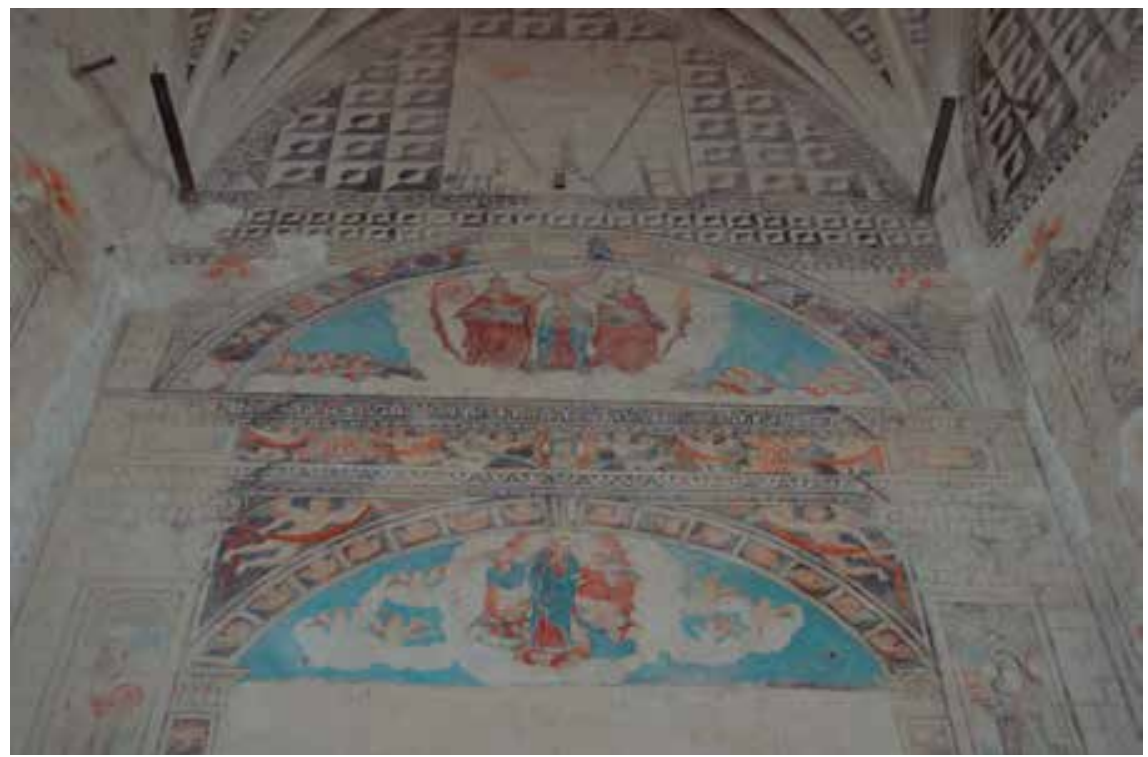

3. Arriba: la Coronación de la Virgen; abajo: la Asunción de la Virgen, muro I, ábside de la iglesia, convento de Santa Clara de Asís, Dzidzantún, Yucatán. Foto: Ana Raquel Vanoye Carlo, julio, 20I3. Secretaría de Cultura-INAH-Méx. "Reproducción autorizada por el Instituto Nacional de Antropología e Historia”.

la última se representó al sol. El pintor colocó un ramo de flores rojas y hojas azules junto a los monogramas de María y una serie de cintas, también rojas y azules que entrelazan las alas de los querubines con las cartelas para sostener estas últimas.

La franja central del entablamento tiene una decoración muy parecida a la de la arquivolta: sobre un fondo negro se pintaron tres cartelas apergaminadas; en la de la izquierda se lee, sobre un fondo rojo claro, con letras color rojo oscuro, el monograma del santo nombre de Jesús coronado con la cruz, la del centro contiene una representación de la Verónica (fig. 4c) y la de la derecha se destinó al monograma de María coronado con la letra omega (fig. 4d). Un par de ángeles con ayuda de listones rojos y azules sostienen cada cartela, estos elementos las atraviesan en distintos puntos y los ángeles sostienen en sus manos los extremos. 
DOI: http://dx.doi.org/10.22201/iie.18703062e.2016.109.2623

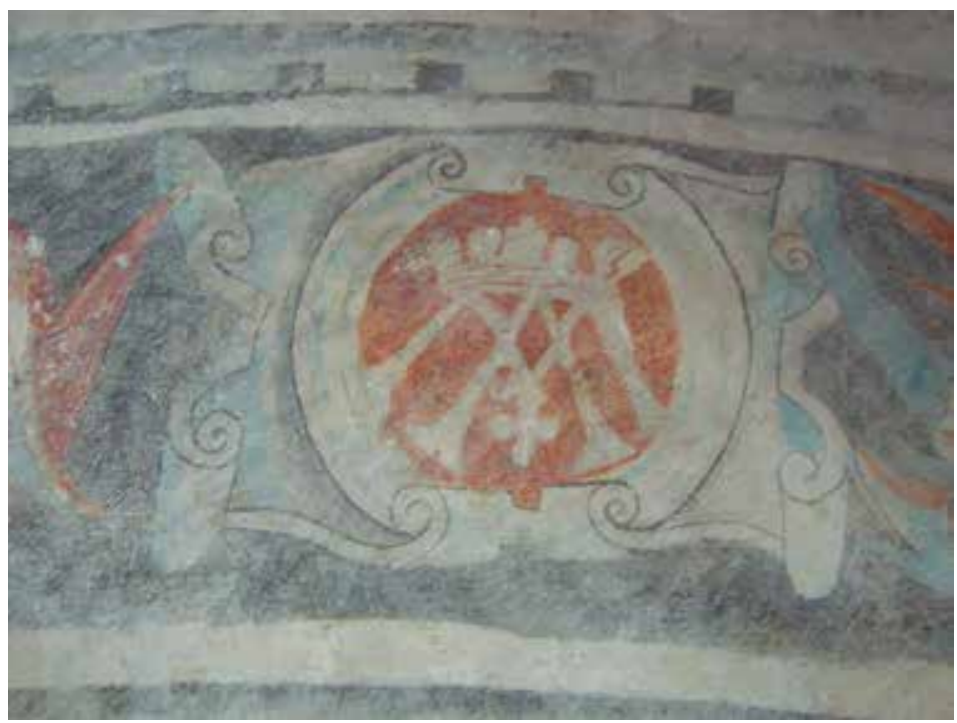

4a) Cartela con el monograma de María coronado en la arquivolta que enmarca la escena de la Coronación. En todos los incisos, muro I, ábside de la iglesia, convento de Santa Clara de Asís, Dzidzantún. Yucatán, junio, 20Ir. Fotos: Ana Raquel Vanoye Carlo.

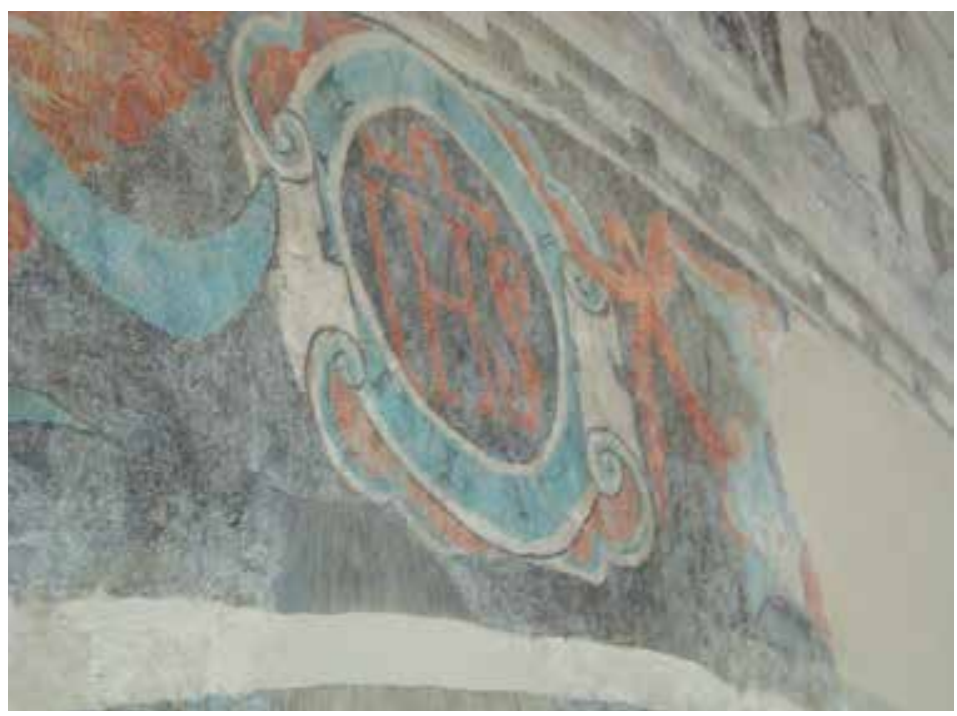

4b) Cartela con el nombre de Jesús en la arquivolta que enmarca la escena de la Coronación. 
DOI: http://dx.doi.org/10.22201/iie.18703062e.2016.109.2623

MURAL DEL CONVENTO DE SANTA CLARA DE ASÍS

4c) Representación de la Verónica en el entablamento que separa las escenas de la Coronación y la Asunción.

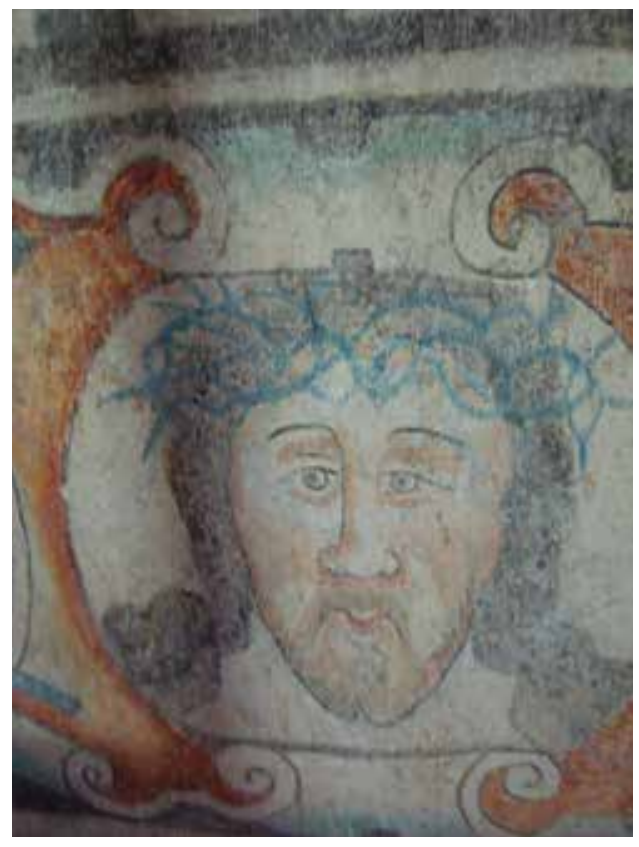

4d) Cartela con el monograma de María, coronado por la letra griega omega, que separa las escenas de la Coronación y la Asunción.

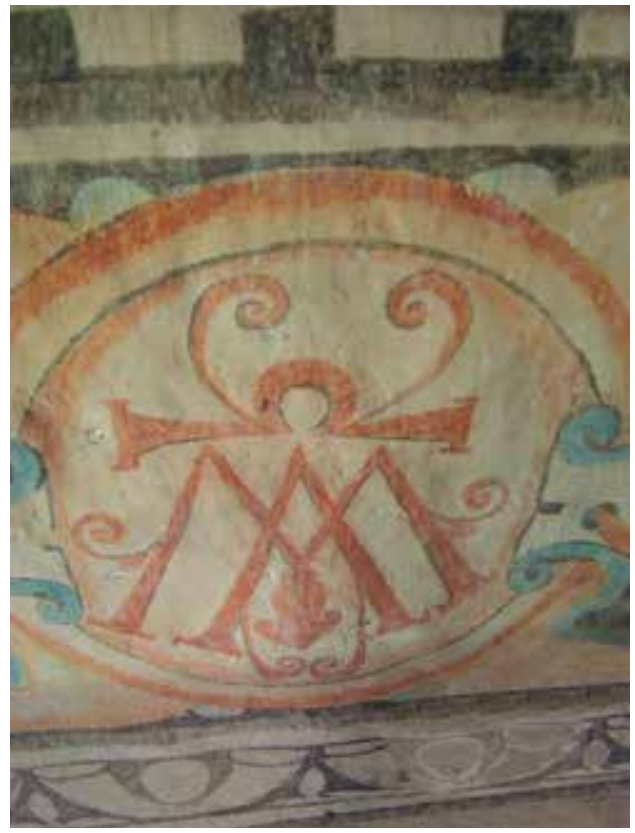


DOI: http://dx.doi.org/10.22201/iie.18703062e.2016.109.2623

Elena Isabel Estrada de Gerlero señala los motivos por los cuales estos monogramas se empleaban frecuentemente como ornamentos de las estructuras arquitectónicas, al respecto señala que:

dentro del convento franciscano, los monogramas de los nombres sagrados estuvieron mayormente visibles a la generalidad de los fieles, en las portadas e interiores de las iglesias y capillas posas de reminiscencias mudéjares y sabor tequitqui, así como en los espacios de clausura conventual de los claustros altos; el monograma simbólicamente reforzará el sentido estructural de las claves de los arcos, encuentro de nervaduras o cerramiento de bóvedas. ${ }^{\text {II }}$

La arquivolta y el entablamento no son los únicos elementos que se decoraron con monogramas: en esta descripción presentaré otros casos que reforzarán esta afirmación respecto de la pintura mural franciscana de la península de Yucatán. En general, el señalamiento de estas similitudes contribuye a construir relaciones entre esta última y la que se localiza en los conventos del resto del país.

Cada una de las columnas que forman parte de la estructura exterior tiene tres nichos. Los santos que ocupan los nichos de la columna izquierda son, de abajo arriba: san Pedro, probablemente san Francisco de Asís y san Bernardino de Siena (fig. 5), mientras que los de la derecha corresponden, considerando el mismo orden, a san Pablo, san Antonio de Padua y santa Clara de Asís. Detrás de los arcos de medio punto y de la escena de la coronación aparecen unas bases que, al parecer son el remate de las columnas, coronadas por la cifra rodeada de rayos solares. ${ }^{\text {I2 }}$

Además de contener la escena de la Coronación, la función del entablamento de la estructura exterior también separa ambas escenas; las enjutas que se forman entre esta estructura arquitectónica y la delgada arquivolta que rodea el momento de la Asunción fueron decoradas, cada una, con un ángel.

II. Elena Isabel Estrada de Gerlero, Muros, sargas y papeles. Imagen de lo sagrado y lo profano en el arte novohispano del siglo XVI (México: Universidad Nacional Autónoma de México-Instituto de Investigaciones Estéticas, 20II), 88.

I2. "San Bernardino de Siena, reformador y vicario general de los observantes, predicó la devoción al Santo Nombre de Jesús a un nivel popular, como una eficaz rama de conversión, e insistió en que sus raíces provenían de la Iglesia primitiva, que comprende tanto la evangélica, como la de los mártires y los confesores. Fue en una de estas ocasiones que se hizo acompañar de la cifra rodeada de rayos solares sobre fondo azul, pintada en una tableta, carente en absoluto de todo vestigio antropomorfista”, Estrada de Gerlero, Muros, sargas y papeles, 79. 


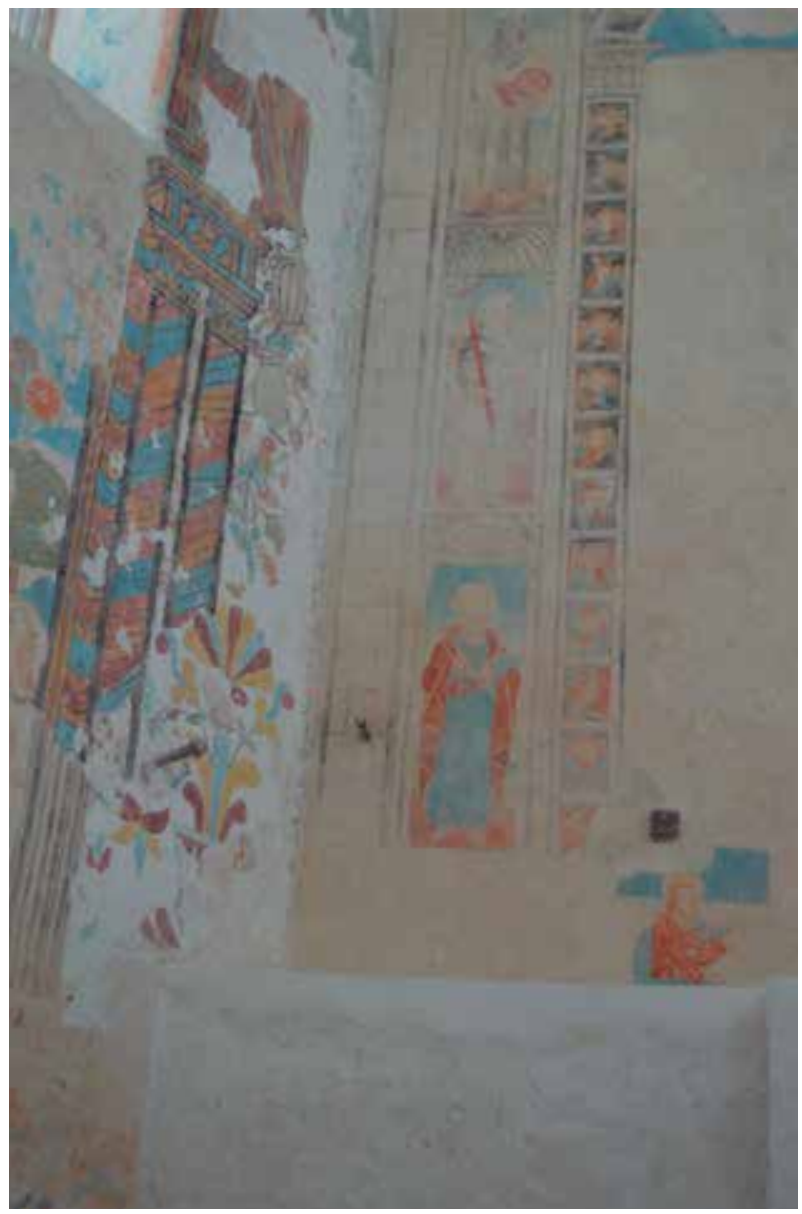

5. De abajo arriba: san Pedro; probablemente san Francisco de Asís y san Bernardino de Siena; a la izquierda: decoración floral correspondiente a la cuarta etapa. En la extrema izquierda se aprecian las arquivoltas que decoran las columnas de la primera decoración y que funcionan como guías de las columnas de los retablos de la tercera decoración, nicho inferior de la columna izquierda del retablo, muro central del ábside de la iglesia, convento de Santa Clara de Asís, Dzidzantún, Yucatán. Foto: Ana Raquel Vanoye Carlo, julio, 20I3. Secretaría de Cultura-INAH-Méx. "Reproducción autorizada por el Instituto Nacional de Antropología e Historia”. 
DOI: http://dx.doi.org/10.22201/iie.18703062e.2016.109.2623

Además, esta arquivolta, que está hecha con sillares decorados, cada uno, con el rostro de un querubín alado, se convierte en las columnas que sostienen el frontón curvo de la estructura interna; todos los elementos anteriores enmarcan el rectángulo rosado cuya característica principal es el nicho que tiene en la parte inferior central. Tal vez, dentro de este espacio se colocaba el Sagrario y sobre el rectángulo un lienzo o un pequeño retablo, o al menos eso es lo que indican las cuatro anclas que se localizan en la parte superior del nicho.

Como ya lo mencioné, a cada lado de este retablo hay un arco de medio punto apoyado sobre un par de pilastras. El arco está decorado con molduras de diferente grosor, la central es la de mayor anchura y está ornamentada con hojas de acanto. En el lugar de la clave se colocaron cartelas que albergan monogramas, para el caso del muro 2 se utilizó el de Jesús y para el 3, el de María. Encima de esta arquivolta central hay dos franjas más: la exterior es un poco más gruesa que la que está en contacto con la central, para decorarlas se emplearon cuadrados negros, equidistantes, dispuestos a lo largo. Por debajo de la franja central hay tres arquivoltas, la relación entre éstas y el capitel indica que están detrás de este último elemento, es decir, no son parte del frente del arco sino de su ancho, por eso se extienden hasta las pilastras. El fuste de estos elementos está ornamentado con un panel rectangular que contiene listones entrelazados. En cada uno de los tímpanos que se forman entre estos arcos y el borde superior de las ventanas, que tienen ambos muros, se colocaron un par de ángeles sosteniendo una cartela.

A continuación describiré la composición del muro 2. Los bordes de la cartela son rojos y lanceolados y en su interior hay un rectángulo de lados azules en el que probablemente se escribió alguna frase en latín aunque, hoy día, sólo puede apreciarse lo que parece una letra $c$ en el ángulo superior izquierdo, debido a que encima se ejecutó otra pintura que abordaré en la tercera etapa. Cada uno de los ángeles está vestido con una falda roja, larga y un blusón azul en cuyo borde se pintó una franja roja, de tono más intenso que el que se empleó en la falda (fig. 6).

La composición que sobrevive en el muro 3 es similar a la anterior, aunque presenta algunas diferencias en su diseño. La cartela tiene los mismos colores pero están invertidos: los bordes lanceolados son azules y el marco del rectángulo es rojo. En el interior, con letras negras, había una leyenda, probablemente en latín, hoy ilegible debido al severo deslavamiento que presenta el mural. Los ángeles que la sostienen están desnudos, cada uno porta un listón 
DOI: http://dx.doi.org/10.22201/iie.18703062e.2016.109.2623

MURAL DEL CONVENTO DE SANTA CLARA DE ASÍS

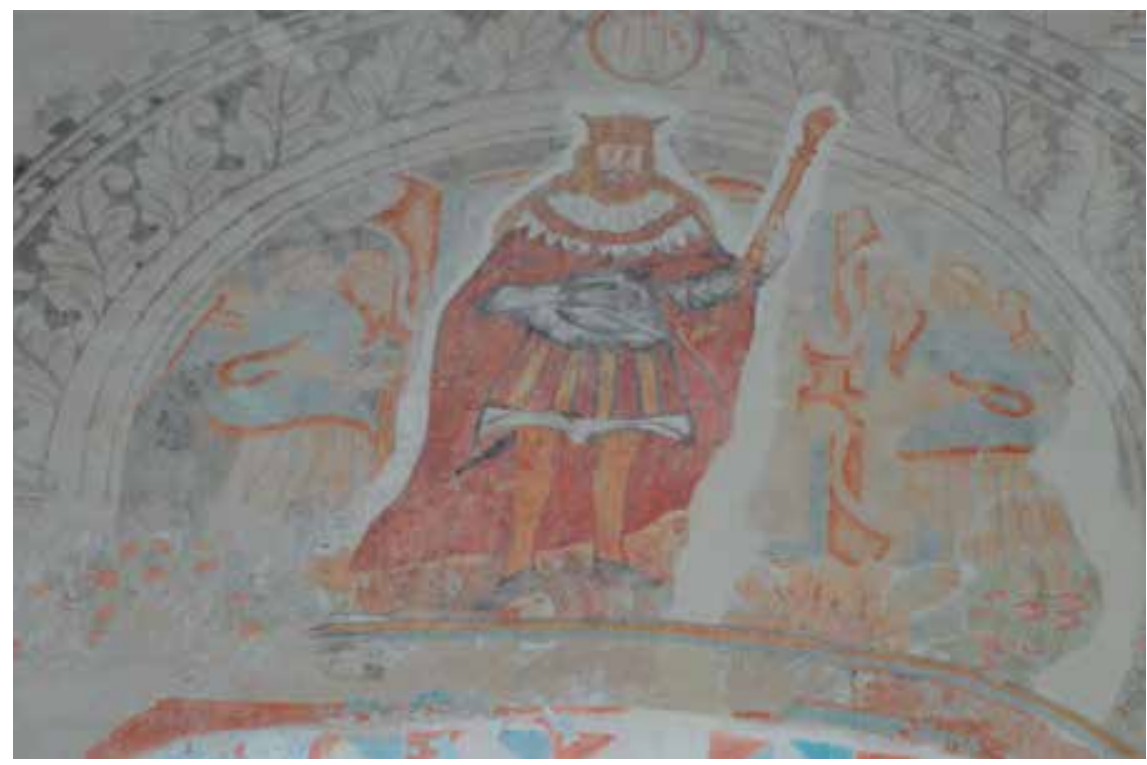

6. Cartela con ángeles tenantes y rey en el remate del retablo, muro 2, ábside de la iglesia, convento de Santa Clara de Asís, Dzidzantún, Yucatán. Foto: Ana Raquel Vanoye Carlo, febrero, 20I5. Secretaría de Cultura-INAH-Méx. "Reproducción autorizada por el Instituto Nacional de Antropología e Historia”.

rojo largo, la parte central de este elemento ha sido colocada alrededor de su cuello, sus dos extremos los cruzaron primero en el pecho del ángel y después lo anudarían en la cintura y caderas, uno de los extremos se entrelaza con la cartela y el otro lo sostienen los ángeles (fig. 7).

Entre las columnas de cada arco y debajo de de cada ventana también había una escena que en ambos casos casi se ha perdido. Para el muro 3, sólo sobrevive la parte superior izquierda de una concha de gran tamaño, en grisalla, rodeada por una franja de cuadrados negros que alterna con otros de color rosa (fig. 2I). Probablemente, coronaba una hornacina parecida en composición a las que se encuentran en el cuerpo de las columnas de la estructura arquitectónica exterior que forma parte del retablo ubicado en el muro central del ábside. El caso del muro 2 es diferente, pues, a pesar del severo deslave que la pintura ha sufrido, aún es posible identificar, en café-rojizo, el rostro, las manos y los pies de san Francisco de Asís y, en gris, su hábito y su cordón. Frente a él hay 
DOI: http://dx.doi.org/10.22201/iie.18703062e.2016.109.2623

236

ANA RAQUEL VANOYE CARLO

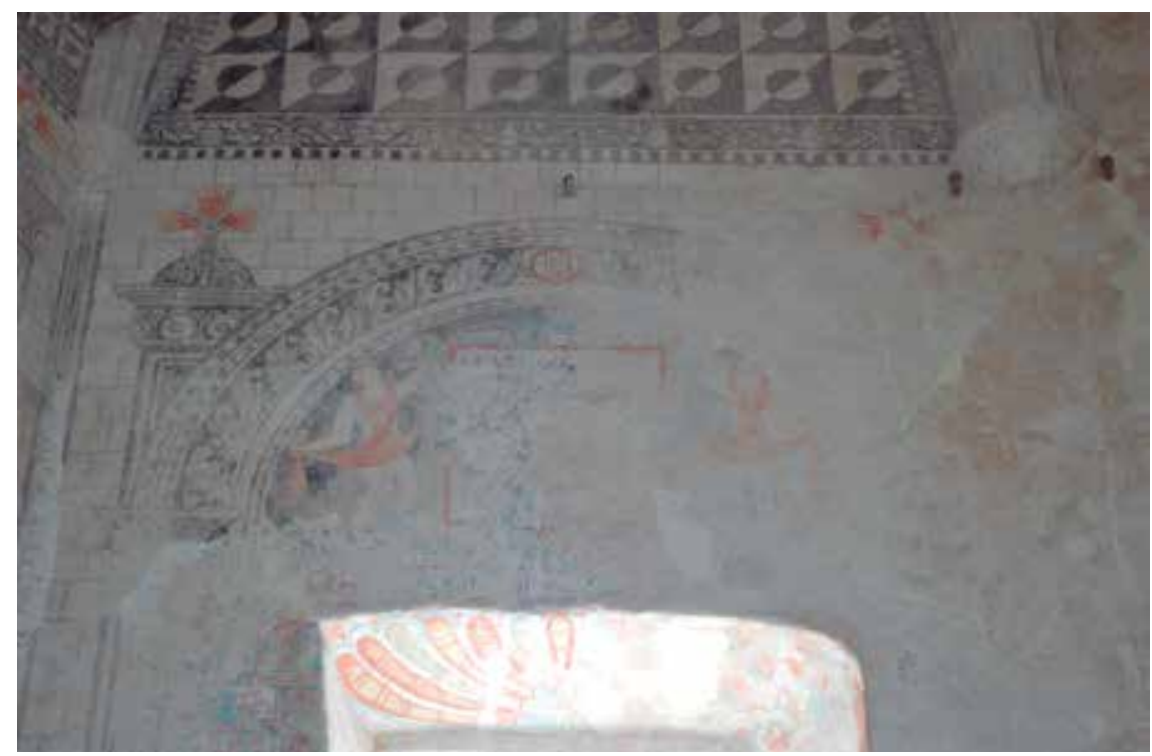

7. Detalle de la cartela con tenantes, muro 3, ábside de la iglesia, convento de Santa Clara de Asís, Dzidzantún, Yucatán. Foto: Ana Raquel Vanoye Carlo, febrero, 2015. Secretaría de Cultura-INAH-Méx. "Reproducción autorizada por el Instituto Nacional de Antropología e Historia”.

un rompimiento de nubes, y detrás un árbol de hojas verdes y frutos sepia (fig. 8a). A su derecha y en la parte inferior se aprecia la silueta de fray León sosteniendo un libro en sus manos. Los elementos anteriores son suficientes para indicar que la escena representada es la de san Francisco de Asís cuando recibe los estigmas. ${ }^{13}$ La línea ejecutada para definir la silueta de ambos franciscanos proporciona información sobre otra de las característica de la técnica: los pintores empleaban una línea café-rojiza para hacer el dibujo preliminar, para esbozar toda la composición, incluso los hábitos, y posteriormente utilizaban el color gris para rellenar los hábitos y cubrir las líneas preliminares, tal y como puede apreciarse en la ropa de fray León. Al final, aplicaban un delineado en negro (fig. 8b).

Como ya lo mencioné, a los lados del retablo y de los arcos es posible apreciar el sillar utilizado para enmarcar estos elementos arquitectónicos, y que se

I3. Comunicación personal, Linda K. Williams, University of Puget Sound, abril de 2013. 
DOI: http://dx.doi.org/10.22201/iie.18703062e.2016.109.2623

MURAL DEL CONVENTO DE SANTA CLARA DE ASÍS

8. a) San Francisco de Asís recibiendo los estigmas; b) detalle de fray León sosteniendo el libro, en la manga del hábito se aprecia la línea café-rojiza, correspondiente al dibujo preliminar, muro 2 del ábside de la iglesia, convento de Santa Clara de Asís, Dzidzantún, Yucatán. Fotos: Ana Raquel Vanoye Carlo, julio, 2012 y 20I3. repectivamente. Secretaría de Cultura unAm-Méx. "Reproducción autorizada por el Instituto Nacional de Antropología e Historia.
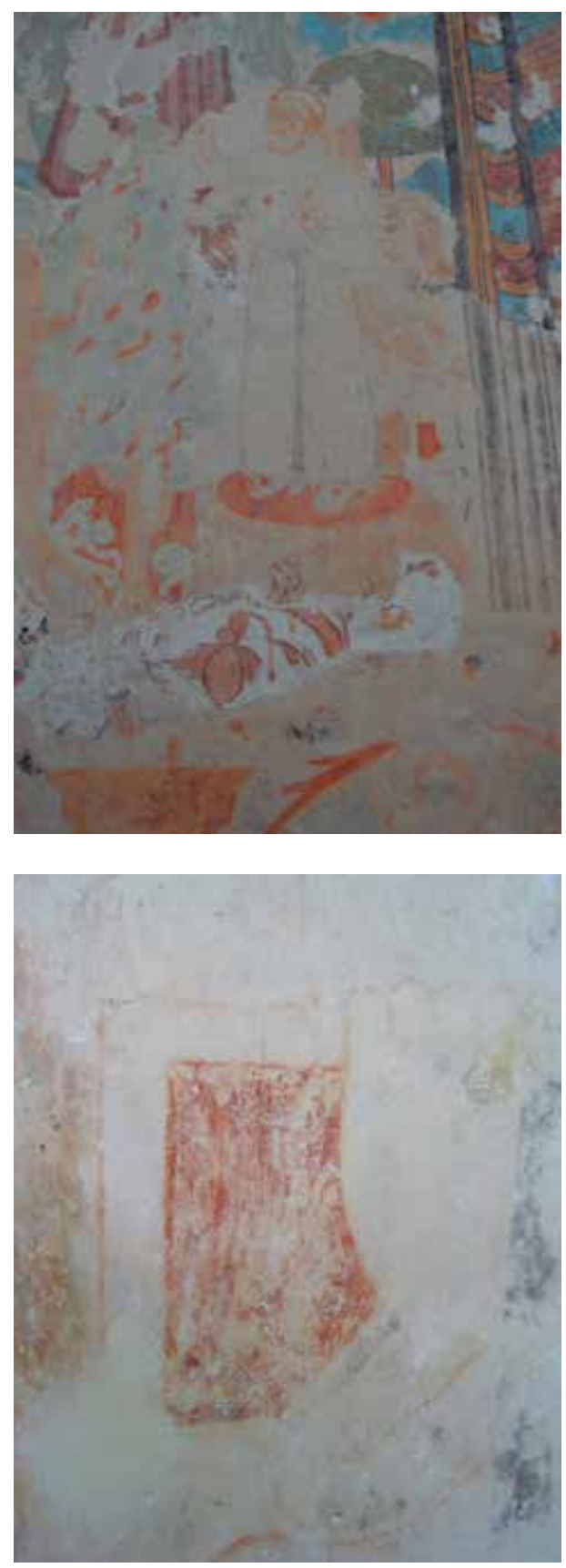
DOI: http://dx.doi.org/10.22201/iie.18703062e.2016.109.2623

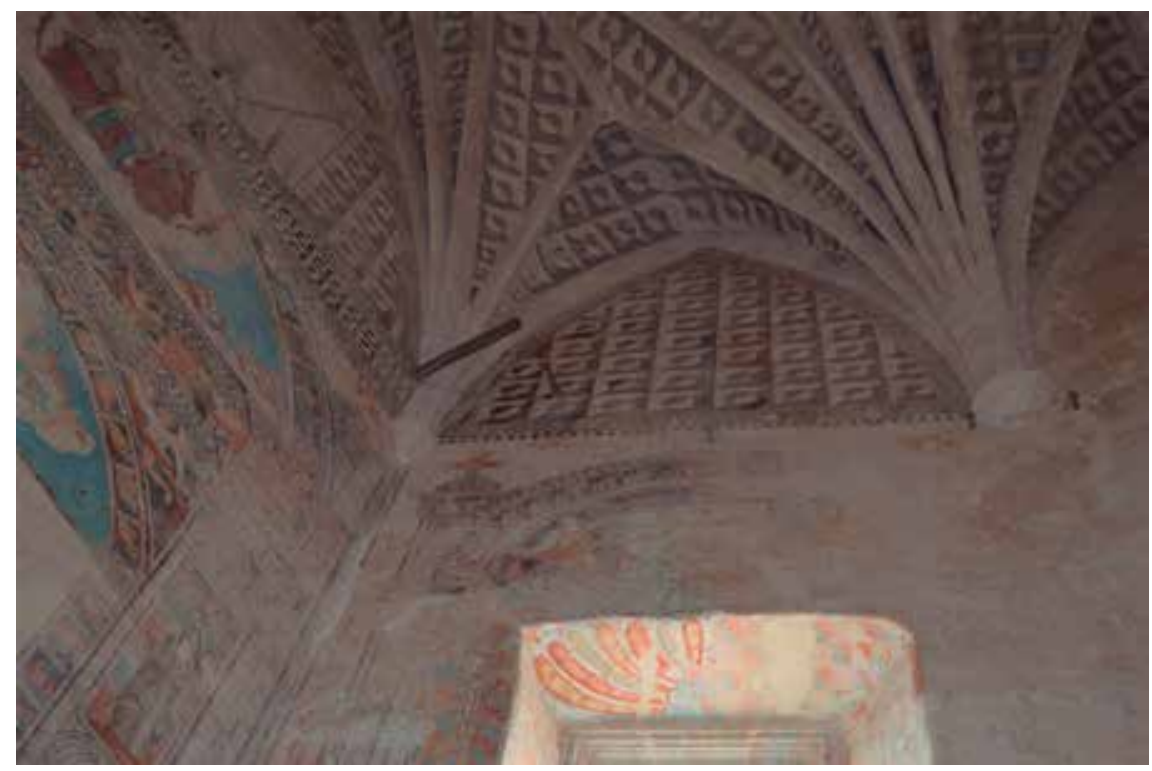

9. Decoración geométrica de los tímpanos y la bóveda de lacerías de la iglesia, muro 3, convento de Santa Clara de Asís, Dzidzantún, Yucatán. Foto: Ana Raquel Vanoye Carlo, julio, 2013. Secretaría de Cultura-INAH-Méx. "Reproducción autorizada por el Instituto Nacional de Antropología e Historia”.

extiende hasta el extremo superior de los muros del ábside, ${ }^{\mathrm{I}}{ }^{4}$ debido a esto, el límite superior de la composición anteriormente descrita es una decoración geométrica que se localiza en los tímpanos y también en la bóveda de lacerías. Se trata de una trama cuyo diseño emplea como unidad un círculo inscrito en un cuadrado (fig. 9), esta ornamentación en general se aplicó con mucha frecuencia para adornar diversas estructuras arquitectónicas como bóvedas, tímpanos y guardapolvos. ${ }^{\mathrm{IS}}$ En la península de Yucatán, el ex convento de

I4. "Son ilustrativos los pasajes de la Retórica cristiana, de fray Diego [de] Valadés, para explicar los grabados acerca de las jerarquías civil y eclesiástica, donde se emplean las imágenes arquitectónicas de origen bíblico: 'la piedra angular' (Cristo), 'las piedras vivas' y las ' piedras cuadradas' (los fieles) que conforman la Iglesia y que son mencionadas por Pedro y Pablo en sus epístolas; de manera que la simulación de sillería [..] para el recubrimiento de parámentos, parece responder a esta necesidad simbólica, ya que los padres de la Iglesia y los liturgistas emplearon frecuentemente dichos símbolos", Estrada de Gerlero, Muros, sargas y papeles, 69.

I5. El diseño de este mosaico es románico, comunicación personal, Elena Isabel Estrada de 
DOI: http://dx.doi.org/10.22201/iie.18703062e.2016.109.2623

MURAL DEL CONVENTO DE SANTA CLARA DE ASÍS

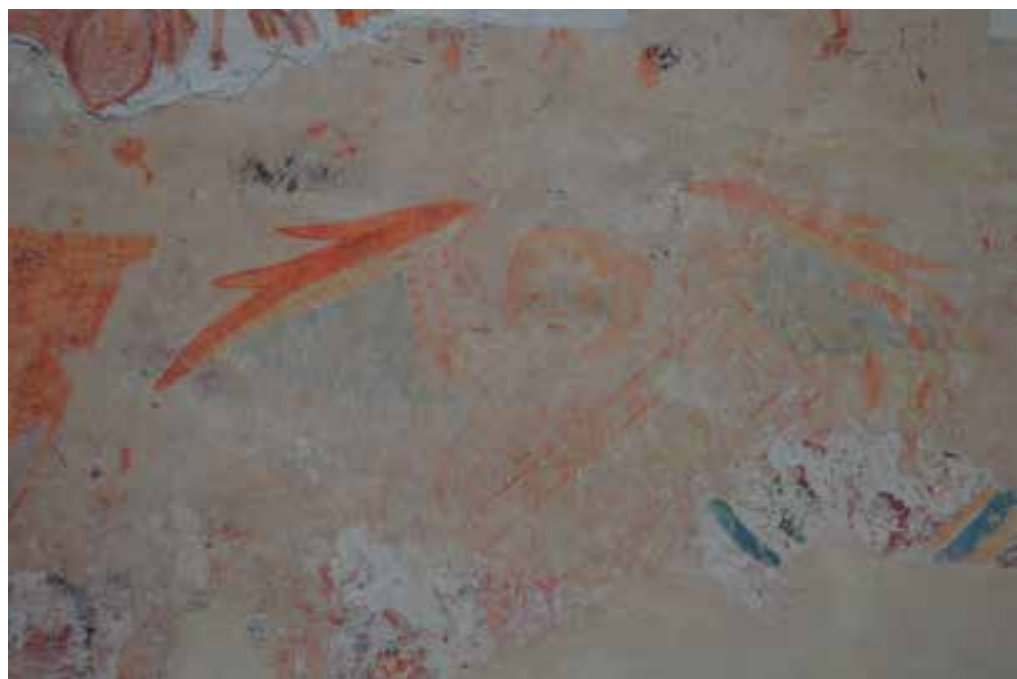

Io. Ángel, borde inferior de la composición del muro 2 del ábside de la iglesia, convento de Santa Clara de Asís, Dzidzantún, Yucatán. Foto: Ana Raquel Vanoye Carlo, julio, 20I3. Secretaría de Cultura-INAH-Méx. "Reproducción autorizada por el Instituto Nacional de Antropología e Historia”.

Maní (I549) también ofrece ejemplos de estructuras arquitectónicas decoradas con esta traza geométrica en la parte superior, como el intradós del arco que comunica la portería con la capilla abierta y la bóveda de cañón corrido que la techa. Una cenefa cierra, por la parte inferior, la composición descrita en los párrafos anteriores, su diseño incluye rostros de ángeles que probablemente sostienen en sus manos instrumentos musicales (fig. IO). Cabe destacar que éstos son los únicos ángeles que exhiben en las alas una franja amarilla que separa la zona superior roja de la inferior azul.

En general, estas pinturas murales presentan suficientes características que permiten afirmar que toda la composición anterior se ejecutó simultáneamente. Por ejemplo, los empates entre las escenas y las estructuras arquitectónicas que las enmarcan, y entre estos últimos y el sillar, la uniformidad y el color rosado de los enlucidos, el uso de una paleta de color similar y los detalles del extremo de las mangas de las ropas que incluyen un doblez. Sin embargo, las diferencias sugieren que no se trató del mismo pintor, probablemente había, al

Gerlero, IIE-UNAM, noviembre de $20 I I$. 
DOI: http://dx.doi.org/10.22201/iie.18703062e.2016.109.2623

240

ANA RAQUEL VANOYE CARLO

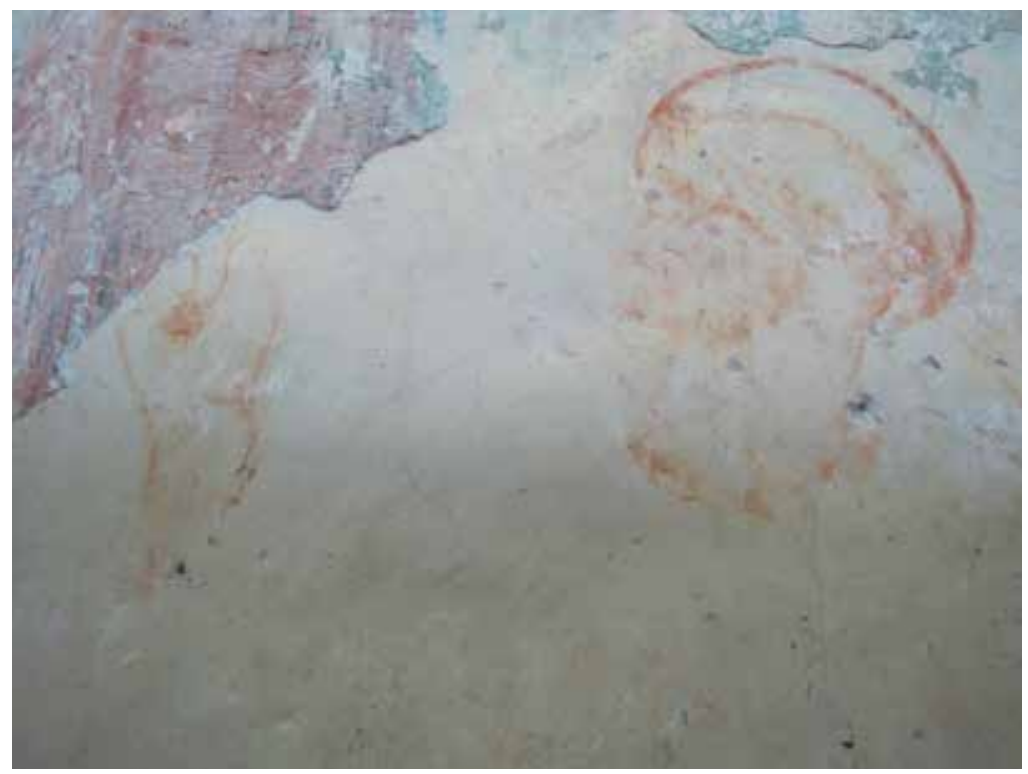

II. Detalle de la figura 8a, brazo izquierdo de san Francisco de Asís que muestra ausencia de pliegues, muro 2 del ábside de la iglesia, convento de Santa Clara de Asís, Dzidzantún, Yucatán, julio, 20I3. Foto: Ana Raquel Vanoye Carlo. Secretaría de Cultura-INAH-Méx. "Reproducción autorizada por el Instituto Nacional de Antropología e Historia”.

menos, dos pintores o equipos de pintores: uno se encargaba de las decoraciones de la superior y el otro de las de la inferior. Entre estas últimas es posible considerar las diversas paletas de color usadas en la ejecución de las alas de los ángeles y en la variedad de facciones plasmadas en los rostros de los personajes (figs. Io y II).

Al parecer, la ornamentación del ábside con retablos murales también fue muy común en la península de Yucatán, tal y como lo sugiere el que decora el ábside de la iglesia del ex convento de San Miguel Arcángel, en Maní (fig. I2). Esta estructura arquitectónica comparte algunas características con la anterior como la paleta de color y diseño, aunque este último es más simple, tal vez se deba a que el ábside sólo tiene tres muros a diferencia del de Dzidzantún que está formado por cinco. Otra característica común es que al retablo mural de Maní también lo corona una representación de los símbolos pasionarios. 
Al igual que en el caso de Dzidzantún, esta escena se encuentra en el tímpano del muro central, sin embargo, su composición es diferente: en Maní, los símbolos están dentro de una pila bautismal (compárese la parte superior de la fig. 3 con la de la fig. I2). Ésta es el elemento central de una cartela apergaminada a la que sostienen dos ángeles, y cuyo borde se dibujó con dos líneas curvas, negras y paralelas entre sí. En algunos fragmentos la línea interior es más gruesa que la exterior, esta característica probablemente representa una sombra que se aplicó para representar la perspectiva. Cada uno de los ángeles viste una falda larga y un blusón, las ropas del de la izquierda son negras y las del de la derecha, azules. En general, el ángel de la derecha está mejor proporcionado que el de la izquierda, ya que las piernas de este último son aproximadamente dos veces su torso y su cabeza. Justo debajo de la pila bautismal, están pintados en rojo, la cartela franciscana de las cinco llagas y a cada lado, el escudo de Castilla y de León. De estos últimos, todavía es posible apreciar los leones, los castillos con sus tres almenas y el cordero que pende del toisón. Al igual que la cartela de los símbolos pasionarios, las almenas y sus ventanas también tienen sombras: la de la izquierda las tiene a la derecha y viceversa. Esta composición es parecida a la que existe en el tímpano del arco de medio punto del muro 2 del ábside de la iglesia de Santa Clara de Asís (compárese la fig. 6 con la I2). Una de las similitudes es la ropa de los ángeles pues en ambos conjuntos éstos visten blusones y faldas largas y, tal vez, las diferencias residan en el contenido de las cartelas y en que el delineado de la representación de Dzidzantún se hizo en azul y rojo, mientras que en la de Maní se ejecutó en azul y negro. La presencia de esta escena en ambos conventos muestra que los temas y la forma de representarlos se difundieron e intercambiaron ampliamente entre ambos edificios religiosos y, quizá, entre todos los conventos de la región.

De hecho, la composición antes descrita se ejecutó con frecuencia en la pintura mural de todos los conventos fundados por los franciscanos en la Nueva España. Por ejemplo, en el claustro del convento de San Miguel Arcángel, en Huejotzingo, Puebla, es posible apreciar este tipo de representaciones, sin embargo, existen amplias diferencias en sus diseños. Para el caso de Puebla, el pintor prefirió emplear cartelas redondas en lugar de apergaminadas, además, la posición de los ángeles sugiere que vuelan mientras sostienen la cartela, en vez de estar de pie. Por último, también difiere la vestimenta, los ángeles del convento de Huejotzingo portan sólo una túnica en lugar del blusón y la falda que visten los tenantes de Maní y Dzidzantún. 
DOI: http://dx.doi.org/10.22201/iie.18703062e.2016.109.2623

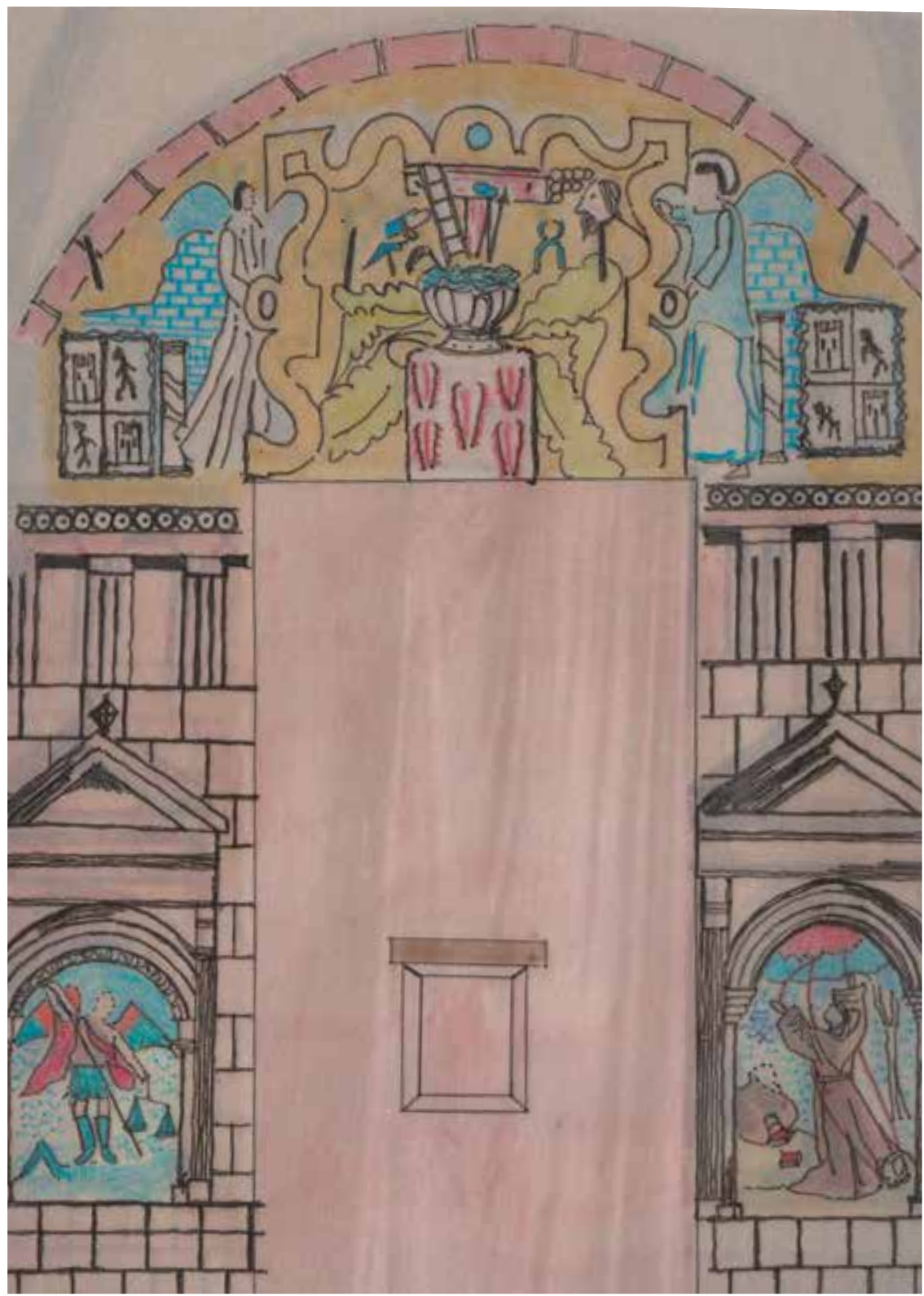

I2. Retablo mural, muro central del ábside de la iglesia, ex convento de San Miguel Arcángel, Maní, Yucatán. Dibujo: Ana Raquel Vanoye Carlo, 2005. 
Sin embargo, la pintura mural del ex convento de Maní presenta algunos elementos adicionales, como los escudos de Castilla y León y la cartela franciscana con los cinco estigmas, además, los símbolos pasionarios se encuentran dentro de la pila bautismal, todo lo anterior sugiere ahondar en el significado de esta representación. ${ }^{16} \mathrm{Al}$ respecto Estrada de Gerlero comenta que a finales del siglo $\mathrm{xv}$ "tuvieron gran difusión en Europa estampas plenas de indulgencias, con el tema de las armas de Cristo, dispuestas heráldicamente dentro de una panoplia como las Armas del Rey de Reyes"17 (fig. I3). Según la autora:

Exactamente el mismo tipo de panoplias fueron representadas en Nueva Espańa en varios conventos principalmente agustinos y en uno dominico, esculpidas en un programa en conjunción a monogramas del Santo Nombre de Jesús, en el claustro de Acolman; pintadas en un muro del aposento y en la parte alta de la [iglesia del convento] de Actopan, del lado de la epístola [...], también en Itzmiquilpan hay una [fig. 14$].^{18}$

Estrada de Gerlero señala que, en algunos de estos ejemplos, el escudo con las armas de Cristo está inscrito dentro de la panoplia y las diferentes insignias en la cresta del yelmo de torneo.

De todos los ejemplos consignados por la autora, la pintura mural de Maní guarda con la representación del convento de San Miguel Arcángel, en Ixmiquilpan, Hidalgo, una gran similitud: en ambos casos la escalera, la cruz, la lanza y la cańa con la esponja aparecen dentro de una pila bautismal y la corona de espinas apoyada en el borde; debajo de ella se encuentra la cartela franciscana con los cinco estigmas. De acuerdo con las afirmaciones de Estrada de Gerlero, la pila bautismal también debe estimarse como un yelmo invertido, bajo esta consideración es posible identificar las tiras lanceoladas ubicadas en la base de la pila como la cresta del yelmo.

Existen otras similitudes entre estas dos representaciones murales. En ambos casos, la disposición de los símbolos pasionarios que están fuera de la pila bautismal es la misma: a la derecha de ésta se colocaron la calavera, las pinzas, los dados, la linterna, las monedas y el rostro de Judas Iscariote, de hecho, algu-

I6. Para hacer posible la comparación véanse dos fotografías del convento de Maní en Vanoye, "Esbozo de la historia", I05 y 106.

17. Estrada de Gerlero, Muros, sargas y papeles, 187.

I8. Estrada de Gerlero, Muros, sargas y papeles, 187. 
DOI: http://dx.doi.org/10.22201/iie.18703062e.2016.109.2623

244

ANA RAQUEL VANOYE CARLO

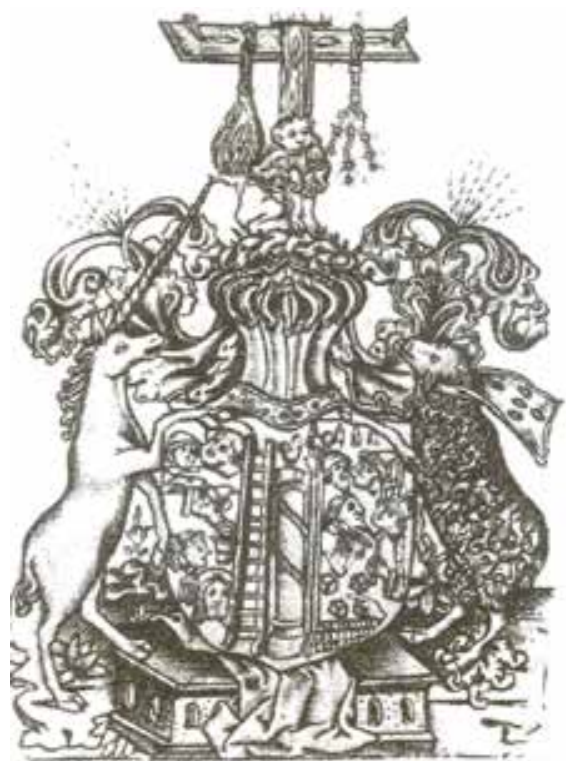

I3. Maestro de la Pasión de Berlín, Escudo de armas con instrumentos de la Pasión, grabado, $9.2 \times 6.7 \mathrm{~cm}$, tomado de Hollstein's German Engravings, Etchings and Woodcuts (I400-I700), ed. Tilman Falk, vol. 24A (Ámsterdam. A. L. van Gendt, 1986), I74.

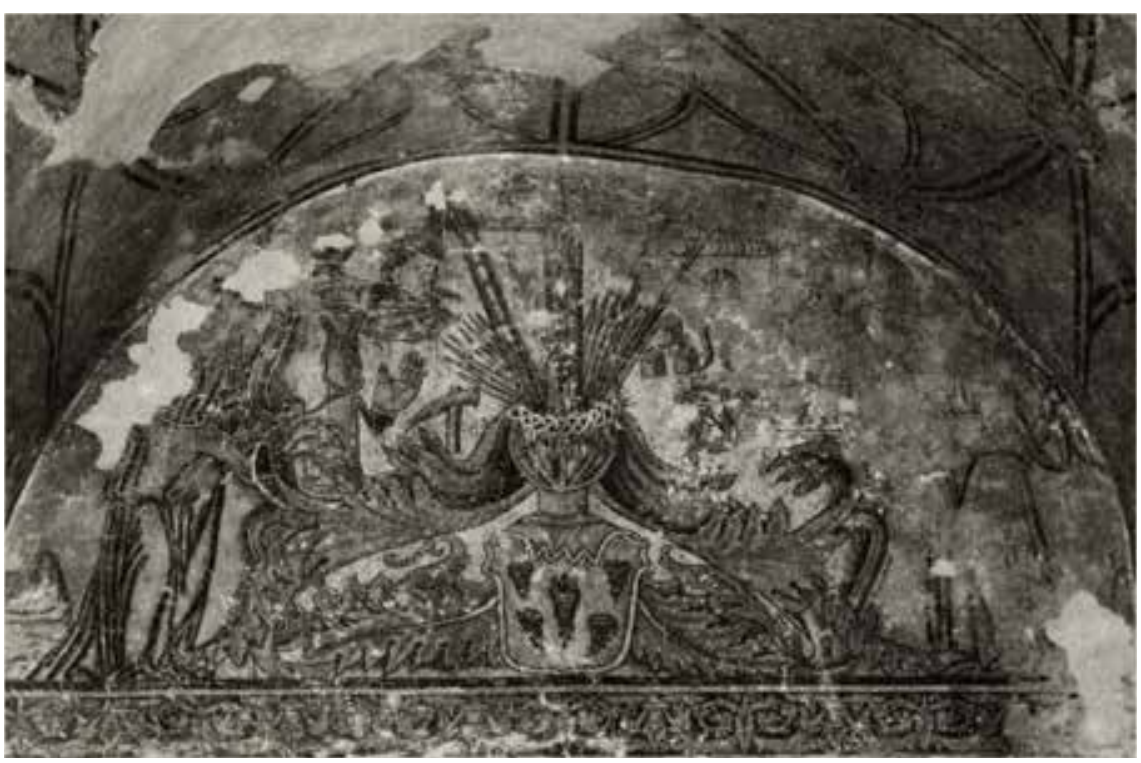

I4. "Panoplia en el paso de ronda, pintura, convento de Itzmiquilpan", así descrito por Elena Isabel Estrada de Gerlero en Muros, sargas y papeles. Imagen de lo sagrado y lo profundo en el arte novohispano del siglo XVI (México: Universidad Nacional Autónoma de México-Instituto de Investigaciones Estéticas, 20II), 192, de donde se tomó la imagen. 
nos de estoselementos también tienen el mismo diseño, por ejemplo, las monedas que, en ambos casos se han pintado en hilera y sobrepuestas. En el lado izquierdo se representaron: el gallo sobre la columna, la mano, el martillo y el rostro de san Pedro. La existencia de la misma iconografía en dos conventos tan distantes es prueba contundente de que todas las actividades relacionadas con la pintura mural estaban planeadas y se ponían en marcha de manera conjunta y organizada y demuestra que la información, así como las investigaciones que hasta el momento se han desarrollado para la pintura mural de los conventos que se localizan en el centro de México se puede utilizar para los que se localizan en el sureste mexicano.

Por último, es importante mencionar que los estudios sobre la pintura mural del ex convento de Maní son escasos. La mayoría de los textos sobre esta escena sostienen que, sin duda, un indígena debió ejecutarla debido a la "ingenuidad de sus rasgos". ${ }^{9}$ Actualmente hay un consenso que indica que la calidad de la representación no es suficiente para determinar cualquier rasgo del pintor, de hecho, para el caso de la pintura mural es conocido que la combinación de la escala y la cercanía necesarias para su ejecución son, en muchas ocasiones, las responsables de distorsiones, sobre todo en las proporciones, que sólo son visibles hasta el final del proceso. Para el caso del mural de Maní, hasta antes de la comparación con la pintura que alberga el convento de San Miguel Arcángel, en Ixmiquilpan, lo único que era posible afirmar era que su autor aún necesitaba entrenamiento.

Sin embargo, el mural de este último convento puede proporcionar información adicional: del lado izquierdo se aprecian las representaciones de dos elementos relacionados con la narrativa de la Pasión: el rostro de san Pedro y la mano. El primero hace alusión al pasaje del Nuevo Testamento en el que Pedro niega conocer a Jesús y el segundo rememora las bofetadas que Jesús recibió como parte de su martirio. Para el caso de Maní, ambos elementos se fusionaron en uno: la mano emerge del cuello de san Pedro; este rasgo pone de manifiesto que el autor del mural tampoco dominaba del todo el relato de la Pasión, por lo cual, muy probablemente se trata de un pintor maya. Antonio de Ciudad Real señaló que el convento de Maní se construyó en sólo seis meses, incluyendo la

19. "La pintura mural localizada en el tímpano representa los símbolos de la pasión, probablemente fue realizada por artistas indígenas dado lo ingenuo o primitivo del dibujo", en Rolando Araujo, "Mural del presbiterio y retablo principal. Criterios de intervención, ex convento de Maní, Yucatán, Maní", Archivo de la CNCPC-INAH, G/3I-047-000/OIN/I, 2002, 3. 
DOI: http://dx.doi.org/10.22201/iie.18703062e.2016.109.2623

246

ANA RAQUEL VANOYE CARLO

iglesia, por tanto, tal vez este mural se pintó a principios de $1590,{ }^{20}$ y constituye un testimonio del contraste entre la rapidez con la que los mayas aprendieron las nuevas técnicas de ejecución y la serie de problemas que los franciscanos tuvieron que vencer para lograr que los indígenas asimilaran los contenidos de la religión católica y las nuevas formas de representación.

En Maní, como señalado, también hay un retablo mural (fig. I2). Al igual que en el caso de Santa Clara de Asís, se usó una cenefa para separar la escena de los símbolos pasionarios y el retablo mural que tiene un diseño de ovas y dardos. El mismo diseño también se empleó en la franja que separa la pintura del luneto y del muro de la capilla abierta. Esta similitud en la composición no es suficiente para afirmar que las pinturas son contemporáneas, pero lo es para sugerir que una de las actividades relacionadas con la ejecución de la pintura mural era la división de los muros con la finalidad de organizar y distribuir la pintura, y las cenefas eran los elementos asociados a esta actividad. En particular, el empleo de la misma cenefa en la pintura de diferentes recintos indica la intención de los franciscanos de unificar visualmente las decoraciones del convento para que proyectaran unidad visual, es decir, no sólo los temas de la pintura mural anterior se tomaban en cuenta para realizar los nuevos murales, sino que ciertas características como la paleta de color, la composición y los ornamentos también se consideraban en los nuevos diseños.

Como en el de Dzidzantún, la composición del retablo mural de Maní es el resultado de un conjunto de elementos arquitectónicos monumentales que delimitan escenas religiosas. El más visible es un sillar que decora los tres muros del ábside y que está coronado por un friso rematado con metopas y triglifos. En la parte inferior tiene dos nichos: en el de la izquierda se representó a san Miguel Arcángel (fig. I5) y en el de la derecha a san Francisco de Asís recibiendo los estigmas (fig. I6). La composición anterior enmarca un rectángulo central, rosado, que alberga un nicho en la parte inferior central (compárese la fig. 3 con la I2), por lo cual, este retablo mural, al igual que el localizado en el ábside de Santa Clara, funcionaba como el marco de un elemento que se colocaba sobre el rectángulo rosado y que probablemente se trataba de un lienzo, un cuadro o un pequeño retablo.

Las escenas de san Francisco y san Miguel Arcángel están entre una doble estructura arquitectónica: la exterior está formada por un frontón triangular

20. Véase Luis Vega Bolaños, coord., Catálogo de construcciones religiosas del estado de Yucatán, vol. II (México: Talleres Gráficos de la Nación, 1945), 96. 


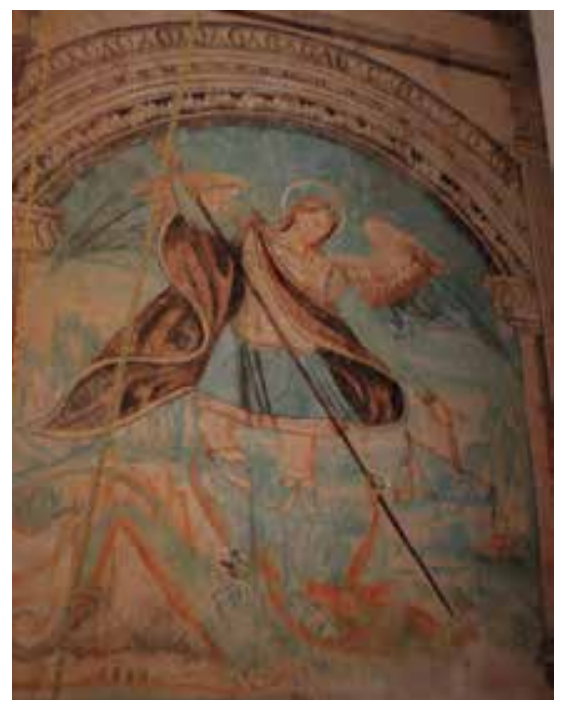

I5. San Miguel Arcángel, muro central del ábside de la iglesia, convento de San Miguel Arcángel, Maní, Yucatán. Foto: Ana Raquel Vanoye Carlo, agosto, 2005. Secretaría de Cultura-INAH-Méx. "Reproducción autorizada por el Instituto Nacional de Antropología e Historia”.

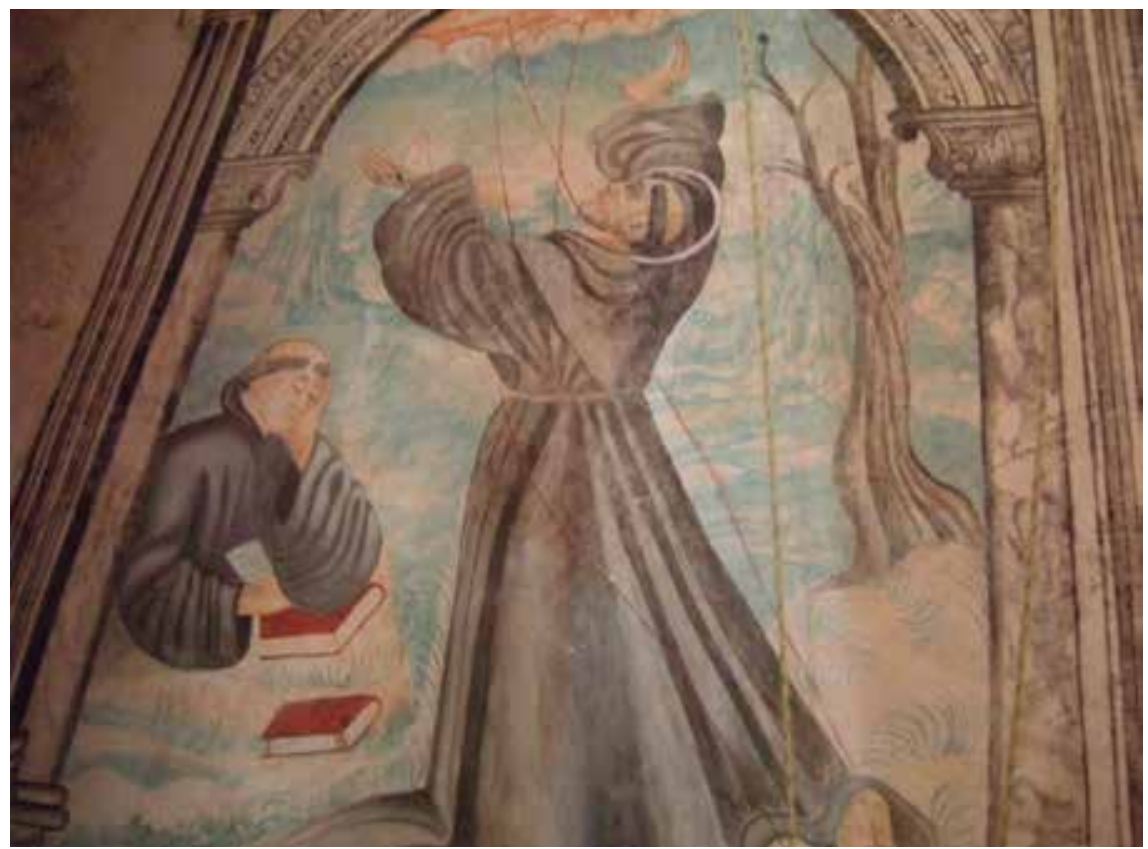

16. San Francisco de Asís recibiendo los estigmas, muro central del ábside de la iglesia, convento de San Miguel Arcángel, Maní, Yucatán. Foto: Ana Raquel Vanoye Carlo, agosto, 2005. Secretaría de Cultura-INAH-Méx. "Reproducción autorizada por el Instituto Nacional de Antropología e Historia”. 
DOI: http://dx.doi.org/10.22201/iie.18703062e.2016.109.2623

248

ANA RAQUEL VANOYE CARLO

apoyado sobre un par de columnas, y la interior es un arco de medio punto que también descansa sobre un par de soportes.

$\mathrm{Al}$ parecer esta pintura se ejecutó sobre un enlucido grueso, rosado y bruñido, o al menos, éstas son las características apreciadas en el rectángulo central y en la bóveda de lacerías que techa el presbiterio, sin embargo, la intensiva reintegración pictórica que las representaciones de san Miguel Arcángel y san Francisco de Asís recibieron junto con la pintura blanca utilizada para rehacer el sillar dificultan la apreciación de otras características que pudieran compartir con las de Dzidzantún. El color empleado en el dibujo preliminar, al cual durante la restauración se le añadió un delineado negro, como en el diseño de los fondos de las escenas, son ejemplo de ello, ya que para el caso de Maní, la parte superior de éstos, la que corresponde al cielo, se reintegró usando unas líneas azules, delgadas y onduladas que no se sabe si corresponden al diseño original. A pesar de estas dificultades, es posible afirmar que las pinturas del muro 2 del ábside de la iglesia del convento de Santa Clara de Asís, en Dzidzantún, fueron el modelo de la composición absidal que decora el presbiterio de la iglesia de Maní.

Posiblemente, en el tímpano del muro central del ábside de la iglesia de Maní se pintó la escena de los ángeles que sostienen una cartela ubicada en el tímpano del arco y en el muro 2, una representación de san Francisco de Asís recibiendo los estigmas (véanse las figs. 6 y 8 a y compárense con la I2 [tímpano] y la I6), que también es el tema planteado entre las columnas que sostienen el arco. No fue difícil decidir quién debía ocupar el otro nicho si recordamos que la advocación del convento de Maní es san Miguel Arcángel.

La posible existencia de una relación entre las composiciones murales de ambos ábsides vuelve a sugerir un intercambio dinámico de temas y modelos de representación en el cual necesariamente estaban involucrados al menos todos los conventos que se encuentran a lo largo del camino y que une estos dos edificios religiosos. La extensión de los conjuntos de murales en grisalla, azul y rojo de ambos conventos indica que esta técnica de ejecución tuvo mucha aceptación. La similitud en los temas, las composiciones y la paleta de color es de utilidad para reconstruir el aspecto que debieron exhibir incluso los edificios religiosos que ya no existen, en particular el convento Grande de San Francisco, de Mérida. 
DOI: http://dx.doi.org/10.22201/iie.18703062e.2016.109.2623

MURAL DEL CONVENTO DE SANTA CLARA DE ASÍS

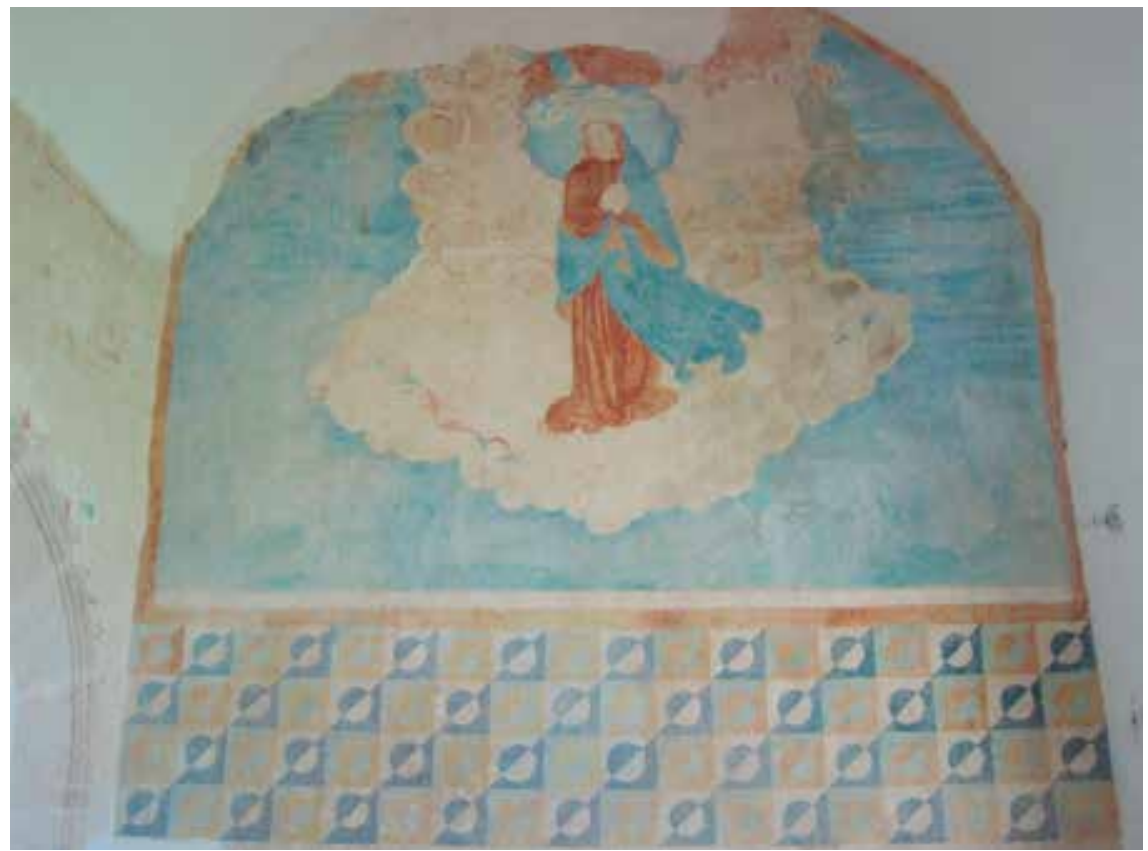

I7. Inmaculada Concepción, muro sur de la portería, convento de Santa Clara de Asís,

Dzidzantún, Yucatán. Foto: Ana Raquel Vanoye Carlo, julio, 20I2. Secretaría de Cultura-InAHMéx. "Reproducción autorizada por el Instituto Nacional de Antropología e Historia".

\section{La segunda decoración del ábside (I625-I700)}

La pintura correspondiente a esta etapa se localiza en el ábside (fig. 28, anexo), en la portería (fig. 17) y en el vano de la puerta que comunica el claustro con la iglesia. A pesar de presentarse en un número mayor de recintos que el caso anterior, cuenta con menos murales. Su característica más destacada es la cantidad del punzón en el trazo de algunos elementos geométricos, como los círculos, y arquitectónicos, como las columnas. Hay una disminución drástica en el uso de elementos arquitectónicos, de hecho, sólo se incluyeron en las pinturas del vano de la puerta claustral de la iglesia, sin embargo, su diseño es más complejo que los correspondientes a la etapa anterior (figs. I8 y 19). Además, las pinturas se ejecutaron, en su totalidad, en azul, rojo, blanco y sepia. La manera de aplicar los dos primeros colores es similar a la empleada en la decoración anterior: de forma alterna; una de las principales diferencias respecto 
DOI: http://dx.doi.org/10.22201/iie.18703062e.2016.109.2623

250

ANA RAQUEL VANOYE CARLO

a esa primera decoración es que el uso de esta paleta cromática incluye los elementos arquitectónicos y geométricos.

En el ábside, las pinturas que corresponden a esta decoración se encuentran en los muros 4 y 5 . En el 2 y 3 sólo hay rastros que sugieren su presencia. El central no conserva ningún indicio. En el paramento 4 se aprecia el lado derecho del marco de un caballete, el izquierdo quedó bajo el muro que se construyó para apuntalar la bóveda. El marco tiene cinco franjas. La central es blanca, es la más gruesa y el cordón franciscano la recorre longitudinalmente, y tiene, a cada lado, otras dos más delgadas: las exteriores son rojas y las que están en contacto con ella son azules. Sobre este marco y en el extremo derecho descansa un ornamento sepia que no es posible describir debido al deterioro que presenta.

En el muro 5 se aprecia la parte izquierda de una estructura similar a la descrita en el párrafo anterior. Aunque la escena central e incluso parte del marco de este caballete también se han perdido, sobreviven algunos detalles que proporcionan una idea de cómo debieron haber lucido ambos lienzos: en las esquinas superior e inferior izquierdas se dibujaron rostros de ángeles, flores y copones en colores sepia, azul y rojo. Al parecer, estos elementos funcionaban como una delimitación interna de la escena central. A diferencia del caso anterior, es posible apreciar que el extremo superior izquierdo está decorado con dos cintas sepia entrelazadas (fig. 20).

Debajo de estos caballetes hay rastros de la trama geométrica, la cual consta de círculos inscritos en cuadrados, que en la primera etapa se ejecutó en grisalla, en los tímpanos del ábside y en la bóveda de lacerías; sin embargo, hay tres diferencias importantes: se aplicó en el guardapolvo, está hecha en azul y rojo y se usó un punzón para trazar los círculos. También hay marcas de círculos hechos con este instrumento en los muros 2 y 3 del ábside: se encuentran sobre los rostros de los ángeles que cierran, en la parte inferior, la composición del muro testero que pertenece a la etapa previa, pero no hay rastros del uso de este instrumento sobre los arcos de medio punto, lo cual indica que, probablemente, éstos fueron rescatados e integrados a la segunda decoración. De hecho, el borde superior de la decoración geométrica de los muros 2 y 3 coincide con el borde inferior del retablo del muro I, perteneciente asimismo a la etapa anterior, lo cual indica que quizá este último elemento también lo rescataron e integraron en esta segunda decoración absidal. Este rasgo, la tendencia a no romper drásticamente con el programa pictórico anterior, es otra de las características de este periodo. 
El patrón geométrico, con los rasgos antes mencionados, también se aplicó en el guardapolvo del muro sur de la portería del convento. Arriba, en el luneto, hay una representación de la Inmaculada Concepción (fig. 17). El empate que existe entre la escena y los motivos geométricos sugiere que toda la pintura de este paramento se ejecutó simultáneamente.

La Virgen aparece coronada, vestida con una túnica roja y un manto azul por el anverso y rojo-naranja por el reverso, a sus lados, todavía son visibles, delineados en sepia, el sol, la luna, la torre de David, el espejo sin mancha y debajo de ella un grupo de ángeles dispuestos en forma de luna creciente. Está rodeada de nubes que en la parte superior ofrecen un rompimiento que permite la entrada de un elemento sin identificar y que apareció después de la intervención de 20II. La escena está enmarcada con una línea roja, de unos 5 centímetros de ancho, que sigue la forma del luneto que la alberga.

Las diferencias existentes en las representaciones humanas, que corresponden a la etapa anterior y ésta, refuerzan la idea de que su ejecución se efectuó en momentos distintos. Entre éstas puedo mencionar el tratamiento en la caída de las vestimentas. Para el caso de la primera etapa, los pliegues de las telas se concentran en la parte inferior de las túnicas, mientras que en la segunda, éstos también están presentes en la parte superior de las ropas, incluso se dibujaron los que corresponden a las posiciones flexionadas de los diferentes miembros del cuerpo. Por ejemplo, en la Inmaculada de la portería se aprecian los pliegues de la ropa correspondientes a la postura de sus brazos, a diferencia de los ángeles que sostienen la cartela del muro 2 del presbiterio para los cuales, a pesar de tener los brazos doblados, no se consideró su representación (compárense las figs. 6 y 17). El movimiento de la ropa constituye otra diferencia. En el caso de la Inmaculada, el rompimiento del cielo implica un desplazamiento brusco de las nubes que se refleja en la inclinación y en las orlas de los extremos del manto y la túnica. Al igual que esta escena de la Inmaculada, que corresponde a la de san Francisco de Asís recibiendo los estigmas (muro 2 del ábside, etapa anterior) (fig. 8a), también se representó un rompimiento de nubes, del que probablemente emanaba el serafín quien, según el relato, es el responsable de estigmatizar al fraile; sin embargo, el pintor o pintores de la escena no han podido transmitir los efectos correspondientes de este suceso en la ropa del santo, pues el manto del fraile no presenta inclinaciones, orladuras o pliegues (compárense las figs. II y i7).

El uso de algunos elementos que también aparecen en la etapa anterior, como el círculo inscrito en el cuadrado, la paleta cromática y la forma de emplear los 
DOI: http://dx.doi.org/10.22201/iie.18703062e.2016.109.2623

252

ANA RAQUEL VANOYE CARLO

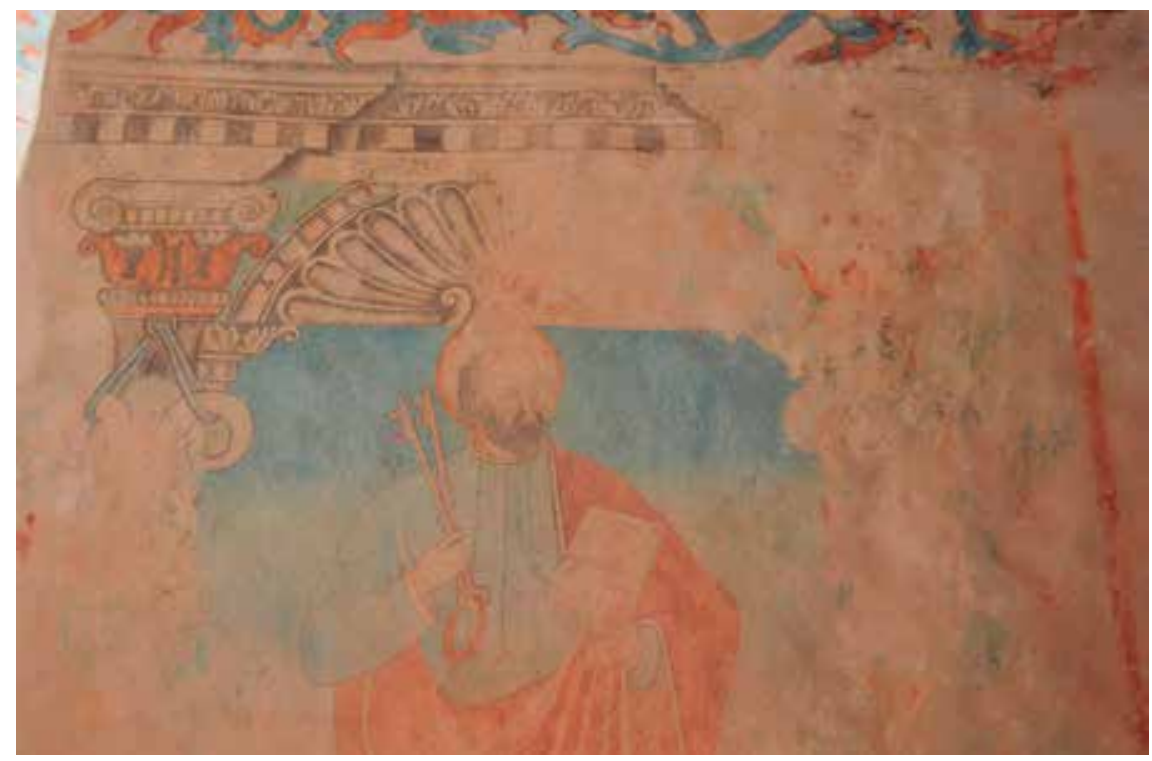

I8. San Pedro, jamba oeste del vano de la puerta que comunica el claustro con la iglesia, convento de Santa Clara de Asís, Dzidzantún, Yucatán. Foto: Ana Raquel Vanoye Carlo, julio, 20I3. Secretaría de Cultura-INAH-Méx. "Reproducción autorizada por el Instituto Nacional de Antropología e Historia”.

colores, refuerzan la idea de que la segunda decoración recuperó algunas características de la primera. Esto vuelve a sugerir que dicha solución ornamental tuvo una amplia aceptación, lo cual motivó el uso continuo y prolongado de algunos de sus recursos. Aunque, otra posibilidad es que los frailes no hubieran podido o querido llevar a cabo la renovación de la pintura mural de todo el convento, por lo cual las nuevas representaciones debían considerar a las anteriores con la finalidad de evitar romper la unidad visual y temática.

Alguna de estas posibilidades determinaron las características que presenta la serie de murales que decoran la puerta claustral de la iglesia; antes de abordarlas, describiré brevemente las escenas que aquí se localizan: en la jamba oeste del vano se pintó un nicho formado por un dintel apoyado sobre un par de columnas balaustradas. Debajo del dintel se aprecia una hornacina avenerada que también descansa sobre las columnas balaustradas. Es san Pedro quien ocupa este nicho: su túnica es azul, su manto rojo y el fondo azul (fig. I8). En la jamba este hay otro nicho que tiene un diseño arquitectónico similar, pero está 


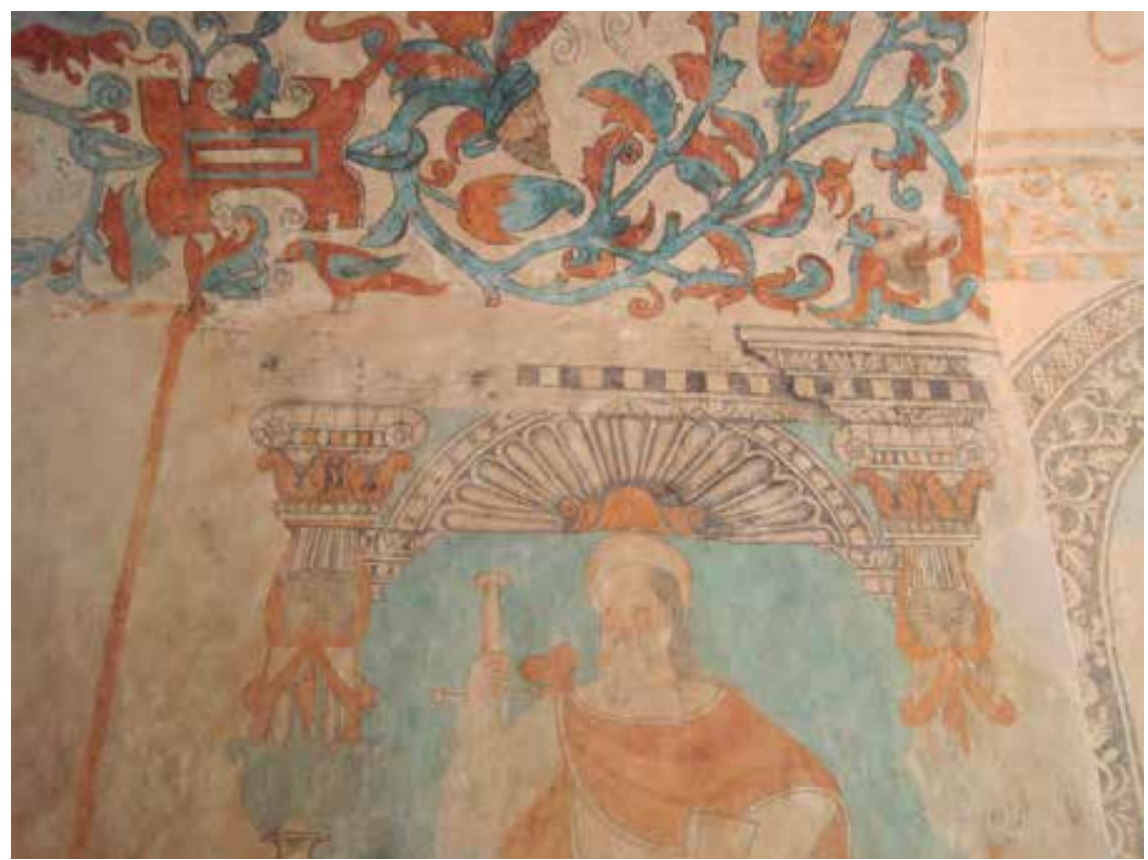

I9. San Pablo, jamba este del vano de la puerta que comunica el claustro con la iglesia, convento de Santa Clara de Asís, Dzidzantún, Yucatán. Foto: Ana Raquel Vanoye Carlo, julio, 20I3. Secretaría de Cultura-INAH-Méx. "Reproducción autorizada por el Instituto Nacional de Antropología e Historia”.

ocupado por san Pablo, quien viste con una túnica blanca y un manto rojo, al igual que en el caso anterior, el fondo de la escena es celeste (fig. 19).

Aunque este par de pinturas comparte algunos rasgos con las que pertenecen a la primera decoración absidal, como la paleta de color, la forma de aplicarla, las composiciones arquitectónicas que enmarcan las escenas y algunos de sus elementos ornamentales también presenta semejanzas con los murales de la portería. Por ejemplo, el uso del punzón para realizar los trazos guía de las columnas: la línea vertical que funciona como eje y la serie de líneas paralelas y transversales a la anterior, que delimitan cada uno de los elementos que componen el fuste balaustrado de las columnas. Otra similitud es la línea roja que rodea ambas escenas, parecida a la que enmarca la escena de la Virgen de la portería (compárense las figs. 17 y 19). Por último, el ángulo izquierdo superior 
de la escena de san Pedro muestra un adorno al que decora, en los extremos superiores de los marcos de los caballetes localizados en los muros 4 y 5 del ábside de la iglesia: un par de listones entrelazados color sepia; al parecer, en este caso, el ornamento pende del extremo exterior de los capiteles. La presencia tanto de características que corresponden a la primera etapa, como de rasgos propios de la segunda indica su pertenencia al último conjunto.

En su conjunto la pintura mural de la etapa posterior indica que los nichos del vano de la puerta que comunica el claustro con la iglesia son las únicas composiciones arquitectónicas que aparecen en este segundo programa mural. Esto sugiere un cambio en la preferencia para presentar las escenas, al parecer, en esta etapa prevaleció la tendencia a utilizar marcos rectangulares, tal y como lo indican la línea roja que enmarca las escenas de san Pedro y san Pablo y los caballetes de los muros 4 y 5 del ábside.

\section{La tercera decoración del ábside (siglo XVIII) ${ }^{2 I}$}

El muro central de esta estructura es el único que no conserva pinturas correspondientes a la tercera decoración. ${ }^{22} \mathrm{~A}$ pesar de la ausencia de un elemento central en torno al cual organizar el tercer programa absidal, éste presenta simetría entre las composiciones de los muros 2 y 3 así como 4 y 5 (fig. 29). Tiene también algunas otras características, sobre todo materiales, que lo diferencian de las etapas anteriores, para ejecutarlo no se aplicaron nuevos enca-

2I. Los murales de esta etapa se trabajaron en el apartado "La pintura mural a colores" del capítulo titulado "El análisis de la pintura mural", en Vanoye Carlo, "Esbozo de la historia de la pintura mural virreinal de Yucatán," I2I-I34.

22. Durante la intervención de 20II, Garcés Fierros encontró restos de murciélagos y aves sobre el banco que se encuentra en la parte inferior de este muro y en las fisuras de las nervaduras. Lo anterior indica que esta pared sostuvo un retablo, porque esta fauna acostumbra vivir detrás de ellos. Con seguridad, tanto el guano como el excremento de paloma dańaron los encalados exteriores. Cuando el retablo se retiró del muro el daño fue evidente. Según el restaurador, el muro debía limpiarse pues constituía un foco de infecciones. Él pensaba que quienes habían retirado el retablo también habían tenido que desprender los encalados superficiales para eliminar los restos de esas sustancias y evitar que el deterioro continuara a los encalados interiores. Comunicación personal, Fernando Garcés Fierros, agosto de 20II. Lo anterior responde a la interrogante del porqué se observa en los muros 2, 3, 4 y 5 del ábside pintura correspondiente a diferentes periodos, mientras que en el muro I la pintura que sobrevive al parecer corresponde a la misma etapa. Comunicación personal, Fernando Garcés Fierros, junio de 2011. 
DOI: http://dx.doi.org/10.22201/iie.18703062e.2016.109.2623

MURAL DEL CONVENTO DE SANTA CLARA DE ASÍS

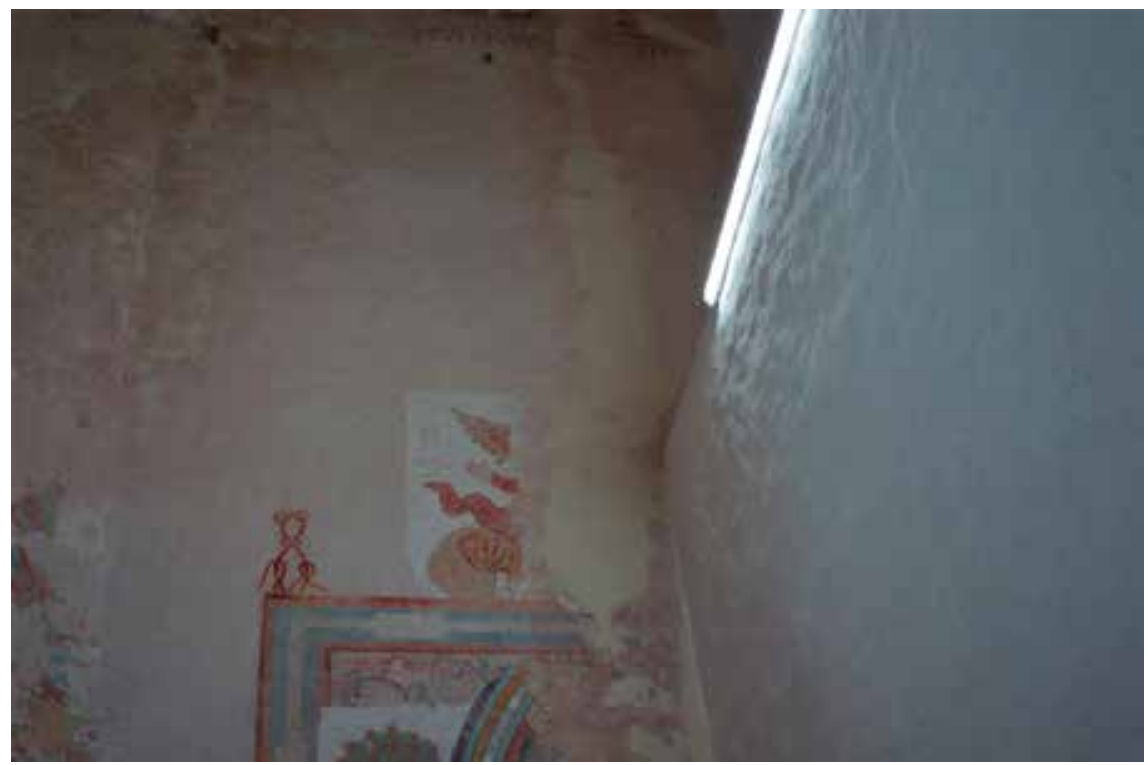

20. Esquina superior izquierda del caballete del muro 5. Foto: Ana Raquel Vanoye Carlo, julio, 20I2. Secretaría de Cultura-INAH-Méx. "Reproducción autorizada por el Instituto Nacional de Antropología e Historia”.

lados sobre los muros, sólo lechadas de cal y aunque proporcionan un soporte para recibir la nueva pintura, éstas no son tan durables como un encalado, a esto se debe que las pinturas se desprendan en pequeñas lajas en lugar de deslavarse como es el caso de la que corresponde a las etapas anteriores. Por otro lado, las lechadas no cubrieron por completo la decoración mural previa, lo cual permitió que ésta sirviera como una plantilla. ${ }^{23}$ Otra de sus características es el uso de una paleta de color más amplia, pues el pintor utilizó, además de negro, azul, rojo, y blanco, verde, amarillo, rosa, café y anaranjado. Asimismo, la línea con la cual se ejecutó el dibujo preliminar de la mayor parte de estas representaciones es negra, al igual que la empleada para los delineados finales.

23. El deterioro de los murales fue útil para mostrar que las columnas de los retablos de los muros 2 y 3, correspondientes a esta tercera decoración, se hicieron tomando como molde las arquivoltas que adornan las columnas, las cuales sostienen los arcos de medio punto pertenecientes a la primera etapa. Esto, aunado a que la decoración geométrica de círculos inscritos en cuadrados en rojo y azul no invade los arcos de medio punto, vuelve a sugerir que estos arcos se rescataron e incluyeron en el segundo programa pictórico absidal. 
DOI: http://dx.doi.org/10.22201/iie.18703062e.2016.109.2623

256

ANA RAQUEL VANOYE CARLO

La ampliación de la paleta de color permitió consolidar uno de los rasgos particulares de la pintura mural para esta región: la imitación de diferentes materiales de construcción y objetos. El desarrollo de este aspecto comenzó desde las etapas anteriores y se traduce para la primera decoración absidal en la imitación de elementos arquitectónicos monumentales en piedra, por eso toda la arquitectura está ejecutada en grisalla, y para la segunda, en la representación de las pinturas de caballete. Eventualmente, se imitaron una gran gama de materiales y objetos en pintura. Entre los materiales más representados se encuentra el mármol veteado aplicado sobre los elementos arquitectónicos a manera de franjas paralelas inclinadas en colores rosa, café y amarillo.

En general, los conventos franciscanos de la península de Yucatán ofrecen diversos ejemplos de objetos artísticos representados en pintura mural, entre los que destaca la serie de pinturas de caballete que adornan la sacristía del convento de San Pedro y San Pablo en Teabo, para las cuales incluso se pintó el clavo y la cuerda del que penden; por ejemplo, la pintura de caballete de santa Bárbara, que se encuentra en la portada de la iglesia de San Antonio de Padua en Izamal y que, muy probablemente, en su representación inicial fue una escultura, al igual que la Virgen del convento de San Francisco de Asís, en Conkal, ya que en ambas es posible observar, en la parte inferior, la peana sobre la cual se apoyaba el cuerpo de las santas, y los cuatro retablos que ornamentan el antiguo presbiterio de la iglesia del convento de Santa Clara que presentaré en este apartado.

Antes de abordarlos, mencionaré que el tamaño y la disposición de estos ejemplos respecto al recinto que los alberga indican algunos cambios en la relación entre la pintura mural y la arquitectura. En esta etapa, a diferencia de las dos anteriores, ambas juegan un papel más equilibrado: no hay una preeminencia de la pintura sobre la arquitectura. Los retablos, y en general todas las representaciones pictóricas, son mucho más pequeños, lo cual indica que la pintura mural no sustituye a la arquitectura ni se encarga de la reconstrucción del aspecto de los espacios interiores, sino que se coordina con ella para lograr su configuración.

Como ya lo mencioné, el muro central del ábside es un eje de simetría porque la composición en los dos muros de la derecha es igual a la de los dos de la izquierda. En los muros 2 y 3 se ejecutó un retablo que tiene composición y diseño similares, pero diferente temática; en ambos casos la estructura arquitectónica se localiza alrededor de la ventana que hay en ambos paramen- 
DOI: http://dx.doi.org/10.22201/iie.18703062e.2016.109.2623

MURAL DEL CONVENTO DE SANTA CLARA DE ASÍS

2I. Retablo mural, muro 3, ábside de la iglesia, convento de Santa Clara de Asís,

Dzidzantún, Yucatán.

Foto: Ana Raquel Vanoye Carlo, julio, 20I3. Secretaría

de Cultura-INAH-Méx.

"Reproducción autorizada por el Instituto Nacional de

Antropología e Historia”.

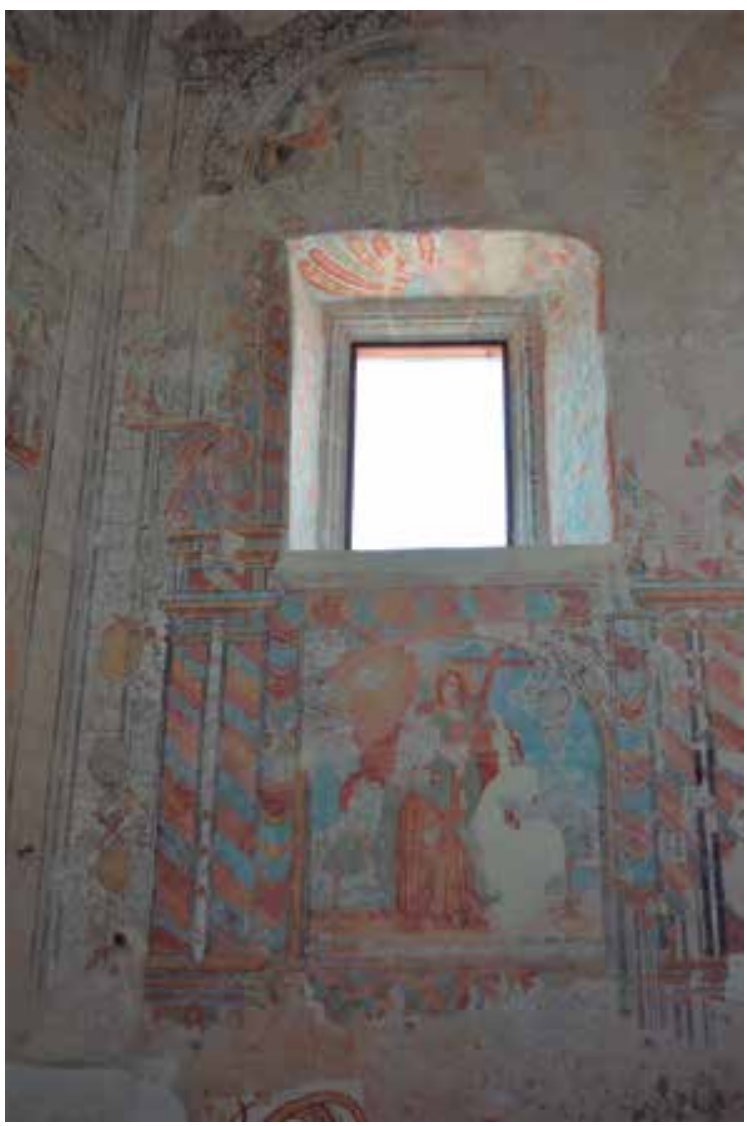

tos. El retablo del muro 3 (fig. 2I) está mejor conservado y, por eso, es conveniente comenzar la presentación de esta etapa con su descripción.

El elemento central de este retablo es una escena enmarcada por cuatro columnas veteadas, dos a cada lado; aunque la basa y el capitel guardan relación con el orden corintio, este último presenta algunas modificaciones: se han omitido los caulículos y algunas hileras de hojas de acanto y en su lugar se pintaron flores azules con centro café. Sobre cada par de columnas descansa un ábaco moldurado que también está decorado con franjas, imitando el mármol, además, tiene una característica muy peculiar: la perspectiva, lo cual, junto con el banco de cal y canto adosado al muro I, sugiere la presencia de un retablo de madera, del cual la pintura mural copió algunas de sus características. 
DOI: http://dx.doi.org/10.22201/iie.18703062e.2016.109.2623

258

ANA RAQUEL VANOYE CARLO

En la escena central se representó un arco apoyado sobre un par de soportes que en el interior alberga un personaje sin identificar. Al parecer no era prioridad del autor de esta pintura mostrar el arco, sino lo que contenía, debido a eso, los soportes laterales no son visibles: únicamente la moldura interior en amarillo. El diseño de este elemento permite apreciar parte del muro que se extiende sobre el arco y al cual también se le aplicó un tratamiento para imitar el mármol veteado. A la derecha del soporte izquierdo, y viceversa, se aprecia un rectángulo paralelo, negro y que se desvanece conforme se acerca a la clave del arco: es la representación del ancho de los soportes y del intradós del arco; su presencia indica que el autor trató de imprimir profundidad a la escena que contiene un personaje sin identificar vestido con una túnica amarilla y un manto verde y que porta en la mano izquierda una cruz de tamańo natural de la cual penden, en la parte central, unas llaves, en la derecha sostiene un libro. Detrás del personaje hay un paisaje, o al menos eso sugiere el color azul del fondo que tal vez representa el cielo y los árboles colocados a cada lado del personaje. La escena se delimitó como si se tratara de una pintura de caballete: usando un marco lobulado azul, ocre y sepia. Las características de esta representación muestran que, aunque los enmarcamientos arquitectónicos siguen formando parte de las composiciones murales, su diseño ha prescindido de los ornamentos e incluido el uso de paisajes.

El ángulo superior derecho de esta pintura muestra otro rasgo característico de esta etapa: presenta algunos faltantes que dejan al descubierto un fragmento de la pintura mural que está debajo, correspondiente a la primera decoración: el lado derecho de la venera, de gran tamaño, en grisalla descrita en el apartado correspondiente a la primera decoración del ábside. Este faltante pone en evidencia que el borde superior de la venera se utilizó como guía para trazar la moldura amarilla inferior del arco, éste es un indicio que señala que estos murales consideraron a las pinturas murales correspondientes a las etapas anteriores como guías de trazo. Más adelante señalaré otros ejemplos que refuerzan la afirmación anterior.

Hasta antes de 20II, lo anterior era todo lo que podíamos observar de este retablo, después de los procesos de intervención llevados a cabo por Garcés Fierros emergió la parte superior izquierda que corre paralela al vano de la ventana. Dicha sección es suficiente para poder reconstruir el aspecto que debió tener el retablo. Sobre el ábaco, del lado izquierdo, se apoya una ménsula invertida, del ángulo inferior izquierdo penden unos arreglos de flores, frutos y vainas, del lado derecho, se colocó una columna delgada y veteada, detrás 
hay una base sobre la cual descansa un ángel que sostiene una cartela ovalada, apergaminada con una leyenda ilegible en latín. De la parte superior de la columna emerge una banda ondulante que probablemente tenía otra leyenda en latín y la cual corre paralela al vano superior de la ventana. El final de esta banda probablemente se conectaba con una estructura muy similar a la que he descrito, paralela al lado derecho del vano de la ventana y que está perdida. En la etapa uno, arriba de esta banda y encima de la pintura de los ángeles sosteniendo una cartela descrita, se aprecia el brazo de un fraile franciscano, o al menos eso es lo que sugiere la ropa que porta, muy parecida a una túnica. La mano muestra la palma por lo cual al parecer el brazo está extendido. No hay ninguna conexión material entre este fragmento y el retablo descrito en los párrafos anteriores. Sin embargo, tal vez la representación superior del retablo del muro 2 pueda proporcionar la información faltante para establecer dicha relación.

La intervención de Garcés Fierros descubrió también, en el muro 2, la mitad derecha superior de una estructura arquitectónica similar a la descrita en el párrafo anterior. Antes de ese descubrimiento ya podía apreciarse el lado derecho inferior del retablo junto con algunos elementos de la escena central, por lo que actualmente disponemos de todo el lado derecho del retablo, que es similar en estructura, composición y color al que se localiza en el muro 3 (fig. 22).

La escena central es parecida a la del muro 3: aún son visibles algunos fragmentos de la moldura amarilla correspondiente a la parte inferior del arco y del soporte derecho sobre el que también corre paralela la franja negra que representa el ancho. En el interior de este arco se representó un personaje de pie, de frente y con los brazos extendidos en dirección al suelo, con la mano izquierda señala al sol mientras que con la derecha probablemente a la luna, pues aunque está en actitud de señalar, el mural presenta un faltante, el cual impide conocer a qué está haciendo referencia. Sin embargo, es muy probable que se trate de la luna porque es común la presencia conjunta de los dos astros. Tampoco es posible identificar los rasgos del rostro, pero el hábito café indica que se trata de un franciscano y nuevamente, como fondo se pintó un paisaje o al menos eso sugiere la presencia del fondo azul y los dos árboles que se encuentran, uno a cada lado del fraile. La existencia de la pintura anterior de san Francisco de Asís recibiendo los estigmas, correspondiente a la primera decoración insinúa que, quizá esta escena es una renovación de la representación anterior de este santo. Sólo sobrevive el lado derecho del marco de este caballete y al igual que el del retablo del muro 3, es lobulado. 
DOI: http://dx.doi.org/10.22201/iie.18703062e.2016.109.2623

260

ANA RAQUEL VANOYE CARLO

Los fragmentos de este retablo indican que su diseño es igual al descrito en los párrafos anteriores: paralela a la sección del marco existente se encuentran un par de columnas veteadas, de las cuales la basa y parte del cuerpo se han desprendido, lo que permite apreciar que las pilastras, que sostienen los arcos de medio punto correspondientes a la primera etapa, sobre todo las molduras que las decoran, se utilizaron como plantillas para trazar el nuevo retablo. Los capiteles de las columnas presentan modificaciones similares a las del retablo del muro 3: flores o mońos han sustituido los caulículos y las hojas de acanto de la hilera superior. En este retablo es posible apreciar que, entre las dos columnas se pintaron pequeñas flores formadas por cuatro pétalos azules y un centro rojo. Entre cada uno de los pétalos se agregó una hoja verde.

Sobre el ábaco, veteado y con perspectiva, que corona ambas columnas se aprecian a la derecha, la ménsula invertida y el arreglo floral y frutal que pende del vértice derecho; a la izquierda, la columna delgada y detrás de ella, la base sobre la cual se apoya un ángel que sostiene una cartela ovalada cuyo contenido es ilegible, en este caso es posible apreciar que viste una túnica roja, un manto azul, sus alas también son azules y porta en la mano derecha una palma. La parte superior de la columna es el arranque de la banda blanca cuyo extremo se conecta con una estructura igual a la descrita y la cual corre paralela al lado izquierdo del vano de la ventana.

La franja está decorada, en sus extremos, por dos líneas delgadas: la exterior es ocre y la interior azul, y encima de ella se encuentra una representación de un rey, la corona, la capa y el cetro que porta en la mano izquierda se conservan en buen estado, al igual que la vestimenta, que incluye camisola, calzas, jubón, greguescos y collar (fig. 6). El personaje aparece de pie sobre un piso café, en realidad se trata de una mancha oscura que sigue la forma de la banda superior del retablo, y rodeado de arbustos que tienen frutos café rojizo. Al parecer, esta composición coronaba el retablo. Tal vez, una similar remataba también el retablo del muro 3 y el lugar del rey estaba ocupado por el franciscano del que sólo sobrevive la mano derecha.

De acuerdo con esta idea, la posición de los temas en los retablos está invertida, es decir, en el del muro 2, la escena superior es un rey, mientras que la inferior es un franciscano y para el caso del muro 3, en la escena superior aparece un franciscano y en la inferior debe corresponder a Jesús, que es un rey. Este recurso de inversión lo emplearon los franciscanos para señalar coincidencias entre su origen y desarrollo y el de Jesús y su familia y con ello dotarlos de legitimidad. 


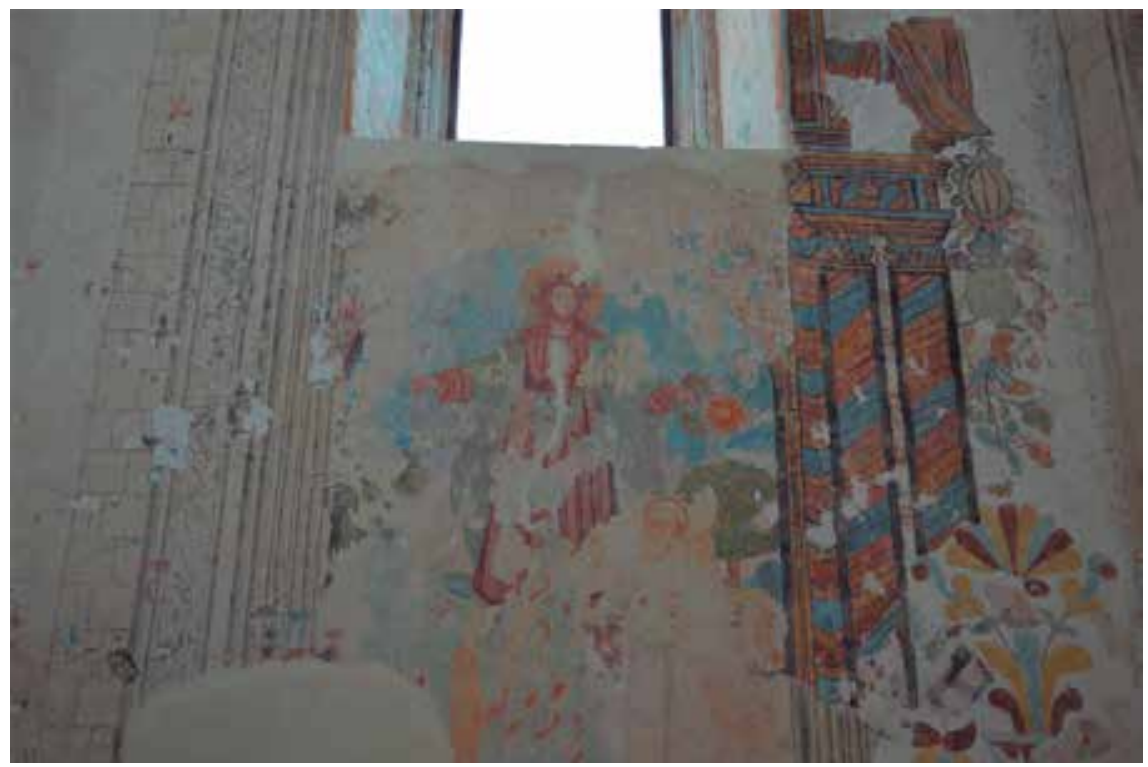

22. Sección inferior del retablo del muro 2 del ábside de la iglesia, convento de Santa Clara de Asís, Dzidzantún, Yucatán. Foto: Ana Raquel Vanoye Carlo, julio, 2013. Secretaría de Cultura INAH-Méx. "Reproducción autorizada por el Instituto Nacional de Antropología e Historia".

Las características de los retablos de los muros 4 y 5 refuerzan la idea anterior y, además, revelan la existencia de una relación entre los cuatro elementos arquitectónicos. El primer retablo está en el muro 4, a la izquierda del que he descrito en el párrafo anterior, si bien sólo sobrevive la mitad derecha; la izquierda quedó debajo de la pared con la pilastra que apuntala la bóveda de nervaduras. Probablemente se trata de la genealogía de Jesús (fig. 23). Está formado por dos cuerpos de diferente altura y el ático; la altura del inferior es aproximadamente el doble del superior. Dentro de estas estructuras hay medallones: dos en el cuerpo inferior, dispuestos en columna, uno en el superior y otro en el ático. La composición que albergan los medallones es muy similar; en ellos se colocaron los bustos de cuatro personajes vestidos con mantos y túnicas de diferentes colores y que portan una corona. Debajo de cada uno hay un óvalo blanco sobre el que se escribieron textos en latín, ahora perdidos (fig. 24b). Arriba de los personajes hay una filacteria blanca cuyos textos latinos también se han borrado, a la derecha de cada figura hay un pequeño rombo blanco, 
DOI: http://dx.doi.org/10.22201/iie.18703062e.2016.109.2623

262

ANA RAQUEL VANOYE CARLO

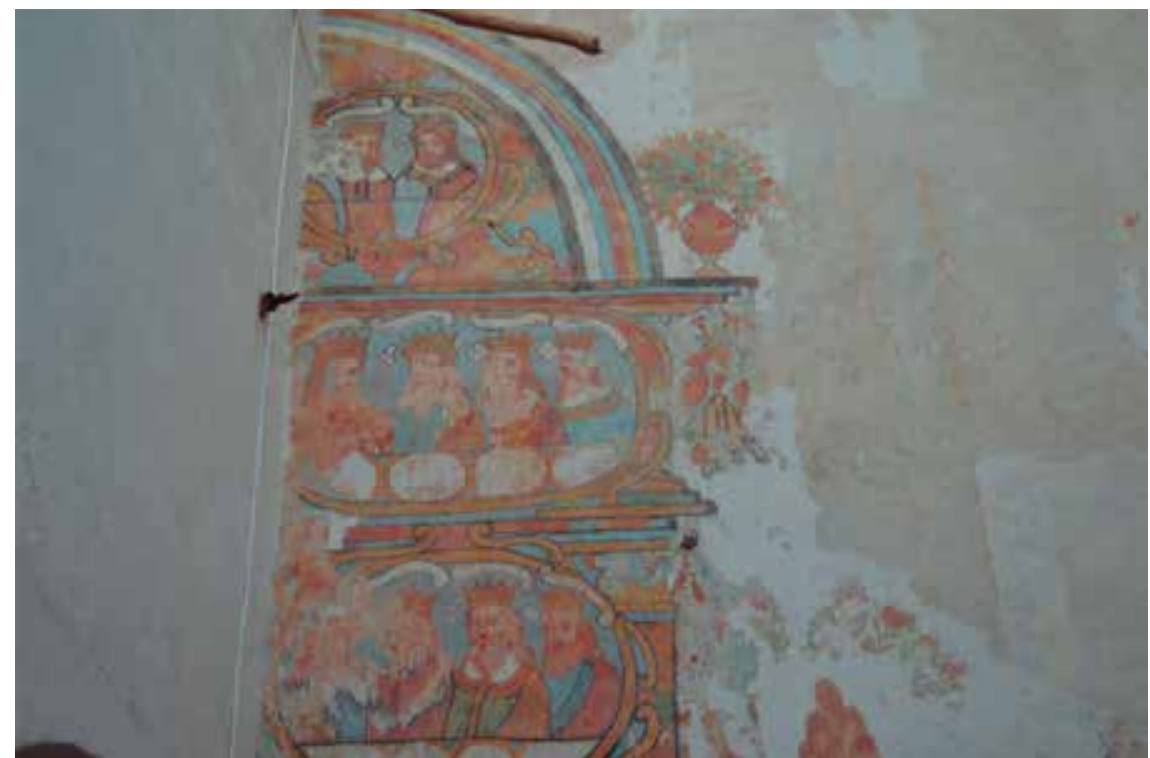

23. Retablo mural, la genealogía de Jesús, muro 4 del ábside de la iglesia, convento de Santa Clara de Asís, Dzidzantún, Yucatán. Foto: Ana Raquel Vanoye Carlo, julio, 20I3. Secretaría de Cultura-INAH-Méx. "Reproducción autorizada por el Instituto Nacional de Antropología e Historia”.

en cuyo interior todavía es posible distinguir la letra $m$ mayúscula. El diseño del medallón que se encuentra en el ático es un poco diferente pues no tiene ninguno de los elementos que, en el caso anterior, albergan los textos y además, sólo aparecen dos personajes que presentan las características señaladas.

El ático tiene forma semicircular y está decorado con un conjunto de manchas rojas, anaranjadas y azules que indican la imitación de mármol veteado; el borde está adornado con molduras cuyos colores son, de la interior a la exterior, negro, blanco, azul, rojo, ocre y azul con negro, sobre la estría blanca hay fragmentos de palabras en latín (fig. 24c). Este frontón descansa sobre un dintel de cuatro molduras cuyos colores son, desde la superior, negro, azul, rojo y ocre, en el extremo derecho se colocó un copón de flores que flanquea el ático. La parte derecha de esta estructura se apoya sobre una columna veteada de la que sólo se aprecia la base y el capitel, porque el cuerpo queda detrás de uno de los medallones, es decir, su altura es la misma que la de esta última estructura. Tanto éste como la pequeña columna descansan de nuevo sobre un 
dintel de cuatro molduras cuyos colores son, comenzando desde la superior: azul, ocre, ocre y café, azul y ocre. Del extremo derecho de la inferior penden unos arreglos florales y frutales. El cuerpo descrito anteriormente descansa sobre otro de composición similar, pero de doble altura.

En el muro 5 también sobrevive la mitad izquierda de un retablo. La derecha quedó debajo de la pared que apuntala la bóveda de nervaduras. Este retablo, al parecer, trata de la genealogía de los franciscanos y comparte la paleta cromática, la composición plástica y la arquitectónica con el retablo descrito en el párrafo anterior. Dentro de los medallones se representaron bustos de personajes franciscanos: cuatro que forman parte de los cuerpos arquitectónicos y dos que están en el ático (fig. 24a).

La posición encontrada de los retablos (fig. 2) indica, una vez más, la presencia de un ejercicio de legitimización de los orígenes de los franciscanos mediante su equiparación con los de Jesús. La serie de manchas y franjas paralelas, simulando mármol veteado, que sobrevive en la parte superior del vano de la puerta que comunica el claustro con la nave de la iglesia sugiere que, posiblemente, este recinto exhibió una decoración parecida.

El convento de San Miguel Arcángel, en Maní, también alberga un conjunto extenso de murales ejecutados con una paleta de color similar a la considerada en este apartado. Las similitudes son suficientes para afirmar que las que abordo aquí no se emplearon de manera exclusiva en el convento de Santa Clara de Asís y las diferencias permiten asegurar que existió un conjunto muy amplio de posibilidades para decorar los muros de los conventos del que sobrevive una pequeña parte.

Entre las semejanzas están las franjas inclinadas, simulando mármol veteado, que aún es posible apreciar en algunas estructuras arquitectónicas, como las columnas de la portería en colores rojo, azul y ocre.

Las pinturas murales de la iglesia se encuentran en el intradós de los dos arcos formeros de la iglesia más próximos al presbiterio. Actualmente, ambos albergan retablos: el que se localiza en el muro sur está dedicado a san Antonio de Padua y el del muro norte, a La Dolorosa. Las pinturas que se encuentran en el intradós de este último son las siguientes: en la parte central una representación de Cristo niño parado sobre el mundo, hacia abajo, al este, hay otras dos pinturas, en la más cercana a la anterior se ejecutó a san Diego de Alcalá y el Milagro del Pozo y debajo de ésta, a José de Arimatea recibiendo el cuerpo de Jesús. Al oeste, también hay dos escenas, junto a la representación del Niño Jesús parado sobre el mundo se encuentra una de san Diego de Alcalá y el Milagro del Hor- 
DOI: http://dx.doi.org/10.22201/iie.18703062e.2016.109.2623

264 ANA RAQUEL VANOYE CARLO

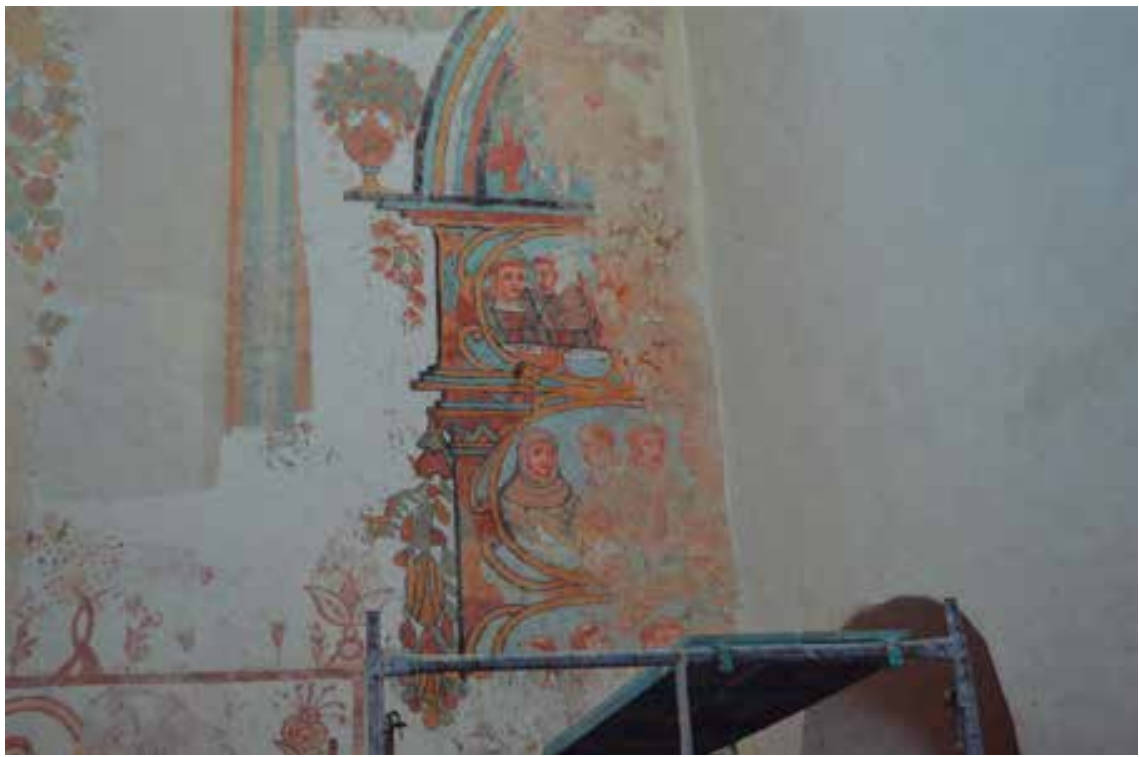

24. a)Retablo mural, probablemente la genealogía de san Francisco, muro 5 del ábside de la iglesia, convento de Santa Clara de Asís, Dzidzantún, Yucatán.

no, junto a ésta se pintó un entierro franciscano del que no es posible obtener información sobre la identidad del personaje. Unas líneas gruesas, amarillas, separan cada una de las escenas anteriores.

La presencia conjunta de las escenas del entierro franciscano y del Descendimiento nuevamente vuelve a sugerir la tendencia de los menores a encontrar en la vida de Jesús la legitimización de su origen y su misión. La presencia de estos ejercicios en las iglesias de Dzidzantún y Maní señalan que éste era el recinto adecuado para llevarlos a cabo.

Toda la decoración mural que sobrevive en el arco formero del muro sur de la iglesia también se localiza en el intradós, sin embargo, y a diferencia del anterior, sólo sobreviven las tres escenas centrales, las dos de los extremos se han perdido. Al igual que en el caso previo, en el centro hay una representación de Cristo niño parado sobre el mundo, al oeste se ve a san Antonio de Padua y el Milagro de la Mula, y al este a san Antonio de Padua discutiendo con un par de herejes. Ambas escenas ocupan el mismo lugar que las representaciones de los milagros de san Diego de Alcalá, por lo cual, quizá las dos pinturas perdidas también cumplan la relación entre las genealogías de 
DOI: http://dx.doi.org/10.22201/iie.18703062e.2016.109.2623

MURAL DEL CONVENTO DE SANTA CLARA DE ASÍS

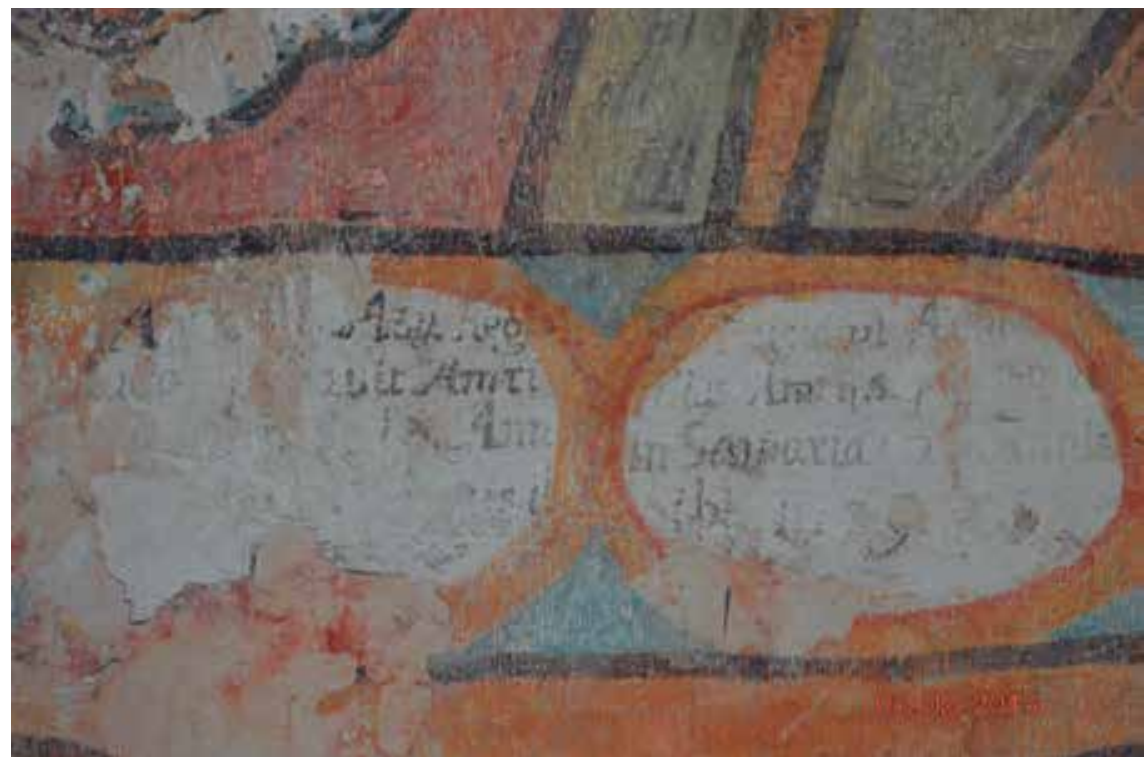

b) Detalle de los óvalos que se encuentran debajo de cada uno de los reyes.

c) Detalle de las molduras que decoran el frontón curvo del retablo. Fotos: Ana Raquel Vanoye Carlo, julio, 2013. Secretaría de Cultura-INaH-Méx. "Reproducción autorizada por el Instituto Nacional de Antropología e Historia”.

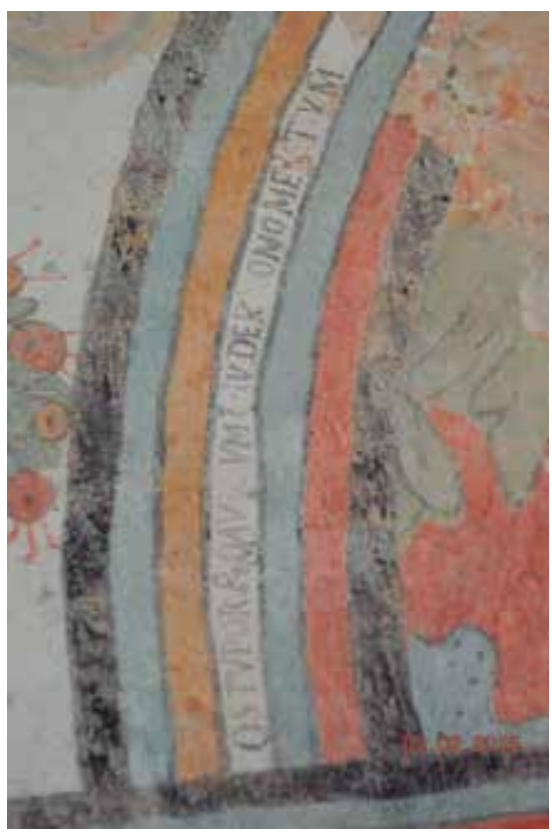


DOI: http://dx.doi.org/10.22201/iie.18703062e.2016.109.2623

Jesús y san Francisco de Asís. De este modo, el tema de una podría ser un pasaje de la vida de Jesús y, la otra podría contener una experiencia de la vida de este santo franciscano.

Probablemente las decoraciones del ábside de la iglesia de Dzidzantún y las de los arcos formeros de la iglesia de Maní eran complementarias. El uso de la misma paleta de color, el empleo de paisajes como los fondos de las escenas y la relación mesurada entre la pintura y la arquitectura así lo sugieren. Tal posibilidad indica que la pintura mural incluida en esta etapa esboza el aspecto que pudo haber exhibido cualquier iglesia.

\section{La cuarta decoración del ábside (siglo XIX, principios del siglo XX)}

La última decoración mural está integrada solamente por elementos de ornato; no hay escenas de la vida de los santos; para su diseño se eligió un motivo que se repite a lo largo de todos los paramentos tal y como lo indica la presencia de fragmentos correspondientes a este tipo de adornos en todos los muros del ábside.

La primera decoración se trata de una cenefa, que tiene aproximadamente un metro de altura y sus elementos han sido delineados en color ocre y rellenados con amarillo. El diseño es una cinta ondulante que funciona como un eje alrededor del cual se articulan diversas formas como lazos, pequeños árboles, hojas, flores y hostias y que está enmarcada por un rectángulo sepia sobre el cual se apoyaron de manera alterna pequeños árboles y flores (fig. 25).

Debajo de esta capa se aprecian los restos de otra pintura decorativa, se trata de flores hechas a base de figuras geométricas: los pétalos, el tallo y las hojas se representaron utilizando triángulos azules y amarillos, para el centro, de color sepia, se empleó un círculo ejecutado con un punzón. Las flores que se localizan en la parte inferior del muro descansan sobre una cenefa compuesta por dos franjas paralelas, pintadas, por segmentos rectangulares, en diferentes colores, entre los que destacan amarillo, ocre, azul claro y oscuro (fig. 5).

La tercera decoración es la más reciente, sólo los muros de la iglesia y del claustro conservan rastros de ella, se ejecutó en azul marino y naranja. En el primer recinto el azul se aplicó como el guardapolvo, el cual se remató con una franja delgada y naranja, sobre él se delinearon en azul unas cartelas hexagonales y alargadas que contienen seis racimos de uvas del mismo color. En el claustro, cada uno de los arcos se decoró con una franja azul gruesa y encima de ésta, una delgada en color naranja. 


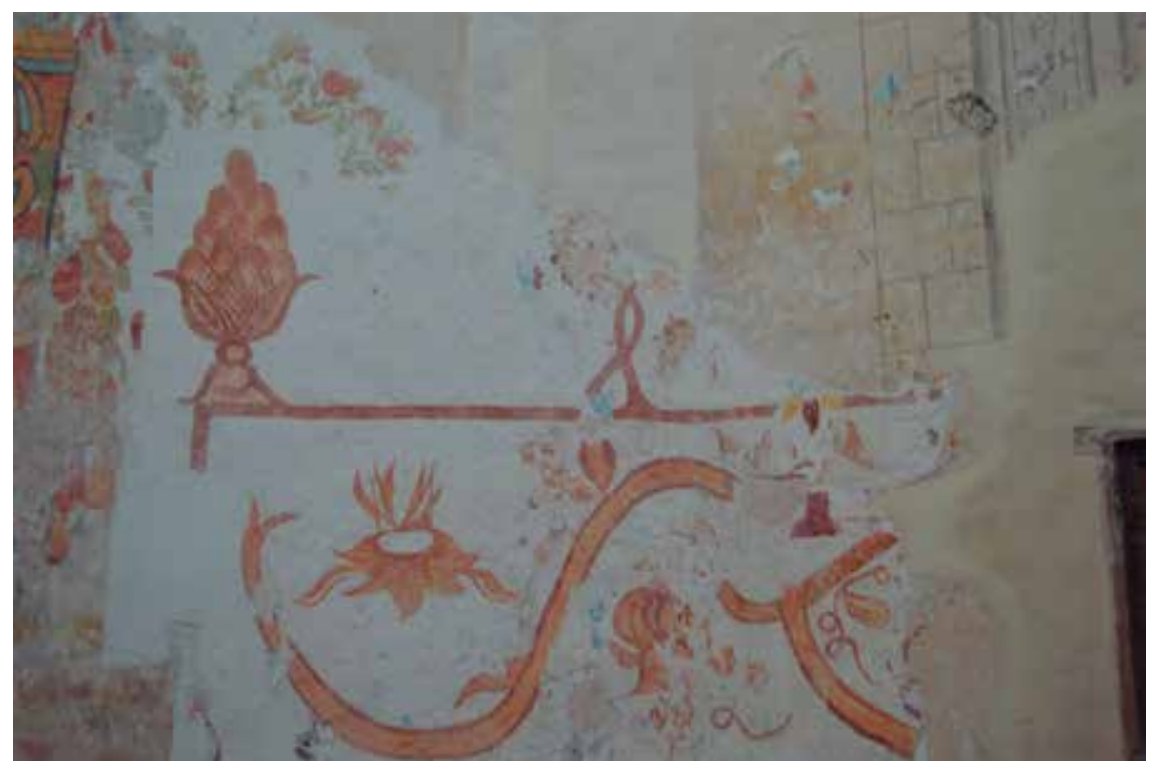

25. Cenefa, ábside de la iglesia, convento de Santa Clara de Asis, Dzidzantún, Yucatán. Foto: Ana Raquel Vanoye Carlo, julio, 20I3. Secretaría de Cultura-InAH-Méx. "Reproducción autorizada por el Instituto Nacional de Antropología e Historia”.

La anterior es la pintura mural que he podido describir y organizar dentro de la secuencia, sin embargo, no es toda la que sobrevive en el convento de Santa Clara de Asís, abajo de los cuatro retablos descritos en la tercera etapa hay una gran cantidad de fragmentos que indican que existieron otras decoraciones murales de las cuales ya no es posible obtener información que permita incluirlas en la secuencia. Sin embargo, las pinturas descritas hasta aquí son suficientes para explorar algunas líneas de investigación.

La ventaja principal que ofrece la secuencia es por un lado, la posibilidad de establecer relaciones entre las pinturas que forman parte de ella y las que provienen de otros edificios religiosos localizados también en el norte de la península de Yucatán. La construcción de estas relaciones es útil para inferir la persistencia en las características de ciertas tendencias decorativas, por ejemplo, la paleta de color, los elementos decorativos y los cambios en la relación entre la arquitectura y la pintura mural. Por el otro, permite determinar cuáles son los murales que no guardan relación con la secuencia propuesta y estimar su proporción. Por lo que la organización de los murales del con- 
DOI: http://dx.doi.org/10.22201/iie.18703062e.2016.109.2623

vento de Dzidzantún constituye, en última instancia, el primer paso para el ordenamiento y la definición de los rasgos particulares de la pintura mural franciscana del norte de la península de Yucatán.

La descripción de las pinturas murales presenta sus propios alcances; constituye un testimonio del aspecto que exhibían antes de la restauración de 20II, pues aunque este procedimiento favoreció la construcción de la secuencia al revelar nuevos murales, también determinó grandes cambios en el aspecto de la pintura debido a que los faltantes de los diferentes encalados se restituyeron y la capa pictórica se reintegró. Actualmente, ya no es posible apreciar desniveles en las pinturas murales, lo que impide apreciar diferentes momentos de su ejecución y construir propuestas alternas a la que este trabajo presenta.

A su vez, las descripciones de estos murales permiten plantear problemáticas relacionadas con su datación, con la definición de los cambios en los patrones preferidos para representarlos, así como con su relación con otros objetos artísticos y su papel en los fenómenos antropológicos.

\section{Conclusiones}

En general, muy pocos conventos del norte de la península de Yucatán conservan pintura mural, la cual con frecuencia está muy deslavada o fragmentada. El caso del convento de Santa Clara de Asís fue excepcional porque, hasta antes de la restauración de 20iI, conservaba una gran cantidad de murales sin intervenir y sus encalados presentan faltantes. Estas características permitieron definir diferentes etapas de ejecución, es decir, la pintura fue óptima para la reconstrucción de una secuencia que organizara las pinturas desde las más antiguas hasta las más recientes. Este estudio propone una secuencia y también expone los argumentos que sostienen su validez, muchos de ellos proporcionados por la información que surgió durante los procesos de desencalamiento, limpieza y consolidación de la intervención de 20II, los cuales permitieron la identificación de nuevos rasgos materiales y plásticos que ayudaron a definir algunas particularidades de la secuencia propuesta y afinar algunas otras ya establecidas.

Por un lado, la organización y la presentación de la pintura mural en cuatro etapas preservan los rasgos que caracterizaron estos objetos antes de la reintegración de su capa pictórica y contrarrestan parcialmente el aspecto homogéneo proporcionado por este proceso. Por otro, también constituyen una base indispensable a partir de la cual es posible desarrollar otro tipo de estu- 
dios, por ejemplo, los que se centran en establecer la relación existente entre la pintura mural y la arquitectura, o aquellos cuyo objetivo es inferir, a partir de los fragmentos existentes, y en la medida de las posibilidades, el aspecto que debió haber exhibido el ciclo pictórico completo. También representan un antecedente sólido para la investigación relacionada con la historiografía.

La existencia de estas etapas organizadas de acuerdo al orden de ejecución de la pintura mural también muestra que es necesario ampliar los estudios sobre la materialidad de la pintura mural, sobre todo los correspondientes a las primeras etapas y por último indica que existe una gran cantidad de pintura mural que queda fuera de ella y para la cual son necesarias nuevas aproximaciones bajo las cuales sea posible estudiarla. \$

N.B. Este trabajo ha sido posible gracias al apoyo y asesoría de muchos especialistas, en particular quiero reconocer a Marco Tulio Peraza Guzmán (FA-UADY), quien ha coordinado gran parte del trabajo de campo llevado a cabo en los conventos franciscanos del norte de la península de Yucatán; a Elena Isabel Estrada de Gerlero (IIE-UNAM), quien numerosas veces ha identificado los aspectos más relevantes de esta investigación y aportado ideas para su desarrollo; y al arquitecto Javier Martínez Burgos (FA-UNAM) por transmitirme su conocimiento e ideas sobre los conventos franciscanos localizados en el centro de México. 
DOI: http://dx.doi.org/10.22201/iie.18703062e.2016.109.2623

Anexo documental 
26. Aspecto actual de la pintura mural del ábside de la iglesia, convento de Santa Clara de Asís, Dzidzantún, Yucatán. Dibujo: Ana Raquel Vanoye Carlo, junio, 2013

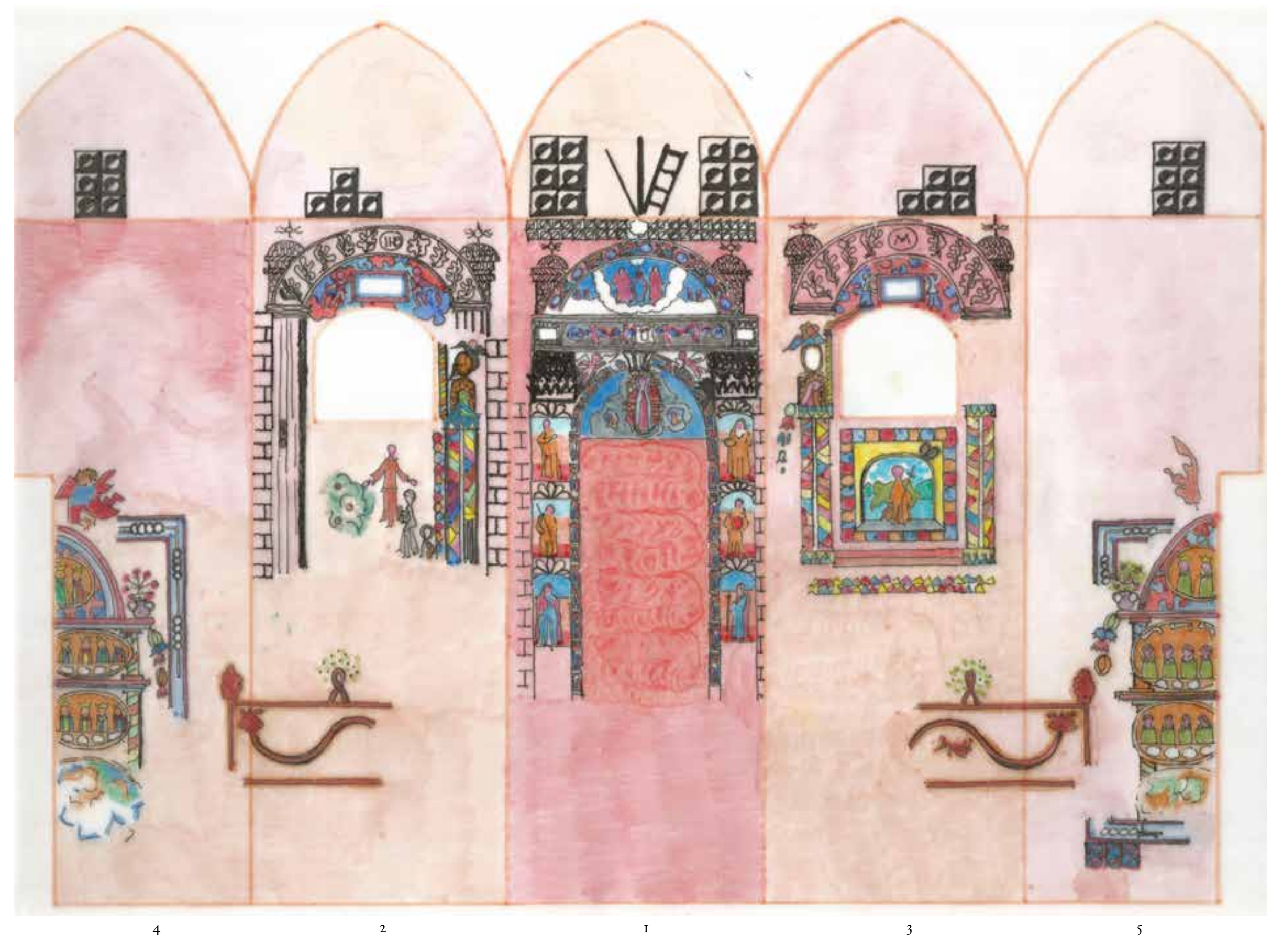




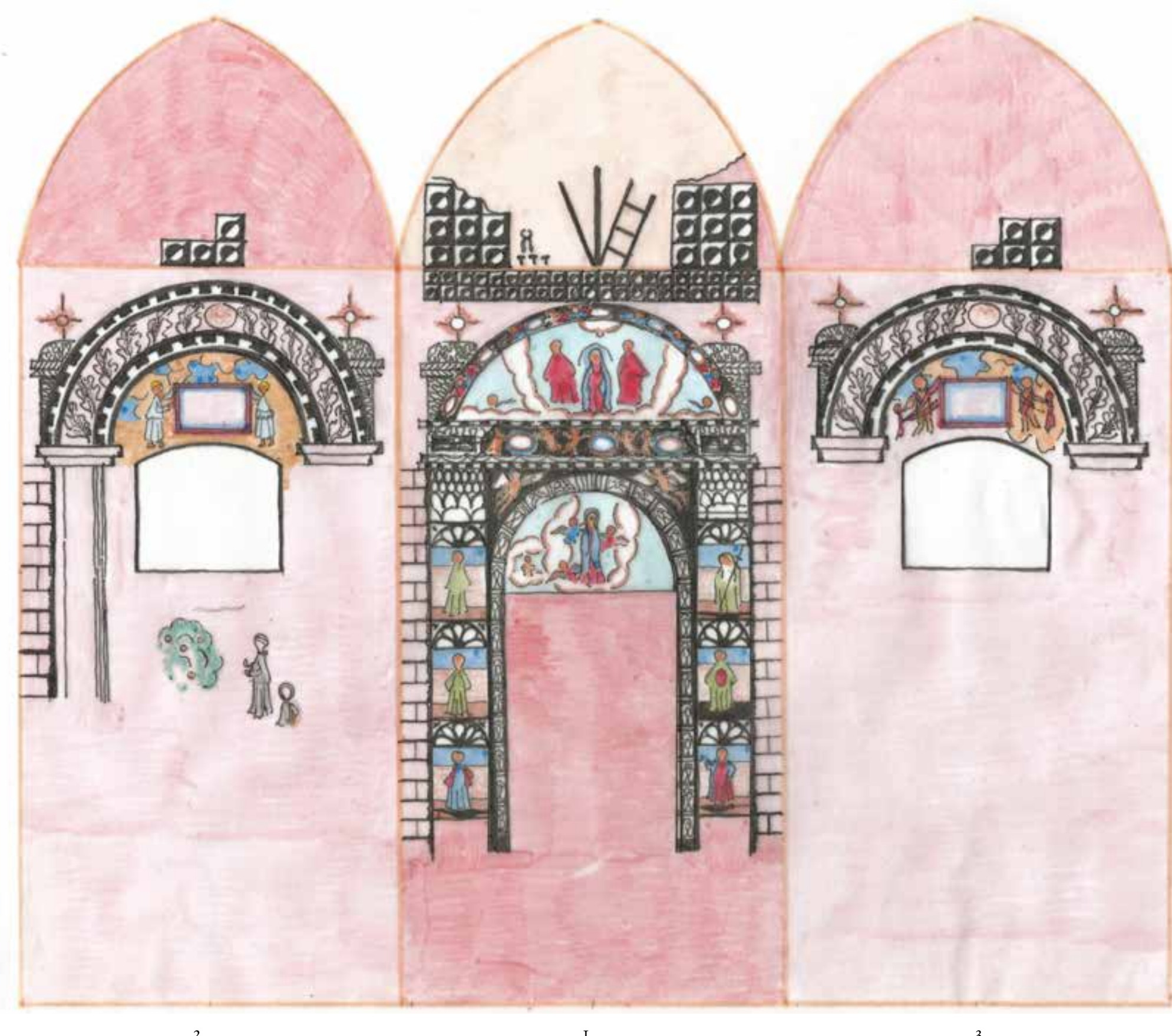

27. Primera decoración del ábside de la iglesia (I 575-I 700), convento de Santa Clara de Asís, Dzidzantún, Yucatán. Bosquejo: Ana Raquel Vanoye Carlo, junio, 2013. 


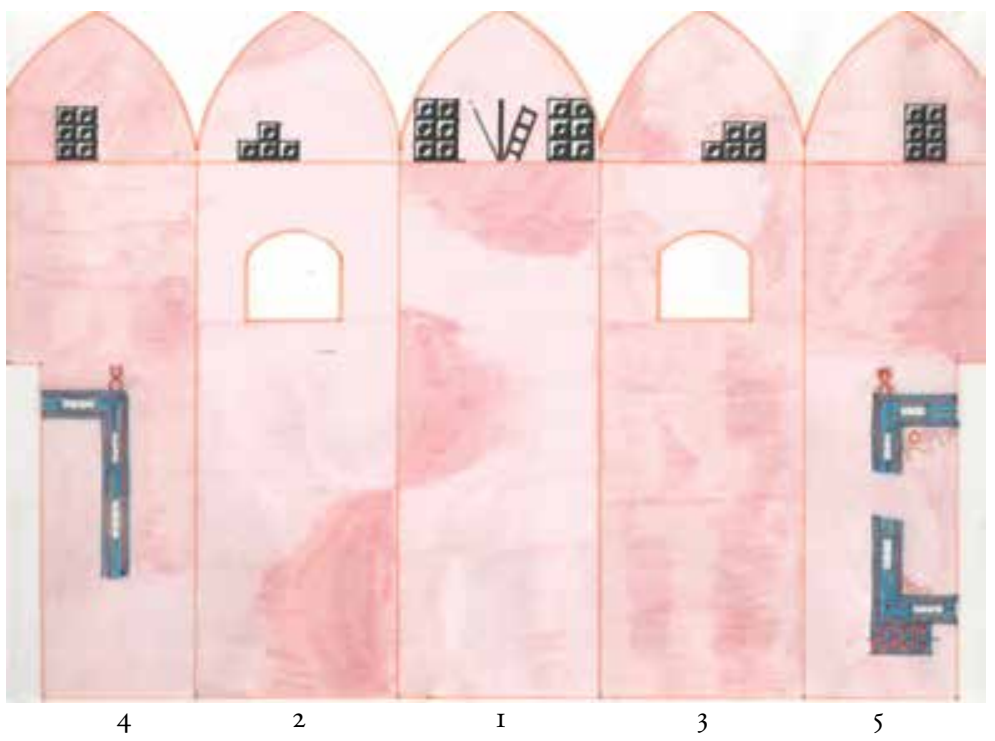

28. Segunda decoración del ábside de la iglesia (I625-1700), convento de Santa Clara de Asís, Dzidzantún, Yucatán. Dibujo: Ana Raquel Vanoye Carlo, julio, 2012.

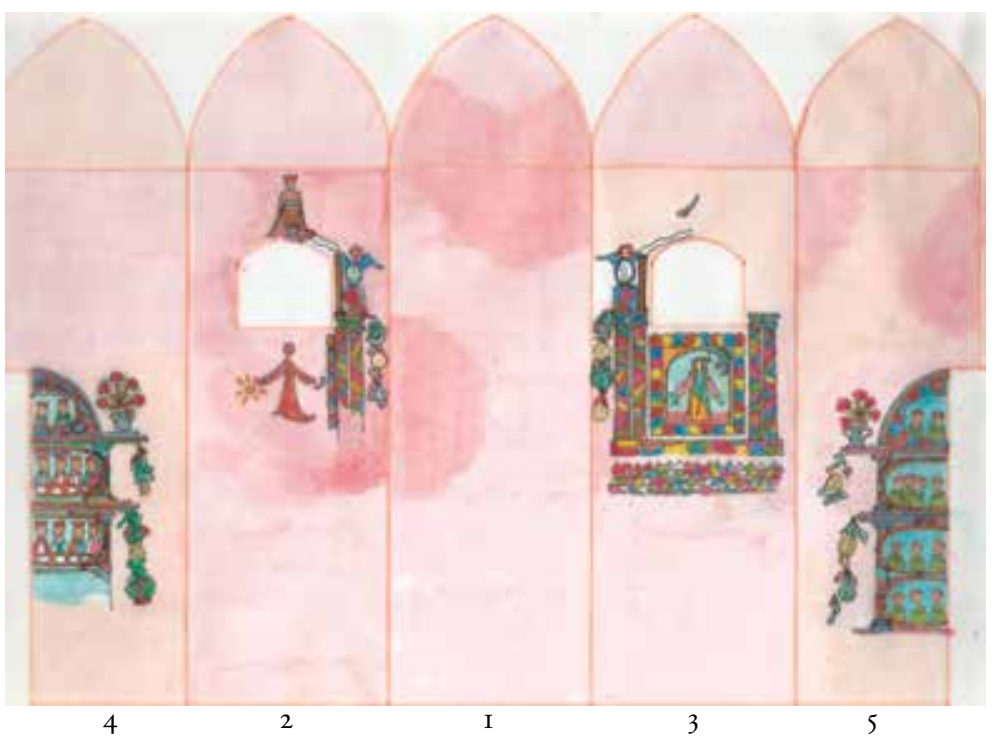

29. Tercera decoración del ábside de la iglesia (siglo XVIII), convento de Santa Clara de Asís, Dzidzantún, Yucatán. Dibujo: Ana Raquel Vanoye Carlo, julio, 2012. 
DOI: http://dx.doi.org/10.22201/iie.18703062e.2016.109.2623 
DOI: http://dx.doi.org/10.22201/iie.18703062e.2016.109.2623

\section{Libros}


DOI: http://dx.doi.org/10.22201/iie.18703062e.2016.109.2623 


\author{
$\$$ \\ Silvia Arango Cardinal \\ Ciudad y arquitectura. \\ Seis generaciones que construyeron \\ la América Latina moderna* \\ México: Fondo de Cultura Económica/Consejo Nacional \\ para la Cultura y las Artes, 2012 \\ por \\ ALEJANDRINA ESCUDERO**
}

Ciudad y arquitectura. Seis generaciones que construyeron la América Latina moderna es la primera historia general del siglo XxI que aborda el tema; la investigación tomó a Silvia Arango Cardinal Is años, en los que recorrió las ciudades latinoamericanas y exploró trabajos históricos de la arquitectura citadina, monografías, estudios de caso, libros, revistas y tesis, lo mismo sostuvo entrevistas, conversaciones, hizo consultas a especialistas, y puso especial atención en la lectu-

\footnotetext{
* Texto recibido el 9 de diciembre de 20I5; devuelto para revisión el 9 de febrero de 2016, aceptado el Io de marzo de 2016.

** Doctora en Historia del Arte por parte de la Universidad Nacional Autónoma de México.

http://dx.doi.org/I0.2220I/iie.18703062e.2016.109.2582
}

ra e interpretación de los documentos gráficos, fuente entrañable para la investigadora colombiana. En 451 páginas y cerca de 300 imágenes, el libro explica un proceso histórico de 90 años (I885 y 1975), en los que los contemporáneos de cada generación insistieron en autoidentificarse como modernos y construyeron esa "obra prodigiosa" que es la ciudad latinoamericana; ellas son la cientificista (I885-I900), la pragmática (I900-I9I5), la modernista (I915-I930), la panamericana (1930-I945), la progresista (19451960) y la técnica (1960-1975).

Antes de ofrecer una glosa del libro, en compañía mano de la autora, tengo dos observaciones; la primera es mi beneplácito por la manera en la cual la autora logra abordar el tema, que al historiador actual pudiera sorprender; se refiere a la metodología generacional, por tradición utilizada en la literatura, lo cual resulta un acierto de Arango, al aprovecharla en un campo diferente con el propósito de englobar y explicar un dilatado proceso de larga duración, desplegado en varios países; la segunda apunta a su inmediato impacto no sólo en la academia, sino en el ámbito estudiantil universitario; de ahí mi interés por rescatar un estudio publicado hace algunos años, no obstante muy vigente en la casi inexistente historiografía de la modernidad arquitectónica y urbanística latinoamericana, libro que desde su aparición se ha convertido en un "clásico". 
El primer asunto por dilucidar se refiere al concepto de generación que, de acuerdo con Julián Marías, es el lapso mínimo para entender una estructura histórica; de esta manera, el texto se organiza con el método generacional, herramienta metodológica que permite pensar el pasado a partir de un sujeto colectivo: la generación, entendida ésta en la acepción propuesta por el filósofo español José Ortega y Gasset, cuando dice que los lazos que unen a cada uno de sus integrantes son sus vigencias, es decir, el "conjunto de ideas, percepciones, creencias, valores y costumbres que forman la interpretación de la realidad." (I6). Éstas, aclara la escritora, se forman como respuesta a las circunstancias que se viven y constituyen un soporte desde el cual se enfrentan los retos. La generación vista así no está directamente relacionada con la fecha de nacimiento sino con el desarrollo profesional de sus integrantes en su etapa creativa o participativa, que va de los 45 a los 60 años. El desafío de Arango Cardinal es explicar cómo, en cada generación, circunstancias y vigencias (incluso sueños y deseos) dan forma a las ideas urbanísticas y arquitectónicas, que no son puras sino que se mezclan con vigencias heredadas y en las que se sobreponen tres generaciones.

\section{I.}

La llamada generación cientificista (I8851900) funciona como bisagra entre dos estructuras históricas, porque a la vez que rompe, hereda de la generación emprendedora que le antecedió. En ella se da una enorme importancia a las formas de pensamiento deductivo que parten de la evidencia inmediata. Un término que la define es la curiosidad.

La cientificista se encargará de culminar el prolongado proceso decimonónico de conformar las unidades nacionales, una vez delineados los perfiles de sus territorios y de sus historias patria, por lo que se trata de la primera generación "plenamente nacional". Al respecto dice la autora: "El alcance de la incidencia de ciertas ideas positivas, científicas o políticas en América Latina sólo puede entenderse dentro de su articulación, con una lógica vital, con el propósito de construir naciones modernas, contando con la herencia de vigencias subsistentes de largo plazo como la vastedad territorial y la escasez de minorías educadas" (32). La noción de la ciudad capital simboliza y consolida su idea de nación, ya que constituye el lugar donde se concentra el liderazgo espiritual, la evolución y el progreso.

Esta generación se ocupará del transporte y del saneamiento con obras de canalización y alcantarillado; entre ellas, se distingue: "Una de las obras de ingeniería más prodigiosas del siglo XIX en América Latina: la construcción del Gran Canal del Desagüe del Valle de México, el cual retoma, rectifica y amplía proyectos que se remontan a la época precolombina” (43).

En las ciudades latinoamericanas se inician expansiones ya planificadas, mediante lotificaciones periféricas que, a la manera de barrios, se incorporan a la ciudad y siguen, por lo general, el mismo trazado. Gran parte de los fraccionamientos - o colonias en el caso de México- son propuestas de empresarios privados. Una característica común es la introducción de uno o dos ejes que marcan el centro a una ciudad entendida como un todo neutro, por encima de las viejas divisiones de barrios, parroquias o cuarteles. Un fenómeno naciente es la aparición de las nuevas urbes, como La Plata en Argentina y Bello Horizonte en Brasil. 
En el periodo de creación de la generación cientificista, la arquitectura la hacen los ingenieros, y las obras públicas ejecutadas se relacionan con la idea de saneamiento ambiental y moral, con el fin de resolver aspectos de la vida cotidiana, por ello destaca la construcción de mercados, rastros, cementerios, hipódromos y plazas de toros.

\section{2.}

Aunque en la generación pragmática (I9001915) predomina la confianza en el progreso, su relación con la técnica varía y se centra en los inventos y de ella surgirá un grupo de inventores.

Algunas metrópolis como Buenos Aires y Río de Janeiro superan el millón de habitantes y en ellas se experimenta un crecimiento paulatino, con rasgos comunes, como la construcción de una arquitectura monumental, la apertura de grandes avenidas y la inauguración del primer metro de Latinoamérica. La Avenida de Mayo en Buenos Aires y la Avenida Central (Río Branco) en Río de Janeiro sirven de modelo para las demás ciudades; se trata de calles rectas y amplias que enlazan lugares simbólicos y, a sus flancos, se construyen edificios de seis a siete pisos. Avenidas, paseos y calzadas tienen una función higienista $y$, a la vez, funcional en su relación con el tráfico.

Además, se despliega un frenesí constructivo, público y privado, sin precedentes, que sigue las tendencias académicas y cuyas obras serán de los arquitectos; se concretan importantes trabajos de saneamiento y electrificación y despuntan puertos, parques, avenidas y un repertorio significativo de edificios monumentales, llamados comúnmente "palacios", tales como capitolios, casas de gobierno, tribunales de justicia, estaciones de ferrocarril, edificios de correos, teatros, escuelas, bibliotecas y museos, ubicados por lo general en la ciudad consolidada. Por otro lado, se produce un desplazamiento de varias cuadras del núcleo simbólico tradicional; en Buenos Aires, la Plaza Lavalle, en Río de Janeiro, la Plaza Floriano y en la ciudad de México, La Alameda. Los teatros sustituyen a las catedrales, como edificios simbólicos, y logran aglutinar, a su alrededor, el corazón de la vida urbana; entre los principales están el Teatro Colón de Buenos Aires, el Teatro Municipal de Río de Janeiro y el Teatro Nacional de México (después, Palacio de Bellas Artes); de igual forma, se advierte un contraste entre la ciudad antigua y la moderna.

3.

Simultánea a las ideas, percepciones y valores está la relación que cada generación establece con la técnica; la cientificista la consideró la promesa de un mundo interconectado, la pragmática, un instrumento útil para el bienestar y la modernista (I915-1930), un recurso para la diversión y para hacer placentera la vida, lo que lleva a privilegiar hallazgos técnicos como el radio, el fonógrafo y el cine.

La modernista presupone la libertad y una escasa intervención del Estado, porque éste es superado por la iniciativa privada. Ahora la ciudad se ve como un negocio, al volverse las urbanizaciones una actividad muy rentable por lo que se puede "vivir de la renta". Esta generación aspira al ocio y a las formas de evasión, quiere tiempo libre para dedicarlo a la diversión, al deporte, al vértigo de la velocidad y a las sensaciones límite; se le otorga gran importancia al cuerpo y se practica el futbol, tenis, polo y remo; de cara al placer de viajar abunda la edificación de hoteles, balnearios y casinos. 
La ciudad se conforma por un núcleo central y una gran cantidad de urbanizaciones, fenómeno ya existente, pero del cual ahora se desprenden de manera aleatoria, enfrentados al ajedrezado antiguo, los nuevos trazos hechos, a veces, con calles curvas o siguiendo las sinuosidades de la topografía. En esta comparecencia, el centro tendrá signos negativos y las periferias, positivos.

En la generación modernista predominará la arquitectura ecléctica y la profesión se afianzará mediante escuelas, revistas, congresos y asociaciones; el primer Congreso Panamericano de Arquitectos se celebra en Uruguay en I920.

\section{4 .}

En los años que van de 1930 a 1945 se confrontan tres generaciones de muy distinto carácter; todavía se hace visible la declinante modernista y aparece tumultuosa la progresista (1945-1960); en el medio, resistiendo el empuje, está la panamericana (1930-1945), que saldrá victoriosa en la década de 1930.

En lo político, Is de los 2I países latinoamericanos tienen regímenes militares; de esa manera, la generación panamericana "vive la creencia de que no sólo la política sino todas las actividades que busquen legitimidad moral deben tener como objetivo fundamental mejorar las condiciones del pueblo" (210). En la noción de pueblo confluyen tres conceptos: raza dominada, desposeídos y masa. Dos pensadores que exploran el espíritu de los pueblos americanos, apelando a las nociones de raza y cultura, son el mexicano José Vasconcelos y el peruano Víctor Raúl Haya de la Torre. En los arquitectos hay un sentimiento americanista, al enfrentar el problema de conseguir una obra verdaderamente americana y a la vez moderna.
A pesar de las conmociones políticas y de los dramáticos años que van de 1928 a 1933 , en la década de 1930, los arquitectos panamericanos serán prolíficos y responsables. En su búsqueda por modernizarse salen en defensa del estilo nacional, mezclado con otras referencias artísticas y culturales; al sentirse iniciadores de un mundo totalmente nuevo dieron a conocer manifiestos con los medios que pudieron; por ejemplo en el VI Congreso Panamericano de Arquitectos (1930, Río de Janeiro) "se sepulta simbólicamente a la generación modernista y su concepción del arquitecto como un defensor de la belleza". En México destaca el ciclo "Pláticas de arquitectura”, celebrado en 1933 .

La ciudad se considera un organismo único y homogéneo y los planos reguladores son los instrumentos para transformarla, involucrando ahora a la región; en ellos se incluyen los anillos concéntricos, cuyos ejemplos característicos son los esquemas de Francisco Prestes Maia para São Paulo, de Karl Brunner para Santiago de Chile y de Carlos Contreras para el Distrito Federal; paralelo a un plan vial, que tiene por objeto la regulación urbana, estará la zonificación, es decir, la división de la urbe por funciones.

Ahora, la técnica se referirá no tanto a los sistemas constructivos o a la introducción de nuevos materiales, sino a la posible producción en serie de los elementos industrializables; el arquitecto se ve como un servidor social, al desarrollar los repertorios del Estado, con obras dirigidas al bienestar colectivo, como hospitales, escuelas y equipamientos deportivos, aunque no deja la práctica privada, una fuente de trabajo importante, con la edificación de casas individuales y edificios en renta para la clase media. 


\section{5.}

Después de la guerra, la generación progresista (I945-1960) ejerció plenamente su profesión en ciudades en franco crecimiento y transformación. Las circunstancias y vigencias que vivió se dieron en una situación política, la cual se explica no sólo por las polarizaciones que resultan de la segunda guerra mundial sino por las inercias continentales y nacionales, centradas en la derecha e izquierda. Arango Cardinal argumenta que la vigencia más compartida por esta generación es "el anhelo de garantizar el desarrollo como sinónimo de progreso, plasmado en realizaciones urbanas y arquitectónicas, con un sentimiento desarrollista. En donde las nociones de modernización e industrialización se identifican" (277).

Así vista, la arquitectura se convierte en un vehículo privilegiado de transmisión de ideas y proyectos, logrando las obras más interesantes, creativas y originales. Para las grandes masas de población latinoamericana, el desarrollo se concretará en obras públicas, en las cuales se aplican las técnicas más avanzadas, reforzando la idea de progreso, y se plantea una arquitectura diáfana y luminosa; "la responsabilidad de los arquitectos de la generación progresista fue la de plasmar una idea de desarrollo que se identificara con lo moderno" (276).

Durante la segunda guerra mundial, América Latina experimentó un desarrollo industrial y económico, que a partir de 1945 se traduce en una aceleración del crecimiento urbano; las principales ciudades casi duplicaron su población; Buenos Aires, México, Río de Janeiro y São Paulo superan los cuatro millones de habitantes, en tanto que La Habana, Bogotá, Santiago, Montevideo, Lima y Caracas, el millón.
En la posguerra inmediata construir vivienda se convirtió en el objetivo central de todos los gobiernos latinoamericanos, al obedecer a las demandas del acelerado crecimiento; es la época de construcción de grandes conjuntos habitacionales, que aprovechan las experiencias anglosajonas de los green belt towns y las reflexiones sociales de la Escuela de Chicago. Entre 1945 y 1950, los conjuntos estatales se diseñaron a la manera de unidad vecinal, cuyo paradigma fue Radburn (1928, Nueva Jersey), formada por las llamadas súper manzanas y separando el tránsito vehicular del peatonal; algunos casos sobresalientes son la Unidad Vecinal Número 3, en Lima, el Centro Urbano Miguel Alemán, en la Ciudad de México, el Conjunto Habitacional Pedregulho, en Río de Janeiro, el Conjunto Residencial Várzea do Carmo, en São Paolo. Obras características del periodo fueron las ciudades universitarias modernas y una paradigmática nueva ciudad, Brasilia, con la que los arquitectos de la generación progresista culminan su prolífica aventura arquitectónica y sus planteamientos urbanos.

Los arquitectos buscan expresarse en sus obras con sinceridad, autenticidad y verdad, objetivos éticos de una estética. Como signo de modernidad, la arquitectura significa un trabajo individual y expresivo y será de gran calidad, original y auténticamente latinoamericana. La experiencia vital se vuelca en un interés por la libertad plástica y por las situaciones contingentes cambiantes, como la luz, el viento y la vegetación, cuyos casos característicos son las obras del mexicano Luis Barragán y del brasileño Roberto Burle Marx.

6.

Para la generación técnica (1960-1975) la industrialización y el desarrollo se convierten 
en una creencia indiscutible, por lo cual se asume la racionalización y la organización de los procesos de producción arquitectónica; la manera de ser modernos de este grupo radicará en la eficiencia y eficacia. La técnica no será un medio ni un fin sino una destreza, una habilidad, que tiene sus propias reglas, jerarquías y programas autónomos. El sentimiento de radicación fundamental de la técnica es la pertenencia a una comunidad de naciones, cuando Latinoamérica se inserta en los procesos generales mundiales de manera subordinada, en lo económico, como países subdesarrollados, y en lo político, como tercer mundo.

El periodo que abarca las décadas de I960 y 1970 marca la cúspide del crecimiento urbano; a finales de 1970, Buenos Aires, México y Sao Paulo se han convertido en conglomerados inmensos; las ciudades sufren grandes cirugías en respuesta al incremento del tráfico; las vías rápidas tasajean las ciudades, cortan barrios y separan las orillas; al mismo tiempo, se construyen con gran alarde técnico pasos a desnivel y tréboles. Las obras serán de una sorprendente homogeneidad, de gran envergadura $y$ pericia técnica, entre ellas están centros de producción energética, carreteras, puentes y sistemas de transporte masivo.

Los ingenieros vuelven a alcanzar un papel importante en las decisiones formales, mientras que los arquitectos alcanzan una sólida formación en los procesos constructivos y se dedican a experimentar, muestra de ello son las estructuras laminares de concreto reforzado, comúnmente llamadas "cáscaras", siendo célebres las de forma paraboloide-hiperbólicas de Félix Candela. En el diseño de las casas-habitación, los arquitectos técnicos miran hacia las experiencias de Mies van der Rohe, que resultan "una sencilla caja alargada de concreto que enmarca grandes planos de vidrio y parece estar suspendida en el aire" (408).

En la década de 1960 , en particular, persiste la marca de esta generación, en obras tales como el edificio sede de la Comisión Económica para la América Latina (CEPAL) en Santiago de Chile, la Facultad de Arquitectura de la Universidad de São Paulo, el Banco de Londres en Buenos Aires, el Museo Nacional de Antropología en la Ciudad de México.

Bajo un clima desarrollista, habrá una nueva actitud ante la vivienda masiva; se construyen unidades vecinales semejantes a las de la generación anterior, pero ahora con una marcada tendencia hacia las altas densidades, los edificios de altura y un urbanismo más cercano a los congresos internacionales de arquitectura moderna (CIAM), entre ellos se hallan el Centro Urbano Antonio Nariño en Bogotá, la Unidad Vecinal Portales en Santiago, la Unidad Vecinal Habana del Este y la Unidad Vecinal 2 de Diciembre en Caracas, así como la Unidad Habitacional Jardín Balbuena en la Ciudad de México.

Finalmente, con la generación técnica, argumenta la investigadora colombiana, se cierra un ciclo construido a lo largo de seis generaciones que, en términos arquitectónicos y urbanos, podemos llamar moderno.

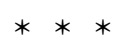

Ciudad y arquitectura. Seis generaciones que construyeron la América Latina moderna de Silvia Arango Cardinal no se reduce a la narración de acciones y menos aún da cuenta de un repertorio de constructores u obras arquitectónicas y urbanas sino desentrańa cómo seis generaciones latinoamericanas viven la modernidad, y si bien hay una apropiación de los avances internacionales existe un am- 
plio margen para la creatividad. Con razón, la autora explica: "Las formas arquitectónicas y urbanas que se hicieron en América Latina en la época moderna no vienen de formas generadas en otra parte, que copiamos, adaptamos o adoptamos, sino del hecho de compartir y debatir ideas generales que produjeron, creativamente, alternativas arquitectónicas en suelo latinoamericano" (I5). \\ Alejandro Andrade \\ El pincel de Elías. José Joaquín Magón \\ y la orden de Nuestra Señora \\ del Carmen* \\ (Puebla: Benemérita Universidad Autónoma \\ de Puebla, 2015) \\ por \\ ANTONIO RUBIAL ${ }^{* *}$
}

Desde que apareció el libro de Manuel Toussaint, La pintura colonial, la historia del arte novohispano ha vivido profundas transformaciones, no sólo en las maneras de aproximarse a las obras y a sus autores, sino también en su inserción en las esferas de la historia social y cultural, al expandir los estudios hacia los

* Texto recibido el 28 de abril de 20I6; devuelto para revisión el 7 de junio de 2016; aceptado el I7 de junio de 2016.

** Facultad de Filosofía y Letras, UnAm. http://dx.doi.org/Io.22201/iie.I8703062e.2016.109.2583 espacios de la producción artística, de los usos de la imagen, de la recepción y del mecenazgo. Entre otras cosas se ha revalorizado el siglo XVIII, visto por los autores de mediados del siglo xx como decadente, pero recuperado ahora como lo ha sido en Europa el rococó. Con esta nueva perspectiva se ha pasado de una visión que hacía depender a los pintores novohispanos del xviıI de la obra de Bartolomé Esteban Murillo a otra en la cual se acreditan otras influencias incluso de fuera de España, como la francesa y la italiana.

Otro avance novedoso respecto a la obra de Toussaint consiste en que se ha pasado de las generalizaciones a los estudios monográficos sobre pintores, reconstruyendo el catálogo de sus obras, estudiando sus influencias y a sus contemporáneos. El proceso se inició con la obra pionera sobre Juan Correa realizada por Elisa Vargaslugo y su grupo de colaboradores y seguido del magnífico estudio sobre Cristóbal de Villalpando de Juana Gutiérrez Haces, Rogelio Ruiz Gomar, Clara Bargellini y Pedro Ángeles. La valiosa tesis inédita de Paula Mues sobre José de Ibarra dio muchas luces sobre los inicios de la pintura del siglo xvinI, y ahora un grupo de especializados investigadores en el que se encuentra la misma Paula Mues, Jaime Cuadriello, Ilona Katzew y María Elena Alcalá preparan una magna exposición sobre la generación de Miguel Cabrera.

Hasta ahora el espacio privilegiado de los investigadores ha sido la Ciudad de México, centro de la vida artística y cultural del virreinato, aunque también se han develado varios trabajos importantes sobre pintores poblanos del siglo xviI (Diego de Borgraf, Pedro García Ferrer, Miguel de Mendoza, Juan Tinoco), no han recibido la misma atención los del xviII. El libro que aquí nos ocupa 
sobre el pintor José Joaquín Magón escrito por el joven investigador Alejandro Andrade es por esta razón un estudio muy novedoso.

La primera noticia que se tiene de este pintor, según nos cuenta el autor al comienzo de su libro, aparece en la relación de la fiesta con que se celebró en Puebla en 1760 el ascenso al trono de España de Carlos III. A Magón, como encargado de realizar el arco triunfal, lo compara el autor de la relación con Apeles, el paradigmático pintor griego de la Antigüedad. Alejandro Andrade utiliza esta noticia como portal para introducirnos en el contexto del imperio borbónico en el cual vivió Magón y que ha sido descrito cuidadosamente por Paula Mues. Según estos jóvenes investigadores, varios factores influyeron en el cambio artístico que se dio al iniciar el siglo XviII con el gobierno de los borbones en España: la creación de academias de pintura que pretendían separar a los pintores de la organización gremial y por tanto darles un estatus profesional distinto al de los artesanos; el aumento de la riqueza y de un sector aburguesado que hizo posible multiplicar los encargos; y la llegada de las influencias europeas, francesas e italianas, a la corte de Madrid. Tales cambios no sólo llegaron a la capital del virreinato sino que influyeron también en Puebla, urbe que desde el siglo Xvir había recibido artistas y pinturas procedentes de la Ciudad de México. Andrade muestra cómo la llegada de varios cuadros de José de Ibarra y Miguel Cabrera a la catedral de Puebla en este periodo influyeron en Magón, quien comenzó a hacerse eco del gusto por la modernidad estilística que se desarrollaba en la capital.

Después de introducirnos en el contexto, Andrade, con una gran sensibilidad histórica, inicia la narración sobre la biografía del pintor. Un importante dato sobre su participación en la milicia de pardos nos muestra a un personaje que, como otros pintores contemporáneos (como el mismo José de Ibarra) ascendió socialmente desde el ámbito de las castas gracias a sus dotes artísticas, pero también a su participación en estas organizaciones policiales que fueron los regimientos urbanos. Después, a partir de una cantidad mínima de datos y de semejanzas formales con otros artistas contemporáneos, Andrade concluye que Magón pudo realizar sus estudios en el taller de Luis Berruecos y propone la existencia de vínculos con otros pintores jóvenes, en un ambiente donde tres familias controlaban los encargos artísticos de la ciudad: los Berruecos, los Talavera y los Polo. Con las tres tuvo relaciones y su formación profesional estuvo ligada a ellas, aunque también se vio influido por los pintores Miguel Cabrera y José de Ibarra, quienes trabajaban en la Ciudad de México, pero cuyos cuadros pudo observar de manera directa, pues varios de ellos se encontraban en la catedral de Puebla y en otros espacios religiosos.

Abrirse paso en una sociedad fuertemente corporativizada y estamental no debió ser fácil para un joven mulato como Magón, por lo que, además de su talento, su ascenso se debió a los lazos clientelares entablados con la orden del Carmen. El convento de los carmelitas en Puebla poseía una de las pinacotecas más importantes de la ciudad y José Joaquín Magón fue uno de los pintores que más la enriqueció. Este contacto lo llevó también a trabajar para los dos monasterios de religiosas de esa orden en Puebla (el recién creado de la Soledad y el de Santa Teresa), así como para los conventos de varones de Atlixco y Orizaba. El autor del libro analiza no sólo los cuadros que se encuentran en dichos espacios, 
sino también muchos que están en diferentes repositorios y que atinadamente Andrade ha vinculado con los carmelitas. Para él, Magón no sólo puede ser considerado un colaborador del Carmelo sino el creador de una novedosa iconografía carmelitana.

Cuando este pintor entró en contacto con la orden, los carmelitas tenían un fuerte conflicto con la Compañía de Jesús a causa de que varios de sus miembros cuestionaron la supuesta fundación del instituto por el profeta Elías. Desde mediados del siglo XvII, fray Francisco de Santa María, en su Historia general profética de la orden de Nuestra Señora del Carmen (Madrid: imprenta de Diego de la Carrera, I64I) insistía en que ésta había aparecido en el Monte Carmel con Elías y Eliseo, y que varios profetas ermitaños habían sido sus miembros hasta llegar a san Juan Bautista, "príncipe de los monjes essenos e hijos de Elías: por medio de Juan, así como se ató la sinagoga con la Iglesia, así se unió la vida monástica de la ley con el Evangelio”. En I675 el jesuita bolandista Daniel Papenbroeck puso en duda esa supuesta filiación y, en la Nueva España, carmelitas y jesuitas se enfrentaron continuamente por esa causa. En la época de Magón la disputa estaba en pleno auge y la orden utilizó la pintura como un recurso para reafirmar y defender la antigüedad de su linaje. Para Andrade, Magón fue una pieza clave en la formación de esta nueva iconografía y de ahí el título que lleva su libro.

La relación de Magón con los carmelitas fue también la que lo llevó a colaborar con su segundo gran mecenas, el obispo Domingo Pantaleón Álvarez Abreu, quien lo convirtió en lo que podríamos llamar su "pintor de cámara”. Este prelado canario fue gran promotor de las artes, mandó pintar a Magón varios retratos e incluso su efigie se hizo presente en cuadros devocionales como la Confirmación de san Pedro Nolasco en el templo de la Merced de Atlixco, en la Oración del huerto en el convento del Carmen de Puebla, o en la parroquia de Tochtepec, donde este obispo está representado en un lienzo sacramental administrando el orden sacerdotal. Don Pantaleón fue también gran promotor del santuario de Ocotlán y encargó en I754 a José Joaquín Magón un conjunto de lienzos para ese espacio sobre la pasión de Cristo, y concedía indulgencias a quien rezara frente a ellos. El mismo obispo aparece también en una monumental pintura del Patrocinio de la Virgen de Guadalupe sobre las monjas jerónimas de Puebla, el cual pudo haber sido un exvoto por la curación de la comunidad de una "epidemia" de epilepsia, enfermedad que el mismo Magón padecía.

En otro cuadro excepcional, Andrade encuentra también la presencia del obispo canario, aunque no esté él directamente representado. Se trata de una pintura devocional denominada La santa Pulqueria, obra realizada en un contexto jesuítico a partir de una novena dedicada a ella escrita por Antonio de Paredes, quien la menciona como abogada contra los terremotos. Este cuadro, utilizado para ilustrar la portada del libro, formaba parte del acervo del colegio del Espíritu Santo, de donde Paredes fue rector. A raíz del terremoto que destruyó Lisboa en 1756, el obispo Pantaleón mandó hacer novenarios y procesiones para librar a Puebla de una catástrofe similar y el jesuita Paredes lo secundó publicando su novena en México en la imprenta de Joseph de Hogal. Al año siguiente, el prelado recomendaba a Magón al colegio poblano para que realizara la obra. La santa emperatriz bizantina fue representada en compañía de su casto esposo Marciano, de sus tres hermanas vírgenes, 
de su hermano Teodosio II y de su cuñada (la causante de que la joven princesa fuera expulsada de Constantinopla). En el pecho la santa lleva un águila bicéfala hispana, alusión quizá a que la monarquía era defensora del dogma inmaculista. Pulqueria estuvo también relacionada con los concilios de Éfeso y Calcedonia, por ello porta sobre la mano izquierda las actas de dichas asambleas colocadas debajo de una iglesia; al mismo tiempo, aplasta con sus pies a los herejes Nestorio y Eutiquio, condenados en dichos concilios. Es por demás curioso que un pintor que trabajó con tanta dedicación a la orden carmelita, aceptara pintar una de sus obras más importantes para la Compañía de Jesús, la enemiga acérrima de sus más constantes mecenas. La catedral fue en este tema, como en muchos otros, la intermediaria de tan insólito encuentro.

Alejandro Andrade considera que Magón promovió un estilo más intimista y una forma de pintar que tuvo una influencia en artistas coterráneos posteriores como Miguel Jerónimo Zendejas, Manuel Caro y Juan Manuel Yllanes. La obra termina con un apéndice donde se aclara una confusión común que se tenía entre el pintor José Joaquín Magón y su hijo del mismo nombre, quien fuera llevado a la Inquisición por blasfemo.

Como el mismo Alejandro Andrade lo señala en su reflexión final, el arte virreinal no solamente puede conocerse a partir de los pocos datos que se tienen de los pintores, sino sobre todo por medio de inferencias que comparen los documentos de archivo con las pistas dadas por los mismos cuadros. En un trabajo detectivesco este joven autor ha conseguido un bosquejo bastante completo de la vida y obra de uno de los pintores más importantes del periodo virreinal y del contexto poblano donde desarrolló su actividad artística. 
DOI: http://dx.doi.org/10.22201/iie.18703062e.2016.109.2623

\section{Normas para la presentación de originales}

L

a revista Anales del Instituto de Investigaciones Estéticas de la Universidad Nacional Autónoma de México es una publicación bianual, especializada en la teoobras artísticas, noticias, semblanzas y reseñas sobre publicaciones dentro del campo de la producción artística en todas sus manifestaciones.

\section{Requisitos para la presentación de originales}

I. Al entregar un texto, el autor se compromete a firmar la declaración ética — misma que se le enviará al recibir el material_- en la cual asienta que se trata de una colaboración inédita, original y relevante para su disciplina. Los textos podrán enviarse a anliie@unam.mx, o bien a la revista Anales del Instituto de Investigaciones Estéticas, Circuito Mario de la Cueva s/n, C.P. 045Io, Ciudad Universitaria, México, D. F. Se aceptan textos en español, inglés y portugués. Los autores que deseen enviar un texto en algún otro idioma, favor de contactar a los editores.

2. El archivo de Word deberá estar a doble espacio, con márgenes de tres centímetros y deberá tratarse de la versión definitiva del texto. La extensión debe fluctuar entre 25 y 40 páginas para todos los artículos; análisis críticos de testimonios documentales y reportes de obras artísticas deberán tener una extensión de entre 5 y 25 páginas; en el caso de reseñas, noticias y semblanzas de entre 3 y io páginas. La primera página debe incluir título y subtítulo de la colaboración, nombre del autor e insti- 
tución a la que pertenece. Todas las divisiones o secciones se señalarán con cabezas alineadas a la izquierda y separadas del texto por una línea blanca previa y una línea posterior. Las citas textuales mayores de cinco líneas se transcribirán en un párrafo aparte, sin modificar la interlínea general, y en un puntaje menor. Los llamados a notas a pie de página se compondrán en números arábigos volados, ordenados consecutivamente, y se colocarán después de los signos de puntuación.

3. Asimismo, debe incluirse un resumen (abstract) del contenido del artículo con un máximo de 140 palabras, así como una síntesis curricular del autor, no mayor a I20 palabras (con nombre, adscripción, correo electrónico, líneas de investigación y publicaciones). También es necesario proporcionar entre 5 y 7 palabras clave para la identificación del contenido.

\section{Aparato crítico}

El aparato crítico (el conjunto de citas, referencias y notas a pie de página que dan rigor y solidez al texto) debe seguir los lineamientos establecidos por The Chicago Manual of Style, cuya guía rápida puede consultarse en: http://www.chicagomanualofstyle.org/tools_citationguide.html

I. Las referencias bibliográficas deberán incluir: autor (nombre y apellidos en altas y bajas), Título del libro (ciudad: editorial, año), páginas citadas; por ejemplo: Ernst Hans Gombrich, Arte e ilusión. Estudio sobre la psicología de la representación pictórica, trad. Gabriel Ferrater (Madrid: Debate, 1998), 286.

2. Cuando se trate de la obra de más de dos autores únicamente se mencionarán los dos primeros seguidos de la locución latina et al.

3. En el caso de citar un capítulo de algún libro: autor, "nombre del capítulo", en autor, Título del libro (ciudad: editorial, año), páginas citadas; por ejemplo: Jorge Sebastián Lozano, "Veritas Filia tempori: Gombrich y la tradición”, en ed. Paula Lizárraga, E.H. Gombrich, in memoriam (Pamplona: EUNSA, 2003), 387-406.

4. Las referencias hemerográficas deberán incluir: autor, "Título del artículo", Nombre de la Publicación (en altas) número del volumen, número (fecha de publicación): páginas citadas; por ejemplo: Francisco Egaña Casariego, "Joaquín Vaquero Palacios en Nueva York”, Archivo Español de Arte 86, núm. 343 (2003): 237-262. Cuando se trate de periódico: Autor, "título del artículo", Nombre del Periódico, volumen, número, sección, fecha, año, página; por ejemplo Teresa del Conde, "Naturaleza herida: González Serrano", La Jornada, vol. 54, núm. 24, secc. Opinión, 20 de agosto, 2013, I2. 
5. Si por la naturaleza del texto es necesario hacer referencias a las obras dentro del mismo y utilizar el sistema de documentación autor-año entre paréntesis, se pide seguir también lo establecido por The Chicago Manual of Style; por ejemplo: (De la Fuente 1996, II4).

6. Las referencias a documentos en archivos se presentarán de la siguiente manera: emisor; título del documento; fecha; nombre completo del repositorio la primera vez que se cite y, entre paréntesis, las que serán utilizadas posteriormente; localización interna del documento y fojas consultadas, por ejemplo: Archivo del Cabildo Catedral Metropolitano de México (en adelante Ассмм), Actas de cabildo, libro 22, foja 3, 7 de enero de 1684 .

7. Las páginas web se citarán como sigue: nombre del autor, "título", liga directa al texto (consultado y la fecha), ejemplo: Rocío Robles Tardío, "La metáfora y la huella del ferrocarril en la formulación de la vivienda moderna en Le Corbusier", www.dialnet.uniroja.es/servlet/ejemplar?codigo=339925 (consultado el 30 de octubre, 2013).

8. Para las referencias filmográficas: director, Título de la película (lugar: casa productora, año), duración; por ejemplo: Federico Fellini, La dolce vita (Roma/París: Riana Film/Pathé Consortium Cinéma, 1960), I74 min.

9. Las referencias a grabaciones sonoras se formularán de la siguiente manera: nombre del compositor, Título, director, casa discográfica, año; por ejemplo: Silvestre Revueltas, Tragedia en forma de rábano (no es plagio), Enrique Diemecke, Gramophone, I990.

\section{Ilustraciones}

I. Se enviará un archivo de Word como referencia con las imágenes y sus pies correspondientes numerados conforme a su aparición en el texto, acompañadas por el "Formato para la entrega de imágenes" debidamente llenado. Es importante cuidar que las imágenes cumplan con ciertos requisitos generales, tales como: nitidez, definición, buen encuadre.

2. Si se tienen placas, diapositivas o fotografías impresas en papel fotográfico el tamaño debe ser, cuando menos, de $5 \times 7 \mathrm{~cm}$ para la calidad de impresión. Una vez digitalizado, el material original les será devuelto.

3. Si se entregan imágenes digitales, éstas deben cumplir con los siguientes requisitos: a) fotografías y medios tonos: a $300 \mathrm{dpi}$, en formato tif y a $\mathrm{I} 4 \mathrm{~cm}$ de ancho; b) dibujos a línea (mapas, esquemas, diagramas): a I200 dpi, en formato tif y a 
I4 $\mathrm{cm}$ de ancho. Deben entregarse numeradas dentro de un CD (etiquetado con el nombre del autor, el del artículo y la fecha en que se grabó el disco); o pueden enviarse por correo electrónico o Dropbox, para lo cual es necesario que los archivos estén numerados acorde a sus pies de ilustración.

4. No se aceptan digitalizaciones de libros o revistas.

5. Pies de ilustración: la numeración irá acorde con los nombres de los archivos entregados, seguida de: autor, Título de la obra, fecha, dimensiones, ciudad. Fuente o acervo. Crédito fotográfico (c) o a quien correspondan los derechos patrimoniales de la imagen para edición en papel y electrónica.

6. Permisos de reproducción: el autor deberá remitir por escrito los permisos de reproducción de las ilustraciones que así lo requieran, tanto para la edición impresa como para la edición en línea. Únicamente cuando el Instituto tenga convenios interinstitucionales, los permisos podrán ser tramitados por el área jurídica del Departamento de Publicaciones.

\section{Proceso editorial}

I. Una vez confirmada la recepción del texto éste se somete a una preselección por parte de los editores de la revista en la que se determinará su pertinencia temática. Cuando el trabajo se califique como pertinente para su publicación, se someterá al arbitraje confidencial; en el caso de artículos de investigación, de análisis documentales y de obras se dictaminarán por dos es-pecialistas en el tema; las semblanzas y reseñas se turnarán a un solo árbitro.

2. Los dictaminadores deberán ser externos al equipo editorial de la revista y no tener ninguna relación con el autor. Deberán contar con estudios de maestría o doctorado y haber publicado al menos un artículo de investigación, de reflexión o revisión crítica relacionado con la temática del manuscrito. Asimismo se pondrá a su disposición un formato de evaluación con el que podrán articular su opinión sobre la calidad de los originales recibidos.

3. Independientemente de los resultados, el contenido de los dictámenes se entregará a los autores. En todo momento se conservará el anonimato tanto de los evaluadores como de los autores.

4. Los editores de la revista podrán solicitar modificaciones o rechazar la contribución atendiendo las resoluciones de los dictámenes que podrán ser: a) aprobado sin cambios, b) aprobado con sugerencias, c) aprobado condicionado a la realización de los cambios indicados, o d) rechazado. 
5. En caso de que se trate solamente de atender sugerencias o condicionamientos, el autor detallará los cambios realizados a su texto. Los editores revisarán las modificaciones introducidas por el autor en relación con las sugerencias o condicionamientos de los dictámenes para después proceder, sólo en caso de su cumplimento, a su aceptación.

6. Si el autor no estuviera de acuerdo con los dictámenes, podrá argumentar su inconformidad por escrito. Los editores de la revista en conjunto con el Consejo editorial valorarán la situación y, en caso de ser necesario, solicitarán un tercer dictamen.

7. La Universidad Nacional Autónoma de México requiere que los autores cedan la propiedad de los derechos de autor a la revista Anales del Instituto de Investigaciones Estéticas para que su artículo y materiales sean editados y publicados en papel o medios electrónicos o en cualquier otra tecnología para fines exclusivamente científicos y culturales y sin lucro. Para ello, los autores deben remitir el formato de carta-cesión de la propiedad de los derechos de autor, debidamente llenado y firmado. Este formato se enviará por correspondencia o correo electrónico en archivo PDF en el proceso de revisión de galeras.

8. Una vez aceptado el texto y cumplidos los requisitos previamente seńalados se revisará el material complementario (imágenes y permisos de reproducción). Es obligación de los autores sustituir cualquier material que no cumpla con la calidad para impresión.

9. En caso de ser necesario, los editores, de común acuerdo con los autores, podrán solicitar a éstos modificaciones, con el fin de respetar el diseño editorial.

Io. Los autores deben comprometerse a revisar tanto galeras (con el fin de dar su visto bueno a la corrección de estilo) como pruebas finas (para corroborar que la secuencia de las imágenes sea correcta y que correspondan con sus pies de ilustración). En ningún caso se aceptarán modificaciones mayores al texto.

\section{Normas éticas de la publicación}

La revista Anales del Instituto de Investigaciones Estéticas cuidará que todas las partes (editores, dictaminadores y autores) cumplan con las normas éticas en el proceso de publicación. Anales sigue las normas éticas basadas en los estándares internacionales que son: 
Los editores

I. Se comprometen a garantizar el anonimato de autores y dictaminadores durante el proceso editorial.

2. Se asegurarán de que todos los textos sean revisados por dictaminadores especialistas en su campo y deberán garantizar que el proceso editorial se lleve a cabo de manera transparente.

3. Se comprometerán a resguardar la libertad y objetividad académicas, a cumplir sus labores con eficacia y calidad.

4. Ante cualquier duda, consultarán al Consejo editorial de la revista.

\section{Los dictaminadores}

I. Cuidarán de asegurar la originalidad de los textos y denunciarán cualquier posibilidad de plagio.

2. La dictaminación de las colaboraciones es estrictamente anónima. Los dictaminadores deberán revisar con cuidado el texto que se les ha enviado dentro de los plazos establecidos y declinar en caso de no considerarlo dentro del ámbito de su competencia.

3. Se comprometen a no divulgar ni utilizar el contenido de un artículo que aún no ha sido publicado. La violación de este requerimiento ético será sancionado.

4. Deberán ser justos e imparciales y juzgar el trabajo según criterios estrictamente académicos.

\section{Los autores}

Se comprometen a firmar el formato de declaración ética que se les enviará al momento de recibir su artículo y a cumplir con las normas de conducta estipuladas a continuación:

I. El trabajo de investigación deberá ser original e inédito, es decir, no haber aparecido en algún otro medio impreso o digital ni haber sido puesto a consideración simultáneamente a otro organismo editor. No puede ser sometido un artículo que haya sido publicado aunque haya aparecido en un medio de poca circulación. En dado caso se deberá obtener la aprobación previa si se justifica con argumentos sólidos la publicación dual.

2. En caso de que el autor proponga una traducción al español de un texto previamente publicado, deberá fundamentar su pertinencia. Con base en ello, los editores, asistidos por el Consejo editorial, decidirán sobre su publicación. 
DOI: http://dx.doi.org/10.22201/iie.18703062e.2016.109.2623

NORMAS PARA LA PRESENTACIÓN DE ORIGINALES

3. Se compromete a no incurrir en la autoría injustificada, que consiste en la inclusión como autores de personas cuyas contribuciones fueron mínimas o nulas en el proceso de elaboración del texto. El autor se compromete a dar crédito a las personas e instituciones que lo hayan apoyado en cualquier parte del proceso.

\section{Sanciones}

Las faltas éticas se castigarán dependiendo de su gravedad. En el caso de sospecha o acusación fundada de plagio, se instituirá un comité de ética compuesto por pares que investiguen las imputaciones y recomienden las sanciones. En caso de confirmación de plagio se procederá a retirar el artículo de la revista y se colocará una leyenda con los motivos por los cuales fue retirado. 
DOI: http://dx.doi.org/10.22201/iie.18703062e.2016.109.2623 
DOI: http://dx.doi.org/10.22201/iie.18703062e.2016.109.2623

\section{Submission Guidelines for Authors}

he journal Anales del Instituto de Investigaciones Estéticas of the Universi-
dad Nacional Autónoma de México is a biannual publication, specialized
in theory and history of art and esthetics and open to all related disciplines. It includes research papers, critical analyses of documentary testimonies, reports on works of art, news items, biographical sketches, and reviews of publications within the field of artistic production in all its manifestations.

\section{Requirements for the submission of manuscripts}

I. When submitting a text, the author undertakes to sign the ethical declarationwhich will be sent to him/her on receiving the material —in which the author assures that the work is an unpublished and original contribution, relevant to his/her discipline. The texts may be sent to anliie@unam.mx, or to the journal Anales del Instituto de Investigaciones Estéticas, Circuito Mario de la Cueva s/n, C.P. 04510, Ciudad Universitaria, México, D. F. Texts are accepted in Spanish, English and Portuguese. Authors who wish to send a text in any other language are advised to make contact first with the editors.

2. Word files must be in double space, with margins of three centimeters and must represent the definitive version of the text. Articles should have an extension of between 25 and 40 pages; critical analyses of documentary testimonies and reports on works of art may have an extension of between 5 and 25 pages; in the case of reviews, news items and biographical sketches, between 3 and Io pages. The first page must include the title and subtitle of the contribution, author's name and the institution to which he/she belongs. All divisions and section shall 
DOI: http://dx.doi.org/10.22201/iie.18703062e.2016.109.2623

296 SUBMISSION GUIDELINES FOR AUTHORS

be indicated with headings aligned to the left and separated from the text by a blank line before and after. Textual quotations of more than five lines must be transcribed as a separate paragraph, without modifying the general spacing and in a font one point smaller than the text. Footnote references will take the form of superscript Arabic numerals in consecutive order placed immediately after punctuation marks.

3. An abstract must also be included summarizing the contents of the article in a maximum of $\mathrm{I} 4 \mathrm{O}$ words, as well as a résumé of the curriculum vitae of the author, in not more than I2O words (with name, academic post, e-mail, lines of research and publications). It is also necessary to provide between 5 and 7 keywords identifying the contents.

\section{Critical apparatus}

The critical apparatus (set of citations, references and footnotes that give academic rigor to the text) must follow the guidelines established by The Chicago Manual of Style, whose "Quick Guide" can be consulted at:

http://www.chicagomanualofstyle.org/tools_citationguide.html

I. Bibliographical references must include: Author (received name and surname in upper and lower case), Title of the Book (place: publisher, year), pages cited; for example: Ernst Hans Gombrich, Arte e ilusión. Estudio sobre la psicología de la representación pictórica, tr. Gabriel Ferrater (Madrid: Debate, 1998), 286.

2. In the case of works by more than one author, only the first two are to be mentioned, followed by the Latin abbreviation $e$ al.

3. When citing a particular chapter of a book: Author, "Chapter Title," in author, Title of Book (place, publisher, year), pages cited; for example: Jorge Sebastián Lozano, "Veritas Filia tempori: Gombrich y la tradición," in ed. Paula Lizárraga, E.H. Gombrich, in memoriam (Pamplona: EUNSA, 2003), 387-406.

4. References to printed journals should include: Author, "Title of Article," Name of Publication (respecting capitals) number of volume, part number (date of publication): pages cited; for example: Francisco Egaña Casariego, "Joaquín Vaquero Palacios en Nueva York," Archivo Español de Arte 86, no. 343 (2003): 237-262. In the case of a newspaper: Author, "Title of the Article," Name of Periodical, volume, number, section, date, year, page; for example, Teresa del Conde, "Naturaleza herida: González Serrano," La Jornada, vol. 54, no. 24, sect. Opinión, August 20, 2OI3, I2. 
5. Should the nature of the article require making references to works within the text, and hence use of the author-year system of documentation between brackets, authors are similarly requested to follow the guidelines established by The Chicago Manual of Style; for example: (De La Fuente 1996, II4).

6. References to documents in archives are presented in the following manner: issuer; title of document; date; complete name of the archive when citing for the first time and (in brackets) the abbreviation that will be used thereafter; internal classification or location of the document and the folios consulted, for example: Archive of the Cabildo Catedral Metropolitano de México (henceforth Ассмм), Actas de cabildo, book 22, folio 3, January 7, I684.

7. Websites are cited as follows: Author's name, "Title," direct link to the text ("consulted" and the date); example: Rocío Robles Tardío, "La metáfora y la huella del ferrocarril en la formulación de la vivienda moderna en Le Corbusier," www.dialnet.uniroja.es/servlet/ejemplar?codigo=339925 (consulted October 30, 2013).

8. For film references: Director, Title of the film (place: production company, year), duration; example: Federico Fellini, La dolce vita (Rome/Paris: Riana Film/Pathé Consortium Cinéma, 1960), I74 min.

9. References to sound recordings are formulated as follows: Name of composer, Title, director, recording company, year; for example: Silvestre Revueltas, Tragedia en forma de rábano (no es plagio), Enrique Diemecke, Gramophone, I990.

\section{Illustrations}

I. A Word file will be sent as reference with the images and their corresponding captions numbered in the order in which they appear in the text, accompanied by the duly completed "Form for the submission of images." It is important to make sure that the images fulfill certain general requirements, such as: clarity, definition, good framing.

2. If plates, slides, or prints on photographic paper are submitted, the size must be at least $5 \times 7 \mathrm{~cm}$ to ensure good printing quality. Once digitalized the original material will be returned.

3. In the case of submitting digital images, these must fulfill the following requirements: a) photographs and midtones: $300 \mathrm{dpi}$, in .tif format and $14 \mathrm{~cm}$ breadth; b) line drawings (maps, sketches, diagrams): I200 dpi, in .tif format and $14 \mathrm{~cm}$ breadth. They must be delivered numbered in a CD (labeled with author's name, name of article and the date on which the disc was burned); or they can be sent 
by electronic mail or Dropbox in which case it is necessary that the files should be numbered in accordance with their captions.

4. Digitalized reproductions from books or journals are not accepted.

5. Captions: the numeration must be in accordance with the names of the submitted files, followed by: author, Title of the work, date, dimensions, place. Source or collection. Photographic credit (C) or details of the holder of the ownership rights over the image for publication on paper or in electronic form.

6. Reproduction rights: the author must remit licenses in writing, for both printed and on-line editions, permitting reproduction of those illustrations that require such authorization. Only where inter-institutional agreements exist between this Institute and other institutions involved may the permits be sought by the legal area of the Publications Department.

\section{Editorial process}

I. Once reception of the text has been confirmed, the work will be submitted to a process of pre-selection by the editors of the journal so as to determine its thematic suitability. Once the work has been rated as relevant for publication it will be submitted for anonymous peer review; in the case of research articles, documentary analysis, and studies of works of art, opinions will be sought from two specialists in the field; biographical sketches and reviews will be submitted to a single referee.

2. Referees shall be external to the journal's editorial team and shall have no relationship with the author. They must have completed studies of master's or doctorate level and have published at least one article of research, reflection or critical review related to the subject of the manuscript. They.

will be provided with an assessment form with which to express their opinion on the quality of the originals received.

3. Whatever the nature of the results, the contents of referees' opinions will be delivered to the authors. At all times the anonymity of both authors and evaluators will be respected.

4. The editors of the journal shall be empowered to request modifications to- - or to reject-the contribution in attendance upon referees' determinations. Decisions may take the form: a) accepted without changes; b) accepted with suggestions for changes; c) accepted on the condition of carrying out the changes indicated; or d) rejected. 
5. When attending to suggestions or conditions, the author shall highlight the changes made to his/her text. The editors will then review the modifications introduced by the author in relation to the suggestions or conditions made by referees, before proceeding - assuming that the suggestions or conditions have been fulfilled-to accept the work.

6. If the author disagrees with a referee's opinion, he/she can set forth the points of disagreement in writing. The editors of the journal, together with the editorial committee, will then evaluate the situation and, if necessary, request a third peer review.

7. The Universidad Nacional Autónoma de México requires authors to transmit intellectual ownership rights to the journal Anales del Instituto de Investigaciones Estéticas for the effects of publishing the article and accompanying material both on paper and by electronic or any other technological media, for exclusively scientific or cultural and non-commercial purposes. Authors must therefore send back the duly completed and signed form for transmission of author's rights. This form will be sent by mail or e-mail in a PDF format during the process of galley proof revision.

8. Once the text has been approved and all previously indicated requirements have been met, the complementary material (images and reproduction licenses) will be checked. It is an obligation of the authors to resubmit any material that does not meet the quality requirement for printing.

9. If necessary, the editors may, subject to authors' agreement, request modifications in order to respect editorial design criteria.

Io. Authors must undertake to check both galleys (in order to give their approval of the copy editing) and final page proofs (so as to corroborate that the sequence of images is correct and corresponds with the captions). In neither case will major modifications to the text be accepted.

\section{Ethical norms of publication}

The journal Anales del Instituto de Investigaciones Estéticas shall ascertain that all parties (editors, referees and authors) comply with the ethical norms in the process of publication. Anales adheres to ethical norms based on international standards, which are: 
DOI: http://dx.doi.org/10.22201/iie.18703062e.2016.109.2623

300

SUBMISSION GUIDELINES FOR AUTHORS

The editors undertake:

I. To guarantee the anonymity of authors and referees during the editorial process.

2. To ensure that all texts are reviewed by specialists in the field and guarantee that the editorial process is carried out in a transparent manner.

3. To respect academic freedom and objectivity and to carry out their work with efficiency and to high standards of quality.

4. In case of doubt, to consult the editorial committee of the journal.

\section{Referees shall:}

I. Guarantee that submitted texts are original and alert to any possibility of plagiarism.

2. Ensure that opinions on the collaborations are maintained in strict anonymity. Referees shall review the texts sent to them with care and within the periods of time established and decline whenever they consider a text to lie outside the field of their competence.

3. Undertake not to divulge or make personal use of the contents of any article that has not yet been published. Violation of this ethical requirement shall be subject to sanction.

4. Be fair and impartial, judging the works in accordance with exclusively academic criteria.

\section{Authors:}

Undertake to sign the ethical declaration form which will be sent to them at the moment of receiving the article and to comply with the ethical guidelines which are listed as follows:

I. Shall guarantee that research articles are original and unpublished; i.e., have not appeared in any other printed or digital medium, nor have been offered simultaneously for consideration by another editorial body. No article that has been published beforehand may be submitted, even in the case of having appeared in a medium of very limited circulation. Exceptionally, notwithstanding, should strong grounds exist for dual publication, prior approval may be sought for the purpose with the support of solid arguments justifying the proposal.

2. In the case of an author proposing a translation into Spanish of a previously published text, he/she must offer convincing grounds for the relevance of the pro- 
posal. On that basis the editors, assisted by the editorial committee, shall decide whether to publish the work.

3. Authors shall undertake not to commit any unjustified accreditation (consisting in the inclusion as authors of names of persons whose contribution to the drawing up of the text was minimal or inexistent). Authors shall likewise undertake to give credit to all those persons or institutions who have given support during any part of the process.

\section{Sanctions}

Ethical misdemeanors will be sanctioned in proportion to their seriousness. In the case of well-founded suspicion or accusation of plagiarism, a committee of ethics formed of peers will be set up to investigate imputations and recommend the sanctions to be imposed. In the case of confirmation of plagiarism, the article will be withdrawn from the journal and a notice will be inserted explaining the reasons for withdrawal. 
DOI: http://dx.doi.org/10.22201/iie.18703062e.2016.109.2623 


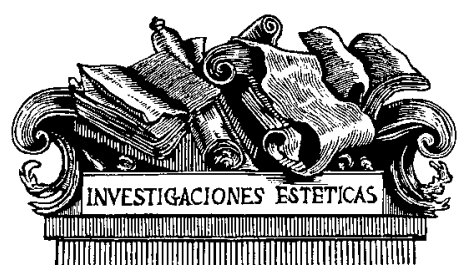

\title{
INSTITUTO DE INVESTIGACIONES ESTÉTICAS
}

\author{
Director \\ RENATO GONZÁLEZ MELLO
}

IDA RODRÍGUEZ PRAMPOLINI, ELISA VARGASLUGO, JORGE ALBERTO MANRIQUE, ELISA GARCÍA BARRAGÁN, EDUARDO BÁEZ MACÍAS, ALBERTO DALLAL, RITA EDER ROZENCWAIG, FAUSTO RAMÍREZ ROJAS, AURELIO DE LOS REYES, JULIO ESTRADA, ALICIA AZUELA DE LA CUEVA, MARTHA FERNÁNDEZ GARCÍA, ROGELIO RUIZ GOMAR, MARIE-ARETI HERS, CLARA BARGELLINI, GUSTAVO CURIEL MÉNDEZ, ELIA ESPINOSA LÓPEZ, OLGA SÁENZ GONZÁLEZ, LOUISE NOELLE, TERESA DEL CONDE, ARTURO PASCUAL SOTO, DÚRDICA ŠÉGOTA TOMAC, ELENA ISABEL ESTRADA DE GERLERO, PABLO ESCALANTE GONZALBO, ARNULFO HERRERA CURIEL, EMILIE CARREÓN BLAINE, DIANA MAGALONI KERPEL, JAIME CUADRIELLO, MARÍA ELENA RUIZ GALLUT, RENATO GONZÁLEZ MELLO, CUAUHTÉMOC MEDINA GONZÁLEZ, MARÍA DE LA LUZ ENRÍQUEZ RUBIO, LETICIA STAINES CICERO, MARÍA TERESA URIARTE, MARÍA JOSÉ ESPARZA LIBERAL, ENRIQUE X. DE ANDA ALANÍS, ANGÉLICA VELÁZQUEZ GUADARRAMA, PETER KRIEGER, PATRICIA DÍAZ CAYEROS, JESÚS GALINDO TREJO, ERIK VELÁSQUEZ GARCÍA, HUGO ARCINIEGA, PABLO F. AMADOR MARRERO, CONSUELO CARREDANO, DEBORAH DOROTINSKY ALPERSTEIN, LAURA GONZÁLEZ, FERNANDO BERROJALBIZ, LINDA BÁEZ RUBÍ, OSCAR FLORES FLORES, DAVID M. J. WOOD, ROBERT MARKENS, GENEVIÈVE JEANINE ALICE LUCET, KARLA LETICIA JASSO LÓPEZ, MARIANA AGUIRRE, HELENA CHÁVEZ MC GREgOR, ANA GUADALUPE DÍAZ ÁlVAREZ, DENISE FALLENA MONTAÑO, NASHELLI JIMÉNEZ DEL VAL, DANIEL MONTERO FAYAD, IVÁN RUIZ GARCÍA, RIÁNSARES LOZANO DE LA POLA. 
DOI: http://dx.doi.org/10.22201/iie.18703062e.2016.109.2623

Anales del Instituto de Investigaciones Estéticas, volumen XXXVIII, número Io9 (otoño de 20I6), se terminó de imprimir el 2I de octubre de 20I6, en los talleres de Offset Rebosán, S.A. de C.V. Composición tipográfica: El Atril Tipográfico, S.A. de C.V. El tiraje consta de 500 ejemplares. 